\title{
THE SLENDER THREAD: IRISH WOMEN ON THE SOUTHERN AVALON, \\ 1750-1860
}

CENTRE FOR NEWFOUNDLAND STUDIES

TOTAL OF 10 PAGES ONLY MAY BE XEROXED

(Without Author's Permission)

WILLEEN G. KEOUGH 
002311

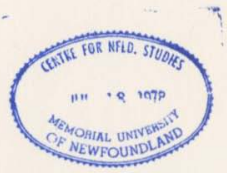





\section{INFORMATION TO USERS}

This manuscript has been reproduced from the microfim master. UMI films the text directly from the onginal or copy submitted. Thus, some thesis and dissertation copies are in typewriter face, while others may be from any type of computer printer.

The quality of this reproduction is dependent upon the quality of the copy submitted. Broken or indistinct print, colored or poor quality illustrations and photographs, print bleedthrough, substandard margins. and improper alignment can adversely affect reproduction.

In the unlikely event that the author did not send UMI a complete manuscript and there are missing pages, these will be noted. Also, if unauthorized copyright material had to be removed, a note will indicate the deietion.

Oversize materials (e.g., maps, drawings, charts) are reproduced by sectioning the original, beginning at the upper left-hand comer and continuing from left to right in equal sections with small overlaps.

ProQuest Information and Learning 300 North Zeeb Road, Ann Arbor, MI 48106-1346 USA 800-521-0600

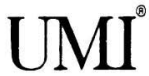


National Library

of Canada

Acquisitions and Bibliographic Services

395 Wellington Streen Otown ON K1A ONA Canada
Bibliotheque nationale du Canada

Acquisitions et services bibliographiques

395. no Wollington Otama ON K1A ONA
The author has granted a nonexclusive licence allowing the National Library of Canada to reproduce, loan, distribute or sell copies of this thesis in microform, paper or electronic formats.

The author retains ownership of the copyright in this thesis. Neither the thesis nor substantial extracts from it may be printed or otherwise reproduced without the author's permission.
L'auteur a accordé une licence non exclusive permettant à la Bibliothèque nationale du Canada de reproduire, prêter, distribuer ou vendre des copies de cette thèse sous la forme de microfiche/film, de reproduction sur papier ou sur format électronique.

L'auteur conserve la propriété du droit d'auteur qui protège cette thèse. $\mathrm{Ni}$ la thèse ni des extraits substantiels de celle-ci ne doivent être imprimés ou autrement reproduits sans son autorisation. 
The slender thread Irish women on the southern Avalon. 1750-1860

by

Willeen G. Keough

\begin{abstract}
A thesis submitted to the School of Graduate Studies in partial fulfilment of the requirements for the degree of Doctor of Philosophy
\end{abstract}

Department of History Memorial Lniversity of Newtoundland

August. 2001

St. John's, Newtoundland

2001 Willeen Keough 


\section{TABLE OF CONTENTS}

Abstract

Acknowledgments

List of tables

List of tigures

List of abbreviations _.....

Preface $\quad$ xii

Chapter I - Picking up the thread: Introduction and literature review 1

I I Newfoundland and early settlement

1 The Irish diaspora in North America 17

13 Anglo-European immigration and early settlement in Canada 37

$1+$ Colonial women in America $\quad+6$

15 Theoretical perspective 54

16 Sources 61

1.7 Study area $\quad 76$

18 Transition $\ldots$

Chapter 2 - The slender thread cast off. Migration and reception at Newioundland 79

21 Early migration $\quad 82$

2.2 A "notoriously disaffected" and "Wicked \& Idle People" Early reception $\$ 5$

23. there is not a saint in the calendar that was not invoked.$\cdot$
$19^{\text {th }}$-century passages

Chapter 3-Cyphering cyphers: Tracing Irish women on the southern Avalon 136

$\begin{array}{ll}3.1 \text { Source areas } & 140\end{array}$

32 Motives and patterns of migration $\quad 1+5$

$\begin{array}{ll}3.3 \text { Intermarriage and assimilation } \ldots \ldots & 171\end{array}$

3 + A maturing population........... 185

3.5 Transition to household production $\quad 190$

36 Conclusion $\quad 204$

Chapter + - "A good, hard-working stump of a girl". Irish women 's work and the construction of identity on the southern Avalon $\quad 208$

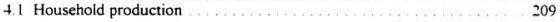

4.1 Cod fishery ......................... 211 
4.1.2 Subsistence agriculture $\ldots \ldots \ldots \ldots \ldots \ldots \ldots \ldots \ldots$

+1.3 Housewifery .............. $\quad 233$

$+1+$ Wrecking and salvaging 241

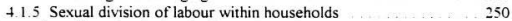

4.2 Women in paid work, the hospitality trade. and proto-professions $\quad 256$

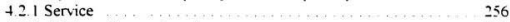

+22 Paid washing and sewing $\quad 266$

+2.3 Agriculture - production for market and paid labour $\quad \ldots \quad 280$

$+2+$ Hospitality trade $\ldots \ldots \ldots \ldots . . . .288$

+2.5 Community healing and midwifery $\quad .299$

+26 School teaching $\quad 312$

+3 Conclusion ... 324

Chapter 5 - "She made the cannonballs, and he fired them" Irish-Newfoundland women and informal power in tamily and community 329

51 The family ........ 333

52 The economic sphere $\quad 338$

53 The spiritual realm ......... $3+8$

$5+$ The information highway 366

55 What 's in a name? 385

5.6 Collective actions and private wars $\quad 388$

57 Conclusion +22

Chapter 6 - "Humble petitioners" and "litigeous person[s]" Southern Avalon women and encounters with formal justice $\quad+28$

6.1 Civil litigation ..... +31

61.1 Debt coilection +32

6.1.2 Employment disputes . +42

6.1.3 Landlord-tenant matters _... +51

$6.1+$ Trespass ........ 460

6.2 Criminal matters - female complainants and defendants $\quad+64$

6.3 Female witnesses $\quad+78$

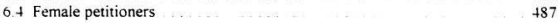

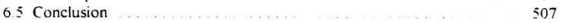

Chapter 7 - "Whilst Grass Grows or Waters Run". Women and testation practices on the southern Avalon $\quad \$ 16$

71 Wills, deeds of gift, and deeds of convevance . $\quad 523$

72 Women s wills and deeds of gift or convevance $\quad 538$

73 Gender. ethnicity. class, and testation practices $\quad \leqslant 46$

$7+$ Intestacies ...................... $\$ \mathbf{5 0}$ 
Chapter 8.-To fix [their] character in virtue and innocence". The regulation of Irish female sexuality on the southern Avalon

8.1 Irish womanhood within plebeian culture on the southern Avalon $\quad 565$

8.2 Irish plebeian womanhood and the court svstem …....... $\quad 573$

8.2.1 Seduction and paternity suits $\quad 57.4$

8.2.2 Infanticide and concealment of birth ... 581

8.2 .3 Prostitution .................................... 583

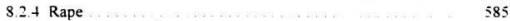

8.25 Loss of consortium $\quad 588$

8.2.6 Wifebeating ......... 590

8.2.7 Desertion, separation, and maintenance $\quad 593$

8.3 Irish plebeian womanhood and the Catholic church 603

$8+$ Conclusion $\quad 612$

Chapter 9. The other woman: Gentry life on the southern Avalon 614

91 English gentry women $\quad 014$

92 Exceptional women 049

93 Conclusion 659

$\begin{array}{ll}\text { Chapter 10. The slender thread cast on } & 061\end{array}$

Appendix A - The plebeian community ..... 670

Appendix B - Questionnaire tor oral history project $\quad 680$

Appendix C - Women's presence in the mercantile accounts of the southern Avaion 697

Appendix D - Marital and other family arrangements in Ferryland district. C. $1800 \quad 713$

Appendix E - Partial family tree - Morry-Carter families. Caplin Bay and Ferryland. mid-18th to mid-19th centuries

Bibliography 


\begin{abstract}
Women's vital participation in early community formation in Newfoundland has long been overlooked by the traditional historiography Recent writings on migration and early settlement have been more inclusive. but women's lives still appear secondary and peripheral in texts dealing primarily with the activities of men To broaden the scope of the discussion, this thesis examines the multi-generational group of Irish-Newtoundland women who were co-founders of fishing communities along the southern Avalon peninsula in the late $18^{\text {th }}$ and early $19^{\text {th }}$ centuries.

Irish women came out to Newfoundland to take advantage of opportunities in the tishing economy. tollowing weil-established trade routes between the southeastern counties of their homeland and the island. On the southern Avalon, they and their daughters provided demographic continuities and stability in tishing populations that rose and ebbed with the movements of transient fishermen. In both family and community. they held considerable status and authority. They not only pertormed vital reproductive work for their households, but also became essential shore workers in family work units in the tishery, and were visible in various other capacities in the economic life of the area. These women were primary household managers. They were important spiritual guides in both orthodox Catholic practice and in an ancient. non-Christian system of beliefs and practices. They participated occasionally in communal actions and more frequently in individual interventions to defend property, farnily, reputation, and community standards. They also readily employed the evolving court system in pursuit of justice. often
\end{abstract}


manoeuvring between formal legal mechanisms and informal confrontation to assert their claims. Thus, the construction of Irish-Newfoundland womanhood that evolved in this new-world setting contrasted strongly with the middle-class feminine ideals of domesticity. fragitity, and dependence that increasingly circumscribed the lives of English gentry women in the area.

Irish-Newtoundland women also resisted the pressures of gender ideology more successtully than their non-emigrating sisters. As the homeland underwent massive demographic and economic transitions throughout the $19^{\text {th }}$ century, rural trish women were increasingly channelled away from productive work and into domesticity and economic dependence. By contrast. Irish women on the southern Avalon remained economically active. and their status and power in the social. economic. and political lives of their communities remained intact. 


\section{ACKNOWLEDGMENTS}

I would like to extend my deep appreciation to my supervisory committee. Dr Linda Kealev. Dr. Shannon Ryan. and Dr. Peter Hart. for their wise counsel and suppor in the completion of this dissertation and their encouragement throughout my program of study. I must also thank my 'unofficial supervisor." Dr. John Mannion. for his insights on Irish migration to Newfoundland and for generously giving me access to his extensive name tile collection on Irish immigrants to the island. To his wife, Maura, $f$ am also gratetul tor sharing this data, which she helped to collect and organize, and tor several useful leads in relation to sources. I would also like to thank Dr Greg Kealev, Dr Cyril Byrne. Dr. Terrence Murphy, and Dr. John Fitzgerald tor their continuing interest and encouragement. Dr Hans Rollmann and Dr. Thomas Nemec for their helpful suggestions on sources. and the faculty of the History Department for the insights they have shared through the years.

Funding for my research has been provided by the Social Sciences and Humanities Research Council of Canada and the Institute for Social and Economic Research. Memorial Lniversity of Newfoundland. I thank them for this tinancial support. which made this study possible.

I am grateful to the staff members of the various repositories I have visited in the course of my research. In particular. I must thank the staff of the Provincial Archives of Newfoundland and Labrador. the Centre for Newfoundland Studies, the Maritime History Archives, and the Memorial University of Newfoundland Folklore and Language Archive 
for their invaluable assistance. I also extend special thanks to Dorothy Agriesti and Maxine Dunne of the Ferryland Museum for generously sharing their time and historical materials with me

I owe a deep debt of gratitude to all the people along the southern Avalon who agreed to be interviewed during my oral history project. They were unstinting with their time, their knowledge, and their hospitality as they opened their homes and their collective memories to me They have enriched my understanding of the area immeasurably

I owe a special debt of gratitude to Tracy English for her generosity of time and expertise in transtorming my hand-scrawled graphs into presentable charts and figures. I would also like thank Fran Warren and Beverly Evans-Hong of the History Department for their assistance in so many practical matters. and their good-natured support regardless of how often I jammed the office photocopier.

1 have enjoyed the companionship of all my fellow graduate students through the years, but I would like to extend special thanks to the members of the Imposters Club and affiliated lunch group - Maudie. Carla. Tracy. and Michelle - for their friendship and unfailing good humour through all the highs and lows of the programme.

To my family. for their infinite patience. encouragement. and support. I am grateful beyond measure. And to Michael, a special thank-you for riding out a very long two years.

This thesis is dedicated to Julianne. whose life story inspired its writing. 


\section{LIST OF TABLES}

Table 3. I - Source and destination areas of Irish women migrants to the southern Avalon to 1860

Table 32 - Catholic marriages to 1860. southern tvalon

Table +1 - Wages of seamen (per month) and fishermen (per season)

$$
\text { - selected years }
$$

Table +2 - Prices tor provisions - selected years

Table +3 - Washerwomen and seamstresses - earnings and purchasing power $\quad 275$

Table $+4-$ Mary Folev. Renews - account with Goodridge's, 1841 282

Table + 5 - Midwives earnings compared with fishermen's wages 306

Table +6 - Teacher salaries and class sizes on the southern Avalon 317

Table 51 - Julia McCarthy. Renews - accounts with Goodridge's. 1839 and 1841

Table 52 - Profile of women s cases involving gossip

Table 6.1 - Creditors and debtors in cases involving women

Table 6.2 - Female creditors and debtors - causes of action

Table 6.4 - Women's employment disputes - causes of action

Table 6.5 - Matters involving femaie witnesses 


\section{LIST OF FIGURES}

Figure 1 I - Study area - the southern Avalon - Bay Bulls to Dog Point

Figure 31 - Source areas of Irish immigrants as percentage of total

Figure 32 - In- and out-migrations (non-local). Ferryland district. spring, 1800

Figure 33 - Local out-migrations from harbours within Ferryland district. spring. 1800

Figure $3+$ - Local in-migrations to harbours within Ferryland district. spring, 1800

160

Figure 35 - Partial family tree. Oldridge family. Cape Broyle

Figure 36 - Over-wintering population. southern Avalon. 1735-1857 (ten-year intervals) - men, women, children, and total as well as Catholics as percentage of total

Figure 37 - Example of complex interrelationships within middle-class families on the southern. Avalon

Figure 38 - Over-wintering population. southern Avalon. 1735-1857 (five-vear intervals) - planter group and servants

Figure 39 - Summer inhabitants, southern Avalon, 1735-1857 (five-year intervals) - planter group and servants

Figure 3.10 - Percentage of working-aged population emploved in the tisherv, southern Avalon, 1857 


\section{LIST OF ABBREVIATIONS}

CNS Centre for Newtoundland Studies, Memorial University of Newfoundland

Cy. Newtoundland Currency

FUDB Ferryland Museum Database. Ferryland

ISER Institute of Social and Economic Research. Memorial Lniversity of Vewtoundland

MH. Maritime History Archives. Memorial Lniversity of Newtoundland

MLNFLA Memorial Lniversity of Newfoundland Folklore and Language Archive

NLGS Newtoundland and Labrador Genealogical Society. St. John's

PAVL Provincial Archives of Newfoundland and Labrador, St. John's

PCA Presentation Convent Archives. Mother House. Cathedral Square. St. John's

PRL Provincial Reference Library. St. John's

RCA.ASJ Roman Catholic Archdiocese Archives. St. John's

SPG Society for the Propagation of the Gospel in Foreign Parts

Stg. British Sterling 


\section{PREFACE}

Three slender things that best support the world: the slender stream of milk from the cow's dug into the pail: the slender blade of green corn upon the ground: the slender thread over the hand of a skilled woman.

Irish triad, trans. c. $9^{\text {th }}$ century ${ }^{1}$

This enquiry into the lives of Irish women on the southern Avalon emanates from more than academic interest. My maternal roots are in the study area. where I have encountered a tradition of strong, resourceful Irish 1 -Newfoundland foremothers my greatgreat-great-great grandmother. Catherine, who raised a large family in Ireland. otten alone while her husband worked at the Newfoundland fishery. until she finally joined him on the southern Avalon in the 1790s. my great-great-great aunt Margaret. who came out from Ireland, became mistress of a planter household, and inherited from her first husband land and fishing premises - property which she gifted to her brothers upon her remarriage and which is still in the family name today, my great-great aunt Sally, who provided board and medical services to tishermen to earn extra income for her family: my great-grandmother Bridget, who nursed her family alone during a diphtheria epidemic. carrving the black waste of infection down to the sea in the early morning under the watchful eyes of the quarantine officer: my great aunt Sarah, who kept a gracious three-storev home in Shore's

${ }^{1}$ From "The Triads of Ireland." translated from the Irish (c. 9th century) by Kung Meyer, in Charles Sullivan, ed. Ireland in Poetry (New York: Harvey N Abrams. 1990). p. 161 . 
Cove on the proceeds of a shebeen house she ran on the side: my grandmother. Julianne. her hands work-roughened. large as oven mitts, from making tish and hay and clothing and endless loaves of bread to leed her brood of twelve, my own mother. Gertrude, whom a priest warned my tather not to marry because Southern Shore women had "far too much to say for themselves."

Yet Irish-Newfoundland women appear to be curiously passive. when they are mentioned at all. in the historiography of early settlement in Newfoundland. In my examination of their lives on the southem Avalon. I hope to bring these women more clearly into focus in the discussion of migration and settlement experiences. to stretch the slender thread across the ocean, to understand the source of its suppleness and strength 
Chapter 1-Picking up the thread: Introduction and literature review

The southern Avalon peninsula of Newfoundland' is one of the oldest sites of European contact with North America. English. Portuguese. Spanish. and French vessels carried out tisheries along the coast from Bay Bulls to St. Mary's Bay throughout the $16^{\text {th }}$ century. and a migratory fishery from the West of England continued in the area in the $17^{\text {th }}$ and $18^{\text {th }}$ centuries. Four English colonization attempts also took place on this portion of the island in the early $17^{\text {th }}$ century. although the patentees ambitions did not come to truition except, to a limited extent, at Ferryland. 'Early census reports. however. indicate that individual English planter' families were established in a number of harbours in the

'The term 'southern Avalon' in this dissertation incorporates the area from Bay Bulls to Dog Point in St. Mary s Bay - the latter being the cut-off point in carly census material dealing with St. Mary`s Bay See Figure 1.1

'Several proprietary grants in the early 1600 s incorporated the study area. including patents to Sir William Vaughan (primary site established at Renews, c. 1617). Henry Carey. Lord Falkland (Renews. c. 1623). George Calvert, Lord Baltimore (Ferryland, 1621 ) and Sir David Kirke (Ferryland. 1638). The traditional historiography indicated that all these official colonizing efforts failed and that any inhabitants who remained thereafter did so on an individual basis. More recently. Gillian Cell reinforced this interpretation in English Enterprise in Newfoundland, 1577-1699 (Toronto Cniversity of Toronto Press. 1969). Peter Pope. however. has since argued that while proprietors left and patents expired, in the case of Ferryland at least. continuities in planter tamily names up to the end of the $17^{\text {th }}$ century indicate that proprietary efforts had built a foundation for sustained settlement. See Peter Pope. "The South Avalon Planters. 16301700 " (Ph.D Thesis. Memorial University of Newtoundland. 1992)

'The 'planter' was a resident (as opposed to migratory) proprietor of fishing premises. Planters in the early centuries of the Newfoundland fishery relied almost exclusively on hired 'servants' (employees: fishing crews, shore crews. and household servants) for labour: by the late $18^{\text {th }}$ and early $19^{\text {th }}$ centuries. the term also referred to heads of household production units using family labour supplemented by some hired 
study area by the late 1600 s. The southern Avalon was also one of the earliest venues of Irish migration to North America. The Irish began arriving there in the late 17 th century as cheap labour tor West Country fishing ships and planter families, and their numbers increased with the development of an Irish-Newfoundland trade in provisions and passengers in the $18^{\text {th }}$ century. Overwhelmingly, they were Catholic migrants from the southeastern ports of Ireland and their hinteriands. In the early decades of the $19^{\text {th }}$ century, there were turther large waves of Irish migration to Newfoundland. particularly during the periods $1811-1816$ and 1825-1833. ${ }^{4}$ and by mid-century, a substantial population of Irish settlers, and particularly, a vibrant Irish plebeian community.' had established itself along the southern tvalon. This thesis will explore female components of this pre-Famine Irish migration and settlement experience, focussing on the period from the 1750s. the eve of the influx of lrish migrants into the area. to 1860. when the transition to a tamily production unit in Irish fishing households was virtually complete.

Lsing gender as an analytical concept, refracted through the lenses of ethnicity. class. and religion, the discussion will concentrate on female dynamics of migration and

labour.

'John J. Mannion. "Introduction," in Mannion, ed. The Peopling of" Vewtoundland: Essays in Historical Geography, Social and Economic Papers No 8 (St. John's Institute of Social and Economic Research [ISER]. Memorial Liniversity. 1977). pp. $1-13$

'For a discussion of the usage of the terms 'plebeian' and 'middle class" in this dissertation. see Appendix A. 
Figure 1.1 - Study Area - The Southern Avalon - Bay Bulls to Dog Point

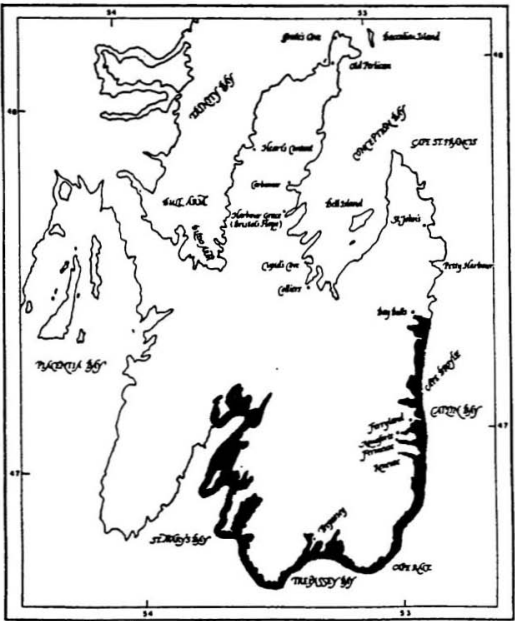

SOURCE: Adapted from a map showing $17^{\mathrm{t}}$-century colonization attempts in Newfoundland in Cell, English Enterprise, p. 82. 
community formation - not only employing traditional paradigms such as push and pull tactors or adaptation and change. but also attempting to discem the meanings that women ascribed to their experiences and the understanding of lrish-Newfoundland womanhood" that was constructed within the new-world context. It is not my intention, however, to examine women's lives in terms of a separate women's culture. but rather to root them tirmly within the family and community contexts in which they evolved. Nor will some essentialist woman's experience unfold in the following chapters - for women's lives on the southern Avalon were marked by difference as well as similarity. Finally. I do not mean to equate 'gender' with 'women' or to suggest that the study of masculinity is unnecessary. for understandings of gender within any historical setting have always involved the juxtaposition of masculine and feminine components. However, the ensuing discussion will revolve around the lives of Irish-Newfoundland women - a female-centred perspective that contributes to an ongoing and very necessary corrective in several broad areas of the historiography: writings on early settlement in Newtoundland: the history of the Irish diaspora: and literature on Anglo-European immigration and early settlement in Canada.

'The terms 'Irish womanwomen' and 'Irish-Newfoundland womanwomen' in this dissertation apply to both Irish immigrant women and women within the multigenerational ethnic group (including those with mixed English-Irish ties) in the study area (Ocrasionally, Irish women in Ireland or in Newfoundland in general are discussed. but the context of the discussion will make the distinction clear.) 


\subsection{Newfoundland and early settlement}

Almost every family history here begins with "Two brothers came out from Ireland or England

This insight came trom one of my oral informants as she tried to warn of the difficulties in mining the oral tradition for information about women on the southern Avalon in the period of early settlement. She had certainly arrived at the crux of a methodological problem. for she was not only articulating the conventional opening for. but also identifying the main protagonists in. most family histories in the Irish- or EnglishVewfoundland tradition. There are. of course, some departures from the formula in one variation. an older brother remains in the home country while the younger comes out to Vewfoundland: in another, a tather and his sons cross the Atlantic to seek their fortune in the tishery But in plot and focus. the stories are similar. The family narratives tell how those men carved a living out of relentless sea and barren soil, and how they hore large families in a mysterious process that. with its seeming absence of women. must surely have equaled the miracle of the virgin birth. The sagas continue to follow the patriline sons and grandsons are named. their lives chronicled. while daughters remain peripheral sometimes numbered, rarely named, often ignored altogether

While my intormant was discussing the oral tradition. her comments could well

DA. Interview July 20. 1999. 
have applied also to the traditional historiography on Newfoundland settlement, in which this male-centered focus resounds. Granted, this preoccupation was rooted in the nature of the main industry at Newtoundland - the cod fishery - which, until the second half of the $18^{\text {th }}$ century, was largely migratory in aspect and carried out primarily by men, with a smattering of planters' wives and temale servants. Logically linking the course of settlement with the pursuit of the tishery and the vicissitudes of its migratory and sedentary branches, earlier writings either overlooked or vastly underplayed the one essential ingredient for the stabilization of the local population: the presence of women

Traditional historiographical offerings explained settlement as a process which occurred within the context of conflict between inhabitant tishermen and avaricious merchants from the West of England, who controlled the migratory trade and effectively pressured successive governments to prohibit settlement. or at least to discourage it actively, in order to block the development of a competitive resident fishery. Hence. it was argued. settlement in Newtoundland followed an erratic course. with resident tishermen relegated to marginal areas. their premises hidden in tiny coves or hanging precipitously off cliff faces - out of the way of the privileged migratory fishermen and out of the sight of visiting fishing admirals and naval authorities *

"This 'retarded settlement' theory was first articulated by John Reeves in History of the Government of the Island of Newfoundland (London. 1793, reprint Waketield: Vew York: S. R Publishers: Johnson Reprint Corporation, 1967). A century later, the argument was taken up by perhaps its most vehement proponent. Daniel $W$. Prowse. in $\underline{A}$ History of Newtoundland from the English. Colonial and Foreign Records (London. New York: MacMillan. 1895, reprint Belleville: Mika Studio, 1972). The interpretation still 
With his 1968 doctoral dissertation. Keith Matthews provided overwhelming evidence that this theory of 'retarded settlement' was incorrect. Although the Western Adventurers had briefly opposed settlement during the middle decades of the $17^{\text {th }}$ century, many of them soon came to realize that the migratory and sedentary branches of the tishery could be complementary (indeed, there was increasing interchange or overlapping of personnel between sectors); thus. most of these merchants evolved into suppliers and marketers tor the inhabitant fishery while maintaining their migratory interests into the $18^{\text {th }}$ century. The home government. spurred by its desire to preserve a nursery for seamen' through: the traditional migratory ship tishery, did attempt to restrict settlement by delaving the development of governance and property ownership in Newfoundland. Matthews observed. Their goal was undone. however, by the need to establish increasingly sophisticated agencies to enforce the very anti-settlement laws they were passing and to maintain law and order between residents and visiting fishermen." Several years later. C Grant Head weighed into the debate with a geographer's perspective. indicating that the distribution of settlement followed the logic of exploiting the inshore cod resource. The scattered nature of tishing communities reflected not a fear of

appeared in the literature at the middle of the $20^{\text {th }}$ century. See, for example: $\mathrm{A}$. H. McLintock. The Establishment of Constitutional Government in Newfoundland, 17831832 (London: Longmans. Green, 1941 ); and Harold A. Innis. The Cod Fisheries: The Study of an International Economy (Toronto: Liniversity of Toronto Press, 1940. 1954)

"Keith Matthews. "A History of the West of England - Newfoundland Fishery" (D. Phil. Thesis. Oxford University. 1968). 
discovery by officials or harassment by migratory fishermen, but rather the suitability of the sites tor pursuing the fishery - proximity to fishing grounds, for example, access to water and wood, and availability of other resources such as seals and salmon. As inshore activity increased throughout the $18^{\text {th }}$ century and as appropriate sites were reaching maximum sustainable yields, settlement moved out to peripheral areas. ${ }^{\text {to }}$ In the early 1980s. Shannon Ryan added to the literature by arguing that large-scale year-round settlement at Vewfoundland was only made possible by the development of a seal spring fishery - a complementary industry to the cod fisherv in that it emploved fishermen. boats. and artisans in the off-season. "Meanwhile. by the 1970s and 1980s. writers such as Keith Mattheus. Thomas Nemec, and John Mannion were uncovering information on the substantial numbers of Irish servants who came out to the Newtoundland fishery. particularly from the mid- $18^{\text {th }}$ century onwards. and their imprint on the demographic and

${ }^{\text {t"}} \mathrm{C}$ Grant Head. Eighteenth Century Newfoundland (Toronto: McClelland and Stewart in association with the Institute of Canadian Studies. Carleton University, 1976). The following year. a collection of monographs by historical geographers associated with Memorial Lniversity - including Rosemary Ommer. Patricia Thornton, and Michael Stavelev - proposed demographic models for the spread of various European ethnic groups into and around the island. See Mannion, ed. Peopling of Newfoundland. See. also. Patricia A Thornton. "Dynamic Equilibrium: Settlement. Population and Ecology in the Strait of Belle Isle. Newfoundland. 1840-1940" (Ph.D. Thesis. Lniversity of Aberdeen. 1979)

"Shannon Ryan. "Fishery to Colony: A Newfoundland Watershed, 1793-1815," tcadiensis, X11:2 (Spring. 1983), 34-52 
cultural patterns of early Newfoundland communities. ${ }^{12}$ John Mannion, in particular.

brought considerable light to bear on source areas of migrants, cultural transfers. and the

motivations tor migration. Notably, he stressed the agency of Irish emigrants to

Newtoundland, many of them from artisanal or farming backgrounds who exercised

\begin{abstract}
${ }^{12}$ Keith Matthews discusses the Irish at Newfoundland in "West of EnglandNewtoundland Fishery" and in Lectures on the History of Newfoundland, 1500-1830 (St John's: Breakwater Books. 1988). Thomas F Nemec's writings on the Irish include: "The Irish Emigration to Newtoundland." Newfoundland Quarterly, 69:I (1972b). 15-24: "Trepassey, 1505-1840 A.D. The Emergence of an Anglo-Irish Newtoundland Outport." Vewtoundland Quarterly, $69+(1973), 17-28$, "The Irish emigration to Newtoundland: a critical review of the secondary sources" (Guest lecture delivered to the Newfoundland Historical Society. St. John's. March 30. 1978). "Irish Settlement in Newtoundland. " in Joseph R. Smallwood, ed. Encyclopedia of Newfoundland and Labrador. vol 3 (St John's: Harry Cuff Publishers, 1991), pp. 71-7, and "Trepassey. 1840-1900; an ethnohistorical reconstruction of an Anglo-Irish outport society." in Maura Hanrahan. ed. Through a Mirror Dimly Essays on Newtoundland society and culture (St. John's: Breakwater, 1993), pp.145-62. John Mannion's extensive offerings include: "Irish Imprints on the Landscape of Eastern Canada in the Nineteenth Century: A study in Cultural Transter and Adaptation" (Ph.D. Thesis. University of Toronto, 1971): "The Irish Migrations to Newfoundland" (Unpub summary of a public lecture delivered to the Newfoundland Historical Society, St. John's, October 23. 1973): Irish Settlements in Eastern Canada: \& Study of Cultural Transfer and Adaptation (Toronto: Liniversity of Toronto Press. 1974): "The Impact of Newfoundland on Waterford and its Hinterland in the Eighteenth Century" (Paper delivered at the Annual Conference of Irish Geographers. University College. Galway, April 22. 1977); "Introduction," in Mannion, ed. Peopling of Vewfoundland. "Patrick Morris and Newfoundland Irish Immigration," in Cyril J Byrne and Margaret Harry, eds. Talamh An Eisc Canadian and Irish Essays (Halifax: Nimbus Publishing. 1986), pp. 180-202: "Migration and Upward Mobility: The Meagher Family in Ireland and Newfoundland. 1780-1830." Irish Economic and Social History, XV (1988). 54-70: and "Tracing the Irish: A Geographical Guide." The Newfoundland Ancestor, 9:1 (Spring. 1993). +18. Aso, see an article co-authored with Fidelma Maddock. "Old World Antecedents, New World Applications: Inistioge Immigrants in Newfoundland." in William Nolan and Kevin Whelan, eds. Kilkennv: History and Society - Interdisciplinary Essays on the History of an Irish County (Dublin: Geography Publications. 1990). pp. 346-7
\end{abstract}


choice in pursuing opportunity in the Newfoundland fishery in the face of declining (but not dire) prospects in the home country.

Yet as the historiographical debates on settlement in Newfoundland evolved. the movements of men were carefully traced and analyzed while the activities of women remained out of focus. Even though the Newtoundland fishery had been primarily (aithough not exclusively) a male enterprise up to the middle of the $18^{\text {th }}$ century. in Newtoundland. as elsewhere. populations and communities did not stabilize until women were present in increasing numbers. Yet even as the literature spoke of the rising supremacy of the resident tishery and the increasing stability of the population in the latter $18^{\text {th }}$ century, women's experiences were muted. Occasional references appeared to fishermen's marrying 'local" women (a term that generally referred to women of English or Irish, not aboriginal, descent) - as if their presence needed no further explanation, as if these women had somehow sprung from the ground. Like Topsy. a character of 19 thcentury American fiction. they had apparently just "grow d."15 Treating them as mereiy a factor in a demographic equation. the literature said little or nothing of their motives for migrating, their lived experiences, their role in early community formation

Outside the disciplines of history and historical geography, leminist scholars began

${ }^{13}$ Topsy is a young female slave in Harriet Beecher Stowe's Uncle Tom's Cabin When quizzed about her parentage and where she has come from. Topsy has no knowledge of her background. but ventures an opinion nonetheless: "I spect 1 grow"d. Don't think nobody never made me." See Joan D. Hedrick. The Oxford Harriet Beecher Stowe Reader (New York; Oxford: Oxford University Press. 1999). p. 256. 
to question women's absence from accounts of early fishing communities. and to offer some insights of their own. Sociologist Ellen Antler measured the monetary value of women's work in the traditional household production unit in the fishery. arguing that they were vital co-producers in producer-owned enterprises until the industrialization of the fishery after the second world war forced them into low-paying waged labour in fish plants or non-waged labour in the domestic sphere. ${ }^{14}$ Folklorist Hilda Chaulk Murray examined the vital contribution of women's work to tishing households in Bonavista Bay. and the estimation of their worth was embodied in her title: More Than Fifty Percent ${ }^{15}$ Sociologist Marilyn Porter challenged the assumption of patriarchal authority that had underwritten recent sociological and anthropological studies of local fishing communities and argued that women used their vital role in fish production to negotiate spheres of intluence in which thev exercised a paramount authority - in shore work, in cash management. and in the 'public' and communal space of Newtoundland kitchens. ${ }^{1 n}$ These writings dealt with women in fishing tamilies of the latter $19^{\text {th }}$ and earlv $20^{\text {th }}$ centuries, but

"Ellen Antler. "Women's Work in Newfoundland Fishing Families." Atlantis. $2: 2$ (1977), 106-13

${ }^{15}$ Hilda Chaulk Murray. More Than Fifty Percent Women's Life in a Vewfoundland Outport. 1900-1950 (St. John's: Breakwater Books. 1979).

"Marilyn Porter. "She was Skipper of the Shore Crew: Votes on the History of the Sexual Division of Labour in Newfoundland." Labour/Le Travail, 15 (Spring. 1985). 104-25, reprinted in Carmelita McGrath. Barbara Neis. and Marilyn Porter, eds.. Their Lives and Times: Women in Newfoundland and Labrador \& Collage (St. John's: Killick Press. 1994), pp. 33-47. 
they were observing phenomena that were rooted in an earlier period and begged several questions: How did the sexual division of labour evolve in early Newfoundland fishing villages? What was the value of women's work and the extent of women's influence in family and community in the period of initial settlement? Did gender retations transfer intact trom the old world to the new. or did migration and settlement experiences provide a new plaving field for the negotiation of gender?

By the late 1980s, some necessary. if somewhat conservative. adjustments were being made to the Newfoundland historiography in terms of women's participation in the settlement process. In a 1989 publication, historical geographer W Gordon Handcock recreatef English migration and settlement patterns in northeast Newfoundland up to the

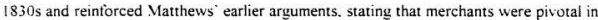
the settlement process. not only as suppliers and marketing agents for inhabitants in original sites of settlement. but also as channels of migration to secondary and tertiary sites - sending out labour and providing infrastructure to exploit resources in new areas that would. in turn, become sites of permanent settlement. ${ }^{17}$ He also introduced a gender component to his study, articulating the link between the presence of women and population growth by using the numbers of female winter inhabitants in Newtoundland as an index of permanence. Using the formula $2 \mathrm{~F}-\mathrm{C}$ (where $\mathrm{F}=$ the number of adult women in the over-wintering population, multiplied by 2 to allow for a male partner. and

\footnotetext{
${ }^{1-W}$ Gordon Handcock. Soe longe as there comes noe women: Origins of English Settlement in Newtoundland (St. John's: Breakwater Books. 1989).
} 
$\mathrm{C}=$ the number of children), he found significant population growth through the late $18^{\text {th }}$ and early $19^{\text {th }}$ centuries as the numbers of women in the population increased, although the significance of this phenomenon was muted in the remainder of his discussion. He also noted that matrilineal bridges were stronger than patrilines in family perpetuation before the 1800 s, but underplayed their importance in terms of settlement continuity. Working from the assumption that "a consolidated. stable population tends to have a strong patrilineal-patrilocal character, ${ }^{-18}$ he fell back on a male-centered demographer's technique of surname sieving to measure the stability of settlement. noting some matrilineal extensions merely as interesting diversions rather than evidence of earlier. women-centred continuities. And although his discussion was lightly peppered throughout with descriptive and demographic observations of women as migrants within family units or as single servants, it did not provide any in-depth analysis of women's vital contribution to household economies or to settlement processes (although arguably, this would have been beyond the scope of what was primarily a demographic study).

Other writers began to add sections on women's work and status to their examinations of early Newfoundland communities. Peter Pope. in his interdisciplinary study of planter society on the southern Avalon in the $17^{\text {th }}$ century. found that women were important contributors to planter households in terms of brewing. baking. and dairying. He estimated that they provided services equivalent to those of one fishing

\footnotetext{
${ }^{18} \mathrm{Handcock}$. Soe longe, pp. 140-1.
} 
servant (planters with wives hired, on average, one fewer servant than those without) and correlated their presence with household capacity to care for larger herds of cattle and pigs. He also found that a number of women were household heads or even prominent planters in their own right - a phenomenon that he found to be more of an anomaly than perhaps it warrants (see Chapter 4 , below). In general. he concluded that these women "were powerful relative to their sisters elsewhere, in a century in which women were powertil. relative to their great-granddaughters ${ }^{-1,9}$ - apparently assuming that patriarchy would re-root itself on the island and a slide in women's status would ensue as permanent settlement increased in the $18^{\text {th }}$ and early $19^{\text {th }}$ centuries. Sean Cadigan provided additional insight into women's experiences in fishing households in his examination of merchantsettler relations in Conception Bay in the period 1785-1855. Part of his discussion dealt with the transition in the fishery in the early $19^{\text {th }}$ century from waged labour to family production as an adaptive response by planters to capital requirements in the face of high wage demands and oppressive wage and lien laws. Within this context, he devoted a section to women's vital role within the family work unit." However. Cadigan assumed an unproblematic transplanting of patriarchy from the old world to the new - untempered

${ }^{19}$ Peter Pope provides a mixture of historical and archeological evidence in "The South Avalon Planters". the quotation appears on p. 307

"Sean Cadigan. Hope and Deception in Conception Bay Merchant - Settler Relations in Newfoundland, 1785-1855 (Toronto: University of Toronto Press. 1995) Cadigan's interpretation of the transition to family labour in the fishery is discussed further in Chapter 3 
by migration and early settlement experiences." Not surprisingly, then. he presented women's work rhythms as dictated by male decision-making, and women's status as secondary within a patriarchal family structure that was reinforced by the formal legal system and male "discipline... by the fist. "I In these three writings. there was an assumption of an inexorable 'evolution' towards a patrilineal. patriarchal society in which women's status and contribution were seen as either secondary. diversionary. or anomalous.

Throughout the 1990s. some significant efforts have been made to broaden our understanding of women's lives in Newfoundland in the period of early settlement - most notably in the area of legal history. Linda Cullum and Maeve Baird have provided an extensive overview of the development of laws affecting women from the $17^{\text {th }}$ to the $20^{\text {th }}$ centuries This is a significant contribution to the historiography. although their focus on statutory and common law does not allow for an examination of how laws plaved out on the ground. and therefore overestimates the dependence and subordination of women. particularly those in traditional fishing communities ${ }^{-3}$ Trudi Johnson has found a happier

"Summarizing Handcock's findings in relation to English settlement at Newfoundland, he concluded: A process of transatlantic family migration in fact established the patriarchal family structure of West Country English society in Vewfoundland in the early modern period." See Cadigan. Hope and Deception, p 65

"Cadigan, Hope and Deception, pp. 64-82, quote from p. 82

"Linda Cullum and Maeve Baird. "A Woman's Lot: Women and Law in Vewtoundland from Early Settlement to the Twentieth Century." in Linda Kealev. ed.. Pursuing Equality. Historical Perspectives on Women in Newfoundland and Labrador. 
balance between law and application in her recent examination of matrimonial property law in Newfoundland. Johnson demonstrates that the reception of English inheritance law, a system that favoured primogeniture, was tempered by island conditions and customary practices, resulting in a much more gender-inclusive system of testation practices which were used to adapt or circumvent the matrimonial property regime inherited trom the home country:

Still, as McGrath. Neis, and Porter have recently pointed out, there are significant gaps in our understanding of early settlement, not just in terms of women's experiences. but also in terms of perceiving gender and patriarchy as dynamic. ongoing processes rather than as fixed. transhistorical categories. $"$ This thesis will attempt to contribute to our understanding of these processes of negotiation, and to examine whether the march of patriarchy was as unproblematic in the Newtoundland context as the traditional historiography presupposes

Social and Economic Papers No 20 (St. John's. ISER. Memorial Liniversitv. 1993). pp. 66-162

${ }^{2}$ Trudi D Johnson. "Matrimonial Property Law in Newtoundland to the End of the Nineteenth Century" (Ph.D. Thesis. Memorial University of Newfoundland. 1998).

"McGrath, Neis, and Porter, "Editors' Note: Women, the migratory Fishery and Settlement." in Their Lives and Times, pp. 22-6. particularly p. 25. 


\subsection{The Irish diaspora in North America}

Another area of the historiography to which this dissertation seeks to contribute is the literature on Irish migrations to North America - a corpus that has traditionally been preoccupied with Famine and post-Famine migrations and resonates with motifs of disruption and alienation. This concentration has had a profound impact on popular understandings of the diaspora on both sides of the Atlantic. There is a timeless sorrow, a lingering sense of mourning and loss. that clings to our perceptions of Irish movements to the new world. The very phrase ' Irish emigration' evokes images of poverty and desperation - of suffering masses huddled in the dank holds of cotfin ships. fleeing hunger. disease, and economic devastation in the home country Such impressions emanate from one relatively brief but intensely poignant moment in Irish migration - the period of the Great Famine and its immediate aftermath. But because of the magnitude of this mid-19th century trauma, these images linger in the popular consciousness as the essence of the Irish diaspora through time.

These shades and spectres haunt the traditional historiography on Irish migrations. Lp to the mid-1980s, the Great Hunger often cast its pall over discussions of other movements of Irish people: vestiges lingered in explanations of later relocations: its shadow also stretched back in time. as historians used earlier migrations to set the stage for the Famine exodus without considering that the prior movements mav have had dynamics of their own. When movements in the late $18^{\text {th }}$ and early 19 th centuries were 
mentioned at all, they were usually presented as a prologue to the great Irish emigration drama of the mid- $19^{\text {th }}$ century, and images of exile and exclusion pervaded the texts.

This was particularly tne of the works of Irish-American historians, from William Forbes Adams, Oscar Handlin, and William Shannon to Lawrence McCatfrey and Kerby Miller. whose writings, until very recent years, have tended to dominate the literature on movements to North America. ${ }^{36}$ The perspectives they provide of the ghettoization of impoverished and poorly skilled Irish immigrants in urban landscapes do not provide usetul models tor the study group of this thesis or the Irish in rural areas in general Indeed. this portrayal of the Irish as predominantly disadvantaged urban dwellers has been roundly challenged by several writers. Donald Akenson. David Doyle, and Cecil Houston and William Smyth have all effectively demonstrated that most of the Irish in North America ultimately tanned out into rural areas, where the majority were employed in primary industries - particularly farming, and, to a lesser extent, fishing or lumbering - with a smaller but still significant number entering skilled trades and professions. Those who

${ }^{2}$ See. for example. William Forbes Adams. Ireland and Irish Emigration to the Vew World from 1815 to the Famine (New York: Russell \& Russell. 1967. reprint of 1932 ed ): Oscar Handlin, Boston's Immigrants (Cambridge. Mass.. Harvard University Press, 1941): William V Shannon. The American Irish (New York: Macmillan, 1963): Lawrence J McCaffrey. The Irish Diaspora in America (Bloomington: London: Indiana Lniversity Press. :976), Kerby A. Miller, "Emigrants and Exiles: Irish Cultures and Irish Emigration to North America, 1790-1922." Irish Historical Studies, XXII 86 (September, 1980). 97-125: Miller. Emigrants and Exiles: Ireland and the Irish Exodus to Vorth America (New York; Oxford: Oxford Liniversity Press. 1985); and Miller. "Emigration. Capitalism. and Ideology in Post-Famine Ireland," in Richard Kearney, ed.. Migrations: The Irish at Home \& Abroad (Dublin: Wolthound Press, 1990), pp 91-108 
lived in cities were not more numerous, they have argued, but merely more noticeable as minorities: and for many who first entered larger ports. life in the city was a temporary existence - the first stage of a series of moves that brought them to the rural sector. This was especially true of pre-Famine migrations: the processes of urbanization. ghettoization, and proletarianization were a later phenomenon in the Linited States, and that model does not apply at all to the Canadian experience. ${ }^{2 *}$

In addition to his urban bias. Miller has also come under tire tor his representation of Irish Catholics as being handicapped by religious and cultural traditions in adapting to their new environments. Miller distinguishes three types of emigrants throughout the period from 1607-1921: 1) those who saw themselves as "victims' of English tyranny and casualties of modernization - a group who struggled to maintain traditional lifestyles and resisted permanent emigration until catastrophes like the Great Famine cut their choices: 2) those who emigrated voluntarily to improve their economic opportunities as a rational response to declining material conditions at home - emigrants who tended to embrace

"See Donald H Akenson: Being Had: Historians, Evidence, and the Irish in Vorth America (Don Mills. Ont.: P. D. Meany Publishers. 1985). pp. 40-2. 69-72. and 84-5, and Small Differences: Irish Catholics and Irish Protestants, 1815-1922 An International Perspective (Kingston: Montreal: McGill-Queen's University Press. 1988). pp. 102-3. See also Cecil J. Houston and William J Smyth: Irish Emigration and Canadian Settlement: Patterns, Links, and Settlers (Toronto: Lniversity of Toronto Press, 1990), p 21, and "The Irish Diaspora: Emigration to the New World. 1720-1920," in B. J Graham and L. J Proudfoot, eds., An Historical Geography of Ireland (London. Academic Press Limited. 1993). pp. 338-65. particularly p. 353. And see David Dovle. "The Irish in North America, 1776-1845," in W. E. Vaughan, ed.. A New History of Ireland, Vol. V (Oxford: Clarendon Press, 1989), p. 706 
ambition and the individualistic and acquisitive values of entrepreneurship, and 3) those who made a conscious decision to leave Ireland, but who sought to maintain traditional goals and ties in their new communities - a transitional group between the traditional and the modern who sought self-sutficiency rather than upward mobility in their new homes Miller argues that there was a vast preponderance of Irish Catholics in the traditional groups. while the more adaptive migrants drew from the Protestant pool. He explains the phenomenon in terms of "a distinctive Irish Catholic worldview" - emanating from Gaelic culture and the Catholic religion - which devalued individual ambition and action. making Catholics less adaptable than Protestants as a group to increasing modernization and commercialization in Ireland and. ultimately, to immigrant experiences in the new world :

Miller's treatment of the Irish Protestant as a superior migrant tvpe to the Irish Catholic has provoked some controversy. Akenson challenges this invocation of a "Gaelic-Catholic Disability Variable". citing three longitudinal studies of the Irish ethnic group in North American as well as data from his own cross-geographical comparisons of

"*Miller. "Emigrants and Exiles: Irish Emigration" and Emigrants and Exiles Irish Exodus. Other Irish-American historians have also differentiated between Irish-Protestant and Irish-Catholic experiences in America. Shannon does so in American Irish. Marjorie Fallows also perceives a contrast, which she attributes to attitudes in the Anglo-American host society. where. she argues. the Protestant ethos and anti-Catholic climate of the $18^{\text {th }}$ and $19^{\text {th }}$ centuries made assimilation tar more difficult for Irish Catholics. See Fallows. Irish Americans: Identity and Assimilation (Englewood Cliffs: Prentice-Hall. 1979). pp 14-3 In his recent study of Boston's Irish community. Thomas O'Connor re-iterates Willer's theory about the effect of the Catholic worldview on the Irish-Catholic immigrant experience. See O'Connor. The Boston Irish: A Political History (Boston: Northeastern Lniversity Press. 1995), pp. 19-22. 
Irish immigrants in Australia, New Zealand, and Canada, he finds no appreciable differences in adaptability between immigrants of the two religious groups, other than a slightly lower occupational protile of Irish Catholics in Canada immediately upon arrival. which adjusted upwards within the immigrant generation. ${ }^{*}$ Bruce Elliott also questions Miller's differentiation of Irish-Catholic and Irish-Protestant perceptions of immigration." as does David Doyle. who feels that the contrast has been overdrawn, especially if one moves beyond initial urban experiences and looks at adaptation over time ${ }^{31}$ The current thesis will reintorce their tindings. portraving a largely Catholic migrant group as responsive to opportunity and often upwardly mobile in their new environment.

Here. it will follow a major paradigm shift in the historiography - a trend to move away from connotations of exile and alienation, and to view lrish emigration as a rational. adaptive strategy employed in response to changing social and economic conditions is Akenson argues, Irish emigrants were not "passive bits of flotsam on some alleged

"See Donald Akenson: Being Had; Small Differences; "The Historiography of the Irish in the Lnited States of America." in Patrick O'Sullivan. ed., The Irish in New Communities. Irish World Wide Series. vol. 2 (Leicester: London: Leicester Liniversity Press. 1992). pp. 99-127; and The Irish Diaspora. A Primer (Toronto: P D Meaney. 1993). Akenson by-passed US data in this analysis as the religion of immigrants was not systematically recorded in America.

"Bruce S Elliott. Irish Migrants in the Canadas: A New Approach (Kingston. Montreal: McGill-Queen's University Press. 1988).

${ }^{31}$ David Doyle. "The Irish in Australia and the United States: Some Comparisons. 1800-1939," Irish Economic and Social History, XVI (1989), 73-94, particularly pp. 92-3. 
historical tide. ${ }^{132}$ but rather, informed individuals who weighed intormation and made conscious choices to migrate within a range of available alternatives. Doyle and David Fitzpatrick have each commented on the capacity of Irish emigration to respond to the rises and downtums in employment opportunities in destination areas. based on a largescale, sensitive feedback network between North America and the home country. The success of the response. they argue. was evidenced in appropriate variations in volume and age structure of the migrants and in relatively low unemployment rates in North America. indicating a coherent movement of migrants as demand arose in the host economy ${ }^{13}$ Other writers - Patrick Blessing. Liam Kennedy and L. A. Clarkson. Houston and Smyth have presented emigration as an adaptive strategy whereby Irish individuals and tamilies adjusted to deteriorating conditions in the old country by responding to the promise of opportunity in the new "is In particular, they claim. pre-Famine migrants were tar less passive and restricted than they have traditionally been portraved. According to Houston and Smuth

"Akenson, Primer, p. 11

"See Dovle. "Irish in North America." p. 685. and David Fitzpatrick. "Emigration. 1801-70," in Vaughan. ed. New History, pp. 562-622, particularly p. 574

"See Patrick Blessing. "Irish Emigration to the United States. 1800-1920: An Overview." in P. J. Drudy, ed. The Irish in America: Emigration. Assimilation and Impact, Irish Studies + (Cambridge, London; New York: Cambridge University Press. 1985). pp 11-37: Liam Kennedy and Leslie A. Clarkson, "Birth, Death and Exile Irish Population History. 1700 -1921." in Graham and Proudfoot. eds.. Historical Geography (London. Academic Press Limited. 1993), pp. 158-84, and Houston and Smyth. "Irish Diaspora." and Irish Emigration and Canadian Settlement. 
[They were responding to] changing regional economies. Collectively they represented the most advanced sectors of the contemporary Irish economy.... The earliest emigrants emerged not from the hopelessness of a backward depressed economy but rather they were opportunists from economic regions affected by structural changes and restricted growth Their leaving was not motivated by abject poverty but rather by a perception of diminished opportunities for themselves and future generations. and the critical perception that emigration offered a solution to their dilemma. Catholic artisan and Presbyterian farmer alike were motivated by such a sense of individualism and the desire for improvement. 35

From this perspective. most pre-Famine Irish migration experiences meshed with those of other European nations. Recent scholarship has acknowledged that migration became a common adaptive strategy in Europe in the modern era and that Europeans moved in signiticant numbers, over short. middle. and long distances. on both temporar. and permanent bases. in response to socio-economic tactors in their home communities and to the demands of an increasingly international economy. "hous, it was not unusual that in Irish society. internal and external migration had become a "habit of life ${ }^{n 3^{3 *}}$ by the

\section{"Houston and Smyth, "Irish Diaspora." p. 343}

is See, for example: Dudley Baines. Emigration from Europe, 1815-1930. Economic History Society Studies in Economic History (Houndmills. Hampshire: Macmillan Education Ltd. 1991); and James H. Jackson. Jr., and Leslie Page Moch. "Migration and Social History of Modern Europe," in Michael Drake. ed., Time, Family and Community Perspectives on Family and Community History (Oxford. Cambridge: Open Lniversity in Association with Blackwell Publishers, 1994). pp. 181 -98

${ }^{37}$ Fitzpatrick. "Emigration. 1801-70," p \$64. See also David Fitzpatrick. "The Modernisation of the Irish Female." in Patrick O'Flanagan. Paul Ferguson. and Kevin Whelan, eds. Rural Ireland: Modernisation v Change, 1600-1900 (Cork: Cork 
$18^{\text {th }}$ century

A warning bell must be sounded, however, about the economic reductionism that often underscores these more recent interpretations of Irish emigration. As Jim Mac Laughlin observes, they tend to portray migration purely as a "transfer mechanism." whereby migrants responded to the logic of labour surplus at home and labour demand in overseas markets while muting the negative aspects of emigration - the fraumentation of families and home communities, the re-mapping of social and political terrains While emigration was a rational response to structural changes in Irish agriculture and increasing opportunities in the global economy. he argues, the representation of migration as the 'tree' choice of individuals ylosses over the influence of local, national. and international forces and also discourages any political and class analyses of the causes and effects of migration. This type of interpretation is an over-corrective of the traditional literature, he argues. and overly "sanitizes" the phenomenon."

University Press. 1987). pp. 162-80. particularly p. 175

${ }^{\text {th }} \mathrm{Mac}$ Laughlin's "world-systems" model focuses on the modern period of Irish emigration trom the mid-19th century onwards. It is a structuralist perspective that sees emigration as rooted in the development of export-led rural capitalism which produced agricultural labour surpluses and ultimately an "emigrant nursery" of cheap, adaptable labour for a burgeoning international economy. The results of this extensive drainage of the sons of daughters of the rural poor and working-class from the country. Mac Laughlin savs. were the consolidation of hegemonic control of the middling tenantry, small farmers, and petty bcurgeoisie in rural Ireland; and the "senilisation of Irish politics" which. in turn. contributed to the consolidation of patriarchy in Ireland. See Jim Mac Laughlin. Historical and Recent Irish Emigration: A critique of core-periphery and behavioural models (London: University of North London Press. 1994). particularly pp 9-11 and 45-6: and "Emigration and the Construction of Nationalist Hegemony in Ireland 
Furhermore, there has still been a reluctance among Irish historians - particularly those of the growing school of econometrics who have risen to prominence in the latter part of the $20^{\text {th }}$ century - to delve too deeply into pre-Famine experiences because of the lack of 'hard' evidence on population sizes and emigration figures for the period. ${ }^{3 "}$ Even

The Historical Background to "New Wave' Irish Emigration," in Jim Mac Laughlin, ed. Location and Dislocation in Contemporary Irish Society: Emigration and Irish Identities (Cork: Cork Lniversity Press. 1997), pp. 5-35.

"Numerous writers have commented on the lack of reliable statistics on Irish populations and migrations. No thorough census records were kept in Ireland before 1821. other than an incomplete set compiled in 1813 Furthermore. a number of records. including census materials for 1813-1851, were destroyed in fighting at the Four Courts in 1922. There was no systematic collection of vital statistics in Ireland until 1864, prior to that, churches kept records of births, marriages and deaths, but these records are tragmentary and not always reliable. The numbers of hearths in Ireland were recorded trom the latter $17^{\text {th }}$ century onwards. but efforts to evade the hearth tax collectors resulted in substantial under-recording. Furthermore, the multipliers used by demographers and historians in relation to the hearths records are also open to question With respect to emigration. there is a virtual absence of statistics before 1819: volume estimates in the historiography are based on incomplete port data. newspaper advertisements. and inferences based upon tonnage of shipping that may well err on the high side. As the $19^{\text {th }}$ century progresses, three major sets of 'official' Irish migration figures become available: annual enumerations by L.S. immigration authorities based on the passenger lists provided by ships' captains (available from 1819 onward); returns of total 'overseas' emigrants (i.e. moving outside Britain) compiled by the Emigration Commissioners (available from 1825 onward); and annual returns of the Registrar General for Ireland. based largely on reports received from the Irish Constabulary at key ports (available from 1851 onward). Historians have noted profound inconsistencies in the three sets of data. however. and have raised concerns about methodology of collection (e.g.. informed guesswork. secondhand reports). It is evident that lrish emigration statistics must be used with caution and qualitied with a discussion of concerns about the data. See the following: Gale Edward Christianson. "Population. the Potato and Depression in Ireland 18001830," Eire-[reland, 7:4 (Winter. 1972). 70-95. particularly p. 71. Kenneth H. Connell. The Population of Ireland. 1750-1845 (Oxford: Clarendon Press, 1950), pp. 1-14. Fitzpatrick. "Emigration. 1801-70." pp. 564-5; Houston and Smyth. "Irish Diaspora." pp 340-1, Kennedy and Clarkson. "Birth. Death and Exile." pp. 158-9; Janet A. Nolan. 
those works that draw more heavily from qualitative sources, or use a combined methodology, rarely reach back further than the 1840 s $^{\text {t0 }}$ For example, one of the most

Ourselves Alone: Women's Emigration from Ireland, 1885-1920 (Lexington: University Press of Kentucky. 1989). pp 4-5: and Cormac O Grada. "A Note on Nineteenth-Century Irish Emigration Statistics," Population Studies 29:1 (March. 1975), 143-9. Still. some studies have attempted to deal with earlier periods, for example: Doyle. Fitzpatrick, and Miller have included brief discussions of earlier migrations in works already cited. Audrey Lockhart looks at earlier migrations to America and Newfoundland (although she tends to treat Newtoundland primarily as a stepping-stone to America and uncritically accepts contemporary reports that Irish migrants to the island were vagrants and the refuse trom Irish jails who had been pressed into service in Irish ports) - see Some Aspects of Emigration from Ireland to the North. American Colonies Between 1660 and 1775 . The Irish-Americans Series (New York: Arno Press. 1976, reprint of M.Litt. Thesis. Trinity College. Dublin. 1971), Graeme Kirkham provides a brief overview of migration from LIster in the tirst half of the $18^{\text {th }}$ century in "The Origins of Mass Emigration from Ireland. in Kearney. ed. Migrations, pp 81-90: Marianne S Wokeck includes a chapter on $18^{\text {th }}$-century trish immigration to the Delaware Valley in Trade in Strangers: The Beginnings of Mass Migration to North America (Lniversity Park, Penn. Pennsylvania State Lniversity Press. 1999). pp 167-219

${ }^{\text {th }}$ This is particularly true of migrations beyond the British Isles. There is. however. a growing body of literature on Irish emigrants to Britain in the pre-Famine period. particularly seasonal labourers in agriculture and semi-skilled. unskilled. and casual workers in textile, construction, and transportation (railway, canals. docks) industries. Much of the literature reveals processes of urban ghettoization and proletarianization as seasonal movements gave way to permanent migration - dynamics that contrast with the experiences of the Irish on the southern Avalon in the same period. See. for example: B Collins, "Irish Emigration to Dundee and Paisley During the First Half of the Nineteenth Century." in J M. Goldstrum and L. A Clarkson. eds.. Irish Population, Economy and Society: Essays in Honour of the late K. H. Connell (Oxford: Oxford University Press. 1981). pp 195-212, Collins. "The Irish in Britain, 1780-1921," in Graham and Proudfoot. eds . Historical Geography of Ireland, pp. 366-98. Roger Swift and Sheridan Gilley. eds. . The Irish in the Victorian City (London: Croom Helm. 1985): Swift and Gilley, eds. The Irish in Britain, 1815-1939 (London: Pinter Publishers. 1989): Swift and Gilley. eds. The Irish in Victorian Britain. The Local Dimension (Dublin: Four Courts Press. 1999): RuthAnn Harris. The Nearest Place That Wasn t Ireland: Eariy Nineteenth-Century Irish Labor Migration (Ames: Iowa State University Press. 1994); Jeffrey G. Williamson. “The Impact of the Irish on British Labour Markets During the Industrial Revolution." Joumal 
ambitious studies of Irish migration in recent years - an interdisciplinary compilation of six volumes edited by Patrick O' Sullivan and published over the period 1992 to 1997 - still tocuses primarily on the period from the mid-19th century onwards. ${ }^{11}$ A more recent collection edited by Andy Bielenberg covers a broader time frame. but the leaning towards later migrations and later source materials is still apparent, while discussions about earlier migrant groups are often preliminary and tentative. ${ }^{42}$ There is thus significant room in the

of Economic History, XLV1 3 (September. 1986), 693-720; Graham Davis. The Irish in Britain, 1815-1914 (Dublin: Gill and Macmillan, 1991). Anne O'Dowd, Spalpeens and Tattie Hokers: History and Folklore of the Irish Migratory tgricultural Worker in Ireland and Britain (Blackrock: Irish Academic Press. 1991); and various offerings in Patrick O'Sullivan, ed.. Irish Women and Irish Migration, Irish World Wide Series. vol. 4 (London: New York: Leicester University Press, 1995) A recent offering by Donald M. MacRaild examines the similar types of 'frontiers - economic, social. political. psychological - that had to be negotiated by Irish immigrants to Britain and America in the $19^{\text {th }}$ century, but again, the concentration is on urban experiences from the Famine period and bevond. See MacRaild. "Crossing Migrant Frontiers Comparative Reflections on Irish Migrants in Britain and the Lnited States during the Nineteenth Century." Immigrants \& Minorities, $18 \cdot 2$ and 3 (July/November, 1999), 40-70

"This series explores a variety of themes, as encapsulated in the titles of the various volumes. See Patrick O'Sullivan. ed., Patterns of Migration, vol. 1 (1992). The Irish in the New Communities, vol. 2 (1992). The Creative Migrant, vol. 3 (1994). Irish Women and Irish Migration, vol + (1995). Religion and Identity, vol 5 (1996). The Meaning of the Famine, vol. 6. (1997). Irish World Wide Series (Leicester: London: New York Leicester Lniversity Press. 1992-7). There are several studies in the collection that extend back into earlier time trames, but they deal with specialized groups such as indentured servants. religious personnel, and soldiers abroad.

12See Andy Bielenberg, ed. The Irish Diaspora (Harlow Pearson Education. 2000). Some offerings that do discuss earlier migrations to varying degrees include: Graham Davis. "The Irish in Britain, 1815-1939." pp. 19-36. Donald Akenson, "Irish Migration to North America. 1800-1920." pp 111-38. Kerby Miller. "'Scotch-Irish". -Black Irish" and 'Real Irish": Emigrants and Identities in The Old South." pp. 139-57. Ruth-Ann M. Harris. "Searching for Missing Friends in the Boston Pilot Newspaper. 
historiography for trish migration studies, such as the current project, that emphasize earlier movements and emigrant agency without underplaying the human costs or reducing the phenomenon to a purely economic response mechanism.

John Mannion's work on the Irish in Newtoundland follows more recent trends in the literature. emphasizing the influx of Irish servants into the Newfoundland tishery as an adaptive response to declining opportunities in the homeland. His writings. however, illustrate a further limitation of the historiography until recent years - a tendency to homogenize trish migration in terms of male experiences. As Akenson has noted. women in the Irish diaspora (and I would particularly suggest women in pre-Famine migrations) are still "the Great Lnknown."

The low visibility of Irish women in migration studies reflects a deficiency in the broader corpus of Irish historical writings. Irish women's history in general is still very much in its pioneering stages, although an increasing body of research has developed over the past two decades. ${ }^{1}$ Still, a search for the female emigrant in much of the secondary

1831-1863," pp 158-75, and Bielenberg, "Irish Emigration to The British Empire. 17001914," pp. $215-34$

${ }^{43}$ Akenson. Primer. The quotation comes from the title of Chapter 7 : "Women and the Irish Diaspora: The Great Linknown."

"Much of the research until very recently has been "recovery' work - largely descriptive or biographical in nature with little or no reference to theoretical debates in the field Many deal with the most readily accessible material on Irish women - late $19^{\text {th }}$ - and early $20^{\text {th }}$-century involvement in nationalism. unionism. socialism. or feminism. This is largely true even of some more recent offerings, such as: Mary Cullen and Maria Luddy. eds. Women, Power and Consciousness in 19th-Century Ireland (Dublin: Attic Press, 
literature becomes a frustrating hunt for random pieces of a puzzle that is missing essential interlocking parts. Two decades ago. L. A. Clarkson claimed that Kenneth Connell's work at mid-century on rising tertility rates had finally brought Irish women into focus in the emigration saga ${ }^{45}$ However, Clarkson's optimism was premature. Once the Irish woman's role as prodigious breeder of children had been established, she was still lett to

1995), and Maryann Gialanella Valiulis and Mary O'Dowd. eds. Women in Irish History (Dublin: Wolthound Press, 1997), Other recent publications, however, have provided more analytical discussion of Irish women s lives and have broadened the scope to include women from rural and working-class culture. such as homeworkers. prostitutes. domestic servants, and women in labouring families. See, for example: Janice Holmes and Diane Urquhart. eds. Coming into the Light: The Work, Politics and Religion of Women in Ulster. 1840-1940 (Belfast: Institute of Irish Studies. Queen's University. Belfast. 1994): Maria Luddy and Cliona Murphy, eds. Women Surviving: Studies in Irish Women's History in the 19th and 20th Centuries (Dublin: Poolbeg Press. 1989), Margaret MacCurtain, and Mary O'Dowd, eds.. Women in Earlv Modern Ireland (Edinburgh. Edinburgh (iniversity Press. 1991), Joanna Bourke. Husbandry to Housewiferv Women. Economic Change, and Housework in Ireland, 1890-1914 (Oxford: Toronto: Clarendon. 1993). Jane Gray, "Gender and Plebeian Culture in Ulster," Journal of Interdisciplinary History, 24:2 (1993). 251-70: Janet K. TeBrake, "Irish Peasant Women in Revolt. The Land League Years." Irish Historical Studies, XXVIII 109 (May. 1992), 63-80: Rita Rhodes. Women and the Family in Post-Famine Ireland: Status and Opportunity in a Patriarchal Society (New York: Garland, 1992), and Maria Luddy, Women in Ireland, 1800-1918: A Documentary History (Cork: Cork University Press. 1995). For an overview of the state of women's history in Ireland up to the 1990s. see: Mary Cullen. "Women's History in Ireland," in Karen Offen. Ruth Roach Pierson, and Jane Rendall. eds. Writing Women's History: International Perspectives (Bloomington, Indianapolis Indiana Lniversity Press, 1991), pp. 429-41; Margaret MacCurtain and Marv O'Dowd. "An Agenda for Women's History. 1500-1800." Irish Historical Studies, XXVIII 109 (May, 1992) 1-19; and Maria Luddy, "An Agenda for Women's History. 1800-1900." Irish Historical Studies, XXVIII: 109 (Mav. 1992). 19-37

${ }^{45} \mathrm{~L}$. A Clarkson, "Love, Labour and Life: Women in Carrick-on-Suir in the Late Eighteenth Century." Irish Economic and Social History, XX (1993), 18-34, particularly p. 19. The reference to Connell's work relates to Population of Ireland. 
linger on the periphery of migration experiences until recent years.

The search for Irish women emigrants is doubly confounded by a lack of attention to the pre-Famine period. This trend has already been observed in the general historiography. but it is also true of the few writings that deal specifically with Irish female emigration. Jerrold Casway's work does specifically cover women in an earlier period. concentrating on female indentured servants in America and the Caribbean primarily betore the American Revolution. His writing, however, harks back to the earlier 'emigrant-as-exile' genre, although here it seems more appropriate. given that his study group includes a significant number of enforced-servitude emigrants. ${ }^{\text {th }}$ There are also several community or regional histories or family chronicles that span several centuries. but women's lives are subsumed in the discussions under the experiences of men or the larger family unit. ${ }^{\text {* }^{-}}$The most gender inclusive of these is Malcolm Campbell's study of the trish in Boorowa district. New South Wales. The study is still male-centred. focusing

"Jerrold Casway, "Irish Women Overseas, 1500-1800." in MacCurtain and O'Dowd, eds. Women in Early Modern Ireland, pp. 112-32.

"See. for example: Elliott's study of Tipperary Protestants in the Ottawa Vallev in Irish in the Canadas; Wokeck's examination of Irish immigration to the Delaware Valley in Trade in Strangers, Akenson's discussion of Irish migrations to Ontario in The Irish in Ontario A Study in Rural History, $2^{\text {nd }}$ ed. (Montreal, Kingston; London. Ithaca McGillQueen's Liniversity Press. 1999): Ronald Hoffman's chronicle of the Carroll family. Princes of Ireland. Planters of Maryland: A Carroll Saga. 1500-1782, collaborated with Sally D. Mason (Chapel Hill: Liniversity of Norh Carolina Press. 2000); and Malcolm Campbell's study of the Ryan family in New South Wales in The Kingdom of the Rvans The Irish in Southwest New South Wales, 1816-1890 (Sydney: University of New South Wales Press. 1997). 
as it does "on two generations of the Ryan family, father. and son, whose leadership of the Irish community plaved a vital role in shaping its composition, identity, and relationship with Australian society. But Campbell does provide a chapter on the centrality of the Irish family in terms of economic production and cultural continuity, the importance of women in establishing and maintaining stable family life. and the impact of middle-class constructions of femininity and masculinity on rural lrish communities in Australia. ${ }^{2 x}$ Some other writings on women deal briefly with the pre-Famine period For example. Ann Rossiter's examination of the intersection of gender. ethnicity. nationality. and class in the experiences of Irish migrants to Britain in the 1800 s provides some insights on women migrants betore mid-century - particularly seasonal auricultural labourers and textile workers, but her article is heavily weighted towards the Famine and post-Famine periods, retlecting the literature she is reviewing, and deals very much with dysfunctional experiences in urban settings that were not shared by the Irish women who emigrated to the southern Avalon." Indeed. while the body of writing focusing on Irish women emigrants has grown in the 1990 s. most have examined movements from the mid- 19 th century and beyond, when the Great Famine had established a new set of parameters tor Irish migration experiences. This concentration is understandable, for the demographic

${ }^{18}$ Campbell. Kingdom of the Rvans, particularly Chapter 5, quotation from p 11

"Ann Rossiter, "In Search of Mary's Past: placing Nineteenth Century Irish immigrant women in British feminist history," in Joan Grant. ed. Women, Migration and Empire (Stoke-on-Trent: Trentham Books. 1996), pp 1-29. 
and economic changes emanating from the Famine years and its aftermath had particular impact on women and wrought a profound change in their status in Ireland. Much of the literature dealing with this shift has provided essential context for this dissertation in comparing the lives of Irish women who came out to the study area with those who remained behind, and will be discussed in greater detail in the chapters that follow

\footnotetext{
S"Dierdre Mageean, for example, examines women's emigration from Munster in the $19^{\text {th }}$ and early 20 th centuries. and provides a very enlightening discussion of the changes in women's lives before and after the mid- $19^{\text {th }}$ century, but it is aimed at understanding the motivations of women who left home during the Great Famine and thereatter See Mageean. "To Be Matched or to Move Irish Women's Prospects in Munster." in Christiane Harzig. ed. Peasant Maids - City Women From the European Countryside to Urban America (Ithaca. London. Cornell University Press. 1997). pp 57. 97. Other writings that deal with women's declining status and emigration from the famine onwards include: Robert E. Kennedy, Jr. The Irish Emigration, Marriage and Fertility (Berkeley: Lniversity of California Press. 1973): Hasia R. Diner. Erin's Daughters in America: Irish Immigrant Women in the Vineteenth Century (Baltimore: London. The Johns Hopkins University Press. 1983). Fitzpatrick. "Modernisation". Janet Volan. "The Great Famine and Women 's Emigration from Ireland," in E. Margaret Crawford. ed. The Hungry Stream Essavs on Emigration and Famine (Belfast: Centre for Emigration Studies, Llster-American Folk Park. and Institute of Irish Studies. Queen s Lniversity. 1997), pp. 61-70, and Nolan, Ourselves Alone. Miller, Doyle, and Patricia Kelleher cover the $19^{\text {th }}$ century in $\cdots$ For love and liberty Irish women, migration and domesticity in Ireland and America. 1815-1920." in O Sullivan. ed. Irish Women and Migration, pp. 41-65. Their discussion is still focused on the Famine and bevond. but they brietly touch upon some "push factors" of female emigration in the pre-Famine period primarily revolving around illiteracy and social and economic subordination. It must be noted. however. that their conclusions on Irish women's lowly status before the famine appear to stem from middle-class understandings of femininity and are. therefore. unconvincing, they also run contrary to the other literature noted above There are various other writings that deal primarily with Irish women migrants from the mid-19th century and beyond. including: Sheelagh Conway. The Faraway Hills are Green: Voices of Irish Women in Canada (Toronto: Women's Press. 1992); Grace Neville. "'She Never Then After That Forgot Him. Irish Women and Emigration to the Linited States in Irish Folklore," Mid-America: In Historical Review, 74:3 (1992), 271-89: Maureen Murphy. "Charlotte Grace O'Brien and the Mission of Our Lady of the Rosary for the Protection of
} 
few of these writings provide insight into the motivations and experiences of earlier women migrants.

In looking for the Irish woman emigrant of the late $18^{\text {th }}$ and early $19^{\text {th }}$ century, we find ourselves staring down an historiographical funnel. As we shift our perspective from overseas Irish emigration in general to focus on Irish female emigration experiences in particular and finally to hone in on the study period of the current dissertation. our viewing screen becomes increasingly constricted. The story of the Irish women who emigrated to North America before the Famine can only be patched together from pieces and fragments of evidence on an emigration phenomenon that is, in itself, tragmentary in the literature

Much of the intormation on women migrants in this earlier period is statistical - a relentless array of sex ratios, average ages, marital categories, fertility rates, and occupational profiles. drawn from aggregate data for a broad range of destination areas and extended time periods. Several writers, for example. note that while single males dominated migration streams in the $18^{\text {th }}$ century, Irish women, and particularly single Irish women, became increasingly prominent in overseas movements through the tirst half of

Irish Immigrant Girls," Mid-America: An Historical Review, 74:3 (1992), 253-70, and Tracy M. English, "Big Wages. Glorious Climate and Situations Guaranteed: A Study of the Migration of Irish Women to Great Britain for the Period 1861 to 1911" (M.A. Thesis. Memorial Lniversity of Newfoundland, 1999). Suellen Hoy's study period straddles the $19^{\text {th }}$ and early $20^{\text {th }}$ centuries. but she is looking at a very specific occupational group, in -The Journey Out: The Recruitment and Emigration of Irish Religious Women to the United States. 1812-1914." The Journal of Women's History, 6:4/7:1 (Winter/Spring, 1995), 64-98 
the $19^{\text {th }}$ century - much more so than fernales of other ethnic migrant groups from western countries." David Fitzpatrick estimates the proportions of women in the Irish emigrant stream to North America in the $19^{\text {th }}$ century at one-third in 1803-5, a ratio that increased to two-tifths in the 1820s, and to roughly one-half in the Famine years "2 Fitzpatrick and Miller explain the predominance of single women in the stream to North America as a rational response to the high demand for domestic servants in destination areas (an observation that is. itself, slewed towards the urban American experience by the aggregate data)." After parading out some statistical data on women. however. many of these writers then allow the female immigrant of the pre-Famine period once again to be subsumed by the male experience.

Perhaps one of the most well-known (and provocative) proponents of quantitative over qualitative approaches in studying Irish migration is Donald Akenson, who has used aggregate data to provide a 'yardstick' - based on average sex ratios and age, religious. and occupational protiles - against which Irish migrations to various parts of the English-

"See Adams. Irish Emigration, p. 223. Akenson. Primer, p. 166: Fitzpatrick. "Emigration. 1801-70." p. 573. Joel Mokyr. Why Ireland Starved A Quantitative and Analytical History of the Irish Economy, 1800-1850 (London: Boston: Sydney: George Allen \& Lnwin, 1983), p. 247. and Mokyr and Cormac O Grada. "Emigration and Poverty in Prefamine Ireland." Explorations in Economic History, 19.4 (October. 1982). 360-84. particularly p. 367

"Fitzpatrick. "Emigration. 1801-70," p. 573

"See: Fitzpatrick. "Emigration. 1801-70," p. 574: and Miller. Emigration and Exile: Irish Exodus, p. 200. 
speaking world can be measured. Again, however, the index is based on data from the post-Famine period to Partition. The pre-Famine period remains veiled in mystery. he claims, although he does venture some comments on women's migration from 1815 onwards He traces the following periodization, for example:

1815-45 Mostly tamily groups or childless couples; unmarried adult women comprised slightly less than one-half of the migrant stream

18-6-51 Women left Ireland in large numbers, but little is known of their age or marital status

1851-76 'Classical era of ' Irish emigration' in which males usually outnumbered fermales

1876-1920 Female migrants were in the majority

He also provides some other aggregate findings on women migrants. He observes. tor example. that most Irish women immigrants entered domestic service. especially in the Lnited States. but that looking at the data from all countries, combined agricultural, industrial and commercial occupations exceeded domestic service. Lising data on the period 1876-1920, primarily that from the Vogel sample for New Zealand of 1876. he extrapolates a breakdown of women immigrant types' based on marital status and children

Akenson is trving to provide a means of gauging the typicality of specific movements against a broad geographical and temporal canvas. Yet the problem in presenting the average as typical is that it overlooks the possibility that this statistical measurement may not reflect the actual experience of many. or even most, of the migrants 
involved. In his effort to present the Irish diaspora as a 'worldwide phenomenon. Akenson seeks to blur the nuanced edges of specific migrations, seeming to imply that those experiences that do not fit the mould are irrelevant. or so anomalous as to be unworthy of historical examination other than as a curiosity. More troubling. his analysis leaves us with a series of unrelated. unexplained. and non-contextualized statements that provide little insight into migration experiences as they were actually lived by the peopie involved

Akenson's writings are representative of an increasing focus in the Irish historiography on quantitative analysis in the latter decades of the $20^{\text {th }}$ century. a shift which has led some critics to bemoan the predominance of 'cliometricians' in the tield In fairness, however, these approaches have been quite useful in banishing stereotypes and blanket assumptions about phenomena such as Irish migration or the Great Famine. and other historians have often been pleased to cite their findings (as I have done above). secretly relieved that someone else has performed the task of crunching the numbers. But without context and anecdotal vitality. such analyses remain clinical and bleak. and without interpretation. they are unsatisfying. They demonstrate little understanding of emigration as a movement of people. not just economic or demographic tariables. And they provide even less insight into how gender. ethnicity. and class affected the migration experience. or how migration, in turn, affected the negotiation of gender, ethnicity. and 
class in new-world contexts. ${ }^{\$ 4}$

In general. then. a study of Irish women migrants. focusing on the pre-Famine period, that is rooted in historical context and seeks to explain the multi-layered dynamics of the experience can make a contribution to the historiography of the Irish diaspora

\subsection{Anglo-European immigration and early settlement in Canada}

The paucity of material on Irish women immigrants in North America corresponds with a traditional obscuring of the female experience in immigration literature in general By the late 1980s and early 1990s. women's historians had observed this lack and were working towards a more balanced interpretation of immigration history that incorporated women's experiences and more gender-inclusive categories of analysis. In an exchange in the Journal of American Ethnic Histon in 1992," for example. Sudnev Stahl Weinbery. Hasia Diner. and Maxine Schwartz Sellar noted that there was still a tendency to assume that female migrants experienced migration in the same way as males or larger family

"A similar exposition of quantitative material, focusing on literacy and skill levels of Irish women migrants to Australia and extrapolated from convict records for the period from 1826 to 1840 and assisted immigration records from 1840 to 1852 . is provided by Robin Baines, Margrette Kleinig. Deborah Oxley, and Eric Richards in Migration and Opportunitv: An Antipodean Perspective." International Review of Social History. 432 (1998). 235-63

"see Sydney Stahl Weinberg. "The Treatment of Women in Immigration History A Call for Change," Hasia R. Diner. "Comment," and Maxine Schwartz Seller. "Comment." in Journal of American Ethnic History, 11 4 (Spring. 1992). 25-67 
groups. Weinberg called for more flexible categories to examine areas such as work. family life. the interrelationship between public and private spheres, informal neighbourhood and kin networks created or maintained by women, the alteration of women's lives in the new world, and female components of adaptation and socialization. in order to bring women's roles, activities, and perceptions into our understanding of the immigrant experience. Diner added that gender analysis would require not just closer work on the temale components of immigration. but further analysis of the maleness of the experience and the dynamics through which the two intersected and contlicted within immigrant communities. Schwartz Sellar suggested some necessary first steps: "filling in the missing women." both in traditional male contexts of migration as well as in nontraditional women-centered categories; and also positioning men within female contexts History must "not only redefine traditional categories in the light of the experiences of both sexes," she argued: "it must also look at the interaction between women and men within these categories" if a more "gender tair" interpretation of migrant experiences is to be attained ${ }^{\text {sn }}$

As the need to rewrite immigration history - to gender migration experiences - has come more sharply into focus, the result has been a growing body of work on immigrant women in North America. In Canada, historians such as Franca lacovetta. Varpu Lindstrom. Ruth Frager. Agnes Calliste, and Francis Swyripa have examined ethnic

\footnotetext{
"Seller, "Comment," p. 64.
} 
women and cultural maintenance/adaptation, domestic service, the industrial workforce. labour politics, and radical activism - studies that have added significantly to our understanding of the inter-related processes of gender. race, and class. ${ }^{57}$ But there is a late- $19^{\text {th }}$ - and/or $20^{\text {th }}$-century concentration in this literature and a focus on ethnic minorities and urban experiences The history of women in earlier migrations from the British Isles to what is today Canada has. until recently. remained largely unexplored terrain: in much of the literature, these women have remained part of the amorphous entity 'white settler society.' with little recognition of the gendered dynamics of their experiences or the ways in which dimensions of race. ethnicity. and class also affected their lives.

One early exception was Sylvia Van Kirk's examination of the impact of the arrival of white women on fur trade society the increasing denigration of marriages a la factom du perss and social stratification of the community, as trading company. church. and white

"See, for example. Franca lacovetta. "Making New Canadians: Social Workers. Women and the Reshaping of Immigrant Families," in Franca lacovetta and Mariana Valverde, eds. Gender Conflicts: New Essavs in Women's History (Toronto: Lniversity of Toronto Press. 1992): Varpu Lindstrom. Defiant Sisters A Social History of Finnish Immigrant Women in Canada, $2^{\text {nd }}$ ed. (Toronto: Multicultural History Society of Ontario. 1992): Ruth A. Frager. Sweatshop Strife: Class, Ethnicity, and Gender in the Jewish Labour Movement in Toronto, 1900-1939 (Toronto, Buffalo, London: Lniversity of Toronto Press. 1992): Agnes Callista. "Canada's Immigration Policy and Domestics from the Caribbean. The Second Domestic Scheme." in Jesse Vorst et al.. eds.. Race. Class. Gender: Bonds and Barriers (Toronto: Between the Lines in cooperation with the Society for Socialist Studies. 1989). pp. 133-65. Calliste. "Race. Gender and Canadian Immigration Policy: Blacks from the Caribbean. 1900-1932," in Joy Parr and Mark Rosenfeld. eds.. Gender and History in Canada (Toronto: Copp Clark. 1996), pp. 70-87. and Francis Swyripa. Wedded to the Cause. Ukrainian-Canadian Women and Ethnic Identity, 1891-1991 (Toronto: University of Toronto Press. 1993). 
women. themselves. asserted the cultural 'superiority' of wives of European descent over aboriginal wives who had contributed so effectively - by their experience, their work. and their contacts - to the trade ${ }^{\leq x}$ Some more recent offerings have been made on the push west in the latter $19^{\text {th }}$ century Adele Perry has looked at the lives of white women in British Columbia in the second half of the $19^{\text {th }}$ century, for example. and found that the combined impact of a skewed gender ratio and colonial race politics resulted in enhanced heterosocial contact but restricted socio-economic opportunity for these women. ${ }^{5 n}$ Sarah Brooks Sundberg has examined the roles of prairie farm women in the late $19^{\text {th }}$ century. and finds that their substantial contributions as homemakers. home manufacturers. field hands, wage earners, and teachers was understated in the persistent image of 'helpmates in emigrant promotional literature ${ }^{* 1}$ Overall, however, there are tew studies of AngloEuropean women's migrations to or within Canada in the literature

The general corpus of Canadian women's history has grown significantly in the

"Sylvia Van Kirk. "The Impact of White Women on Fur Trade Society," in Alison Prentice and Susan Mann Trofimenkoff. eds. The Veglected Majority Essays in Canadian Women's History Volume 2 (Toronto: McClelland and Stewart. 1985). pp 2748. reprint of "Women and the Fur Trade," The Beaver, (Winter. 1972), +-21

"Adele Perry, '.'Oh I'm Just Sick of the Faces of Men" Gender Imbalance. Race. Sexuality, and Sociability in Nineteenth-Century British Columbia." BC Studies, 105 and 106 (Spring/Summer. 1995). 27-43

${ }^{m}$ Sara Brooks Sundberg. Farm Women on the Canadian Prairie Frontier: The Helpmate Image." in Veronica Strong-Boag and Anita Clair Fellman, eds., Rethinking Canada: The Promise of Women's History (Toronto: Copp Clark Pitman, 1986). pp. 95106. 
past two decades, but the focus has been on late- $19^{\text {th }}$ - and $20^{\text {th }}$-century subject areas. Still, some promising contributions have also been made to our understanding of Anglo-colonial women's lives in pre-contederation Canada. Beth Light and Alison Prentice have provided a collection of primary documents on women in British North America up to 1867 - organized around women's passage through the life cycle with additional sections on women in public life and the regulation of women's roles and status through law. community pressure, and prescriptive literature. ${ }^{\text {of }}$ Constance Backhouse has examined court records and statutory law (particularly those involving the regulation of women's sexuality and reproductive capacity) to shed light on women 's legal status in Canada in the $19^{\text {th }}$ century and the ways in which women's experiences with the justice system were tempered not just by gender but also by race and class :" Cecilia Morgan has recently examined the complex interplay between understandings of gender and public discourses of Lpper Canada - each informing and reshaping the other - as concepts of middle-class masculinity and femininity were constructed and contested. and as images such as 'virtuous woman' and 'public man' were created through the gendered languages of politics and patriotism, it ieligion and social morality. Her work focuses on the construction of a white. colonial middle class, however, and does not discuss marginalized

"Beth Light and Alison Prentice, eds.. Pioneer and Gentlewomen of British Vorth America 1713-1867. Documents in Canadian Women s History. vol 1 (Toronto New Hogtown Press. 1980).

"Constance Backhouse. Petticoats and Prejudice: Women and Law in VineteenthCenturu Canada (Toronto: Osgoode Society, 1991). 
groups, other than to note that these ideals often had little meaning for aboriginal, immigrant. and working-class cultures. even though such public discourses shaped the social. economic. and political environment in which they lived. But we are left to speculate about the extent of this impact on the everyday lives of women on the periphery ${ }^{\text {t3 }}$ Elizabeth Errington makes an effort to include different class experiences in her discussion of women's work in Lpper Canada in the period from 1790 to 1840 She examines the intersection of gender, class, and region in shaping the nature of women's work. and specifically contrasts the lives of women in farm/artisan tamilies with those in

${ }^{13}$ Cecilia Morgan. Public Men and Virtuous Women: The Gendered Languages of Religion and Politics in Lpper Canada. 1791-1850 (Toronto. Buffalo. London Lniversity of Toronto Press. 1996). Morgan has also authored an article on the political discourses of the reform period - demonstrating that both reformers and conservatives constructed political participation in terms of maniy virtue and independence, while both emploved teminine imagery to denigrate their political opponents. See Morgan. $\cdots$ When Bad Men Conspire. Good Men Must Unite!: Gender and Political Discourses in Cpper Canada. 1820s-1830s." in Kathryn McPherson. Cecilia Morgan, and Nancy M. Forestell. eds. Gendered Pasts: Historical Essavs in Femininity and Masculinity in Canada (Oxford Oxford Liniversity Press. 1999). pp. 12-28. Two other articles in that collection provide valuable insights on women in pre-confederation Canada. Mary Anne Poutanen examines female vagrancy in urbanizing. Montreal and finds that profound socio-economic and demographic flux provoked anxieties among the emerging male bourgeoisie, who sought increasing state intervention in the street life of the city - a process that had particular ramifications for popular-class women as urban public space was increasingly defined as a male domain. Lynne Marks explores the efforts of Protestant churches in Lpper Canada to establish a single code of sexual behaviour for both men and women in their congregations. despite the double sexual standard entrenched in the secular legal tradition. See Poutenan, "The Homeless. the Whore, the Drunkard. and the Disorderly. Contours of Female Vagrancy in the Montreal Courts. 1810-1842," and Marks. "No Double Standard? Leisure. Sex. and Sin in Upper Canadian Church Discipline Records. 18001860," in McPherson, Morgan, and Forestell. eds., Gendered Pasts, pp. 29-47 and +8-64. respectively. 
the 'big' house, as she argues that women's contributions, although varying with social level, were all essential to the preservation of their households. ${ }^{\text {th }}$ Her discussion, however, is heavily reliant on newspapers and the diaries and correspondence of gentry women - and thus her interpretation of plebeian women's lives has been mediated by middle-class male editors and women outside their class. Both Errington's and Morgan's discussions demonstrate a pervasive difficulty in women's history - the problem of uncovering the lives of women whose presence is quite muted in the written records

Margaret Conrad has encountered a similar difficulty in her work on the diaries of Maritime women. Conrad has mined these diaries for insights into everyday experiences and emotions. trying to interpret not just the words written on the page but also the "understatement," the "obliqueness," and sometimes, the "silence" in women "s reporting of their lives. Through her examination. she has tound that women had different priorities than men in their recording, that they experienced time and place primarily "through the prism of the family." and made life choices on the basis of gendered expectations as daughters. wives, and mothers." But Conrad has noted a class and ethnic bias in her

${ }^{n}$ Elizabeth Jane Errington. Wives and Mothers, Schoolmistresses and Scullery Maids Working Women in Upper Canada, 1790-1840 (Montreal. Kingston. London: Buffalo: McGill-Queen's University Press. 1995).

${ }^{65}$ See Margaret Conrad: "Recording Angels: The Private Chronicles of Women from the Maritime Provinces of Canada. 1750-1950," in Susan Mann Trotimenkoff and Alison Prentice. eds. The Neglected Majority: Essays in Canadian Women's History (Toronto McClelland and Stewart. 1977). pp $+1-60 ;$ Recording Angels: The Private Chronicles of Women from the Maritime Provinces of Canada. 1750-1950 (Ottawa: Canadian Research Institute for the Advancement of Women. 1982); and '"Sundays 
sources. for most were written by Protestant. Anglo-Saxon. middle-class women. As in Morgan's work, the lives of women at the peripheries of hegemonic culture are not well represented.

More enlightening in terms of the lives of plebeian colonial women is the third offering in the Planter Studies Series published by Acadiensis. This volume contains some insightful contributions on women in Nova Scotian communities settled by New England planters in the latter $18^{\text {th }}$ century. Kenneth Paulson, for example. describes inheritance practices in Lunenburg and finds that the largely German population maintained its tradition ot partible inheritance that included temales in the distribution of real property - a testamentary system that contrasted with the male-centred practices of AngloLunenburgers or New Englanders in Nova Scotian townships in general. Through her examination of merchant account books in Horton. Nova Scotia. Elizabeth Mancke demonstrates women's participation in early exchange economies - occasionally as independent economic agents. more frequently as consumers (through men's accounts) of goods that would be reprocessed in household production, or as paid workers whose sale of labour was often reflected in third-party payments in the store ledgers. And Judith Vorton reports on violence against women in planter Vova Scotia and finds that women

\footnotetext{
Always Make Me Think of Home : Time and Place in Canadian Women's History," in Veronica Strong-Boag and Anita Clair Fellman. eds. Rethinking Canada. The Promise of Women's History (Toronto. Copp Clark Pitman. 1986). pp. 67-95. See also Conrad's collaborative effort with Toni Laidlow and Donna Smyth. No Place Like Home: Diaries and Letters of Nova Scotia Women, 1771-1938 (Halifax: Formac Publishing. 1988).
} 
were "particularly vulnerable" to assault both within and outside the home ${ }^{\text {to }}$ This volume has provided some useful comparisons and contrasts for my study group and time period.

Similarly, a 1994 collection on Canadian Maritime women edited by Janet

Guildford and Suzanne Morton has been helpful, particularly contributions by Rusty

Bittermann and Gail Campbell. Bittermann discusses the prominent, and often quite physical, participation of rural women in the Escheat Movement in Prince Edward Island in the 1830 s. observing their involvement, and often critical roles. at the levels of spontaneous household detence and more organized communal resistance. Campbell observes a high level of women's participation in petitioning in Vew Brunswick in the $18+0 \mathrm{~s}$ and $1850 \mathrm{~s}$, using well-established procedures to seek individual benefits as well as to lobby for broader moral retorm ${ }^{n-}$ As can be seen. however. there is no comprehensive

${ }^{*}$ The overall series is edited by Margaret Conrad and published in Fredericton by Acadiensis. It is comprised of the proceedings of several conferences in the late 1980 s and early 1990 s respecting the New England planters who moved to Nova Scotia between 1759 and 1768 and the communities that evolved up to the $19^{\text {th }}$ century. Women's experiences were quite muted in the first two renderings. See Thev Planted Well: Vew England Planters in Maritime Canada (1988) and Making tdjustments: Change and Continuity in Planter Nova Scotia. 1759-1800 (1991). However, efforts to address this lack were made in the third volume of the series. See the following offerings in Intimate Relations. Family and Community in Planter Nova Scotia, 1759-1800 (1995). Kenneth Paulson. "Land. Family, and Inheritance in Lunenburg Township. Vova Scotia: 1760 1800." pp. 110-21: Elizabeth Mancke. “At the Counter of the General Store: Women and the Economy in Eighteenth-Century Horton. Nova Scotia." pp. 167-81; and Judith A. Norton. "The Dark Side of Planter Life: Reported Cases of Domestic Violence," pp. 1829

"Rusty Bittermann. "Women and the Escheat Movement: The Politics of Evervday Life on Prince Edward Island." and Gail G. Campbell, "Disenfranchised but not Quiescent: Women Petitioners in New Brunswick in the Mid-19th Century." in Janet 
literature on Anglo-colonial women in early Canada. and plebeian women, in particular. are barely visible; the current project will merely be one small drop in a slowly filling well

\section{$1+$ Colonial women in America}

Anglo-European colonial women are better represented in the American historiography. Beyond early 'recovery' and "contribution" histories, ${ }^{\text {,x }}$ by the 1970s and early 1980 s. a number of writers began to grapple with gender, race. and class as social constructions. Signiticant among these earlier works was Mary Ryan's sweeping study of three primary aspects of American women's experience - family. work, and feminism from colonial times to the present. Her study was quite broad temporally, and has been criticized for presenting patriarchy as an ahistorical phenomenon and tor stressing women's victimization over their agency. But Ryan raised important challenges to current conceptual trameworks she moved outside the male-centred periodization of the

Guildford and Suzanne Morton, eds.. Separate Spheres: Women's Worlds in the 19thCenturv Maritimes (Fredericton: Acadiensis Press, 1994), pp. 23-38, and 39-66. respectively.

${ }^{1,8}$ That is. 'filling in the missing woman and looking at her contributions in a maledominated world. using more traditional. male-centred frameworks. See. for example. Seima R. Williams, Demeter's Daughters: The Women Who Founded America, 15871787 (New York: Atheneum, 1976), which describes the contributions and accomplishments of women - aboriginal. African slave. and. predominantly. AngloEuropean - to various aspects of American life - home, family. religion. politics. arts, and war - up to the immediate post-revolutionary period. 
historiography. for example, and also demonstrated that while women shared certain experiences because of gender. their lives often diverged on the bases of race. ethnicty, region, and class. ${ }^{n 9}$ Another groundbreaking work was Laurel Thatcher Ulrich's exploration of the lives of colonial women in northern New England. ${ }^{\circ}$ Her innovative use of sources - from the more standard offerings of church documents, court records, and newspapers to more woman-centred sources such as diaries, recipes, poetry, embroideries. flat irons, and garden hoes - allowed her to uncover the lived experiences of these women and shed light on what she argues was a complexity of "discrete duties" rather than an "all-embracing sphere" which defined women's lives. Examining women's roles as housewives. deputy husbands, household mistresses, consorts. mothers. neighbors. Christians, and sometimes viragoes and heroines, she revealed the complexity of women's lives as they played out in tamily, community, and religious life and argued that women were able to use their status and authority in these roles to protect and promote their own interests. She also demonstrated that while gender was a central category around which early New England life was organized. women 's lives were also defined by race, region. political structures. and religious culture.

A spate of monographs and collections on Anglo-European colonial women have

"Mary P. Ryan. Womanhood in America: From Colonial Times to the Present (New York: New Viewpoints. 1975).

"Laurel Thatcher Ulrich. Good Wives: Image and Reality in the Lives of Women in Northern New England, 1650-1750 (New York: Alfred A. Knopf. 1982). 
appeared in the American literature from the 1980 s onward, covering a range of

experiences and influences, including the legal system. ${ }^{-1}$ work. ${ }^{-2}$ participation in the public world of business. ${ }^{3}$ property and inheritance practices. ${ }^{-4}$ religious and political ideology. "

"For example. Comelia Hughes Dayton examines the emergence of a double standard in the legal culture in Connecticut as a male-centred system of individual rights replaced the confessional and moralistic influences of Puritanism - change which she attributes to increasing commercialization and familiarity with English common law. See Davton. Women Before the Bar Gender. Law, and Society in Connecticut, 1639-1789 (Chapel Hill University of North Carolina Press, 1995). Other writings on American women and the law include. Cornelia Hughes Davton, "Turning Points and the Relevance of Colonial Legal History." William and Mary Quarterly, 50:1 (1993). 7-17. G S Rowe. "Intanticide. Its Judicial Resolution, and Criminal Code Revision in Early Pennsylvania." Proceedings of the American Philosophical Society, 135:2 (1991). 200-32: and Jeffrey K. Sawver, "'Benetit of Clergy" in Maryland and Virginia." American Journal of Legal History. $3+1(1990)+49-68$

"There are richly textured descriptions of work performed by women in various capacities in colonial America in Llrich. Good Wives: Kathleen M. Brown. Good Wives, Vasty Wenches, and Anxious Patriarchs: Gender, Race, and Power in Colonial Virginia (Chapel Hill: London. University of North Carolina Press. 1994): and Carol Berkin. First Generations: Women in Colonial America (New York: Hill and Wang. 1996) In addition. Gloria L. Main looks at women in the waged labour market of colonial Vew England. examining pay rates, wage regulations, and labour market specialization in both rural and urban contexts. See "Gender. Work. and Wage in Colonial New England," William and Mary Quarterly, $51: 1$ ( 1994). 39-66

${ }^{-3}$ For example: Lion G Miles examines the life of Anna Bingham. who ran her tamily"s inn after her husband's death and remained an active participant in its business and legal affairs. ultimately becoming the first woman to appear before the US Supreme Court. in "Anna Bingham: From the Red Lion Inn to the Supreme Court." New England Quarterly 69:2 (1996). 287-99: Patricia Cleary discusses the substantial number of women shopkeepers and traders in Philadelphia and New York from 1740 to 1775 who made a significant contribution to the local and national economy, and whose trade had political ramifications in the period leading up to the revolution. in "-She will be in the shop : Women's Sphere of Trade in Eighteenth-Century Philadelphia and New York." Pennsylvania Magazine of History and Biography, 119:3 (1995). 181-202: Laurel Thatcher Llrich examines the vital participation of women in informal trade networks. 
and class formation. ${ }^{76}$ Like the Planter Studies series in Canada. a recent collection on

where they acted as agents tor their husbands and sometimes for themselves in the sale of the surplus goods produced in cottage industries, in '.'A Friendly Neighbor'. Social Dimensions of Daily Work in Northern Colonial New England," Feminist Studies, 6.2 (1980), 392-405; and Jean P. Jordan looks at the presence of women in the early business community of New York in "Women Merchants in Colonial New York." New York History, $58:+(1977),+12-39$

"For example: Norma Basch, "Family Values in Colonial New York." Reviews in American History, 23:3 (1995), 397-401: Toby L. Ditz. Property and Kinship Inheritance in Early Connecticut. 1750-1820 (Princeton. Princeton University Press, 1986): Carole Shammas. Marylynn Salmon, and Michel Dahlin, Inheritance in America. From Colonial Times to the Present (New Brunswick: Rutgers Lniversity Press. 1987): Marylynn Salmon. "The Legal Status of Women in Early America: A Reappraisal." Law and History Review, $1: 1$ (1983), 129-51. Linda Briggs Biemer. Women and Property in Colonial New York: The Transition from Dutch to English Law, 1643-1727 (Ann Arbor LMI Research Press. 1983): and Linda E. Speth, "More that her 'Thirds' Wives and Widows in Colonial Virginia." Women and History, $+(1982), 5-+1$.

"Both Mary Beth Norton and Linda Kerber. tor example. examine the evolution of the concepts of 'republican womanhood' and 'republican motherhood' in postrevolutionary. American and the tensions between domesticity and citizenship as women were urged to nurture sons and support husbands in their efforts to be upright citizens of the republic. See: Norton, Liberty's Daughters: The Revolutionary Experience of American Women, 1750-1800 (Boston; Toronto: Little. Brown and Company, 1980). and Kerber. Women of the Republic: Intellect and Ideology in Revolutionary America (Chapel Hill University of North Carolina Press. 1980). In a later offering. Norton stresses economic and religious factors in analyzing the changing status of American women over time. from a subordinate position in patriarchal puritan families of the colonial period to relative independence in the $18^{\text {th }}$ century due to economic prosperity and population growth. followed by a slide in status as the image of the self-sacrificing republican mother urged women into domesticity after the revolution. See Norton. "The Evolution of White Women's Experience in Early America," American Historical Review, 89.3 (1984). 593-619 See also: Marilyn J. Westerkemp, Women and Religion in Early America, 1600-1850: The Puritan and Evangelical Traditions (London: New York: Routledge. 1999); Carol F. Karlsen. The Devil in the Shape of a Woman: Witchcratt in Colonial New England (New York: Norton, 1987), and Joan R. Gundersen. "The Noninstitutional Church: The Religious Role of Women in Eighteenth-Century Virginia." Historical Magazine of the Protestant Episcopal Church, 51:4 (1982). 347-57 
colonial America edited by Larry Eldridge contains a number of contributions in women's history that have provided useful comparative material for the current project. The following items are of particular note. Judith Ridner argues that women in frontier Pennsylvania were such integral parts of their family economic units that they enjoyed a high degree of economic authority and independence compared with their eastern sisters Johanna Miller Lewis assesses the presence of women's names in merchant account books in colonial North Carolina and finds that some women, particularly single and widowed protessional women. achieved real economic independence, and that even some married women carried out separate dealings from those of their husbands. despite their legal status as femes coverts. Vivian Bruce Conger's examination of widows' testamentary practices in colonial Massachusetts and Maryland demonstrates how they reshaped gender roles within colonial families - adding ambiguity to the perceptions of fatherhood and motherhood by assuming both roles. and redefining accepted notions of property by leaving 'male' property to daughters. Merrill Smith examines the similarities and differences in the social. economic. and legal status of deserted wives and widows in early

"Kathleen Brown and Carol Berkin both provide discussions of women's place in the evolution of gentility and the construction of gentry identity. See Brown. Good Wives, Nasty Wenches, and Berkin. First Generations. In addition. Jessica Kross looks at how the multi-roomed mansion in $18^{\text {th }}$-century British North America had evolved into gendered spaces which segregated elite men and women. facilitating men s integration into the political, economic. and intellectual life outside the home. while marginalizing women from these public spaces. See Kross. "Mansions, Men. Women, and the Creation of Multiple Publics in Eighteenth-Century British North America," Journal of Social History, 332 (1999). 385-408. 
Pennsylvania. finding that while both had to cope in terms of emotional and financial loss. widows generally had more flexibility and enjoyed greater respect in the community. Julie Richter finds a significant degree of participation by women in the court life of York County. Virginia - as petitioners. witnesses. testators. and as parties in matrimonial matters or actions involving debt or property - although she finds that their experiences were tempered by matrimonial status and life cycle and sees little evidence of women's stepping outside their assigned gender roles of wives and mothers. Deborah Rosen observes that women in colonial New York circumvented social, economic, and political obstacles to the formal legal system by pursuing informal methods of justice. such as church intervention, physical confrontation, and, most particularly, discretionary official justice through the mechanism of petitioning, still, she argues, these alternative routes "only partially mitigated colonial women's lack of freedom and became less negotiable as the legal system became increasingly formalized by the $19^{\text {th }}$ century, so that women found their access to any form of justice increasingly restricted. ${ }^{-}$

-Tee the following contributions in Larry D. Eldridge. ed. Women and Freedom in Early America (New York; London. New York Lniversity Press. 1997): Judith Ridner. "'To Have a Sufficient Maintenance Women and the Economics of Freedom in Frontier Pennsulvania. 1750-1800," pp. 167-90, Johanna Miller Lewis. "Women and Economic Freedom in the North Carolina Backcountry." pp. 191-208. Vivian Bruce Conger. ' If Widow. Both Housewife and Husband May Be- Testamentary Freedom in Colonial Massachusetts and Maryland." pp. 244-66: Merril D. Smith. "WWhers Gone to She Knows Not". Desertion and Widowhood in Early Pennsylvania," pp. 211-28. Julie Richter. "The Free Women of Charles Parish, York County. Virginia, 1630-1740," pp. 290-312., and Deborah A. Rosen. "-Mitigating Inequality: Women and Justice in Colonial New York." pp. 313-29. 
While the Eldridge collection is generally empirical in its approach. other writings have followed the contours of poststructuralist theory in conceptualizing the construction of colonial womanhood in terms of overlapping systems of meaning Two major works that have been particularly insightful have been Carol Berkin's First Generations and Kathleen Brown's Good Wives, Nasty Wenches. Berkin's discussion of women in colonial America demonstrates that it is impossible to generalize and construct overarching models about the lives of women in any given area or period. at best. one can attempt to draw a "collective portrait" in which the unifying theme of gender is tempered by difference In First Generations, she attempts to contribute to the broader canvas with discrete chapters on aboriginal, African-American, and European women, on women in New England. the middle colonies. and the Chesapeake. on middle-class women and republican women, to demonstrate the complexity of colonial women's lives as gender intersected with the axes of race. region. and class in early America ${ }^{*}$ Brown s writing is even more densely textured as she looks at the inter-relationship of gender. race. and class

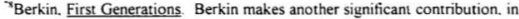
collaboration with Leslie Horowitz. in an annotated collection of primary documents from colonial and revolutionary America. The documents are organized under themes central to women's lives - sex and reproduction. marriage and family. work. religion. politics and the legal system, and republican gender ideology - and again. efforts are made by the editors to demonstrate both similarity and difference in women's experiences. See Berkin and Horowitz. eds.. Women's Voices, Women's Lives: Documents in Early American History (Boston. Northeastern University Press. 1998). Another collection that contains a small but useful section of primary and secondary writings on women in the colonial period is Linda K. Kerber and Jane Sherron de Hart. eds. Women's America: Refocusing the Past. 3 eds. (New York: Oxford: Oxford University Press. 1982. 1987. and 1991)
} 
in the creation and maintenance of the social order in colonial Virginia: in particular, how gender discourse was integral to intensifying patriarchy and defining slavery and middleclass culture. She notes that in the period of early settlement, the Virginia Company and early colonial legislatures and courts celebrated woman's domesticity, economic dependence, and political subordination as virtues In official discourse. "good wives" were contrasted with 'nasty wenches' - women who worked in the fields. who deviated trom the 'natural order' and were therefore associated with moral corruption. Still, the nature of women's work in colonial Virginia undermined rhetoric about female dependence, domesticity, and physical frailty, because 'good wives' initially had to work in the tobacco tields alongside men in response to high tobacco prices and the shortage of other forms of labour However. as alternative field workers - indentured servants and African slaves - became available, increasing numbers of white English women retired into genteel domesticity, and the distinction between 'respectable' and 'degenerate' women sharpened. Intersecting this understanding of womanhood was a perception of African 'otherness' such that by the $18^{\text {th }}$ century, the concepts of 'good wife' and 'nasty wench' were also racial oppositions in which white English women embodied virtue and African women embodied evil and lust. ${ }^{-n}$ Brown's analysis of the contestation of patriarchy in a colonial setting, the intersection of gender. race. and class in the creation of meaning. the disparity between rhetoric and lived reality. and the differences in systems of knowledge of

\footnotetext{
"Brown. Good Wives, Nasty Wenches.
} 
gender in different cultures (English. Irish, Algonquin, and West African) have provided some particularly useful insights for this thesis.

\section{Theoretical perspective}

It is intriguing that I have found both the Eldridge collection and Brown's monograph both so helpful, as a great tension exists in the discipline between their respective theoretical approaches - empiricism and poststructuralism. Empiricism has traditionally rested on the assumption that there is some historical 'truth' residing in the 'tacts' that can be brought torth by the historian through careful examination of primary evidence. impartial research. and inductive reasoning Over the years, various limitations of the method have been articulated: for example. that the focus on written documents has channeled historians towards the study of the literate elite; that the keepers of the written record have agendas of their own which might not always be detected by the researcher, that the historian, with best efforts at impartiality, still brings certain personal biases to the conclusions s/he draws from the evidence. Empiricists have responded with efforts to incorporate history from below in their offerings, and have learned to qualify their conclusions by acknowledging the pitfalls of uncovered agendas and personal limitations A humbler perception of historical 'truth. or perhaps an acknowledgment of its elusiveness, has become part of the their perspective.

Still. empiricism is not out of the woods. and perhaps its most severe critic is 
poststructuralism. This latter theoretical approach challenges the assumption that language is linked to some concrete external social reality beyond the words we use to construct that social reality. Thus, there can be no such thing as documentary objectivism or an ultimate historical truth. for the very language that supposedly reflects reality in documentary evidence is, itself, involved in the process of constructing experience and meaning. Furthermore. these meanings, themselves. shift and change over time as they are contested and either legitimated or reconstructed. Because of the instability of meaning. any reading of a text must be a misreading: and indeed, the historian's very own rhetoric undermines his or her own effort to convey the meaning s/he has ascribed to the text

While poststructuralism's critique of conventional readings of language has instilled in many empiricists a fear that it is bent on paralyzing all efforts at communication and debate. poststructuralism has opened up whole new avenues of exploration in histor: as it has challenged the traditional white, male, middle-class bias of the discipline. In women's history, for example. Denise Riley and Joan Scott have been in the vanguard in deconstructing or dismantling conventional understandings of gender In her landmark Am I That Name?", Riley describes the category woman' as "historically. discursively constructed. and always relatively to other categories which themselves change" as they are historically, discursively constructed. She examines the shifting category of 'woman' through time as it crystallized within various contexts in relation to other categories central to the concept of personhood - the 'soul," the "mind." "reason." the body." 'nature. the "social' - and argues that constructs of "woman' and 'man' have been 
positioned asymmetrically from these shifting concepts of what it means to be 'human' (for example, 'women' were seen as closer to the 'body' and 'nature : 'men, closer to the 'mind' and 'reason'). 'Women' were positioned turther than 'men' from concepts such as rationality." ethics. and "culture." she argues, and thus. their remoteness from "humanity" Was underscored ${ }^{\text {xil }}$

In a complementary argument. Joan Scott observes that the construction of gender is a complex process. involving perceptions of categorical oppositions (male/female. strong/weak, rational/emotional) that are interdependent in that each derives its identity from its contrast to the other. This interdependence is hierarchical, involving relationships of power - of domination and subordination. It also involves a politics of inclusion and exclusion, whereby one set of subjects is naturalized and the other, disqualified and repressed. Gender is not a tixed entity. says Scott. but a dynamic process. in which gender hierarchies are constructed, legitimated, contested, and either maintained or redetined. Constructions of gender vary across cultures. social groups. and time. And history plays a part in the process - not just in recording changes in the organization of sexual difference over time. but also as an actual participant in the production of sexual difference i.e. by the way it analyzes the meanings of sexual difference in various historical contexts. history becomes part of the power struggle by which gender is produced. reproduced. and

\footnotetext{
"Denise Riley Am [ That Name?. Feminism and the Category of Women in History (Minneapolis: Lniversity of Minnesota Press. 1988).
} 
transformed. ${ }^{\text {s1 }}$

Such writings have provoked an examination of the male-centered bias of traditional history and heralded the need to re-examine the content. methods and epistemology of the discipline, to determine how 'knowledge' is constituted, how some people are assigned to the center of the historical narrative while others are relegated to the margins, how evidence is selected, verified, and transmitted to portray a particular vision of social reality. how the silences in history speak as much about biases as the written text. and how gender, as a system of meaning, is used to legitimize power relations in society. And while teminist historians were initially. and understandably. pre-occupied with gender, they soon developed an awareness that the complexity of relations in society played out along several axes of difference and power - not just gender, but others, such as race, class, sexuality. ethnicity, nationality, religion, and sexual orientation. The interrelationship of these constructions of difference in strategies of domination and subordination had to be taken into account - not just between men and women, but among women themselves.

Much of this theory has informed the current dissertation: that systems of

"Ioan Wallach Scott. Gender and the Politics of History (New York: Columbia Lniversity Press. 1988)

: These inroads of poststructuralist. feminist theory on the discipline are summarized by Ann-Louise Shapiro in "History and Feminist Theory: or. Talking Back to the Beadle," in Shapiro, ed. Feminists Revision Historv (New Brunswick: Rutgers Liniversity Press. 1994), pp. 1-23. See also McPherson. Morgan, and Forestell. eds.. "Introduction: Conceptualizing Canada's Gendered Pasts." Gendered Pasts, pp 1- | I 
meaning are used to signify difference and organize power relations; that 'patriarchy' is not fixed, monolithic, or transhistorical; that gender is constructed within specific historical contexts vis-a-vis other categories of meaning, and that all these categories shift and change over time, that there is no essential 'womanhood' but that other systems of meaning such as ethnicity, class, and religion intersect with gender to temper women's experiences and intorm relations between women, that certain groups have long been marginalized from the historical record because the discipline. itself, has served to reinforce power relations within society. My problem with poststructuralist approaches arises with their exclusive concentration on discourse analysis in retrieving understandings of the past. Discourse analysis has proved itself to be an effective method of shaking the tree of conventional wisdom. The danger. however, lies in abandoning experience altogether such that discourse, itself, becomes the sole focus of historical study. While it is useful and necessary to deconstruct language to understand the processes by which meaning is created, these systems still need to be contextualized by lived experiences - in terms of both the subjects and the objects of the discourse - in order to understand how these systems actually plaved out on the ground. Those writings that 1 have found to be most successful are those that find some balance between the two approaches and are able to demonstrate "the interaction of cultural discourses and material processes." ${ }^{3}$. Whether

${ }^{x^{2}}$ Anna Green and Kathleen Troup. eds., The houses of history A critical reader in twentieth-century history and theory (New York: New York Lniversity Press. 1999), p 258. The editors are referring here to a position articulated by both Mary Maynard and Kathleen Canning. 
deconstructing voices of hegemony or of resistance. the historian is best served by monitoring the interplay between rhetoric and reality

Thus, while poststructuralist theory has strongly influenced my thinking and preparation for this dissertation. I have not abandoned empiricism, for to do so would draw me too far away from the lives of the women I had hoped to incorporate into the historical narrative. Discourse analysis still channels the historian away trom understanding groups on the periphery. especially those from periods before the mid-19th century. because s/he must. of necessity, tocus on texts. And while the category of 'text' incorporates not just written words, but speeches, rituals, cartoons. films. photographs. and other cultural symbols - an inclusiveness that has opened wide avenues of exploration in working-class history. tor example. or more recent women s history some groups are still marginalized by the concentration. at least in terms of agency or subjectivity. Irish-Newtoundland women of the late $18^{\text {th }}$ and early $19^{\text {th }}$ century left few 'texts' in the historical record. Must they therefore be disregarded, other than as mere objects of the hegemonic discourses that attempted to shape their lives') Surely not. In order to find the Irish-Newtoundland woman as subject of the historical narrative. then. I have had to use her lived experience as 'text.' And in order to uncover this 'text, I have had to use empirical methods. with all the problems and limitations this entails.

My examination of the construction of Irish-Newtoundland womanhood, then. will be grounded in historical context and lived experiences as best as thev can be determined from available sources. I will examine (or deconstruct) the legal. religious. and middle- 
class discourses that attempted to set parameters for women on the southern Avalon: but I will also present evidence that these discourses were slow to intrude into the day-to-day life of plebeian culture. This is not to dismiss the effects of the persistent legal. social. and political discrimination which shaped the environment in which women moved Much insighttul literature has already been written in these areas and will be cited throughout this dissertation as background. But as Bridget Hill warns, it is important in women's history not to tocus only on patriarchal mechanisms by which women have been oppressed. tor such an approach distorts our understanding and " miss[es] the subtlety of the complex interaction of the many other factors" that have shaped women's lives. ${ }^{* 1}$ Irish-: Vewfoundland women on the southern Avalon did exercise a signiticant degree of authority at the local level and reached beyond the boundaries of the prescribed gender roles of hegemonic culture in myriad ways. It is this phenomenon I am most interested in exploring: how and why they deployed this power, despite increasing pressures from certain quarters to resign their authority. and how gender. ethnicity. class. and religion intersected within the context of family and community power relations.

These broader questions will underpin the discussion as a range of Irish women's experiences on the southern Avalon are examined in the following chapters: migration to and reception in Newfoundland; women's essential role in early community formation and

${ }^{\mathrm{xt}}$ Bridget Hill. "Women's history a study in change, continuity or standing still?" in Pamela Sharpe. ed. Women's Work: The English Experience 1650-1914 (London: New York: Sydney. Auckland: Arnold. 1998), pp. 42-58, particularly p. 55 
the transition to household production in the fishery: women and the sustenance of IrishCatholic ethno-religious identity; work and the sexual division of labour; informal power exercised by plebeian women in family and community. women's access to the formal justice system. women and inheritance practices: and attempts to regulate Irish female sexuality. A final chapter provides a brief overview of the lives of the other women on the southern Avalon - middle-class women of English descent - and observes the centrality of gender in middle-class tormation. Throughout the discussion, comparisons will be drawn with the experiences of other colonial and/or maritime women and with the lives of plebeian women who remained in rural Ireland.

\section{Sources}

When Akenson speaks of women in the Irish diaspora as "the Great Unknown." he urges historians to resist the temptation to reconstruct the past from bits and pieces of anecdotal evidence. calling for a systematic gathering of 'hard' evidence on women's migrations. ${ }^{\text {s }}$ Here, he demonstrates a lack of sensitivity to the dilemma that confronts

*s Intriguingly. having warned against over-generalizing from anecdotal evidence. Akenson then produces some blanket statements of his own. He tells us, for example, that various governments all over the English-speaking world wanted and encouraged temale immigration (see Primer, p. 174), a principle that certainly did not apply to the Newtoundland situation during the study period of this thesis (see Chapter 2). He represents his women immigrant "types," extrapolated on data primarily from New Zealand and from the period 1876-1920. as "a window on the entire history of female emigration" from Ireland (see Primer. p. 167) - surely, a rather broad stretch. He also claims that 
historians of women and other groups who have been marginalized by the keepers of the written record in earlier periods. If historians remain fixated on 'hard "evidence. the absence of these groups from the historical narrative may never be corrected. If we limit ourselves to studying only those who are more easily traced in order to ensure the certainty of our conclusions. we are in danger of losing large segments of our past.

Decades of pouring over statistical data have not lifted the veils of mystery from the history of Irish women migrants, and it is highly unlikely that a hidden stash of material lies waiting for discovery Nor would such a cache. if it did exist. necessarily provide us with an ideal picture of the past. As Akenson's own work often demonstrates by umission. ${ }^{\text {th }}$ qualitative material is necessary in order to contextualize and explain the phenomena that the quantitative data uncover. anecdotal evidence is needed to help us understand the specific dynamics that shaped specific movements and the particular meanings which migrants derived from their migration and early settlement experiences.

This thesis will present a blending of both. Several sources have enabled me to create a database from which 1 have extrapolated some basic quantitative information about Irish-Newtoundland women: source areas in Ireland. intermarriage and assimilation. the growth of permanent population. the transition to the family production unit in the

knowing about the Irish experience in one situation helps historians till in the holes in the data for other places - a make-shift assumption indeed for someone so bent on scientific rigour. Evidently. then. the sin of over-generalization is not limited to those historians who work with 'soft' evidence.

the notable exception is Akenson's Irish in Ontario. 
fishery, and the frequency of women's involvement in cour proceedings. petitioning, and inheritance practices. Most helpful in this regard have been the following: a privately held. extensive collection of name files on Irish immigrants to Newfoundland compiled by geographer John Mannion and his wife Maura from numerous primary sources in various repositories throughout the city of St. John's: governors' annual returns on the fisheries and inhabitants of Newfoundland in the Colonial Office [C O $] 194$ Series. of which microfilm copies are available at the Provincial Archives of Newfoundland and Labrador. St. John's [PANL] and the Centre for Newfoundland Studies at Memorial Lniversity [C.NS], a nominal census for Ferryland district for 1799-1800 commissioned by Governor Charles .M Pole [the Pole Papers], housed at the PANL. the court records of the southern districts of Ferryland and Trepassey-St. Mary's held at the PANL and the Provincial Reference Library. St. John's [PRL]: the Registry of Wills held at the PANL. which covers the period from 1824 onwards. the Mildred Howard Collection - an assemblage of vital statistic records from early Newfoundland newspapers. Newtoundland parish registers held at the PANL and the offices of the Neufoundland and Labrador Genealogical Society [NLGS], and the fledgling genealogical database in progress at the community museum in Ferryland [FMDB]. However, the collection and presentation of quantitative information has presented some difficulties. and several limitations must be noted. The problems with migration data in Ireland, for example, are echoed and magnified in the Newfoundland context (see Chapter 3) In addition. parish registers for the study area and period are not at all comprehensive (see the bibliography for a complete 
listing). They were introduced in particular parishes at different times, with the earliest Catholic records appearing in the 1830s. and the earliest Anglican. in the 1820s And even atter introduction, they were piecemeal - with births, marriages, and deaths covering different time spans even within specific parishes. Nonetheless, a comtoning number of earlier vital statistics for the southern Avalon appear in the Mannion Name File Collection - some from various sources in the late $18^{\text {th }}$ century and a substantial amount from the records for the Basilica parish (Catholic). St. John's, from 1793 onwards - and this material has helped to plug holes in my database. The court records also require qualification, for they are not complete. There are various temporal gaps. and while a system evolved whereby matters were entered under several heads - such as causes. writs. minutes, and judgments - rarely are the full set of records for any given case available (either they have not survived or they were never fully recorded in the first place). thus. one might tind the writ and minutes of an action, for example. but not the final judgment. or the judgment may be given without particulars of the case. The minutes. themselves. are not court transcripts. but summary descriptions. and the degree of their thoroughness depended on the ability. energy, and interest of the court clerk on any given day: surprisingly, some of the most detailed minutes were provided for hearings in the $18^{\text {th }}$ century. Still, the court records provide a broad range of cases to work with and a rich lode of evidence on women of the study group 
Anecdotal evidence in general is more readily available ${ }^{x 7}$ - although sometimes the absence of women in the sources is as eloquent as their presence. Again, the court records for the area provide a wealth of material on Irish-Newfoundland women. Less inclusive but still useful in terms of discerning official attitudes towards the study group is government correspondence tor the period. The C O 194 Series encompasses the correspondence of various governors at Newfoundland with the Colonial Office. The PANL also contains the papers of specific governors of the period - John Duckworth and Thomas Cochrane - as well as copies of local incoming and outgoing correspondence of the governor's office as recorded by the local colonial secretary. Catholic clergy at Newfoundland frequently commented on the state of religion and social conditions they found on the island. with occasional references to women included In this regard. the collection of letters of early bishops and missionaries compiled and edited by Cyril Byrne has been very useful. ${ }^{* x}$ as have the papers of Bishops O Donel. Lambert. Scailon, and Fleming and a notebook penned by Dean Cleary. parish priest of Witless Bay, all housed at

${ }^{27}$ A more comprehensive listing of primary sources appears in the bibliography. In quoting these various primary sources, I have tried to preserve their period ambience without imposing modern-day standards of spelling or grammar. In quotations, original (and sometimes conflicting) spellings. abbreviations. punctuation. and capitalization are maintained as much as possible and without the use of " [sic] " Very occasionally. I have tilled in missing letters in square brackets or provided minimal punctuation for the sake of clarity. But for the most part. I have tried not to intrude in the style and cadence of the original.

${ }^{*}$ Cyril J. Byrne, ed. Gentlemen-Bishops and Faction Fighters: The Letters of Bishops O Donel, Lambert, Scallan and other Irish Missionaries (St. John's: Jesperson Press. 1984). 
the Roman Catholic Archdiocese Archives, St. John's [RCAASJ]. The collection of papers of the Society for the Propagation of the Gospel in Foreign Parts [SPG], available on microfilm at the PANL, helped in tracing the assimilation of the English-Protestant population in the study area into the Irish-Catholic ethno-religious group. In addition. the published writings of several $19^{\text {th }}$-century clergymen on the island - Michael Howley. Lewis Anspach. and Charles Pedley - lent some insights to the perception of the Irish at Vewtoundland." Early Newtoundland newspapers housed at the C.NS and P.ANL provided information about the horrors of the passenger trade from Ireland to Newfoundland. a perspective that was balanced by the more mundane descriptions of 'vew Ross merchant Edward Kough in his letterbook. housed at the Maritime History Archives. Memorial Lniversity [MHA] A number of other manuscript collections were mined for information on women: the papers of merchant firms. Alan Goodridge and Sons (operating out of Renews) and Saunders and Sweetman (operating out of Placentia, with dealers in St. Mary's Bay and Trepassey), both at the P.ANL. were helptul in examining women's participation in the exchange economy of the area, and the Carter Family Papers. the Carter-Benger-Nason Papers, and Mary Ann Simms Scrapbook (all available at the PANL) as well as the diary of $19^{\text {th }}$-century magistrate Robert Carter (housed at the PANL

\footnotetext{
"See: Rev. Lewis A Anspach, A History of the Island of Newtoundland (London. Anspach. 1819), Rev. Charles Pedley. The History of Newtoundland (London: Longman. Green. Longman. Roberts and Green. 1863): and Rev Michael F. Howley. Ecclesiastical History of Newfoundland (Boston: Doyle and Whittle. 1888; reprint Belleville. Ont.: Mika Publishing, 1971)
} 
and the Ferryland Museum, with a partial typescript version at the MHA) revealed the gradual incursion of middle-class feminine ideals on gentry women living in the study area.

As can be seen, however. most of this anecdotal evidence derives from middleclass administrators, churchmen, newspaper editors, and merchants. What are missing are the voices of the women, themselves. If any women's journals from the period have survived, they are not contained in public repositories (other than the poetic outpourings of Mary Ann Simms and her friends in her scrapbook, noted above). Indeed. if any women's diaries or journals existed at all. their authors were likely middle-class women. not the Irish plebeian women who are central to this study. (This was certainly the case of women's diaries in (anada in general. ${ }^{\text {*s) }}$ ) A small amount of correspondence written by middle-class women of the period has survived, providing insight into their experiences and sharpening the contrast between middle-class and plebeian culture: these include the letters written to the mother convent in Ireland by the first Presentation sisters to come out to Newtoundland. available at the Presentation Convent Archives at the Mother House, Cathedral Square. St. John s [PC.A], and some letters written by Harriet Carter at

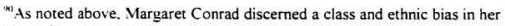
examination of Maritime women's diaries. Similarly, in her bibliography of the women's diaries written in English and available in public repositories in Canada. Kathryn Carter observes a "systematic bias" in the collection in that they reflect the experiences of white middle-class women of British or European ancestry. many of whom were associated with men or events deemed historically significant within traditional historical paradigms. See Kathryn Carter. Diaries in English by Women In Canada, 1753-1995: An Annotated Bibliography (Ottawa: Canadian Research Institute for the Advancement of Women. 1997). p. 7. There is also a temporal bias in the collection from the mid-19th century onwards. 
Ferryland to her relatives in England, part of the Carter Family Papers housed at the PANL. But there are no surviving writings of Irish-Newfoundland women from plebeian culture of the study area and period. Most of these women would not have had the luxury of time. or likely the necessary writing to skills. to correspond or maintain journals, those pernicious silencers, time and illiteracy, have muffled the cadences of their daily lives

Because I am attempting to reconstruct the past of a group so muted in the written record. I have used the oral tradition in the area to help flesh out information I tound in documentary sources. Although this approach has gained considerable legitimacy as a means of retrieving the history of marginalized groups, it still requires justification in some quarters Indeed. with its increasing use by the academy in the 1960s and 1970s, the tield quickly came under attack from traditional documentary historians. who warned of the indiscriminate use of oral evidence at face value Memory was unreliable. they argued. subject to the distortions of time and age, personal bias, and the impact of retrospective interpretations of the past. Oral historians countered with arguments that traditional documentary sources were also selective and biased, furthermore, they channelled thinking towards traditional methodologies and categories of understanding. thus reinforcing the continuing exclusion of certain groups from the historical narrative. The result for women's history. as Katherine Jensen noted. was that "Questions about women's lives [had] consistently fallen between the cracks of disciplinary conceptual frameworks. time 
periods, and territorial boundaries ${ }^{\cdots+n}$

In response to concerns about the 'accuracy' of oral history. an effort was made to lend 'scientitic rigour' to oral evidence: methodologies were devised to measure bias in oral evidence, to quantify oral responses and codify the results. to corroborate oral testimony with written sources By the 1980 s, however, theorists were realizing that the subjective elements of oral history were not necessarily methodological flaws. Distortions and lapses in memory could actually provide insight, not distraction, from understanding. Practitioners were urged to deconstruct memory - to understand the process of remembering, itself, the link between memory and identity, and the significance of memories to individuals and cultures. But as memory has become an object of study in its own right. the original. democratizing intention of using oral history to retrieve information about the past of minority groups seems to have faded trom view. As oral historian Alistair Thomson has observed, some practitioners "have lost sight of oral history's aims of recovering unrecorded histories and empowering the silenced witnesses of history $^{\cdots 12}$ Or as Michael Frisch has noted rather than using theory to help interpret

\footnotetext{
"Katherine Jensen. -Oral Histories of Rural Western American Women: Can They Contribute to Quantitative Studies?" International Journal of Oral History, 5:3 (November. 1984). 159-67: quotation from p. 160.

"Alistair Thomson. "Tales of the Century: Biennial National Conference of the Oral History Association of Australia, 2-5 September 1999. State Library of Victoria. Velbourne," Oral History, 281 (Spring. 2000), 25-7, quotation from p. 27.
} 
experiences, the experiences are being used to help make sense of theory. ${ }^{33}$

The use of oral history in this thesis harks back to the original aim of recovering the history of a marginalized group - in this case. sidelined by gender. ethnicity. region. and class. This is not to dismiss the importance of the subjectivity of memory, and. indeed. a study of the retrospectivity of collective memory and the way in which Irish migration experiences to the southern tvalon have been imagined and remembered over time. how it contributes to cultural identity in the present, would be a worthwhile project But it is not the focus of this work. The current effort is to understand how migration and early settlement were experienced by women of a particular socio-economic and ethnic group on the southern Avalon. Certainly. oral history has been used effectively in other migration studies. Of course, most practitioners have actually been able to interview the emigrant generation as well as succeeding generations about the meanings ascribed to their experiences, the construction of ethnic community identity. cultural continuities. displacements. and transformations, and inter-generational tensions ${ }^{14}$ Interviewing

${ }^{133}$ For a discussion of some of the debates in the field. see: Alistair Thomson. Michael Frisch. Paula Hamilton, "The Memory and History Debates: Some International Perspectives." Oral History, $22: 2$ (Autumn. 1994). 33-43; Jensen. "Oral Histories". Rebecca Sharpless. "The Numbers Game: Oral History Compared with Quantitative Methodology." International Joumal of Oral History, 7:2 (June. 1886). 93-108: Selma Levdesdorff. Luisa Passerini, and Paul Tompson, eds. Gender and Memory, International Yearbook of Oral History and Life Stories, vol. IV IOxford: Oxford Liniversity Press. 1996): and Green and Troup, eds.. The houses of history, pp. 230-8.

${ }^{24}$ See, tor example. Alistair Thomson, "Moving Stories: Oral History and Migration Studies," Oral History, 27:1 (Spring, 1999). 24-37. 
informants about the more distant past. of which they were not actually 'eye-witnesses but rather receivers (and adaptors) of collective cultural memories of the process is another matter. Still, it has been done with some success. especially in terms of fleshing out historical context. Folklorist Gerald Pocius. for example, has relied on collective historical memory in recreating the landscape of cultural space, past and present, in Calvert ${ }^{1 / 2}$ Ethnohistorian Thomas Nemec has also emploved oral history effectively, in combination with other sources, in reconstructing the history of two communities on the southern Avalon * He argues that oral history. or 'memory culture.' is not only a useful approach in retrieving the distant past of rural communities, but is actually less likely to produce the multiplicity of versions more frequently encountered in interviews about the more recent past." Similarly, Margaret MacKay has used contemporary oral evidence as well as documentary sources in her reconstruction of three $19^{\text {th }}$-century Hebridean immigrant settlements in Ontario. Indeed. MacKay insists that her task would have been impossible without the use of oral material - some of it relating to events that were 150 years old. She says

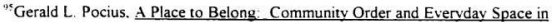
Calvert. Newfoundland (Athens: London: University of Georgia Press. 1991).

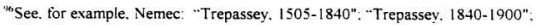
and 'An Ethnohistorical and Ethnographic Study of the Cod Fishery at St. Shott's. Neufoundland" (Ph.D. Thesis. University of Michigan. 1980).

${ }^{n 7}$ Nemec. "A Multi-disciplinary Approach to the Reconstruction of the Historv and Culture of Rural Populations: A Newfoundland Example." in Neil V Rosenberg. ed. Folklore and Oral History (St. John's: Memorial University. 1978). pp. 51-6. 
Although relevant documentary material, much of it statistical, does exist, it is only in the light of orally-transmitted information, largely family lore and tradition, that it can be used most effectively. Some themes are obscure or virtually impossible to extract from the written records... Furthermore. many subjects of vital importance to an understanding of any community and how it functioned in the past are not touched upon at all by the documents... [for example] the importance of kinship links and neighbourhood ties to their inhabitants, their values and ways of expressing these in work and relaxation, their language, their cultural life both traditional and creative. their customs and beliets, their religious practices. their knowledge of particular skills and processes, as well as aspects of the everyday round and details of their economic life which the statistics merely hint at. ${ }^{3 x}$

Like MacKay, I could not answer all the historical questions about my study group merely through an examination of available written records and have found the oral tradition invaluable. not just in uncovering the rhythms of daily and seasonal routines, but also in constructing the cultural backdrop of these women's lives. and in provoking insights about understandings of Irish-Newfoundland womanhood that would never have emanated trom documentary evidence alone.

Granted. the way in which intormation from the distant past has been remembered over generations may tell as much about the evolution of a migrant culture or the construction of modern-day ethnic identity as it does about the migration experience itself It does not logically follow, however, that because such oral evidence tells us much about

"Margaret MacKay, "Nineteenth Century Tiree Emigrant Communities in Ontario," Oral History, 9:2 (Autumn. 1981), 49-60: quotation from p. 59. Mackay is writing about the research she conducted with Eric Cregeen in the $1970 \mathrm{~s}$ in relation to the history and traditions of Tiree communities in Scotland and $\mathrm{Canada}$. 
the present. it can tell us absolutely nothing about the past. I have, therefore, used oral testimony and treated it like all my other sources - trying to ascertain bias or hyperbole. and looking for corroboration (either oral or documentary) when available. Occasionally. the oral evidence roughly corresponds with the written record. which will placate traditional documentary historians (although missives begrudgingly penned by frustrated colonial civil servants and irate priests require caretul scrutiny as well, and I could just as easily state that the oral tradition corroborated the documentary evidence in these cases) If the material presented comes from the oral tradition, alone. $I$ identifv it as such. Information introduced in the thesis with phrases such as "according to the oral tradition" meet the following criteria the majority of my informants have provided me with the same intormation, and it passes the common sense test - i.e.. the crux of the material (minor hyperbole need not discredit the entire anecdote) makes sense within the context of other information I have gathered. I also use material provided by only one or two informants if it passes the 'common sense' test, but I specify the more individual nature of' the memory in the text or by footnote to differentiate it from broader collective historical memories. This lack of corroboration. however. does not diminish the significance of individual renderings in my eves. Like Samuel Schrager. I acknowledge my oral informants to be "bearers of truth" in their telling of oral history in the sense that they are providing an interpretation (not necessarily a literal transcription) of processes or events based on their best understanding and knowledge of the matter. tempered by what they teel is significant and worth repeating to the interviewer. In this regard. there is a marked 
difference in their attitude towards the retelling of oral history and their retelling of a legend or tall tale." With the retelling of their past, there is a deep-seated feeling that the information they are imparting is important: they want to 'get it right'. and they want the historian to 'get it right' as well. ${ }^{(1)}$ And if there has been some refashioning of material in the process, so has there been in all historical accounts - written or oral, past or present. As Selma Leydesdorff et al. point out. "... no history reaches us unmediated. "1111

The oral testimony presented here is drawn primarily from interviews conducted from 1999-2001 with 21 male and temale informants from seven communities in the study area - Brigus South, Cape Broyle, Calvert. Ferryland. Renews. Trepassey, and St. Mary's. ${ }^{102}$ The informants were advised of the general subject areas to be covered in the interview either in an advance meeting or by correspondence. A questionnaire with broad.

"Samuel Schrager. "What is Social in Oral History" International Journal of Oral History, +2 (June. I983). 76-98, particularly page 78 In only one interview did I feel that the informant was not making this distinction, and I have used his information minimally and with due caution.

${ }^{10(1)}$ I I am aware. here. of my own participation, as interviewer. in the processes of collective historical memory - in selecting particular memories that I wished to explore and the effect that this may have on the way the material will be remembered and retold in the future.

twi."Editors" Introduction" in Leydesdorff. Passerini, and Tompson, eds . Gender and Memory, p. 12.

${ }^{102}$ Several of the interviewees had moved from their home communities in adulthood. but all had spent their childhood and early adulthood on the southern Avalon and all have roots in the plebeian fishing community of the area. Because a number of them did not wish to be identified. I refer to all informants throughout this dissertation by initials only. 
open-ended questions was used in the actual interviews (see Appendix B), but only to give the interviews shape and flow, certainly not for statistical purposes. The interviewing process itself was as interactive and open as possible. My original intent was to taperecord as many interviews as possible; however, most informants - indeed. all the women interviewees - were quite dismaved by the sight of the recorder, and in order to maintain a more relaxed and productive atmosphere, I resorted to careful note-taking only ${ }^{10,3}$ As I was seeking historical context rather than personal narratives, this method was not problematic. As a result, however, the only direct quotations that appear in the thesis are short, and I have only employed those of which the accuracy of the wording 1 am certain. This recent interview material has been supplemented by oral material which I gathered as an under-graduate in the early 1970 s (see Bibliography). as well as by a small amount of material collected in the study area by other interviewers, housed at the Memorial Lniversity of Vewfoundland Folklore and Language Archive [MLNFLA], and several undergraduate student papers using oral history (including one of my own) that were prepared for anthropology. geography, or history courses in the 1970 s and are available at the MH.A.

One final note must be made in relation to the paucity of Irish primary sources in my bibliography. This dissertation would have been far richer with their inclusion. Lnfortunately, time and financial constraints mitigated against my conducting research in

${ }^{103} \mathrm{All}$ interview notes will remain in my possession. 
Ireland. While there is a substantial Irish newspaper collection at the CNS, it did not prove to be a useful source of information about Irish-Newfoundland women. ${ }^{114}$ There is also a collection of parish records from the southeast of Ireland available at the MHA. but the extensive demographic work involved in using such a source would have required quite a different methodology and focus than the current project. The only other Irish source utilized to any degree herein is the copy of the Edward Kough letterbook at the MH. noted above.

\section{Study area}

The parameters of the study area also require some qualification. Although 1 have detined the 'southern Avalon' as extending along the coastline from Bav Bulls on the Southern Shore to Dog Point in St. Mary's Bay, the reader should be advised that the boundaries of the study area sometimes contract with the accessability or organizational peculiarities of the sources and the exigencies of time and the researcher's resources.

All anecdotal information for the entire area was considered for inclusion in the thesis. Much of the quantitative data - including material on source areas, population growth. intermarriage and assimilation. and the transition to the family production unit -

${ }^{\text {ta }}$ Several Irish newspapers, as listed in the bibliography, were spot-checked. with a particular focus on periods when migration traffic to Newfoundland was heavier No useful information for the dissertation was found. and thus this potential source was set aside to pursue more promising avenues of exploration. 
also relate to the entire study area. However, it became necessary to rein in the scope of research in relation to two major sources for the thesis: the court records and the oral tradition. By an organizational quirk of the court system, the portion of the study area trom Bay Bulls to Toad's Cove (now Tors Cove) was included within the jurisdiction of the central district of St. John's (although it was, more logically, included in Ferryland district in the electoral divisions that accompanied self-government in the 1830 s). The collection of records for the central district court is massive, including as it does the numerous cases and estate matters emanating from the colony's capital. Most of the material is not indexed. and thus wading through it to find cases from Bay Bulls to Toad's Cove would have been tar too time-consuming for the anticipated return and a task not manageable within the scope of the current research. Therefore. only those cases mentioned in governors" correspondence or the Mannion Name File Collection tor that section of the shore have been included in the database for this thesis (and when Mannion provided specific references, the original court records were also checked). The exigencies of time. limited finances. and accessibility also dictated that the oral history component of this project be restricted. I therefore chose to carry out interviews in the same area as that covered by the court records - opting for depth of research rather than breadth (a decision that was reinforced by my stronger contacts on that part of the shore). This makes the coverage of the area from Brigus South to St. Mary's more comprehensive than that of the segment closer to St. John's. I am confident, however, that extended research on the Bay Bulls-Toad's Cove section would reveal more similarities than 
differences in the experiences of Irish-Newtoundland women within the overall study area.

\section{Transition}

In the current historiography on early Irish migrations and settlement. Irish women are shadowy tigures. They speak to us in sighs and whispers only from footnotes and after-thought chapters - mere helpmates to male migrants who are presented as the active shapers of new world experiences. This dissertation will attempt to retrieve at least one group of these Irish women - the multi-generational group who settled in the southern Avalon up to the mid- $19^{\text {th }}$ century - from the periphery of the record on migration and community formation. Hopefully. it will encourage the custodians of the historical narrative - oral and written - to tind a more gender-inclusive way of recounting early European settlement in Newtoundland than the conventional " $T$ wo brothers came out trom Ireland or England..." 


\section{Chapter 2 - The slender thread cast off: Migration and reception at Newfoundland}

When Michael and Mary Ryan were coming from County Wextord Ireland to Nfld. their first child was born at sea. It was the year 1826. the boy was named Thomas Ryan... Michael Rvan ... was drowned near Petty Harbour Motion. in the year 1835 on a sealing voyage. His wife Mary Ryan was left with 3 three young children. Thomas who was born at sea. Michael and Thimothy Ryan. After some years Mary Ryan married again. Edward Coady also a native of County Wexford. They had a family of 2 sons and $\mathrm{I}$ daughter... They have many decendents at Cape Broyle. many places in Canada and also in the United States.

These homespun words, transcribed from the oral tradition by an elderly community historian in 1971. provide a skeletal story of an Irish woman who came to Cape Broyle on the southern Avalon in the early $19^{\text {th }}$ century. It is a sparse and piainspoken chronicle of her life. but Mary Ryan's story could be the stuff of movie directors

'James Joseph O'Brien. "Cape Broyle" (Linpub. chronicle of the old families of Cape Broyle. (971), pp. 6-7. Jim Joe was a repository of the oral tradition and the acknowledged community historian of $\mathrm{C}$ ape Broyle during his long life-time. In his $70 \mathrm{~s}$. he began to transcribe much of the information he had accumulated about the community and individual families who had settled there. His writings. when compared with more traditional historical sources such as the Pole Papers at the PANL, are amazingly accurate. In terms of the Ryan family. similar intormation appears in the FMDB. File 02B (Morry and Carter Families), notes on Coady family tree, with the following exceptions: Mary's name appears as Margaret: Michael Ryan is said to have died in 1830. not 1835: and the remarriage to Edivard Coady is said to have taken place in 1832. not post-1835. This latter version corresponds with reports of the loss of the sealing schooner ('onficience off Petty Harbour Motion in 1830: see Shannon Ryan. The Ice Hunters: A History of Newfoundland Sealing to 1914 (St. John's: Breakwater, 1994). pp. 285-6. Local newspapers reveal no sealing disasters in 1835 , although this does not rule out the possibility of an individual drowning. Regardless of the finer details, however, the essence of the Ryans' experience remains the same in both retellings. The FMDB file also notes that the Ryans and Edward Coady had initially come out together from Wexford. 
dreams. A young Irish woman leaves her home in Wexford to accompany her husband on a perilous journey that will bring her to a landscape and lifestyle quite different from those of the green tarmlands of her home country. There has been some urgency in their leaving, for Mary is well into her pregnancy upon departure, and the trans-Atlantic crossing, difficult at best. will be a dangerous venture tor a woman about to give birth. Perhaps they are responding to economic recession or land shortage. Almost certainly. they have heard of the potential tor earning a livelihood in the Newtoundland fishery And so they leave. despite Mary's condition. and somewhere on the heaving mass of the Vorth Atlantic, she gives birth to a boy named Thomas. Despite the primitive conditions on board the passenger vessel. she and her newborn son both survive the journey. The Rvans begin to carve out a living in the Newfoundland fishery, supplementing their living with subsistence farming - all that is possible in the short growing season and the rock-strewn soil of the southern Avalon. Michael also finds winter employment in Newtoundland's second industry, the seal fishery. Then tragically. he dies on a sealing voyage, leaving Mary with three young bovs to raise on her own. Still. she remains in her new home and eventually remarries Mary and her new husband. Edward Coady. another native of Wexford. go forth and populate the new world.... [and fade to finish].

The narrative of Mary Ryan's journey to the southern Avalon can easily be burnished with dramatic gilt. A more difficult task is to determine how much of the story is representative of the experiences of other Irish emigrants to the study area. Certainly. when Michael and Mary Ryan left county Wexford in 1826 to come to the southern 
Avalon, they were not venturing into the great unknown. Irish-Newfoundland trade connections had been forged long before, and news of living conditions and emplovment opportunities in Newfoundland would surely have permeated all but the most hidden villages of southeast Ireland. Indeed, it is not only possible, but likely that Michael had already been out to the southern Avalon, the Pole Papers list a Michael Ryan as a 'dieter' in Cape Brovle in the winter of $1799 / 1800$ and a fishing servant of John Mackev in Brigus South the following summer." Perhaps Michael had participated in the Newfoundland fishery from his teenage years and was now a man in his forties, coming out to Newtoundland with his younger bride (a common marriage pattern along the southern Avalon in the period). Or perhaps he was a son or other relative of an earlier Michael Ryan who had been involved in the fishery. More assuredly, the Ryans were part of a larger swell of Irish emigrants who came to Newfoundland in the period 1825-1833 And this movement was, in turn, part of an extended period of Irish migration to Vewfoundland dating back to at least the late $17^{\text {th }}$ century

Vice-Admiral Charles M. Pole was Governor of Newfoundland in 1800 and 1801 . He commissioned a nominal census of Ferryland district which was carried out by local magistrate Robert Carter. The census details the names of families. fishing employers. tishing servants, and 'dieters' (servants who remained in Newtoundland beyond the fishing season, without contracted employment, and worked for the planters for bed and board) who were resident in the district in the winter of 1799-1800 and/or the tollowing summer of 1800 . 


\subsection{Early migration}

Early nominal census material. haphazardly recorded in the crabbed hands of British naval officers stationed at Newfoundland, indicates a strong English presence on the southern Avalon in terms of planter families by the late $17^{\text {th }}$ century ${ }^{3}$ - the demographic outgrowth of a West of England-Newfoundland fishery that was almost two centuries old. But the naval officers also enumerated servants working tor the planters. and although ethnicity was not revealed in the records. certainly an Irish element had crept into this migration stream - an element that included Irish women, for as early as 1681. Captain James Story made the following marginal note in his accounting of the fisheries and inhabitants in Newtoundland

The trade of Irish to Newtoundland is all sorts of frises, linen cloath. candles, cloath Hatts, shooes, stockens, beefe, porke, bread, butter. cheeze $\&$ all sorts of small merch'dise. there returnes for it are tish. they like wise bring over a great many women passengers $w^{\text {th }}$ they seil for serv $\&$ alittle atter theire coming they marry among the fisherman that live with the Planters....

'See, for example: MHA. Keith Matthews Collection. 16-C-2-035. Sir John Berry, "A list of ye Planters Names with an acct of their Concerns from Cape de Race to Cape Bonavista." September 12. 1675 (from C.O. 1/35 [17ii], ff. 149v-156): PANL. GN 2/39/A. Berry Census. 1675 and 1677 (from C.O. 1), and MHA. R 95/20. "List of Inhabitants' Names. the No of Their Families, 1708" (trans. from C.O 194/4, If. 253-56. by W Gordon Handcock)

${ }^{4} \mathrm{MHA}$. Matthews Collection. 16-D-1-006. Capt. James Story. "An account of what fishing ships. Sack Ships. Planters \& boat keepers from Trepasse to Bonavist $\&$ trom 
But while there were some Irish vessels trading at Newfoundland. ${ }^{5}$ initially. the primary carriers of Irish "passengers ${ }^{* 0}$ to Newfoundland were vessels from the West of England. Certainly by the late $17^{\text {th }}$ and early $18^{\text {th }}$ centuries. fishing ships from north Devon ports (Bideford and Barnstaple especially, but also Appledore and Northam) were regularly stopping at southeast Irish ports for cheap salted provisions and labour. In 1720 . British naval authorities at the island noted the "great numbers of Irish roman Catholick servants, who all settle to the southward." ${ }^{.7}$ At this time. however. the migration to Newtoundland was largely temporary: for while the fishery at Newfoundland had both a migratory and a resident component." the majority of fishing servants. regardless of which

thence to faire Island the Northward part of Newtoundland." September 1. 1681 (from C O. $1 / 47$ [52i]. If. $113-121 v)$.

'In 1679. two years previous to Story's account. for example. five sack ships from Ireland (three from Waterford. one from Youghal, and one from Dublin) had been reported in Vewfoundland In 1715.20 vessels from Ireland were reported by local naval officers. See Head. Eighteenth Century Newtoundland, p. 86.

'Initially, the term 'passenger' in the Newfoundland context referred specifically to fishing servants brought out for employment in all branches of the tishery. But certainly by the latter half of the $18^{\text {th }}$ century. a number of 'passengers' were coming out to Newtoundland with the hope of settling there

Head. Eighteenth Century. Newfoundland. p. 89 (quoting Calendar of State Papers. Colonial, 1720. p. 178).

'The traditional ship fishery at Newfoundland consisted of large vessels that transported smaller boats and large crews to Newfoundland each spring for the fishery. returning to home ports at the close of the season in the fall A resident sector was also carried out by inhabitants who remained on the island in the wake of official colonization attempts and fishing personnel who opted to stay in Newfoundland for the longer term 
branch they served, returned home after the period of time contracted by their 'shipping papers" (usually a summer. or two summers and a winter. but occasionally longer terms). Even many planters (still a predominantly English group in the early $18^{\text {th }}$ century) would eventually return to their home country to pursue other work or retire.

But wartime conditions wreaked havoc on the West of England-Newfoundland trade. particularly the migratory sector, and wartime was almost continuous in the latter half of the $18^{\text {th }}$ century ${ }^{\text {to }}$. North Devon's traffic collapsed during the Seven Years War. but its role in the Irish passenger and provisions trade was assumed by ports in south Devon and Poole in Dorset. At the same time, the Irish migration stream swelled as increasing numbers of Irish fishing servants filled the void left by English servants who had either been pressed into naval service or had moved inland to avoid roving press gangs After the war, some merchants in southeast Irish ports - especially Waterford. but also Ross and Youghal - developed an independent trade with the southern Avalon and Burin.

By the middle of the $17^{\text {th }}$ century, the bye-boat fishery had also developed: byeboatkeepers kept their fishing shallops in Newfoundland. while they and their small crews travelled to and from Newfoundland each season as passengers on the larger fishing ships There were variations in pattern as well as interchanges of personnel between the ship. bye-boat. and sedentary fisheries. All three sectors tished inshore in the $17^{\text {th }}$ century. A bank. or offshore. fishery did not develop until the early $18^{\text {th }}$ century. See Matthews. "West of England-Newfoundland Fishery". and Head. Eighteenth Century Newfoundland

"A written contract that outlined the terms of employment. such as type of work. length of employment, and compensation.

${ }^{\text {to }}$ For a comprehensive examination of the impact of wartime conditions on fishing and trade. see Matthews. "West of England-Newfoundland Fishery " 
and these ports and their hinterlands would become a major source area for Irish emigrants to the study area (and to Newfoundland in general). Other southern Avalon Irish initially entered through the port of St. John's. attracted by its increasing commercial activity and potential for employment - ultimately wending their way southwards from the town (mirroring a similar diaspora to the northwards into Conception Bay)."

\subsection{A "notoriously disaffected" and "Wicked \& Idle People" Early reception}

Meanwhile, as the $18^{\text {th }}$ century unfolded. British authorities at Newfoundland watched the growing numbers of Irish migrants with levels of concern ranging from wariness to near-hysteria In March. 1702. in the midst of Anglo-French hostilities which had manifested in local confrontations between the French at Placentia and the English along the English Shore. ${ }^{12}$ authorities charged that several French and Irish Catholics at

\footnotetext{
"See the various writings on Irish migrations to Newfoundland by Mannion.
} Nemec, and Matthews cited in Chapter 1 . In relation to the Irish fanning out from St John's. Mannion and Maddock say that St. John's especially became a major port of disembarkation for all Irish passengers to Newfoundland from 1800 onwards: see Mannion and Maddock. "Inistioge Immigrants." pp. 346-7.

"The fishery at Newfoundland had initially been an international tishery. involving English. French. Spanish, and Portuguese vessels. While the fishermen of other countries salted their catch and brought it home in a 'green' state. the English developed a lightly salted cure that required shore space for drving. The English Shore' was that part of the east and southeast coast between Cape Bonavista and Cape Race where English fishermen traditionally cured their fish: it would eventually become the site of initial settlement by people from the British Isles. 
St. John's were "spyes. corupting \& debauching his Majos Servants. and other his subjects to desert their Service and bring in a French power. ${ }^{-13}$ That autumn. several principal inhabitants of the town requested that the naval commodore ban the hiring or entertaining of "any foreigner or Roman Chatholick" without the permission of the commanding officer at Fort William. ${ }^{14}$ In 1705. the naval officer at St. John's articulated a theme that would echo throughout the $18^{\text {th }}$ century and into the next:

That $C$ are may be taken of the Irish residing in the Country for they by our daily Experience have proved very detrimental to the Governm ${ }^{t}$ hereof for when the Enemy makes any Incursion upon us they doe take up armes and informe our Enemy and prove very treacherous and our greatest Enemy. 15

In 1738. Captain Van Brugh (Governor. 1737-38) fired a similar volley

The most material and universal complaints are against the great numbers of Irish Roman Catholics yearly brought into Newfoundland. and remain the winter season. to the very great prejudice of His Majesty's Protestant subjects. who dred the consequense that may attend them in case of war: and humbly beg their case may be laid before vour lordship

${ }^{17}$ MH.A. MF-105. Letterbook of Capt. Michael Richards. Commander at Fort William. 1700-1703. ff. 134-55. Hearings at Fort William. March 9-12. 1702.

${ }^{14}$ MHA. MF-105. Richards Letterbook, ff. 215-7, "Request to $y^{4}$ Commodore Leake." September 20. 1702.

${ }^{15}$ C O 194/3. If 424-5. particularly f 425. Remarks of Naval Officer Cummins in relation to Newfoundland. 1705 ? (n d.. but received at the Colonial Office via the House of Commons February 25. 1706). 
that a method may be found to prevent such imbarkation in Ireland. ${ }^{16}$

As the numbers of Irish arriving in Newfoundland increased, so too did official concerns about their loyalty to the crown. By 1749. Governor Rodney was warning the Colonial Office that the Irish Roman Catholics in Newfoundland were not to be trusted ${ }^{1-}$ The following year. Governor Drake wrote in a similar vein that the Irish "are notoriously disaffected to the government, all of them refusing to take the oath of allegiance when tendered to them. ${ }^{-18}$ The southern Avalon, with its growing numbers of lrish wintering over, was seen as one of several potential breeding grounds of Irish treachery ${ }^{(5)}$ In Governor Drake's warning missive. tor example. he specifically drew the Colonial Secretary's attention to the fact that "The majority of inhabitants to the Southward of St. John's are Papists .... ${ }^{\text {st }}$ During the American Revolutionary War, a petition to Governor Montague from the merchants and principal inhabitants of Renews, all of them members of

1"MH.A. Matthews Collection, 04/058. Coll. 24. Box 9. Sub-series 04-056/01. File 25-B-2-1. Capt. Van Brugh to Commissioners for Trade, November 6. 1738 (transcribed trom C O 194/10. ( 93)

${ }^{17}$ Raymond J, Lahey. James Louis O'Donel in Newfoundland 1784-1807. The Establishment of the Roman Catholic Church, Shannon Ryan and G. M. Story, eds. (St. John's Newfoundland Historical Society. Pamphlet No. 8. 1984), p. 5.

${ }^{18} \mathrm{C}$ O 194/25. ff 107-111. particularly f. 110. Governor Francis Drake. Answers to the Queries Contained in His Majesty's Instructions," November 22. 1751

"Other areas of particular concern. because of their significant Irish populations. were Conception Bay and St. John's.

${ }^{20}$ C. O. $194 / 25$, f 110 , Drake, "Answers." 
the English ethnic group. stated that despite depredations committed by American vessels along that shore, "we are more in danger from some of them [Irish inhabitants], than from the Americans, as they are determined to plunder the Stores $\&$ turn Rebels. "Il That same year. Governor Montague admonished the people of Ferryland district in general for their refusal to assist in defending the interests of the crown along that coast from enemy vessels: $:$ In 1800 , when the failed United Irish rebellion of 1798 sparked a mutiny amongst Irish troops in the Newfoundland Regiment at St. John's, concerns were again expressed about the disaffection of the Irish population, hundreds of whom were thought to be involved in a larger plot to murder British authorities. merchants, and their supporters on the island. Again, particular concern was expressed about the southern Avalon. Debrieting Governor Waldegrave of the episode. Surrogate and Deputy Vaval Officer (later. Chief Justice) John Ogden reported

we knew not who we could depend upon tor support in case of resistance. having every reason to believe the defection was very extensive not only through the Regiment. but through the Inhabitants of this and ail the Out Harbours. particularly to the Southward almost to a Man have taken the Linited Oaths... it would be absurd to suppose it might not take place again ... the security of Trade and Fishery, nay the security and salvation of this Island itself will entirely depend upon a proper Military Force [of $800-1.000$ men] at this place, with sufficient strength to afford

"P.ANL. GN 2/1/A. 7-reverse end/96-8/1778, Petition from the merchants and principal inhabitants of Renews to Governor John Montague, July 29. 1778.

"-PANL. GN 2/1/A. 7-reverse end/159-60/1778. Governor Montague to Robert Carter. Magistrate. October. 1778 
small detachments to some of the Out Harbours to the Southward to watch their motions, and assist the magistrates when necessary ${ }^{23}$

Traditional fears that England's difficulty would prove Ireiand's opportunity had carried from the old world to the new.

Otficial discourse also equated the Irish with vagrancy. drunkenness, and misrule Concern was frequently expressed. for example, about the idle and disorderly conduct of Irish men and women left to over-winter in Newtoundland without employment. Lord Vere Beauclerk, a naval commodore at Newtoundland, articulated such fears in 1728. as did Governors Clinton (in 1731). Cadre Smith (in 1742). and Byng (in 1743) ${ }^{\text {24 }}$ On September 22. 1755. Governor Dorrill ordered that all masters of ships bringing passengers to Newtoundland must return them home after the fishing season unless special permission was granted otherwise. The measure dealt with tishing servants in general. but was particularly aimed at reducing the Irish element of the population. as revealed by the wording of the preamble:

Whereas a great Number of Irish Roman Catholicks are Annually

${ }^{3} \mathrm{C} . \mathrm{O}$ 194/42, ff. 167-69. Jonathan Ogden to Governor Waldegrave. July 2. 1800 ,

${ }^{2}$ See. Michael McCarthy. The Irish in Newfoundland 1600-1900: Their Trials. Tribulations and Triumphs (St. John's: Creative Publishers. 1999). pp. 8-9. and MHA. Matthews Collection. 04/058. Coll. 24, Box 9. Sub-series 04-057/02. File 25-A-27-56 Governor Cadre Smith to Commissioners for Trade. 1742. and Governor Byng to Commissioners for Trade. 1743 (citing C. O. 194/11. fol. 41). 
brought over here, a great part of which have but small wages. so that after paving their Passages to this Place, and the charges of Clothing etc. during the fishing season. their whole wages are spent \& they have not the wherewith either to Pay their Passages home. or to Purchase Provisions for the Winter. by which means they not only become chargable to this Place but many Robberys and Felonys etc. are committed, by them to the great loss and terror of His Majesty's Liege subjects in this Island.'s

Two vears later. Governor Edwards complained to the Board of Trade in a similar vein that too many Irish servants were being abandoned by fishing masters during the winter. otten without their summer wages, and lett at large "to the great terror and distress of the Inhabitants $\cdots$

Three important contextual elements must be noted in relation to the attitude of British authorities towards the Irish-Catholic population at Vewtoundland Firstly. their opinions retlected contemporary. English perceptions of difference between the AngloSaxon and Gaelic "races." Secondly, their actions were justified by law. for Vewtoundland Catholics (a predominantly Irish group) suffered under a penal regime in the $18^{\text {th }}$ century that was similar to that which existed in Ireland and Great Britain For

\footnotetext{
"s.NL. GN 2/1/A. 2/236/1755. Proclamation of Governor Dorrill. September 22. 1755

"Innis, Cod Fisheries, p. 153. fn. 32.

"While theories of race propagated by British anthropologists and phrenologists of the Victorian age lent 'scientific' validity to Anglo-Saxon claims to superiority. English perceptions of Irish difference - of racial and cultural inferionity - long pre-dated the study period.
} 
example. Catholics at Newfoundland could not hold office within the rudimentary system of governance on the island because of the requirement to swear an oath repudiating Iransubstantiation. They were not permitted to bear fire arms, hold property, or run public houses. A special tax was imposed on Catholics involved in trade on the island :8 Catholics were not permitted to exercise their faith openly until Governor John Campbell issued a Declaration of Liberty of Conscience in 1784. Before this edict. the Catholic religion operated underground, with a handful of priests travelling incognito (and otten without official church sanction) to various harbours to serve the growing Catholic population The oral tradition of the southern Avalon. for example, tells of a priest who escaped authorities at Witless Bay disguised as a tisherman. and of another priest who had to hide in the cellar of a home in Toad's Cove to avoid detection: it also tells of midnight meetings at the 'Mass Rock' in Renews to say the Mass. the rosary. and other pravers "

${ }^{2}$ P.ANL. GN 2/1/A 3/149-50/1762. Order from Governor Thomas Graves to JP's of St. John's, October 29, 1762, indicated that they were "to Continue in due force the Tax levied on the Roman Catholicks p[er] late Governor Webb..." The reference here is obscure. but Howley. in Ecclesiastical History, p. 178. explains that this was a tax on Catholic and Irish traders. which had apparently lapsed due to irregular collection during the latter stages of the Seven Years' War

'Timilar anecdotes also appear in. Howley, Ecclesiastical History, p. 181. Frank Galgay. Michael McCarthy. Sr. Teresina Bruce, and Sr. Magdalen O'Brien. A Pilgrimage of Faith: A History of the Southern Shore from Bav Bulls to St. Shott's (St. John's Harty Cuff Publications, 1983), pp. 27 and 65: and RCAASJ, Michael A. Fleming Papers. 103/32. Dean Patrick Cleary. "A note of church history." pp. 4, 6-7. and 18. (Cleary was a parish priest at Witless Bay and kept a rough scrap book of local events and general church history on the island that covered the period 1784-1850. It is more commonly known as "Dean Cleary's Notebook.") Visual displays of these episodes also appear at the Capt. William Jackman Museum at Renews. 
The potential consequences for those who harboured priests or permitted the Mass to be said in their homes were heavy fines. house burnings. and deportation ${ }^{\text {to }}$ Granted. this penal regime was enforced with varying degrees of rigour. depending on the individual attitudes of governors and surrogates of the day. But certainly, the intensity of entorcement increased in proportion to the numbers of Irish arriving in Newtoundland from the mid- $18^{\text {th }}$ century onwards.

Finally, it is also important to view many of these regulations within the context of a final struggle on the part of British authorities to promote the migratory fishery at the expense of a resident fishery in order to preserve the hub of the industry in the West of England and to maintain Britain's nursery for seamen. Throughout the latter $17^{\text {th }}$ century. the English government had tried to discourage settlement altogether; but by the turn of the next century. after several successtul incursions by the French into the English Shore (inroads later reversed by treaty), Britain was beginning to see the wisdom of maintaining a year-round presence in Newfoundland. Still. the migratory fishery retained its priority in official policy, as the British endeavoured to limit settlement, especially by limiting the degree of government instituted in Newfoundland. While some elements of rudimentary governance had to be established throughout the $18^{\text {th }}$ century in order to maintain a

\footnotetext{
"Precisely these measures were taken in 1755 by Governor Dorrill and his Surrogate. Thomas Burnett, against Catholics who were caught flying the Irish colours. harbouring a priest and celebrating Mass in the Harbour Grace area. Fines were imposed. houses burned. and deportations ordered in Harbour Grace. Carbonear. Harbour Main. Crockers Cove. and Mosquito Cove from August 15 to the end of September. 1755. See various orders in P.ANL. GN 2/1/A. 2/202, and 251-64/1755
} 
semblance of order on the island, ${ }^{31}$ various governors at Newfoundland upheld the privileges of the ship tishery that had been introduced by Western Charters in the previous century and legislated by the Act $10 \mathrm{\&} 11 \mathrm{Wm}$. III. Cap. 25 [the Newfoumdland Act of $1699]^{32}$

One of the strongest advocates of the ship fishery in the $18^{\text {th }}$ century was Hugh Palliser. While governor at Newtoundland during the summers ${ }^{13}$ of 1764 to 1768 inclusive, he unleashed a battery of orders and proclamations to prohibit the enclosure of

"For example: the appointing of the first naval governor in 1729 with power to appoint justices of the peace; the establishment of a Vice Admiralty Cour and a Court of Oyer and Terminer in the 1750s; and the establishment of a Customs House after the Seven Years War

"In response to large-scale, organized colonization attempts at Newfoundland in the early $17^{\text {th }}$ century, West of England interests involved in the Newtoundland trade became concerned that resident fishermen would have an advantage over migratory men. They requested and were granted a Western Charter in 1634 that established the priority of the migratory tishery at Newtoundland and acknowledged the customary rights of a free tishery. As the ship fishery went into a decline at mid-century, primarily due to wars and market conditions. tishing ship interests found scapegoats in the bve-boat and resident tisheries. and effectively lobbied to have their concerns addressed in revised Charters in $1660 / 1$ and 1670/1. They began to abandon their anti-settlement lobbying by the end of the $17^{\text {th }}$ century, however. once they realized that their trade would only be enhanced by a resident fishery and that the various sectors - ship, bye-boat, and resident - were complementary in nature. Still. they agreed with the policy to limit local government. which would have reduced their powers established by the Western Charters and the later Vew foumdland Act of 1699 , and lobbied against the various embryonic measures of governance introduced in the $18^{\text {th }}$ century. See Matthews. "West of EnglandVewfoundland Fishery."

${ }^{33}$ Palliser's term at Newtoundland was unusually long. Note. also. that at this point. naval governors only served at Newfoundland during the fishing season. Not until 1818 were governors instructed to over-winter in Newfoundland. 
lands suitable tor the ship fishery and to remove any buildings. gardens. or other encroachments thereon ${ }^{34} \mathrm{He}$ also enforced strict adherence to the law that fishing servants who were not contracted for winter work were to be returned to their native countries at the end of each fishing season and ordered that sufficient money be held back from their wages to pay their passages home. Like Dorrill and Edwards before him, he noted that thousands of servants were left behind each winter in "misery, distress and hardships." with no money and no employment to provide for themselves. and thus became a burden on community ${ }^{\text {s }}$

But while Palliser expressed concem about fishing servants in general. his regulations, like those of Dorrill and Edwards, targeted Irish servants in particular Palliser wildly overestimated the proportion of Roman Catholics (and hence. Irish) in the population at three-quarters of the total. reflecting a commonly held attitude that the Irish were protligate in their family sizes. ${ }^{\text {th }}$ He spoke generally of the inhabitants of

"PANL. GN 2/1/A 4/2-3/1766, "Order rel[ative] to the property of Land \& cutting grass in this Country." Governor Hugh Palliser. Julv 31. 1766, \$/9/1766. Order. Governor Hugh Palliser. August 16. 1766: and 4/19/1766. Order. Governor Hugh Palliser. September 15, 1766

${ }^{15}$ P.NL. GN 2/1/A, 4/41-44/1767. Order. Governor Hugh Palliser. June 2. 1767 "Given at sea." Palliser's regulations would provide the backbone of the Act 15 (ivo. III. ( $a p .3 l$ - the British government's final major effort to bolster the ship fishery at Newfoundland; it was passed in 1776. after Palliser's term as governor. but became known locally as Palliser's Act because he had formulated its spirit and intent.

${ }^{37} \mathrm{C} \mathrm{O}$ 194/16, f 188, Annual Return on the Fisheries and Inhabitants. etc., at Yewfoundland for the year 1765. Palliser's overestimate was handily bested by Governor Waldegrave, at the time of the United Irish scare. when he warned that nearly nine-tenths 
Newtoundland in disparaging terms, arguing that for a full six months, they are pertectly idle. abandon d to every sort of debauching and wickedness. become perfect savages, are strangers to all good Order, Government and Religion by habitual Idleness and Debauchery's ... They would never become industrious tishermen or seamen. he continued. and would always pose a security risk. "for they always did and always will join an Invading Enemy and full $3 / 4$ of them are Roman Catholics ${ }^{-37}$

On October 31, 1764, Palliser issued the following regulations tor the upcoming winter:

For better preserving the Peace preventing Roberies. Tumultuous Assembly's. and other disorders of Wicked \& Idle People remaining in the Country during the Winter Order'd -

That no Papist Servant man or Woman shall remain at any Place where they did not Fish or serve during the Sumer Preceeding.-

That not more than two Papist men shall dwell in one House during the Winter. except such as have Protestant Masters .

That no Papist shall keep a Publick House or Vend Liquor by Retail -

That no Person keep Dyeters during the Winter.-

That all Idle disorderly, useless men \& Women be Punished according to Law and sent out of the Country.... ${ }^{38}$

of the inhabitants of Newfoundland were natives of Ireland or their descendants. See C.O 194/40. If 93-95. Governor Waldegrave to Colonial Office. June 19. 1798

${ }^{17} \mathrm{C} \mathrm{O}$ 194/16. f 188. "Annual Return. 1765."

${ }^{38}$ P.ANL. GN 2/1/A. 3/272-3/1764, Order of Governor Hugh Palliser. October 31. 1764 . 
The order clearly conflated "Wicked \& Idle People" with "Papists." and the "Papists" of Newfoundland at the period were virtually all Irish. The majority of dieters at Newfoundland were also Irish by this period. So the order was specifically aimed at reducing the numbers of "wicked and idle" Irish on the island during the winter. Even Palliser's efforts to remove encroachments from fishing 'rooms ${ }^{-19}$ targeted Irish inhabitants. A large number of Irish Catholics were erecting huts, he posited, in which they entertained "Rogues and Vagabonds" and encouraged them to remain on the island "to the great disturbance of the Peace, and danger of His Majesty's Subjects Lives. and to the exceeding great prejudice of the Fishing Trade." The magistrates were to tear down the offending buildings immediately and not permit any similar encroachments in the tiuture. "i) The Irish were a 'problem' that must be controlled.

While Palliser was perhaps the most virulent of Newfoundland's governors in his mistrust and even dislike of the Irish. the spirit and intent of his regulations were carried out by succeeding Governors up to the turn of the $19^{\text {th }}$ century. Regulations concerning the removal of fishing servants over the winter were re-issued by Governors John Byron. Molinoux Shuldham. Robert Duff. John Montague, Mark Milbanke, Richard King.

"The term 'room' reters to fishing premises, including stages, tlakes' istructures for drying fish). sheds, wharves. and fish stores for the landing, processing. and storing of fish. as well as 'cookrooms' for the accommodation of the crew. A large 'room" was otten referred to as a plantation.

${ }^{41}$ PANL. GN 2/1/A. 4/79/1767, Order given in Court, Governor Hugh Palliser. October 23. 1767 
William Waldegrave, and John Gambier ${ }^{+1}$ Until the late 1770s, they appeared overtly in conjunction with the anti-Papist regulations initiated by Palliser. Indeed. Byron's 1770 order respecting over-wintering Catholics included the additional penal provision that "the Children of Roman Catholic's born in this Country be Baptized according to Law [i.e.. according to the precepts of the Church of England $]^{.42}$ In the last two decades of the $18^{\text {th }}$ century, the overtly penal tone of the regulations disappeared. but their spirit could still be Pelt in the entorcement of the regulations respecting the largely Irish-Catholic dieter

${ }^{4}$ PANL. GN 2/1/A \$/201/1769. Order. Governor John Byron. September 29. 1769; 4/285/1770. Order. Governor John Byron. October 31. 1770: 5/60/1772. Governor Molinoux Shuldham. Order. June 24, 1772, 5/102/1772. Order. Governor Molinoux Shuldham. July 13. 1772. 5/143/1772. Order. Governor Molinoux Shuldham. October 12. 1773, 6/17/1775. Order. Governor Robert Duff. July 12. 1775, 6/100-1/1775. Orders 12). Governor Robert Duff. October 16. 1775: 7/33-35/1777. Circular Letter. Governor John Montague to the Magistrates of the various districts in Newfoundland. October 6, 1777. 7/70/1778. Order. Governor John Montague, October 3. 1778, 12/38-+1/1789. Proclamation and Public Notice. Governor Mark Milbanke. October 13. 1789: 12/157/1792. Public Notice. Governor Richard King, September 19. 1792, 14/2827/1 798. Proclamation, Governor William Waldegrave. and covering correspondence to the Magistrates of Newfoundland September 27. 1798: and 16/282-87/1802. Proclamations (2). Governor John Gambier. September 18. 1802. After Waldegrave's 1798 Proclamation, the magistrates of St. John's convinced him that dieters had become essential to the island "s economy, particularly in terms of the "Western" (or bank) fisherv. which began earlier than the regular fishing season. and the seal fishery. which was carried out completely in the off-season. Waldegrave modified his regulations to permit a limited number of fishing servants to remain over the winter. provided their names, intended residences. and previous and potential employers were registered. See PANL: 14/4038/1798. Magistrates at St. John's to Governor Waldegrave. October 16. 1798: and $14 / 409-414 / 1798$. Governor Waldegrave to Magistrates at St. John's. October 17. 1798. Vonetheless, Gambier's 1802 Proclamation re-iterated earlier warnings that houses that kept dieters during the winter would be torn down.

42P.ANL. GN 2/1/A. 4/285/1770. Order. Govemor John Byron. October 31. 1770. This provision was not repeated in the orders of succeeding governors. 
population. When Catholic Prefect-Apostolic James $O$ Donel requested permission of Governor Milbanke to build a chapel at Ferryland, tor example, Milbanke dictated the following response on board the vessel that was returning him to Britain for the winter

The Governor acquaints $\mathbf{M}^{\tau}$ O Donell that so far from feeling disposed to allow an increase of Places of Religious Worship to the Roman Catholics of this Island, he very seriously intends next Year to lay those already established under particular restrictions. $\mathbf{M}^{r}$ O Donnell must be sensible that it is not the interest of Great Britain to encourage people to Winter in Newtoundland. and he cannot be ignorant that many of the lower Order of those who now stay. would if it were not tor the convenience with which they obtain absolution here. go home for it at least once in two or three Years: And the Governor has been misinformed it ' $\mathrm{M}^{\prime} \mathrm{O}$ Donell instead of advising their return to Ireland does not rather encourage them to winter in this Country ${ }^{1 .}$

Orders prohibiting the enclosure of lands also continued to be anti-Irish-Catholic in tenor after Palliser's term. In 1771. for example. Governor Byron ordered the Justice of the Peace at Bonavista to remove some marking posts which an "Irish Papist" had put up on a vacant fishing room "with an Intent to Build a stage \& Flakes thereof, \& Possess the same as his Right \& Propery," contrary to the Vewfoumulkald Act of 1699 , and to wam

${ }^{43}$ P.ANL. GN 2/1/A. 2/102-103/1790. Govemor Milbanke to "Mr O Donnell. R. C Priest" [note the refusal to acknowledge O Donel's ecclesiastical rank], November ?. 1790. while on board the Salisbury. To a large extent. Milbanke was reacting to a recent large-scale Irish faction fight that had occurred in Ferryland His decision was influenced by the Surrogate who heard the ensuing cases. Capt. Edward Pellew. who felt that Catholic priests should be removed from the island altogether. This incident is discussed in greater detail in Chapter 5 . 
him and all other "Papists" from marking vacant fishing rooms as property.

Gubernatorial ire was not limited to cases of Irish encroachments on shore space that

should have been reserved for the fishery. Irish servants who were squatting inland in

Ferryland district, particularly Renews. provoked the following directive by Governor

Montague in July, 1777

Whereas information has been made to me that there are a great number of Irish Servants belonging to Boatkeepers in the District of Ferryland and particularly in the Harbour of Renewse who have inclosed Lands and built Hutts, at half a mile Distance at the Back of their Fishing rooms. without any permission for so doing which is not only a great Violation of the Law, but will be the means, if not timely prevented. of contention and strife.

These are therefore to require \& direct all people who may have fenced in any Lands and built Houses thereon. without my Permission immediately to cause all such Fences to be pulled down. and that they do not presume to build any Hutts. Stages, or Cookrooms. or to inclose any Lands at the back thereot, otherwise than for the service of the Fishery without my Permission for so doing, upon paid of Forfeiture of Five Pounds for every such offence. to be stopped out of their Wages if Servants and have no other Effects. And I do hereby require and direct all His Majesty's Justices of the Peace within the said District to see this My Order is strictly obeyed *s

The Proclamation was accompanied by a letter to local justice of the peace Robert Carter advising that if the fences were not taken down voluntarily and expeditiously. Carter was

${ }^{4}$ PANL, GN 2/1/A, 5/23/1771. Governor John Byron to William Keen. JP. Bonavista. October 14. 1771

${ }^{15}$ P.ANL. GN 2/1/A. 7-reverse end/12-13/1777. Proclamation. Governor John Montague. July 7,1777 
to make arrangements to have them removed by force. ${ }^{\text {ts }}$

British authorities at Newfoundland did not have to bend the rules to harass the growing Irish population on the island. All the orders and regulations cited above were in keeping with the laws that governed Newfoundland in the $18^{\text {th }}$ century Furthermore, it was not unusual for local officials in colonial contexts to be concerned about large numbers of unemployed. unsettled people within their jurisdiction, even if they were often unretlective about the underlying causes of the undesirable behaviour they were trying to rein in The focus of official efforts in Newfoundland, however, was decidedly anti-IrishCatholic. aimed at reducing the numbers of Irish remaining on the island, there were no corresponding proclamations respecting English Protestant inhabitants. for example. who were also enclosing land and building huts. contrary to law. And throughout this official discourse ran a construction of "Irishness" as inherently feckless. intemperate, idle. disorderly. and treacherous: the Irish were a problem group that required constant regulation and surveillance.

Part of this official discourse focussed particularly on an image of the Irish woman emigrant as vagrant and whore. Again. this must be seen within a broader context in which British authorities had discouraged the presence of all women in Newfoundland Amidst the debates leading up to the revision of the Western Charter of 1671 - the most

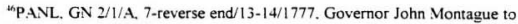
Robert Carter. JP. July. 1777. 
oppressive revision in terms of settlement ${ }^{47}$ - the spectre of the inherently immoral woman. a threat to the moral and social order, arose. West Country merchants involved in the Newtoundland trade. not yet convinced that settlement was to their advantage, claimed that planters used their womenfolk to "debauch ignorant mariners ${ }^{\cdots 4 x}$ The respectable inhabitants of St. John's at the turn of the $18^{\text {th }}$ century requested special monitoring of single servants (male and temale), but especially those "scandalous \& prostitute Women" who remained after the fishing season, to the "great prejudice $\&$ ill Example to $v^{2}$ sev" Harbours..... This was a construction of womanhood that British authorities did nothing to discourage in relation to Newtoundland; for ironically, the very characteristics touted by British colonial policy in encouraging women to participate in colonizing ventures on the mainiand - their stabilizing effect on community formation. their essential role in permanent settlement - were perceived as threats to British enterprise at Vewfoundland. where a resident fishery would weaken the migratory sector (and hence, Britain's nursery

${ }^{17}$ The 1671 Charter banned inhabitation within six miles of the shore and prohibited the transportation of any passengers to Newtoundland whatsoever. It was followed by an Order-in-Council in 1675 stipulating that all plantation at Newfoundland be discouraged and any inhabitants encouraged to remove themselves to New England or back to their home country, another Order in 1676 directed that the inhabitants be forcibly removed. tfter pro-settlement reports by naval commodores Berry and Russell. as well as an effective petition campaign led by planter John Downey, the Orders were rescinded

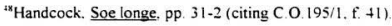

${ }^{37}$ MHA. MF-105. Richards Letterbook. ff. 215-17. "Request to $y^{*}$ Commodore Leake," September 20.1702, see also ff. 129-30. "Instructions for $\mathrm{y}^{\varepsilon}$. Harbour Guard relating to $\mathrm{v}^{\mathrm{E}}$ Inhabitants," n.d but c. February. 1702. 
for seamen). ${ }^{\text {s) }}$ As Capt. Francis Wheler, naval officer at Newtoundland, reported to the home government in 1684: "Soe longe as there comes noe women they are not fixed" "51

The policy of discouraging women migrants to Newfoundland persisted well into the $18^{\text {th }}$ century, and local authorities tound occasion to remark particularly about the undesirability and unsuitability of Irish women in the population. When Capt. Story had commented in 1681 on the Irish women servants who came out as servants and married tishermen [see above], he had added:

\& alittle after theire coming they marrv among the fisherman [men] that live with the Planters, \& being Extreamly poor. contract such debts as they are not able to pay so yt if course be not speedily taken tor the preservation of such passengers coming over the countrey they will be ruined ":

In particular, the construction of the undesirable woman took on ethnic undertones as the numbers of Irish increased after the mid 18th-century ${ }^{\text {s. }}$ In 1764. for example. Governor

\footnotetext{
5i'The Newfoundland situation also contrasts with that of New South Wales. where women were recruited into the southwest after an initial perception of women who ventured into the bush as whores was quickly over-written by images of women as civilizers and moral guardians who would help to regulate men s behaviour and establish stable family life in frontier settlements. See Campbell. Kingdom of the Ryans. pp 118 20

${ }^{5} 1$ Handcock, Soe longe, p. 32 (citing C O 1/55.f. 241).

"MHA. Matthews Collection, 16-D-1-006, Capt Story. "An Account." 1681

${ }^{53}$ Cullum and Baird provide a discussion of various efforts to discourage women settlers at Newtoundland in the $17^{\text {th }}$ and $18^{\text {th }}$ centuries, but they do not examine the element of ethnicity in these actions. See Cullum and Baird. 'A A Woman's Lot, ' pp. 68-
} 
Hugh Palliser linked Irish women servants with poverty, improvidence, and disorder when he issued the following notice:

Whereas great Numbers of Poor Women are frequently brought into this Country, and Particularly into this Port by Vessels arriving from Ireland who become ditress ${ }^{\circ} \mathrm{d}$ and a Charge to the Inhabitants, and likewise Occasion much disorder and Disturbance against the Peace of our Sovereign Lord the King.-

Notice is hereby given to all masters of Vessels arriving in this Country that from the First day of April next no Women are to be Landed without Security being first given for their good behaviour and that they shall not become Chargable to the Inhabitants. ${ }^{4}$

Although Palliser was generally wary of the increasing numbers of Irish arriving in Vewfoundland (otten through its chiet port at St John's and hence right under the governor's nose), it was significant that with this - the very tirst of his anti-Irish-Catholic proclamations - the governor honed in on the perceived threat of the unattached Irish woman. Two years later, the alleged sexual immorality of just such a woman provoked another strong reaction trom Palliser and the magistrates at St. John's. In the case of Penclergraxx 1: Blakener. fishing servant Thomas Pendergrass sued tor wages denied him by his master. John Blakener, because Pendergass had been having sexual relations with Blakener's Irish female servant. Pendergrass recovered his wages "without any Deduction

${ }^{4}$ PANL, GN 2/1/A, 3/232/1764, Order. Governor Hugh Palliser. July 2. 1764. 
on acc' of his Intercourse with [the] Woman Servant to the said Blakener." but the magistrates were instructed "to Order the Woman who occasion"d this disturbance. to leave the Country. \& oblige the master of the Ship who brought her, to carry her away " Both the 1764 proclamation and the 1766 deportation order reflected a fear of the single Irish woman, whose sexual autonomy and social and economic independence from father or husband cast her. in the eves of colonial authorities, as deviant - a danger to the social and moral order.

The construction of Irish women servants as immoral. unproductive, and menacing was re-iterated in Governor Montague 's proclamation of 1777 . which expressed particular concern about their arriving in Newfoundland pregnant and becoming a drain on the populace

Whereas it has been represented to me that the Ships and Vessels that come trom Ireland trequently bring unmartied Women. and Young Girls. who are destitute of Friends and come over with no other View but to be hired as Indentured Servants. that on their arrival and having hired themselves to Masters. have proved to be with Child. which is attended with Difficulties to the Masters, and is the cause of bringing many Incumbrances upon the Inhabitants of this Island and of this Place in particular

These are therefore to forbid all Masters of Vessels from bringing any Women as Servants from Ireland, on pain of Forfeiting Ten Pounds for every Person so found on board, or that can be proved by Information to have been brought over by them.

And I do further Declare if any such Women be hired to a Master

"PANL, GN 2/1/A. 4/23/1766. Order, Governor Hugh Palliser. October 2, 1766. in the matter of Thomas Pendergrass v. Jonathan Blakener. 
on Shore and she proves to be with Child at the time she was so hired, the Master [of the vessel] shall not be paid tor her passage.

But in the Case he shall be paid for such passage before the Person so brought over is Discovered to be with Child, He [the master of the vessel] shall be obliged to refund whatever Sum he received. ${ }^{\text {so }}$

This order fashioned an image of the Irish woman servant as promiscuous and conniving. It implied that large numbers of such dissolute women (at least, sufficient numbers to warrant an official Proclamation) became pregnant outside of wedlock, either in the home country or on board passenger vessels bringing them to Newfoundland. where they entrapped unwary employers by contracting their services without revealing their condition. L'Itimately (and here was the oft-repeated theme on the 'teckless' Irish), they would become a charge on the more 'respectable' inhabitants of the island.

In 1805 . Governor Erasmus Gower observed that "a considerable number of unmarried women" were arriving on the island "without having any relatives or Friends residing here," Having "reason to fear" that many of them were "persons ot bad character." he resurtected Governor Palliser's regulations of July 2. 1764. and ordered that the Masters of vessels bringing passengers to the island be advised that they would be held accountable tor the financial security and moral behaviour of female passengers ${ }^{\text {s* }}$ 1777

${ }^{56}$ P.ANL. GN 2/1/A. 7/35-6/1777. Order. Governor John Montague. October 10.

${ }^{17} \mathrm{PANL}$. GN 2/1/A. 18/307-8/1805, Governor Erasmus Gower to the Magistrates of St. John's. September 18. 1805 
Although Gower did not specify ethnicity in his order. there can be little doubt that the target group was Irish. given their predominance in the passenger traffic at that period The same regulations were re-invoked by Governor Holloway three years later ${ }^{58}$

The Irish woman immigrant, then, was a particular 'problem' for local authorities. requiring special regulation of her own. In particular, the single Irish female servant required monitoring, for her independence from a patriarchal tamily context and her potential sexual agency contravened a growing middle-class teminine ideal that embodied domesticity. dependence, tragility, and sexual passivity. Yet all Irish women migrants were pariahs. for implied though not directly stated in the discourse was the fear that once these women were permitted to remain. the equation for reproducing this undesirable ethnic group on the island would be complete.

The linkage of degeneracy and Irish womanhood was further reinforced when an Irish convict ship put ashore 114 Irish convicts - including 12 women - at Bay Bulls and Petty Harbour in late August. $17899^{59}$ After using up the provisions that had been left

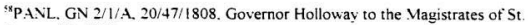
John's, August 29. 1808

"See: C.O. 194/38, ff. 86-101. 110-8, 180-2, 282-3, and PANL, GN 2/1/A. $11 / 458-60 / 1789,12 / 8-13,30-1,48$, and 54-5/1789. See also Bob Reece, "'Such a Banditti Irish Convicts in Newfoundland. 1789. Part I." Newfoundland Studies, 13:1 (Spring. 1997), 1-29. A listing at C.O 194/38. ff 94-6. provides details such as name. age, birthplace, crime, and sentence for the male convicts at St. John's but contains no intormation on any female convicts. A further, partial listing at $\mathrm{C}, \mathrm{O}, 194 / 38, \mathrm{f}, \mathrm{I} 12$, does provide the names of the 74 male and six female convicts who were removed to Spithead on board the Brigantine Elizabeth and Clare, but no details on those who remained in vewfoundland. The number of female convicts who actually arrived in St. John's is 
them, the convicts dispersed to "Principal Towns" in the area where they "Committed various depredations upon the Fishermen and Inhabitants." ${ }^{\text {"() }}$ A large group moved on to St. John's. where 63 of the male convicts were rounded up and confined in a former hospital located on the "Barrens," about a mile inland from the town. While the inhabitants of the island, and particularly of St. John's. Peverishly made plans to have this menace removed from the island. steps were taken to protect the town from those convicts who were still at large. Even so, particular concern was expressed about the 12 women convicts who remained at liberty.

the most effectual step that has been taken is the appointment of a Patrol of six to eight men a Constable and a reputable Housekeeper at their head properly Armed who Walk the paths from ten in the Evening till Gun Firing in the Morning ... this elen mas be insufficient to keep (jockl order while welve women convicts (more abandon d than you can concerve of ure suffer 't to remain at l.arge [italics added] $\sim^{\text {th }}$

As the women convicts would not likely have posed more of a threat to life and propeny

unclear. but likely included the six who sailed on the Elizaheth and ( lare as well as one other who was deported shortly thereafter for prostitution. This leaves the possibility that all or some of the remaining five women from the original 12. as well as a number of their male cohorts. remained on the southern Avalon where they had originally landed and where they may have melted into the predominantly trish population.

${ }^{5 \times 1} \mathrm{C}$ O 194/38, ff. 86-7. Governor Milbanke to Grenville. September 20. 1789

${ }^{\circ 1} \mathrm{C}$. O. 194/38, ff. 282-3, "Extract of a Letter from Newfoundland." August 21. 1789 
than the male convicts at large, the perceived danger of leaving these women free must have been the threat they represented to the moral order and to growing middle-class ideals of masculine self-control and sexual restraint. ${ }^{\text {nz }}$

Yet despite official discourse that equated Irishness with rebellion and disorder. and Irish womanhood in particular with vagrancy and immorality, Irish servants - men and women - continued to be hired for service in the fishery and domestic work, particularly in

"Although this episode was an isolated one in Newtoundland, it can be contextualized by the larger-scale transportation of women convicts to Australia from 1788 to the mid- $19^{\text {th }}$ century Joy Damousi's study of this period reveals that the presence of convict women in colonial society inspired in local authorities profound anxieties about the existing social and moral order. Their visibility in public spaces, their drunkenness and loitering, their sexual assertiveness were seen as polluting, contaminating, a source of social chaos. An essential component of the response of male authorities was not just their fear of, but their tascination with, the perceived '- excess' passion and sexual deviancy" of these women - so removed trom the sexual passivity of the middle-class feminine ideal Says Damousi:

The unsettling impact of convict women... [was based on] a tear of female sexuality, of its assertiveness, power and danger... The public expression of convict women's desire. pleasure and potential for sexual activity was perceived not only as a social threat but was also a challenge to the psychic layers of masculine desire and self-control.

It is interesting to note that both Newfoundland and Australian authorities used the same term in describing the convict women: "more abandon "d than you can conceive of." wrote the Niewfoundland correspondent. above. " thoroughly abandoned." wrote Governor Darling in Australia in 1826 Likely. a similar combination of fascination and tear of female sexuality acted upon male authorities in Newfoundland as they scrambled to have the convicts removed from their midst. See Damousi. Depraved and Disorderly: Female Convicts, Sexuality and Gender in Colonial Australia (Cambridge. Cambridge University Press. 1997): quotations from pp. 40. 42, and 47 Babette Smith's A Cargo of Women. Susannah Watson and the Convicts of the Princess Royal (Kensington: New South Wales Cniversity Press. 1988) also provides descriptive evidence of the perception of women convicts as moral and social degenerates 
Conception Bay, St. John's, and along the southern Avalon. Poole merchants defended their use of Irtsh servants to the Commissioners for Trade in 1752. arguing. in response to concerns that Irish Catholics bred in prodigious numbers, that they increased "in no greater proportion than protestants" and that "their behaviour has given no cause to apprehend any dangers to the well being affected to His Majesty's person. ${ }^{\text {th }}$ Indeed. regardless of the unavailability of English servants in wartime. some employers preferred Irish servants to English. For example. Saunders and Sweetman - a mercantile firm operating at Placentia, St. Mary's Bay, and Trepassey - sent at least one vessel. and in some years. two. to Watertord to pick up Irish passengers tor the fishery As Pierce Sweetman noted in 1788

We have been very lucky in having no runaways, this Spring we have lost but 2 men \& an Eng ${ }^{\text {h }}$ Boy. I would advise you never to send out more Engh yourself than will just clear the Vessels. the most of all that ran away from this the Winter before this were Eng' Boys \& young they never any of them stick to the place or have any attachment to it. \& for hard labour one Irish young ${ }^{\mathrm{rn}}$ is worth a Doz ${ }^{\mathrm{n}}$ of them.... ${ }^{\text {s }}$

${ }^{n 3}$ MH.A. Matthews Collection, 04/048. Coll. 24. Box 9. Sub-series 04-057/05. File 25-A-27-57. Petition of Poole merchants to Commissioners for Trade. November 8, 1752 (citing C O 194/13, f 34)

"A youngster' was a novice servant in the Newfoundland fishery. The term retlected inexperience. not necessarily age. although most of them were. indeed, voung.

"PANL. MG 49. Sweetman Collection. Box 5. Saunders and Sweetman Letterbook 1788-93 and 1802-04. Pierce Sweetman at Placentia to "Dear Brother." May 11. 1788 
Sweetman's attitude may have been shared by other employers along the shore; certainly. the Pole Papers (1799-1800) indicate an overwhelming majority of Irish among the fishing servants in Ferryland district at the turn of the $19^{\text {th }}$ century. In addition. court records for the study area are peppered with cases involving Irish-Newfoundland women who were contracted servants (see Chapter 6) or were providing other services for the single male fishing population (washing, sewing, nursing, hospitality trade - see Chapter 4 )

Furthermore, regardless of official regulations aimed at preventing Irish settlement. the predominantly temporary nature of the Irish migrant stream was taking on more permanence. as the migratory fishery. plagued by almost continuous years of wartare. declined and the resident fishery grew in both absolute and proportionate terms. especially from the American Revolutionary War period onwards. And while large numbers of migrant servants were still hired for the fishery - whether in the migratory or the resident sector - there was an increasing tendency for these servants to stay beyond their contracted period of service. The letterbook of Saunders and Sweetman for 1788-1804 indicates a general reluctance of servants to retum to Ireland. especially from 1789 onwards. ${ }^{\text {" }}$ and the Pole Papers indicate that while large numbers of servants were still

"hn the late 1790 s and early 1800s. Saunders and Sweetman sent at least one vessel back to Waterford each fall with returning servants, and sometimes had to send a second vessel with overflow passengers, in the winter, they kept on a winter crew only to cut ships timber in Mortier Bay. See PANL. MG 49. Sweetman Collection. Box 5. Letterbook. September 6 and 26. November 3 and 4, and December 22. 1788: November 3 and 4 and December 3 and 11, 1789. October 13 and 27, 1793. October 9 and 21. 1802. 
being hired in the fishery in Ferryland district in 1800, many had 'dieted' during the winter of $1799 / 1800$ Furthermore, a number of these male servants had wives and children living with them in the summer of 1800 . And a number of Irish masters were hiring servants of their own for the fishery. Along the southern Avalon, removed from the watchful eves of visiting governors, an Irish planter society was taking root in most harbours and would be reinforced through increasing Irish migration. temporary and permanent, through the close of the $18^{\text {th }}$ century and into the middle of the $19^{\text {th }}$ century Irish women like Mary Ryan were an integral part of that migration in terms of community formation, economic production, and community power dynamics. they would also play an essential role in establishing an essentially Irish society on what had once been part of an English planter shore

But before examining the role of Irish women in early settlement on the southern Avalon, let us first board them on passenger vessels of the day and try to understand their experiences of leaving home and crossing the North Atlantic to a new world

and July 20,1804. By 1789 and 1790, however. Pierce Sweetman. who was running the Placentia branch of the business (including dealers in St. Mary's Bay and Trepassev). was observing the growing numbers of "unshipped" men who were staying through the winter and anticipating that many of the Bills drawn for servants" wages would likely be returned to the local store for provisions by servants who had no work. See Letterbook, Box 5. "PS" to "Dear Sirs" (likely. principals). November 3. 1789: "PS" to John Blackney. November, 1789: and "PS" to John Blackney. November 1. 1790. Similarly, in 1802. he reported low numbers of servants wanting to return to Ireland and wondered whether it was sensible to send a ship to Waterford at all, although he later relented. feeling that it would not be prudent to allow too many unemployed servants to remain the winter. See Letterbook: Pierce Sweetman in Placentia to Mr. Francis Eamond [?]. October 9. 1802: and "PS" to "My D' Saunders," October 21, 1802. 
2.3 .* there is not a saint in the calendar that was not invoked.." $19^{\text {th }}$-century passages

Mary Ryan did not keep a journal of her 1826 passage from Wexford to Cape Broyle. Indeed. there are no surviving written accounts of women passengers from Ireland to the southern Avalon for the study period. Many of these women would not have had the luxuries of time. paper, and ink or the level of literacy required to maintain records of their journevs. But several accounts of the Atlantic crossing by lrish women who arrived in St. John's have survived trom the study period: letters written to their home convent in Galway by Presentation nuns twho came out to Newtoundland in 1833 Although the sisters initially landed at St. John's. not the southern Avalon. one of them Mother Mary Bernard Kirwan - would later establish the first convent school in the study area (in Admiral's Cove, now Port Kirwan) in 1853. But even without this connection to the southern Avaion, as Irish women travellers of the day. their writings can help us gain some insight into their feelings at leaving home and starting a new life in an unfamiliar land

Wy ever dear Revd. Mother.

I am sure you will be delighted to hear we are at last arrived at St John's atter a most unpleasant voyage of 25 days... We were only a tew hours on board when we all got sick and were obliged to go to our berths. We were almost insensible. Any expressions I can make use of could give you but a faint idea of $\mathrm{Dr}$. Fleming's kindness and attention. Nothing was left undone which could in any way contribute to our comfort. He was like tender parent. physician and priest... We had one consolation... that was he would allow no passenger on board so that we had the vessel to 
ourselves and when we were a little recovered we went occasionally on deck. These artangements must have been very expensive..., but it was a great comfort to us.

On the third day after we lett Ireland we had a storm. One of the masts was broken and some others damaged. It lasted for three days but we were not much frightened because we were almost regardless of what was going on we were so deadly sick, but we soon had another storm to encounter which was most awful. It was on the $10^{\text {th }}$. It lasted 36 hours The sails were tom in pieces, it came on so suddenly, the waves were monstrous high and used to wash over the deck in so terrific a manner that you would suppose every moment was your last. We were obliged to stay in bed because the vessel heaved so much that we could not stand for a minute. You may be sure there is not a saint in the calendar that was not invoked during this violent storm.... [As we came in view of land, we] were in great spirits thinking we could go on shore in a short time, but we met another disappointment: heavy fogs and contrary winds prevented us from landing and we were for three days tossed about within a few miles of St. John's

At length the jovtul day arrived. We entered the harbour on the $21^{\text {tt }}$. St. Matthew's day .... [Sister Magdalene O'Shaughnessey] ${ }^{\text {t }}$ ?

We crossed the harbour in a small boat and when we came near the shore there were crowds of small boats till of people, the banks and hills were crowded and as soon as the boat that the Bishop and we were in arrived there was nothing to be heard but shouts of joy and acclamations Protestants. Orangemen and all kinds of people came to welcome us and you may guess how we felt when we found ourselves in the midst of such a concourse of people and received in the most tlattering manner.... As soon as we arrived. they had a carriage ready to receive us

We are as happy as can be. separated trom our dear Sisters. Tell each and every one of them that I can never torget them and that no distance or length of time shall ever alter my love, affection or gratitude for my dearest Community ... [Sister Mary Xavier Lynch] ${ }^{\text {os }}$

${ }^{\text {n7} P C A . ~ S i s t e r ~ M a g d a l e n e ~ O ' S h a u g h n e s s e y ~ t o ~ R e v . ~ M o t h e r . ~ P r e s e n t a t i o n ~ C o n v e n t ~}$ in Galway. September 22. 1833.

${ }^{4 x}$ PCA. Sister Mary Xavier Lynch to Rev. Mother. Presentation Convent in Galwav. September 22. 1833 
I almost despaired of ever writing to you again. I was so ill for ten days I was almost insensible to everything. The Sisters thought I would never reach St. John's... I would be happy if I could forget all those I parted with that were so dear to me. I can never think of them without regret. This day six weeks we left Galway. I can scarcely think it possible. dear Rev. Mother, that I am never again to see you and all my dear Sisters tor whom 1 every day feel a greater affection but we will I hope yet be united.... [Mother Mary Bernard Kirwan] ${ }^{\circ \%}$

We are just beginning to feel the severity of the weather... You may imagine what the cold is when in our bedrooms we cannot leave a drop of water in the basins or jugs. We must wait ever so long betore we can get it to melt. As for our towels you might as well have a sheet of paste board for after using them and putting them to dry they are frozen quite hard and stiff. I washed my stockings and put them to dry. What was my amazement when going to mend them to see them stiff as a board and icicles hanging from them. Water freezes in a room even with a tire and the water which is left on the altar for the priest is in ice betore he uses it. though only left a little before he comes. As for the milk for breakfast it is like lump sugar and we are obliged to cut it with a knife... When we are out walking our breath freezes on our cloaks.... As for the clothes, when they are put in to steep they become a complete mass of ice, and the meat is obliged to be sawn. I suppose. dear Ann. you think all this incredible for we thought so ourselves until we began to experience it.

Once more give my love a thousand times to all my dear

Sisters .. It is often I think of you all. I must do violence now and stop for if I were to indulge myself much longer my tears would tlow ... [Sister Mary Xavier Lynch] ${ }^{\top 0}$

"PCA. Mother Mary Bernard Kirwan to Rev. Mother. Presentation Convent in Galway, undated. but shortly after arrival in Newfoundland. 1833.

${ }^{\circ}$ PC.A. Sister Mary Xavier Lynch to "My dearest Ann". January 6. 1834. 
We had ice-cream for weather to-day.... [Sister Magdalene O'Shaugnessev $]^{\top 1}$

Of course, the sisters' experience, in many ways, provides a study in contrast with that of most Irish women who came out to Newfoundland during the study period. The sisters passage was not typical in terms of either accommodations or reception. The nuns were well-educated, middle-class women, travelling as the invited guests of Vewfoundland's Roman Catholic bishop Michael Anthony Fleming on a ship purposely hired to bring them to Newfoundland as safely and comfortably as possible. Indeed. Bishop Fleming had rejected the tirst ship that had been provided for the sisters passage. judging it "rather small to make comtortable accommodation for the ladies," and had gone in search of better vessel at Liverpool. where he had considered several vessels before tinally settling on the $f$ rie $\left.\right|^{=}$Certainly, then, the sisters accommodations were as comtortable and commodious as the bishop could provide: their diet. although uninspired. was adequate, they were not crowded into the bowels of a passenger vessel with hundreds of other emigrants, fighting for scarce provisions and sleeping space: their privacy was assured. They did not have families to tend to, nor did they have the additional stress of being pregnant on the journey - a condition that was not uncommon for Irish women

\footnotetext{
"PCA. Sister Magdalene $\mathrm{O}$ 'Shaugnessey to "My ever dearest Sister M Augustine." November 21, 1833

"Howley. Ecclesiastical History, pp. 281-2 and 284-6. Bishop Fleming to Mother Superior of Galway convent, July 17, 1833, and August 5. 1833.
} 
passengers. judging from Mary Ryan's experience and the rationale for Governor

Montague's 1777 edict. Neither did they have to ward off the unwanted advances of the ship's crew or male passengers, as was likely the case of other single women travelling without family ${ }^{-3}$ Furthermore, they crossed the ocean in September, while most Irish passengers coming out on ships involved in the Newfoundland trade would have been travelling in the spring, when cold weather, trost, snow, sleet, and coastal ice added to the discomfort and anxiety of the journey. Consider, by contrast, the experience of John and Vellie (Lyons) Welsh, who headed out trom Wexford to the southern Avalon in 178.4. their ship was driven into Petty Harbour by arctic ice and John had to tow Vellie and their belongings over the ice to safety (they arrived in Cape Broyle the following year with an intant son named Michael) ${ }^{-4}$ Or consider the ordeal of emigrants on board an 1817 Irish passenger ship that could not enter Renews harbour because of coastal ice. the passengers had to leave the ship and crawl ashore on their hands and knees " Furthermore, while the

${ }^{-2}$ In 1773 . for example. Governor Molinoux Shuldham instructed the Vice Admiralty Court at St. John's to look into the complaint of Bridget Kent in relation to the "inhuman and Barbarous treatment she received on Board the Brig ... [blank in original] Charles Durell Master. in the course of her passage trom Waterford to Harbour Grace last Spring. and as those Acts of Violence said to have been committed upon her. were done upon the High Seas. ... to bring all and every the Offenders to Justice." See P.A.YL. GN 2/1/A. 5-reverse end/74/1773. Governor Molinoux Shuldham to Edward White. Judge of the Vice Admiralty Court. St. John's. July. 1773

"IJim Joe O'Brien. "Cape Broyle. 1959-60" (Linpub community history written c 1960). p.1; and O'Brien, "Cape Brovle" (1971). p. 8.

"Prowse. History of Newfoundland, p. 406 . This information is also on display at the Capt. William Jackman Museum. 
sisters were destined to hard work in difficult conditions, they did not have the immediate concerns borne by some immigrants of finding work, shelter, and food upon arrival. And the welcoming "shouts of joy" they received from people of all classes and religious persuasions were far different from the negative pronouncements on the Irish immigrant woman "problem" by local authorities. Still, there were elements of the sisters" experience that would have been shared with other travellers, both male and female, of the day sorrow and misgivings about leaving home. fear of the Atlantic crossing. a sense of adventure and new beginnings. and the process of adjusting to a new environment until one could finally shrug aside the task of sawing one's milk and meat in its frozen state to observe. "We had ice-cream for weather to-day

Other written accounts of passages from Ireland to Newtoundland - less personal in tone and content - do exist. They survive in governor's correspondence, business papers, and newspapers of the period, and several are outlined below. Most deal with vessels that arrived in St. John's: however. they still provide insight into the experiences of migrants to the southern Avalon, for sometimes vessels that cleared customs at St. John's moved on to the study area. and as noted earlier. St. John s was also a stop-off and dispersal point for many passengers that ultimately made their way to the study area. particulariy that section from Bay Bulls to Trepassey It is important to note in relation to these accounts that much of Newtoundland's passenger traffic from Ireland was excluded from British passenger legislation of the early decades of the $19^{\text {th }}$ century. The British government passed a series of passenger acts. beginning in 1803. which sought to increase 
the safety and comfort of emigrants by restricting the ratio of passengers to vessel tonnage and requiring certain minimal amenities on board. In 1804, however, the legislation was rescinded in relation to fishing vessels carrying shipped servants for the Newfoundland fishery. Furthermore, because of insufficient supervision, owners and masters of passenger vessels that were still covered by the legislation could easily circumvent the regulations - transporting people whether shipped or not under the guise that all had employment and thus avoiding the niceties of sufficient space and provisions tor their complements. By 1815, the governor and local Board of Trade were calling for a more stringent regulation of the trade. and their suggestions were incorporated into the British Passenger .tct, 56 (jeo 3 ( a ap. \$3. passed in 1816 " Local authorities carefully monitored the arrival of passenger vessels thereatter, even the slightest infraction was repored to the governor and attracted a fine tor master and/or owner. - However. large numbers of Irish continued to arrive in St. John's (the major port of disembarkation) without employment prospects. They came. one magistrate observed:

"Various correspondence involving the Colonial Office. the governor and other local authorities. and merchants of both St. John's and Waterford appear at P.ANL. GN $2 / 1 / A .27 / 16-24$ and $33-46 / 1815$, and $27 / 117-122$ and $205 / 1816$

${ }^{+-}$See, for example, correspondence and documents at PANL. GN 2/ $/$A. 27/408$11 / 1817.28 / 362-4,409-15.433-4,446$. and 482/1818. 30/139-40, 166-7, and 192/1819. and $31 / 423-5 .+73$. and $490-2 / 1821$. Even masters and owners who had followed the spirit of the legislation, if not the exact letter of the law (e.g. provided adequate provisions and space. but failed to produce a satisfactory passenger list). were subject to fines. aithough some penalties were eventually mitigated. Local and Irish customs officers were also occasionally brought to task for insufficient attention to enforcing compliance to the regulations 
in consequence of the most flattering and fallacious prospects of advantage held out by public advertisement circulated throughout a wide extent of [Ireland] for the purpose of enticing a vast number of poor people to embark, merely trom the mercenary motive of procuring additional treights for their Vessels bound from thence for Newtoundland; immediately on their arrival at St. John's, these unfortunate poor wretches were all turned on shore to shift for themselves without any possible means of Subsistence. or of getting employment...."

Despite local protestations. however, in 1825. restrictions on the Newfoundland passenger trade were lifted altogether, triggering another major wave of Irish migration to the island and a heightening of concern among local authorities and merchants " Not surprisingly. then, most of the tollowing accounts deal with voyages ending in tragedy, and feature prominently in material dealing with the peak periods of Irish migration (1811-1816 and $1825-1833)^{x 10}$

In 1811. for example. Govemor John Duckworth reported to the Colonial Office on the trial of James Lannon, master of the schooner Famm out of Watertord, who was charged and convicted of a "misdemeanour" under the Passenger .Act The vessel had carried a passenger complement of 184 men, women, and children - a full 70 passengers over the number permitted by the ship's tonnage. Depositions of various survivors of the

"PANL, GN 2/1/A, 27/408-10/1817, Thomas Coote. Chief Magistrate at St. John's, to Governor Pickmore. April 28. 1817

"See correspondence at PANL. GN 2/1/A. 35/329-30.339-1, and 288-90/1826.

"Mannion. "Irish Migrations" and "Tracing the Irish." 
vovage - testimony that was remarkably consistent in details - revealed a serious lack of water and provisions on board the Fanmy. For the first three days, passengers had received no water or food. The remainder of the first week. adults had received one quart of water per day, an allowance that had dwindled to one-half pint by the third week (children's allowances had been one-halt adult amounts). The only provisions that had been provided were sporadic rations of bread. ${ }^{x t}$ One passenger stated that he had been in such distress from lack of water that he had preserved his own urine and drunk it. In all. 32 passengers had died on the voyage and several others expired after landing in St. John's ${ }^{\text {: }}$ Roughly 20 women and ten children survived the trip: how many women and

${ }^{*}$ Compare this food and water allowance with that of the Irish convicts who had been returned from Newfoundland to Spithead in 1789 i.e., 3-1/2 lbs of bread. 2 lbs of tlour, $3 \mathrm{lbs}$ of pork, 3 pints of peas, $\mathrm{l} / 2 \mathrm{lb}$ of butter, and 7 gallons of water ecach per week. See C.O. 194/38. ff 86-101, particularly f. 101. Advertisement for a vessel to transport the Irish convicts to Spithead. dated September 17. 1789. enclosure in Governor Vilbanke to Colonial Office. September 20. 1789 In addition, Governor Milbanke had arranged for the convicts to be supplied with forty beds. bolsters. blankets and coverlets. and each was issued "navy slops." consisting of shirt. frock. trousers. shoes. and stockings. See C O. 194/38. ff. 180-2. particularly f. 182. An Account of the Expense of Maintaining and Sending to England in the Brig Elizaheth and ( Yare a Number of Irish Convicts. who were landed upon the Island of Newfoundland in the Year 1789." enclosure in Milbanke to Colonial Office. December 8. 1789

x=C.O 194/51. ff. 17-23, Governor Duckworth to Colonial Office, November. 1811. See also C.O 194/56. ff. 63-70, particularly f. 66, "A List of Vessels that have arrived at St. Johns Newtoundland from Ireland with Passengers." enclosure in Governor Richard Keats to Colonial Office. October 1. 1815. This correspondence with attachments also appears in P.ANL, GN 2/1/A, 27/16-8/1815 See also Cyril Byme. "The Case of the Schooner Famm: from Waterford to St. John's, 1811." An Nasc, 3:1 (Spring/Summer. 1990). 19-22. 
children had originally left Ireland is not known. ${ }^{83}$

Vegligence and tragedy in the passenger trade from Ireland continued as ever increasing numbers of Irish sought passage to Newfoundland over the following years. In 1815. alone, 11 overcrowded and under-provisioned passenger vessels from Ireland (seven trom Waterford. three from Ross, and one from Youghal) arrived at St. John's. carrying 2060 passengers, including 172 females. ${ }^{x / 4}$ One of the vessels was the brig (irace.

${ }^{*}$ An abstract of Irish passengers on various vessels arriving at St. John's in 1811 indicates that 125 men, 20 women, and ten children disembarked at St. John's from the Finn!" however. these must be approximations because, allowing for 32 deaths en route. this would bring the total passenger complement to 187 . not 184 See PANL. GN 2/1/A. 22/24/1811. " $\mathrm{N}^{\circ}$ of Passengers arrived from Ireland 1811" However, these estimate are closer than that of the original list of survivors torwarded to the Colonial Office. which contained only the names of 100 men. See C.O. 194/51, ff. 17-23

"This proportion of males to females is high. but representative of the Viapoleonic War period. when there was an employment boom for male servants in the Vewfoundland tishery. Total numbers of Irish passengers arriving at St. John's are available tor the following years:

$\begin{array}{llllr} & \text { Men } & \text { Women } & \text { Children } & \text { Total } \\ 1807 & 614(91.6 \%) & 56(8.4 \%) & & 070 \\ 1811 & 1026(8+6 \%) & 128(10.6 \%) & 59(49 \%) & 1213 \\ 1812 & 1541(92.2 \%) & 116(6.9 \%) & 1+10.8 \%) & 1671 \\ 1815^{\circ} & 2060(92.3 \%) & 172(7.7 \%) & & 2232 \\ \text { "Passengers were reported as "male" or "female". whether these numbers } \\ \text { included children is not clear. }\end{array}$

Still. some individual vessels carried larger complements of women passengers: e.g. the Harmom out of Cork brought 25 men and 10 women out in 1807, and in 1811. the Josce arrived in August with 24 men. 18 women. and 13 children, while the Jemn came in October with 3 men, 11 women. and 8 children (given the late arrivals. these two vessels were obviously not carrving servants shipped for the current fishing season). Indeed. the foyce, a vessel out of Ross, usually carried a significant number of women passengers 
which had cleared Waterford for Newtoundland with 150 male and 20 female passengers.

The water allowance on board was only one quart per person per day. and provisions were vastly inadequate 70 bags of bread, and 28 barrels of spoiled pork. a portion of which was so inedible that the passengers threw it overboard. Ultimately, the passengers were torced to break open the foodstuffs in cargo to stave off potential starvation. Governor Richard Keats was appalled at the poor conditions on board all the vessels and complained to the Colonial Office about "the Loss of Life and Misery which has been sometimes produced by the manner in some instances (shocking to humanity) Passengers have been brought from Ireland " He argued that the rescinding of the provisions of the Pcrsvenger $A c t$ in relation to the Newtoundland fishery had given too much leeway to vessel masters and owners and urged "some legislative Regulation" of the passenger trade involving tishing servants ${ }^{\text {s }}$

We do not know the name of the vessel that Michael and Mary Rvan sailed on. but

even when it came out in the spring ( 36 in 1812, and 35 in 1815). See abstracts of passenger lists at P.ANL. GN 2/1/A.19/103/1807. 22/24/1811. and 22/297/1812. And see C O 194/56, ff. 63-70. Governor Richard Keats to Colonial Office. October 1. 1815.

Linfortunately, there are no other abstracts of passenger lists available for the study period. and thus it is impossible to estimate the overail proportion of women passengers to men outside the boom period of the Napoleonic Wars. However. it is safe to assume that passenger complements were predominantly male, although not always as heavily weighted as in the above years. In 1825, for example. women made up 30 percent of the passengers on board Edward Kough s vessel (oncord (see below).

*E C 194/56. ff. 63-70. Governor Richard Keats to Colonial Office. October 1. 1815. Keats noted that the same problems did not exist on ships from England and Jersev. and that at any rate, the volume of traffic from these countries was not comparable to that from Ireland. 
several accounts from that period exist. The year 1825 marked the beginning of another major influx of Irish to Newfoundland, and by May 1. eight passenger vessels had arrived from Ireland. all of which failed to comply with the provisions of the Passenger .Act. The masters or owners, however, advised local authorities that a recent Treasury Order had dispensed with the provisions of the legislation as regards the Newfoundland passenger trade and "that therefore they might bring as many as they could stow whether shipped servants or not." In addition to cramming passengers atop cargo. many vessel owners had also initiated a sustem of having passengers provide food and water for themselves, and many passengers - ill-intormed about the length of the passage and unable to afford the fare. ${ }^{\text {st }}$ let alone provisions - found themselves without food or water early in the vovage ${ }^{x-}$

Lack of proper regulation continued to plague the Irish-Newfoundland passenger trade ${ }^{* *}$ In 1827, tor example, the Freedom arrived from Ireland with its passengers in

${ }^{*}$ Many Irish passengers to Newfoundland travelled "on bond" or "on bail. They promised to pay their fares upon arrival, and provided the names of bondsmen in both Ireland and Newtoundland, who would be held responsible for their fares in default of payment. Often, the security in Newfoundland was given by fishing emplovers in partial fulfilment of the terms of shipping papers

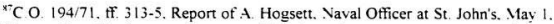
1825. The practice of having passengers provision themselves was a great cost-cutting measure, but sometimes vessel owners or masters felt a backlash. In this same report. Hogsett tells of the (eres. recently arrived from Cork. which " had not been at sea more than ten days, by the Masters [Bowman] own confession. when the Passengers were quite out of Provisions and he further states that he was obliged to walk the Deck armed until he got supplied from another vessel at Sea."

${ }^{\text {qR }}$ Repercussions of the slackening of regulations in the Newfoundland trade were also felt in the broader passenger trade. as some owners and masters of vessels clearing 
deplorable condition - a number either dead or dying of dysentery. Local authorities determined that had the Passenger Act still been in effect in relation to Newfoundland, the vessel could have been charged with carrying twice the number of passengers permitted by its tonnage and. indeed, because of insufficient space between the deck and cargo hold. would actually have been disqualified from carrying passengers altogether. Indeed. the vessel had only one deck and the passengers had literally been stowed on top of the cargo of salt within a space that measured no more than three feet in height. Furthermore, no distinct supply of provisions had been issued to the passengers. The vessel itself was filthy and had not been ventilated throughout the month's voyage. causing "an intolerable stench" in the passengers' hold. Authorities estimated that total infractions of the former legislation would have incurred penalties in the amount of $£ 82200^{* 7}$ Indeed. John Moore.

Ireland declared their passengers destination to be the Newfoundland fishery when. in actuality, they were intended for elsewhere. Such was the case of the brig Thomas Firrell, which cleared Ross in the spring of 1825 with 100 men and 62 women reportedly destined for the Newfoundland fishery. The passengers had actually contracted with the owner for passage to Quebec. but the owner's false declaration enabled him to overcrowd the vessel and to require the passengers to provision themselves. The vessel did make a stop at St. John's as a formality. but the passengers ultimately moved on to Quebec See Cyril Byrne. "The Brig Thomas Farrell." An Nasc, 41 (Winter, 1991), 6-7 (citing C O 194/71, ff, 322-3). Another intriguing episode occurred in 1833, when the brig (jood Intem out of Youghal arrived in St. John's with a passenger list which, according to the inspecting customs officer, "so totally differs both in name and description with the Persons actually on board. that of the whole number containing in that List. not one Individual is to be found which corresponds with the names therein stated." See PANL. GN 2/2. 13/77-78/1833. Customs Officers. St. John's. to James Crowdy. local Colonial Secretary. May 24, 1833

${ }^{47}$ See PANL. GN 2/1/A. 36/180-3/1827: Governor Cochrane to J. Moore. Surveyor of Navigation for St. John's. May 18. 1827, and Chief Magistrate to Governor 
the Surveyor of Navigation who inspected the vessel at St. John's, observed that while he had had occasion in the past to fine masters severely for breaches of the "late Act." he had never seen "an Instance that would have called for more Severity, than that of this Vessel. $^{(n)}$ A turther case of abuse presented itself on August 26. 1831. when the Ne/son. sailing out of Killala en route to Quebec, arrived in St. John's with its passengers in a high degree of distress owing to severe overcrowding and a lack of proper provisions and water. The vessel had cleared Killala claiming 183 passengers, but had actually carried somewhere between three and four hundred on the ten-week voyage. In this case. however, as the passengers were not intended for the Newfoundland fishery, the master was charged under the Passenger. Act and fined £350. The owner. merchant Charles McCallagher of Balina. Mavo, begged leniency, stating that the master had taken on additional passengers without his permission. that poor weather had stretched the voyage beyond the capacity of the provisions, and that only a few aged, infirm. and weakly young children had died on the voyage. Generally. he blamed the tragedy on his own inexperience, but whether he was successful in mitigating his responsibility is not stated in

Cochrane. May 17, 1827: J Moore to Governor Cochrane. May. 1827. as well as related correspondence and documents at 36/191. 215, 218, 283-4. and 361-74/1827. 36/3923/1828, and 37/95-101/1828. And see PANL, GN 2/2, 2/110-121, 132-34, 199-206, 25676 . and $462-8 / 1827$, various correspondence and reports in May, August, and November. 1827

${ }^{n}$ PANL. GN 2/2, 2/110-12/1827. John Moore. Surveyor of Navigation. St John's, to W, A. Clarke. local Colonial Secretary, May 17. 1827. 
the record."

The spectre of sick and starving passengers staggering from the holds of passenger vesseis added a new component to the construction of Irishness in Newfoundland in the period after 1815 - the image of contagion and disease Vessels arriving in port with sick or dead passengers and crew were inspected by local medical ofticers. who came back ashore with warnings of flux, bilious and putrid fevers, and other dire offerings from the medical lexicon of the early $19^{\text {th }}$ century. Always, there was a tear of contamination spreading to the inhabitants, especially in the main port of St. John's. where many of the vessels initially landed and where a rising population and cramped quarters increased the potential of epidemics. As the influx of Irish increased from 1815 through the 1820 s and early $1830 \mathrm{~s}$. the images of tilth. pollution, and disease became tirmly linked with Irish passenger vessels and the Irish 'lower orders' living in the town in general In reporting to the magistrates at St. John's on the possible connection between the arrival of the Freedom and the presence of typhus and other fevers in St. John s. for example. surgeon William Warner explained:

The great want of attention to accomodation \& cleanliness is the source

${ }^{4}$ See: PANL, GN 2/1/A, 38/163-4, 174, 177-8, and 196/1831, various correspondence and reports through August and September. 1831: PANL. GN $2 / 2$. 13/199-202/1833. Customs Officer. St. John's, to Colonial Secretary. April 25, 1833. enclosing memorial of Chartes McCallagher. January 1. 1833. Public Ledger, August 26 and 30. 1831, and Roval Gazette and Newfoundland Advertiser [Royal Gazette]. August 31. 1831 . 
whence it emanates - This disease I presume might with more propriety be called Putrid Fever, It is generated by whatever lessens the Nervous power - as bad diet, fatigue - foul atmosphere. or want of Ventilation \& Cleanliness - A crowded Vessel at sea - where moisture is combined with heat and the putrid Efflu[v]i[u]m arrising from the Excremeatitious Matter of living bodies, pent up below for many davs as was the Case in the Freedom - cannot fail to produce such diseases as Fluxes \& Putrid fever and become the source of infection of others - I therefore consider that had not the passenger Vessels brought so Many infected persons among us. that the town might have been but little diseased from the mere influence of season \& the habits of the people.

Still. Warner went on to state. sanitation in the town left much to be desired. and while the seeds of the disease may have been carried in passenger vessels, they found fertile ground in the "the present filthy state of the streets. Cook rooms. and dwellings of the lower orders ${ }^{\cdots \cdot}$

Five other doctors had been consulted on the matter and four reached similar conclusions (the fifth declined to comment) ${ }^{33}$ - that the current round of typhus and other tevers had spread from passengers of the Freedom and found a welcome breeding ground amidst "the poverty, filth \& manner of living of the lower orders here ${ }^{\cdots / 4}$ One embellished this more conventional epidemiology with additional moralistic comment. stating that "the

\footnotetext{
"PANL. GN 2/2, 2/258-61/1827. William Warner to the Magistrates at St. John's. tugust 1,1827 .

${ }^{33}$ P.ANL. GN 2/2. 2/256-76/1827, various medical reports to the Magistrates at St John's. August 1-3. 1827 1. 1827 .

${ }^{21}$ PANL. GN 2/2, 2/266-7/1827. J Shea to the Magistrates at St. John's. August
} 
disease lay lurking [within the passengers] appearing some days after their landing with violence from the drinking of bad Spirits and too great excess." ${ }^{\text {"s }}$ Surgeon Edward Kielley agreed with his colleagues that the disease was "generally confined to the hovels of the poor." which were "absolutely reservoirs for filth and evident contagion". however. he found himself in the awkward position of having treated some cases in "respectable families", obviously these, he noted, had been "communicated by the imported contagion" rather than poor sanitary conditions. ${ }^{\text {25 }}$ Meanwhile, the 'respectable' inhabitants of St John's had called a town meeting and formed a special committee to check contagion They sent a deputation to the governor to express their concern that

the Extremely dirty state of the Streets etc. contributed materially to augment disease - \& requesting the Govt to use his influence to prevent the future introduction of diseased persons in Crowded Vessels which had in a great degree led to the present Calamity ${ }^{47}$

"P.A.VL. GN 2/2, 2/263-4/1827. " [signature indecipherable] to the Magistrates at St. John's. August 1,1827

"xp PANL, GN 2/2, 2/268-70/1827. Edward Kielley to the Magistrates at St. John's. August 3. 1827. Not surprisingly, when the brig. James arrived from Ireland less than two week later with several sick passengers and crew members. the alarm was raised by attending doctors and clergy, who urged that immediate measures be taken to prevent any intercourse between the vessel 's complement and the town. See PAVL. GN 2/2. 2/306312 1827. various correspondence and reports. August 13.1827. See also related correspondence at PANL. GN 2/1/A, 36/266 and 344-5/1827.

"PANL. GN 2/1/A. 36/241/1827. Mr. Bumstead, Chairman of the Committee for checking Contagion. to Governor Thomas Cochrane. July 28, 1827, and related correspondence at $36 / 242$. 254-265. and 276/1827 
As the numbers of Irish arriving at Newtoundland increased within the context of declining standards in the passenger trade. then, 'imported contagion became one more facet of the perception of Irishness by the 'respectable' inhabitants of the island

It is difficult to determine how typical or exceptional the above passages were in terms of the Irish passenger trade to Newtoundland at the time. Certainly, newspaper reports and governors' correspondence of the day were more likely to deal with the exceptional than the routine (aithough this does not rule out the possibility of 'requent abuse). A different perspective of less eventful passages can be gained by reviewing the letterbook of Edward Kough, a merchant of New Ross who was involved in the provisions and passenger trade with ports in Newfoundland (including. over the course of time. St. John's. Ferryland, and Placentia)

Details about the 1825 voyage of the passenger vessel c incord - bound for $\mathrm{St}$. John's - are particularly enlightening ' ${ }^{\text {*x }}$ Recruitment of passengers had begun by February. and demand for passages to Newfoundland was brisk. Potential employment in the Newfoundland fishery was the largest drawing card. "the success of these passengers in procuring employment will influence many more in emigrating from this country ." he

${ }^{3 *}$ The following account of the Concord's vovage is taken from various correspondence in the MHA, MF-191. Letterbook of Edward Kough (1818-1834). February - September. 1825. In particular. see: Kough to James $\mathbf{M}$. Henderson. Liverpool. February 21. 1825: Kough to John Boyd. March 25 and April 9. 1825: and Kough to the Inspector General of Customs for Ireland. September 21. 1825. John Bovd was Kough's associate who co-ordinated orders for passengers and provisions in the St. John's area. 
informed an associate, "and if you can procure orders for the shipping of youngsters, they can be got here to any number required." Women were charged a different fare than men: " for men I obtain $£ 610.0$ British on bail but have taken two for $£ 10.10 .0$ [ $\$ 5.50$ each] Irish cash. Women £7,10.0 British on Bail four of which I have taken for £24.18.6 [£6 + 7-1/2 each] cash." ${ }^{\text {49 }}$ Fear of the Atlantic crossing obviously played on potential passengers' minds, for a number were dismayed by the ('oncorc's small size and poor appearance (a situation that Kough sought to remedy with a coat of paint) LItimately. however. finances dictated the fate of many emigrants, who opted for cheaper passage (as low as $\varepsilon+$ ) on board vessels from Waterford, regardless of travelling conditions. ${ }^{\text {11* }}$

'The higher fares for women are intriguing. The higher bond rate could be explained by their being deemed a slightly greater risk in terms of being able to tind employment and pay their passage once in Newtoundland. However. the cash fare - at least in this example cited - also appears to have been higher.

in' A comparison of fares to Irish wages of the period would be useful. but the information is difficult to come by on this side of the Atlantic. Perhaps the most readily available. and only through the secondary literature. are wages earned by irish agricultural labourers of the period, but even here. the data are not consistent. Cormac $\mathrm{O}$ Grada estimates the mean nominal wages of agricultural labourers in 1829 at $61 \mathrm{ld}$. per week. See Cormac O Grada. Ireland: A New Economic History, 1780-1939 (Oxford: Clarendon Press. 1994). p. 237. He does not indicate an average or mean number of weeks worked. but even assuming full employment. the maximum earnings would have been only £132.12 per vear - likely a high estimate as this type of employment was rarely continuous Lising evidence presented to the Poor Inquiry Commission of the early 1830s (appointed 1833 , reported 1836 ). Kenneth Connell estimates that the average daily wage of a labourer was 8-1/2d. with a potential employment period of up tol 35 days per vear: the maximum average earnings would, therefore, have been $£ 4.9 .7-1 / 2$ per year. See Connell. Population of Ireland, p. 76, fn. 2 . Both Connell's and O Grada's figures. however, are based on aggregate data for Ireland. and it is difficult to determine how representative they are of the southeast counties from which the Newfoundland Irish came. Furthermore, neither discusses total family earnings, including women's and 
Kough notes that the (oncord finally sailed with 79 passengers (although he had

children's paid work or earnings from pigs and poultry. A more nuanced set of estimates is provided by Mary Cullen, using the same Poor Inquiry evidence to estimate family cash incomes (labourer's wages and income from pigs and fowl) for specific baronies in various counties - several from the southeast, e.g.:

\begin{tabular}{|c|c|}
\hline Kilkenny & $\S 7.0 .0$ (occasional labourer) - $₹ 9.0 .0$ (cottier) \\
\hline Kerry & 乏6. $10.0-\sum 8.18 .0$ \\
\hline Limerick & $£ 6.15 .0-£ 90.0$ \\
\hline Tipperary & $\sum 1168$ \\
\hline Waterford & $\Sigma 8.00-\Sigma 1000$ \\
\hline
\end{tabular}

The mean number of days worked in these specific counties was 200 days per year Cullen also provides some tamily budgets (for counties outside the southeast) indicating that all or the better part of family cash incomes were expended on necessities - such as potatoes, rent, turf - with small amounts left for clothing, soap, and tobacco. Saving for passages would, therefore. have been difficult. See Cullen. "Breadwinners and Providers: Women in the Houschold Economy of Labouring Families, 1835-6," in Luddy and Murphy. Women Surviving, pp. 85-116. particularly pp. 92-103. Cullen's estimates. however. do not include women's and children's earnings trom occasional agricultural labour (spring and harvest) or women's earnings from cottage textiles (particularly, the woollen industry). In a documentary collection. Maria Luddy includes a Poor Inquiry report on women's and children's agricultural wages in the $1830 \mathrm{~s}$. Based on an earning group of a wite and four children of working age, reports trom Munster indicated potential earnings ranging from lows of $£ 1$ per wife and $£ 1.10 .0$ per child ( $£ 6$ total) and $\sum 7$ per year to highs of $£ 20$ and $£ 22.100$ per year. No information was cited for Leinster. The report indicated that women's paid work in both the agricultural and cottage industries sectors was in decline. See "Report from His Majesty"s Commissioners for Inquiring into the Condition of the Poorer Classes in Ireland. Appendix D (1836)," in Luddy. Documentary History, Doc 47 3. pp. 166-72

Indeed, in general, agricultural wages had been declining and unemployment had been rising between the sailing of the concord in 1825 and the hearings of the Poor Inquiry in the early 1830 s. Granted, also, small-holders and artisans who also formed part of the emigrant stream to Newtoundland would have earned higher incomes (but had higher expenditures as well). The overall picture on incomes is murky. But certainly. most emigrants would have been hard pressed to save passage money for trans-Atlantic crossings - a feat that must have been extremely difficult for family groups travelling together. The high incidence of emigrants booking their passage to Newfoundland "on bond is therefore hardly surprising, given the far higher earning potential in the fishery (see Table 4.1) 
hoped for over one hundred). The average fare was £6.15.0 (this suggests that most passengers travelled 'on bail'). Provisions were generous compared with the other accounts above and were comprised of the following: 14 pipes of water "in addition to the casks belonging to the vessel": 31 cwt of bread: ten cwt. of oatmeal: 420 stones of potatoes; $89 \mathrm{lbs}$ of butter: one tierce of beer; $213 \mathrm{lbs}$ of beef: $1116 \mathrm{lbs}$ of pork. ${ }^{101}$ Every two passengers were permitted to bring on board one chest containing personal effects. ${ }^{102}$ and while the vovage out was lengthier than usual owing to contrary winds and weather, ${ }^{\text {th }}$

in' A pipe' was a cask holding two hogsheads or 126 gallons. Kough's average tare was likely higher than that of many vessels out of Watertord because Kough. unlike many others in the trade, was actually provisioning his passengers. In 1831 . because of damages to one of his ships and continuing competition from Waterford vessels, he considered having his passengers provision themselves as other carriers were doing Whether he actually succumbed to this practice is unclear. See MHA. MF-191. Kough Letterbook: Kough to Robert Hutton \& Co. March 1. 9. 14. \& 30, 1831. Kough to Capt Taylor, March 2. 1831, and Kough to William Kydd. April 12, 1831

to: The Saunders and Sweetman Letterbook at PANL. MG 49. also details arrangements tor transporting fishing servants chests to and from Waterford: these would contain some clothing, small items of gear. and other necessities for the fishing season.

${ }^{1103}$ Kough does not specify the actual length of the voyage, although he indicates in mid-August that he still has not heard news of the (oncort's arrival and that relatives and friends of passengers are becoming concerned. See MHA, MF-191, Kough Letterbook. Kough to John Boyd. August 15. 1825. Lengths of voyage. when stipulated in the previous accounts. ranged from one month to 10 weeks. The diary of Ferryland magistrate Robert Carter mentions the travelling time of several vessels arriving in the study area from Ireland - ranging from a very short passage of 12 days. through more average lengths in the 20s, to a longer passage of 49 days. See P.ANL. MG 920. Robert Carter Diary, 1832-1852. The Sweetman Collection contains a notebook detailing the arrival and departure of vessels at Placentia. 1831-1835. Lengths of voyages from Waterford ranged from very short passages of 15,16 . and 18 days. to exceptionally long passages of 50,54 , and 60 days. Most voyage lengths, however. fell within the range of $22-38$ days. The average passage time was 31.47 days, and the mean length of passage. 
no passengers complained (according to Kough) during the voyage of inconvenience or lack of room between the cargo hold and the deck. Although not all the passengers had arranged employment before leaving Ireland. Kough was in no doubt that their purpose in going to Newtoundland was to find work in the fishery. "I am warranted in saying they went for no other purpose, as they would all have preferred shipping here for it to running the risk of obtaining Masters when they got out...."

Kough and his St. John's partner. John Boyd. appeared to have been a more scrupulous operators than many, and the passengers of the (incord appeared to have had a less traumatic crossing than some Irish migrants coming out to the Newfoundland fishery. Still, a footnote must be added to this account. for a report received at the Colonial Office on this same passage indicates that the 60 male and 25 female passengers on board (evidently, the complement had increased slightly from Kough's reporting) "were literally stowed in bulk, and but for the shorness of the passage which had been pretty general this spring. many of them must have been in a distressing condition. "ipd Kough and Bowd. then, were aiso susceptible to bringing out "as many as they could stow whether shipped servants or not."

The above accounts of the passage from Ireland to Newfoundland provide insight into a range of emigrant experiences - from the relative comfort of the Presentation sisters.

30 days. See P.ANL. MG 49. Sweetman Collection. Box 2. File 12.

${ }^{11}$ Byrne. "Thomas Farrell." 
travelling on the Ariel. to the distress and debilitation suffered by the passengers of vessels such as the fimm or the unfortunately named Freedrm. In the middle of the spectrum, there was the more benign crossing provided by Edward Kough and his vessel. Concord. The nurs' experience was surely atypical. But just as surely, there must have been other more responsible operators like Kough, who wished to deliver their passengers in tit condition to work at the fishery By contrast, there were also those carriers who merely wanted to maximize profits by cramming their vessels tor the crossing. with few scruples about sutficient provisions of food and water. One can only speculate about the representativeness of these passage experiences. In terms of women passengers. given the lack of personal accounts, we must also deploy our imaginations to recreate their fears and reservations. expectations of future prospects. and the tremendous effort to care for families in often primitive conditions - confined to close living quarters for a month and sometimes even two. maneuvering for cooking space on the cabouse' or sawed-otf puncheon tubs shared by passengers. ${ }^{\text {to? }}$ jostling for scarce provisions - on board ships that they hoped would transpon them to better lives.

Still. despite difficult passages and despite an often inauspicious welcome (in terms of both physical environment and official attitudes). Irish women came to the southern

\footnotetext{
${ }^{105}$ A 'cabouse' or 'caboose' was an iron hearth and copper on board passenger vessels for cooking. Sawed-off puncheons tubs were also used for cooking the fire was laid on sand and rocks, which served as insulation. See, for example. PANL. MG 49. Sweetman Collection. Box 5 . Saunders and Sweetman Letterbook: Pierce Sweetman at Placentia. instructions to Capt. John Sheppeard on the Brig Chamont. November 4. 1789: also Pierce Sweetman at Placentia. instructions to John Blackney. November I. 1790
} 
Avalon in increasing numbers after the middle of the $18^{\text {th }}$ century. They were an integral part of lrish migrations to the southern Avalon during the study period and would be key players in community formation and survival. The numbers of women who came from Ireland. their home counties and motives for migration. and their role in stabilizing early settlement will be explored in the next chapter. 


\section{Chapter 3-Cyphering cyphers: Tracing Irish women on the southern dvalon}

There were there 110 men. at least half of them armed. not counting women and children.... This place is very fine. There are 17 houses. and about 116 men, not counting women and children. We found sheep and cows here. ${ }^{1}$

Like other 17th-century observers in Newfoundland. Father Baudoin demonstrated a knack for "not counting women and children" and a propensity for lumping them together with the livestock. English naval officers in the late $17^{\text {th }}$ century were also somewhat relaxed about counting women. and certainly about identifying them, in their census reports to the Commissioners of Trade: a mistress of a fishing plantation. if she was enumerated at all, appeared only as the numeral ' 1 ' next to her husband's name in a column headed 'Wife'. servants were tabulated together in another column. undifferentiated by sex. However, the census system became more systematized with the passage of the Vewfoundland Act of 1099 . and numbers of mistresses and women servants were more regularly (if not always accurately) reported by the naval governors annually from that point onwards. Still. the task of tracking Irish women immigrants to the study area is not an easy one

Yewfoundland is not exceptional in the paucity of its early census and immigration

'Taken from the observations of Father Baudoin. a Recollet priest who accompanied French forces in their campaigns out of Placentia eastwards and northwards along the English Shore in 1696 and 1697. See Alan F. Williams. Father Baudoin's War: D'lberville's Campaigns in Acadia and Newfoundland, 1696, 1697, Alan G Macpherson. ed. (St. John's: Memorial University. 1987). p. 60. 
records. Historians studying early migration patterns to other parts of North America have also encountered difficulties in ascertaining the actual numbers that arrived in the new world. The task is further complicated by any attempt to separate the permanent migrant from the sojourner (a task that was. no doubt. almost as difficult for official recorders of the day). Because of Newtoundland's unique status as a tishery rather than a colony (at least in official terms) until the early $19^{\text {th }}$ century, historians of early settlement continue to struggle with the question of how to measure accurately the transient vis-à-vis the permanent elements of Newtoundland's population. While early census material exists. - summer populations show numbers temporarily intlated by ship-tishermen, byeboatkeepers. and fishing servants hired only for the summer. or perhaps two summers and a winter, even over-wintering populations included large numbers of transient servants and dieters ( although many did settle in time). Furthermore. even as the migratory fishery entered its prolonged demise in the latter $18^{\text {th }}$ century. the ascendant sedentary fishery continued to employ significant numbers of fishing servants. both migrant and resident. at least until the post-Napoleonic War period, when the traditional planter fishery waned and was replaced by household production in the industry (see below). Additionally. some

\footnotetext{
'Vaval commodores' reports on the population and fisheries for the late $17^{\text {th }}$ and early $18^{\text {th }}$ centuries are available at the MHA and PANL. Also, from 1699 onwards, the commodores. and later governors (from 1729 onwards). at Newfoundland were required to forward to the Colonial Office each fall, after the fishing season had ended, a return of the fisheries. inhabitants. imports and exports of Newfoundland, these annual returns are contained in the C O. 194 Series at the CNS and PANL, a nominal census of Ferryland district for 1799-1800 [the Pole Papers] is housed at the PANL. MG 205: Newfoundland Population Returns, 1836. 1845, and 1857 are available at the CNS. MH.A. and P.ANL.
} 
migrants used Newfoundland as a stepping-stone to colonies on the mainland - a phenomenon difficult to measure as it was not systematically recorded. although it was frequently referred to in anecdotal evidence of the period. ${ }^{\prime}$

There are other reasons why early Newfoundland census material does not provide a firm data base for calculating the dimensions or components of migration and population growth. There are sometimes internal anomalies within individual censuses as well as inconsistencies between censuses. Also, estimates in round numbers were sometimes recorded by observers when exact information was not available tor particular communities or districts. Additionally, categories shifted over time and were not clearly detined. Betore the 1836 census, tor example. women were enumerated as either 'mistresses or "women servants, with no category to differentiate unmarried women who were not servants. ${ }^{5}$ Indeed. the category of 'temale servant is itself problematic. for it

'For example, various proclamations were issued throughout the second half of the $18^{\text {th }}$ century and into the early decades of the $19^{\text {th }}$ century that banned the transportation of passengers - especially artisans. tishermen, and seamen - to the mainland without the governor's permission. indicating that the attrition of skilled workers through stepmigration to the mainland was an ongoing problem. See PANL. GN 2/1/A. Relatively cheap fares to Newfoundland made it an attractive lay-over for migrants intending to go elsewhere in North America.

${ }^{4}$ For example. the Pole Papers at the P.ANL list only one woman servant in the district during 1799-1800. although the annual return in the C.O. 194 Series for 1801 (a return for 1800 is not available) indicates that there were 136 female servants in that district

'Handcock provides an educated guess that 'women servants' included all unmarried women over 15 years of age, although he does not explain his rationale. See Handcock. Soe longe, p. 93 
does not differentiate between domestic servants and fishing servants. Age groupings present a turnher complication. In annual reports up to the early 1830 s. "children' were reported separately from adults, although the age demarcation was not given. From 1836 onwards, males and temales were reported under specific age groupings, yet even these categories changed in 1857 (the most notable, in terms of separating adults from children in the population, was the shift from an 'under $14^{\prime}$ category to an 'under $10^{\prime}$ category).

Precise information on Irish immigration and ethnicity is also elusive. There are no specific immigration statistics available for the study period, and ethnic origins of the inhabitants were not recorded until the 1857 census; even then, the category only recorded non-natives such as 'Irish-born' and 'English-born' - not the entire ethnic group. The C O 194 returns did enumerate a category of 'passengers' by source area, yet even this word is open to interpretation. Certainly, passengers in the early years of reporting were people coming to the island as seasonal workers in the fishery (either for the migratory fishery or the resident fishery). But gradually, throughout the $18^{\text {th }}$ century. increasing numbers of passengers came to Newfoundland in the hope of remaining on the island; thus the line between seasonal and permanent migrants became further blurred. In terms of determining ethnicity and gender, the passengers were demarcated by major source region (England. Ireland. Jersey). but not by sex. Research on the southern Avalon is further complicated by the fact that many Irish passengers to that area from the turn of the $19^{\text {th }}$ century onwards likely disembarked at St. John's, separate passenger figures for most of the 'Southern Shore' (Bay Bulls to Cape Race) rarely appeared thereafter. and not at all 
after the Napoleonic War period, although passengers to Trepassey and St. Mary's continued to be recorded separately

Given the drawbacks of early census material, it is difficult to provide precise baseline data on the migration of Insh women to the study area up to the mid-19 century It is possible. however, to capture impressions of these movements. using the breakdowns that are available in terms of winter and summer inhabitants. masters and mistresses. male and temale servants. and religion. Parish records. birth. marriage. and death notices in newspapers, name tile collections. and the oral tradition provide additional insights into source areas. migration networks. marriage and settlement patterns. and early community formation

\section{Source areas}

When Mary Ryan left county Wexford in 1826 to come to the southern Avalon. she was following one of the most well-travelled Irish migration streams to Newfoundland in general. and to the southern Avalon in particular.

The Historical Atlas of Canada provides a mapping of known emigrants to Newtoundland. 1780-1850, from Ireland. It demonstrates that overwhelmingly. the Irish in Newfoundland came from the southeastern counties: Kilkenny (1.835) provided the greatest number of emigrants. Wexford (1.685) slightly edged out Waterford (1.625) for second place. while Tipperary $(1,135)$ ran a respectable fourth: Cork (505) and Carlow 
(190) followed distantly as source areas, while the remaining known emigrants $1+20$ ) came from other Irish counties." The logic of the emigrant stream was intrinsically tied to the Newfoundland tishery. These counties formed the hinterland of ports that had been stopping points tor the West Country fishing ships in the $17^{\text {th }}$ and early $18^{\text {th }}$ centuries. and which had developed a passenger and provision trade in their own right in the $18^{\text {th }}$ century The ttlas also provides a breakdown for inhabitants of Ferryland district in 1830 who had been born outside Neutoundland. This analysis indicates that the major source regions for those who were Irish-born were similar to those of the larger Irish migrant stream to Vewtoundland, with a slight re-ordering of the top three source areas Wexford first (78), then Kilkenny (73), and Watertord (71). Tipperary (34) was not as well represented as in the general Irish emigrant population - sending only half as many emigrants as either of the top three. As with the larger immigrant stream, Cork $(10)$ and Carlow (7) followed in fifth and sixth place. respectively. Another 14 persons hailed from other Irish counties.

Intormation on source areas of Irish women emigrants to the southern Avalon is

"John Mannion and W Gordon Handcock. "The Southeast Ireland Homeland" and "The Southwest England Homeland." in R. Louis Gentilcore. ed.. Historical tilas of Canada, vol. II (Toronto. Liniversity of Toronto Press. 1983), plate 8.

A pie chart showing source counties appears in Mannion and Handcock. "Origins of the Newtoundland Population. 1836." in Gentilcore, ed. Atlas, vol. II. plate 8 The precise figures were provided to me by John Mannion from his private database. Note that the boundaries of Ferryland district were not coterminous with those of the study area of this thesis: Trepassey Bay and St. Mary's Bay were not included. 
very sparse indeed. ${ }^{8}$ I have been able to identify only 67 women who came directly from Ireland and to track only 63 of these to their home counties (information on towns. villages. and parishes is even more scarce and statistically negligible)." While data are limited. they certainly trace a picture that does not vary far from the two mappings outlined above and, indeed, correspond closely with that for the Irish-born of Ferryland district: Wexford (18) was the leading source area, with Waterford (14) and Kilkenny (13) ranking second and third, respectively: again. Tipperary (9) was a respectable fourth (indeed, better represented among women migrants to the area than among the Irish-born in Ferryland district), while Cork (5) ranked tifth (see Table 3.1). Although it is difficult to ascertain the representativeness of this material. the impression it creates is that Irish women's migration to the study area was generally linked to overall Irish movements to the southern Avalon (see Figure 3.1 ) In other words. there does not seem to have been a separate migration stream - a distinct cluster or pocket of source areas for women migrants - that was out of character with a movement that was overwhelmingly linked to

"I had hoped to compensate for the lack in the written record with family histories. Cnfortunately. limited information is retained in the oral tradition in the study area in terms of the precise backgrounds of male or female forebears. Most informants advised that such matters were rarely discussed in their families or within the community

"Given the nature of the industry that attracted this migration, and the reliance on male shore crews in the period before the transition to household production. the small number of 'hits' in terms of women's migration is indicative of smaller numbers of women migrants compared with male migrants. However. given the overall lack of attention to women in records of the day. the numbers of female migrants would have been far more numerous than the limited segment represented here. 


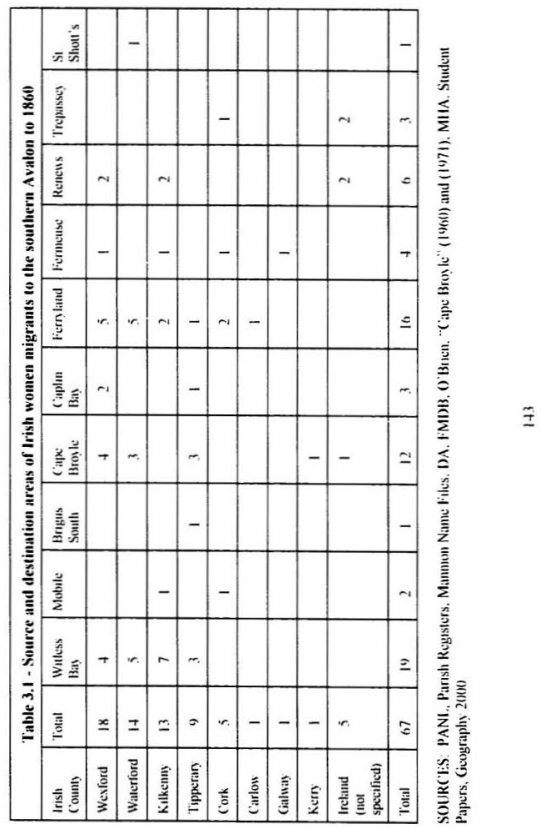


Figure 3.1 - Source areas of Irish immigrants as percentage of total

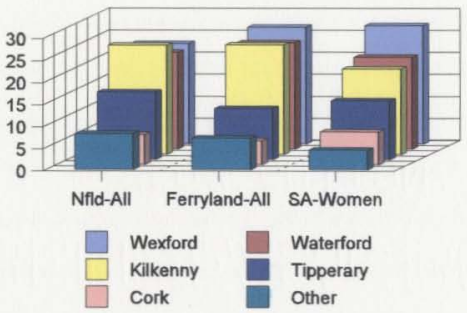

SOURCES: Gentilcore, ed., Atlas, Vol. II, Plate 8; Mannion Name File Collection; PANL, Catholic Parish Registers; MHA, Student Papers, Geography 2000; O'Brien, "Cape Broyle" (1960 and 1971); FMDB; DA. Note that the chart does not include the 7.5 percent of Irish female immigrants to the study area whose home county was not given. 
the Newfoundland tishery.

\subsection{Motives and patterns of migration}

Writers such as Mannion. Head, and Nemec have already described the particular blend of push and pull factors which attracted many migrants from the southeast of Ireland to Newtoundland. A series of crop failures from 1726 to 1729. the severe frosts in the winters of $1739 / 40$ and $1740 / 41$. a devastating drought in $17+1$, and high unemployment triggered by the Spanish War provided an impetus for migration by the middle of the $18^{\text {th }}$ century that happily corresponded with an increasing demand tor lrish servants in the Veuvfoundland fishery Furthermore, in the latter $18^{\text {th }}$ and early $19^{\text {th }}$ centuries, the southeastern counties. like other parts of Ireland. were experiencing the ill effects of overpopulation and land shortage. Subdivision and subletting of land were increasingly undermining the viability of holdings and eventually came under prohibition altogether. leaving tew options for surplus offspring in small-holder or cottier tàmilies. Meanwhile. the domestic textile industry was struggling. particularly in the post-: Vapoleonic War recession. The agricultural sector was also badly hit by the post-war slump, as prices for farm produce dropped and markets for provisions declined. And although advances were made in tarming technology, they created a surplus of labour that was not absorbed by any corresponding increase in town manufacturing. Still, the southeast was not as harshly affected by these developments as other parts of Ireland (the west and north). These push 
factors, however, combined with the drawing power of employment in the Newfoundland fishery to create a very specific migration stream from the southeast to Vewfoundland one that, in its largely Catholic composition, was quite distinctive from the markedly northern and Protestant character of the broader Irish migration flow to North America up to the post-Napoleonic War period, "' and one that. in its responsiveness to emplovment demands in Newtoundland and declining conditions in the mother country. challenges Miller's perception of an inferior Irish-Catholic migrant type.

Other written sources. historical and contemporary. contirm the pull of the Vewfoundland fishery for Irish immigrants. "The oral tradition on the southern Avalon aiso acknowledges the role of the fishery in drawing the Irish to the area. In addition, it offers some alternative motivations: the Irish rebel running from the law: the Irish Catholic tleeing trom religious persecution; the Irish cottier escaping the great potato famine But while isolated cases such as these may have existed. these explanations are far

"A number of Irish migration historians have noted that more than half of those who relocated from Ireland to North America before the 1820 s were Protestants. particularly Llster Presbyterians: many were small farmers and artisans who were suffering the effects of competition from large-scale agriculture and restrictions on the linen and woollen industry. See, for example: Akenson. Being Had; Doyle. "Irish in North America". Fitzpatrick, "Emigration. 1801-70": Houston and Smyth. "Irish Diaspora" and Irish Emigration and Canadian Sertlement, Kirkham, "Origins of Mass Emigration". Miller. Emigration and Exile: Irish Exodus; and Nolan, "Great Famine and Women's Emigration.

"See. for example: MHA. MF-191. Kough Letterbook: PANL. MG 49. Box 5 . Sweetman Letterbook: Howley. Ecclesiastical History, Prowse. History of Newfoundland: Matthews. "West of England-Newfoundland Fishery". and Innis. Cod Fisheries. 
more retlective of an inherited mythology of grievance than actual experience: the Irish rebel was more likely a deserting servant hiding from a tishing master; the religious refugee most likely sought religious tolerance elsewhere than a British possession with a similar penal regime: and while crop failures and regional famines may have encouraged movement to the southern Avalon, the hungry peasant of the mid-19th century most likely went to the mainland. for most Irish immigrants to Newfoundland had arrived by the early $1830 s^{12}$

So we return to the economic lure of the Newtoundland tishery and the opportunity provided for migration, tirst by West Country fishing ships and later, by Irish vessels involved in the passenger and provision trade. But how did women feature in this distinctive migration stream? While the current literature has identified male migrants to Vewfoundland as craftsmen, farm labourers, or the sons of small tarmers, it does not speculate on the socio-economic backgrounds of female migrants. Specitic data are scarce. but some logical inferences can be drawn from Irish literature on their source areas. According to $\mathrm{O}$ Grada. the triangular area from Cork to Dundalk to Wexford - an area that corresponds roughly with the southeastern homeland of many southern Avalon

\footnotetext{
"This is not to dismiss these communal myths of migration. for they provide insight into the evolution of ethnic identity and reflect a sharing of collective memory with the home country and with other Irish migrant groups that is, in itself. a significant cuitural continuity The inconsistencies between the myths and actual experience are themselves insightful for, as Alistair Thomson points out. they demonstrate "the role and power of such generalizations as mechanisms of solidarity and defence" within immigrant communities See Thomson. "Moving Stories." p. 34.
} 
immigrants - was a high tillage zone in the relevant period. with labour-intensive agriculture and a relatively complex social structure. including farm labourers, tradesmen. artisans, and small farmers as well as middling and large farmers ${ }^{13}$ The inference. then. that Irish women immigrants on the southern Avalon came from agricultural or artisanal family backgrounds who were feeling the squeeze of demographic and economic pressures in Ireland is a reasonable one. It is also highly likely that many had worked in cottage textile industries. In particular, there was a high degree of women s participation in the domestic woollen industry. which was flourishing in the southeast until at least the late $18^{\text {th }}$ century and was as important economically to that area as the linen industry was in the north. Thereafter. it declined steadily as a result of rising wool costs and competition from English woollens and cottons. and had virtually disappeared in some areas by the taking of the $18+1$ census. ${ }^{14}$ On this front as well. then. Irish women were facing the spectres of recession and unemplovment. It is thus hardly surprising that a number of women from the southeast turned their eyes to the Newfoundland tishery as an attractive alternative to declining opportunities in Ireland.

As naval officers and governors at Newtoundland had occasion to remark. a

${ }^{13} \mathrm{O}$ Grada, Ireland.

${ }^{14}$ See L A Clarkson, "Ireland 1841: pre-industrial or proto-industrial; industrializing or de-industrializing?" in Sheilagh C Ogilvie and Markus Cerman. eds.. European proto-industrialization (Cambridge: Cambridge University Press. 1996). pp. 6784. Mageean, "Irish Women's Prospects". and Luddy, Documentary History, Part III. "Work." 
significant number of single Irish women came to Newfoundland in search of work as servants and ultimately married among the fishermen or planters and remained. ${ }^{\text {ts }}$ One such woman was Mary Crane, who came out to Ferryland from county Cork in the late 1820s. According to family folk history, she espied local carpenter Tade Bryan on the wharf as she was disembarking and declared then and there that he was the man she was yoing to marry - a prophecy that proved correct in fairly short order ${ }^{\text {th }}$ But romance likely took a back seat to the exigencies of earning a living for most of these women ffew became fishing servants - heading, splitting, salting, and drying cod as pari of shore crews; far greater numbers contracted themselves as domestic servants to merchants, planters. administrators, and their families - but this type of service. itself, was often an important component of the sedentary tishery (see Chapter + ) In either case. the women may have

\footnotetext{
15 Much anecdotal evidence from authorities on the island discusses the arrival of signiticant numbers of single women, as has already been seen. Passenger lists are not readily available; at best, numbers only are cited in official reports. In newspaper notices to passengers who have not paid their fares, however, there is also an impression of significant numbers of single women travelling alone. There were 16 women s names among the $5+$ names of passengers arriving on the brig. Joyce from Ireland in 1809.1810 . and 1811 who had not paid fares; only two of them appeared within a clustering of surnames that could be taken as a family groups. Similarly, of the 52 non-paying passengers listed from the brig Good Intent from Waterford in 1817, six were women, but none were clustered with other family members. See PANL. Mildred Howard Collection (citing The Roval Gazette and Newfoundland Advertiser, July 30, 1812, and October 14. 1817). Granted, some of these women may have travelled with family members whose tares had already been paid. but surely many were single travellers. Their situation can be contrasted with the 62 women on board the brig Thomas Farrell out of Ross and bound tor Quebec. of whom three-quarters were travelling within tamily groups. See Byme. "Thomas Farrell." pp 6-7

${ }^{16}$ Correspondence from DA. March 8. 1999
} 
been shipped (either by oral contract or by a written shipping papers ${ }^{17}$ ) in Ireland or upon arrival in Newfoundland. When women were specifically recruited for work in this fashion, the law looked upon the arrangement as a formal contract, just as in the cases of men contracted as fishing servants. In a 1787 court case in Ferryland, for example. Elizabeth Cullen complained that she had been shipped in Ireland to serve James Shortall in Ferryland "on order" But the vessel had had a long passage over, and Mr. Shortall had run out of patience and hired another servant instead. When Elizabeth finally arrived. Mr Shortall "reshipped" her to his neighbour. Mary Sanders. Elizabeth served Sanders tor a while, but they had a falling out and parted. Elizabeth went back to Shortall, but he refused to take her in, and she was forced to take lodgings with a Hannah Gaffney Finally, Elizabeth took her original emplover - Mr Shortall. the one who had recruited her

"Although I have encountered references to women's shipping papers in the court records of the area. I have not found any surviving contracts signed by twomen. The following is an example of shipping papers signed by a shoreman for Sweetman s and likely provides a rough equivalent in terms of wording:

I hereby engage to serve R. F. Sweetman on order from the date hereof until the $20^{\text {th }}$ October as an Able Shoreman Engaging to do every thing also in my power for my Employer's Interest \& the good of the voyage agreeably to the custom of the fishery. In consideration of $\mathrm{my}$ services well \& duly performed without hinderance or neglect I am to be paid as Wages the Sum of Sixteen pounds Currency

My Wages to rate from I" May next my diet being an equivalent for my labor the winter

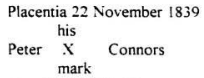

See PANL. MG 49. Sweetman Collection, Box 1. File 59. 
from Ireland - to court for her boarding expenses. and the Cour agreed with her. ordering Shortall to pay for Elizabeth's lodging and diet with Hannah Gaffney. and to take her back into his own care. Of course, not all trish women servants signed shipping papers: but verbal employment agreements were also recognized by law. And the existence of this system conjures up an image of the Irish woman servant that was tar more informed and purposeful than the impoverished, immoral woman of $18^{\text {th }}$-century governors

proclamations. ${ }^{14}$. Most of these women were making intormed decisions to improve their lives when they left Ireland to come to Vewfoundland - even those who gambled on finding work upon arrival. ${ }^{19}$ It was their intention to lead purposetul lives on arriving in Vewfoundland, not to become a burden on their new community ${ }^{24}$

In addition to single servants. numbers of women migrated as part of family groups

${ }^{1}$ The fact that Edward Kough (see Chapter 1) was transporting women "on bail" with securities on both sides of the Atlantic implies that the system was still in place in 1825. for some of these women likely had prospective emplovers in Newfoundland who had shipped them "on order" and stood security for their tares.

${ }^{12} \mathrm{Not}$ all vessels owners in the passenger trade required securities in both Ireland and Newtoundland for passengers travelling on bond. In 1813. Lieutenant Edward Chapell, R . $\mathrm{N}$. of the HMIS Rosamond, noted that significant numbers of fishing servants travelled on speculation with securities only in Ireland. hoping to tind employment on arrival. See $\mathrm{McC}$ arthy. Irish in Newtoundland, pp. 122-3. This may have been a more common practice with male servants. however, as their likelihood of readily finding employment in the fishery was greater than that of women, and hence the risk for vessel owners was lower.

2"Women servants will be discussed in greater detail in Chapters 4 and 6 . 
- particularly as wives. or potential wives or common-law partners. ${ }^{.1}$ of men who were involved in the fishery " Some of these men had already migrated to Newfoundland and sent passage money back to Ireland or made arrangements with their employers to bring out wives or future brides In the fall of 1830, for example, James Whelan at Salmonier made the following request of his employer. Saunders and Sweetman:

I have request to beg of you that is to give Elinor Hannigan a passage out to Placentia in the spring of the vear and I shall pay you and by doing so you will oblige me very much and I shall be for ever under a compliment to you and please to let me have a Answer if you will be so obliging :"

"I In this dissertation, the term "common-law." when applied to a relationship between a man and a woman, indicates that the couple were not married by a religious. civil, or informal ceremony, but were cohabiting and having a sexual relationship as if they were husband and wife. Common-law relationships had no legal status during the study period and were deemed a 'civil inconvenience' by central authorities because they deviated from a moral order that bolstered a patriarchal system of property inheritance See Cullum and Baird. '..A Woman's Lot, '” p. 119. Court records. census material. and early missionaries writings indicate that common-law relationships and informal marriages were not uncommon in the area. certainly up to the early 1800 s. This aspect of women's lives will be discussed more fully in Chapter 8

"The oral tradition provides the most romantic variation on this theme: Julia. the daughter of a wealthy Irish man, gave up family and eloped in the early 1800 s with her father's stableboy/footman, named Ryan: they came to the southern Avalon - possibly to Caplin Bay (now Calvert) or Trepassey - to pursue the fishery. The story of "Lady Julia Ryan" is particularly intriguing to me as Julia Rvan is the name of my maternal grandmother and great-grandmother, both of Caplin Bay

23. P.NL. MG 49. Sweetman Collection. Box 4. File 16. James Whelan to R. F Sweetman, October 30,1830 . 
The company letterbook provides further evidence of arrangements made by fishing servants to send money home or have wages paid to wives or other family members in the home country ${ }^{3+}$ While these letters do not designate the use of the money, there can be little doubt that in some cases, remitted wages would have been saved to pay passages for tamily members - male and temale - to Newfoundland.

There is strong evidence of Irish women migrating as part of family units to join the tishery at Cape Broyle and Caplin Bay in the late 1700s and early 1800s." and this was likely reflective of much female migration to the study area in general, and especially to smaller outharbours where there would have been less demand for female servants than in longer-established and more populous centres such as Ferryland. Bay Bulls. and Renews. In Cape Broyle, tor example, the first permanent tamilies - Kelly. Aylward. Grant. Walsh. Fitzgerald. Bryan. Kent - were all Irish. and they migrated as family units in the 1780 s.

${ }^{2}$ See. for example, PANL. MG 49. Sweetman Collection: Box 3. File 55. Capt. David Doody to Mrs. Brownrigg re: wages of Michael Mahoney to be paid to his wife. Betsy Mahoney, February 17, 1837, and Box 4, File 20, Peter Carew to R. F. Sweetman re effects of son John received by daughter Mary. February 16. 1835

'This pattern diverges from the one described by Handcock in relation to early English settlement at Newfoundland. Handcock savs that sailors and servants tended to marry "local" women while men of status or rank tended to bring their wives out with them. See Handcock. Soe longe While most irish fishing servants also found wives among those women already residing in Newfoundland. a significant number also brought out wives and young families from Ireland - likely after they had established themselves in some capacity in the sedentary fishery. Indeed, the migration of women in family groups was actually the most common pattern of female emigration in pre-Famine Ireland See volan, "Great Famine and Women's Emigration," p. 63 
1790s, and early $1800 \mathrm{~s}^{-6}$ In some cases, male members of the family had already been involved in the Newfoundland fishery for some time. This was possibly the experience of Michael and Mary Ryan, whom we encountered in the previous chapters. It was certainly the case of the Bryan (also O Brien) family. Catherine and Michael Bryan of the parish of Hook. Wexford, had likely married by 1767-8 (when their first child was born). Michael mav have already been tishing at Newfoundland at that time, but he was certainly fishing at Brigus South as early as 1774 , for a reference is made to his plantation there in a grant of fishing premises to John Weish and John Sullivan "Y Catherine remained in Wexford in the early years and raised their growing tamily (six boys and one girl by 1787-8) in the absence of her husband for at least several months of the vear (and possibly. for vears at a time if Michael overwintered at Newtoundland). But in 1791-2. Catherine and the children joined Michael on the southern Avalon. They settled in Cape Broyle harbour. although the Pole Papers indicate that by 1800 . Michael was still fishing off Brigus South by this time. as a boatmaster for merchant Richard Hutchings - and that four of his sons

${ }^{7}$ O Brien. "Cape Broyle" (1960) and "Cape Broyle" (1971): informant DA savs that the Grants might have been English Protestant Loyalists who migrated to NF after the American Revolution, but she has also heard that thev were Irish. E. R. Seary says that the name could be English. Irish, or Scottish. See Seary with Sheila Lynch. Family Vames of the Island of Newtoundland, rev ed (St. John's: Memorial University of Newfoundland, 1984), pp. 200-1.

27PANL. GN 2/1/A, 5/195/1774, Grant, October 19. 1774. 
(Michael. Jr.. James. Richard, and Thomas) had joined him in Hutchings' employ ${ }^{28}$ Some details survive of other family migrations to Cape Brovle. Elenor (Nellie) Lyons and her husband. Richard Welsh. lett Wextord in 1784 to come to the southern Avalon. They arrived in Petty Harbour in 1784, where their first child. Michael, was born. and they moved on to Cape Broyle the following year. In 1788 or 1789. Nellie gave birth to their second child. Thomas - the first child born in Cape Broyle harbour :" Mary Ann and William Leahy (or Lahey) and their two children. Michael and Margaret. came out to Cape Brovle in 1812 , to take advantage of the high wages in the Newfoundland fisherv in the latter stages of the Napoleonic War period. They were part of the "Kehoe [or Kough] gang," recruited by George and Thomas Kough, Irish-Protestant merchants from Ross with a base of operation at Cape Brovle. The Leahys were the tirst tamily to settle across the river in Fairy Pond ${ }^{\text {to }}$ Johannah Doran and her husband. Richard Furlong. were natives of Tipperary who arrived in Cape Broyle c. 1813-1815: like the Leahys, they were probably lured by the prosperity of the Newfoundland fishery. According to the local oral

${ }^{2 \times}$ This tamily chronicle is a composite of information from: $\mathrm{O}^{\prime}$ Brien. "Cape Brovle" (1960) and "Cape Brovle" (1971): PANL. MG 205. Pole Papers. 1799-1800. P.ANL. GN 2/1/A. 5/195/1774. Grant. October 19. 1774: and Mannion Name File. Cape Broyle. "Bryan" (various).

"See: PANL. MG 205. Pole Papers. 1799-1800, and O'Brien. "Cape Broyle" (1960) and "Cape Broyle" (1971).

"See: O'Brien, "Cape Broyle" (1960) and "Cape Broyle" (1971), also, Jim Joe O Brien. "Leahy Family" (Unpub. and untitled notes on the Leahy family at Cape Broyle. n.d. but likely c. 1971). 
tradition. they were married in a church in county Galway and then walked straight to the ship that would carry them to the southern Avalon. "Interestingly, a widow, Sarah 'Drohan and her children were listed in the Pole Papers as residing at Cape Broyle in 1800, it is possible that Johannah 'Doran' Furlong may have been related to this group and that she and Richard may have come to Cape Broyle through family connections on Johannah's side of the family. ${ }^{32}$

Irish families also featured in the early settlement of Caplin Bay (now Calvert) Diarist Aaron Thomas noted in his journal that an Irishman named Poor (or Power) was living in the harbour in 1794 with a young wife. "very tair and beautiful." and four children." This was likely Michael and Alice Power, who were still in the community. with seven children, in $1800^{\text {"H }}$ The oral tradition also tells of early Irish family migrations to the area, noting that among the first permanent Irish settlers in the harbour was a group that arrived in the summer of 1805 from county Wexford. consisting of a Wade family. three Sweyne (or Swain) families, a Kehoe (or Keough) family, and a Meaney family. They initially lived at Stone Island. a headland at the mouth of the harbour close to the

"O Brien. "Cape Broyle" (1960) and "Cape Broyle" (1971)

"PANL. MG 205. Pole Papers. 1799-1800

${ }^{17}$ Aaron Thomas. The Newtoundland Joumal of Aaron Thomas, Jean M Murray. ed. (London: Longmans. Green. 1968), p. 155. Thomas was a seaman with the Royal Navy and was serving on the HMS Boston in 1794 when it was assigned as a convoy ship to Newfoundland.

${ }^{4}$ P.NL. MG 205. Pole Papers. 1799-1800 
fishing grounds. but soon moved further inwards for protection. They were joined by a young man named Joseph Sullivan, also of Wexford. who married one of the Swevne daughters, Mary ${ }^{35}$

So despite the cool reception of naval officers and governors at Newtoundland. Irish women joined the migration stream as single servants, as prospective partners or married women, and as daughters. In various outharbours along the southern Avalon. they began to live productive lives within family units and providing essential services to the growing fishing population (see Chapter 4 ). And the increasing population of Irish women would have a particular impact on community formation in the study area. Given the transient nature of employment in the Newfoundland fishery. it was quite common for male tishing servants to tind employment in different harbours from year to vear. Figures 3.2. 3.3, and $3+$ are based on nominal census data in the Pole Papers: they trace the movements of male servants and dieters who over-wintered in Ferryiand district in 17991800 as well as those who worked in the fishery in the area in the summer of 1800 . Figure 3.2 traces non-local migrations at Ferryland district for the spring of 1800 , and demonstrates a significant movement of men into and out of the district at the start of the tishing season. Figures 3.3 and 3.4 . tracking local out-migrations and in-migrations.

${ }^{35}$ See: MHA. 43-B-1-47. Undergraduate Research Paper-Geography 2000 Collection. Lorraine Hawco, "Ledwell [family surname], Calvert. Caplin Bay," n.d. but likely c early 1970s: FMDB. File 03B. Swain family, and File 015B, Sullivan family. and Calvert Come Home Year Committee. "From Caplin Bay. 1920 to Calvert. 1995" (Calvert: Calvert Come Home Year Committee, 1995), p. 9. Also, interview with AS. July 21. 1999 
Figure 3.3 - Local out-migrations from harbours within Ferryland district, spring, 1800

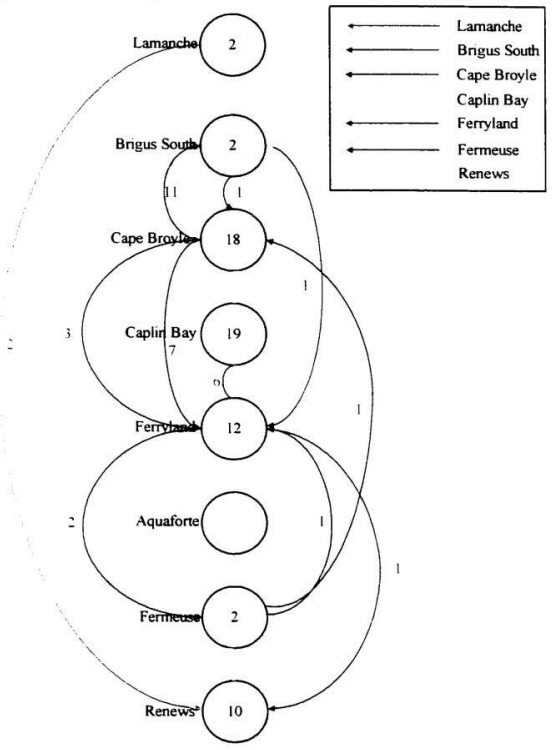

SOURCE: Mannion Name File Collection. Ferryland Distnct, loose matenats: replication of a figure compiled by John Mannion and his students from the Pole Papers. 1799 - 1800 
Figure 3.4 - Local in-migrations to harbours within Ferryland district, spring, 1800

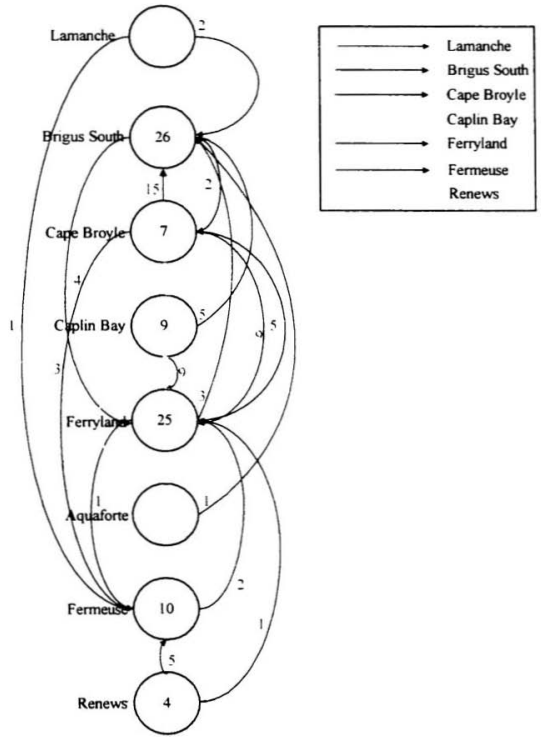

SOURCE Mannon Name File Collocton. Ferryland District, loose matenals, replication of a figure compled by John Mannion and his students trom the Pole Papers, 1799 - 1800 . 
respectively, between the winter of $1799-1800$ and the spring of 1800 , illustrate further movements of male fishing personnel from harbour to harbour within the district itself as the fishing season began. Granted, these local migrations would include some men who had already settled in the area - men such as Michael Bryan and his sons, encountered above, who had been living in Cape Broyle tor some time but worked in Brigus South. However, many others were shifting locales - in and out of the study area or between harbours of the area - as work opportunities demanded.

It was the presence of women that would eventually tie most of these men to particular communities. Some Irish fishermen were joined by wives or fiancees from the home country. Yet in more significant numbers. single male servants arriving on the shore found wives not only among the small English planter group already established there. but increasingly among Irish women immigrants and. certainly by the turn of the century. among an expanding group of first- and second-generation Irish-Newtoundland women living in the area. Matrilineal bridges otten factored in the clustering of families in particular coves and harbours; and matrilocal or uxorilocal residence patterns played an intrinsic role in community formation. as many couples established themselves on land already occupied by the wife or apportioned from or adjacent to the family property of the wife. Unlike some other ethnic migrations, in which men established themselves first in new communities and then sent for fiancees, wives and children, this was a phenomenon in which a large number of men joined women - setting down roots and raising families in their wives home communities. 
This occurred in Cape Broyle, for example, with the wave of young male servants who arrived in the latter stages of the Napoleonic War period and during the final large wave of Irish immigration in the $1820 \mathrm{~s}$. When John Cashin came from Wextord in 1812 , he first worked in Caplin Bay: but he met Mary Welsh. the tirst-generation IrishYewtoundland daughter of Nellie Lyons and Richard Welsh, and married her in 1814 , the couple settled in Mary's community of Cape Broyle. Philip Hays of Kilmaback. Wexford. married Bridget Brennan, first-generation Irish-Newtoundland daughter of James and Anstice Brennan of Cape Broyle. in 1813: the couple remained in Bridget's home community John Dalton arrived in Cape Brovle in the 1820s, he married Mary Grant. first-generation Irish-Newtoundland daughter of Richard and Margret Grant. who had come out from county Tipperary in the 1780s, John and Mary settled in Cape Brovie (their daughter. Mary Dalton. would also marry an immigrant - Charlie Oldridge (or Aldridge) of the London area - around mid-century, and settle on her family property on Dalton's Lane). Edward Hartery was also a new arrival from Ireland in 1820s: he married Elizabeth Kelly. first-generation Irish-Newtoundland daughter of Cornelius and Catherine Kelly of Cape Broyle. and remained in the community of Elizabeth's birth. ${ }^{36}$

In nearby Brigus South, Irish-Newfoundland woman Catherine Henlev married newcomer Michael Hayes of Ireland c. 1790 and the couple settled in Catherine's home

"O'Brien, "Cape Broyle" (1960) and "Cape Broyle" (1971), also Jim Joe O'Brien. "The Oldridge Family" (Unpub. notes on the Oldridge family at Cape Broyle. $n$.d. but likely c. 1971). 
community. By a will dated 1826. Catherine's tather or brother, Patrick Henley, left her a plantation, lands. and houses in the community. Catherine died in 1828, and her husband. Michael. applied for letters of administration of her estate in 1829, which were granted in 1830. The couple's sons, Michael and James, married local Irish-Newfoundland women Johannah Neil, most likely of Brigus South, and Elizabeth Kelly, of Cape Broyle (the same Elizabeth Kelly who had previously married Edward Hartery of Ireland, above, now widowed). The two younger couples settled in Brigus South on the lands from Catherine's estate and were stili there in 1871.3

Irish and Irish-Newtoundland widows, like Elizabeth Kelly Hartery Henley. who remained in Newfoundland and raised families on their own, or remarried and formed new families. also provided essential continuities in early settlement. The Pole Papers provide various examples of widows raising families without male partners in 1800 Maryret Whelan. Elizabeth Forehan, and Mary Whelan, for example, were all widows living in Ferryland with large families (four or tive children): Sarah Drohan was living in Cape Broyle with two teen-aged children. Margret Aylward of Fermeuse was widowed with five children: Bridget Flaherty was raising a family of four young children under the age of 12 alone at Fermeuse. This census also provides instances of families with children whose surnames differ from those of the listed 'fathers' - indicating that the mothers had been either previously married or in common-law relationships. Margret and James Veill of

\footnotetext{
"See: Mannion Name File. Brigus South. "Henley, Catherine". and PANL, GN 5/2/C/1. Probate Court. September 10 and March 2. 1830.
} 
Ferryland, for example, were raising a family of children with surnames Murphy, Furlong. and Neill: Anstice and Edmund Dunphy were living in Brigus South with two children with the surname Buckley; Mary and James Ready of Fermeuse were raising a tamily of seven children - three with the surname Ready and three with Clancy: the children of Fanny and Edmund Chidley at Renews had surnames Chidley and Gearn. ${ }^{3 \times}$

Anecdotal evidence provides turther examples of widows who helped to establish communities on the southern Avalon. Catherine Cooney of Kilkenny, for example. married Peter Weston, magistrate and merchant at Ferryland. c. the mid- $18^{\text {th }}$ century. later became mother-in-law of William Carter. Judge of the Vice-Admiralty Court of Newfoundland, and gained the status of matriarch of these two very influential families At Peter's death, she and her two daughters inherited equal shares of his extensive estate While the Westons and Carters were Protestants. Catherine remained Catholic and had a high degree of influence with several priests at the Catholic mission at Ferryland. ${ }^{\text {i9 }}$ Mary Veill. the wife of Constantine Neill, originally of Ballymartin. Kilkenny (Mary's birthplace is not known), was widowed at Fermeuse c. 1810. She had 11 children at the time. nine of whom were 18 years of age and younger (the older two were 28 and 30 . and likely the

${ }^{3 \times}$ Veither of these lists from the Pole Papers is exhaustive

${ }^{39}$ Byrne. Gentlemen-Bishops, pp. 105-6. Father Phelan at Watertord to Archbishop Troy of Dublin, 4 February 1788. See also: PANL. GN 2/1/A. 6/149-53/1776. Governor John Montague. Grant to Catherine Weston and daughters Catherine and Sarah. September 26. 1776: and PANL. GN 5/4/C/I. Ferryland. Box 1. March 8 and October 5. 1787. August 17. September 15. and October 15, 1790. 
offspring of an earlier marriage of Constantine's). Constantine, an intestate, left a considerable estate worth approximately $£ 1800$ (£2142.8.9, less sundry debts of E3 42.8 .9$)$, and it was ultimately distributed one-third to the widow and two-thirds to the children. Mary staved on in Fermeuse to raise her family and remarried - a James Dalton c $1814^{\text {tit }}$ We have already encountered Mary Ryan of Wexford, who remained in Cape Brovle with her three young sons after Michael's untimely death, eventually married James Coady of Wextord. and raised a second tamily with him. Another example is provided by Margret Bryan. who came out to Cape Broyle from Wexford with her tamily in the 1790s (see above). Margret initially married John Kelly, son of Catherine and Cornelius Kelly (agent at Cape Broyle for the Koughs). John died at an early age. and Margret inherited his fishing premises at Cape Brovle, which she gave to her brothers and which were operated by family production for the next century and a half Margret remarried. her new husband was Michael Gregory, the son of an established English planter family at Brigus South (the couple were practising Catholics. although whether Michael's family had already converted from Protestantism is unclear). ${ }^{+1}$

It is apparent. then. that matrilocality and uxorilocality played an intrinsic role in community tormation in the study area. The pattern repeats in various communities along

${ }^{41}$ Mannion Name File. Fermeuse. "Neill" (various) - (citing PANL: GN $5 / 2 / \mathrm{A} / 9$. October 14 and 26, 1810, and $\mathrm{GN} 5 / 2 / \mathrm{A} / 1$. December 8. 1828. and January 5. 1829)

"O'Brien. "Cape Broyle" (1960) and "Cape Broyle" (1971). Also. JJOB. Interview. 1972. 
the southern Avalon. In 1799. Thomas Power of Carrick-on-Suir married Elizabeth Connelly of Ferryland and remained. James Murphy of Wexford married Margaret Power of Witless Bay in 1806 . Patrick Corane (possibly Crane or Careen) married Judith Cullotin of Fermeuse in 1807. Daniel Wright of Tralee married Bridget Phelan Makis of Ferryland in 1808 . Matthew Meaney of Carlow married Mary Bryan of Ferryland in 1813 Richard Lacey of Waterford married Bridget Condon of Ferryland in 1814. John Bagley of Watertord married Eleanor Cahill of Witless Bay in 1817. Michael Molloy of Wexford married Mary McGee of Ferryland in 1823. Thomas Gower of Watertord married Bridget Doyle of Renews in 1825 Tobias Thomson of Watertord married Catherine Neal of Renews in 1826. Patrick Tobin of county Kilkenny married Sarah Dunn of Ferryland in 1827 and settled in the harbour at Sunny Hill. Maurice Daly from Waterford married Mary Whelan trom St. Mary's in 1814. Patrick Shanihan of Wicklow married Mary Kennidy of Mobile in 1844 William Grant Malone of Wexford married Esther McCarthy of Renews in 1847. William Kimey of Tipperary married Mary Murphy of St. Mary's in 1853 Michael Moore of Wexford married Anne Gready of Mobile in 1853. Edward Roben of Tipperary married Margaret Dinn of Witless Bay in 1854. John Hurly of Cork married Ellon Murphy of St. Mary s in $1858^{\text {*2 }}$

A standard demographer's technique tor measuring the stability of community populations is surname-sieving - tracing the persistence of surnames over time in a given

${ }^{12}$ Derived from various parish records for the southern Avalon. Mannion Name File Collection, and $\mathrm{O}^{\prime}$ Brien works cited. 
locality to establish the transition to a permanent population. As noted in Chapter I. Handcock uses this method in his examination of English migrations to and settiement in Newfoundiand. ${ }^{43}$ But this technique has a patrilineal-patrilocal bias that does not accommodate alternative forms of continuities in early community formation in Newfoundland. Figure 3.5, for example, shows a partial tamily tree for the Oldridge family in Cape Broyle. Surname-sieving would not locate any significant clustering of the Oldridge name until the late $19^{\text {th }}$ century. But continuities in the family line date back to the late $18^{\text {th }}$ century: through the wife of the first Cape Brovle Oldridge, Mary Dalton, a second-generation Irish-Newtoundland woman on her mother's side. whose grandparents came out from Tipperary in the 1780s: and through their son John's wife. Kathleen Walsh. whose grandparents on her father's side had come out to Cape Broyle from Wexford in the 1780s. and whose maternal roots in the community went back three generations to Michael and Catherine Bryan of Wexford. Furthermore, the Oldridge surname no longer exists in Cape Broyle, although numerous relatives through maternal links and sister marriages continue to live in the area. Granted. this chart demonstrates an unusual case of a surname establishing itself late and subsiding quickly. Most Irish surnames would have established themselves earlier in the $19^{\text {th }}$ century and many remain in the area today However. the example effectively demonstrates the limitations of surname-sieving. The technique gives the demographer something to work with. for written records on men are

\footnotetext{
${ }^{13}$ Handcock. Soe longe.
} 
Figure 3.5 - Partial family tree. Oldridge family, C
Michael Brien
Co. Wexford

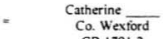
CB 17912
СB 17912

$\begin{array}{cccc}\begin{array}{c}\text { Richard Welsh } \\ \text { Co. Wexford }\end{array} & \text { Nellie Lyons } & \text { John Brien } \\ \text { CB } 178+5 & \text { Co. Wexford } & \text { Co. Wexford } \\ \text { CB 1784.5 } & \text { CB } 17912\end{array}=\begin{gathered}\text { Man Kennedy } \\ \text { Renews }\end{gathered} \quad \begin{gathered}5 \text { other sons } \\ 1 \text { daughter }\end{gathered}$

5 other sons

1 daughter

John Welsh

c. $1830 \mathrm{~s}$

$=\quad$ Catherine $O^{\prime}$ Brine

4 sons

2 other daughters

Charles

Lonc

CB

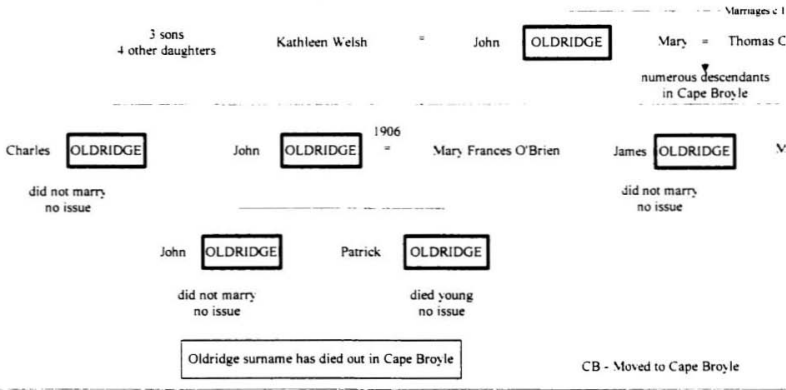

SOLRCES: O'Brien: "Cape Broyle (1960): "Cape Broyle (1971)": a 
ial family tree. Oldridge family. Cape Broyle

Richard Grant
Co. Fipperan
CB 1780 s $\quad \begin{gathered}\text { Mary } \\ \text { Co. Tipperary } \\ \text { CB } 1780 \text { s }\end{gathered}$

5 other sons

I daughter
John Dalton

Co. Wexford CB 1820 s c. 18205

- Mar Grant
4 sons

1 other daughter

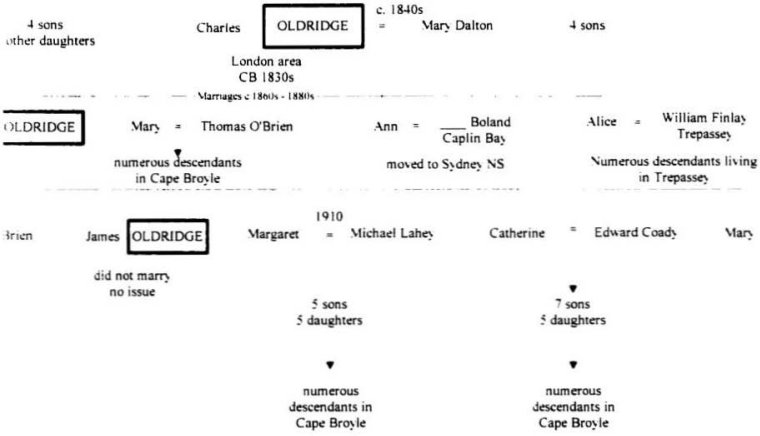

CB - Moved to Cape Broyle

rosle (1960): "Cape Broyle (1971)": and "The Oldridge Family 
much more readily available than those on women. But certainly it needs strenuous qualification if used in the Newfoundland context. for it misses the matrilineal bridges and matriloca//uxorilocal residence patterns that often predated patrilineal-patrilocal patterns in early community formation. For every marriage of an immigrant male to a local woman. a similar family chart would extend back at least one generation and laterally among collateral kin If these women-centred networks are taken into account, it becomes evident that the tendency towards permanence began earlier than surname-sieving can reveal.

The themes of matrilocality, intermarriage, and matrilineal bridges are interwoven in the family history of the Ryans of Biscay Bay. Denis Ryan came from Ireland (possibly Cork) to Trepassev c. 1800-1810 and fished for four summers with Goodridge's at Renews. He built a house at North West River in Trepassey and married Susanna .Moure (likely of English or mixed English-Irish ancestry) of the Lower Coast. Trepassev. sometime before 1810 (when their first child was born). After their marriage. the couple moved to 'the Dock' in Trepassey and built on land nearby Susanna's family home (possibly on land owned by her family). The couple had seven children - two boys and five girls. All five daughters married and remained in the Trepassey-Portugal Cove South area to raise their tamilies. The two sons married local women from nearby Daniel's Point and Portugal Cove South, and they, too, stayed in the area. One of the sons. Thomas. had met his tuture wife. Bridget Hartery of Portugal Cove South. while tishing as a servant with her family. The couple married about 1850 , and through this connection, Bridget's 
brother Richard met and married Thomas's sister Margaret. Thomas and Bridget moved to Island Pond Gulley, Biscay Bay; they were joined by Richard and Margaret shortly thereafter. and the two couples became tounding families of the area. ${ }^{.4}$

Women's agency was virtually absent in the manuscript in which this family history - primarily a retelling from the oral tradition - appeared. The chronicle was developed from the perspective of the men involved; we were told that Denis had two boys and five girls. for example. and that Thomas built a house. kept a cow. and raised a large family at Biscav Bay - without any reference to the participation of their wives: lineage and settlement patterns were traced through the patriline only. But with a slight re-emphasis of the limited information on women in the family, it is possible to bring forward the centrality of Susanna Moore, of the Ryan sisters. and of Bridget Hartery in this particular clustering of families in the Trepassev/Portugal Cove South/Biscay Bay area

Given the paucity of records on women in early settlement. it is not possible to ascertain the representativeness of the anecdotal evidence presented above. But it is possible to find within these stories the cues we need to rethink the processes of immigration and community formation in Newfoundland - to shift the focus of family and community histories to include women in the frame.

${ }^{4}$ MHA. +3-A-1-42. Undergraduate Research Paper - Geography 2000 Coilection. Francis Corrigan. “The Ryans of Biscay Bay (1850-1970): A Study of Settlement." n.d. but likely early 1970s, pp. 3-7. Some of the details were also confirmed by interview with AS. July 21. 1999. 


\subsection{Intermarriage and assimilation}

Irish-English intermarriages. such as those between Susanna Moore and Denis Ryan or between Margret Bryan and Michael Gregory, were common on the southern Avalon, especially in older communities with mixed populations such as Brigus South. Ferryland. Bay Bulls, Renews, and St. Mary's Irish male servants married women of English or mixed English-Irish ancestry (daughters and granddaughters of English planters; widows). John Macaboy of the parish of Ross, Wexford, for example married Mary Midleton of Bay Bulls in 1800: John Murphy of Cork married Mary Peterson of Ferryland in 1804: and Bartholomew Dumpty (or Dunphy) of Wexford married Mary Jordan of Brigus South in 1813 . As well. Irish or Irish-Newtoundland women married English fishing servants and men from English planter tamilies. Margaret Gibbons Muny (or Mooney) of Ferryland. for example, married John Prose of Dorsetshire in 1805. Mary Hennessy of Ferryland married John Moody of Greenock in 1809: Mary Power of Tipperary married Thomas Norris of Witless Bay in 1810: Mary Bryan Bull of Ferryland married John Browse (possibly Prowse') of South Hampton in 1817: Johanna Mackey of Brigus South married James Binning of Devonshire in 1818, and Mary Dalton of Cape Broyle matried Charlie Oldridge of England at the mid-19th century ${ }^{\text {ts }}$

${ }^{45}$ Derived from various parish records for the southern Avalon. Mannion Name File Collection. and various $\mathrm{O}^{\prime}$ Brien writings already cited. Again, this list is not exhaustive. 
Most of these intermarriages resulted in conversions to the Catholic religion and/or the raising of children in the Catholic taith: ultimately, they resulted in assimilation to Irish culture. ${ }^{\text {th }}$ Census material for the period provides evidence of the inexorable integration of much of the English-Protestant population into an expanding Irish-Catholic society The Governor's annual reports contained in the C O 194 Series can be used in combination with the census returns for 1836.1845 , and 1857 to draw a snapshot of the population of the southern Avalon in terms of growth and structural components. as demonstrated by Figure 36. This figure traces roughly in intervals of decades the growth of the population wintering over ${ }^{47}$ in the study area from 1735 to 1857 . Perhaps the most striking feature is the rapidly rising proportion of Catholics in the population, as indicated by the line at the top of the graph. As noted in the previous chapter. in the late $17^{\text {th }}$ century, there had been a strong English-Protestant presence on that shore. one century later, the inhabitants were almost totally Catholic. In particular, there was a dramatic

"Today, the area has been dubbed the 'Irish Loop." for better or for worse, by government road signage and tourist information. Residents pride themselves on living in the most Irish corner of Newfoundland. Families that bear English surnames consider themselves as much a part of the Irish ethnic group as those that bear Irish surnames. Indeed. until recently, many were not aware of their partial English-Protestant ancestry. although there is a growing awareness of mixed lineages. particularly among younger generations.

${ }^{47}$ It should be noted that this population includes temporary migrants. including transient workers contracted for two summers and a winter. some of whom may have ultimately remained in Newfoundland, many of whom returned to the mother country. It is an extremely rough measure of residency only and is by no means an absolute indicator of permanent settlement. 


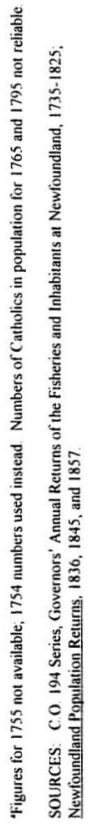




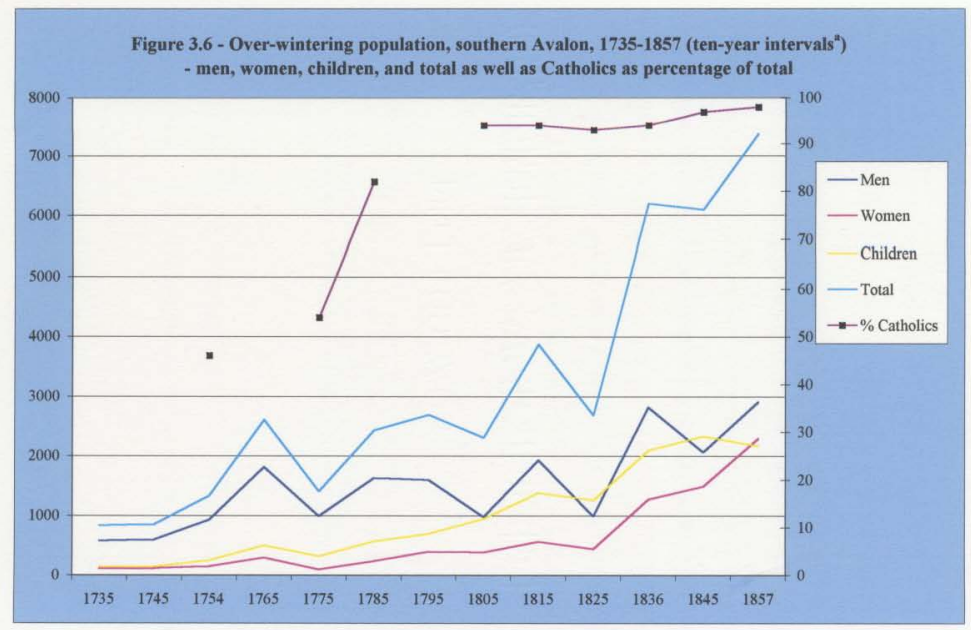


increase in the percentage of Catholics in the population between 1754 and 1805 . Certainly, this period witnessed an influx of Irish into the study area. and using the standard Newtoundland formula of ethnicity $-{ }^{-}$Catholic $=$Irish: Protestant $=$English ${ }^{-}$ one could view this movement purely in terms of a net movement of incoming lrish migrants and outgoing English inhabitants. Anecdotal evidence provided by Catholic priests and ministers of the SPG. however. strongly suggests that the processes of intermarriage, conversion, and assimilation were at work in conjunction with Irish inmigration.

In reporting on the satisfactory "progress of religion" in the Catholic mission at Ferryland. for example. Father Thomas Ewer was able to boast to his superiors in 1796 of making considerable inroads in the Protestant population:

The many truitless attempts of Methodist Preachers have been successfully baffled \& there is now but one of that sect in the district of Ferryland \& Trepassey whose family became Catholic this year. The Protestants likewise lose ground \& their minister oblidged to decamp notwithstanding his $£ 70$ a vear from the Society. Their feelings at such an event are easily conceived

By 1801. the SPG still had a mission on the Southern Shore. but the missionary's report that year revealed only 225 . Anglicans (with 7 actual communicants) in the district.

${ }^{4 *}$ Byme. Gentlemen-Bishops, pp. 140-2. Father Thomas Ewer to Archbishop Troy: Dublin. September 20. 1796 
compared with 1579 dissenters, "particularly Papish." ${ }^{49}$ By 1845, the Anglican congregation on that shore had shrunk further to 132 members in Ferryland. Aquatorte. and Renews. ${ }^{\text {so }}$

Indeed, a sense of fatalism pervades the records of the SPG in relation to the increasing Catholic presence on the southern Avalon. As early as 1773. the Protestant inhabitants of Bay Bulls had indicated "that to their great concern they find the Roman Catholic Religion daily gaining ground .." $\mathrm{By}$ 1842, when Anglican Bishop Aubrev Spencer visited Bay Bulls and "some adjoining settlements," he found "but one single Protestant family. where the Church of England had once sixteen hundred persons in her Communion " The bishop continued on to Ferryland "with deep gratitude to Almighty God, that he had guided me to these few sheep in the wilderness, who have not followed the multitude into the strange pastures. ${ }^{*}:$ His tinal wording here strongly suggests

"PA.VL, MG 598. SPG Collection. C Series, Box IA/18 (Nova Scotia and Newfoundland), t. 180. Rev. John Dingle to Rev. Doctor Morris. Secretary to the SPG. November 22. 1801 .

${ }^{50}$ P.ANL. MG 598. SPG Collection. E Series, n.f. Report on the Diocese of Vewtoundland. Mission of Ferrvland. 1845

5.PAL. MG 598. SPG Collection, C Series. Box 1 (Newfoundland). f 56. Petition of the Inhabitants of Bay Bulls for a clergyman. October $19.1773 \mathrm{~A}$ Also contained in SPG Collection. D Series. n $\mathrm{f}$.

52P.ANL. MG 598. SPG Collection, G Series, vol. 1, if. 9-10. Bishop Aubrey Spencer to Rev. A. M. Campbell. June 22, 1842. Spencer did not indicate how few were the "sheep in the wilderness" in Ferryland, but in 1826. the clergyman stationed there. Rev. Charles Blackburn. had indicated that the Protestant population numbered only 129 See PANL. GN 2/2,1/49-50/1826, Rev. Charles Blackman to Edmund. B Brenton. Colonial Secretary. November 6, 1826 
intermarriage and conversion rather than out-migration of Protestant families. In 1845 . Anglican Bishop Feild reported that "all in St. Mary's Bay and along the whole coast from thence to Renews are now Romanists." while only four families in Placentia "remain of our Communion (and some of these wavering)." He concluded. "Nothing can keep the remaining members of our church stedfast in their profession but an immediate increase of Ministers " "st Once again, the impression is one of assimilation rather than exodus. Catholic Bishop Michael Fleming, on the other hand, was able to commend his priests for the gains they had made in the battle for souls on the southern Avalon. While touring that shore in 1835 , for example. he was pleased to stop in the mixed community of Renews and confirm 140 candidates. "the great part of whom had been converted to our holy religion. ${ }^{\prime \$+}$ In the island in general. he was pleased to see the numbers who had turned from "the tlock of the stranger" to "the bosom of Christianity" upon the arrival of the Catholic missionaries."

But while the Catholic bishop and his priests congratulated themselves on their success in converting the Protestant population, and there is no doubt that their official

53.ANL. MG 598. SPG Collection. G Series. vol I. f. 159. Bishop Edward Feild to Rev. Ernest Hawkins, November. 1845

${ }^{54}$ Monsignor Michael Fleming. Report of the Catholic Mission in Newtoundland in Yorth America, submitted to the Cardinal Prefect of Propaganda (Rome: Printing Press of the Sacred Congregation. 1837). p 39. Copy at the RCA.SJ. Fleming Papers. 103/26

"RCAASJ, Fleming Papers. 103/26. "The State of the Catholic Religion in Newfoundland Reviewed in Two Letters by Monsignor Fleming to P. John Spratt." 1836. p. 91 Also. Fleming, Report (1837), p. 39 
presence after 1784 contributed greatly to the process. Figure 3.6 suggests that assimilation was aiready well under way before their arrival. There was certainly a dramatic jump in the percentage of Catholics by 1785, but it is far more likely that with the proclamation of Liberty of Conscience issued in 1784. more Catholics finally admitted their faith openly than that the founding of a Catholic mission had had such a dramatic and immediate effect in terms of conversions It appears that the process of assimilation had gained momentum at an earlier period - roughly trom the 1740 s to the 1770 s. The presence of a few itinerant priests, hiding in cellars and fishing boats. would hardly have accounted for such a significant shitt. A more logical explanation would be found in the increasing number of Irish arriving in the area and conversion and assimilation resuiting trom intermarriage. The effectiveness of the priests in conversions likely correlated significantly to the increasing numbers of Irish Catholics in the marriage pool

A comparison of available records of Catholic and Protestant marriages (covering primarily the period from the turn of the $19^{\text {th }}$ century onwards) confirms that this process gained momentum in the latter half of the study period. Very rarely does one encounter an Irish surname in the Anglican parish records of the area. Within the Catholic parish records. by contrast. English sumames are frequently interspersed amongst the Irish indicating a high degree of assimilation of English-protestant patrilines into the spreading Irish-catholic culture by the early $1800 \mathrm{~s}$. A more in-depth breakdown of marriage patterns within the two groups adds further texture to the impression of a growing and maturing Irish-Catholic population, steadily incorporating new members, vis-a-vis a beleaguered 
English-Protestant group, mostly middle class ${ }^{.6}$ in retreat and turning inwards on itself or recruiting from outside the southern tvalon to maintain its homogeneity.

Table 3.2 demonstrates patterns of marriage within the Catholic community on the southern Avalon - using those marriages for which the places of birth for both spouses could be identified. While data for the period to 1800 are too sparse to be significant. and information for the period up to 1830 is less comprehensive than that for later years, it is still possible to detect a Catholic population that is growing and becoming increasingly established in the area. The table indicates that significant recruitment of marriage partners from Ireland continued up to the 1840 s; within this group. the pattern of southern Avalon women marrying lrish men was two to three times more common than the reverse. once again emphasizing the importance of matrilocality in initially establishing an Irish population in the study area. By the 1830 s, there was a shift in the prevailing pattern to that of wife and husband who both hailed from the southern Avalon. indicating that the peak years of Irish in-migration were over. This pattern markedly predominated the latter

th Anglican parish records for Ferryland district from 1823 onwards, available at the PANL, provide occupations of fathers in baptismal entries until the incoming minister in 1855 stopped recording this information. The occupational profile for Anglican fathers in the district between 1823 and 1855 was: 3 clergyman: 19 merchants or merchant/planters. 2 merchants/sub-collectors of customs: 1 merchant/naval lieutenant: 7 masters of merchant vessels: 1 master of merchant vessel/merchant: 1 master of merchant vessel/planter. 3 planters. I mercantile agent. I gentleman, 4 carpenters. I sail-maker. I blacksmith; I labouret/mason; 1 laborer; 12 tishermen: 3 not given. Intriguingly, no fishermen fathers were listed before the mid-1830s. and all but two baptisms in this group occurred in the 1840 s and beyond. See PANL. Church of England Parish Records - Petty Harbour Parish. Box 2. Baptisms, Ferryland District (recorded from 1823 onwards). 


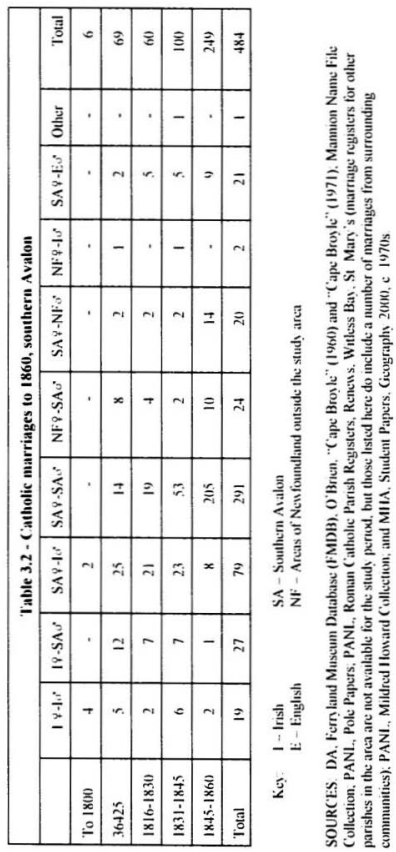


part of the study period. reflecting an established population that was replenishing itself internally. Throughout the period, there was a constant incorporating of English surnames. A number of these family lines may already have been incorporated into the Catholic population in the previous century and thus already had mixed English-Irish bloodlines: but the trend continued. and was reinforced by continuing intermarriage with the Irish in the $19^{\text {th }}$ century

A similar table on English-Protestant marriage patterns ( Table 33 ) provides a strong contrast. Only 62 Protestant marriages on the southern Avalon could be traced for the study period. retlecting two significant factors about the English-Protestant population in the study area its small and relatively declining size vis-a-vis the Irish-Catholic and mixed Catholic community: and the tact that this small. mostly middle-class group continued to recruit members from outside the southern Avalon (hence. many marriages were registered elsewhere. particularly in parishes in St John s or England) "* From the limited data that are available, the pattern of south Avalon wite marrying south Avalon husband was the most common in the latter decades. but only in the $1831-45$ period did it account for over half ( 54 percent) of the marriages and. thereafter. declined to 40 percent (compared with the climb from 53 percent to 80 percent within the Catholic population for the same periods) Overall. marriages between local spouses accounted for only 39 percent of Anglican marriages in the area - indicating significant recruitment from outside

\footnotetext{
${ }^{8}$ An examination of such records would be outside the scope of this thesis.
} 


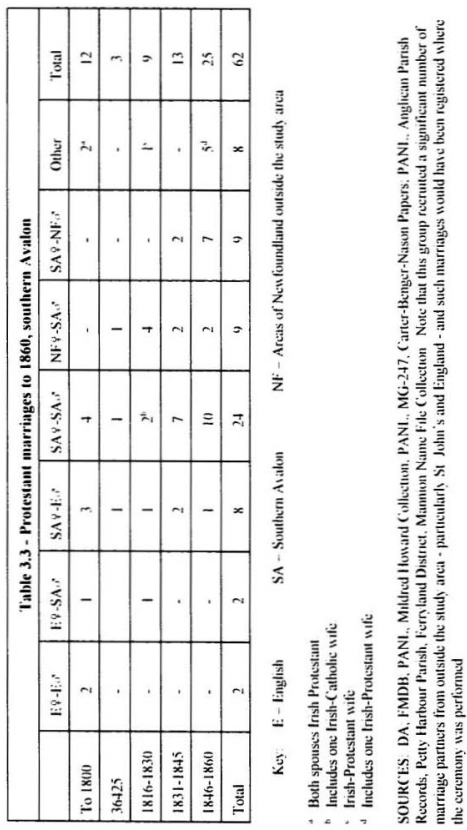


the area. Also, unlike the expanding Irish-Catholic population, the English-Protestant group married aimost exclusively within itself. either choosing local spouses from the same ethno-religious group or continuing to recruit English-Protestant spouses from the outside to maintain its homogeneity. Thus, a limited set of local surnames - Carter, Coleman. Johnston, Morry, Pavne Saunders, Sweetland, and Weston - predominate the records. while the regular appearance of certain St. John's tamily names - Tessier. Livingstone. Lemessurier, Rendell, and Skinner - indicate that connections with this particular segment of the St John's middle class were being reintorced through marriage. Endogamy within such a small group resulted in some complex webs of relationships (see Figure 3.7 ).

Thus the equation of ethnicity and religion in the study area must be qualified. The -Protestant $=$ English portion of the formula held true, for the most part, among the middle class ( with the exception of some tew Irish-Protestant mercantile families in the $18^{\text {th }}$ century. such as the Bengers. Dobels, Nasons, and Ludwiggs): but the 'Catholic = Irish segment faltered among plebeian families as many English-Protestant patrilines (families with sumames such as Yetman, Glynn, Williams. Yard, Carew, Maddox, and Martin) were incorporated into the Catholic population. On the southern Avalon. the Irish ethnic group subsumed the English. with the exception of a small group predominated by middle-class mercantile tamilies, Here, again. the southern Avalon Irish experience was quite different from the initial segregation and ultimate assimilation described in much of the literature on Irish migrations to America and Britain. The Irish in the study area not only intermingled with the English population but actually became the dominant ethnic 

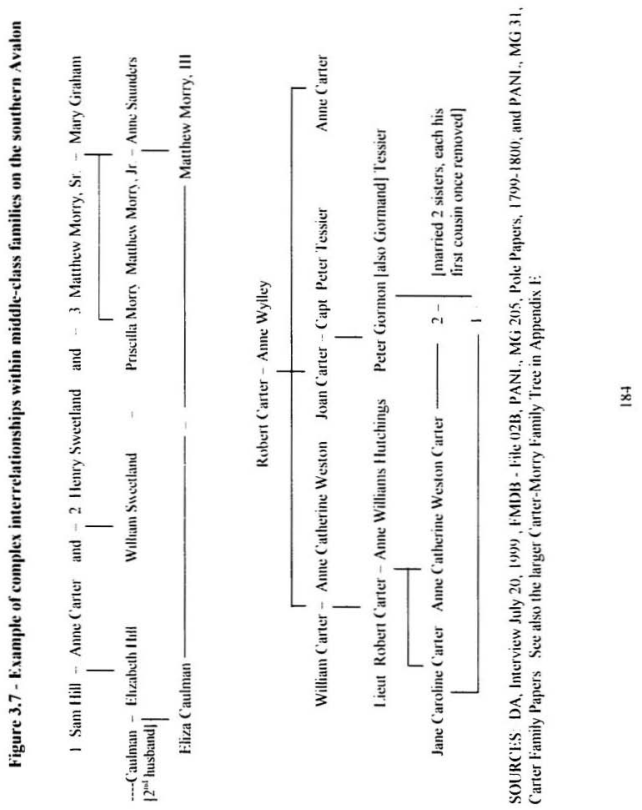
group. And it was a process in which Irish or Irish-Newtoundland women played a vital part. as marriage or common-law partners of not only incoming Irish-Catholic migrants but also men of English-Protestant descent. ${ }^{5 x}$ The growing Irish culture was reinforced by further Irish migration and intermarriage as the study period unfolded. But even by the turn of the $19^{\text {th }}$ century, a high proportion of the Catholic population (and hence, of the plebeian community and even the total population) was either of direct Irish extraction or had some Irish in the bloodline.

\section{$3+$ A maturing population}

Figure 36 also illustrates that there was a generally increasing trend in the total winter population (as noted. a loose approximation of the permanent population), with peaks and troughs paralleling the fortunes of the fishery. The male population line has similar sinuosities to that of the total. reflecting influxes of male fishing servants during peak periods in the sedentary fishery. The numbers of women and children wintering over. however. follow a generally more even. upward course, particularly after the American Revolutionary War period. and are reflective of a more stable resident group. And because of the process of intermarriage and assimilation. it is logical to inter that an increasing proportion of these women and children were Irish or Irish-Newfoundland

${ }^{58}$ Handcock suggests that Irish women were key in absorbing the English population on the southern Avalon. but does not anaiyze the phenomenon as his study is focused to the north. See Handcock. Soe longe. 
persons (with some Irish in the blood line). The figure shows significant increases in all sectors in the intervals 1805-1815 and 1825-1835: these movements correspond with the two main periods of total Irish migration to Newtoundland and are therefore highly suggestive of Irish in-migration, particularly as there was no significant increase in total English migration to Newtoundland during the same periods. Figure 3.6 also demonstrates a maturing population with the sex ratio moving closer to one by the middle of the $19^{\text {th }}$ century. (The 1857 results are skewed somewhat by the Trepassey-St. Mary's area, where there was still a relatively high male-to-female ratio of 1.56 , Ferryland district. by contrast. had moved to a more mature ratio of 1.17 .)

A breakdown of masters. mistresses, children, male servants, and female servants in the winter population of the southern Avalon is provided by Figure 38 The close alignment of the numbers of masters and mistresses wintering over. with roughily corresponding sinuosities in the line representing children, reinforces the impression of a family settlement pattern among the planter group." The steady increase in this sector ftom the American Revolutionary War period onwards also corresponds with anecdotal evidence about the growing influx of Irish and an expansion of Irish planter society on the southern Avalon. The line representing male servants again supports anecdotal evidence

50 One exception - a larger peak in the numbers of masters in 1815 - corresponds with extremely prosperous conditions in the resident fishery: a significant number of single males (or at least males without families at Newtoundland), having earned high wages as servants, may have tried their fortunes as planter fishermen at this period. 


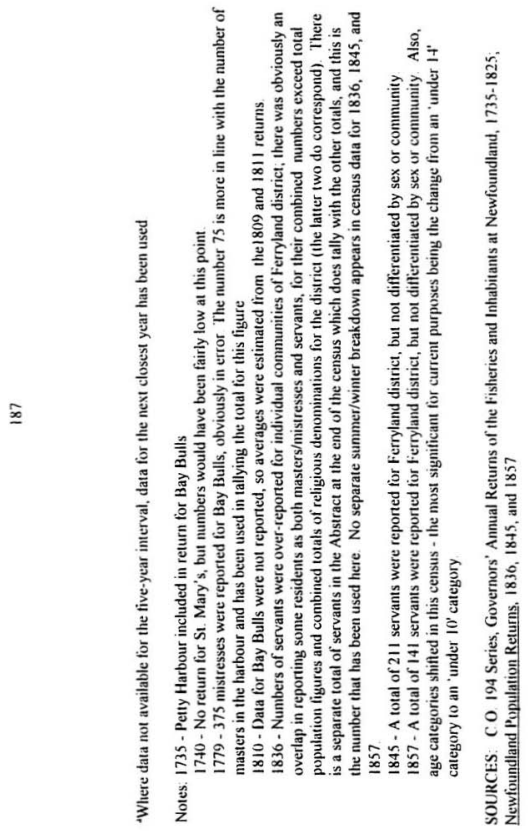




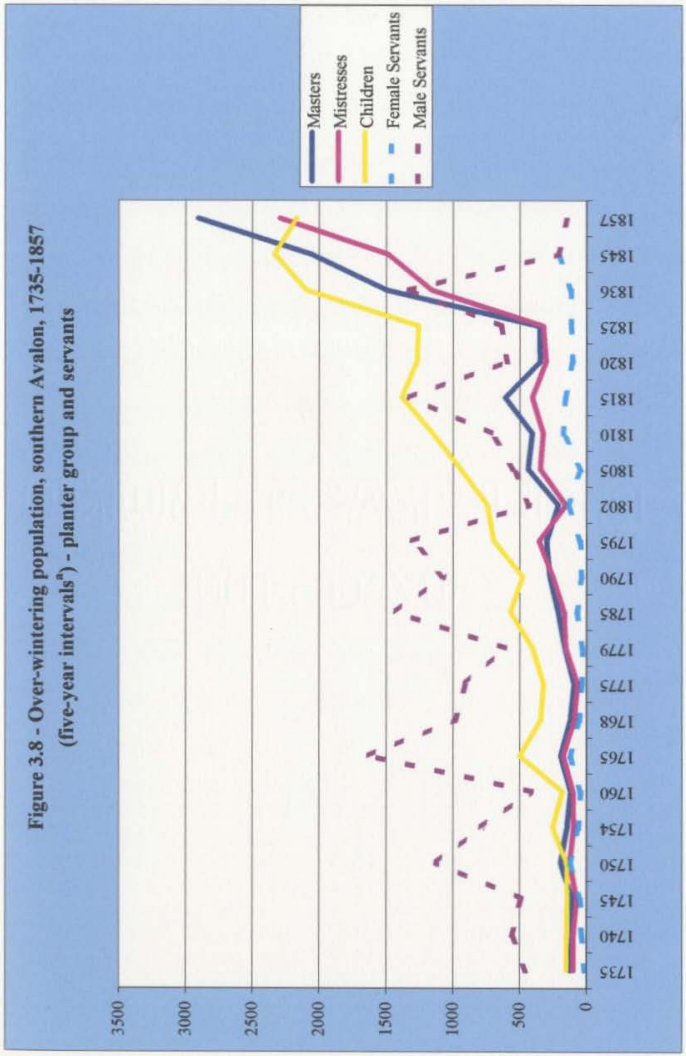

$\infty$ 
about Irish immigration to the area: note, for example, the sharp increase over the period of the Seven Years' War. when the Irish began to replace English servants in signiticant numbers, note also the surges during the American Revolutionary War, the period immediately following the outbreak of hostilities with France in 1793, and the latter stages of the Napoleonic Wars, when servants for the resident fishery were in particular demand. It must be noted also that by this time. significant numbers of male tishing servants were long-term residents themselves, the Pole Papers of 1799-1800, tor example. provide ample evidence of servants living with their families in Ferryland district. In addition, the smaller. vet still discernible. surges in the women servants ' line during the Seven Years' War, the American Revolution. and the latter stages of the Napoleonic Wars also suggest that the recruitment of women as servants, either domestic or fishing, was linked to the fortunes of the resident tishery

The increasing number of women in the area is very significant tor this phenomenon permitted the re-establishment of the key social, cultural, and economic unit of rural Ireland the family ${ }^{\text {nt }}$ This revival had significant implications for production in

${ }^{n} \mathrm{C}$ Campbell discusses the family-centred nature of $18^{\text {th }}$ - and 19 -century rural Irish society - both the conjugal unit and the extended kinship network with its physical manifestation. the clachan (the traditional clustering of families in which kinship ties detined community boundaries and property was communally owned and rotated in a system known as rundale). Campbell observes: "The family was of crucial importance in Irish rural society, not only as the primary economic unit of rural production. but also as the foundation of cultural continuity, social stability and support." See Campbell. Kingdom of the Rvans, pp. 112-3. By contrast. Kevin O' Neill sees family formation as having decreasing relevance in pre-Famine Ireland, arguing that declining opportunities caused a decrease in the labour demand/supply ratio which actually discouraged tamily 
the fishery and the actual survival of fishing communities along the southern Avalon.

\section{Transition to household production}

Figure 3.8 in conjunction with Figure 3.9 provide evidence of another integral part that women played in the establishment of early communities - their pivotal role in the transition to the household production unit. The two figures represent inhabitants and personnel involved in the sedentary fishery in the study area for roughly five-vear intervals during winter and summer, respectively ${ }^{\text {th }}$ The critical components to observe in each chart, but particularly the chart representing residents during the summer fishing season.

formation and led to increased emigration, particularly among farm labourers and smaller and larger farming households; only middling farming families remained relatively unaffected by the dictates of inheritance practices and the vagaries of employment demands in determining family growth. For the rest. reduced or delayed family formation was a means of population control in the tace of demographic and economic pressures. 0 . Neill provides a very detailed and caretully researched analysis of the specific demographic responses of different household types to economic change. However. the economic reductionism of his 'market impulsion model' does not measure the social impact of these forces on Irish families and communities and does not satisfactorily dismiss the cultural importance of family in Irish rural society. See Kevin O'Neill. Family and Farm in Pre-Famine Ireland The Parish of Killashandra (Madison. The University of Wisconsin Press. 1984). For a detailed description of rumdale, see Robert James Scally. The End of Hidden Ireland: Rebellion. Famine, and Emigration (New York: Oxford: Oxford University Press. 1995).

${ }^{n}$ As there are frequent gaps in the data. a slightly shorter or longer interval than tive vears may appear in both figures: after 1825, the gaps range from nine to 12 years in accordance with the census years. Note that these figures exclude personnel in the ship. bve-boat, and bank fisheries, which were reported under separate categories in the C.O. 194 returns, these designations had lapsed altogether by the taking of the 1836 census. 


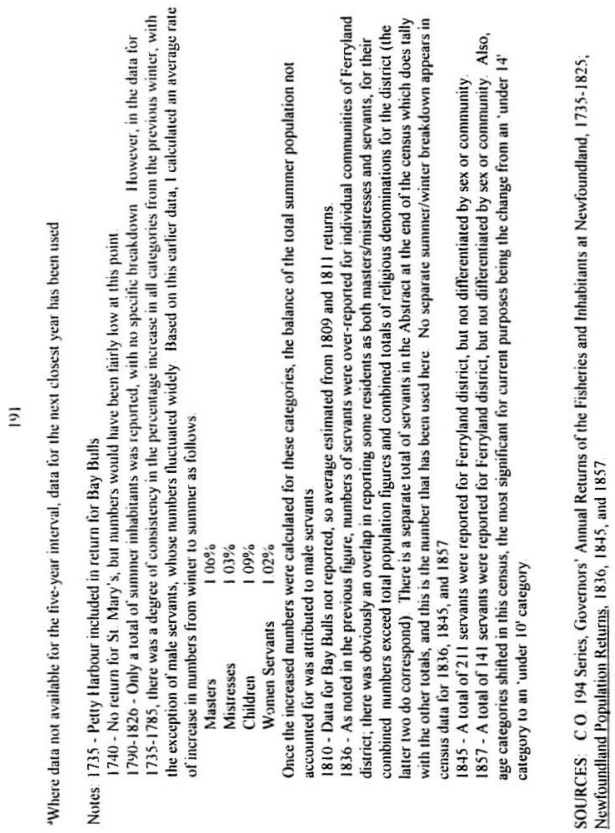




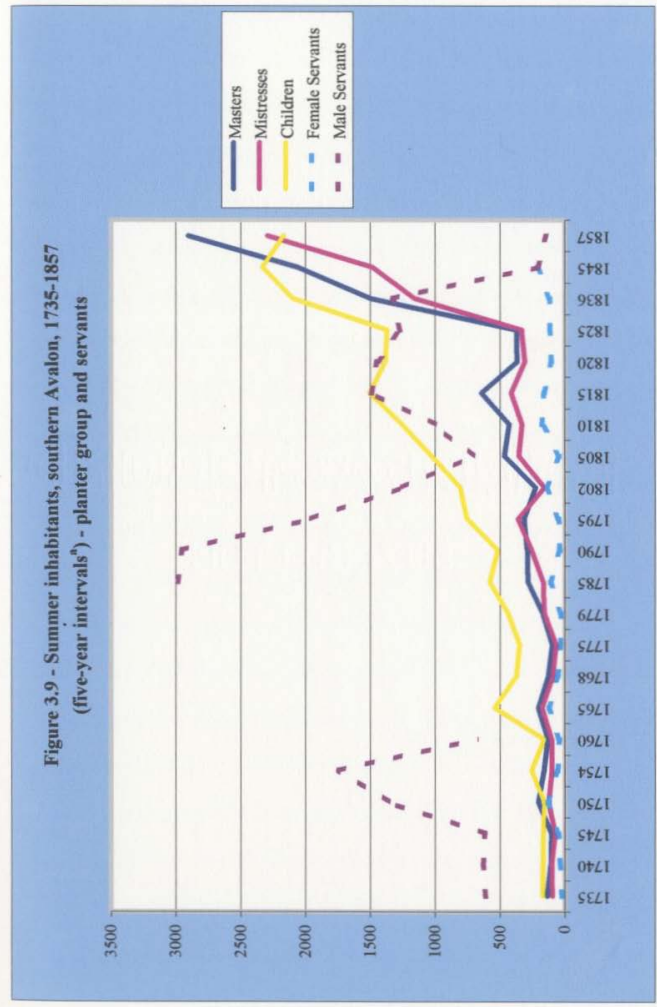


are the broken line representing hired male fishing servants (who initially provided the bulk of the labour in the sedentary fishery) and the three solid lines representing the planter family group (masters, mistresses, and children). Both figures clearly demonstrate an overwhelming reliance on hired servants in the resident fishery as the study period began at mid- $18^{\text {th }}$ century. As the migratory tishery at Newtoundland went into decline due to almost constant wartime conditions, particularly from the American Revolutionary War onwards, the resident sector moved into ascendancy in both actual and relative terms However, this ascendant position was not reflected in an increased hiring of servants by the sedentary fishery on the southern Avalon beyond the early 1790s, after this point. significant numbers of servants continued to work in this sector. but never again in the same proportion to the planter group. Rather, we see the solid lines representing the planter tamily group rising to meet and subsume the plummeting broken line representing hired male servants. By 1805, we see the numbers of servants converging with the planter group. with numbers of male servants dropping towards numbers of masters and mistresses. If the resident fishery had continued to rely overwhelmingly on hired labour. this convergence would not have happened. What had occurred over this period was a significant shift towards household production. in which family members took over fishing and shore work, with women assuming much of the work of shore crews - especially salting and drying, although in some cases. heading and splitting as well (see Chapter $\rightarrow$ ) Within this household production unit. servants continued to be hired. but in much smaller numbers that supplemented the family unit. At this stage. the resident fishery consisted of 
two types of planter groups: planters who continued to depend primarily on the labour of hired servants, and planters who hired servants to reinforce the farnily production unit. with the latter group predominating in most areas after the turn of the century.

The latter years of the Napoleonic War period witnessed the final decline of the migratory fishery and consolidated the position of the sedentary fishery. Prosperous conditions in the inhabitant fishery at this time created a final surge in the numbers of hired servants in the study area. In his study of Conception Bay, Cadigan has represented these years as a period of potential growth of a planter class of industrial-capitalist producers. employing waged labour. not family members. He sees evidence of this in the increased hiring of waged servants ${ }^{h_{2}}$ and elevated investment of capital in the tishery by planters during the boom created by the re-opening of markets that had been closed due to war. by the removal of French and then American competition from fish markets, and by intlated fish prices - all in conjunction with the local development of a North Shore and Labrador tishery as well as a seal fishery. But the growth of this class of petty industrial producers. and hence the potential to challenge merchant hegemony, ground to a halt with the end of the war period. he argues. In the post-war recession, the waged labour foundation of the planter tishery was undermined as fish prices dropped while inflationary wages and provision prices persisted. Adding to the planters' dilemma was a wage and lien system.

${ }^{2}$ Note that not all fishing servants worked for wages, or for wages alone. Significant numbers were hired 'on shares' and therefore had more of a stake in the enterprise: others were paid by a combination of wages and shares. 
carried over from the days of the migratory fishery, in which waged servants had a first lien on a planter's fish and oil for their wages, contracted in advance and payable in tull. regardless of the outcome of the fishing season; the planter's current supplier had a second lien on his tish and oil. Given this combination of factors in the post-war period. numerous bankruptcies ensued and the planter tishery based on waged labour collapsed. After this, says Cadigan. the resident fishery settled into a dependence on household production and merchant credit. Fishing servants continued to be hired. but as a supplement to. rather than a substitute for. family labour ${ }^{n 3}$

Cadigan provides a comprehensive overview of the demise of the planter fishery based on hired labour. Still. in terms of the transition to the family production unit. there are several aspects of his argument that I find troubling. Firstly, there is a sense of tailure and opportunity lost in the tinal shift to family labour. The pervasive image in his discussion of this transition is one of the planter fishery in retreat. "Post-war depression had erected the planters' position. forcing them to retreat trom the use of hired labour. he writes, the "legal imflexibility" of the wage and lien system "smothered" the capacity of planters to accumulate capital and "discouraged" planters from relying on waged labour: "those who wanted to remain solvent retreated into household production through family based labour and dependence on merchant capital [italics added] ${ }^{* \text {, th }}$ The language here is

"Cadigan. Hope and Deception, particularly Parts 2 and 3

"Cadigan. Hope and Deception, pp. 42.84. and 99: similar images of retreat appear elsewhere, for example, on pp. 37, 4 . and 167. Cadigan's more recent work does 
very evocative of defeat and withdrawal. Missing from the discussion are the positive aspects of the shift to a family fishery. Surely, family members with high stakes in the outcome of the season would have been more reliable than waged labour. even servants hired on shares might not have had the same kind of long-term commitment to the enterprise. being able to contract their services elsewhere as labour demand and the fortunes of the tishery dictated. In terms of capacity, the tamily production unit that incorporated the extended family would certainly have matched the output of a small-scale planter fishery: and it was likely a rational economic response to contracting market conditions and the vagaries of the tish resource. Secondly. Cadigan's language implies a connection between household production and continuing reliance on truck that perhaps could have been broken had this planter class of producers been able to continue on course after the Napoleonic Wars. Yet Cadigan does agree with Matthews that the dependence on merchant capital was pervasive. given Newtoundland's inability to provision itself. and predated family production; so how the planter fishery based on hired labour might have broken the reliance on truck - even had the wage and lien system not had its dampening impact - is not made clear. Finally, the lack of women 's agency in

present a more benign interpretation of the transition. He presents the process as a matter of planter preference and portrays the moral economy that mediated family fisheries as the basis of a community-based resource management that was more sustainable than the capitalist management regime that developed in the $20^{\text {th }}$ century. See Cadigan. "The Moral Economy of the Commons: Ecology and Equity in the Newfoundland Cod Fishery. 1815-1855." Labour/Le Travail, 43 (Spring. 1999), 9-42. This positive reading of the transition to a family fishery is not apparent in Hope and Deception. 
Cadigan's discussion of the trend towards a family fishery is disturbing. Working from his assumption of a strongly patriarchal family structure, he sees the transition purely in terms ot male-centred agendas and male decision-making. Because women and children did not have to be paid wages by a male household head. he argues, and because household patriarchs were not only permitted, but expected, by the courts to discipline family members by force (a finding that does not emerge from the southern Avalon data). planters resored to family labour to minimize their overhead. to avoid the legal niceties of shipping agreements. and to avail themselves of non-economic forms of discipline Within the patriarchal organization of household production, women's work rhythms bent to the dictates of male schedules, and decisions were frequently enforced by male violence This is a very different perception of family power relations from those which I have observed on the southern Avalon. where women were commonly seen as partners in tamily enterprises, as the following chapters will reveal.,

I do agree with Cadigan that the conditions created by the Napoleonic War period were an anomaly, and that the period witnessed the last stand of the traditional planter tishery in a period of abnormally favourable conditions. However. I do not see the wage

${ }^{n}$ Cadigan, Hope and Deception, pp. 64-82, especially pp 72-82.

"x It should be noted. however. that Cadigan's study area contained a different ethnic mix of English and Irish from mine. and that there was greater economic diversification in Conception Bay with the development of the North Shore. Labrador. and seal fisheries. and various related trades. It is possible that these contrasting circumstances resulted in different gender relations within fishing households in the two areas that would certainly provide an interesting avenue for future study 
and lien system as being a major determinant in spelling its demise. Even had this system not existed in Newtoundland, it is doubtful that a planter fishery based on hired labour would have ultimately challenged the growing logic of a family production unit. given the wide fluctuations in the trade and in tish catches. Certainly, this is the impression created by the southern Avalon data. ${ }^{67}$ While good markets and high wages stimulated production and attracted large numbers of servants to the fishery, their numbers never did reach their tormer proportions of the $18^{\text {th }}$ century and remained subsumed by the numbers of the planter tamily group (see Figures 3.8 and 3.9). By contrast. the shift to the family production unit may even be detected in the steady climb of the planter family group from the 1780 s onwards. and it had certainly gained considerable momentum by the turn of the century. This transition was not set off course, despite increased hiring of servants during the late Napoleonic War period: rather. family production (with some hired servants) continued and ran in tandem with the traditional planter fishery. In the post-war recession, the sedentary fishery was stressed and retreated to pre-boom levels. But the transition to the family production unit accelerated and solidified, while the planter fishery based on hired labour collapsed. As Figures 3.8 and 3.9 demonstrate. by 1836. the number of masters had passed that of male servants for the first time, the number of mistresses had taken a dramatic upswing towards male servant numbers. and the overall family group had

\footnotetext{
${ }^{67}$ Again. regional variations in economic development must be kept in mind. There was no southern Avalon involvement in the North Shore/Labrador fishery and a verv limited participation in the sealing industry. There was, however, a significant banking fleet.
} 
completely subsumed the servant group, who were now likely supplementing family labour - continuing a process that. with perhaps slight diversion due to briefly abnormal conditions, had been underway since the last quarter of the previous century. ${ }^{6 x}$

The numbers of male servants illustrated in the two figures drop off precipitously in the vears 1845 and 1857 . The censuses for those years did not methodically record the number of servants in Newfoundland - an administrative decision that was. in itself.

${ }^{5 *}$ This transition from the late $18^{\text {th }}$ century is supported by sporadic anecdotal evidence trom the period. Head. for example. cites the "First Report on the State of Trade to Vewtoundland" (Great Britain. House of Commons) as evidence that most planters were using family labour in the tishery by the end of the $18^{\text {th }}$ century. with women and children processing the catch. See Head. Eighteenth Century Newtoundland, p. 218 Sweetman's were noting through the 1790 s the inability of planters to meet inflationary wage demands of fishing servants, and by 1804 were complaining that there were insufficient shore crews to split, salt, and dry fish on shore. M. Sweetman wrote to the firm's principals: "From the very great Scarcity of men, both with me and planters we have not been able to get a Fish in pile as vet. Certainly. these were factors that were precipitating. and perhaps even reflecting, a shift to family production units. See PAVL. MG-49. Sweetman Collection. Box 5. Letterbook: James Downey, agent, to Saunders and Sweetman. August 29 and October 4 and 5. 1792, and M. Sweetman to Saunders and Sweetman. June 15. and July 14. 1804 In 1819. Lewis Anspach, an Anglican missionary in Conception Bay but writing about Newfoundland in general. noted the participation of women in the curing process. See Anspach. A History, p. 468. In 1838. American observer Ephraim W. Tucker was impressed by the skill of women in processing fish on the Labrador coast. and wrote: "At the fish stands. while the cod fishery is in the full tide of operation, the women are seen among the most constant and dextrous in dressing the fish, thrown up by the fishermen. Some of these females will dress two or three thousand tish in a single day... See Light and Prentice, eds. Pioneer and Gentlewomen, pp. 58-9. citing Tucker. Five Months in Labrador and Newfoundland During the Summer of 1838 (Concord. 1839), pp. 119-20. And Norwegian tisheries investigator Peter Stuwitz observed that women and children were involved in processing fish in the St. Mary's Bay area in 1840. See Helge W. Vordvik and Lewis R. Fischer. "Peter M. Stuwitz and the Newfoundland Inshore Fishery in 1840, Newfoundland Studies, $1: 2$ (Fall. 1985). 129.40, particularly pp. 135 and 138 . 
indicative of change. Indeed. Ferryland was the only district in Newfoundland to report any servants for these years (21I and $1+1$, respectively), and whether these were fishing or domestic servants, male or female, was not specified.

However, the 1857 census does provide evidence of a system of family production tully in place on the southern Avalon, as demonstrated by Figure $3.10^{\circ 9}$ When examining the figure. there are some anomalies in the census figures that must be considered. There were two categories under which people involved in the fishery could report: "Persons engaged in catching and curing tish" and "Able-bodied Seamen and Fishermen in this Colony and its Dependencies." There were obviously variations in recording along the study area. depending on the census taker given the distribution of numbers for the area between Bay Bulls and Lamanche, it seems likely that women were reported under the tormer category while men were reported under the latter: on the shore between Brigus South and Cape Race. both women and men were recorded under the former category: for the section from Cape Race lighthouse to Cape Dog. again. only the former category was used. but it seems likely. given the low numbers, that men only were recorded (It is impossible to accept that no women in the Trepassey-St. Mary's were involved in the

${ }^{n 9} \mathrm{~A}$ similar figure cannot be attempted for the 1845 census vear as there were obviously profound problems in terms of reporting those involved in the fishery. The 1845 census contains a category "Planters. Fishermen. and Shoremen." but the numbers reported seem very low, not accounting for even half the adult male population: for some communities, none are recorded at all. 
'Using the age categories in the census (grouped by ten-year increments), the working population has been approximated as all persons between the ages of 10 and 70 .

SOURCE: Newfoundland Population Retums, 1857. 


\section{Figure 3.10 - Percentage of working-aged population employed in the fishery, southern Avalon, 1857}

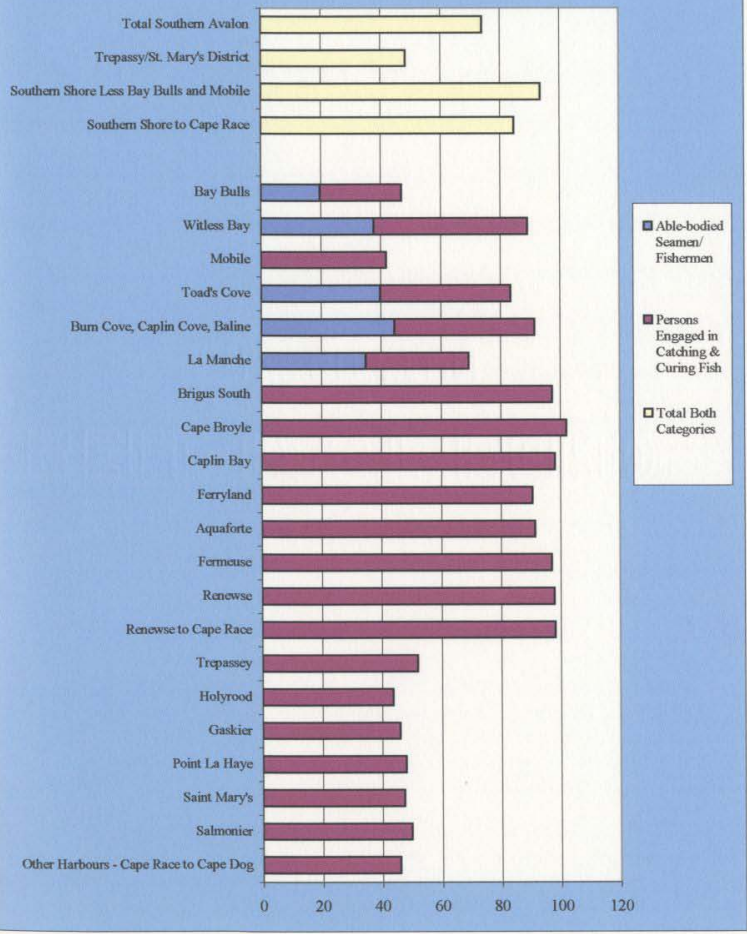


fishery - C. O 194 census material, anecdotal evidence, court records, and the oral tradition argue otherwise.)

Given these limitations, there is still strong evidence of an almost complete shift to household production. Figure 3.10 shows those involved in the fishery in key communities as a percentage of the population between the ages of 10 and $70^{\circ}$. As can be seen. participation in the fishery in some areas was extremely high - particularly in the area between Brigus South and Cape Race, where percentages ranged from 9071 percent (Ferryland) to 102.71 percent $^{* 1}$ (Cape Broyle) of the approximated working population. The low percentages for the Trepassey-St. Mary's area have already been explained as an anomaly in recording. Reportings tor Bay Bulls and Mobile also seem low and may also reflect an aberration in the recording. Nonetheless, the overall percentage of the working population in the study area reporting under the two categories was $7+19$ percent. If one removes the anomalous Trepassey-St. Mary's area. the percentage climbs to 84.94 percent: and if one removes the low reportings of Bay Bulls and Mobile from this sector.

\footnotetext{
7'The targeting of the group between the ages of 10 and 70 is an attempt to approximate the population of working age within the confines of the census age categories. Obviously, this is an imprecise measurement: for example, a number of children would not have been working at age 10 or in their early teens: they are counterbalanced to some extent. however. by those adults over the age of 70 who may still have been involved in the fishery but are not included in the target group.

${ }^{-1}$ This percentage exceeds 100 because the number of people working in the tishery exceeded the number of people in the approximated working population. Clearly. then. there were several persons older or younger than this group who were also employed in the fishery. This was likely the case in other communities as weil. but not as obvious with percentages below 100
} 
the percentage climbs again to 93.71 percent. The evidence of the shift to household production on the southern Avalon is overwhelming - the culmination of a process that had already gained momentum in the late $18^{\text {th }}$ century

\subsection{Conclusion}

The Irish women who arrived on the southern Avalon during the study period came from the southeastern counties - primarily Wexford, Waterford, Kilkenny. and Tipperary Like most Irish male migrants to Newtoundland, they were responding to economic recession and land shortage in Ireland and the economic lure of the Vewfoundland fishery They came out as single servants (fishing and domestic) and as members of family groups. and it was their intention to lead productive lives within their family units and the broader tishing community. These women weighed the evidence before leaving Ireland and made conscious decisions in the interests of themselves and their families; to re-iterate Akenson, they were not just "passive bits of flotsam on some alleged historical tide. " And regardless of the popular refrain of $18^{\text {th }}$-century governors proclamations. most did not become a charge upon the community

Women plaved an integral role in early settlement. for it was their presence that was kev in stabilizing community populations through the late $18^{\text {th }}$ and early $19^{\text {th }}$ centuries

\footnotetext{
"Akenson Primer, p. 11
} 
in the study area. Had British authorities had their way in stemming the numbers of women immigrants, the migration stream to the southern Avalon (and, indeed, the entire English Shore) would have remained largely temporary and transient, given the nature of employment in the Newfoundland fishery. As they had so accurately observed " Soe longe as there comes noe women, they are not fixed." But women came and remained; they formed a marriage pool for incoming planters and fishermen and provided the basis tor permanent settlement. While male fishing servants moved in and out of the southern Avalon. and trom harbour to harbour within the study area. women were a more permanent element in local populations. Migrant tishermen found wives or common-law partners. first among the English planter families already on the shore, but in the later decades of the $18^{\text {th }}$ century and beyond, among increasing numbers of Irish and IrishVewfoundland women - especially tirst- and second-generation Irish-Newtoundland women atter the turn of the century. Matrilocality and uxorilocality were important elements of community tormation as couples built on land occupied by the wife or apportioned from or adjoining the family property of the wife.

Irish women were also instrumental in the processes of intermarriage. conversion. and assimilation that saw the English-Protestant planter society of the study area almost completely subsumed by an Irish-Catholic culture. Numerous English patrilines - families with surnames such as Glynn, Martin, Critch, Williams. Yard. Carew, Maddox - were incorporated into the Catholic population: in time. they would consider themselves as much a part of the Irish ethnic group as those who bore Irish surnames. The processes 
were reintorced by continuing Irish immigration. and by the end of the $18^{\text {th }}$ century. the population of the southern Avalon was almost completely Catholic. $\mathrm{Up}$ to the end of the study period. a small group of (mostly) middle-class English Protestants struggled to maintain their homogeneity, but they were a group in retreat

From the American Revolutionary War period onwards. there was a steady increase in the planter group - a group that was becoming more and more Irish as Irish inmigration increased and as the process of assimilation of the English ethnic group continued. Initial momentum for the transition to the family production unit in the fishery can also be discerned from this period. Although the resident fishery was moving into ascendancy over the dying migratory fishery, there was no corresponding surge in the hiring of fishing servants by the sedentary fishery atter the 1780 s. Indeed from the 1790 s onwards. tishing servants were never again hired in the same proportions to the planter group as earlier in the century - not even during the boom of the late Napoleonic War period. After the tum of the century. the numbers of servants converged upon and were subsumed by the numbers of the planter group. suggesting that the transition from the planter fishery based essentially on hired labour was steadily giving way to a planter fishery based on family labour, with some supplemental hired labour. The Napoleonic War period saw the final stand of the former, and its collapse in the post-war recession. The transition to the family production unit continued steadily thereafter and was completely in place in the southern Avalon by the 1857 census.

Here. then, was another essential contribution of women to the stability of early 
communities on the southern Avalon. Throughout the late $18^{\text {th }}$ and early $19^{\text {th }}$ centuries. women increasingly took on shore work in the emerging family production unit. Particularly in the wake of the Napoleonic Wars. when the migratory tishery had all but collapsed and the traditional planter tishery was in its death throes due to depressed fish prices that could not meet inflated servant wages and provision prices, women stepped into the breach and took the place of male fishing servants in producing saltfish for market Along the southern Avalon. most of these women were Irish or IrishVeufoundland women (with either Irish or mixed Irish-English ancestry) And they would contribute in other essential ways to community life. as the following chapters will examine 
Chapter 4 - "A good, hard-working stump of a girl". Irish women's work and the construction of identity on the southern Avalon

As we have seen, Irish female immigrants to the southern Avalon came primarily from counties Wextord. Watertord, and Kilkenny. Like their male counterparts, most of them likely came from artisanal or farming backgrounds in southeast Ireland with some involvement in the domestic textile industry. As such, they would certainly have had to modulate their skills and work rhythms to harmonize with a fishing/subsistence farming economy on the southern Avalon. Witness the following account from the travel musings of Aaron Thomas while visiting Newtoundland in 1794-5

Do you know that in this Country. in the Winter time. a girl can Milke a Cow into her. Apron and carry the Milke home in it? If she Milkes the Cow in the open air the intensity of the weather will freeze the Milke as it talls from the Cow into the Apron and [it will] remain there. a hard, conglutinated. frozen mass. until melted by heat ${ }^{1}$

Even allowing for Thomas's stylistic leaning towards an occasional tall tale, it is certain that an immigrant woman from the more moderate climate of southeast Ireland would have found herself in somewhat altered circumstances in terms of work routines in Newfoundland. Still. she also found herself far removed from the congested farmlands of Ireland in a place where she and her tamily could occupy property for fishing and subsistence agriculture with minimal interterence, and move freely through woods and

\footnotetext{
${ }^{1}$ Thomas, Newfoundland Journal, p. 187.
} 
meadows. gleaning tirewood and foraging for local plants and berries. a place where the game in the forests and fish in the streams were available to all comers.

This chapter will examine the nature of women's work on the southern Avalon. and the continuities and changes as Irish women adapted to a new physical and socioeconomic environment. It will also discuss the sexual division of labour and how the understanding of women's place within the work cycle contributed to the configuration of self-identity and the construction of Irish womanhood within the Irish plebeian community in the study period. The feminine ideal. which boarded the ship in the home country and thrived within the context of migration and early settlement, was that of "a good, hardworking stump of a girl.":

\section{\pm 1 Household production}

Transient fishermen and shoremen had comprised the primary work crews of the early Newfoundland fishery in both its migratory and sedentary aspects. But by the beginning of the study period of this thesis. the evolution of the family work unit in the planter fishery had begun. and the momentum of this transition increased through the end of the $18^{\text {th }}$ century and into the $19^{\text {th }}$ Household production became key to survival in both

"A saying from Irish peasant lore signifying the ideal qualities of a wife: a similar sentiment was expressed in the saying "Good looks don t boil the pot." See Nolan. Ourselves Alone, p. 20 
the fishery and subsistence agriculture, and men and women followed the rhythms of complementary work routines. These rhythms were grounded primarily in efficiency and pragmatism. As will be seen, traditional gender dichotomies that attempt to differentiate men's and women's work in terms of physical strength/weakness or outdoor/indoor work are too inflexible for examining the sexual division of labour within this particular historical context. ${ }^{3}$

\footnotetext{
'Much of the following material on household production. unless otherwise specified, comes from the oral tradition and student papers in the MHA (see bibliography) Most of the work routines were still in existence within the memory of many oral intormants and. indeed. some had been carried out by a number of the people interviewed When asked, these older informants were firm in their belief that these routines had been established in the study period of this thesis. Other writers have discussed the role of women in household production in the Newtoundland fishery. including: Antler. "Women's Work". Cadigan. Hope and Deception; Murray. More Than Fifty Percent: Pope, "South Avalon Planters". Porter. "Skipper of the Shore Crew". and Miriam W'right. "Women, Men and the Modern Fishery: Images of Gender in Government Plans for the Canadian Atlantic Fisheries." in McGrath. Neis. and Porter. eds.. Their Lives and Times. pp. 129-43. The importance of women's work in proto-industrial family economies has also been observed by various writers on the British Isles, including: Anna Clark. The Struggle for the Breeches: Gender and the Making of the British Working Class (Berkeley: Lniversity of California Press. 1995): Clarkson. "Love. Labour and Life.". Cullen. "Breadwinners and Providers", Mary Daly. "Women in the Irish Workforce from Pre-industrial to Modern Times," $\underline{\text { Saothar, }} 7$ (1981), 74-82: Catherine Hall. "The History of the Housewife." in Hall, White, Male and Middle-Class Explorations in Feminism and History (New York: Routledge. 1992). Chapter 2: Mageean. "Irish Women's Prospects". Nolan, Ourselves Alone; Jane Rendall. Women in an Industrializing Society: England. 1750-1880, Historical Association Studies (Oxford: Basil Blackwell. 1990), Sharpe. ed. Women's Work; and Deborah Valenze. The First Industrial Woman (New York; Oxford Oxford University Press, 1995). Women were also essential in household production within colonial contexts of Canada and America. See, for example: Berkin, First Generations, Berkin and Horowitz, eds., Women's Voices; Bittermann. "Women and the Escheat Movement" : Brown. Good Wives, Nasty Wenches; Light and Prentice, eds.. Pioneer and Gentlewomen; Ridner. "To Have a Sufficient Maintenance"*: Ryan. Womanhood in America; Sundberg, "Farm Women", and Llrich, Good Wives.
} 


\section{+11 Cod tishery}

One of the greatest adaptations required of Irish women as well as men in coming out to the study area was the shift from an agricultural base to a fishing economy The cod tishery was the primary industry of Newfoundland and the mainstay of the local economy on the southern Avalon during the study period. By contrast, Ireland, although also surrounded by the sea. had not developed a significant fishing industry outside a small-scale effort on the west coast. ${ }^{4}$ Most immigrants from the southeast of Ireland. then, would have had to learn a new set of skills to earn their livelihood at Newtoundland For a number of men. the transition was gradual. coming out to Newfoundland on a migratory basis as youngsters, gaining experience as they found a niche within the ranks of shore and boat crews. ${ }^{5}$ and ultimately making the decision to remain. But women tended to be permanent immigrants, and thus they were pitched headlong into this new form of enterprise with little preparation or training. Their capacity to adjust quickly to fishing production, then, was a critical aspect of new-world adaptation and a vital contribution to

'Cormac $\mathrm{O}$ Grada notes that there was a small Irish fishing industry on the west coast but that it remained undeveloped due to lack of infrastructure and equipment $\mathrm{A}$ bounty system initiated in 1819 brought some prosperity to the industry. but Westminster pulled the plug on the scheme in the late 1820 s within the context of a broader economic policy of laussez-faure. See O Grada. Ireland.

'The labour force in the fishery was differentiated by skill and experience: e g.. on shore - ordinary shoreman, splitter, header, salter, master of the voyage: in boats - seaman (migratory fishery only), fisherman, midshipman, foreshipman, and boatmaster. 
the success of the settlement process."

Some women. primarily widows, became fishing employers or household heads who operated fishing premises in their own right. For example, in 1787, a notice was issued by Ferryland magistrate Robert Carter that fishing servants were not to be served liquor "unless it be by and with the Consent of his.Master or M/istress in writing [italics added]" - implying that women did employ servants in the industry. not just as wives in planter households (in which case, under the principle of coverture, the consent of the "Master" would have been sufficient), but under the status of feme sole" Indeed. a number of these women were mentioned by name in the records. In August. 1768, for

"Note that this section deals only with women's participation in the fishery as boatkeepers and within their own family production units. Women's involvement as tishing servants will be discussed below as paid work in the section on service. This is a rather artificial separation tor organizational purposes only. and is not meant to divert attention from the variety of women's involvement in the industry, particularly in the $18^{\text {th }}$ and early $19^{\text {th }}$ centuries.

'Pope observed that a significant number of women in $17^{\text {th }}$-century Ferryland were also single heads of fishing enterprises, and that many others were partners in household production. Lising census data. he compares the numbers of servants in households with and without mistresses. and finds that those with mistresses had at least one fewer servant than those without, suggesting that a planter's wife performed the equivalent work of a male servant. See Pope. "South Avalon Planters," pp. 306-13

"PANL. GN 5/4/C/1. Box 1. f. 23. Notice. Magistrate Robert Carter to "all Merchants. Traders. Boatkeepers and Innkeepers in the District of Ferryland," January 8. 1787. The English common law doctrine of coverture dictated that the legal personality of a married woman was subsumed in that of her husband. Lpon marriage. she became a feme coverte: a single woman. by contrast. maintained her own legal identity as feme sole Repercussions of the principle of 'marital unity' are discussed more fully in Chapters 6 and 8. 
example. Governor Palliser ordered the magistrate at Ferryland to tax 24 persons in the district who had kept dieters the previous winter "as the entertaining [of] Idle People. is the cause of all disorders and mischiefs in this Country.... Listed among the employers was Mary Shea, who had housed three dieters over the winter (slightly more than the average of 2.75 and the median of two hired by the total group), her fine totalled $£ 1.2 .6$ (7s $6 \mathrm{~d}$. per servant), and in default of payment, fish and oil of equal value were to be seized" Five years later, the same Mary Shea was granted a fishing room on the northwest side of Ferryland harbour. which had already been in her possession for a number of years. "to quietly and peaceably possess the same so long as you shall employ it to the advantage of the Fishery "10 In 1775. Alice Thomas, a fishing employer at Renews. was sued by two fishing servants for their wages. Alice had assumed control of the premises after the death of her planter husband. Thomas ${ }^{\text {" }}$ Similarly. Catharine Clements was the proprietor of a fishing premises and fishing employer in Renews in the $1780 \mathrm{~s}$ and 1790s. having also taken over the management of the premises at the death of her husband. "2 In 1794. Jane Holly was one of several boatkeepers in Ferryland district 1773

"PANL. GN 2/1/A. +/95-6/1768, Order. Governor Hugh Palliser, August 2. 1768

t"PRL. 340.9 N45, n.f. Grant of a Fishing Room to Mary Shea. September 15.

"PRL. 340.9 N45. Lawrence Dumn \& J. Whealon v. flice Thomas, October 5. 1775

1'See PANL, GN 2/1/A, 10/49-51/1784. Petition of James Rows. c. August 14. 1784. and Order. Governor John Campbell. August 27. 1784: PRL. 340.9 N45, n.f. (atharine ("lements v: James Rouse, August 31, 1785; and PANL. GN 5/4/C/1. 
entangled in a dispute between a former and current supplier ${ }^{13}$ In the $1820 \mathrm{~s}$, Ann Ryan was renting a tishing room and premises in Caplin Bay - including stages. flakes. beaches. dwelling house, gardens and lands - from Philip Tree for £6 per annum. ${ }^{1+}$ The rent of a lishing room was charged against the account of Mary Row of Renews in the Goodridge ledgers of 1839 and $1841^{15}$ The names of several women - Sarah McCarthy, Mary Murphy. Dorothy Cantwell. Mary Morris. Widow Blanch (and Son) - appeared in the Sweetman ledgers for the 1820 s and 1830 s as being credited for fish and oil. indicating that they were either tishing employers or heads of tamily production units. ${ }^{\text {in }}$ Family ventures in Renews operating under the names of "Catherine Kenny and Sons"1" and "Elizabeth Beaves and Son"1\$ were most likely tishing production units. In addition. liquor licensees in the $18^{\text {th }}$ and early $19^{\text {th }}$ centuries were required to operate at least one

Ferrvland. Box 1. n.t., (iraham Lithle : . James Bran. April 11. 1791

"PANL, GN 5/4/C/1, Ferryland, Box 1. n f. Thomas (jibbs \& ("). W: William Knox. Sohn Rice. of Henry. Studetr. August 11. 1794.

${ }^{14} \mathrm{PANL}$. GN $5 / 1 / \mathrm{C} / 1$. Ferryland. ff. 97-8. Philip Tree, Mortgage to John Teague. November 29.1823

15.A.NL. MG 473. Alan Goodridge \& Son Collection: 1839 Ledger. $f+13$, and $18+1$ Ledger, t: 292

${ }^{10}$ PA.NL. MG 49. Sweetman Collection. Boxes 2 and 3

${ }^{1}$ PA.NL. MG 473, Goodridge Collection, 1841 Ledger, f. 266.

"After the death of Thomas Beaves of Renews. his account with merchants Hunt. Stabb. and Preston was continued under the head "Elizabeth Beaves and Son." See PANL. GN 5/1/C/1. Ferryland. ff. 124-5 and 162. Hum. Stabb. Preston k ( 0 . 1 . the Fistate of Thomas Beaves, November 6 and December 11. 1820. 
fishing shallop in the fishery, so by inference, any female licensees were al so boatkeepers (see section on hospitality trade, below). And these were but the women's names that have survived in the written record, they likely do not comprise an exhaustive list of all women who operated tishing premises as femes sole in the period.

Certainly. however, a far greater number of women managed fishing plantations with their husbands or common-law parners - with the responsibility of boarding fishing servants and dieters added to their other household and subsistence duties. And increasingly, plebeian women processed fish in family production units, replacing the hired. transient. primarily male shore crews of the traditional planter fishery. ${ }^{\text {th }}$ As noted in the previous chapter, this assumption of shore work occurred at a critical juncture in the tishery Without women's presence and their capacity to adapt their routines to include this additional. labour-intensive work on tlakes. the beleaguered planter tishery would have been hard-pressed to survive the roller-coaster effects of the French-Revolutionary and Napoleonic War periods and, more particularly, the recession that followed.

Most women who worked in family units were primarily involved in 'making fish' i. e. curing and drying cod on shore. After the fish was headed, gutted. and split (operations usually, but not exclusively, performed by men), men or women carried awav

\footnotetext{
"As noted earlier, smaller numbers of fishing servants continued to be hired. but mostly to supplement household units.
} 
the fish in "barras ${ }^{-20}$ for salting. Larger fish were laid in salt bulk." while smaller fish were usually pickled in puncheon tubs. After about 5 days, the fish was washed, again by men or women or both, using water drawn trom the ocean in large tubs. They then loaded the fish (at this stage. called 'waterhorse ) on barras and transported it over rocky shorelines and hills. sometimes even over steep cliffs, to a 'flake ${ }^{* 27}$ or a beach for drying. Although the carrying at this stage was most commonly done by men. due to the heaviness of the 'green' (salted, undried) fish, it was not unusual tor a hardy woman to carry one end of a barra when necessary " At this point. the women's work began in earnest Every morning (weather permitting), the tish were spread flesh-side up for drying. in the evening. the fish was gathered up in "yaftles." or armfuls. and turned skin-side up in small piles called 'faggots " Throughout the process, women had to guard against "tly-blows."

${ }^{3}$ Flat. wooden trames with handles at each end. like stretchers

"Multiple lavers of fish. laid on the floor of the stage and salted.

A long. table-like structure for drying fish, comprised of planks and boughs. with 'longers' (wooden poles) placed at intervals to mark the 'lists' (spaces for drving fish).

3'Several informants from Calvert told of a local woman of the early $20^{\text {th }}$ century. Mrs. Maggie Johnny Kavanagh. who illustrates the point by latter-day example. She regularly carried one end of the barra over a steep hill from the shore to her family's flake. while two young teenaged sons manned the other end. The physics of the barra dictated that in order to share a load equally, both carriers had to hold the handles by the ends. However. if one person decided to take the brunt of the load. he or she would grip the handles closer to the fish. One day. Maggie Johnny was carrying a load with an adult male member of the work unit. He was a very slight man, not nearly as hardy as she. As they climbed the hill to the flake and he was clearly faltering. she was heard to say. "Ah, ya poor little bugger. Ill have to "catch that in for ya now." (This specific anecdote was told by RB. Interview March 26, 2001.) 
waving away tlies with boughs to prevent them from laying eggs on the fish that would hatch into maggots and spoil the cure. As the fish became drier through respreading, the size of the faggots was increased until the fish could be placed in piles. ${ }^{\text {24 }}$ When almost completely dried, the fish was laid in small bulks in a fish 'store ${ }^{29}$ and after several more dryings on the flake, it was piled in larger bulks in the store. ready for shipping to market.

Women's skill and judgement were critical throughout this process, for if the fish did not contain the right amount of salt or moisture for its intended market, the quality was ruined. Also. as more and more fish was processed. various stacks were at different stages of drying, requiring good organizational skills and a caretul eve to detail. An examination of the relatively high wages paid to hired shore crew (see Table +1 ) - and arguably some women performed the equivalent duties of a master of the voyage demonstrates the monetary value. and hence the importance. assigned to this work by the industry Of course. making tish had to be juggled with childcare and housework as well as other outdoor work (notably. weeding. milking. and haymaking at the end of the summer). And if a shower of rain threatened during the daily drying process. women had to drop anything else they were doing and run to the flakes to cover the fish with long strips of dried tree bark, kept in place by a network of boughs and rocks Indeed, while all

\footnotetext{
:Large circular stacks containing several quintals of fish. A quintal was equal to $112 \mathrm{lbs}$ avoirdupois. shipment.

$\because A$ building on the tishing premises for storing supplies, gear. and fish awaiting
} 
Table +1 - Wages of seamen (per month) and fishemen (per scason) - selected vears

1798 English Shore - separate reportings bv distnct not given

Fishermen $\quad$ E21

Shoremen E19

1802 English Shore in general

Wages of Seamen and Fishermen from ع 30-50 for the season.

1810) English Shore in general

Master of Vovage and splitter

$\mathrm{C}+5-50$

Salter

$\varepsilon+()-45$

Header (Old Hands)

E30-35

Youngster

E.15-18

Fishermen

c50-5:

Old Hands

ع26-30

Young Hands

[18-22

1815

St John's Bav Bulls

Furnland

Tripassex

Placentia

Fisherman ع25-65

Boatmaster

Uidshipman

E33
E45
E52
E55
E12 \&
passage

乏 $30-50$

ع $30-40$

Foreshipman

ع20-30

Captain

Header

Salter

Splitter

Master of

Vounge

Youngster

Scaman

ع20-25

40s - $-801 \mathrm{~s}$

'This wide range likely uncludes wages for all ranks of boat and shore crews. 


\begin{tabular}{|c|c|c|c|c|c|}
\hline Fisherman & $\varepsilon 25$ & About & Aver E18 & E3500 total & \\
\hline Boatmaster & $\varepsilon 35$ & ع.7000 total & & in district & $230-40$ \\
\hline Midshipman & $\varepsilon 25$ & in district & & & ع20-25 \\
\hline $\begin{array}{l}\text { Foreshipman } \\
\text { Header }\end{array}$ & & & & & E16-18 \\
\hline Salter & $\varepsilon 20$ & & & & \\
\hline Splitter & $£ 30$ & & & & \\
\hline Master of & & & & & \\
\hline Vovage & $\varepsilon+0$ & & & & \\
\hline Shoreman & $\varepsilon 12.25$ & & & & \\
\hline Youngster & EIt & & & & E12-15" \\
\hline Scaman & & & & & $40 \mathrm{~s}-50 \mathrm{~s}$ \\
\hline
\end{tabular}

This wage range is itemized under the heading of "Captans" for Placentia. but must surely refer to Youngsters.

\begin{tabular}{|c|c|c|c|c|c|}
\hline 1820 & St John's & Bat Bulls & Ferraland & Trupassev & Placentia \\
\hline $\begin{array}{l}\text { Fishcrman } \\
\text { Boatmaster }\end{array}$ & $\varepsilon 20-30$ & $\varepsilon \mid 6-30$ & E $18-45$ & & $\varepsilon=0-30$ \\
\hline Header & $\varepsilon 20-24$ & & & & \\
\hline Salter & $£ 28-32$ & & & & \\
\hline Master of & & & & & \\
\hline Votage & E32-38 & & & & \\
\hline Youngster & Elt & & & & \\
\hline Seaman & & $30 \mathrm{~s}-45 \mathrm{~s}$ & $\begin{array}{l}21\left(24^{\prime}\right) \mathrm{s} \text { - } \\
60 \mathrm{~s} .\end{array}$ & & 40s. \\
\hline 1827 & St John's & Bay Bulls & Ferrvland & Irepersey & Placentia \\
\hline Fishermen & E18-2+ & E16-2t & $\varepsilon 18 \div-22.10 .0$ & & E18 \\
\hline Scamen & $50 s$. & & & & $40 \mathbf{s}$ \\
\hline
\end{tabular}

- The minimum wage reported was actually $£ 8$. but this was very low. gaven wages in nearbo distrets. and was likely an error in recording. The more likely lower end of the range was $£ 18$. 


\begin{tabular}{|c|c|c|c|c|c|}
\hline 1825 & St. John's & Bav Bulls & Ferriland & Trepasser & Placentia \\
\hline Fisherman & $£ 16-26$ & & & \& $1 x-2\}$ & c. $\{23$ \\
\hline Boutmaster & & $\varepsilon 25$ & & & \\
\hline Midshipman & & $\varepsilon 22$ & & & \\
\hline Header & $£ 20$ & $\varepsilon 20$ & & & \\
\hline Salter & $£ 25$ & $\varepsilon 23$ & & & \\
\hline \multicolumn{6}{|l|}{ Master of } \\
\hline Vovage & £30-35 & $\varepsilon 28$ & & & \\
\hline Youngster & E12-16 & Elt & & & \\
\hline Seaman & 50 s. -23 & & & & $45 \mathrm{~s}-50 \mathrm{~s}$. \\
\hline
\end{tabular}

SOURCES C O 194. Governors' Annual Returns. Additional Information. and Obsersations on Instructions: 1798. vol 40. ff. 135-7: 1802. vol +3, f. 122: 1810. vol 49. ff. 120-22. Schedule E. 1815, vol. 57. f. 12.1818, vol. 61. f. 158, 1820, vol 64. f. 24. 1822, vol. 65. f. 121. and 1825. vol. 70, f 227. Also PANL. GN 2/1/A. 17/62/1803. Blank spaces indicate that the data was not available or not entered. Note that a fairly thorough itemization of wages was being recorded by the governor by 1810 and broken down by district by 1815 . These reports were discontinued altogether in the late $1820 \mathrm{~s}$. 
duties had to be balanced efficiently, none was to take priority over making the fish properly As one elderly Cape Broyle woman observed, "If the fish wasn't spread when the men came in [from the water], there $\mathrm{d}$ be some racket. ${ }^{-36}$

In peak periods. when fish were plentiful, women worked at the fish through the nights along with the men. At such times, it was not uncommon to find women on the 'stage 27 involved in the pre-drying stages of processing. Some women helped the men prong the fish from boat to stage head. More commonly, women pewed $2 x$ the cod through the open windows onto the cutting table; skill and precision were required to stab the tish in the head only, for tish that was 'broken, or damaged in the body, brought a low price. Women also assisted in splitting fish," again, a stage that required care and dexterity to protect the quality of the tinished product (again, note the high wages paid to hired splitters. Table +1 . and hence the value of this work). And a woman who was proficient at cutting tongues and 'sculps ${ }^{\cdot 311}$ for local consumption was a highly regarded worker as well. But while tishing was seen solely as men's work. and women who

'MOB, Interview July 22, 1999

2"The stage consisted of a wharf with a small house-like construction at its inshore end accessed by a door and two unglazed windows. Inside were the cutting table and the cuvels or barrels into which cod livers were thrown as the fish were split.

${ }^{2}$ Transferred the fish using a 'pew' - i.e., a prong with only one tine. A 'pew' was also used to throw fish from boats to the stage

${ }^{29} \mathrm{Cutting}$ around the backbone of the fish to open it for salting and drying.

${ }^{\text {"t) }}$ Cod cheeks. a local delicacy. One elderly informant advised: "My dear. that's the best part of the fish." AOT, Interview July 19,1999. 
worked at the earlier cutting and splitting stages were usually deemed to be 'helping the men' (except those few women who did this work on a regular basis). 'making fish' came to be considered within fishing families as much women's work as it was men 's. In the eyes of the local plebeian community. women were not merely 'helping on the flakes and beaches, rather. "Women made fish along with the men." Indeed. in peak catching periods. the curing of tish became almost exclusively the preserve of women and children Furthermore, although the work performed by Irish-Newfoundland women in the fishery was difficult in terms of physical labour and time management. these women did not wiew the task as drudgery Indeed. according to $20^{\text {th }}$-century informants who split and made fish themselves, women "loved to be out at it." Many women 'shipped girls" (i.e. hired domestic servants) not just to help with household routines. but to 'tree' them from their housework so that they could join the men on the stage and flake. others relied on older daughters or grandmothers to supervise the household and younger children in their absence. and it was not an uncommon event for a nursing infant to be breast-fed on stage or flake and then settled away in a sawed-off puncheon tub while the mother worked on

"This distinction was not always made by outside observers. In describing Vewfoundland women. for example. Anglican missionary Anspach noted the very valuable assistance which they afford during the season for curing and drying the fish. [italics added]." See Anspach. History, p. 468. Norwegian observer Peter M. Stuwitz was perhaps more inclusive in his 1840 remarks on the inshore fishery at St. Mary's: in the processing of fish. he noted. the men s families. women and children. "participate" and "also work with them." See Nordvik and Fischer. "Peter M. Stuwitz." pp. 135 and 138.

${ }^{12}$ Quotation came from $\mathrm{JK}$. Interview August 24. 1999: but virtually the same sentiment was also expressed by GK. AK. MOB. JOB, and MK. 
Nor was the 'respectability' of these women at issue. Women saw it as their right to participate in a family enterprise in which they held an equal stake. and they took pride in their capacity to contribute to the process. At the same time, the value and dignity of their work was acknowledged by the larger community. The perception of these women as essential. skilled workers in the fishery was an integral part of their own self-image and of the construction of womanhood within the plebeian community in general. ${ }^{53}$

\section{+12 Subsistence agriculture}

While saltfish production was a new venture for immigrant women from southeast Ireland, many would have been quite comfortable with the performance of agricultural work. Still. adjustments had to be made in adapting to their new environment. even if they

"It must be noted that while family production in the fishery was pervasive by the end of the study period. it was not universal - e.g. some men fished in areas too far from their own harbours to return daily. and their catch was processed by male boat crews. But the exclusion of women from the processing in these cases had nothing to do with concerns about respectability or the difficulty of the work; indeed, these women had to shoulder additional duties in terms of caring for children. households, gardens, and livestock. In the early $20^{\text {th }}$ century, women's work in processing continued. although small inroads were being made by discourses on female respectability and domesticity. However, women's participation declined significantly with the introduction of freshtrozen technology at mid-century See: Antler, "Women's Work": and Wright, "Women. Men and the Modem Fishery." But until women were sidelined by the modernizing industry, they saw themselves as not only obligated. but entitled. to take part in family processing: those women who did not participate, unless they had acceptable family or outside work reasons for their absence. were perceived as being not quite up to muster either "too sickly" or "too grand to go on the flake." (These quotations came from MOB. Interview July 22, 1999: but similar sentiments were expressed by MK and GK.) 
were not quite as dramatic as diarist Aaron Thomas would have had his readership believe. Most certainly, Irish migrants encountered less fertile soil conditions and a less temperate climate. with later springs, hotter summers, and much harsher winters than in their southeastern home counties. With poor soil and a short growing season, there was very little development of commercialized agriculture on the island, and thus the smail-scale tarming or agricultural labouring backgrounds of many Irish immigrants were refocused on subsistence agriculture to support tishing incomes.

Some adjustments also had to be made in terms of produce - although there was a good deal of continuity as well as change. The potato had been introduced to Newtoundland by the middle of the $18^{\text {th }}$ century. ${ }^{\text {H }}$ before the major intlux of Irish to the island, and grew well in local conditions. However, the potato was not as large a teature of the pre-Famine Irish diet in the home country as traditional historians have indicated. Granted, the diet of cottiers and landless labourers was rather monotonous, although still nutritious. with staples of potatoes, milk. eggs, and fish until dependence on the potato increased in the decades before the Famine But outside this class, the Irish ate a varied diet, including meat (pork/bacon, mutton, some beef), milk and its products. cereals and grains (bread. porridge. stir-about. oatcakes). potatoes. peas, beans, cabbage, fish, fowl.

${ }^{3}$ Head. Eighteenth Century Newfoundland, p. 142 and p. 187. tin. 5 . Head notes that the first mention in the written record of the use of potatoes in Newfoundland appears in a 1754 despatch from the governor to the Colonial Office. 
and eggs. ${ }^{35}$ Most of these items would become available to the Irish in Newfoundland either through their own production efforts or from their supplying merchants. The greatest shift in diet would have been a decreased dependence on cereals and grains. which could not be supported by the local climate (although imported flour and hard bread were available) and a greater dependence on root crops - not just potatoes, but carrots. turnip. and parsnip - that could more readily survive the peculiarities of the Newtoundland growing season.

Some efforts were made to stimulate local agriculture in the late $18^{\text {th }}$ and early $19^{\text {th }}$ centuries, but despite the increasing acreage of cleared land (much of it for meadows), the island remained dependent on outside supplies of many foodstuffs ${ }^{\text {sth }}$ Because of this, there

"The potato was introduced into Ireland in the late $16^{\text {th }}$ century. While Irish historians had long assumed that reliance on a potato diet was widespread by the early decades of the $17^{\text {th }}$ century, M. Drake and K. H. Connell more recently argued that the transition came later, in the $1770 \mathrm{~s}-1780 \mathrm{~s}$. L. M. Cullen states, however, that Drake and Connell have been misled by the evidence of contemporary observer Arthur Young. whose remarks about the dependence on a potato diet applied only to cottiers and labourers. Other areas, especially the north and southeast, maintained much more varied diets into the $19^{\text {th }}$ century. Nonetheless, the population explosion within the cottier and labouring class increased the aggregate dependence on the potato steadily and dramatically after the turn of the century. See: Connell. Population of Ireland; Louis M. Cullen. The Emergence of Modern Ireland, 1600-1900 (New York: Holmes and Meier Publishers. 1981): L. M. Cullen. "Irish History Without the Potato," in C. H. E. Philpin. ed.. Vationalism and Popular Protest in Ireland (Cambridge: Cambridge Lniversity Press. 1987). pp. 126-38. See, also. Mageean. "Irish Women's Prospects."

"See: Head. Eighteenth Century Newfoundland; and Cadigan. Hope and Deception. Newfoundland had originally been supplied by West Country merchants. joined in the $18^{\text {th }}$ century by American and Irish traders. By the end of the century. links had been forged with suppliers in the West Indies (direct) and Canada as well. 
is a tendency in the literature to be somewhat dismissive of farming efforts along the English Shore. But subsistence agriculture did help to support growing populations in local communities - complementing the predominantly salt or dried provisions purchased on credit from the merchant (usually salt pork and beef. flour. tea. butter. molasses, dried peas. and rum) by providing a reasonable variety of fresh produce, meat. eggs, butter. cream. and milk (and hence fresh sources of protein. carbohydrates. vitamins, and minerals) for local consumption. Furthermore, local tamily production cushioned the impact of variations in provision prices and supply trom year to year. and helped to mitigate the hardship of bad fishing seasons. ${ }^{37}$ Women on the southern Avalon contributed significantly to this effort. often in less than ideal circumstances, working to ensure the survival of families and communities.

(iardens and fields: Work in the vegetable gardens (some near the house. some in back meadows) was shared by members of the plebeian household. Indeed. spring planting and fall harvesting were cooperative affairs, with men's and women's efforts complementing each other. In the earliest period of settlement. both men and women engaged in the heavy physical labour of clearing land. stone-picking, digging and fertilizing gardens. trenching potatoes, and digging vegetables for harvest. Indeed. one oral

${ }^{37}$ Lnfortunately. sometimes poor growing and fishing seasons corresponded. as in the 1820 s and 1830 s. with devastating consequences to many communities. 
informant told of women pulling ploughs in the old days, ${ }^{-38}$ although spade and hoe agriculture was likely the predominant form of ground preparation through most of the study period. Still. labour-intensive farming methods were hardly strange to women who had hailed from farming areas in Ireland, where middle-class observers of the $18^{\text {th }}$ and early $19^{\text {th }}$ centuries were horritied at the physical nature of women's agricultural labour. One shocked Englishman noted in 1812 :

Females in Ireland are treated more like beast of burden than rational beings, and although I never saw anyone yoked to a plough... I have seen them degraded in a manner disgraceful to the other sex and shocking to humanity. In the country, they are subjected to all the drudgery generally performed by men; setting potatoes, digging turf and the performance of the most laborious occupations. ${ }^{39}$

But women's work - often hard. physical labour - was essential in tamily agricultural enterprises ranging from the cottier's potato plots to the small, semi-subsistence farms that were a common feature of the pre-Famine Irish countryside ${ }^{\text {th }}$ Rural Irish families could ill afford to koutow to the sensibilities of middle-class observers. And like their home

${ }^{78}$ TB. Interview June 22. 1999

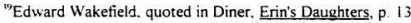

${ }^{40}$ For a discussion of women's vital contribution to family economies in pre-Famine rural Ireland. see: Bourke. Husbandry to Housewifery; Clarkson, "Love. Labour and Life". Cullen. "Breadwinners and Providers": Daly, "Women in the Irish Workforce". Diner. Erin's Daughters; Luddy. Documentary History; Mageean. "Irish Women's Prospects": and Nolan. Ourselves Alone. 
culture. the Irish plebeian community on the southern Avalon had not yet absorbed gender ideology that designated women as the 'weaker' or 'gentler' sex. Women's tarm labour was part of a comprehensive package of survival skills that they brought to all family enterprises

As families on the southern Avalon became more established and grew in size. however, men tended to assume tasks in the gardens that required greater physical strength - digging and trenching. tor example - although this was certainly not a hard and fast rule, with women continuing to participate on an 'as needs' basis (e g. in the case of male absence or of a small tamily with no extended kinship networks) Otherwise. women were generally responsible for setting vegetables. transplanting cabbage. fertilizing. thinning out crops and weeding through the growing season. as well as gathering up the vegetables that had been dug by the men in the fall. Still. this was hard physical labour. and sometimes unpleasant by current standards: spreading cods heads between the transplanted cabbages. for example. or stable manure and caplin on potatoes as the men tollowed behind, trenching and covering the fertilized seeds/plants with soil, were hardly tasks for the fastidious in nature. It is also likely that in the early days of settlement. women may have been involved in a practice that was common in coastal areas of Ireland - carrying seaweed on their backs from the shore to gardens for fertilizing. ${ }^{\text {" }}$ Certainly.

\footnotetext{
${ }^{\text {AT }}$ This practice is generally noted in the Irish literature. above. Luddy also cites some contemporary reports on women's farm work in Munster that indicate that women in that county pertormed this task. An 1822 report. for example. noted that in Watertord. -The females near the sea coast manure the fields with sea weed. which they carry on their
} 
one of women's most specialized tasks on the southern Avalon was "growing seeds" - i.e. sowing and nurturing seedling plants - and they took pride and care in doing so because strong seedlings ensured the harvest. Certain women developed reputations for consistently producing good plants that were sought by others for their own gardens - a source of status in communities that lived so close to the margin.

Aside trom larger gardens, every family also tended a kitchen garden. The kitchen garden supported "a little bit of everything ${ }^{-42}$ - some root crops. cabbage. beets. peas. rhubarb, hops, black currants, yooseberries, strawberries, flowers. and plum and apple trees. Men helped to prepare the beds in the spring of the year. digging furrows while women set their seeds. Thereatter, however, the kitchen garden became a woman's preserve in terms of both responsibility and usage.

Haymaking. by contrast, involved the entire household. although the actual curing was in the women's care. When the long grass in meadows had grown to a foot or more. the men cut it with scythes and left it in swarthes overnight. The task of spreading and drying the hay then became the work of women, assisted by older children - not because it

backs: this dangerous and laborious employment the reporter has never seen performed by men" See Luddy. Documentary History, pp. 163-6, particularly p. 164. Doc. 47.2. First Report of the (ieneral Board of Health in the (itr of Dublin (Dublin. 1822). Munster Women and Farm Work c. 1818 . And in Cork, according to an 1836 report. * the young women assist the men in bringing the seaweed on their backs in baskets from the sea shore....' See Luddy. Documentary History, pp. 166-72. particularly p. 168. Doc 47.3 Report from His Majesty's Commissioners for Inquiring mo the Condition of the Poorer (lasses in Ireland. Appendix D HC 1836(43). xxxi.

42This wording was used by most informants 
was secondary, but because the men had to fish during the daytime, when drying occurred. The women turned it out, or spread the grass, in the morning, turned it again later in the day, and then pronged it into cocks and left it overnight. As with the process of drying fish. the piles were initially small when the grass was green to deter rot. but steadily increased with size The spreading and cocking process was repeated until the grass was sufficiently dry for storing in the family's stable loft. Hay from meadows near the stable was carried on the back. usually (although not always) by men, in hay-cloths made of brin bays. Hay from back meadows was transported on hav-frames (trellis-like structures drawn by horse and cart). Men and women (or in some families. one or the other) pronged the hay into stable lotts. where children compacted the dried grass by jumping into the piles and then stowed it as tightly as possible into every available nook and cranny to maximize storage

Overall. work routines in the gardens were generally dictated by expedience and availability. Men and women worked together in the spring and fall at planting and harvesting: but in the summer. when men spent most of the day fishing. women assumed the greater responsibility for the gardens. Physical strength determined to some extent the division of labour after families had become more established: but women also pertormed hard physical work, and were capable of taking over men's duties when needed.

Animal hushandry: Plebeian families on the southern Avalon kept a variety of livestock - sheep. chickens. cows. horses. pigs. and. to a lesser extent. goats - to meet 
household requirements of food and clothing. Of course. the number and type of animals varied with the affluence of the household, and some poorer households had none at all, but local networks of exchange (some butter traded for some eggs. for example. or some wool for some cabbage plants), third-party transactions through the merchant, or even a neighbour's charity could often compensate for a lack.

Again, the rota of duties associated with men and women meshed with other work rhythms. Men were responsible for the stabling and feeding of animals for the winter In the summer. horses were let out into meadows to graze, and cows, sheep, and goats ranged freely through the community. However. the family cow(s) had to be milked morning and night and therefore had to be rounded up every evening. and as the men were usually occupied with fishing at the critical period, it was women's responsibility to locate the animals, which had sometimes roamed over a mile away, and bring them home for milking betore joining their mentolk on the stages and flakes. Milking cows and goats was mostly done by women, regardless of the season, and the milk was used mainly for household purposes

The family's hens. housed near the stable and within close range of the house. were also primarily the responsibility of women throughout the year. Women fed them twice a day (usually household scraps or a mash of boiled vegetables) and gathered eggs each morning. Both women and men slaughtered chickens for the tamily table: but the preparation for eating - the plucking and cooking - was women's work. Shearing sheep 
was often a joint enterprise. In some families, the men spancelled ${ }^{43}$ and held the sheep while the women clipped their wool and marked them with the family's own distinguishing mark. In others, the process was reversed, with women holding the sheep while the men did the shearing. Some informants stated that the process was done wholly by women. Certainly, further processing of the wool was women's work (see below).

Irish women, then, were actively involved in animal husbandry and field work on the southern Avalon: indeed their intrinsic role in subsistence agriculture continued well into the $20^{\text {th }}$ century - unlike that of women in Ireland and Britain, who were increasingly marginalized from farm work (paid and subsistence) with the growth of capitalist agriculture ${ }^{4+}$ As with women's work in the fishery. there were no connotations of drudgery or lack of respectability attached to women's work in gardens and fields on the southern Avalon. This contrasts with mainiand colonial contexts, where there was considerable pressure to remove the wives and daughters of farming families from the fields into the home and replace their labour with that of indentured servants and slaves. In mainland colonies, white women's fieldwork was seen as aberrant - a sign of poverty

${ }^{13}$ Fettered or hobbled the animal with rope.

${ }^{4}$ See, for example: Bourke. Husbandry to Housewifery; Clark. Struggle tor the Breeches, Daly, "Women in the Irish Workforce", Fitzpatrick, "Modernisation". Mageean. "Irish Women's Prospects": Miller Doyle, and Kelleher. ".For love and liberty "... Nolan. Ourselves Alone; Rendall. Women in an Industrializing Society; Rhodes. Women and Post-Famine Ireland, K. D. M. Snell, "Agricultural seasonal unemployment. the standard of living. and women's work. 1690-1860." in Sharpe, ed. Women's Work. pp 73-120: and Valenze. First Industrial Woman. 
and inferiority (although often a necessary evil in newiy establishing areas). ${ }^{\text {ts }}$ The reverse was true within the plebeian community on the southern Avalon: there. servant girls were employed to release their mistresses from household tasks so that mistresses could contribute effectively to more important family enterprises. Indeed, a family's ability to hire servant giris and free the mistress for productive work was a sign of its increasing affluence, not its poverty, and most women did not aspire to escape outdoor work and immerse themselves in housewifery. Only middle-class women followed the mainland pattern of withdrawing into domesticity during the period: their aspirations to retire from productive work were not absorbed by the plebeian community

\section{\pm 1.3 Housewifery}

A key aspect of women's contribution to household production was the pertormance and management of routines necessary for the efficient maintenance of the household This involved a whole repertoire of tasks and skills, such as cooking. cleaning. sewing, spinning. knitting. the preservation of fruits and vegetables, and household repair Of course. housewifery was not as developed in the first years of settlement as later in the

${ }^{4}$ See. for example: Berkin. First Generations; Berkin and Horowitz, eds. Women's Voices; Brown. Good Wives, Vasty Wenches; Errington. Wives and Mothers: Light and Prentice, eds. Pioneer and Gentlewomen; Ryan. Womanhood in America: and LTrich, Good Wives 
study period. Houses were more rudimentary and had little furniture and few amenities ${ }^{\text {th }}$

Women initially delegated more of their time to outdoor efforts - working with the men to clear land and establish gardens in addition to performing their vital work in the fishery

The basic equipment tor maintaining the household was introduced over time, and

spinning wheels and butter churns were luxuries that came later. if at all (some women had

${ }^{\text {th }}$ The structure that likely provided the initial shelter for many new arrivals on the southern Avalon until a permanent home could be built was the tilt - a primitive. singleroomed hut built of vertical studs or logs and covered with bark or boughs, a form of shelter that had been traditionally employed by the migratory fishermen at Newfoundland. The more permanent housing style built by the Irish in Newfoundland was the one-and-ahalf storey hip - a local variant of housing styles found in both the West Country and southeast Ireland. The house was a small wooden structure (often about $16^{\prime}$ by $24^{\circ}$. although one surviving example in the study area measures only $13^{\prime}$ by $20^{\prime}$ ) with kitchen and parlour (locally, known simply as the room ) on the first floor. two bedrooms upstairs. and a central hearth and stairway. Many also had a back kitchen or 'linhay' serving as a pantry at the back, either with a flat roof or a roofline that extended down from the main roof ('saitbox'). There were some variations: a three-room version, with a kitchen. parlour, and bedroom on the first floor: and a full two-storey variant. The walkin hearth or settle fireplace (with a bench at either side of the hearth) was common. So too was the smaller, open fireplace with a fire set on dog irons in the hearth. These central tireplaces were used for both cooking and heating throughout the study period: after 1860. the wood stove began to replace the fireplace for cooking purposes. By the end of the study period, a housing form similar to the Cape Cod was developing. with two storevs and four (rather than two) bedrooms to accommodate increasing families suggesting a growing expectation of privacy See: Gerald L. Pocius. "English Styles and Irish Adaptations: The Emergence of Newtoundland House Forms on the Southern Shore" (Paper presented to a joint meeting of the lrish Newfoundland Society and the Newfoundland Historical Society, January 29, 1981 ); Pocius, "Architecture on Newfoundland's Southern Shore: Diversity and the Emergence of New World Forms." Society for the Study of Architecture in Canada Bulletin, 8:2 (June. 1983), 12-9; Pocius. A Place to Belong, Chapter 6: Shane O'Dea. "Simplicity and Survival: Vernacular Response in Newfoundland Architecture," Society for the Study of Architecture in Canada Bulletin, 8:2 (June. 1983), 4-11: and Mannion. Irish Settlements. 
to rely on others to spin their wool for them, and many were still churning butter by hand well into the $20^{\text {th }}$ century). But eventually, as families became more established. household routines included more of the duties associated with traditional housewifery. As houses expanded to meet growing family requirements and as nonessentials (e.g. individual dishes and bedsteads. decorative furnishings) increased. women's household duties expanded proportionately.

Still. women had to maintain a balance between productive work and housework. and the former took priority. In Britain, as women increasingly retired from productive work into unpaid housework, the association of household cleanliness with working-class respectability increased. Jane Rendall, tor example. evokes a vivid image of working-class women being constantly joined in battle against pollution and dirt. maintaining new standards of respectability by whitening doorsteps and black-leading grates; this portrayal is echoed in other writings on the British Isles ${ }^{+7}$ While similar standards of cleanliness were certainly maintained by women on the southern Avalon by the 20 th century, it is unlikely that they were possible (or even aspired to) in the earlier days of settlement, although some movement in this direction? may have occurred towards the end of the study

${ }^{47}$ Rendall. Women in an industrializing Society. p. 88-90. See also. for example: Bourke. Husbandry to Housewifery, Dot Jones. "Counting the Cost of Coal: Women's Lives in the Rhondda. 1881-1911." in Angela V. John. ed.. Our Mothers' Land: Chapters in Welsh Women's History, 1830-1939 (Cardiff: University of Wales Press, 1991). pp. 109-33: Elizabeth Roberts, A Woman's Place An Oral History of Working-Class Women, 1890-1940 (Oxford: Basil Blackwell Publisher Limited. 1984): and Ellen Ross. Love and Toil: Motherhood in Outcast London: 1870-1918 (New York; Oxford: Oxford University Press. 1993). 
period. More at the core of housewifery during the period were the techniques necessary for the processing of raw materials (either produced by the family or purchased from the merchant) into usable goods for the household. With this repertoire of skills and activities. women fed. clothed. and generally sustained the family work unit.

Most of the family's agricultural output was readied for household use by women. After milking the cows. for example, women prepared the milk for family consumption. The milk was strained into pans and placed in the pantry to 'set' (let the cream rise), then it was placed on a hot stove to scald and the cream was skimmed off the top. A small amount of "scald cream" was occasionally set aside for eating as a special treat. The skimmed milk was then cooled in the pantry and used as required for drinking or baking. while the cream was churned (often by hand) into fresh butter for the familv table. a product deemed tar superior to the imported product available from the merchant. Buttermilk, a by-product of the churning process, was used in baking.

Similarly, after sheep were shorn, women took over processing of the wool drawing on an expertise developed in the domestic woollen industry of the home country They washed. picked. and carded the tleece. spun the wool and wound it into hanks. then washed and dried it. Through the fall and winter, they knit the wool into a myriad of functional wear for their families - an assorment of durable vests. mittens. sweaters. 
buskins, ${ }^{.14}$ socks, stockings, vamps, ${ }^{.49}$ caps, scarves, palms, ${ }^{.50}$ and winter petticoats. Any family clothing that was not knit was sewn by women, who turned out a full complement of under- and outer-wear for family members - summer drawers and petticoats. skirts. dresses. blouses. shirts. pants. jackets and coats - sometimes using fabrics purchased from the merchant, or more often, recvcling older clothing or cotton sacks that had been boiled in lye soap to remove any markings and then dyed. Women also made all manner of bedding - from quilts. sheets, and pillowcases to mattresses. cushions. and pillows. In addition. they sewed items necessary for outdoor productive work - e. g.. oil skins. 'oil petticoats' (aprons for fish processing), bonnets, and sails tor the fishery: and hay-cloths from brin bags for carrying loads of hay from the meadows And they hooked mats in the winter, transforming piles of coloured rags into patterned rugs (some basic. some quite intricate) by pulling them with a mat hook through a burlap backing stretched across an adjustable rectangular wooden frame.

While gardens provided much of the fresh produce for the family table. women also foraged through woods. meadows. and bogs for other plants for dietary and medicinal purposes. Berry-picking sometimes became a family excursion, but it was most regularly done by women and children. Women made jams and jellies (and, occasionally. wines)

${ }^{18}$ Leggings that kept snow out of boots.

${ }^{19}$ Short socks covering only the foot and ankle.

${ }^{\text {sin }}$ Mittens without fingers, to protect the palm when splitting fish or hauling ropes. 
from a wide variety of local plants - marshberries, cranberries, bakeapples or cloudberries. blueberries, partridgeberries, and rhubarb. They made beer trom spruce boughs. juniper bark, or hops trom their kitchen gardens. The versatile hop was also mixed with molasses to make 'barm' for raising bread. Women collected plants as well for their stock of home remedies: dogwood and cherry branches for cough medicine; wormwood to cure hoarseness, bog vein for tonic; juniper bark for tonic and tea. And while Irish women were accustomed to the role of family healers, their repertoire of cures and ointments had to be adjusted after migration to compensate for the lack of some traditional ingredients with the careful addition of unfamiliar flora of the southern Avalon.

In addition, women collected tirewood - a tamiliar routine for Irish women. who were used to carrying heavy sacks of peat on their backs. sometimes over long distances. in the home country. "Women on the southern Avalon did their gleaning especially in the summer and autumn . Men did more substantial cutting of wood during the winter. bringing their loads home by horse and cart. piling the long poles into 'wharves of wood" until they could be chopped into 'junks' (billets) in the woodvard; but in the summer and early fall. it was women who foraged in the woods for windfall branches. returning home with brin bags full of brambles and loads of "bresneys ${ }^{-52}$ and 'blasty' boughs ${ }^{53}$ on their

"Nolan, Qurselves Alone, p. 50

"Dried branches and twigs.

${ }^{53}$ Fallen branches from coniferous trees whose needles had turned red. or blasty." 
backs so large that "you just could see their feet coming along the road " $\$ 4$ These branches were used to make fast, hot fires in the summer for baking or meal preparation. And throughout the summer, women went to the woodyard to gather loads of "chips ${ }^{\text {"ss }}$ in their aprons to light quick fires for small cooking jobs - baking buns, for example. or trying fish

Women were also primarily responsible for drawing water tor family use, although this task was sometimes passed over to children as they got older. Water for washing tloors and clothing was often taken from nearby ponds or streams, but drinking water preferably came trom wells which were usually uphill and often a quarter to a half mile away trom the house. Wells were usually quite deep, and the water was drawn by lowering and raising a bucket on a string or a 'gaff. ${ }^{.49}$ When water had to be transported over a long distance, women carried buckets with the assistance of a hoop trom a puncheon tub This miracle of engineering simplicity was not attached to the woman in any way. After filling her buckets. the woman laid them on the ground on either side of her. draping the handles outward: she then laid the hoop on top of the buckets. pulling the handles back towards herself as she lifted them. so that the counter-pressure helped to keep the buckets away from her legs and balance the load. Still. this was hard physical

\footnotetext{
${ }^{4}$ MOB. Interview July 22. 1999

"Small pieces of wood, remnants from chopping junks

th $A$ long wooden pole with a hook on one end.
} 
labour, requiring several trips and involving loads of up to five or six gallons. Wash days were particularly demanding, as tubfuls of water had to be transported and boiled up on the stove before soiled washing was added. together with the soap that the women had made from 'fatpork' (suet) and wood ashes from the grate (later in the period, lye could be purchased tor the soap-making process, and soap, itself, was sometimes purchased trom local merchants). On a tine summer's day, however, women often took their washing directly to pond-and river-sides and did their scrubbing on the rocks

Women did most of the baking and cooking for their families - transforming provisions from the merchant's store and their home-produced fruits, vegetables, milk. eggs. saltfish. and (occasionally) fresh fish and meat into a reasonably varied and nutritious diet for the household. In the days of early settlement. meal preparation was done on an open fireplace - a time-consuming task requiring large amounts of firewood and trequent trips to the woodpile as women stoked the fires in central hearths and did their cooking 'on the dog irons. There was one general exception to this assignment of cooking duties to women, when men were tishing, they cooked a meal of stewed fish and potatoes for themselves in a sawed-off puncheon tub insulated with clay and rocks, but it was common for women to prepare the men's 'grub-boxes.' which contained all the items, other than fish. that the men would require for their 'mug-up ${ }^{4-7}$ on the boat - such as tea. molasses. bread. and perhaps a piece of gingerbread. All other meals and mug-ups were women's

-A cup or mug of tea and a snack between meals. usually taken as a respite from work (the equivalent of the modern-day coffee-break) or before retiring for the night. 
responsibility, as was the family's baking - the endless production of raisin buns, frozies. ${ }^{-5 x}$ pies, gingerbreads, bottomers. ${ }^{49}$ and several batches of bread per week (indeed, some women with large families baked bread daily)

Women also had to turn their hands to home repair. While houses, outbuildings. and fences were generally constructed by men (although, again, the initial building of structures was sometimes shared by the sexes in the very first years of settlement), women were very much involved in their maintenance and were expected to be able to lime a house. replace fence pickets. or tar a roof along with the men in the tamily - or more often without them during the tishing season.

In terms of household production, then, women within the Irish plebeian community of the southern Avalon worked indoors and outdoors. through long days in all seasons of the year to sustain their households. And the continuous roster of production and household duties had to be juggled around the requirements of child care and elderly care. which usually fell clearly within the province of women's work.

\section{$\pm 1+$ Wrecking and salvaging}

One household enterprise that was more common on parts of the southern Avalon

\footnotetext{
${ }^{5 x}$ Flat cakes containing 'tat pork' (salt-cured fat from a pig) instead of butter. mixed with eggs. flour. spices. and molasses

${ }^{49}$ Plain flat cakes made with buttermilk, eggs, and flour.
} 
than many other areas of Newfoundland was the salvaging and recycling of items from wrecked vessels. While this type of activity is not usually found in discussions of traditional household production in Newfoundland, it was part of the repertoire of economic coping strategies in the study area and therefore deserves mention in an examination of how families survived in the years of early settlement. The greater incidence of this activity in the study area was not due to the transfer of a wrecking tradition from southeast Ireland, but to the geographical position of the shore - a long and treacherous finger of coast line abutting much-travelled shipping lanes between Europe and North America. According to Frank Galgay and Michael McCarthy, the southern Avalon has been the site of numerous shipwrecks over the centuries due to impenetrable touss, shifting currents, ice movements, and sudden storms, indeed. mariners have labelled the southernmost point of the shore. the area around Cape Race. "the graveyard of the Atlantic ${ }^{-\infty+10}$

There is no doubt that people on the southern Avalon benetitted in varying degrees from many of these shipping disasters, although it is important to differentiate between levels of participation in wrecking and salving activities. There were probably very few incidents of actual, deliberate wrecking of vessels. The oral tradition does ascribe this more sinister activity to certain tamilies in particular areas (usually the more southerly

NFrank Galgay and Michael McCarthy, Shipwrecks of Newfoundland and Labrador, vol. I (St John s: Harry Cuff Publications. 1987), p. 1. Various wrecks in the area are described throughout this volume, as well as in vols. 2, 3, and 4 ( St John's: Creative Publishers. 1990. 1995, and 1997). 
portion of the shore. including Renews. Cappahayden. Trepassey. St. Shott's. and Pornugal Cove South). Some people in these areas, for example. are said to have tied lanterns on the horns of cows on stormy rights to lure unsuspecting vesseis onto the rocks. One particularly ruthless man of an especially notorious family of wreckers is claimed to have bitten the finger off a dead man's hand to obtain a ring that stubbornly clung to the swollen finger of the corpse. Entire families were said to have been involved in these activities. although oral informants were unable to specify the particular role that women may have played. For the most part, however. informants asserted that most people would not have participated in deliberate wrecking activities. Certainly, none of these tales appeared in written documents of the day

Over-zealousness in salvaging items trom a wreck was the more common complaint against the people of the study area in official correspondence during the time trame. Governors' files, court records, and newspapers of the period contain various complaints against local inhabitants for maltreating shipwrecked crews and passengers and stealing items. or at least precipitously removing them. from vessels that had not been fulls abandoned. ${ }^{\text {th }}$ But it should also be noted that while local inhabitants were usually anxious

${ }^{n 1}$ For example: The murder of the crew of a vessel wrecked off St. Peters and theft of items belonging to the vessel was the subject of various letters. depositions, and orders in P.ANL. GN 2/1/A. 3/57-9 and 80-86/1759. September - October. 1759 In 1777. the people of St. Mary's were accused of doing nothing to help the survivors of a shipwreck in their harbour and of stealing items from the doomed French vessel. Governor Montague observed that "every part of the Conduct of the People at and about $S^{\prime}$ Maries concerned in this transaction appears to me the most inhuman and Barbarous proceedings I ever heard of in a Christian Country..." See PANL. GN 2/1/A. 6-reverse 
end/134-8/1777 and 7-reverse end/3-4/1777. In 1782. Capt. Lane of HM/S St. Johms complained that a large portion of a cargo that had been saved by him and his men from a vessel wrecked at Ferryland had been illegally carried away by local inhabitants. See PA.VL. GN 2/1/A 9/363-4/1782. Governor John Campbell to Capt. Lane of HMS St. Johms, October 14, 1782. In 1816, a Notice respecting the loss of HM/S ('omus off St. Shott's was posted in the district of Trepassev, requiring "Persons saving any of the Materials to give information thereof to $\mathbf{M}^{t}$ Jackson of Trepassey when they would be entitled to one third of the Value thereof as Salvage \& cautioning persons against concealing any of the said Stores etc." See PANL. GN 2/1/A, 27/308/1816, Notice. November 16,1816. Obviously, two Trepassey men chose to ignore the order, for the Court of Sessions offered a reward for their capture or information leading to their capture for stealing the sails and rigging from the disabled vessel See PANL. Mildred Howard Collection, vol. 1, citing Royal Gazette, November 26, 1816 In 1817, the Roval Gazette reported that when the brig (jursborough entered Bay Bulls harbour in distress, it was met by a "riotous and tumultuous assembling of people. with apparent intent to plunder" the provisions on board. See P.ANL. Mildred Howard Collection. vol 1. citing Roval Gazette, March 11. 1817 A report bu the magistrates on the event noted: "The Inhabitants of the district of Bay of Bulls being destitute of supplies and their Merchants having none of the necessaries of Life in their Stores, met and sent Messengers to the Owners of the Cargo to request part of it might be delivered to them, at the same time threatening to break open the Hatches of the Vessel and take it by force if their demand should not be complied with " See PANL. GN 2/1/A. 28/309-15/1818 and 29/297. 300/1818. correspondence and case summary. April and c December. 1818 That same year, John Haves of Ferryland district was sentenced to 39 lashes tor assaulting a constable who tried to prevent him and others from removing goods from the wrecked vessel Raptd. See PANL, GN 5/I/C/1, ff 13-4. King L: John Haves, Vovember 8, 1817 In April. 1830. complaints were made about certain inhabitants of Witless Bay who plundered two vessels wrecked near the harbour. See Mannion Name Files. Witless Bay "Carew. Al". "Mullowney. Thomas and Patrick". "Nash, W. M.". "Norris. James". and "Power. Matthew." In 1831. a notice was posted in a local newspaper directing those persons who had recently engaged in the "most barbarous and outrageous plunder of the property of the crew" of the brig William \& Amm. wrecked south of Renews, to relinquish the goods or face prosecution. See PANL, Mildred Howard Collection, vol. 1. citing Roval Gazette, December 17, 1831. In 1836. Robert Carter, magistrate at Ferryland. attended at a wreck site in Toad's Cove, where a West Indian vessel laden with molasses had been dismantled and relieved of its cargo. See P.ANL. MG 920. Robert Carter Diary. January 5.1836. In 1844, a local newspaper reported that when the brig William went ashore in a thick fog in St. Mary's Bay and lay stranded on Point La Haye Beach. "the inhabitants of the neighbourhood plundered the vessel of everything they could lay their 
to obtain their share of salvage, they were also, on a number of occasions, commended for their bravery in rescuing crews and passengers from distressed vessels and for their generosity in housing, clothing. and feeding them and attending to their injuries. ${ }^{12}$

But humanitarian sensibilities aside, the wrecked property from a vessel was seen as a windfall. and boats often came from communities all around the site to reap the rewards. Of course, salvage operations after a vessel had been abandoned bv its captain and crew or had otherwise become derelict were a common and legal means of obtaining property and/or extra income in maritime communities. Generally. local salvors were

hands on." See PANL. Mildred Howard Collection, vol. I, citing Roval Gazette, July 9. 1844 In 1845, various parties at Ferruland were charged with plundering a wrecked vessel. See PANL. GN 5/4/C/1. Box 2, n.f. Regma v: William Williams, John. Dullann: amd John Reed. June 1.2. and 10.1845 In 1850, two men from Chance Cove were accused of taking provisions (beef, butter, porter. sugar, chocolate, oatmeal) and shingles from the lost schooner. Matilda. See PANL. GN 5/4/C/1. Box 2. 1848-66 file, n.t. Complaint of Donald Henry Green. Master of the Matilda of Halifax. January 5,1850 In [853, several men at Renews were charged with cutting the masts of the stranded vessel Hugh and removing its cargo. See $\mathrm{GN} 5 / 4 / \mathrm{C} / 1$, Box 2. n.f. Regina v. William . Neal. Francis (jearin and Martain MF' arthy. December 3. 1853. In 1857, the captain of the Spanish barque La Plata accused the people of Trepassey of cutting the vessel's masts and stealing its cargo after the captain had deliberately run it ashore on the beach to ride out a storm. See Galgay and McCarthy. Shipwrecks, vol. 4. Chapter 4. pp. 31-42.

"Galgay and McCarthy provide several examples from the area in Shipwrecks. vols 1-t See also P.ANL. GN 2/1/A. 27/304-9/1816, respecting the billeting of survivors of the wrecked vessels (omus and Harpoomer by residents of Trepassey The oral tradition also notes that local inhabitants often endangered themselves to save crews and passengers from foundering vessels and did their best to provide comfort and hospitality to those in distress. although clearly, this was not always the case, as the previous footnote attests. 
awarded from one-third to one-half the value of recovered property. ${ }^{03}$ There was considerable discrepancy, however, between legal definitions of salvage and what local inhabitants perceived to be their entitlement. Indeed, the government's introduction in 1860 of a system of wreck commissioners was deeply resented by most people on the southern Avalon. The legislation called tor the appointment of commissioners in every electoral district to attend at the site of wrecks and oversee the salvage and distribution of wrecked property as expeditiously as possible. The statute also established various fines and penalties for taking property from a wreck and failing to report it. and gave the wreck commissioners "full power to suppress all tumults and disturbances" at the site ${ }^{\text {ch }}$ Clearly. then, the legislators were anticipating open hostility and resistance to the measure.

Certainly, within the plebeian community on the southern Avalon. the system was perceived as a scheme for taking a source of income trom "the poor starving people" and hoarding all the spoils for the government. Hence. there was a tendency to anticipate the arrival of the wreck commissioner with a pre-emptive local salvage effort, for "what the people could steal is what they'd get."

${ }^{43}$ This was customary practice according to Harry Newson. The Law of Salvage, Towage, and Pilotage (London: William Clowes and Sons. 1886), p. 71, and matches the impression from various local court cases.

${ }^{\text {HS }}$ Statutes of Newfoundland. 23 tict. ( ap. 5. An Act to Provide for the Prolectlon of Propery Wrecked on the ('oast of Newfoundland, passed May 14. 1860

${ }^{\text {ns} Q u o t a t i o n ~ f r o m ~ T P . ~ I n t e r v i e w ~ J u l y ~ 19 . ~ 1999: ~ s i m i l a r ~ t h o u g h t s ~ w e r e ~ e x p r e s s e d ~ b y ~}$ WC and HOB 
It is difficult to assess women's involvement in salvage activities. While it was unlikely that they actually took to boats to reach foundering vessels, there are suggestions that women attended at wrecks that had come ashore and that they combed the beaches for articles washed in by the tide ${ }^{x_{2}}$ In several of the episodes cited in footnote 60 . above. tor example, gender-inclusive language was used in registering complaints of local plundering - against, for example: "the Conduct of the People at and about S' Maries" in 1777, the "local imhabitams" of Ferryland in 1782: the starving "inhabiatans" and "riotous and tumultuous assembling of people" in Bay Bulls in 1817. and "the mhahitamts of the [Point La Have] neighbourhood" in 1844. Similarly, in the court cases that followed the wreck of the Spanish barque La Plata at Trepassev, the ship's captain discussed ensuing events in gender-neutral terms, referring constantly to the "people" on the beach who. he claimed. disabled and pilfered the vessel. and specifically. he referred to at least two women among the mob - the wife of local magistrate George Simms and another woman who took the captain and crew to their homes for food and dry clothing ${ }^{\circ "}$

${ }^{*}$ Articles washed ashore on the beach clearly tell under the jurisdiction of the 1860 legislation that governed salving activities. Wrecked property was defined in section XX11 as "all wrecks of the sea. or any goods or chattels. jetsam, flotsam, lagan, or derelict. or any boat, vessel, apparel, anchor. cable, tackle, stores, or materials, or any goods. merchandize. or other article or thing .. found floating. or sunk at sea. or elsewhere. in any tideway. shore. or coast of this Island. or cast. thrown. or stranded upon the shore or coast thereof; and whether the same be found above or below high water mark, and whether wholly in water or partly on land. or partly in the water." Thus. beach-combing activities performed by women did qualify as salvage operations.

${ }^{67}$ Galgay and McCarthy. Shipwrecks, vol. 4. Chapter 4, particularly pp. 36-7. 
As E. P. Thompson has argued, there is a tendency among historians. particularly since the late $19^{\text {th }}$ century onwards, to interpret collective nouns such as 'people," crowd,' 'mob, or 'inhabitants' as 'men " - thus colouring more neutral, contemporary reports with latterday assumptions. Especially if the ringleaders or arrestees in such incidents were male. historians have tended to gender the entire crowd male. But compelling evidence of women's central involvement in communal actions - most notably food riots but also other forms of controntations involving property and work - challenge historians of earlier periods to rethink collectivities in terms of participation of not just men, but also women and older children. ${ }^{n x}$

Several oral informants certainly acknowledged that women were involved in this level of salvaging activity, suggesting that it was more common in 'the old days' than within their own lifetimes. One story of a specitic incident in the earlier $20^{\text {th }}$ centurv. although outside the study period, illustrates by next-best approximation what was fikely a long-standing tradition. In the wake of a wreck at Caplin Bay, case-loads of ketchup, or "catsup' as it was labelled, were washed up on the beach. This was a somewhat exotic item by local standards; indeed, inhabitants were not always sure of the purpose of the articles that washed ashore after wrecks (in another instance, for example, macaroni noodles were mistaken for tapers for lighting candles), but they gamely took the items home and tound some use for them. So the catsup was a rare item, but a valued prize 36.

${ }^{68}$ E. P. Thompson. Customs in Common (London: Merlin Press. 1991), pp. $305-$ 
nonetheless. Two local fishermen had found a cache of the cases and were apportioning the catsup between them, when Mrs. Mary Margaret S---- , "a very determined woman," came marching over the beach to fight for her share of it. One of the fishermen, a mildmannered man named Mr. Jim P...., immediately relinquished his portion to her, saying: "I wouldn't have Mrs. Mary Margaret S--- on my back for all the "cat soup in the world ".t" As this anecdote helps to illustrate, salvaging wrecked property from the coast was something that fell within the accepted range of women's work.

And oral informants all agreed that whether or not women were directly involved in salvaging efforts, they had no moral dilemmas about using any items brought home trom a wreck but were ruled by the pragmatism of giving some small extra comfort to their tamilies. Recovered foodstuff's were particularly valued as a means of stretching provisions or varying the diet. " Furniture, shelves, deck planks. canvas, and doors provided welcome additions to household furmishings. Such items were seen as part of the bounty of the sea. a gift that it would be a $\sin ^{*}$ to waste. One informant advised that wrecks were "better than the tall of the year [when tamilies 'settled up' with their

\footnotetext{
"Related by AS. Interview July 21. 1999. with the request that the parties" names remain anonymous

OIder informants reminisced happily. for example. about the bounty from the 'pork wreck' of 1918 - the wreck of a Belgian relief vessel that carried large quantities of food stuffs. including (obviously) salt pork - as well as the cases of raspberry and strawberry jam that washed ashore from the Torhamian in 1926.
} 
merchant and obtained new supplies for the winter $]^{* 71}$ - and virtually everything that was removed from vessels or washed up on the shore found a use. Indeed, most homes visited during the oral history research for this thesis contained at least one item, and sometimes several. from wrecked vessels - some of which had been in the families for generations. others that had arrived as recently as the 1940 s. The salvaging of items from wrecks. then. was one of numerous economic coping strategies in plebeian households, and one in which women played roles as both salvors and consumers as they worked to make economic ends meet for their families."

\section{\pm 15 Sexual division of labour within househoids}

Along the southern Avalon. most tamily members lexcepting the very young and old or the sick) were expected to contribute to household production. and both men and women worked long hours, often at difficuit tasks that involved physical exertion. skill. and experience. But there was a gendered division of labour. although traditional

\footnotetext{
${ }^{\top}$ WC. Interview July 21, 1999
}

"One final aspect of women's participation in this activity can be noted, although it does not relate directly to women's work. The oral tradition holds that children (particularly those in the area from Renews to St. Shott's) ended their prayers every. evening with the request, "Please God. send us a wreck before morning." A utilitarian attitude towards events that would be judged by modern-day standards as tragic was thus instilled early in life Many oral informants saw this as a particularly female influence on younger generations, for "It was women who taught children their prayers." (Several intormants - AS. ATE. GK. WC - used this exact phrasing.) 
dichotomies for conceptualizing work delegated by sex - such as skilled/unskilled, primary/secondary. or indoor/outdoor work - are not useful in differentiating men's and women's tasks in the study area ${ }^{3}$ Indeed, there was a high degree of flexibility in the allocation of work routines.

Still, some duties were more clearly delegated along sex lines than others. It was very unusual for women to actually fish in the ocean. ${ }^{4}$ for example. although they did fish in fresh water for trout. But women's reproductive role together with the degree of physical strength required to row out into the North Atlantic and pull handlines or seines filled with cod steered women landward and prescribed fishing activity to the men in the family unit. Still, there was no traditional belief on the southern Avalon that women in boats were an "aberration "or that they caused bad luck." the universal explanation from oral informants for women's nonparticipation in actual tishing was that they already had

-Marilyn Porter has proposed that a spatial separation of work routines and spheres of authority existed in tishing families with the dividing line at the foreshore. This works effectively in terms of conceptualizing the fishery. but not other areas of productive work. See Porter. "Skipper of the Shore Crew"

${ }^{-1} I$ have found no evidence in the written record of women fishing for cod during the study period. There is living in Calvert today, however. a woman who, from her middle vears to retirement. joined her husband in handlining for cod, having raised a family of fifteen children and worked in the family saw mill through her married life. Another. vounger Calven woman (formerly of Cape Broyle) is currently fishing for crab with her husband.

"Compare this with the perception of women as "pollutants 'on the water"' and "jinkers [jinxes]" in an English-Newfoundland community on the northeast coast of the island described by James C. Faris in Cat Harbour: A Newfoundland fishing settlement (St. John's: ISER 1972), p. 73 
"enough" or "too much" to do on the land. Certainly, women were not excluded because of a lack of capacity to cope with essential work; indeed, their involvement in shore work and in other productive efforts demonstrated quite the opposite. Furthermore, even physical strength was not a clear demarcator. for certainly. much of the work performed by women required a good deal of physical exertion.

Just as it was uncommon for a woman's hand to guide a fishing boat. so it was unusual for a man's hand to rock the cradle. Women generally assumed the responsibility tor childcare. but this was not because of notions of a 'gentler' sex and greater maternal love - cultural tacets of motherhood that were gaining prominence among the middle class but had not made inroads into plebeian culture on the southern Avalon in the time period, ${ }^{\text {h }}$ Indeed, $18^{\text {th }}$ - and early $19^{\text {th }}$-century observers in Ireland noted that parents of both sexes were very tond of their children - a genuine affection that was not just rooted in the need for large tamily work units and security for their old age. ${ }^{-}$Rather. Irish plebeian women's greater role in child care was prompted by women's reproductive role and life

"-Ellen Ross provides a good discussion of the deification of motherhood. with all its cultural aspects - i.e., the definitions and values, the extra social and emotional requirements attached to the construct - in the introduction of Love and Toil. Jane Rendall also discusses the idealization of motherhood and the pressures placed on working-class mothers by middle-class reformers in $19^{\text {th }}$-century Britain in Women in an Industrializing Society. Errington notes the gap between the middle-class ideal of motherhood and the reality of many farm women's lives in Upper Canada in Wives and Mothers. Ryan also dismisses the link between biological motherhood and an instinctive emotional bond between mother and child in Womanhood and. America.

Connell. Population of Ireland. 
cycle and reinforced by a division of labour that sent men out on the water daily in the summer. Still, women did employ alternative methods of child care when possible - a servant girl or older daughter. an elderiy mother or aunt, even, on occasion, a sawed-off puncheon on the stage head or flake - in order to free themselves for productive work. So the responsibility tor child care did not relegate plebeian women to the domestic hearth.

Indeed, in many work assignments, there was much blurring of the boundaries. Heading and splitting fish was generally considered men s work. for example. but some women did it on a regular basis. Some women performed heavier physical labour in fields and gardens. such as digging and trenching. that was normally associated with men And in those families in which men were involved in a fall fishery, the harvesting of crops had to be managed by women (with the assistance of hired servants. if sufficiently affluent) There were also sub-layers of involvement in work routines, such that while cenain work was designated as men's or women's. the other sex also participated in some capacity Trenching potatoes was men's work. tor example, but many women were involved in the process - laving the seed potatoes and covering them over with sod. Then there were the variations in scheduling of the same work. While both men and women worked in gardens and tields, for example, it was logical for women to assume greater responsibility for this work during the summer months because they were not out on the water. Similarly, the care of the tamily cow was the men's responsibility in the winter. and women's during the summer Cutting firewood was men's work in the winter; but in the summer, it was women who scoured the woods for dried alder branches and blasty boughs for cooking. 
The work rota had a certain internal logic and rhythm that delegated tasks as much on the basis of availability and expedience as on gendered notions of ability or strength.

Work roles were also quite tluid. as men and women occasionally crossed over boundaries on an 'as needs' basis. Men might do household chores in the winter, for example, when their wives were busy at more specialized tasks such as spinning or knitting. women might split and head fish at the peak of the season when there were insufficient hands on the stage. When women did 'men's work' or men did 'women's work' on a temporary basis, they were perceived to be 'helping.' A man might 'help' his wite scrubbing tloors, for example; or a woman might 'help' her husband splitting tish. men might 'help' women drying the hav if it was a poor day for fishing; women might 'help' men tarring a roof. Women more often assumed men's duties than the reverse. however: and in cases of men's absence (e g. at the bank fishery or. less commonly. the seal tisherv), women were responsible tor the entire management of all family work at home. While women colonists in New England and Lpper Canada were generally perceived by their communities as 'helpmeets' to their husbands. ${ }^{-1}$ the Irish plebeian community on the southern Avalon did not make this clear-cut distinction. but assigned the status of 'helper' to either sex within specific work contexts. based on a sexual division of labour that designated essential tasks to both men and women. Indeed. there was no perception during the study period or beyond of women's

\footnotetext{
Chapter 2.

${ }^{-7}$ See. Berkin. First Generations, p. 28: Errington. Wives and Mothers, p. 26 and
} 
work in household production (whether reproductive or productive) as secondary. The sentiment expressed by Murray's intormants - that "the woman was more than 50 percent" - could equally be applied to the evaluation of women's contribution on the southern Avalon. As one local informant stated and many others implied: "Women did it all. ${ }^{-9}$ Nor was there any stigma attached to women's productive work within the plebeian community throughout the study period: indeed. there was no perception of a gender divide between productive and reproductive work as work routines intermeshed and were shared by both sexes. Nor was a woman who did men's tasks seen as aberrant. Quite the reverse was true a woman who could juggle all her own routines and step in and do a man's work when necessary was well esteemed. Marriages were seen as economic partnerships in which both sexes held equal shares and carried equal risks. Work routines were roughly delegated by sex, but they were tlexible. Within this schema. women were seen as essential contributors in a collective enterprise and their efforts were highly valued. In essence. a woman's versatility and capacity for hard work were an integral part of the way womanhood was defined - by the women themselves and by the larger community "il

$" \mathrm{AY}$. Interview September 10. 1999

"In her examination of Vila Chã. Sally Cole similarly discusses how women's productive work was linked to self-definition within the fishing community (pescaclores): women proudly identified themselves as trabalhadeiras ('hard-working women ): and men sought trahalhacleiras as marriage partners. This attitude was not shared. however. by the agricultural community (lanradores), where women's productive work was stigmatized. See Cole. Women of the Praia: Work and Lives in a Portuguese Coastal Community (Princeton: Princeton University Press, 1991), especially pp. 40-6 and 80-1. Southern Avalon attitudes also contrasted with those in Upper Canadian farms of the 


\subsection{Women in paid work, the hospitality trade, and proto-professions}

While almost every adult plebeian woman (barring ill health) contributed to household production on the southern Avalon, a smaller but still significant number also pertormed paid work, operated businesses in the hospitality trade, or worked in protoprofessional occupations such as community healing and teaching. This facet of women's work has received only passing reference in the literature on early settlement in Newfoundland - usually only a sentence or two in descriptions of women's work. But for the women involved, it was an important means of earning cash or additional credit to support themselves or contribute to tamily economies

\section{\pm 2.1 Service}

Service was the most common paid work for women during the study period. Originally. young women were shipped particularly from Ireland by the latter $18^{\text {th }}$ century, to work as servants for planters and merchants along the study area. The case of Elizaheth (ullen $v$. James Shortall (see Chapter 3 ) and various other court cases through the study period (see Chapter 6 ) illustrate that the contracts by which these women were

period. where, according to Errington. women's unpaid work was essential to family economies, but often not recognized or acknowledged by male tamily members or the broader society See Errington. Wives and Mothers, p. 86 
hired. whether oral or written, were perceived to be binding, and negotiated terms had to be honoured by both employer and employee alike

Fishing senvice: While most discussions of women servants in Newtoundland during the period assume that they were in domestic service, there is evidence that women were hired by local merchants and planters as fishing servants to process fish on shore. In the fall of 1797. for example. Anstice Dwyer of Brigus South sued Cornelius Kelly for her outstanding wages. Kelly was the agent for Irish merchants George and Thomas Kough. and had received the "entire voyage"st of Anstice's emplover. John Sloan, before her wages had been paid. Anstice produced a shipping paper she had entered into with Sloan - a written agreement by which she had contracted to perform the duties of heading. curing. and drving tish as well as cooking for Sloan's shore crew for wages of £9. Kelly was ordered by the court to pay Anstice $\varepsilon+10.0$, being the balance she had not yet received $^{\mathrm{x}=}$ At the seduction trial of James $\mathrm{H}$. Carter of Ferryland in 1827, testimony revealed that he had hired his alleged victim. Ellen Delahunty, to cut 'sounds ${ }^{-x 3}$ with his

\footnotetext{
"This term applies to all the fish and/or oil taken and processed by the boat-owner in a tishing season.

"Mannion Name File, Brigus South. "Dwyer. Anstice," re: Anstice Dwier 1: Cornetius Kelly: October 27. 1797

${ }^{83}$ The 'sound' was the air-bladder that ran along the inside of the backbone of the cod fish and controlled its buoyancy. It was removed during the splitting process. salted. and eaten as a local delicacy
} 
shore crew. ${ }^{x 3}$ In the fall of 1848 , Ellen Leary of Ferryland sued John Butler for \&2.10.0 Newtoundland Currency [Cy.] in payment for curing 50 quintals of tish that summer ${ }^{\text {st }}$ And various other employment disputes involving female fishing servants appear in the court records of the period (see Chapter 6). There are other references to women's fishing service. In the July 13 entry of his diary in 184 I, for example. Rober Caner commented on the abundance of tish being taken by local boats and noted in the margin that Mary and Betsy Kehoe were among the tour servants processing it at his premises late into the night ${ }^{-*}$. The oral tradition also acknowledges the hiring of women for shore work A local folksong. "Betsy Mealey's Escape." relates the true story of the ill-fated voyage of Betsy and several other women who had been recruited as tishing servants for the fishery at St Mary's Bay. ${ }^{x 7}$ Some might argue that these women were merely isolated examples of an uncommon phenomenon. But given that most have come to light only because of certain difficulties they encountered, it is far more likely that thev represent a somewhat larger pool of women tishing servants. most operating without sutficient

${ }^{* 4} \mathrm{GN} 5 / / / \mathrm{C} / 1$. Ferryland, ff 142-5, Catharine Delahunn $v$. Aames $H$. Carter. October 4. 1827

${ }^{*} \mathrm{GN}$ 5/4/C/1. Ferryland, Box 2, n.f.. Ellen Leary 1: ,ohn Butler. October 5. 18+8

*hANL. MG 920. Robert Carter Diary. July 13. 1841.

"The song also appears as "Betsey Mealy" and "A Newfoundland Heroine." See James Murphy. comp. "Songs and Ballads of Newtoundland. ancient and modern" (St. John's: s.n. 1902). pp. 4+-6. Gerald S. Doyle. ed. The Old Time Songs and Poetry of Newfoundland (St. John's: Gerald S. Doyle. 1927), p. 63: and Ronald Martin. ed and comp. Poems of Action, Sentiment and Reflection (St. John's: s.n.. 1945). 
inconvenience to cause them to appear in court records or ballads of the day.

Indeed. according to local informants. Goodridge's premises at Renews hired large numbers of women to spread fish in the latter decades of the study period, they were supervised by a male master of the voyage and were thus regular shore crew. ${ }^{\text {* }}$ This observation is born out by surviving ledgers of the Goodridge firm. The 1839 and 1841 ledgers are peppered with entries of payments to women for shore work in the fishery Some of these women were employed for only several days, but others worked on the tlakes tor extended periods. Their rate of pay was $2 \mathrm{~s}$. per day - the lower end of the male shore crew's earnings, which ranged from 2s. to $2 \mathrm{~s} .9 \mathrm{~d}$. per day. ${ }^{* 7}$ Here, tor example. is an excerpt from the firm's 'fishery' account for 1841

${ }^{x \times}$ The display on the Goodridges at the Capt. William Jackman Museum. Renews. notes that Alan Goodridge came to NF in 1828 on his own ship the Iiola. He settled in Renews. where his father had started a fish business c 1807 Alan Goodridge \& Sons moved to St. John's in the 1850 s, but maintained a branch in Renews. Alan died in 1884 The Renews branch went bankrupt in 1920 .

5.PAL. MF 473 , Goodridge Collection, Ledgers for 1839 and 1841 . (The collection also includes a ledger for 1892. which is bevond the scope of the present study.) The women were clearly identified as shore workers in the 1841 ledger. In the 1839 ledger, entries sometimes only denoted payment for "work," but as other forms of women's paid work (haymaking, cooking, or washing, for example) were specified in the ledger. as the unspecified "work" entries usually appeared in September. October, and early November. and as the rate of pay was 2s. per day, it is most likely that they related primarily to shore work in the fishery. 


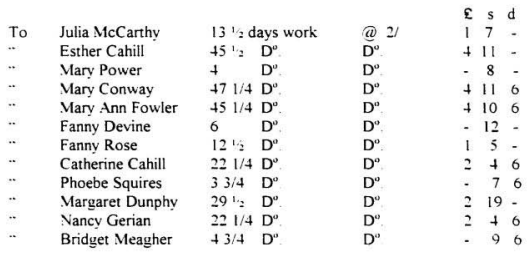

Given the robust participation of women in family shore crews. it is hardly surprising to find tishing concerns who still depended upon hired labour tapping into their expertise and experience

Domestic service: Nonetheless, in greater numbers, women (particularly young women) were hired for domestic service during the study period. In the $18^{\text {th }}$ and early $19^{\text {th }}$ centuries, servant women were regularly recruited from the British Isles. especially Ireland. and became an integral part of planter households - cooking. washing. and sewing not just for family members but for the fishing servants who were hired for each season As the population stabilized, these shipped giris increasingly came from the ranks of local fishing families. and domestic service became a life-stage occupation by which young women earned a small income while they trained for marriage. Whether they worked for traditional planter households or the ascendant family production units. few women on the 
southern Avalon remained servants for life, and most went on to become mistresses of their own households. ${ }^{\text {*i }}$

Indeed. the question of the social mobility of female servants (fishing and domestic) on the southern Avalon (and Newfoundland in general) is an intriguing one." Because of the disproportionate sex ratios in the fishing population, there is reason to believe that servant girls who came out from the British Isles in the period of early settlement were likely more upwardly mobile than those who remained at homes -

${ }^{*} \mathrm{By}$ contrast. Berkin and Horowitz say that it was not unusual tor wives of tenant tarmers and poorer landowners in colonial America to continue to do housework and field work for wages after marriage. See Berkin and Horowitz. eds. Women's Voices, p. 117 Light and Prentice also note that a significant number of married and older women could be found in service in British North America. See Light and Prentice. eds.. Pioneer and Gentlewomen. p. 5 Similarly, in Upper Canada, the wives of small farmers. recent immigrants. squatters, and tenant farmers otten did seasonal field labour and domestic work for others. See Errington. Wives and Mothers, pp. 17.83, and 126. The system of farming out young women before marriage. however. appears to have been common to all colonial North America.

"The following discussion is largely speculative. A combing of parish records in southeast Ireland might reveal the pre-migration status of some southern Avalon women. aithough due to the impoverished state of Irish emigration records and of parish records for the study area, the process of identifying these women would be difficult and timeconsuming. Such an extensive examination of Irish records is beyond the scope of the current thesis research

"Edward Higgs observes that female domestic servants in Lancashire in the $1850 \mathrm{~s}$ 1870 s were not upwardly mobile. See Higgs, "Domestic Service and Household Production." in Angela John. ed. Unequal Opportunities: Women's Employment in England, 1800-1918 (Oxford: Basil Blackwell Ltd., 1986), pp. 125-50. Similarly. Bridget Hill notes that while aspirations towards social betterment through service were common and persistent in $18^{\text {th }}$-century England. the actual incidents of such upward mobility were rare. See Hill. Women, Work, and Sexual Politics in Eighteenth-Century England (Oxford: Basil Blackwell. 1989) 
marrying into planter and, less frequently, mercantile tamilies after their arrival. Perhaps the most striking example from the study area was Mary (last name unknown), an Irish servant who came out to Ferryland c. 1650 in the service of Lady Frances Hopkins. Lady Frances was a political refugee and sister-in-law of Sara Kirke. wife of David Kirke. coproprietor and governor of the island who had headquartered himself at the colony originally established by George Calvert (Lord Baltimore) at Ferryland. ${ }^{13}$ Mary eventually married the Kirkes' son, also named David, but her husband was captured by the French in their last 17th-century incursion into the English Shore, and he died at Placentia in 1697 One or two years later. Mary married James Benger, an Irish-Protestant merchant at St. John's In 1708, she petitioned the British crown to have the Kirke property on the southern Avalon restored to her, as rightful heir to her tirst husband. Thus. the Benger tamily became major landholders in the Ferryland area." Of course. Mary's upward

\footnotetext{
${ }^{13}$ The English government made several proprietary grants of Newfoundland in the early $17^{\text {th }}$ century in the hope of stimulating colonization. In 1637. David Kirke was named co-proprietor and governor of the entire island and moved his family and some 100 colonists to the Ferryland site that had been established in 1827 by Lord Baltimore. Numerous complaints were lodged against Kirke by colonists and migratory fishermen. but his undoing ultimately came from his royalist sympathies during the English civil war. He was replaced as governor by John Treworgie in 1651 and recalled to England to answer various charges against him. Some say he died in an English prison in 1654. others. that he returned to Newfoundland and died there several years later. Nonetheless. his wife. Sara, and family stayed on in Ferryland and managed his considerable estate there. The Kirkes were still substantial planters in the area when the French attacked in 1696. See, for example: Cell. English Enterprise, "Kirke, David." in Smallwood. ed. Encyclopedia, vol. 3. p. 184: and Pope. "South Avalon Planters."

${ }^{14}$ Traces of Mary"s story appear in PANL. MG 247. Carter-Benger-Nason Papers. This anecdote also survives in the oral tradition. and I am especially indebted to DA for
} 
mobility was exceptional, and most men of the merchant-planter group married women of their own class (often women from the home country in the $17^{\text {th }}$ and $18^{\text {th }}$ centuries: later. women trom their local circle or from St. John's). But marriage or cohabitation between servant women and smaller-scale planters was more common. A typical example of the phenomenon was Anstice Dwyer, the above-noted fishing servant who successtully sued for her wages in 1797 by producing a shipping paper that she had entered into with John Sloan. Apparently, they entered into a another concordat as well, for by the taking of the 1800 census. Anstice and John were living together in a common-law relationship ": The oral tradition and contemporary anecdotal evidence, particularly from British authorities at Newfoundland dating back to the late $17^{\text {th }}$ century ( see Chapter 2), suggest that many servant giris like Anstice married or entered into stable cohabiting arrangements with fishermen or planters and became mistresses of their own family fishing enterprises - some of which were quite substantial operations. Many women from service or labouring backgrounds who had come out from Ireland to the southern Avalon had thus likely increased their opportunities for moving up in the world ${ }^{\text {m }}$

her summary of Mary s life history included in correspondence dated March 8. 1999 Additionally. Agnes Field disdainfully mentions Mary in her discussion of the mesalliances [between local men and Irish servant girls by which] the type of Newfoundland settler steadily got worse." See Field. "The Development of Government in Newfoundland. 1638-1713" (M.A. Thesis, University of London, 1924).

"S.ANL. MG 205. Pole Papers. 1799-1800.

${ }^{76}$ It is important to note that many male fishing servants at Newfoundland were also upwardly mobile, moving from the status of inexperienced youngster into the ranks of 
Still, their lives as servants were filled with long days and hard work. The term 'domestic service' had different connotations in local fishing communities than in urban areas. Like servants in the rural British Isles and other rural colonial contexts, most of these women were responsible for performing a variety of tasks both in and out of doors." Women servants cooked meals, performed housework, and looked after young children, but they were also expected to feed livestock. milk cows, and work in the gardens and meadows as work loads demanded. Indeed, at the peak of the tishing season, servant girls on the southern Avalon were sometimes recruited for drying fish on the tlakes as well. More commonly, however, their mistresses within the plebeian community left their women servants to keep the house and care for young children while the mistresses. themselves, pertormed what was seen as more critical work curing tish. milking. gardening. or making hay. Still. the servant girl was generally expected to "do a bit of everything ${ }^{\cdots 1 \times}$ as needed and to be on call day and night. The exceptions were those few servants working for larger mercantile households. where indoor maids responsible tor

skilled labour in the tishery, with many becoming planters (either boatkeepers or the heads of household units) in their own right.

"nsee, for example: Errington. Wives and Mothers; Mona Hearn. Below Stairs: Domestic Service Remembered in Dublin and Beyond, 1880-1922 (Dublin: Lilliput Press. 1993): Higgs. "Domestic Service": Hill, Women. Work, and Sexual Politics; Bridget Hill. Servants: English Domestics in the Eighteenth Century (Oxford: Clarendon Press. 1996): Rendall. Women in an Industrializing Society; Snell, -Agricultural seasonal unemployment". and Valenze. First Industrial Woman.

${ }^{91 \times}$ The direct quotation came from both MOB. Interview July 22. 1999. and AOT. Interview July 19. 1999; but most oral informants made a similar observation. 
childcare and specialized household duties were differentiated from servants hired for more general indoor and outdoor work. ${ }^{\infty}$

Long hours, hard work, low wages, ${ }^{100}$ and lack of privacy were experiences shared with domestic servants elsewhere. But some of the isolation and pressures that existed in situations elsewhere - for example, class tensions between mistress and servant and even antagonism within stratified ranks of household servants - were not as pronounced on the southern Avalon. for the power dynamic in the relationship was muted: many servants were working for tamilies within their own plebeian community: many mistresses thus bore their share of the heavy work load, there was little differentiation among the ranks of servants in most situations: and women servants could look forward to becoming

${ }^{\text {'r }}$ For example, while diarist Robert Carter and his family hired local women tor gardening and haymaking (see below). on several occasions, they recruited servant girls from St. John's. who were more likely hired for specialized work indoors. See. tor example. PANL, MG 920. Robert Carter Diary, November 8, 1836, and May 14, 1837

${ }^{11 x} \mathrm{~W}$ age rates for household servants are difficult to gauge from the limited data available. Wages mentioned in court cases are ambiguous: 'per year' sometimes means "per season or 'per summer' complainants are often suing for the "balance of wages." leaving us with no idea what the full amount was. Still. the total amounts mentioned - ₹2 per season/year (1826). \&2.12.3 per season/year (1829). §3.6.6 Cy. per summer (1836). $£ 3$ per year (1840), £5 per summer (1846) - are quite low in comparison to fishing wages (see Table 4 1). Amounts mentioned in the 1841 ledger tor Goodridge's - e g., E1.76 for "Wages p. Girl last winter \& a Pr of Shoes." £1.4.0 for two months" wages. and $13 \mathrm{~s}$. jd. for 25 days" wages - are also much lower than the wages either women or men were earning in shore work from the firm (2s, and $2 \mathrm{~s}-2 \mathrm{~s} .9 \mathrm{~d}$. respectively). However, one woman. Mary Plece, earned $£ 9$ British Sterling [Stg.] per year for unspecified work debited to "House Expense". likely, she occupied a higher rank in the servant hierarchy of the merchant household, such as housekeeper. 
mistresses of their own households in time ${ }^{101}$ Furthermore, as Chapter 6 will reveal. servants on the southern Avalon had reasonable access to the courts in terms of illtreatment or non-payment of wages, and thus were likely less vulnerable to abuse than many women who entered service in other historical contexts.

\section{+2.2 Paid washing and sewing}

A number of women on the southern Avalon did washing and sewing for community members outside their own families, catering to the large numbers of single men in the population as well as to a small middle-class clientele. Their work contributed to the limited cash incomes of families: indeed. for some fishing families. it was likely the only source of cash in many vears. Additionally, their services were an important link in the local exchange economy as many of their customers. particularly fishermen and shoremen. 'paid' them through their merchant's account book. For example. supplies issued to a washer or sewer were "contra d by making a credit entry in her account in the

"'IS Some historians point to the transition from paternalism to the contractual wage relationship which accompanied industrialization as a major source of tension in master/mistress-servant relations. See, for example. Hill. Servants, and Hearn. Below Stairs. In addition, some have noted that tension. particularly between mistresses and servants, arose from middle-class efforts to "improve' the morals and habits of their servants - interterence that was usually resented by the labouring class. See. for example Valenze. First Industrial Woman; and Rendall. Women in an Industrializing Society These explanations, however, have more explanatory power elsewhere than within the context of the current study. 
name of the appropriate fishing servant or fisherman, with a corresponding debit entry in the latter's account: ultimately, the merchant was paid by a deduction from the fishing servants" wages or from fish and oil collected from independent fishermen in the fall (see Chapter 5 and Appendix $\mathrm{C}$ ).

Of course, catering to a largely transient fishing clientele, washerwomen and seamstresses occasionally found that their customers attempted to abscond at the end of the season without making payment. This was most unfortunate for the women involved. but the ensuing court cases provide the historian with some means of measuring their livelihood. Twenty-six court cases during the period involved or made reference to laundresses and seamstresses - the specific protile being 22 washerwomen and four combined washerwomen/seamstresses. Again, most of these women appeared in the court records due to unusual circumstances and likely represented only a subsection of the total numbers actually involved in these occupations.

The court records indicate a high proportion of married or widowed women sewers and washers. Of the 26 identified, at least 14 of the women could be readily relegated to this category because they were referred to as "Mrs." in the record and/or because their husbands were suing for payment as their legal agents. This does not exclude the possibility that some of the others were also married. widowed. or living in alternative family arrangements. for the flexibility of combining paid sewing and washing with household production and childrearing made it possible for these women to juggle their paid work with their other responsibilities. 
Given the consistency in the amounts claimed in the court actions, it is obvious that most women negotiated a flat rate with their customers for their services (only one woman negotiated a piece rate for washing- $4 \mathrm{~s}$. $6 \mathrm{~d}$. per dozen items - in 1818 ) ${ }^{102}$ While rates are not detailed in all the cases. definite trends can be seen. Only two amounts for washing appear in the records for the $18^{\text {t }}$ century: $£ 5.0$ for washing for 11 fishing servants in the summer of 1779 (or roughly $9 \mathrm{~s} .3 \mathrm{~d}$ per customer); and 21.5 .0 for one customer in 1785 (this seems high and may have been for an entire year. as opposed to a single season. or for washing and sewing services combined). In the early 1800s, the washing rate increased. likely due to increased demand from the high numbers of transient males in the population as well as general inflationary conditions. and fluctuated between $15 \mathrm{~s}$. and $25 \mathrm{~s}$. per customer per season (summer or winter). It then declined after the Vapoleonic War period. from $18 \mathrm{~s}$ in 1820 to a range of $12 \mathrm{~s} .6 \mathrm{~d}-15 \mathrm{~s}$. in the next two decades, likely reflecting fewer transient men in the population and hence a lowering of demand as well as an economy in recession. In the early 1840s. the going rate for washing hovered around the $15 \mathrm{~s}$. mark per season (with two exceptions: 10s. per season, and a very low $12 s$ tür a year's washing). These rates were by now being charged in Newfoundland Currency rather than British Sterling, reflecting a further slide in the remuneration for these women By mid-century. however, the rates were beginning to creep slightly upwards again to the $16 \mathrm{~s}-18 \mathrm{~s}$. range. Of course. combined washing and

${ }^{112}$ All calculations of wages. piece rates. and provision prices in this dissertation have been rounded to the nearest pence. 
sewing services garnered higher rates - with amounts of $£ 2.17 .6$ (1818). £1.5.0 (1832). and $₹ 1.16 .0$ (1835) per customer specifically mentioned in the court records. It is difficult to draw conclusions from these few examples for the combined service, other than to note that they also reflect a slide in rates as the male population became more settled and the economy cooled down

The evidence in the court cases is supported by accounts for laundresses and seamstresses in the Sweetman and Goodridge ledgers (see Appendix C). The Sweetman evidence is sporadic and deals mostly with the $1820 \mathrm{~s}$. However, it again suggests the significant involvement of married women or widows. It also indicates that the flat rate for washing generally ranged from $15 \mathrm{~s} .-18 \mathrm{~s}$. and the charge tor combined washing and

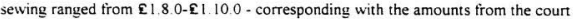
cases for the same period. The ledgers also provide us with an approximate rate for sewing only - with what would appear to be fixed rates tor a season generally ranging from $3 \mathrm{~s}$ 6d. to $6 \mathrm{~s}$., and other amounts obviously reflecting charges for piece work. The Goodridge ledgers for 1839 and 1841 also mirror the court cases in reflecting a slide in value (likely due to lowering demand) in women's washing and sewing services. While washing rates ranged from $10 \mathrm{~s}$. to $17 \mathrm{~s}$. per season. by far the most frequent charge was 12s. Seamstresses were charging 5 s per season or piece rates ranging from is. to Is.6d. with the most frequently appearing rate being $1 \mathrm{~s} .3 \mathrm{~d}$.

Many of these women had multiple customers - reflected in both the court cases and the business ledgers. Indeed. a Mrs. Delany in Bay Bulls washed for 11 fishing 
servants for the summer of $1779,{ }^{\text {tea }}$ while Mrs. James Barron, a laundress and seamstress in Placentia-St. Mary's had 14 customers in $1823^{\text {10 }}$ Most other laundresses and seamstresses had up to five customers per year, although there were several with over five. The records also suggest that women maintained long-term commitments with some of their clients. For example. Margaret Yetman of St. Mary's maintained a working relationship with William Christopher for many years, seeking $£ 62$ from his estate in 1835 for washing and other services performed over Christopher's lifetime. ${ }^{\text {tos }}$

While $18^{\text {th }}$ - and $19^{\text {th }}$-century wardrobes were limited. especially among fishermen customers, the demands on these women's time was considerable, given that most of them likely had tamilies to care for as well. Washing, in particular, was strenuous work. involving the drawing and boiling of prodigious amounts of water as well as soap-making for a process that had to be repeated for the washerwoman's own tamily ${ }^{\text {th }}$ Sewing, while not as physically arduous, required both long hours and skill. It is worth examining their remuneration. then. to ascertain the value attributed to their work

${ }^{103}$ P.A.NL. GN 2/1/A. 8/101-2/1779. Order, Governor. Richard Edwards to John Dingle, JP. Bav Bulls, October 27. 1779, in response to a complaint laid bv Donald Delany against the men's employer. Mr. Brookes, for non-payment of his wife's account.

${ }^{14}$ P. ANL. MG +9. Sweetman Collection. Box 3. File 18a. f. 21

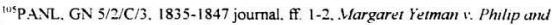
Briget Broun. .James and Mary. Whealan, and Tomas Dee. Administrators to the Estate of the late William Chrisiopher, October 26, 1835; also in GN 5/2/C'8, 1835-1842 journal. tf. $12-13$ soap by $1839 / 1841$.

${ }^{1126}$ The Goodridge ledgers indicate that a number of washerwomen were purchasing 


\section{Table 4.2-Prices for provisionst - selected vears}

1802 English Shore - separate reportings by district not given.

$\begin{array}{ll}\text { Bread - cwt } & 18 \mathrm{~s}-£ 1.8 \\ \text { Pork-bartel } & £ 5.15-£ 6 \\ \text { Flour - barrel } & £ 2-£ 3 \\ \text { Butter - } 1 \mathrm{~b} . & 9 \mathrm{~d} .-1 \mathrm{~s} .1 \mathrm{~d} . \\ \text { Rum-gal } & 3 \mathrm{~s} .3 \mathrm{~d}-\mathrm{s} . \\ \text { Molasses - gal. } & 2 \mathrm{~s}-2 \mathrm{~s} .6 \mathrm{~d} . \\ \text { Salt - hhd. (Portuguese) } & 15 \mathrm{~s}-£ 1.1 \\ \quad & 9 \mathrm{~s} .15 \mathrm{~s} .\end{array}$

1810) English Shore in general

\begin{tabular}{|c|c|c|c|}
\hline & $\underline{\text { Winter }}$ & Summer & Fall \\
\hline Bread - cwt. & $E 210$ & $\pm 2- \pm 2.10$ & $£ 2.10- \pm 2126$ \\
\hline Flour - barrel & E3 10 & $\pm 2.15- \pm 3.5$ & $\$ 3.15$ \\
\hline Potatoss - barrel & $12 s-13 s$ & fos. & $1+s$. \\
\hline Butter - Ib & is $6 \mathrm{~d}$ & Is $3 \mathrm{~d} .-1 \mathrm{~s}+\mathrm{d}$ & is td. \\
\hline Pork - barrsl & E7.7 & E7 & $\$ 7$ \\
\hline Molasses - gal. & 3s. - is $6 \mathrm{~d}$ & $2 \mathrm{~s} 10 \mathrm{~d}-3 \mathrm{~s} .6 \mathrm{~d}$ & Is $10 \mathrm{~d}$ - is $6 \mathrm{~d}$ \\
\hline Salt - hhd & & I8s. - El 5 & $12 \mathrm{~s}$. \\
\hline Cotfice $-\mathrm{lb}$ & $1 \mathrm{~s} .9 \mathrm{~d}$. & is $9 \mathrm{~d}$. & $1 \mathrm{~s} .9 \mathrm{~d}$ \\
\hline Soap - Ib & Is.6d. & Is $6 d$. & is $6 \mathrm{~d}$ \\
\hline Leng Lines - doz, & E1 16 & E1.16 & \pm 1.10 \\
\hline Cordage - cut. & E7 & $\$ 6.15$ & \pm 6.10 \\
\hline twicelaid - cwt & E4 & 53.10 & $\$ 3.10$ \\
\hline Tea - lb. & ts. & is. & ts. \\
\hline Olive Oil - gal. & $12 \mathrm{~s}$ & $14 \mathrm{~s}$. & 145 \\
\hline Rum - gal. & is. $6 \mathrm{~d}$. $-5 \mathrm{~s}$. & is 6 d. - is. & is. $10 \mathrm{~d} .-5 \mathrm{~s}$. \\
\hline Sugar - cut & \pm 2.16 & \pm 2.16 & $\$ 2.16$ \\
\hline
\end{tabular}




\begin{tabular}{|c|c|c|c|c|c|}
\hline$\underline{1815}$ & St John's & Bav Bulls & Ferroland & Trepasses & Placentia \\
\hline Pork-bar'1. & No fixed & 27.7 & At about & $£ 7.7$ & $\$ 7.7$ \\
\hline Butter - lb & prices: & $2 s$ id. & $10 \%$ above & $2 s .6 d$ & 2s. \\
\hline Bruad - cwt. & dependent & E1 15 & St John's & 21.15 & $E 2$ ? \\
\hline Flour - bar 1 . & on demand & E3.15 & prices & \pm 2.10 & E3 10 \\
\hline Salt - hhd. & & Ifs $6 \mathrm{~d}$. & & il & \\
\hline $\begin{array}{l}\text { Molasses - } \\
\text { gal. }\end{array}$ & & & & 6s. & \\
\hline$T e a-l b$ & & & & 5 s. & hs. \\
\hline Becf - bar 1 . & & & & & Et. 10 \\
\hline $\begin{array}{l}\text { Cordage - } \\
\text { cut. }\end{array}$ & & \pm 3.15 & & E7 & \\
\hline 1818 & St John's & Bay Bulls & Fernland & Trepassey & Placentes \\
\hline Pork-bar'l & t5 $10- \pm 6$ & $\pm 6- \pm 7$ & Governud & E6 & E7 \\
\hline Butter - $\mathrm{lb}$ & is. - Is.6d. & Is $6 \mathrm{~d}-1 \mathrm{~s} .10 \mathrm{~d}$ & by prices at & is fid. & Is.xd. \\
\hline Bread - cwt. & & E1.15-E2 & St. John's & E1 15 & E1.16 \\
\hline Flour - bar'l. & $\$ 2.10$ & E310- Et & & 13 & $\$ 310$ \\
\hline $\begin{array}{l}\text { Molassis - } \\
\text { gal. }\end{array}$ & Is ind & & & & Is.6d. \\
\hline Tea - lb. & ss. & & & & is. \\
\hline Rum - gal. & t5.6d. & & & & \\
\hline Salt - hhd & & Its. & & & \\
\hline $\begin{array}{c}\text { Cordage - } \\
\text { cwt. }\end{array}$ & & & & E: & Is td. $|\mathrm{lb}|$. \\
\hline $\begin{array}{c}\text { Canias - } \\
\text { bolt }\end{array}$ & & & & & E5 \\
\hline 1820 & St John's & Bav Bulls & Ferniland & Irepassas & Placentia \\
\hline Pork-bar 1 & $E+10-E 5$ & E5 & $E 5-E 6$ & E5 & E6 \\
\hline Bread - cwt. & $E 1.2-E 1.8$ & E1.10 & E1 8 & E1.5 & 21.10 \\
\hline Flour-bar 1 . & & 22 & E2 & E) 16 & $\$ 2.10$ \\
\hline $\begin{array}{l}\text { Butter - lb } \\
\text { Rum - gal. }\end{array}$ & $\begin{array}{l}\text { is. }- \text { is } 2 \mathrm{~d} \\
\text { 2s. }- \text { is }\end{array}$ & is td. & is. & Is $2 d$. & Is. $2 \mathrm{~d}$ \\
\hline
\end{tabular}




\begin{tabular}{|c|c|c|c|c|c|}
\hline$\underline{1822^{\circ}}$ & $\underline{\text { St. John's }}$ & Bav Bulls & Ferruland & Trepassev & Placentia \\
\hline Pork - bar 1 . & $\$ 3.10$ & $E+10$ & $E 3.15$ & & \\
\hline Becf - bar 1 & E3 & & & & \\
\hline Bread - cut. & E1 2 & E1 + & E1.3-E1.8 & & E1:5 \\
\hline Flour - bar I & E1 10 & unreadable & unreadable & & 22 \\
\hline Butter - lb. & unreadable & $1 \mathrm{~s} .2 \mathrm{~d}$ & & & is $2 \mathrm{~d}$ \\
\hline Sugar - lb. & & & $6 d$ & & \\
\hline $\begin{array}{c}\text { Cordage - } \\
\text { cwt. }\end{array}$ & \pm 35 & & & & \\
\hline 1825 & St. John's & Bav Bulls & Ferriland & Trupasses & Placintia \\
\hline Pork - bar 1 . & ES & $\varepsilon+10$ & \pm 6 & & $E 5$ \\
\hline Buef - bar 1 . & E3 & & & & \\
\hline Bread - cwt. & E1 8 & El 6 & E1 8 & & El 6 \\
\hline Flour - bar 1 . & 12 & $t 25$ & 12 & & $\$ 2.5$ \\
\hline Butter - lb & Is. - Is $6 \mathrm{~d}$ & Is. & $15.3 \mathrm{~d}$ & & Is $6 \mathrm{~d}$ \\
\hline Molasses - & & & & & \\
\hline gal. & 2s.6d. & & 2s. & & $2 \mathrm{~s} .6 \mathrm{~d}$. \\
\hline$T \mathrm{ca}-\mathrm{lb}$ & tos. & & 5 s od. & & is \\
\hline Rum - gal. & is $6 d$. & & ss. & & \\
\hline Cordage - & & & & & \\
\hline ewt. & ES 10 & & & & \\
\hline
\end{tabular}

\footnotetext{
'Prices for 1810 include summer. fall. and winter reportings. The remander of the table relates to prices during the fishing season. Winter prices were often higher, sometimes as much as 20 percent. especially in the outports. Most prices appeared in the orignal returns as shillings and pence: they have been converted here to pounds. shillings. and pence as appropriate.

Some items and prices for 1822 were unreadable due to damage to the original before microtilming.
}

SOLRCES C O '94. Govemors' Annual Returns. Additional Information. and Observations on Instructions: 1798, vol 40. If. 135-7: 1810 , vol. 49. ff. 120-22. Schedule E: 1815, vol. 57. f. 12 . 1818, vol 61, f. 158, 1820, vol 64, f, 24, 1822, vol. 65, f $121 ; 1825$, vol. 70, f 227 . For 1802 prices. see P.ANL. GN 2/1/A. 17/62/1803. Blank spaces indicate that the data was not available or not entered. Note that. as wtth wages. the governor was providing a comprehensive itemization of prees by 1810 , and a breakdown by district by 1815 . This reporting was discontinued altogether in the late $1820 \mathrm{~s}$. 
The most accessible wage information for the area, at least for the early decades of the $19^{\text {th }}$ century, is that tor the tishery. Still, it is difficult to compare the monies earned by these women in a season with the wages paid to fishermen and seamen: there is no way of ascertaining, for example. exactly how many customers these washers and sewers had per season. and it is difficult to find matching data in any given year for both fishery workers and washerwomen/seamstresses. The purchasing power of these women (based on the prices of provisions. as per Table +2 ) is also difficult to ascertain without knowing the numbers of their clientele. The following discussion is, therefore, highly impressionistic. based on the sporadic data at hand.

Given these limitations. Table 4.3 takes women's earnings recorded in cour cases and account books tor years in which fishing wages are available. and projects the amounts that would have been earned based on a clientele of three. five. or ten ${ }^{117}$ per season. When compared with Table +1 , it can be seen that only the earnings of those women who combined washing and sewing for ten customers per season would have approached the earnings of a youngster or less experienced fisherman (indeed. the combined service in 1818 would have netted the equivalent of an experienced fisherman's wage). Ten customers for both washing and sewing. however, would have been a rather large workload for women with other household duties, and probably untenable for many

${ }^{107}$ This was roughly the upper part of the range encountered in the written records. Mrs James Barron, with her 14 customers as noted above, appears to have been somewhat exceptional 


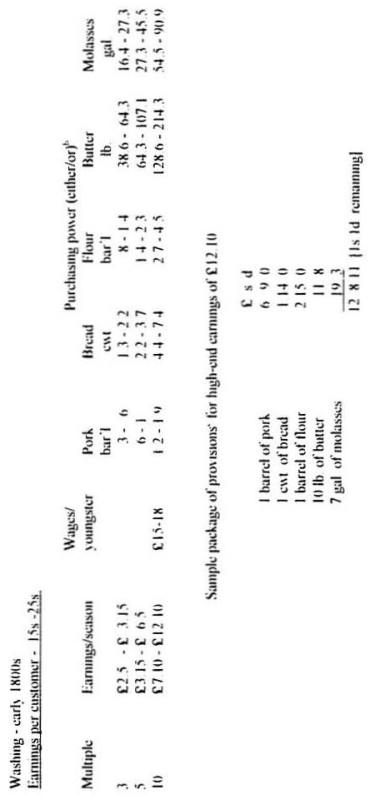


急吉旁
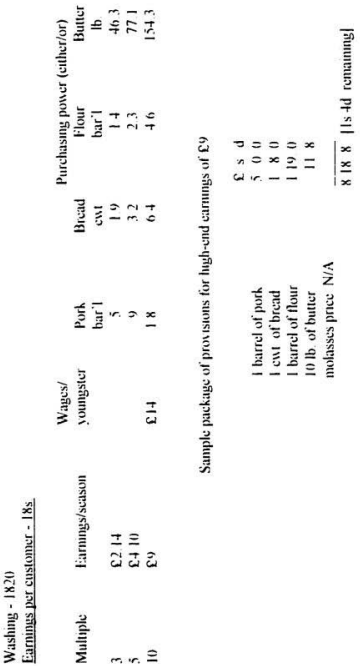


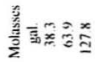
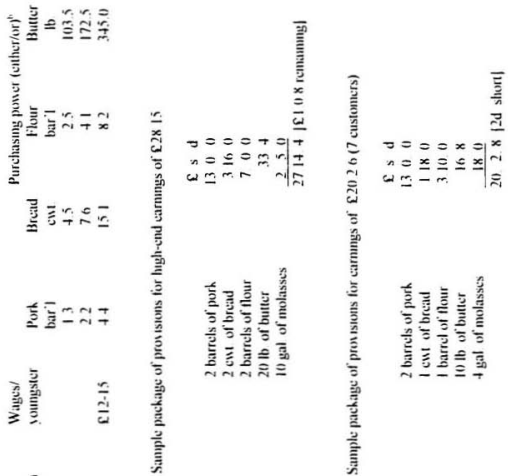

E

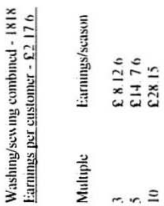



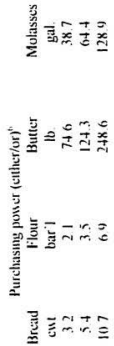

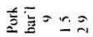
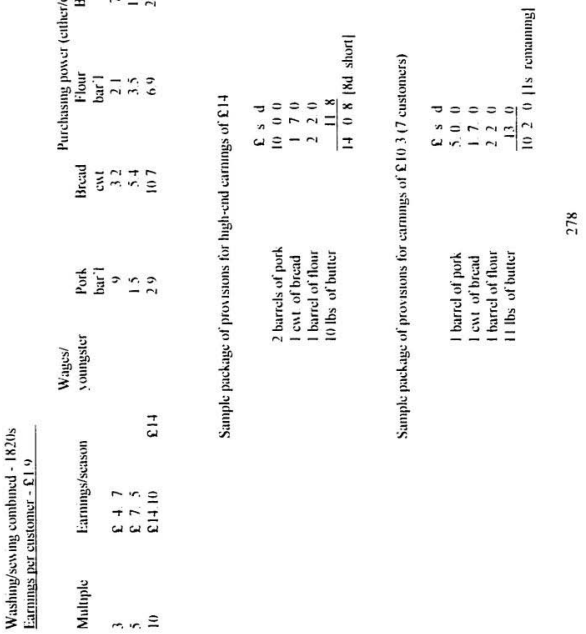

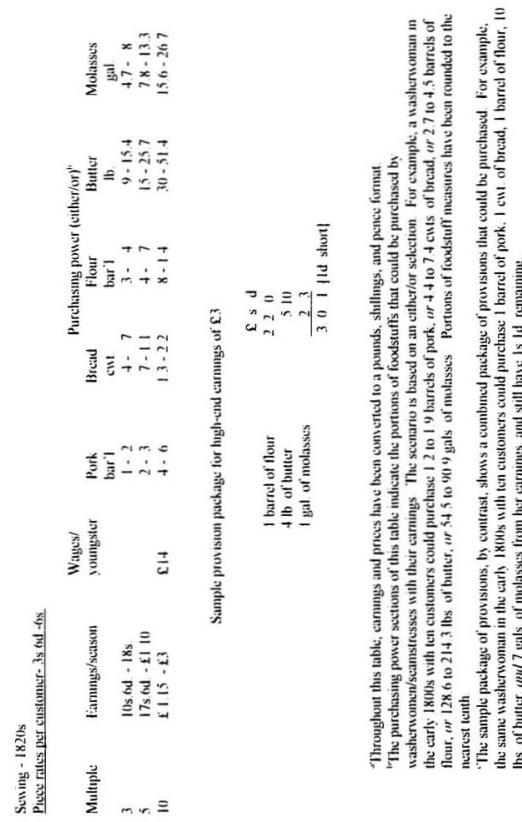
with large families. Overall, then, these women were not being remunerated as skilled workers, likely because their work was seen as an extension of their familial roles.

Nonetheless. some of these women may have had significant purchasing power.

Table +3 also provides examples of the provisions that could have been bought with these women's earnings - again, based on a clientele of three, five, or ten - as twell as a sample package of provisions for those with earnings on the high end. The table demonstrates that their earnings could make significant contributions to their family incomes particularly those who may have had tive or more customers, and most especially. those

who combined washing and sewing services. The table also suggests that even though the rates for washing and sewing declined after the Napoleonic War period. the purchasing power of laundresses and seamstresses did not slide dramatically. given the context of a generally cooling economy. Their work, then, had economic value, even if it was not as highly rated as fishing service, for their efforts brought additional purchasing power to families living on the margin and also helped to drive the exchange economy in the study area.

\subsubsection{Agriculture - production tor market and paid labour}

While most agricultural labour by women on the southern Avalon contributed to family subsistence. there is evidence that some women sold their agricultural labour or the fruit of such labour to outsiders and earned cash or credit for the themselves and their 
tamilies.

The most dramatic example I have encountered - one that encompasses several aspects of women's paid work - is that of Mary Foley in the Renews area. In 1840-41. Mary had obtained from Goodridge's, on credit. large quantities of soap and sewing materials, suggesting that she was sewing and washing for people in the community. or perhaps servants in her own household as part of the contracted terms of their employment. Mary paid for her supplies with various installments of agricultural produce. including potatoes, milk. cream. pigs. and poultry (see Table +4 )

Her commercial activity was well rooted in the traditional activities of rural Irish women: in particular. the sale of the family pig. eggs. and towi were a common means for Irish women to earn income that was essential to their families' survival ${ }^{\text {Iux }}$ On the southern Avalon. women tattened pigs through the summer months - making a tish meal

${ }^{11 x}$ See. Nolan. Ourselves Alone; Luddy. Documentary History, and Mageean. "Irish Women's Prospects." Luddy cites an 1836 report observing that some 50 rural women of county Cork regularly transported eggs into the city of Cork tor ultimate sale in English markets. It stated.

these individuals are generally young women of blameless morals and great industry: the distance they have to travel bare-footed with such a load as 300 eggs in a basket on their backs is to many no less than 50 miles; some will take so many: as 350 of these eggs. others not more than 200; they generally bring as heavy a load back from the city, and make ten or a dozen such journeys every year: the time devoted to such a journey is generally a week: their protits are inconsiderable. perhaps about $₹ 3$ in the year.

See Luddy. Documentary History, p. 169. Doc 47.3 Report ... [on/ the Condition of the Poorer Classes in Ireland. Appendix D HC 1836 (43). 


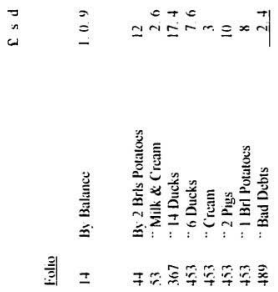

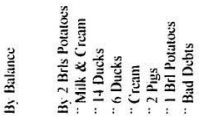

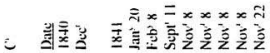

in

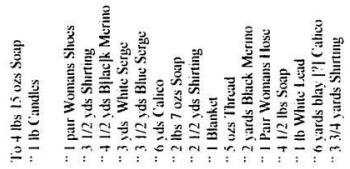

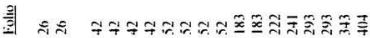

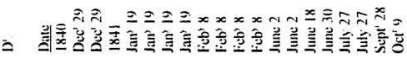


from dabs. ${ }^{(1) 2}$ often duy by children, in the earlier part of the summer, then switching to a boiled mash of potato peels and other household scraps later in the process so that the meat would not taste of fish. The fattened and slaughtered animals were sold to merchants and dealers. or in smaller amounts to community members. It was also likely that poultry-raising was an important source of cash for women in the early days of settlement Several merchant accounts in addition to Mary Folev's suggest that women raised towl for cash or credit: Mary Knox, Margaret Dunphy, and Nancy Shannahan of the Renews area. for example. helped to counter their debts to Goodridge's by the sale of "3 fowls," "9 Ducks," and "6 Ducks," respectively. Various other sales of fowl entered in men 's accounts also likely reflected the husbandry of their wives and/or daughters. ${ }^{116}$ This cash- or credit-producing activity was likely even more prominent in the earlier part of the study period, when larger proportions of the population were more transient and thus had to rely on purchasing such items. In 1794, for example, when diarist/seaman Aaron Thomas was wishing to purchase some fowls. a young servant directed him to a local Irish woman who had sold fowls to his master at 2 s.6d "per Couple". Thomas passed himself off as a priest by showing the woman a Pyx he was carrying. and negotiated the price of his purchase down to $2 s$ a pair, "for your Religion's sake,"

${ }^{\text {tins }}$ Small flatfish.

I'P.PNL. MG 473, Goodridge Collection, 1839 and 1841 Ledgers, particularly ff. 246 and 306 of the 1841 Ledger. Note that formal business ledgers do not show private transactions - either for cash or barter - between individuals.

${ }^{111}$ Thomas. Journal, pp. 114-6. 
young Irish wife in Caplin Bay. a Mrs. Poor (or Power), whose chief concern was that her geese, ducks. and chickens had taken to laying and sitting their eggs in the woods and would likely all fall prey to wild animals; according to Thomas, she did not share the same level of concern tor her children. whom she sent in search of the strays and who became lost in the foggy woods overnight, tinally making their way to the neighbouring harbour of Cape Broyle in the morning. Mrs. Poor's fowl. then. were of great importance to her, and were likely a means of earning income as well as subsistence. ${ }^{112}$ Indeed, the significance of poultry in the family income of Irish women has been commemorated by the local tolksong "Betsy Brennan's Blue Hen." Having enumerated the many tine qualities of her champion fowl. Betsy rains down curses on the "scoundrel" who has stolen her hen and her drake:

May his whiskers turn green

When he eats a crubbeen

And may pork tat and beans

Nearly make him insane:

May two dogs and a crackie

Eat all his tobaccy -

The villain who stole my poor little Blue Hen.

And making no gendered assumptions about the sex of the thief. she also launches several salvoes at a possible temale perpetrator:

11-Thomas, Journal, p. 155. 
May the ravenous baste

Burst her blouse at the waist;

May she not get a taste

Of a dumplin or cake:

May a man from Freshwater

Go back on her daughter.

That lifted my hen and my beautiful drake. ${ }^{113}$

Although this song and Thomas's earlier anecdotes are humorous, there is an underlving gravity in the concern of these women for the tate of fowl that made a significant contribution to their families livelihoods.

Another important source of women's income in rural Ireland came trom dairying. but there is no evidence that large-scale commercial dairying transferred to the southern Avalon with the Irish. Still, a tew isolated examples (some Irish, some English) of smallscale dairying exist in the records. A 1786 court case reveals that a tamily in Fermeuse named Welsh had been supplying the merchant house of Leigh and $\mathrm{Co}$. with milk the two previous years and that Mrs. Welsh was a central figure in the business. ${ }^{114}$ Aaron Thomas mentions in his journal that the widow Mary Keene (also Kean and Keen) was keeping 14

"Johnny Burke, "Betsy Brennan's Blue Hen," in Kevin Major, ed. Doryloads (St. John's: Breakwater Books. 1974), pp. 79-81. It is evident that songwriter Burke has borrowed liberally from a similar folksong in Ireland concerning the death of Nell Flaherty's drake - customizing his offering with local vernacular and rejigging the tragedy from a murder to a theft. See Nolan. Ourselves Alone, p. 31, from whose interpretation of the song I have borrowed. Vell Flaherty's cursing abilities are also noted in Kevin Danaher. Irish country people (Cork: Mercier Press. 1966), p. 14

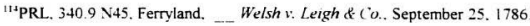


cows in the Grove' at Ferryland in 1794, which in the Newfoundland context, he said, put her "on a par with Job in point of Riches." 11 s Indeed. two years previous, the widow had been ordered to mortgage the herd to Holdsworth \& Co. as partial security for a debt of E125 ${ }^{116}$ therd of this size was surely for purposes beyond her household consumption. Similarly, the five cows that Elenor Tobin of Witless Bay inherited from her husband. Lawrence, at his death in 1852 must have produced more than her family required: and it was evident that some effort was being made to develop the herd, tor a proviso of Lawrence's will stated that the stock was to be kept up and not be permitted to diminish. ${ }^{17}$ Similarly, the Ryan and Hartery families at Biscay Bay had two dozen cattle and two dairies by the middle of the $19^{\text {th }}$ century ${ }^{\text {II }}$ Nonetheless. dairying did not develop as a more substantial industry - doubtless due to insufficient winter feed for large herds and a limited local market. Thus. the large-scale employment of women in dairying (and the subsequent devaluation of their labour which occurred in the British Isles with the rationalization" of the industry) was not a process that played out on the southern Avalon.

Women did, however, hire themselves out for occasional agricultural work -

${ }^{115}$ Thomas. Newfoundland Journal, p. 109

tthpANL. GN 5/4/C/1. Ferryland, Box I, ff. 9-10. Arthur Holdsworth kै (o. 1 : Lañ. Keen. October 9, 1792

${ }^{11}$ PANL. GN 5/1, Registry of Wills, vol. 2. p. 147. Will of Lawrence Tobin, planter. Witless Bay. July 11. 1848. See also Mannion Name File. Witless Bay. "Tobin. Elenor."

"18HA. 43-A-I-42. Corrigan, "Ryans of Biscay Bay." 
particularly weeding, harvesting, and haymaking. Women's paid farm labour was not as common as it was in Ireland. where. particularly up to the early decades of the $19^{\text {th }}$ century, women regularly contributed to family incomes with wages from seasonal work in the spring and fall. Still, there is some evidence from the study area that women hired themselves tor work outside family gardens and meadows. Harriet Carter, the wife of a 'gentleman tarmer' in Ferryland. reterred to hiring a local woman to help her with her kitchen garden in correspondence to her English uncle in the late $1820 \mathrm{~s}{ }^{119}$ Rober Carter's diary contains reterences to occasional labour in the gardens. such as the following 1836 entry: "Biddy Hegarthy's girl weeding part of a day, came after to A.M. ${ }^{* 120}$ Women also made hay tor pay. either in the meadows of emplovers or selling the surplus from their own tamily meadows. Carter. for example. notes in an $18+1$ entry .. bought up 2 cwt Hay from Martin Culliton's Wife-" ${ }^{121}$ The Goodridge ledgers provide further examples of women's sale of hay for cash or credit." And, as noted above, tield work occasionally came on the roster of duties for domestic servants.

Clearly, then, not all women's agricultural labour was for subsistence purposes

${ }^{119}$ P.ANL. MG 31, Carter Family Papers. File 26. Harriet Carter to her uncle (likely George Williams), c. late 1820 s or early 1830 s.

129PANL, MG 920, Robert Carter Diary, July 22, 1836

12PANL, MG 920, Robert Carter Diary, April 14. 1841.

12PANL, MG 473, Goodridge Collection. 1841 Ledger: f: 247 - Susan Layman account credited \&18.3 for 8.0.11 [cwt?] of hay@3s.6d:f. 248-Mary Neill account credited $11 \mathrm{s.4d}$. and E1 14.1 for 3.1 .0 and 9.3 .0 [cwt ?] of hay, respectively: f 248 - Julia McCarthy account credited with 6 s.8d. tor 1.3 .17 [cwt? ? of hay. 
only. For some, paid labour and the sale of farm produce were part of a variety of mechanisms to ensure survival. Susan Layman of Renews. for example, combined the sale of hay with laundering for the Goodridge family and work on the Goodridge flakes to pay her way in the world. Her neighbour. Julia McCarthy, sold hay, worked on the Goodridge flakes, and sewed for the Goodridge family and other community members ${ }^{13}$ Plebeian women's working careers, then, were often more multi-faceted than the traditional model for outport Newtoundland entailing the twofold options of family production or service.

$\pm 2+$ Hospitality trade

The hospitality trade provided another opportunity for women to contribute to tamily economies by cash or exchange through the keeping of boarders. small shops. and public houses ${ }^{1:+}$

Some women in the area kept itinerant. paying boarders - casual travellers, tor example. or teachers. doctors. and priests. As with sewing and washing, this type of work appealed to married women and widows for it could be balanced with household and childcare responsibilities. But the almost universal manifestation of this service was in the

${ }^{13}$ See Appendix C. Also, see PANL. MG 473. Goodridge Collection. $18+1$

Ledge: $t$. 247. Susan Layman account: and f. 248. Julia McCarthy account.

${ }^{124}$ Again. this experience mirrors that of mainland colonies. See. for example: Light and Prentice. eds. Pioneer and Gentlewomen; Berkin and Horowitz. eds.. Women's Voices; and Ryan. Womanhood in America. 
boarding of fishing servants by planter households - in both the earlier boatkeeper phase of the resident fishery as weli as the evolving family production stage Of course, the traditional planter household was generally responsible for more fishing servants than the household production unit. which required fewer servants to supplement family labour. Still. in both cases. servants had to be housed and fed. In the summer months. they usually stayed in separate cookrooms or bunkhouses. where they often prepared their own meals. But provisions were advanced against wages, and often sewing and washing services contra $d$ against pay: these goods and services involved mistresses of the household. ${ }^{12}$ not only as providers. but often as account managers as well (see Chapter 5) Boarding services came more directly under the hand of the houschold mistress in the winter, when households kept dieters to perform winter work in exchange tor their ' diet." or room and board. These winter servants were far fewer in number than the summer fishing servant population, but many resided within the household, itself, and thus full board had to be provided by the mistress of the house. In exchange, the family received valuable labour such as wood-cutting and the repair of fishing premises and gear in preparation for the next season.

Shopkeeping was also a source of income for a small number of women, primarily married women and widows. While merchant premises were the main source of provisions and supplies for local communities, shops also sold a small assortment of goods

${ }^{12}$ Note that a number of mistresses would have been assisted by female servants. 
- e.g., some foodstuffs, notions, small household articles. and home-made goods. Very few of these women appear in the written record, although several names surface. The eight court cases which Jane Austin of Ferryland initiated against customers of her shop in Ferryland. for example. suggest that she was doing a brisk trade in the $1830 \mathrm{~s}$ and $1840 \mathrm{~s}^{12 \mathrm{n}}$ A Mrs Leary was running a shop in Renews when she applied for a license to sell liquor from the premises in $1854^{127}$ And the number and variety of amounts in Mary Morris's account with Sweetman's that were contra'd against fishermen's accounts suggest that she may have been a shopkeeper or tavernkeeper, or both (see Appendix C. Section 8 ) The oral tradition indicates that shopkeepers were otten women, and that they usually also sold "a bit on the side" (i e. sold illicit liquor). ${ }^{12 s}$ thus, the tradition of female shebeen-keeping crossed the Atlantic with the Irish. This claim is substantiated by the 1786 regulations for retailing liquor, which included female shopkeepers in their scope $1: 4$

and +.1855

15.hee discussion on debt collection in Chapter 6

1:PANL. GN 5/4/C/1, Ferryland. Box 2. n.f. Regma i: Thomas l.earn: January 2

${ }^{128}$ The quotation comes from ATE but a similar observation was offered by numerous oral intormants. In this regard. most oral informants mentioned a woman in Shore's Cove. Cape Broyle harbour, who operated her business in the early to mid-20th century. outside the study period, but who serves to demonstrate the tradition. This woman ran a shop attached to her home and sold rum 'on the side that her husband and his brothers smuggled from St. Pierre on a regular basis. Many informants felt that she was the 'brains' behind the whole operation, and some suggested that she had inherited that role from her mother-in-law

${ }^{159} \mathrm{PANL}, \mathrm{GN} 2 / 1 / \mathrm{A}, 11 / 62-5 / 1786$. Instructions from Governor John Elliott to the Justices of the Peace. September 25. 1786. particularly f. 63 (see below). 
Female tavernkeepers appeared slightly more frequently in the records, due to the requirement that all public houses be licensed on an annual basis. Indeed, authorities carefully monitored the retailing of liquor because of its adverse effects on fishermen and seamen, and hence, the orderly operation of the fishing industry, itself. Witness the wording of a license issued to Elizabeth Sutton of Trepassey in 1794:

1 James Wallace the Governor of the Island of Newfoundland do allow and Licence Elizabeth Sutton of Trepassey Widow to keep a Common Ale House or Victualling House and to utter and sell Victuals. Beer. Ale, Cyder and other exciseable Liquors to be drunk in any part of Trepassey where she may chuse to reside for One whole year from the Twenty Ninth day of this present Month of September and no longer so as the true assize in bread. Beer. Ale, and other Liquors hereby allowed to be sold be duly kept. and no unlawtull Game or Games. Drunkness. or any other disorder be suffered in her House. Yard Garden or Backside. but that yood Order and rule be maintained and kept therein according to the Laws of the Realm of England in that behalf made, and that she does not Harbour or entertain at improper times or Seasons. Seamen Marines, or Soldiers belonging to His Majesty's Ships of War and that she do not secret. Harbour nor entertain with undue quantities of Liquors. Seamen and emploved in the Merchants Service or Servants employed in the Fishery during the Fishing season under such Penalties as the Court of Sessions can legally inflict exclusive of being deprived of her Licence. ${ }^{130}$

Although records on the trade are spotty. at leasi nine women received such liquor

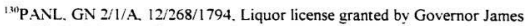
Wallace to Elizabeth Sutton of Trepassey. September 30, 1794 
licenses during the study period. ${ }^{13 t}$ And as noted above, the brisk third-party activity in Mary Morris's account with Sweetman's suggests that she may have been another acknowledged liquor retailer in the period. ${ }^{132}$

This representation. while significant. seems to pale in comparison with the 64 male names that appear as license holders in the same records and suggests that women participated only marginally in the trade. Indeed. there has been a tendency in the historiography to interpret women's operation of public houses primarily as an option in widowhood. for this was certainly the life-stage in which a woman was most likely to have a liquor license issued in her own name. It is true that the selling of liquor helped many widows and their families stave off difficult times. and authorities were cognizant of the often marginal nature of widows' livelihoods when granting licenses; Governor Pole, for example. acknowledged Elizabeth Sutton's need for a means of support as "a Widow with a small helpless Family" in the preamble of her license renewal in $1800{ }^{133}$ But the peculiarities of the licensing regulations and the principle of coverture likely masked a

${ }^{131}$ Lists of liquor licenses issued for the district for various years appear in P.ANL. GN $2 / 1 / A$, and GN $5 / 4 / C / 1$. Ferryland. Box 1 . However, there are many gaps in the records. Only the following years are covered with any degree of comprehensiveness 1750. 1795-1805, 1818-1819, 1831. 1837. 1840-1841. with sporadic references only for the rest of the study period.

${ }^{13}$-There is no indication in the ledgers of Mary's precise residence: she may be trom within the study area. or she may be serving as an example by next-best approximation.

${ }^{133}$ PANL. GN 2/1/A. 16/7-8/1800. Liquor license granted by Governor Charles $\mathrm{M}$ Pole to Elizabeth Sutton. October 12.1800. 
much more robust participation by married women in the trade.

Certainly, early regulations for the selling of liquor suggest a significant female involvement for they were as gender inclusive as they were pervasive. Throughout most of the study period. and particularly up to the early decades of the $19^{\text {th }}$ century. authorities were concerned about the impact of the liquor trade on the efficient running of the tishery. particularly the practice of crediting migratory fishing servants and seamen with liquor "to the Amount of the whole or great Part of their Wages," causing "all kinds of Disorders. debauchery s. Excesses and Idleness...." and leaving many fishermen with insufficient monies to pay their passage home at the end of the fishing season or support themselves during the winter ${ }^{134}$ Not surprisingly, then. orders and regulations to stem the flow of liquor to seamen and fishing servants emanated from various governors on a regular basis - particularly up to the early $19^{\text {th }}$ century ${ }^{134}$ The wording of these orders implied that both men and women were involved in the trade. Take, tor example, the fairly representative

\section{4}

134PANL. GN 2/1/A, 3/251/1764. Order, Governor Hugh Palliser, October 2.

${ }^{135}$ In addition to the above. see. for example. P.NL. GN 2/1/A: 1/17/1749, Order. Governor George Bridges Rodney. August 14. 1749: 1/113/1750 and 1/236/1751. Orders. Governor Francis William Drake, August 21. 1750, and August 13. 1751: 4/84-5/1767. Order. Hugh Palliser. October 31, 1767, 4/202/1769, Order, Governor John Byron. September 30, 1769:5/100/1772. Notice. Governor Molinoux Shuldham, July 4. 1772: 10/166/1785. Instructions to Justices. Governor John Campbell. September 14. 1785: 11/62-5/1786. Instructions to Justices. Governor John Elliot. September 25, 1786. $12 / 153-5.181 / 1792$. Orders. Governor Richard King, September 15 and October 16. 1792: 17/16-17/1802. Prociamation. Governor J. Gambier. October 21. 1802: and 35/268/1826. Proclamation, Governor Thomas Cochrane. February 20. 1826. 
instructions issued by Governor John Elliot to the justices of the peace in 1786 for issuing liquor licenses. In order to ensure the stability and respectability of the licensees, he required that:

every Person who shall be allowed to keep a Public House in this Island do give full \& ample security for his or her good Behaviour. and that no Person whatever be allowed to keep such Public House who does not. or shall not every Season. keep one Fishing Shallop at least: and Whereas further to encourage the Fishery and that it may be the Interest of every Individual resorting to this Island to promote the same His Majesty has been pleased to direct that every Person who shall keep on his, her or thear own Account any Shop or Store for selling or retailing any Goods or Commodities whatever be obliged to keep one fishing shallop at least [italics added]. ${ }^{136}$

Obviously, the spirit of these instructions toresaw the participation of women. However. the requirement that the license holder have at least one fishing shallop employed in the fishery together with the legal principle of coverture dictated that a license would be

${ }^{136} \mathrm{PANL}, \mathrm{GN} 2 / 1 / \mathrm{A}, 11 / 62-5 / 1786$. Instructions from Governor John Elliott to the Justices of the Peace. September 25, 1786. particularly f 63 . These instructions were received by the Ferryland magistrates and entered into the local court records. See P.ANL. GN $5 / 4 / C$. 1 . Box 1 . If $18-9$. The wording is similar, although the local records indicate that a license could be issued only to a person who would keep or give secturth for keeping at least one fishing shallop in the ensuing season. Similar wording appears in many of the orders cited above. To some extent, governors may have used this phrasing at least to maintain the appearance of enforcing Palliser's Act. However, it was also a genuine attempt to ensure the stability of liquor licensees - not a mere formality. When Governor King realized that the system was being abused, for example. he issued an order in 1792 requiring that all fishing boats of licensees be numbered and clearly identified bv the owners names on a conspicuous part of the boat. See PANL. GN 2/1/A. $12 / 81 / 1792$. Order. Governor King to Justices of the Peace. October 16. 1792 
issued in the name of a living husband, whether or not the business was a family enterprise or even being run primarily by the wife. ${ }^{13}$ ?

An example of this type of masked participation by women is provided by Elenor Evoy. later Welsh. of Ferryland. who was obviously involved in the trade through the 1790 s and early 1800 s, even though a liquor license was issued in her name only in the year 1799 Prior to that. the license for the Evoy's public house had been issued in the name of her tirst husband, Michael Evov. By 1800 . she had remarried, ${ }^{13 x}$ and the name of her second husband. James Welsh, appeared on various licenses for the district thereatter But it is likely that the license related to the same establishment, and a vital element of continuity in the enterprise was Elenor. herself. who most likely had been an integral part of the business before Michael died and continued to operate the public house. as the more experienced partner. in her new marriage with James Certainly. court records indicate that she rose to the defence of the business. in physical controntations and court proceedings, during both marriages - once without the benefit of any spousal support (see Chapter 6)

${ }^{117}$ Of course, at the husband's demise, the public house and the tishing shallop often reverted to the widow. By inference. then. these widowed tavern owners were also tishing employers. This criterion for respectability was eliminated by the new colonial legislature, for the first local Act to regulate the retail of liquor. passed in $183913 \mathrm{lic}$. . ('ip. 6). contained no requirement for the employment of a boat in the fishery and justices of the peace were given the discretion to determine who was "fit and proper" to hold a license This act. however. and its successor acts in the 1850 s $1 / 3$ / ict. (ap. 9. and /9 tici.. ('ap. ). did remain gender inclusive in terms of wording.

13×PANL. MG 205, Pole Papers. 1799-1800, 
Another illustration of the point is provided by the case of Thomas Leary and his wife of Renews. In the fall of 1854 , Mrs. Leary applied for a liquor license to operate a public house in the absence of her husband, who was away at sea. The local constable advised her. however. that she would be denied a license as "her husband was the proper person to make application." When Thomas returned from sea. he was apparently too ill to make his way to Ferryland to apply for the license. but evidently, this did not postpone the sale of liquor at the Leary premises. On January 2 of the following year, a summons was issued against Thomas for illegally selling liquor. and he appeared in court two days later as the "proper person," in the eves of the law, to answer the charge. However, the circumstances of the matter strongly suggest that it was Mrs. Leary who was primarily operating the business, and had probably been doing so at least since the previous tall This was not. however, an obstacle to the Learys' obtaining the license. Perhaps in the spirit of the season, or more likely with seasoned pragmatism, the local magistrates issued the license. and even backdated it to the day before the summons had been issued. ${ }^{1.9}$ Indeed, the ever-practical magistrates were often willing to issue liquor licenses

${ }^{130}$ PANL. GN 5/4/C/1. Ferryland. Box 2. n.f. Regina v. Thomas Leary. January 2 and 4. 1855 An episode slightly outside the time frame also adds to the argument that women's involvement was masked by the licensing regulations. In 1867. Peter Winser of Aquaforte was charged with selling liquor in his shop tvithout a license. The main witness for the Crown. James Croft. testified that it was actually Mrs. Winser who sold him the incriminating half pint of rum. Winser paid a small fine and obtained a license in his own name. but it is likely that his wife was working in the shop and selling liquor to the customers. See P.ANL, GN 5/4/C/1. Ferryland. Box 2. n.f. Regina v: Peter Winser. October 18, 1867 
after illicit sellers had been detected (usually. either by local constables or through local informants). This happened in the case of at least two female licensees. In 1794, for example. Margret Keney (or Kenny) was fined for selling liquor without a license. but the lack was rectified the following vear, when she was issued a license by magistrate Robert Carter ${ }^{1+0}$ And again, Elizabeth Sutton of Trepassey serves to illustrate the point. for she let her liquor license lapse by refusing to pay the licensing fee in 1802. In September, the visiting surrogate. Micajah Malbon. issued the following instructions to the local constable:

It is my direction that you go to the house of Elizabeth Sutton of Trepassey aforesaid who lately kept a public house known by the sign of the Ship and give her Notice to immediately take down the said sign and to desist from selling Ale. Beer. Spiritous Liquors or other strong waters, as on the contrarry her house will be pulled down and the penalty of $£ 10$ will be entorced against her

But by November. another surrogate. Lieut. McKillop (also McKellop). had issued her a new license for her house. ${ }^{1+1}$ Authorities could be accommodating, then. but thev were

${ }^{1+1}$ See: PRL, 3409 N45, n.f., Rex r. Margret Keney; July 14, 1794, and P.ANL. GN 2/1/A. 13-225-6/1797. Robert Carter to Governor Waldegrave, October 20. 1797. enclosing various accounts. including a list of liquor licenses that had been issued for Ferryland district for 1795

${ }^{141}$ PRL. 3409 N45. Trepassev, n.f., Re: Elizabeth Sutton. September 28 and November 18. 1802. Also. PANL, GN 2/1/A, 17/35/1802. Governor J Gambier to Lieut McKillop (also McKellop), October 30. 1802. 
equally reasonable with male applicants. and certainly, female publicans were held to the same standards of scrutiny and security as male tavernkeepers.

These cases also suggest a further way that the licensing system masked the involvement of women in the trade - i.e. that some women sold liquor without having the benefit of a license either in their own or their husbands' names. While Elizabeth Sutton. Margret Kenney, and Mrs. Leary eventually complied with regulations, others did not Mary Keating and her husband, tor example. were deported from Ferryland in 1773 for keeping a "disorderly house" in which thev entertained "riotous friends " ${ }^{-12}$ As noted above, the oral tradition acknowledges that women shopkeepers otten sold "a bit on the side" and that women who took in boarders would usually "have a drop" for their lodgers ${ }^{\text {thi }}$ There were also long-standing traditions of smuggling liquor (particularly West Indian rum) and distilling illicit whiskey in the area ${ }^{1+4}$ Smuggled rum was certainly

14:PRL. 3409 N45, n.f. Mary Keating v. Stephen Kennely: September 14. 1773. see also Mannion Name File. Ferryland. "Keating. Mary."

${ }^{113}$ The quotation is from AOT. Interview July 19. 1999: but numerous informants provided the same information.

${ }^{14}$ The local whiskev, called 'moonshine' by the $20^{\text {th }}$ centurv, was made with molasses. hops. and oats boiled in a pot from which a coiling tube extended, the coil was passed through cold water. causing the vapours from the boiling mixture to condense. and the liquid that exited the end of the tube would "tear the guts out of you." (MOB. Interview July 22, 1999 ) Being "pure alcohol," it was also highly tlammable: indeed, "If it wouldn t burn. it wasn t any good " (WC. Interview July 21, 1999.) Oral informants say that " everybody had their own little still" (RB. TP. MK. and WC) or knew who to borrow one from, although the practice appears to have been more common in some communities - e.g. Caplin Bay. Renews. St. Mary's - than others. Whiskev distillation again had long roots in Ireland. and the illicit form of the activity resurfaced in the modern era with the re-introduction of duties on Irish spirits in 1661 . The practice remained 
sold on the side in local shops and public houses, and while local whiskey was made mostly for personal consumption or sharing with family and neighbours. some of it was sold by local establishments or by other enterprising individuals.

In effect, then. there was much more female participation in the liquor retailing trade than a casual perusal of liquor licenses would suggest. Indeed, the entire hospitality trade was a thriving concern for many women in the area and provided considerable scope for them to contribute to tamily economies.

\pm 2.5 Community healing and midwifery

Most women on the southern Avalon managed the first-line medical treatment of their own families. combing their gardens and meadows, the forests and barrens. for medicinal herbs and plants and applying a host of home-remedies - tonics. herbal teas. poultices. salves. and charms - to illnesses and mishaps that occurred on a regular basis The skill and compassion required of effective healing were seen to be feminine characteristics and the medical arts had been handed down from one generation of women

common in the northwest well into the $20^{\text {th }}$ century, although large-scale. legally operating distillers in the southeast homeland of the Newfoundland Irish were making inroads into local markets by the late $18^{\text {th }}$ century because favourable government regulations permitted them to provide a cheaper. legal product. See Kenneth Connell. Irish Peasant Societv Four Historical Essavs (Oxford Clarendon Press. 1968). Chapter 1. Still, there can be little doubt that the long-standing tradition made the trans-Atlantic crossing with the Irish and was reinstated on the southern Avalon by people who could not afford. or chose not to afford. excised liquor. 
to the next.

But some women also nursed community members outside their families on a teefor-service basis. Indeed, this nursing tradition and, in particular, the dependence of visiting fishermen on the medical ministrations of local women stretched back to the days of unofficial settlement. As early as 1677 , for example, the Board of Trade was advised that: "In case the masters or servants of the ffishery are visited with sickness, as oftentimes it soe falls out, heere are noe other Nurseries for them but the Planters houses wch are allwayes at their service and their wives to attend them ..."

Within the study period of this thesis, there is evidence of the continuing tradition in court cases of the area. For example, when Redmond Ellward (or Aylward) was tatally injured in Cape Broyle in 1787. Honour Tobin was called in to attend him in his final days (and ultimately, to lay him out as well). ${ }^{\text {th }}$ That same year, a servant named Stokes was turned off a fishing room in Cape Broyle by the master of the voyage because his hands had become "benumbed" due to rheumatic fever, magistrate Carter arranged for a local woman (unidentified) to lodge and nurse him ${ }^{14 t}$ In 1818, Mary Sweeny of Ferryland brought Patrick Fowler to court for retusing to pay for the board and medical attendance

${ }^{155}$ PANL. GN 2/39/A. Box 1, William Poole to Board of Trade, October (or possibly September) 10.1677 (typed transcript from C O. Series). 26. 1787 .

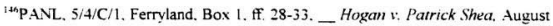

${ }^{14}$ P.ANL. 5/4/C/1, Ferryland. Box 1. ff 36-7. Stokes v:_Butler. August 18. 1787 
of his servant. According to the case record:

James Aylward was Servant to defendant who for the Convenience of Medical attendance was lett in care of the pltiff for Board Lodging and Attendance in his illness and agreed to pay her Twenty Shillings weekly for the same - at the end of Seven Weeks Aylward removed to his Service and the pltiff made a charge against him of Six pounds only requesting it from Fowler who objected to the payment.

An order of Court was sent to deft requesting him to pay plaintiff Six pounds or appear to Shew reason to the Contrary - $-^{148}$

This is the only case that details a tee based on a specific time period (20s. per week) Other records mention amounts without time frames (e g.. an 1831 claim of $£ 800$ against an estate for nursing the deceased. a claim of $\mathbf{E} 1.17 .6$ for "nursing and attendance" in 1847), so it is difficult to determine how representative Mary Sweeny's fee was for the period. Still. it is evident that certain women's expertise in healing was acknowledged and rewarded financially - again, providing cash for some family incomes in an economy that saw little cash from year to year. In the case of Mary Sweeny, her remuneration of 20 s. per week (2s. 10d per day), if projected into a 173-day earning period equivalent to that of the fishing season. ${ }^{\text {it9 }}$ would translate into $£ 24.3 .9$ - well within the wage range of $£ 16$ E30 for most fishermen in the area that year. Mary, then, was obviousiy being paid for 1818

${ }^{14 \times}$ PANL, GN 5/1/C/1, Ferryland, n.f...Mary Sweeny v. Patrick Fowler. October 7.

[19 Wages in the fishery were generally paid for a season that ran from May 1 to October 20 . or 173 days. 
her time as a skilled practitioner by contemporary pay standards.

However, while women who attended transient fishermen charged for their service, as communities stabilized and networks of reciprocal exchange developed between neighbours. women who provided nursing services for other community members more commonly were either paid in kind or rendered their services without charge. The oral tradition speaks of women who were particularly adept at making salves or stitching wounds - much-valued talents in communities where pups ${ }^{.150}$ and open wounds from mishaps with fishing hooks, knives, and saws were pervasive. And some women were known for providing particularly effective remedies for maladies such as persistent coughs. toothache. warts, trostbite indigestion. constipation, or "poor blood" They were consulted by community members on a regular basis, and while payment was rarely solicited. some foodstuff or service was usually proffered in exchange. unless the patient was too ill or poor to provide it. However, the community healer usually supported herself by other means. ${ }^{151}$

One such woman was Johanna (Jackman) Johnson. who lived in Renews in the

${ }^{150}$ Pustules around the wrists commonly caused by chafing at the sleeve edge from jigging and hand-lining in oilclothes.

${ }^{151}$ In her discussion of Martha Ballard. a midwife in Maine from 1785 to 1812 . Laure! Thatcher Ulrich notes that the midwife was just one of a network of female 'social healers' (compared with the "professional' medical men) who provided general health care to the community, although the midwife was, herself, the most visible and experienced of these women healers. See Ulrich. A Midwife's Tale: The Life of Martha Ballard, Based on Her Diary, 1785-1812 (New York: Alfred A. Knopf. 1990), pp. 61-6. 
mid-19th century. ${ }^{152}$ Although some of her nursing experiences may have occurred just beyond the time frame of this thesis, they reflect a tradition rooted in the study period. A display at the Capt. William Jackman Museum in Renews describes Johanna as "a local doctor of sorts" who is "credited with curing many ailments and saving the life of a man who had accidentally shot himself." A surviving great-granddaughter expanded on this very succinct biographical note in an interview. ${ }^{153}$ According to family folklore. Johanna had "nerves of steel." Salves for healing cuts and sores were her speciality, but she was also equal to larger demands on her abilities. When Phil Jackman's gun accidentally discharged and "blew the side otf him." for example. Johanna attended him. packing his wound continuously with a medicinal paste concocted of a flour base: she saved his life. using a whole barrel of flour in the process. Johanna was noted for being able to keep her head in an emergency. On another occasion (c. 1870s), she saved the life of a Miss Waish (later, Mother Patrick), who was walking over the harbour ice with her brother when she fell through a weak spot; Johanna rushed to her assistance and held her "by the bun of the head" until rescue arrived In addition to a caring nature, then, resourcefulness. courage. and calm in the face of crisis were earmarks of the early community nurse.

Similar characteristics were sought in midwives (many of whom were, indeed, also

15:Johanna's Jackman ancestors had come to Renews from the Isle of Wight in 1637. but like many other local English lines (including her in-laws, the Johnson family) had begun to intermarry with the Irish population in the early 1800 s and continued to do so as the $19^{\text {th }}$ century unfolded.

153MK. August 31, 1999 
the acknowledged healers of their communities). Midwives attended at the delivery of babies and cared for mother and child during a nine-day lying-in period. They also made efforts to handle complications that arose in the birthing process or the post-natal period Indeed. many were trusted practitioners who were perceived by women to be "as good as any doctor ${ }^{-154}$ Some, but not all, performed light housework (washing, baking bread) as part of their service. Like women who provided broader healing services, midwives were more likely to leave their patients' bedsides with a block of butter or some tresh eggs in their aprons than coins in their purse And they performed their work pro hono when circumstances required ${ }^{15 s}$ Still, because of their acknowledged expertise in a process that was fraught with danger for mother and child. the community perceived them to be entitled to some form of pavment if the patient could afford it. Certainly, the local courts acknowledged midwives claims for tee payment and recognized midwite expenses as legitimate claims in bastardy cases.

Thus. some evidence of midwifery fees appears in the court records. although

${ }^{13}$ Quotation from AK. Interview August 26. 1999: but many informants expressed the same view

${ }^{154}$ Janet Mcnaughton provides a much more detailed description of traditional midwifery in Newfoundland in "The Role of the Newfoundland Midwife in Traditional Health Care, 1900 to 1970" (Ph.D. Thesis, Memorial University. 1989). Although she is discussing $20^{\text {th }}$-century midwives, her observations on traditional obstetrical practices and the status of midwives in their communities correspond with information from the southern Avalon for the study period of this thesis. 
amounts of claims are not always detailed. ${ }^{156}$ A small clustering of cases around the tum of the $19^{\text {th }}$ century indicate that $2 \mathrm{~s}+\mathrm{d}$ per day, or $£ 11.0$ for a lying-in period of nine days. was a standard fee at that time ${ }^{\text {ts? }}$ (Extra amounts were charged if the mother required additional nursing due to some childbed illness or if the child required extra attendance beyond the regular lving-in period.) In 1822, a midwife charged 40s. for a lying-in period in a bastardy case - almost double the earlier fee

Once again, a comparison of fishing wages with midwifery tees (Table 4.5 ) can make no claims to representativeness. given the scarcity of data. but it does raise some intriguing possibilities. The comparison suggests the possibility that midwives during the period were deemed to deserve payment as skilled workers Midwifery fees at the turn of the century were roughly equivalent. on a per diem basis. to a fisherman's wages in 1798 The proportion declined to $40-67$ percent of fishermen's earnings in 1802 . but this was at the onset of vastly inflated wages in the tishery due to the effects of the Napoleonic Wars.

\footnotetext{
${ }^{150}$ Note that these were fees for medical attendance, not witness tees as were otten allowed in bastardy and fornication matters in courts in colonial America.

${ }^{157}$ The standard fee charged by Maine midwife Martha Ballard from 1785 to 1812 was $6 \mathrm{~s}$. per delivery. although wealthier patients otten paid more. Like southern Avalon midwives. she often received payment in kind or a combination of cash and kind. and sometimes she forgave fees altogether. Unlike southern Avalon midwives, however, she generally did not attend the mother in the lying-in period unless there were complications Thus. she was actually paid a higher rate for her time than midwives on the southern Avalon. Martha also provided general medical services and, for one case. received the sum of $\$ 8.50$ for 17 days attendance. or $\$ 0.50$ per day: this can be compared with the standard charges of contemporary physicians in her area from \$0 50-\$1 00 per visit. See Clrich. A Midwife's Tale, pp. 188-9. 197-200, and 247-8.
} 


\section{Table 4.5 - Midwives' earnings compared with fishermen's wages}

\begin{tabular}{|c|c|c|}
\hline Period & Midwife & Fisherman \\
\hline & & $\underline{1798}$ \\
\hline $\begin{array}{l}1790 \text { s- } \\
\text { early } 1800 \text { s }\end{array}$ & $\begin{array}{l}\text { E1.1.0 per 9-day lying-in period or } \\
\text { 2s.4d per day }\end{array}$ & $\begin{array}{l}\text { E19-21 per season or } \\
\text { 2s.2d-2s. } 5 \text { d per day } \\
\text { OR }\end{array}$ \\
\hline & & $\underline{1802}$ \\
\hline & & $\begin{array}{l}\text { E30-50 per season or } \\
3 \text { s } 6 \mathrm{~d}-5 \mathrm{~s} .9 \mathrm{~d} \text {. per day }\end{array}$ \\
\hline 1822 & $\begin{array}{l}\text { 40s (£2) per lying-in period or } \\
\text { ts 5d per day }\end{array}$ & $\begin{array}{l}\text { E 16-25 per season or } \\
\text { Is } 10 \mathrm{~d}-2 \mathrm{~s} .9 \mathrm{~d} \text {. per day }\end{array}$ \\
\hline
\end{tabular}

Note that the 1798 and 1802 wage ranges for the fishery relate to the entire English Shore, not the southern Avalon specifically.

SOLRCE: Derived from Table 4.1 and various court records from the period

Meanwhile, the 1822 comparison shows a midwife's earnings as representing from 160 239 percent of the daily wages earned by fishermen that year. The comparison. again. is impressionistic. Certainly, all these amounts may have been inflated by the fact that they were being charged in bastardy cases: most certainly. fees charged outside litigation were lower. if fees were charged at all. Yet these substantial rates were allowed by the local courts. and suggest that a midwife"s services were assigned considerable value vis-a-vis the main industry of the period

In addition to occasional monetary return. the role of midwife and also that of community healer attracted respect and status in the plebeian community. There is sometimes a tendency to look upon these practitioners as low-status stopgaps in areas 
where doctors were not available. But access to doctors during the period was not as limited as one might initially suppose. Court records indicate that there were several male medical practitioners operating in the area from the late $18^{\text {th }}$ to the mid $-19^{\text {th }}$ centuries. although the numerous cases initiated by these medical men suggest that the bulk of their practices was taken up with the large male fishing population. ${ }^{15 x}$ In this regard, male practitioners had an advantage over most female attendants through much of the period. because doctors ${ }^{\circ}$ fees for attending fishing servants were secured by a system of holding back set amounts trom servants ${ }^{*}$ wages each season (Greenwich Hospital Fees - known locally as 'doctoring fees') ${ }^{150}$ However, women medical attendants were often called upon by both visiting fishermen and the local community - not just from necessity, but by choice. Granted, their willingness to provide service for little or no pay and their fierce resolve to attend regardless of adverse weather conditions or long distances made them a very attractive alternative Still, their ability to deal with many complications "as good as

${ }^{15 x}$ This impression is created by the large numbers of fishing servants. or their employers. among the debtors in these court actions. Granted, this may also simply reflect the disproportionately high numbers of male servants in the population. or suggest that fishing servants/employers were more recalcitrant bill-payers. Still, their overwhelming. almost exclusive. presence as defendants in court actions initiated by local doctors does suggest that the main focus of the doctors' attentions was the transient fishing servant population.

${ }^{159}$ Even this system was not foolproof. however, as the court records contain numerous cases in which fishermen disputed payment of the fees. In 1836. an insurance fund for sick and disabled seamen, fishermen, shoremen, shareman, sealers. and other fishing servants was established by legislation, with fees being held back from employees wages for medical treatment. See $6 \mathrm{Wm}$. IV. cap. I. An Act for the Relief of Sick and Disabled Seamen, Fishermen, and orher Persons," passed March 30, 1836. 
any doctor" lent them a similar status in the eyes of community members. Like Johanna Jackman Johnson, they were seen as "local doctor[s] of sorts. "t(x)

Indeed. some of these women attained the designation of "doctress" in official reports of the day. An example by next-best approximation, from nearby Fortune Bay, is provided in a report from Lieut. Douglas of the British transport ship HMIS Phyllis, which was wrecked off Cape Ray on October 13. 1795. The officer reported that the survivors were brought into Great Jarvis. Fortune Bay, in terrible stages of trost-bite. There, a

${ }^{1+10}$ Oral informants spoke with great appreciation and affection tor the midwives who had birthed them. A typical example was Mrs Maggie Johnnie Kavanagh of Caplin Bay. who, in addition to her work in raising a large family and her involvement in household production. also worked as a laundress to local middle-class families and was a highly respected midwife. She never refused to come out to a birth, and on one stormy night when the horse drawing her carriage could go no further, she set out and walked the remaining distance herself. Similar stories of irrepressible midwives appear in the literature Elizabeth Smithson. $18^{\text {th }}$-century midwife of Killingworth. Connecticut, was eulogized as "a person of Humility, Affability. Compassion" and "a Midwife... of Superior skill and Capacity." See Ulrich, Midwife's Tale, p. 341-2. Light and Prentice discuss Elizabeth Doane of Barrington. Nova Scotia, whose healing and midwifery skills were so valued by her community that the town proprietors gave her a grant of land to ensure that she would stay: she continued her services into old age, carried around in a basket hung from a pole carried by two men. See Light and Prentice, eds., Pioneer and Gentlewomen. pp. 145-9. Susan E. Merritt tells a similar story of 'Granny Ross' of Cape Breton Island. Nova Scotia. whose abilities were highly esteemed by the community: she practiced in old age, even after being afflicted by blindness, and was transported by family members by sled in the winter and by wheelbarrow in summer. See Merritt. Her Story II: Women from Canada's Past (St. Catharines. Ont: Vanwell Publishing, 1995), pp. 18-26. Catherine M. Scholten discusses the high regard and status that midwives enjoyed as medical practitioners in colonial America until they were squeezed out by formally educated male pysicians in the $19^{\text {th }}$ century. See Scholten. " On the Importance of the Obstetrick Art : Changing Customs of Childbirth in America 1760-1825." in Kerber and de Hart. eds., Women's America, pp. 51-65. 
"native doctress" amputated their frozen limbs and effected a "miracle" cure. ${ }^{16]}$

And within the study area itself, in Trepassey, a local "doctress" was also operating at the turn of the $19^{\text {th }}$ century, rather to the dismay of the visiting surrogate and a local male practitioner who felt that he was being deprived of a significant portion of his doctoring fees In 1802. surrogate Micajah Malbon issued the following warning to Margaret Curry

I hereby give you Notice that you imniediately desist trom tollowing your practice as a Doctress at Trepassey or any other place on the Island of Newfoundland as if I find upon my return you continue to tollow the practice I will cause your house to be pulled down and have you conveved out of the Island toi

Likely, the surrogate felt that Curry had stepped beyond gendered bounds - not operating as a midwife or nurse, as befitted her sex, but as a doctor, providing medical services to local fishing servants. The gender order had been inverted, and the surrogate hoped to use the threat of deportation to set the world aright and bring Curry back in line. His effort

${ }^{16 i}$ Report of Lieut. Douglas. HMIS Phy/lis, cited in Galgay and McCarthy. Shipwrecks, vol. 4. Within the context of $18^{\text {th }}$-century Newfoundland, the term native was otten used to distinguish local inhabitants of European extraction from visiting. migratory fishermen. Douglas is likely referring in his report to a local woman of European extraction, not an aboriginal woman.

${ }^{162}$ PRL. 340.9 N45. Trepassey-St. Mary's, n.f. Notice of Micajah Malbon. Surrogate. to Margaret Curry, September 27, 1802. 
was not immediately successfull, however. simply because some fishing servants continued to use her services rather than those of the male doctor for the district, Michael Davenport Dutton. This did not sit well with Dutton. who was losing potential clients to his female competitor. The following year, he sued local merchant and boatkeeper Clapp \& Co. tor all moneys that had been stopped from servants' wages for medical services to pay. Mrs. Curry. It is evident from the ensuing court hearing that Mrs. Curry had been the medical practitioner of choice for Clapp \& Co in the past: it is also evident that she had continued to practice doctoring, despite Malbon's order to desist, for while some servants were nou being seen by Michael Dutton, others were still going to Mrs. Curry. One servant. for example, explained that he had asked $\mathrm{Mr}$. Clapp to allow him to continue to see Mrs. Curry on account of Dr. Dutton misbehaving to one of his fellow servants by making him an Improper Charge " Another testified that he had applied to Mr Clapp to employ Mrs. Curry as his doctor because $\mathrm{Mr}$. Dutton had refused to attend him and his family When Dutton had approached Clapp for the doctoring monevs. Clapp had told him the monevs had been stopped for Mrs. Curry, and that Dutton must look to the servants he had treated for any payment. As the dispute played out in local court. another visiting surrogate. John McKillop. expressed his opinion that while it was customary for an employer to appoint a particular medical practitioner for his or her servants. Clapp had not. in this case. appointed a "proper person" in Mrs. Curry. Lltimately, the matter was decided by the Chief Justice for the island. Thomas Tremlett. who ordered that Dutton's claim be 
recovered from the servants current wages with their present masters ${ }^{163}$ There is no further evidence of Mrs. Curry's medical activities in the court records, and one can only assume that after this matter, she either stopped her doctoring or, perhaps more likely. went underground with her practice

But while Mrs. Curry was not considered by the court to be a "proper person" to provide medical services. it is important to note that she was operating within. and being paid by, the local community as an acknowledged medical practitioner And fishermen and their families were not consulting her because she was a cheaper alternative. for the tull amount of doctoring fees was being held back from their wages for her services.

Rather, many went to her by choice. because like other female practitioners of the day. she had established trust with her skill, accessibility, and tair dealing. Furthermore, while the increasing male professionalism of medical practice throughout the $19^{\text {th }}$ century eroded the status of community healers in many areas. ${ }^{\text {in }}$ the high regard for midwives and community nurses along the southern Avalon remained intact within the plebeian community throughout the study period.

${ }^{1{ }^{3}}$ PRL. 340.9 N45. Trepassey-St. Mary's. n.f.. H/ichael/ D/avenport/ Dutton v: ( Tapp \& C $O$.. the initial court hearing was undated. but the hearing before Chief Justice Tremlett was dated September 27. 1803.

${ }^{\text {tw }}$ See, for example, Ulrich, Midwife's Tale, p. 214: and Scholten. '. On the Importance of the Obstetrick Art. ${ }^{\text {"N }}$ p 53 


\subsubsection{School teaching}

Another proto-professional occupation open to women on the southern Avalon was school teaching. This occupation provided a limited number of Irish plebeian women with the opportunity to earn not only a regular salary but also community status and prestige ${ }^{105}$ But as they made inroads into the echelons of the 'respectable' folk, school mistresses came up against middle-class assumptions about women 's place and the value of women's work that were not as intrusive in the lives of plebeian women who remained in the household production unit.

The Newtoundland government passed its first Eifucation fct in Mav. $1836^{1000}$ and the newly appointed Boards of Education for the districts of Ferryland and Placentia-St. Mary's began immediately to make provision for establishing public schools along the southern Avalon. There is no evidence of formal schools operating in the study area betore this time. other than a Sunday School established in Ferryland in the 1820s by the SPG. ${ }^{\text {th }}$ Communities may have made some informal arrangements for schooling their youth. For example. the governor reported to the Colonial Office in 1815 that the

\footnotetext{
${ }^{\text {ths }}$ As one oral informant observed: "You had to raise your cap to the teacher." AOT. Interview July 19. 1999.

tho $6 \mathrm{Wm} .1 \mathrm{H}$ : Cip. 13, An Act for the encouragement of Education in this colomy. passed May 6. 1836

${ }^{167} \mathrm{C}$. O $194 / 70$. f. 227. Governor's Annual Return and Additional Information respecting Newtoundland. 1825 .
} 
children in Bay Bulls district were "taught by the women in the summer and by a man in winter ${ }^{-168}$ It is also possible that individuals may have tutored privately in their own homes, but the only evidence encountered was the payment of £2.5 0 in 1841 by Alan Goodridge to Sarah Garland for "' 1 ": years Schooling p. Boys. ${ }^{-169}$ Any trace of other private tutors, if they existed, has been lost from the written record or collective historical memory

The newly established educational system in 1836 was non-denominational. as were the two school boards that were appointed for the area. although their membership came predominantly from the English-Protestant, middle-class community ${ }^{101}$ Still, the initial bye-laws and resolutions adopted by the two boards were ecumenical in spirit requiring that nothing of a sectarian nature be taught in the school, that no religious textbooks be used, and that no religious instruction be given on school premises or during school hours ${ }^{\circ}$ In 1843 , however, legislation was passed that divided the education grant 1815

${ }^{\text {ins }}$ C.O $194 / 57, f .12$. Governor's Annual Return and Additional Information.

In'PANL. MG 473. Goodridge Collection. 18+1 Ledger, $f 306$.

1"In Ferryland, tor example, ten out of 12 members appointed in May. 1836, and ten out of 13 in December. 1836. came from the English-Protestant group. Similarly, in Placentia-St. Mary's, ten out of 13 of those appointed in August. 1836. and nine out of 13 appointed in December. 1836, came from this group. See Journal of the Legislative Council [JLC], 1836 (St. John's. Rvan and Withers. Queen's Printer. 1837). Appendix. "Education Returns" (unnumbered and unpaginated).

"See JLC, 1836. Appendix "Education Returns". Bye-laws. Rules. and Regulations adopted by the Ferryland Board of Education, October 16. 1836: and Resolutions passed at a meeting of the Placentia-St. Mary's Board of Education. August 
to support separate Protestant and Catholic systems, and thereafter. Irish schoolchildren on the southem Avalon came under the jurisdiction of Catholic boards ${ }^{172}$

From the beginning, female teachers were a significant presence in southern Avalon schools. ${ }^{173}$ Women comprised slightly more than half the first teaching roster for Ferryland district in 1836-37, for example, particularly after certain male candidates did not survive the screening process:

Initially appointed or under consideration. 1836 Roster, October 4.1837

$\begin{array}{lll}\text { Renews } & \text { John Dwyer } & \begin{array}{l}\text { John Dywer. pro rem. pending } \\ \text { judgment on complaints received }\end{array} \\ \begin{array}{ll}\text { against him } \\ \text { Fermeuse }\end{array} & \text { Thomas Larassey } & \begin{array}{l}\text { Thomas Larassey } \\ \text { Jane Winsor }\end{array}\end{array}$

22. 1836. See also PANL. GN 21/1/A. Department of Education, Minute Book of the Protestant Board of Education for the District of Ferryland. 1836-37. and 1843-1878. Minutes. September 26 and October 8.1836 (note that while the series is identified as relating to the "Protestant Board." the board was non-denominational until separate Catholic and Protestant systems were created in 1843). These requirements did not become statutory until 1838, with the passing of 2 tict. ( Iap. 5 , An Act to amend. An Act for the Fincouragement of Edication in this Colon: passed October 25. 1838

1"See 6 tict. ('ap 6. An Act for the Encouragement of Euchatuon th this c olony. passed May 22. 1843.

${ }^{177}$ This was not the case everywhere on the island. In Conception Bay schools. for example, there were no female teachers appointed by the non-denominational board from 1836-1843. The Roman Catholic board in the district appointed only one female teacher during the period 1843-1857 - Mary Hearn, at Bryant's Cove. See PANL. GN 21/6/2. Department of Education. Minute Books of the Roman Catholic [again, nondenominational until 1843] Board of Education for the District of Conception Bay. 18361857 


\begin{tabular}{|c|c|c|}
\hline $\begin{array}{l}\text { Ferryland } \\
\text { Caplin Bay }\end{array}$ & Elizabeth Coulman & Elizabeth Coulman \\
\hline & Nicholas Fitzgerald & Elizabeth Coulman \\
\hline Cape Broyle & - & $\begin{array}{l}\text { Ann Coryear (school at Riverhead if } \\
\text { suitable school room found) }\end{array}$ \\
\hline Brigus & Catherine Power & Catherine Power \\
\hline Athlone & - & Jane Cashin \\
\hline Toad's Cove & - & - \\
\hline Mobile & - & - \\
\hline Witless Bay & Nicholas Fitzgerald & Nicholas Fitzgerald (?) \\
\hline Bay Bulls & James Murphy & $\begin{array}{l}\text { Jos }^{\text {h }} \text { Murphy [likely same person. } \\
\text { with error in transcribing name in } \\
\text { Minutes] }]^{174}\end{array}$ \\
\hline
\end{tabular}

(Note that most of the surnames were Irish. or represented English lines that had married into the Catholic community, with two exceptions, reflecting the predominating ethnoreligious group within the school populations of specific communities ${ }^{159}$ ) There was only one school in the St. Mary s region. taught by school-master Lawrence Neill, but of the

${ }^{17}$ PANL, GN 21/1/A. Department of Education. Minute Book of the Ferrvland Board of Education. Minutes. September 26, October 8 and 14, 1836, and April 5 and October 4.1837 . Note that Nicholas Fitzgerald's name does not appear in the final roster of October 4.1837 , but there is no indication elsewhere in the Minutes that he has been replaced. Also. Robert Fitzharris was originally to be offered the school in Caplin Bay. but he had a drinking problem. He was to provide a certificate swearing that he would abstain from all intoxicating liquors (Minutes. October 8.1836 ), but obviously he could not comply and his name did not appear on the final list.

1"SThe most glaring exception was the appointment of Elizabeth Coulman, an English-Protestant woman who was hired to teach the predominantly Irish-Catholic school population of Caplin Bay and Ferryland: while she may have been well-qualified for the job. one wonders how much the predominance on the board of English-Protestant merchants from Caplin Bay and Ferryland, her direct relationship to the locally powerful Carter family. and the fact that she had several relatives on the board. were factors in her hiring. Jane Winsor was also of English-Protestant descent with middle-class ties. but this ethno-religious group predominated in her community of Aquaforte 
total of six teachers for the Placentia-St. Mary's district, three were male and three were female. ${ }^{176}$ By 1860 , the teaching roster for the entire area was divided evenly between the sexes, although there was a marked predominance of male teachers in Bay Bulls district (four out of five) and of female teachers in Ferryland district (six out of eight in public schools, in addition to eight nuns teaching at convent schools). ${ }^{1 T T}$

There was nothing specifically stated in legislation or the bye-laws of school boards in the area during the study period that differentiated by gender in terms of teaching levels and salary scales for teachers during the study period. Nonetheless. it is evident that certain gendered assumptions underwrote many board policies - and the boards had wide-reaching powers in terms of hiring. teachers' salaries. and the overall management of schools. In terms of teachers" salaries, for example, available evidence suggests that masters consistently tended to be paid more than mistresses. regardless of class size and subjects taught. a differential that was magnified when one considers that masters in outharbours were permitted time off in the summer to go tishing if required (see Table +6) ${ }^{1-x}$

${ }^{15} \underline{\mathrm{JLC},}$ 1836, Appendix, "Education Returns."

17. Report upon the Inspection of Catholic Schools in Newfoundland. 1859 (Michael J. Kelly. Inspector). pp 352-418. Note that the inspector did not provide a full return for the St. Mary's area and that four schools in that bay were not accounted for.

${ }^{1 *}$ The Ferryland Board. for example, confirmed that all schoolmasters under its jurisdiction would "be allowed from $15^{\text {th }}$ June to $1^{\text {t }}$ September to their own benefit to employ themselves as they chose. subject to the discretion of two Commissioners [the stipulated time frame indicating that the anticipated employment of choice for those 
Table +6 - Teacher salaries and class sizes on the southern Avalon

School board for Ferniland. 1836-37

Location
Renews
Fermeuse
Aquaforte
Ferryland and Capelin Bay
Cape Broyle
Brigus
Athlone
Toad's Cowe
Wobile
Witless Bay
Bay Bulls

Roster. October 4. 1837

Salar:

Es d

John Dwyer, protem 14. 5

Thomas Larassey 11.5

Jane Winsor 10

Elizabeth Coulman 13.10

Ann Corvear 10

Catherinc Power 10

Jane Cashin $\quad 5$

$\begin{array}{ll} & 10 \\ & 10 \\ \text { Nicholas Fitzgerald |"' } & 15 \\ \text { James lor Joseph| Murphy } & 16\end{array}$

SOLRCE: PANL. GN 21/1/A. Department of Education. Minute Book of the Ferryland Board of Education. Minutes. July 20.1836. and October 4,1837 It should be noted that the Board was attempting to allot teachers salarics on projected class sızes. based on the 1836 census returns: but there is also the sense in the Minutes that the Board made efforts to hire masters in preference to mistresses for the larger ecntres. and pad them higher salanes accordingly: The one exception was Elizabeth Coulman of Ferriland, who was appointed to teach the children of Ferriland and Capslin Bay As indicated in the text. it is likely that the largely middle-class. English-Protestant Board. mostly from the Ferrvland-Capelin Bay area, was determined to have a teacher from their own eircle for their children: and as the men from this class would hardly have been teachers. an English-Protestant woman was the next best alternative.

masters who took advantage of this clause would be tishing]." See PANL. GN 21/1/A. Department of Education. Ferryland Board of Education. Minutes of meeting October 4. 1837. Classes were held vear-round at this period, with short Christmas, Easter, and summer breaks. although most children would not have attended on such a regular basis. Vote also that teachers salaries were supplemented by student fees, but although a scale of fees was legislated. schools boards, and later, teachers, had the authority to remit them in cases where students could not afford them - a common situation in many outports at the time. Thus, the teachers remuneration from pupil fees was very irregular and usually quite small. 
School board for Placentia-St. Manis. 1839

\begin{tabular}{|c|c|c|c|c|}
\hline Location & No. of schools & No of scholars & $\begin{array}{l}\text { Teacher } \\
\frac{\text { Male }}{\text { E }}\end{array}$ & $\begin{array}{l}\text { r's salar } \\
\frac{\text { Female }}{\varepsilon}\end{array}$ \\
\hline Great Placentıa & 2 & 84 & 30 & 20 \\
\hline Little Placentia & 2 & 106 & 30 & 20 \\
\hline Saint Mary's & 2 & 87 & 30 & 20 \\
\hline Red Island & $\overline{1}$ & 27 & $x$ & - \\
\hline Trepassey & 1 & +3 & 30 & . \\
\hline Harbour Bsaufet & 1 & 27 & 24 & - \\
\hline Merasheen & 1 & 29 & - & 25 \\
\hline Point Verd & 1 & 36 & - & 10 \\
\hline Presqui & 1 & 31 & 25 & - \\
\hline Barren Island & 1 & 26 & - & 18 \\
\hline
\end{tabular}

SOURCE. JLC. $18+0$ (St. John's: Rvan and Withers. Queen's Printer. 1840). Appendix (unnumbered and unpaginated).

School board for Placentin-St. Maris. $18+0$

Location Pupils
No of schools Male Female $\quad \begin{gathered}\text { Teacher's salary } \\ \text { Male Female } \\ \Sigma\end{gathered}$

$\begin{array}{llllll}\text { Great Placentia } & 2 & 34 & 30 & 30 & 20 \\ \text { Little Placentia } & 2 & +8 & 33 & 30 & 20 \\ \text { Saint Mary's } & 2 & 20 & 16 & 30 & 20 \\ \text { Trepassey } & 1 & 27 & 9 & 30 & -\end{array}$

SOURCE: JLC. $18+1$ (St. John's: Ryan \& Withers. Queen's Prunters. 18+1). Appendix No. 21 (unpaginated). 
School returns for southem Avalon, 1858

Bav Bulls district

\begin{tabular}{|c|c|c|c|c|}
\hline Location & Tipe of school & № of pupils & Teacher & Salar: \\
\hline & & & & $\varepsilon$ \\
\hline Bay Bulls & Commercial & 76 & Mr Morrissey & 40 \\
\hline Witless Bay & Board & $80)$ & Mr. Fogarty & 40 \\
\hline Mobile & Board & 32 & Miss Hanion & 18 \\
\hline Toad's Cove & Board & +8 & Mr Hanlon & $\begin{array}{l}25 \text { ( }+5 \text { wceks } \\
\text { off for tishing) }\end{array}$ \\
\hline Caplin Cove & Board & 30) & Mr Driscoll & 18 \\
\hline
\end{tabular}

Ferrvland distrier

\begin{tabular}{|c|c|c|c|c|}
\hline Location & Tipe of school & No of pupils & Teacher & Salan \\
\hline & & & & $\varepsilon$ \\
\hline Brigus & Board & 35 & Miss Doyle & 12 \\
\hline Cape Broyte & Board & 30 & Miss Kully & 10 \\
\hline Ferryland & Commercial & 43 & Mr Kelly & 50) \\
\hline Fermeuse & Board & 45 & Mr O Neil & $\begin{array}{l}\text { 2) (-8 wecks } \\
\text { off for tishing) }\end{array}$ \\
\hline \multicolumn{3}{|l|}{ Renews. } & Mr. Ling & 25 \\
\hline \multicolumn{5}{|c|}{ Renews/Fumale } \\
\hline North Side & Board & 60 & Miss Power & 12 \\
\hline \multicolumn{5}{|c|}{ Renews/Female } \\
\hline South Side & Board & 20 & Mrs. Lawlor & 12 \\
\hline Aquatorte & Board & 22 & Mrs, Oliphant & 10 \\
\hline
\end{tabular}

\section{St. Maris district}

No returns avaulable. but five schools in operation in the area at St. Mary s (I). Holyrood (1). Salmonicr (2). and John's Pond (1).

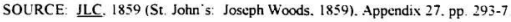


School returns for southern Avalon. 1859

Bav Bulls district

$\begin{array}{ll}\text { Location } & \text { Tvpe of schoo } \\ \text { Bay Bulls } & \text { Commercial } \\ \text { Witless Bay } & \text { Board } \\ \text { Mobile } & \text { Board } \\ \text { Toad's Cove } & \text { Board } \\ \text { Caplin Cove } & \text { Board }\end{array}$

Ferriland district

$\begin{array}{ll}\text { Lecation } & \text { Tspe of schoo } \\ \text { Brigus } & \text { Board } \\ \text { Cape Broyle } & \text { Board } \\ \text { Fermeuse } & \text { Board } \\ \text { Runews/Fumale } & \\ \text { North Side } & \text { Board } \\ \text { Renews/Female } \\ \text { South Side } & \text { Board } \\ \text { Aquaforte } & \text { Board } \\ \text { Kingman's } & \\ \text { Cove } & \text { Board } \\ \text { Caplin Bay } & \text { Board }\end{array}$

St. Maris district

Location Ivpe of school
Pupils Male Female

$\begin{array}{ll}53 & 54 \\ 60 & 40 \\ 21 & 15 \\ 30 & 30 \\ 19 & 16\end{array}$

Pupils

Male Female

$\begin{array}{ll}20 & 30 \\ 14 & 21 \\ 45 & -\end{array}$

$15^{1} \quad$ is

$10 \quad 17$

$5 \quad 12$

$10 \quad 14$

$11 \quad 15$

Pupils

Walc Female Teacher 58 -

Teacher

Miss Doyle

Miss Kelly

$\mathrm{Mr} O \mathrm{~N}$ il

Miss Power

Mr Kichoc

Mr. Walsh
Teacher

Salar: \&

Me Mornssey

40

Mr Fogarty

40

Miss Hanion

Mr. Hanlon

Mr. Driscoll

off for fishing)

20

Salar

$\frac{\text { Salan }}{E}$
15
10
$20(-x$ wicks
off for fishing)
18
12
10
12
$12(-$ summer
off for tishing)

Mrs. Lawlor

Mrs. Oliphant

Miss Condy

off for tishing)

St Maris Commercial

$\underline{\text { Salary }}$

E 56

Returns for four other schools in the district - Holyrood (1). Salmonier (2). John's Pond (1) - not avalable.

'The boys' school at Renews had closed the previous school year. and some of its male students had relocated to the girls' school on the north side of the harbour. The teacher. Miss Power. apparently received a raise of $£ 6$ for this additional responsibility. but her neu salary of $£ 18$ did not approach the $₹ 25$ eamed by the boys former master. Mr. Ling. wen though her total class size was larger.

SOURCE: JLC. 1860, Appendix 36. pp. 383.389. and 405 . Note that this table does not include convent schools in the area. where the Presentation sisters taught without salaries. 
This differential was grounded in the middle-class assumption that men. as primary income earners, required higher salaries than women, who were seen as secondary income earners. It also reflected the desire to offer a more advanced curriculum to boys to prepare them for careers outside the home and the notion that male teachers (the teachers of choice for boys' schools) were more capable of teaching higher level subjects. leaving women to prepare female students for non-professional careers. Certainly, when sexsegregated schools were established in several communities in the study area. ${ }^{179}$ male teachers were hired to teach boys and female teachers, to teach girls. However, many of the board schools in the area remained mixed throughout the period. and with the exception of students in two commercial schools that were operating in Ferryland and Bay Bulls in the late 1850 s. most of the scholars along the southern Avalon. male and temale. remained at elementary levels of reading, writing. spelling. and cyphering. with very tew venturing into intermediate subjects such as history. geography. navigation. or industrial arts Indeed, of the 107 students at the Bay Bulls commercial school in 1859, none were taking geography. English grammar. or navigation. ${ }^{\left|{ }^{*}\right|}$ Thus, any rationale for salary differentials between masters and mistresses based on subjects taught was on tenuous

${ }^{-9}$ During the study period, sex-segrated schools were established in St. Mary's (by 1838). Renews (1840). Admiral's Cove in Fermeuse (1854). Ferryland (1858-59), and Vitless Bay (1860). Just outside the study period. separate schools for boys and girts were established in Cape Broyle (1865) and Bay Bulls (1866). See Galgav et al. Pilgrimage of Faith. See also the various Education Returns in the Appendices of the $\underline{\mathrm{JLC}}$

${ }^{160}$ JLC. 1860 . Appendix No 27. p. 383 
ground. Indeed, one of the most comprehensive curricula of the day was offered by the Presentation nuns in their convent schools. and Bishop Mullock ventured the opinion in I 859 that "it would be a very great improvement if the incompetent Masters, who only receive a small salary in the small outports." were replaced by school mistresses trained by the nuns at their main convent in St. John's (although a prosyletizing agenda may have inspired some of his enthusiasm) ${ }^{\text {int }}$

The assumptions that governed differentials in salaries and training requirements for male and female teachers remained an understated principle until beyond the study period. Thev were more formally introduced in the requirements tor teacher certification that were legislated in 1876: the resulting Syllabus for Grading Teachers stipulated that for Grade I (highest level) certification, female teachers, unlike male teachers, did not have to pass examinations in the advanced subjects of algebra. Euclidean geometry. and practical mathematics. but were required to be able to give instruction in domestic economy. needlework, knitting. and netting. ${ }^{\text {I8z }}$ The arguments for increasing the pay of

${ }^{181}$ UC. 1860. Appendix No. 27. School Return for the Presentation Convent Schools for the year ending December 31. 1859. provided by Bishop John T Mullock. p 399. The sisters taught a curriculum based on that of the Irish National School System: Reading. Writing, Arithmetic. English Grammar, Geography, History. Drawing, and Maps. sewing. marking, needlework. and embroidery. with an Industrial Department that provided classes in weaving. spinning. and knitting. The obvious differences in relation to the desired curriculum for boys' schools was the omission of navigation and the addition of various domestic arts. This emphasis on preparing young women for motherhood and domesticity will be discussed again in Chapter 8 .

${ }^{182}$ LC. 1878 (St. John'S: J. C. Withers, Queen's Printer. 1878). Appendix Vo. 40. Syllabus for Grading Teachers. pp. 417-9 
male teachers expressed by the inspector of Catholic schools in 1880 also provide some insight into the underlying perceptions that likely governed the earlier period "Qualified Female Teachers," he noted, "may be obtained for such [currently low] salaries - 225 or $£ 30$ a year - but it is unreasonable to expect that Male Teachers, possessed of any energy and ability. will give their services at so low a rate." If something was not done soon about the situation, he warned. most schools would be filled with female teachers, a predicament which he felt was untenable. While female teachers were acceptable. indeed better. teachers for young children and girls, most of the schools in the outports were mixed. Given the deficiency of female teachers in cerain advanced subjects such as arithmetic and science due to their natural lack of proclivity in such areas, he asserted. something must be done to attract more male teachers to these schools to ensure a better standard of education in situations where boys must. by necessity. attend school with girls. ${ }^{1 \times 3}$

Thus. schoolmistresses on the southern Avalon. as elsewhere in Newtoundland. became enmeshed in gender ideology that ranked their abilities as secondary, their work. of lesser value than that of their male counterparts. Although they had improved their lot in terms of cash income and prestige within the plebeian community. these benefits had to be traded off against a subordinate status within their own occupational group as they

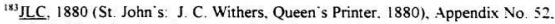
Report on the Public Schools under Roman Catholic Boards for the year ended December 31. 1879. pp. 399-517. especially pp 408-9. 
skirted the edges of middle-class respectability.

\section{\pm 3 Conclusion}

Women in the Irish plebeian community on the southern Avalon were essential contributors to the collective enterprises of household production and survival. They performed vital work in the fishery, in subsistence agricuiture, and other household production. Many also contributed to tamily economies through paid work, the hospitality trade. and proto-professional occupations such as midwifery and teaching. I significant number combined household production with various types of paid work in a broad package of economic coping strategies. as demonstrated by women s accounts in the Goodridge ledgers. Julia McCarthy. tor example, sewed and washed tor fishermen in the Renews area. worked on Goodridge's flakes. and sold hav to the firm. Ellen Fowler washed and cooked for six customers in 1839. Mary Ann Fowler worked on the tlakes. sold oakum to Goodridge's. and hired out her punt to the vessel Pelter for the 1841 tishing season. Margaret Dunphy worked on the flakes and sold poultry Mary Knox also sold fowl and did paid washing and sewing in 1841. Esther Cahill was a laundress and a shore worker for Goodridge's. All made important contributions to family incomes through cash, extra credit. or exchange.

The multi-faceted role of Irish-Newfoundland women in family economies on the southern Avalon was rooted in the traditional work routines of rural Ireland. including the 
southeastern homeland, where women performed a variety of tasks that were vital to the survival of their families. They participated in both paid and subsistence agriculture - from stone-picking and planting to manuring, weeding, and harvesting. They gathered peat for fuel and seaweed for fertlizer and food, carrying it home on their backs. sometimes over long distances. They distilled and sold spirits, sold butter and eggs, and raised pigs and poultry for sale in local markets. And until the decline of the domestic woollen industry by the middle of the $19^{\text {th }}$ century, they earned scarce cash income as domestic spinners and knitters. Indeed. on many small farms, it was women's cash earnings that paid the rent. Thus. in both Ireland and Newfoundland. Irish women were vital co-producers in family enterprises.

Certain work routines within the plebeian community on the southern Avalon were delegated along sex lines. but mutually exclusive gender dichotomies that differentiate men's and women's work in terms of physical strength/weakness, outdoor/indoor work. paid/unpaid work. skilled/unskilled labour, or primary/secondary work are too rigid for examining the sexual division of labour in the study area. Granted, physical strength did dictate that men haul handlines and seines in the fishery. but other work assignments delegated to women - e.g. carrving 'barras' of fish up cliff faces. shouldering massive loads of boughs and bresneys.' transporting 5-6 gallons of water over long distances. digging, fertlizing. and weeding gardens - were hardly based on notions of a 'weaker sex. Granted, men worked primarily outside the household, but women's duties were carried out both in and out of doors. Furthermore, a significant number of women worked for 
pav, albeit to a lesser extent than men in the earlier part of the period. reflecting the disproportionate number of male fishing servants in the population. Some - washers. sewers, teachers - found their work undervalued because it was seen as an extension of women's familial role. But others - fishing servants, midwives, doctresses - were perceived as skilled workers or virtual professionals, even though payment on this basis only occasionally materialized for community healers.

As the family production unit in all its tacets evolved on the southern Avalon, women's work was perceived by the local community to be as skilled and as important as men's. Women were not seen as 'helpmeets, but as essential members of family work units. Furthermore. there was no pressure exerted within the plebeian community to move women away from outdoor work into the household and its close environs. Within the small, middle-class community. by contrast. women's outdoor work was increasingly stigmatized through the period. Middle-class women retreated into their households and focused on child-rearing and the supervision of servants. who now performed more labour-intensive tasks. Just as in colonial America, local middle-class families struggled towards an English. middle-class feminine ideal, and the withdrawal of women trom work in the fields or from other manual labour was perceived as a mark of increasing affluence. gentility, and respectability.

However. women from Irish plebeian cuiture were positioned differently in the division of labour than English women, for there was no stigma attached to their outdoor. manual labour or paid work: and there was no social value ascribed to their economic 
idleness. Granted, plebeian women, like middle-class women, hired domestic servants. and their ability to do so was a sign of some degree of affluence. Within both contexts. servants relieved their mistresses of certain work routines. But plebeian women did not hire servants to 'escape' outdoor work and retire into genteel domesticity. but rather to 'escape their households to pertorm productive work on flakes and in the fields. Indeed. tar from regretting the time spent away from home and family, many looked forward to the break from housework. And a woman who was "too sickly" or "too grand" for outdoor work was an object of pity or scorn within the plebeian community. The capacity to contribute to the household's output was a vital part of the Irish-Newtoundland woman's self-image, a defining component of her identity.

Resourcefulness, resilience. physical hardiness, efficiency, tlexibility, courage. tenacity - these comprised a package of survival skills that defined the Irish plebeian woman in the davs of early settlement and constructed a feminine ideal that has survived in the collective memory of the culture. The 'good. hard-working stump of a girl' of the home country transplanted successfully along the southern Avalon, and indeed, outlasted her Irish counterpart. whose status eroded with the increasing marginalization of women trom agricultural work and devaluation of women's labour as the $19^{\text {th }}$ century unfolded. On the southern Avalon, women's work maintained its social and economic value within the plebeian community well into the $20^{\text {th }}$ century. And the construction of Irish womanhood as hard-working. essential partners in family enterprises had repercussions in the broader social. economic, and political life of their communities. where they enjoyed 
considerable status, power, and decision-making autonomy, as the following chapter reveals 
Chapter 5 - "She made the cannonballs, and he fired them". Irish-Newfoundland women and informal power in family and community

On July 22. 1822. Ellen Veal (also Vail) appeared before the justice of the peace at St. Mary's to lodge a complaint of assault against her neighbour Mary Bowen. Two days previous. Mary had been entertaining her triends Ellen (Nell) Tobin and Mary Molly in her home. The women were chatting companionably while Mary Bowen nursed her baby and putfed contentedly on her pipe. Suddenly. Ellen appeared in the doorway and demanded to know why Mary "shoud have caried Lyes and storys up the harb[our]" about her deceased husband and a Mrs. Bishop. and why she was spreading rumours that her daughter had received a pair of shoes from James Barry (with all that may have implied) Ellen had heard this scandalous news trom Catherine St. Croix. who had. in turn, heard the gossip from the same Nell Tobin who now sat comfortably in Mary's house Mary told Ellen to stop making a tuss and ordered her to leave the house or she would "turn her otf." Ellen "swore God if She did. she woud break the Bucket over her head" and stood her ground. Mary put aside her nursing child, and tried to push Ellen away. but Ellen resisted: she broke off the pipe in Mary's mouth. and battle commenced. Witnesses Vell and Mary could not swear who had struck the first decisive blow, but all agreed that the defendant won the upper hand in the resulting fracas, for Ellen retreated with "blood running..

'PANL. GN 5/4/C/1. St. Mary's, ff. 116-7 and 119-20. Ellen leal v. Lary Bowen. July 22 and August 1, 1822. In the August 1 hearing, both parties were found culpable and required to enter into bonds of $\Sigma 5$ each to keep the peace and be of good behaviour 
This court case illustrates plebeian women on the southern Avalon deploying power - through verbal wrangling, physical brawling, and gossip - in ways that clashed with hegemonic discourses on femininity in contemporary Britain. Within the English common law tradition by the $18^{\text {th }}$ century, women were viewed as dependents and virtual possessions of fathers or husbands - incapable of controlling their own property. skills. and labour. Most restricted was the married woman - the feme coverte - who could not own property in her own right, enter into contracts without her husband's permission. sue or be sued. Meanwhile. Enlightenment thought was underscoring the division between the [rational, active, individualist, masculine] public sphere and the [emotional, passive. dependent. feminine] private domain. Female domesticity was glorified as women's lives were channeled towards marriage and motherhood. Late $18^{\text {th }}$-century and early $19^{\text {th }}$. century evangelicalism reinforced the constructions of public man and private woman as it shaped middle-class ideals of female domesticity. respectability. passivity. and dependence :

for 12 months. Note that although some of the last names above were of English derivation. these family lines had been incorporated into the Irish-Catholic population (see Chapter 3)

'See. for example: Backhouse. Petticoats and Prejudice: Cullum and Baird. ${ }^{\cdots}$ A Woman's Lot '”. Clark, Struggle for the Breeches, Leonore Davidoff and Catherine Hall. Familv Fortunes: Men and women of the English middle class, 1780-1850 (Chicago University of Chicago Press. 1987): Sonya O. Rose. Limited Livelihoods: Gender and Class in Nineteenth Century England (Berkeley: Los Angeles: University of California Press. 1992): Rendall. Women in an Industrializing Society, and G. S. Rousseau and Roy Porter. eds.. Sexual underworlds of the Enlightenment (Chapel Hill: University of North Carolina Press. 1988) 
Newtoundland was a British fishing station and, later, a colony during the study period. and these discourses were certainly infiltrating Newfoundland society through its British legal regime and an emerging local middle class of administrators. churchmen. court officials. and merchants, many of whom maintained strong ties with Britain. ${ }^{3}$ But how did these constructions of womanhood play out within the essentially plebeian Irish community on the southern Avalon of Newfoundland. where community tormation was still in its early stages and where gender relations were very much contested terrain?

This chapter will attempt to demonstrate that Irish plebeian women on the southern Avalon exercised considerable authority in family and community and continued to operate in public spaces throughout the study period. This was true of married women as well as those who were single or widowed. for although the law of coverture dictated that a husband and wife became one legal entity in the person of the husband, the vital roles of plebeian women in the study area as co-producers and reproducers in family economies ensured that their identity was not subsumed in marriage. In this, they were similar to their counterparts in rural Ireland, or certainly $18^{\text {th }}$ - and early I9th-century rural Ireland, where women derived considerable status from their role as co-producers in a

'Up to the early 19th century. most were Anglo-Protestant and many returned to Britain after stays of varying lengths on the island. Even those who remained maintained strong family. commercial. and/or professional connections with Britain. There was a smaller Irish mercantile element in Newfoundland as well; but while this group achieved increasing prominence in St. John's in the $19^{\text {th }}$ century. Irish merchant-planters on the southern Avalon (again, predominantly a Protestant group) had wound up their interests in the area by the late 18 th century. 
mixed farming and domestic textile economy. Within both contexts, married women exercised relative autonomy in the running of their households and also had significant intluence over matters outside the home. While a façade of patriarchal authority was usually maintained in both cultures. male decision-making was frequently directed by women behind the scenes. Clarkson describes this family power structure in Ireland as a "matriarchal management behind a patriarchal exterior "t The oral tradition on the southern Avalon has a more homespun equivalent - She made the cannonballs, and he fired them.".

The strong family matriarch has been identified in other maritime cultures as well. Hector St. John de Creveccoeur. for example, observed the ability of women in $18^{\text {th }}$. century Nantucket whaling families "to transact business, to settle accounts, and in short. to rule and provide for their families" while their husbands were at sea " Llrich notes that wives of New England fishermen and merchant sea captains stood as deputies for absent husbands - keeping accounts. defending shore property from encroachments. acting as attorneys. supervising the planting and harvesting of crops as well as other family

${ }^{4}$ Clarkson. "Love. Labour and Life." p. 30. By contrast. Errington notes that Cpper Canadian farming families were distinctly hierarchical and patriarchal. the image of the "good wife" presented as "caring. quiet. submissive" - although her reliance on middleclass sources may have skewed her perspective somewhat. See Errington. Wives and Mothers, pp. 33 and 39.

'This phrase was first encountered in an interview with AS, dated July 21. 1999. but it also re-surfaced. or a similar opinion was expressed, in most interviews conducted.

${ }^{6}$ Hector St. John de Creveccoeur. Letters from an dmerican Farmer (London; New York: J. M. Dent \& Sons and E. P. Dutton. 1912: reprint 195I). pp. 146-7. 
concerns. Sally Cole discusses the autonomy and decision-making power of pescadore women of Vila Chà, Portugal, which sprang from their vital roles as fishers, marketers, and household managers. ${ }^{x}$ However, women's authority in these contexts was linked to long-term absences of men in terms of their fishing activities: this has no explanatory power for the southern Avalon, where most men fished near their homes and also remained in their home communities in the off-season. The authority of IrishNewfoundland women within the plebeian community on the southern Avalon, then. emanated from something other than the status of proxy husbands or fathers

\section{The tamily}

As noted in the previous chapter. there were gendered spheres of authority that were linked to the sexual division of labour within tishing tamilies, with some overlapping where work routines coincided. Men made decisions about tishing. for example, but both women and men in family production units exercised authority in the curing process: indeed. women usually shouldered greater responsibility in the processing stage as men spent more time on the water in the height of the fishing season. As both men and women

shared gardening and hay-making responsibilities. most married couples jointly discussed

Utrich, Good Wives, pp. 39-42.

${ }^{x}$ Cole. Women of the Praia. 
matters such as the timing of planting and harvesting or the types of crops to be grown. The dominant authority in matters respecting home and family, however, was generally the woman. Most men "didn $t$ know what end went foremost ${ }^{-\mu}$ around the house and left household atfairs and child rearing to the women - occasionally intervening in disciplinary matters when their help was solicited by their wives.

In terms of the day-to-day management of household resources, women's authority was paramount in many tamilies. ${ }^{10}$ Of course. this was self-evidently true of women who enjoved the status of feme sole: but married women were also the primary household managers within the plebeian community on the southern Avalon. In carrying out this responsibility. women had to balance the requirements and contributions of large househoids that, in some cases, included domestic and fishing servants as well as family members Their power as household managers extended to the allocation of any (usually small) amounts of cash the family mav have accumulated. In addition. women who were part of a tamily production unit in the fishery often oversaw, from behind the scenes. the tabulation of the family's account with the supplying merchant. While the male figurehead generally attended at the merchant's store to 'settle up' in the fall. he was otten acting on

"MOB is quoted here. Interview July 22. 1999; but similar information was imparted by all informants

${ }^{16} \mathrm{C}$ arol Berkin also notes the essential role of women as household managers in colonial America. where they were "expected to manage resources. time. and the available labor to best advantage, balancing production against maintenance, the needs of dailv consumption against long-term supply, and the particular capabilities of servants and children against their assigned chores." See Berkin. First Generations, p. 28 
the advice of a wife or mother, who had actually kept track of the various supplies issued to the family and the amounts of fish and oil provided to the merchant in return. Thus, the family matriarch usually had an accurate idea of the balance of the family account: and if the male figurehead did not conclude the negotiations with the merchant to her satisfaction, she would send him back to have the account adjusted accordingly Indeed. it was not unknown for the woman, herself, to attend at the merchant's premises to fine-tune the balance. It is difficult to say how far back into time this practice of account-keeping extended, it was represented by informants as common practice within the family production unit. certainly in the latter decades of the study period. but it may have been in evidence in the traditional planter fishery as well. In a 1793 court case, for example, when Trepassey boatkeeper James Warne was being sued by a servant for outstanding wages. his wife was required to testify as she was the one who was keeping the househoid accounts." And certainly. evidence of women keeping accounts and dealing with merchant suppliers appears in the literature on colonial America, ${ }^{12}$ so southern Avalon women would not have been out of step with their contemporaries elsewhere in exercising this duty

According to the oral tradition, women's ability to manage the household's

"PRL. 340.9 N45. Trepassey-St. Mary's, f. 15. Thomas Murphy v. James Warne. vovember 20, 1793 This case is discussed again in Chapter 6.

"See. for example: Brown. Good Wives, Nasty Wenches; de Creveccoeur. Letters. and Ulrich. Good Wives 
resources in general - to make very little stretch in hard times and put a bit aside in good was critical to the survival of the family. Indeed, most informants feit that it was more important for a woman to be a 'good manager' than a man to be a 'good provider'; for no matter how successtül a man's economic activity (usually, fishing) was, a poor female manager could squander the proceeds and leave the family very badly off, by contrast. the wife of a 'bad provider' could make ends meet if she judged consumption and allocated resources caretully. The female household manager could, therefore, 'make or break' a family, and the wife who could see her family through the long and hungry month of March ${ }^{13}$ was prized indeed. ${ }^{14}$

A woman's powerful status within the household extended into widowhood Even when a man bequeathed the tamily home and property to a child or children, it was done so with the understanding that his wife not only would be looked after but would continue to have a substantial say in the running of the household. The mother was still the boss* and inheriting children would continue to respect her wishes after her husband's death. Of course. this substantial degree of informal power within the family was not

${ }^{12}$ This was a critical period in Newtoundland fishing households, when the winter's 'diet' was virtually gone and the spring supplies not yet advanced by merchants. This expression. and the terms 'good/bad manager' and 'good/bad provider' were used by most informants in discussing this issue.

${ }^{14} \mathrm{~A}$ similar theme on the importance of women's household management strategies to family survival appears in literature on women in urban working-class families. See. for example: Bettina Bradbury. Working Families: Age, Gender, and Daily Survival in Industrializing Montreal (Toronto: McClelland \& Stuart. 1993): Roberts A Woman's Place; and Ross, Love and Toil. 
universally experienced by women on the southern Avalon. There were some who didn't have any say: they just kept the children coming. washing and cooking for them, and died before their time. ${ }^{-15}$ And it was expected that women who did exercise strong authority maintain some taçade of patriarchal authority. If a woman stepped beyond this limit. if she was too domineering in public. she was labeled a 'real boss.' Kathleen Brown discusses the equivalent in colonial Virginia - the 'scold. who subverted gender hierarchies by attempting to dominate her husband. ${ }^{16}$ Yet the term 'boss' did not have quite the same stigma as the "scold." for the southern Avalon label otten carried with it a degree of grudging respect - an acknowledgment of strength of character, particularly for women who had to take over in the absence of male authority Nonetheless. most marriages were partnerships. according to oral informants. While the patriarchal family was the ideal in legal and middle-class discourse. there was a signiticant gap between this rhetoric and the reality within plebeian culture along the southern Avalon. Brown's concept of a gender hierarchy that was fairly tixed. yet occasionally besieged by women. therefore seems too rigid for discussing gender relations in the study area in the period of early settlement.

The concept becomes even more problematic with evidence that the scope of plebeian women's informal power extended beyond the family to the community. Oral

"AOB. Interview August 25, 1999

${ }^{16}$ Brown. Good Wives. pp. 28-9 Thompson notes the underlying fear of the power of the feminine tongue in the use of the ducking-stool and scold's bridle in $18^{\text {th }}$. century England. See Thompson. Customs in Common, p. 501. 
informants agreed that most women had considerable influence over how the family was represented in the larger community by the male figurehead - at public meetings, for example. or at the merchant's store. The veneer of patriarchal authority was maintained in the male spokesperson. As one informant explained "Well. the man was supposed to be in charge [laughs]. That was the way it was given down. But a woman had to have a voice too, you know. ${ }^{17}$ Another pointed out that a man going to a meeting "would be well-informed [by his wife] before he went" as to what his opinions should be ${ }^{18}$ So women would generally let their views be known, even in matters outside the home. and their advice was generally respected by their husbands - reinforcing the notion that there was a gap between the rhetoric of patriarchal authority and the reality of plebeian family power relations. And there were other areas of community life in which women exercised considerable authority, as the following sections will demonstrate. This deployment of women's informal power suggests that gender relations were very much in the process of negotiation during the study period.

\section{The economic sphere}

Chapter $t$ has already presented evidence that plebeian women in the study area informants.

${ }^{17}$ WC. Interview July 21. 1999. Similar thoughts were expressed by other

${ }^{1 *} \mathrm{AS}$. Other informants provided similar information. 
were an intrinsic part of the economic life of their fledgling communities. They played a vital role in subsistence production for their households, and some sold their surplus to local customers. In addition, they ran public houses and shops, took in boarders. provided nursing services. and took in paid washing and sewing - mostly catering to the single male tishing servant population. Women were shipped as both domestic and. less frequently. fishing servants to mercantile. administrative. and planter families by oral or written contracts recognized by law. Some women, primarily widows, were fishing emplovers and operated tishing premises in their own right. A greater number ran tishing plantations with their husbands or common-law partners - with the boarding of fishing servants added to their other responsibilities And increasingly, plebeian women moved into an essential role in the fishery as shore crews tor the household production unit. working on stage head and flake to produce saltfish for the marketplace. Their presence at these public sites of economic production and their vital and recognized contribution to the process was an important source of power tor these women - even into the $20^{\text {th }}$ century

Further evidence of women's participation in the public economic sphere can be seen in mercantile journals and ledgers, which indicate that women were a significant part of the exchange economy of the area. The Goodridge ledgers are intact for the vears 1839 and $18+1$. and provide a comprehensive picture of women's involvement at Renews. albeit 
for a limited time frame. ${ }^{19}$ Women's accounts also appear in the Sweetman records. ${ }^{20}$ Unfortunately, these books are not intact, even for limited years. and many accounts are merely loose leaves in files, but the entries reinforce conclusions drawn trom the Goodridge records. ${ }^{21}$ Appendix $\mathrm{C}$ provides a detailed. but by no means exhaustive. overview view of the types of women's accounts and economic activity revealed by these mercantile records. The following discussion will draw from these examples, with references to appendix section numbers appearing in brackets in the text.

Although women's names appear tar less trequently than men's, a significant number held accounts in their own names and in a variety of capacities. The intact Goodridge ledgers provide some indication of the frequency of this phenomenon. In 1839. for example. 38 women held individual accounts with the firm. while +6 headed accounts in $18+1$. Of the latter. 24 had also appeared in the earlier ledger, reflecting 22 new accounts for $18+1$ Thus, the total number of women holding accounts for the two

${ }^{11} \mathrm{PANL}$. MG 473 , Goodridge Collection, 1839 and 1841 Ledgers.

"DANL. MG 49. Sweetman Collection, various files in Boxes 2 and 3 Not all the women whose names appear in these accounts were strictly from the study area. but those that were not still serve to illustrate the points raised here by next-best approximation.

${ }^{2}$ Other sources also confirm these findings. Similar entries appear in a business journal found in the White-Maher house at Ferryland prior to its demolition c. $1960 \mathrm{~s}$ and currently in the possession of DA of Ferryland. Although the business is not identified. the customer names are from the local area: and while the journal entries are dated 1881 1882, they reflect the continuation of a system of exchange that was in place during the study period. Further evidence of women's involvement in the exchange economy can also be found in the court records as third-party transactions in merchant and boatkeeper accounts entered in evidence. as well as in outstanding accounts presented by women. themselves. for payment. 
years was actually 60 . Of these, one was identified as a "widow": and this was obviously also the status of Catherine Kenny, who headed the account for "Catherine Kenny and Sons." Only two others were specifically identified as married women, operating accounts separate from their still living husbands. It is highly unlikely, however, that the remaining women were all single, given the small population of the area:" some may have been widows. but it is likely that a number were married women holding accounts with the tirm as if they were femes sole "3 This is reinforced by the fact that few, and otten no. supplies of basic foodstuffs appeared in the majority of these accounts. most contained supplies of soap and materials necessary for washing and sewing (see below) and 'extras' such as sugar, shoes, and senna tea, the interence can thus be drawn that many were married women whose food supplies were debited to the accounts of male household heads, but whose separate economic activities warranted separate accounting entries in the merchants books

Still. some women were obviously household heads in their own right (Section 1 of Appendix C). Catherine Kenny and Jane Careen were two such independent householders. for family supplies and credit were advanced in their names. Furthermore.

In 1836, there were 247 women aged 14 and over in Renews and the nearby community of Fermeuse: in 1845, the total was 272. See Newfoundland Population Returns, 1836 and 1845 .

${ }^{23}$ The more sporadic Sweetman records also hint at this. Contrast. for example. the accounts of "Mrs. Jas. Mullaly" and "Mrs. Ths. McCarthy" with those of "Widow Lamb" and "Widow Conway." 
women such as Mary Morris, Sarah McCarthy, Mary Murphy, and Dorothy Cantwell headed household units that were producing oil and saltfish for market. Indeed, the majority of women in both sets of records - whether single, married, or widowed obviously performed some form of autonomous economic activity and held individual accounts with the firms as if they were femes sole. By far the largest number of these were washerwomen and seamstresses (Section 2). Supplies for washing and sewing were advanced to them and were contra $d$ by the accounts of their customers through the merchant 's ledgers. In addition. a significant number of women in the Renews area paid for supplies advanced to them through work on the Goodridge's tlakes (Section 3). And many combined a package of paid services - shore work. sewing. washing, and the sale of poultry, hay, or oakum - which attracted payment either directly from the firm or in thirdparty transactions involving mutual customers of the women and the merchants (Section

4). Occasionaily, wages of women servants or of servants employed by women appeared - some in direct payment from the firm: others in third-party transactions through the employer's account with the merchant supplier (Section 5). Also. payments of rent to and from women were sometimes transacted through the merchants' ledgers (Section 6).

Women. like men, obtained supplies on credit and settled up in the fall. Julia HcCarthy of Renews provides a good example. Her accounts with Goodridge s for 1839 and 1841 are shown in Table 5.1. Julia had a number of local customers, including some of the Goodridge family, for whom she was either washing or, more likely, sewing for piece rates. Her supplies were generally paid by a contra entry that credited her account 


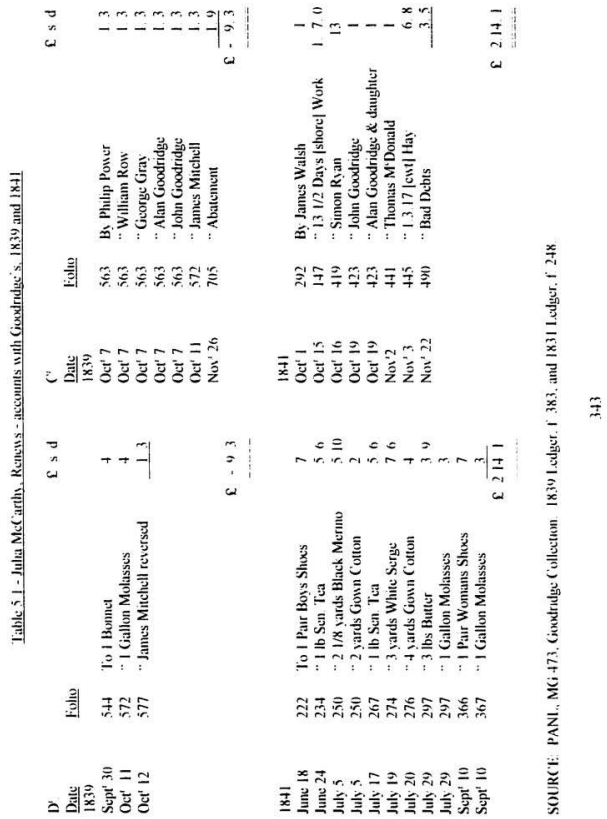


while debiting the account of her customers (note the folio numbers after the dates in the credit column). In addition, in 1841, Julia received credit for working on the Goodridge's flakes and for selling hay to the firm. In 1838, she was fortunate in receiving an abatement in order to balance her account. In 1841. however, she had a debt of $3 \mathrm{~s} 5 \mathrm{~d}$ that was carried forward to the next year. In neither year, then, did she receive any cash, but was able to keep her head above water with the paid work she performed in the community In this. she was like most of the firm's customers, both men and women, in terms of the women account holders. only 12 received cash. generally in the fall of the vear after

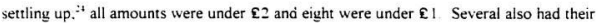
profit applied towards the debt of a male relative - likely a husband or father "s

Several women in the Goodridge ledgers had credit balances in the tall of the vear (three in 1839 and six in $18+1$ ). Similarly, the Sweetman records indicate credit balances for eight women in both 1802 and 18.43 (the only years when itemized lists are available) Some of these balances were quite substantial (Section 7). The majority of women. however. barely broke even or carried some level of debt to the following vear. This was

¿'One exception was Mary Plece, a household servant with the Goodridge tamily. who appeared to receive her wages semi-annually

“For example: Catherine Shannahan's 1839 profit from washing of $195.8 \mathrm{~d}$ was applied towards the account of Mathew Shannahan (1839 Ledger. f. 384): Mary Neill's 1841 profit of 10 s. 4 d. from selling hay to Goodridge's was applied towards the account of William Neill (1841 Ledger, f. 248): Nancy Gerian earned sufficient wages from her work on the Goodridge flakes in 1841 to have 14s.2d. applied towards the account of Thomas Gerian and still receive cash in the amount of 5 s. (1841 Ledger. f. 306). 
a classic feature of the truck system in Newfoundland, and, indeed, it was not unusual to see "bad debts" appear among the entries in accounts for both men and women. Some of the entries in the Goodridge ledgers - seven in 1839 and nine in 1841 - related solely to bad debts without any other indication of economic activity ( similar entries tor men were far more numerous). But in only two cases (one in each year) were the amounts written off completely. In every other case. balances were carried forward. indicating that the firm had some expectation of the debt being paid in time.

Although women account holders were not as numerous as men. then, they were present in the records in significant numbers and participated in the exchange economy in ways that were sometimes distinctive. but more often typical of the merchants broader clientele Furthermore, any discussion of women's participation in the exchange economy must include the invisible presence of women in the accounts of male househoid heads. Fish and oil credited to many of these accounts were produced by family work units which included the labour of women. And of course, many of the goods appearing under the names of male household heads were used by women in household production, using labour and producing goods that were assigned no market value and therefore not included in formal business accounts of the day. Furthermore, merchant books did not record networks of informal trade that involved women - the exchange of eggs for butter. tor example. or milk for wool - what Lewis describes as an "underground economy" which helped women in many early colonial communities keep their tamilies clothed and 
fed $^{26}$

Some useful comparisons can also be drawn with women's participation in the exchange economy of late $18^{\text {th }}$-century Horton. Nova Scotia, as described by Elizabeth Mancke $"$ Vancke finds women's presence in merchant ledgers primarily as consumers (almost always through men's accounts) of untinished goods for household production. concluding that "women consumed to produce and men produced to consume ":* This gender differential was not quite so clear-cut on the southern Avalon. Granted, women in the study area did "consume to produce," often through accounts in men's names; but they also "produced to consume" as part of family work units that provided the chief commodity of the local exchange economy: and some "produced to consume" independently of male householders. performing services for customers in order to purchase goods. often small 'luxuries. for themselves and their tamilies. Mancke interprets the predominance of men's names in the Horton business accounts as an

Thewis, "Women and Economic Freedom," p. 195. Lewis discusses evidence of women's economic activity in the business books of Rowan County, North Carolina. she observes. however, that working for a living was usually a life phase experienced by women before marriage or in widowhood - in contrast to my southern Avalon findings Ridner looks at the economic activity of women in frontier Pennsvivania, who. like their southem Avalon counterparts. were essential members of their family production units after marriage. Although she does not discuss the matter extensively. she notes that women appeared regularly in merchant account books, regardless of marital status. Some maintained their own accounts. while most others transacted their purchases through husbands' and fathers names, even borrowing cash on account. See Ridner. '“To Have a Sufficient Maintenance.”'pp. 167-90. especially p. 169.

\footnotetext{
"Mancke, "At the Counter of the General Store."

"Xancke, "At the Counter of the General Store," p. 171
} 
indicator of women's subservient social status. While the same can be said in relation to the southern Avalon in terms of formal legal status, especially of married women, the ledgers may not have been an accurate portrayal of how gender relations played out on the ground. The merchant or his clerk. in setting up the ledgers, would have been mindful of the law of coverture. which dictated that a husband was responsible for his wife's debts: but this concession to patriarchal authority in the books did not reflect the gap between ideal and reality in terms of family and community life. Furthermore. both Goodridge 's and Sweetman's were obviously willing to extend credit to women in their own names when they performed some autonomous form of economic activity, regardless of marital status Mancke also tinds that accounts in Horton women s own names tended to be small - none over $₹ 10$ and most under $£ 3$. L'sing the same gauge on the Goodridge records. 25 accounts contained balances of $\sum 3$ or more. and six of these had balances over $₹ 10$ Furthermore, some very high balances (debit and credit) appear in women's account in the Sweetman books (Section 6). Both sets of records suggest a higher level of independent economic activity for women on the southern Avalon than in Horton. Finally. Mancke interprets various examples of women's receipt of third-party payments for goods or services as confirming women's subordinate social condition with servitude and wages. But the economic agency of their southem Avalon counterparts also seems apparent. Indeed. the incomes these women made from selling their goods and labour were essential contributions of to their family economies. or. if single. to their own survival. Granted. their participation in activities such as washing, sewing, and service indicated their lower 
social status: but one must be careful in viewing this solely through the lens of gender, for they were in no more servitude than many fishermen in the area. Indeed, in one way, they were more independent, for the income from paid washing, sewing. knitting, etc., had a value that. unlike most aspects of the truck system, could be negotiated with their customers and was not 'fixed'. or perceived to be 'fixed, by the rnerchants: while rates among different providers were often similar in any given year, this can be attributed to competition rather than fees imposed from on high.

In general, then. while separate sphere ideology acted as a powertul impetus to remove women from the workplace and marketplace or to devalue the contribution of those who remained. plebeian women on the southern tvalon remained active and essential in the economic sphere throughout the study period as producers of goods and services and as an integral part of the truck system that underwrote the resident tishery Their participation in productive work, particularly saltfish production, and their significant contribution to the exchange economy (sometimes highly visible. sometimes muted in the merchant account books of the day) enhanced the power and status of these women in their own community

\section{The spiritual realm}

The spiritual life of any group is a site of continuous negotiation between the natural and supernatural worlds. The process is enigmatic; the issues. profound, the 
stakes, unfathomable. Those who are chosen as mediators must, therefore, necessarily enjoy considerable authority and respect within their communities. In various cultures and at various times, women have acted as negotiators and guides of the spiritual landscape. and there is certainly evidence that religion - in both orthodox and informal observance was an alternative source of female power for the Irish women of the southern Avalon. particularly before the encroachment of ultramontanism and the devotional revolution of the mid-to late $19^{\text {th }}$ century (see Chapter 8 ).

Women played an essential role in keeping the Irish-Catholic faith alive in the area within the context of a scarcity of priests that persisted well beyond the penal regime into the middle of the $19^{\text {th }}$ century. Catholic women, for example. performed religious rites and assumed other forms of religious authority during the study period. Indeed. Bishop Michael Fleming complained to his superiors in the 1830 s that before the establishment of the Catholic missions in the 1780s. "The holy Sacrament of Matrimony, debased into a sort of 'civil contract.' was administered by captains of boats. by police. by magistrates. and frequenty by women The Sacrament of Baptism was equally protaned [italics added]...." It is unclear whether Fleming was aware that midwives and other women continued to baptize babies at birth to 'tide them over' until formal church baptisms took place - sometimes many years after the birth: ${ }^{99}$ however. in the same report. Fleming did indicate his dismay that midwives had taken the authority upon themselves to

\footnotetext{
${ }^{79}$ This information comes from the oral tradition.
} 
dispense with Church fasts for pregnant women. ${ }^{30}$ In addition, Dean Cleary tantalizingly refers to an incident (c $1830 \mathrm{~s}-40 \mathrm{~s}$ ) in which the women at St. Mary's took "the sacred fire from the altar to burn a house" - perhaps a rite of exorcism of some sort - at the behest of their priest. Father James Dutfy. ${ }^{31}$ Furthermore, the oral tradition indicates that just as women were the financial managers, so too were they the spiritual overseers of IrishCatholic households Women. more than men. would have observed the rituals and kept the faith alive before the priests came. Indeed, as one informant stated and most others implied: "It it was lett to the men. sure there $d$ be no religion at all ${ }^{-32}$ Every intormant agreed that women played a more vital role in transmitting this facet of Irish-Catholic culture to following generations. for "it was women who taught children their pravers." These references suggest that women played an important custodial role in relation to the Catholic religion and. by extension. the identity of the ethno-religious group in the period of early settlement

In addition, female tigures were prominent in the Irish-Catholic hagiolatry of the

"RCAASJ. Fleming Papers, 103/26. "State of the Catholic Religion." p. 90

"RCAASJ. Fleming Papers. 103/32. Dean Cleary's "Notebook."

"The direct quotation came from AK. Interview August 26, 1999, but most intormants made a similar observation

${ }^{13}$ This observation echoed through numerous interviews. Just as women are credited by oral informants for maintaining the Catholic religion in the past. so too are they primarily blamed. especially by older informants. for current-day lapses in religious practice. To illustrate the enormity of the problem of the lack of maternal guidance in this area. one elderly woman in Calvert exclaimed in exasperation: "Sure now they [children] bless themselves back-foremost!" ER. Interview August 23. 1999 
area - harking back to the powerful position of goddesses and female druids in the pagan Celic belief system. a status that carried over into early Celtic Christianity. Indeed to this very day, the Virgin Mary, St. Brigid ${ }^{14}$ and 'good St. Anne ${ }^{\cdot 35}$ are a triumvirate to be reckoned with on the southern Avalon. Although they were revered by both sexes (men plaited small crosses from straw and erected them over doorways on the feast of St. Brigid for protection. tor example). they were (and are) particularly cherished by women - not as the sanitized feminine ideals presented in the Church calendar of saints, but as women who once lived worldly lives and who could therefore empathize with the experiences of other

\footnotetext{
"The cult of St. Brigid has spread with the seeds of the Irish diaspora. Brigid (c 455-525), or Mary of the Gael. was possibly a female druid before she converted to Christianity. She founded a mixed religious community (not unusual for the Celtic world) at Kildare, and some sources indicate that she may have been ordained a priest, and possibly a bishop, by Mel, bishop of Ardagh. She is said to have had intimate relationships with both a male bishop. Conlaed. and a temale member of her community. When she was brought into the formal Catholic calandar of saints. however, her life story was sanitized: she was made into a model of Christian womanhood, virtue, and piety, her mixed community was transformed into an exclusively female order of nuns. Her adoption by the Catholic church is additionally intriguing in that it provides an example of formal religion's co-opting aspects of pre-Christian belief systems. The feast day of the holy woman of Kildare is celebrated on February 1 - which corresponds with $/ m b o / c$, the ancient Celtic feast of fertility, the coming of spring and the return of light after the dark of winter, as well as the beginning of the lactation of the ewes: the name of the Celtic goddess of fertility - Brigid. See: Peter Berrestord Ellis. Celtic Women: Women in Celtic society and literature (London: Constable, 1995), pp. 27-29 and 146-150, and Shirley Toulson. The Celtic Year: i Month-by-Month Celebration of Celtic Christian Festivals and Sites (Shaftesbury: Rockport: Brisbane: Element, 1996), pp. 73-81

${ }^{35} \mathrm{St}$. Anne was Mary's mother. She, too, is represented by the Catholic church as a model of self-sacrificing Catholic womanhood - particularly for wives and mothers - and is the patron saint of housewives in the Catholic calendar of saints. The cult of St. Anne was a more latter-day phenomenon in the study area. arising out of the devotional revolution in the Irish-Catholic Church.
} 
women. ${ }^{36}$

While Irish women and female saints played an important role in the preservation of Irish Catholicism in the study area, women were also central figures in an informal system of beliefs and practices that had been transported from the home country. On the southern Avalon, as in Ireland. there was an alternative pre-Christian religious system operating in tandem with, and sometimes overlapping, formal Catholic practice ${ }^{1+}$ Today,

to When asked if women prayed especiaily to Mary. Brigid, and Anne, one woman informant advised me. "Oh God, yes. sure I'm still at it" (AOT, Interview July 19. 1999) This devotion is similar to that of maritime women of the Praia. Portugal, to the Virgin Mary, noted by Sally Cole: while the Catholic church saw her as representing motherhood and the denial of female sexuality, says Cole, Vila Chà women saw her as "a friend who understands the trials of being a woman." See Cole. Women of the Praia, p. 102. In recent years, the archdiocese of St. John's (which includes the study area) has moved to defuse the power of the Virgin Mary over its congregation by removing any references to her in the celebration of the mass. In particular, the banning of hymns to Mary during masses. especially funeral masses. has been upsetting to many members of the community The self-fulfilling logic of this directive is that as the mass does not contain any reference to Mary (by design), it would be anachronistic to permit hymns to Mary during its celebration. While the directive is followed by many St. John's churches, it appears to be ignored by most of the churches on the southern Avalon.

${ }^{37}$ In the following discussion. intormation on the pre-Christian religious system in Ireland is taken primarily from: Sean J. Connolly. Priests and People in Pre-Famine Ireland, 1780-1845 (Dublin: Gill and Macmillan, 1982), Sean Connolly, "Popular Culture in Pre-Famine Ireland." in Byrne and Harry, eds., Talamh An Eisc, pp. 12-28, George Casey. "Irish Culture in Newfoundland," in Byme and Harry. eds.. Talamh An Eisc, pp 203-27. Danaher, Irish country people; Mageean, "Irish Women's Prospects". Padraic O Farrell. Superstitions of the Irish Countru People (Dublin; Cork: Mercier Press. 1978): and W G. Wood-Martin. Iraces of the Elder Faiths of Ireland, vol 2 (reprint Port Washington: London: Kennikat Press. 1970). Information on the corresponding system on the southern Avalon comes primarily from oral interviews conducted in 1999 and 2000 . although Casev's "Irish Culture" was again useful in this regard. Some additional information on customary practices associated with death derives from undergraduate papers at MUNFL.A. particularly: Zita Johnson. "Calendar Customs and Rites of Passage 
there is a tendency to look at these ancient beliefs and practices as quaint folk traditions grist for the mill of the modern-day tourism industry. But as Sean Connolly points out in his discussion of the derivative traditions in Ireland, this "body of beliefs and practices. made up a very real part of the mental world of large numbers of Irish Catholics" in the $18^{\mathrm{th}}$ and $19^{\mathrm{th}}$ centuries. ${ }^{\text {II }}$ On the southern Avalon (and probably in Ireland. although the Irish literature does not discuss this). women were important navigators of this mental landscape in the study period. ${ }^{39}$

A belief in the occult powers of certain persons was part of the ancient belief system. and women featured prominently as mediators between the natural and the supernatural worlds. Women were proficient in reading tea leaves and telling fortunes. Certain women. as well as men. had special healing powers - the ability to stop blood with a praver, tor example. A widow's curse, by contrast, had the power to do great harm - to wither crops or drive fish from nets, to cause physical injury or even death. Indeed. a woman's ability to rain down invective on her enemies - as so ably demonstrated by Betsy Brennan in the loss of her hen (Chapter $\downarrow$ ) - was a formidable weapon in her repertoire of

at Renews" (MLNFLA ms 68-011D. Linpub. research paper. Memorial Liniversity. 1967. 1968). p. 030. and Andrew O'Brien. "Wake. Funeral and Burial Customs in Cape Broyle" (MLNFL.A ms. 68-016C. Unpub. research paper. Memorial Liniversity. 1967-1968). pp $7-10$

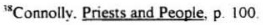

"The following discussion focuses on aspects of the system that had a particular female component. It does not include the myriad other beliefs and practices in which men and women participated equally - e.g.. the belief in good luck charms and omens of misfortune. 
conflict resolution skills, for the repercussions of ritual cursing were not to be taken lightly ${ }^{\text {t1 }}$ And women s special powers were woven into the very physical landscape, for places like Mrs. Denine's Hill, Peggy's Hollow, and the Old Woman's Pond (named for the women who had died there) had supernatural qualities that could cause horses to pull up in their tracks and grown men to lose their way.

The Irish community on the southern Avalon also believed in supernatural beings. and women were again central, either as symbolic figures or intermediaries in deflecting evil from family and other loved ones. The "bibe, or banshee. for example, was a temale tigure - an ancient crone whose wailing cry in the night was the harbinger of death. So too was the "old hag who rode the chest of many a nightmare sutferer through a troubled night. ${ }^{\text {+1 }}$ Sheelagh (or Sheila) - in popular belief, the wife or companion of St. Patrick -

"Patricia Lysaght observes that ritual cursing was an ancient tradition that persisted into the early $20^{\text {th }}$ century in parts of Ireland, and was often a means emploved by women in exacting revenge against enemies and authority figures who had caused them harm. It was not a ritual to be entered into frivolously. as the curse. once uttered. had to fall somewhere. and if undeserved by the intended recipient, would recoil on the invoker. See Patricia Lysaght, "Women and the Great Famine," in Arthur Gribben. ed. The Great Famine and the Irish Diaspora in America (Amherst: Lniversity of Massachusetts Press. 1999). pp. $21-47$. Wood-Martin also notes the potential for curses to return to the utterer in Traces of the Elder Faiths, pp. 57-8.

${ }^{41}$ The 'old hag' was a supernatural creature who came in the night and sat on the chest of her prey in an effort to impede or stop the victim 's breathing. The visitation evoked a choking sensation and left the sufferer in a semi-conscious state from which he or she could only be wakened by calling his or her name backwards. However. not all variations of the 'hag' actually involved a female apparition; sometimes she manifested herself more diffusely in the form of a bad nightmare from which the sufferer could not wake. or a feeling of paralysis that kept the sufferer pinned to the bed. Still. such victims were said to be 'hag-rode" or 'hag-ridden' - bewitched into temporary but terrifying 
was attributed with the tierce ice storms and heavy snowfalls that battered the island on or soon after her feast day of March 18 - a consistent weather phenomenon that is still known today as 'Sheelagh's Brush' or just "Sheelagh. ${ }^{* 2}$

Women also featured prominently in fairy lore On the southern tvalon. the belief in tairies was pervasive. The natural environment was filled with evidence of the existence of the 'little people.' for 'tairy paths.' fairy caps.' and 'fairy pipes' proliferated in the woods and meadows just bevond the garden gate. Fairies had the power to replace human children with changelings and render all humans. young and old. senseless or 'fairystruck: Infants were most vulnerable to their power. for the little people could enter homes and snatch babies from their very cradles. Women played a vital role in protecting their tamilies from these troublesome creatures who moved so easily between the natural and supernatural worlds. It was women. for example. who made and blessed the bread that had special powers to keep the fairies from stealing their children - the same bread that could help people who were 'fairy-led, or lost in back-meadows or woods. find their

paralysis by the powers of this nocturnal female phantasm.

4:Traditionally, the March storms leading up to and including St. Patrick's Day. March 17. were attributed to Patrick. while those immediately following were ascribed to Sheelagh. The association of Patrick with Sheelagh can be traced to Ireland. although the weather belief is purely local. See: Casey, "Irish Culture," p. 219, and Bridget McCormack. Perceptions of St Patrick in Eighteenth-Century Ireland (Dublin: Four Courts Press. 2000), pp 48-9. McCormack observes that Sheelagh was noted for her tempestuous nature and that a possible archetype for her tradition was the sheela-na-gig* - a female icon associated with protection, productivity, and fertility in the middle ages. but transmuted into a talisman to fend off the 'sin' of lust by the early modern Catholic church. 
way home ${ }^{+3}$ It was primarily a woman's responsibility to ensure that loved ones.

particularly children, who moved beyond the safety of the hearth had a 'fairy bun' (blessed bread) on their person. Bread made on Good Friday had special protective powers. and most women ensured that they made a batch on this day specifically for this purpose - a combination of practices from formal Catholicism and the pre-Christian beliei system.

Connolly notes that this overlapping of systems was quite common in Ireland. Some customary observances maintained their original content but acquired Catholic labels, others were modified to fit the Catholic religion (e.g. the dedication of ancient holy wells to Christian saints); or sometimes Catholic rituals were incorporated into magical practices (e.g., use of relics to verify oaths, or a prayer to stop blood). Connolly argues that the Catholic laity saw the two systems not as contlicting but. rather. mutually reinforcing as they moulded the old and the new into a spiritual melange that provided meaning to their lives.

This overlapping of systems can be seen in many practices on the southern Avalon. including those in which women featured prominently. As noted, women used a Christian symbol to give protective power to 'fairy buns' and made special batches of the bread on Good Friday - the most sacred day in the Catholic calendar. Women healers put pieces of

${ }^{43}$ The bread was blessed by making the sign of the cross over the dough before baking. lightly touching down on the dough four times to mark each extremity of the cross. The practice persists today, especially among older women and even among some middle-aged women. They no longer believe in fairies. but they continue the practice as an act of general benediction of their families. in the belief that it will help to ward off harm in a more diffuse sense. 
paschal candles ${ }^{4}$ in their cures to give them extra potency. The efficacy of women's predictions, particularly the identification of future spouses, was greatest on St. John's Eve and All Souls ' Night (Allhallows Eve) in the Catholic calendar - or Midsummer's Eve and the Celtic feast of Samhain in the ancient calendar, days for celebrating fertility and harvest. ${ }^{15}$ Also, women combined formal and informal systems when they anointed their homes with holy water and blessed candle wax to protect their households from general danger and to ward off specific threats such as thunder and lightning. Holy water was any water blessed by a priest or holy person, but it was ideally obtained from a holy well harking back to the ancient beliet in the power of holy and magical sites ${ }^{\text {th }}$ Blessed candle

${ }^{4} \mathrm{C}$ andles used by the Catholic church at Easter time to celebrate the end of mankind's banishment from heaven (and hence the return of light after a long period of darkness) with the resurrection of Christ into heaven.

${ }^{4}$ Another day for effective predictions was the first of Mav, or Bealtinagh in the ancient Irish calendar, when a ritual fire was lit at the seat of the high king at Tara to celebrate the first day of summer. May 1 is not a significant holy day in the Catholic calendar. But in the legend of St. Patrick. he is said to have lit the first paschal fire on the Hill of Slane on the night of Bealtmagh. The fire could be seen from Tara, and the Druids warned high king Laoghaire that if this fire was not quenched. it would consume all of Ireland. Laoghaire was unable to subdue Patrick, and hence. the tire" of Christianity replaced the 'fire' of paganism in Ireland. Of course, the chronology here is skewed. for Easter never occurs as late as May 1 . But the symbolic power of the narrative for the emerging Christian church was profound. and provides yet another example of the intersection of ancient and Catholic belief systems. See John B. Bury. The Life of St. Patrick (Freeport: Books for Libraries Press, 1905, reprint 1971), pp. 104-8 and 301-3.

${ }^{\text {th }}$ Father Duffy's Well, near Salmonier. St. Mary's Bay. provides a local example from the study period. Father Duffy led his congregation at St. Mary's in the destruction of a merchant's fish flake in the mid-1830s (see Section 5.6). When he and eight other ringleaders were walking to St. John's for their trial. they found themselves weary and thirsty, with no source of water in sight. According to the oral tradition. Father Duffy struck the ground with a stick and water sprang forth at his touch. A more latter-day 
wax was obtained from the priest on Candlemas Day, February 2. In his 1819 history of

Newfoundland, Anglican missionary Rev. Lewis Anspach wondered at the devout observance of this feast day by Catholics:

who most eagerly crowd to their respective chapels to receive a few drops from the lighted blessed candles on their hats and clothes, and a piece likewise blessed by their priest, which they carry home and preserve with the most religious care and confidence. as a protection against the influence of evil spirits, etc. ${ }^{47}$

The Catholic church promoted the candles blessed on Candlemas Day (used in services throughout the vear) as a symbol of Christ, deriving from the use of candles in the catacombs of Rome by early Christians who risked their lives to practice their faith. According to The Catholic Book of Knowledge, the bleached beeswax of the candles ${ }^{4 *}$ represented Christ's "spotless body." the wick. "his Soul." and the flame. "the union of the

manifestation of a holy well is the grotto at Renews. built on the site of the 'Mass Rock. where Catholics gathered in penal times (see Chapter 2); in modern times, the site has been kept supplied with holy water from the shrine of St. Anne de Beaupré. Belief in the spiritual and curative powers of the water from both sites was pervasive in the study area as late as the 1960s and 1970s, and continues among the older generation today

${ }^{17}$ Anspach, History, p. 474.

${ }^{4 x}$ Candles made of tallow or fat were not deemed appropriate for this service. although they most likely infiltrated small chapels in remote areas such as the southern Avalon. 
nature of God with the nature of man." ${ }^{-19}$ However, among the Irish community on the southern Avalon. Candlemas was always associated with Mary and a fervent belief in her power to ward off evil. Thus. when women dripped blessed candle wax at the windowsills of their homes, it was Mary's blessing and protection that they sought, and when they dabbed the wax into their children's shoes, they said a prayer to Mary to guide their children's footsteps. According to local belief, Candlemas was the day when Mary was churched. This was an unlikely event in the life of a Jewish woman. but demonstrates the awe in which Mary was held by the lrish community, that a church feast day for venerating Christ was co-opted to honour his mother instead. A further demonstration of the importance of female saints to the Irish community was the effort to tie Brigid. the :Mary of the Gael. to the event. even though the two women were not contemporaries. According to local informants. Brigid walked before Mary as she was on her way to be churched. with rays of light pouring from her head to distract attention away from Mary's shame ${ }^{* 0}$ This. they say. is why St. Brigid's feast day is celebrated the day before Candlemas. on February I (which as noted. was also the Celtic feast of Imbolc. celebrating the goddess Brigid. fertility, and the return of light after the long winter darkness). Here. then. was not only a conflation of Celtic and Catholic systems. but a conflation of time itself The tradition of making Brigid and Mary contemporaries already existed in Ireland

${ }^{49}$ Rev: Leonard Boase. ed. Catholic Book of Knowledge (London: Virtue and Company. 1961. Reprinted Chicago: Catholic Home Press, 1962), vol. 3. p 262.

${ }^{50}$ Churching and shaming will be discussed further in Chapter 8 . 
in other variations. One very compelling version held that Brigid was a midwife to Mary and wet nurse to Jesus - making her a favourite of pregnant women nearing their time of delivery (note. again, the connotations of fertility that hark back to the goddess Brigid) Shirley Toulson describes the convention as a "venture into the spiritual. timeless world that makes nonsense of chronology...." ${ }^{\text {st }}$ But it was a tradition. with women at the core. that helped the Irish communities on the southern Avalon and in Ireland make sense of their spiritual and natural worlds.

Perhaps the most striking example of the combination of ancient practices with Catholic beliet was the wake. Here, women also played an essential role in the rituals associated with death. ${ }^{5}$ The corpse was usually laid out by a woman, who bathed the body and then poured the water on the ashes in the fireplace - a ritual that suggests spiritual as well as physical purification. The woman was sometimes assisted by a man. especially in shaving the face if the deceased was male; but this was decidedly regarded as women's work in which a man might occasionally help. The body was then dressed in a habit that had been made by a woman. preferably by a member of the family but otherwise by another woman of the community with good sewing skills. ${ }^{\text {.j }}$ A woman also made the shroud that covered the coffin and the small white cloth that was placed on the face of the

"Toulson. The Celtic Year, p. 80.

"Diner notes a similarly central role of women at Irish wakes in Erin's Daughters. pp. $27-8$

${ }^{53}$ The habit was a full-length gown. decorated with a breast-piece bearing the letters 'IHS.' with a small white cross above and a small white heart below the inscription. 
corpse before the coffin was closed. Throughout the preparation of the corpse, men would cluster outside. shuffling their feet, waiting for this part of the ritual to be completed before entering the wake-house - a spatial separation that suggests that they were remote from this process of ritual cleanzing and preparation.

As in Ireland, the wake, itself, was a mixed gathering at which stories and practical jokes abounded, the 'God be merciful' pipes ${ }^{5 t}$ were at the ready, and liquor was usually in good supply "2 The body was not left unattended until after internment. and women as well as men 'sat up' with the corpse overnight to guard its spirit, although the practice varied in some instances, only men stayed up, in others, only women, more commonly. however. both sexes were in attendance. It was during the overnight vigil that practical jokes were most likely to occur. with men being the usual perpetrators. and women, the usual victims. The oral tradition abounds with stories of women being terrified by the sight of a corpse smoking a pipe, or its chin whiskers moving, or a body sitting up or rolling over in a cotfin (thanks to some strategically tied string). Middle-class observers of the period often denigrated such practices: Robert Carter. merchant and surrogate at Ferryland. for example, stipulated in his 1795 Will that there be -No Wakings - of my

"These were communal pipes, shared by those at the wake-house. The smoke was drawn into the mouth and then exhaled with the invocation "God be merciful " Both men and women partook of the ritual.

${ }^{55}$ Wakes of those who had died young or under tragic circumstances were perhaps more somber affairs, certainly, they were in the 20th century. 
Bodie, I protest against such practices, its very Indecent. ${ }^{\text {"so }}$ Similarly, modern-day observers might view such rituals and jokes as callous or distasteful. But they actually had important functions in helping mourners cope with the loss of loved ones and, in a broader sense, re-affirming life, even in the face of death.

Both women and men attended at the mass for the dead and the prayers at the graveside: although as the $19^{\text {th }}$ century progressed. women's presence at the actual burial was being discouraged by the Catholic church (with limited success on the southern Avalon) as being an unsuitable activity for the 'gentler' sex. Another ritual performed by both sexes. but primarily by women, was keening - a ritualistic crying. both at the wakehouse and the graveside. to mourn the departed. placate his or her spirit. and mark his or her transition to the afterlife. Anspach observed the practice among the Irish at Newtoundland, again with some awe and trepidation. describing it as "crying most bitterly. and very otten with dry eyes. howling. making a variety of strange gestures and contortions expressive of the violence of their grief...." ${ }^{.57}$ But while keening often struck the outside observer as primitive and strange. it was an accepted and effective mechanism for expressing grief within the Irish community. Furthermore. this characteristic wailing traditionally punctuated a ritual eulogizing, sometimes in rhyming form that required a fair degree of literary finesse. This aspect of keening was not recorded by Anspach (which is 29. 1795 .

${ }^{56}$ P. ANL. MG 31. Carter Family Papers. File 33. Will of Robert Carter. Sr. March

57 Anspach, History, pp. 472-3. 
not to say that it did not occur in Newfoundland), but observers in contemporary Ireland commented on this more formal element of keening and the musical quality of the lament They also noted women's central role in the ritual. Protestant minister James Hall. generally unsympathetic to Irish-Catholic death rites. conceded that "Some of the women rhyme extempore and offhand with wonderful facility. particularly when they have got a little (but not too much) whiskey" And others described the "plaintiveness" and "melancholy sweetness" of the crying accompaniment. ${ }^{5 x}$ Indeed. Angela Bourke points out that the Irish word caomeadh. from which the English word keening derives. actually suggests, in one of its meanings, a stylized tradition of women's poetry. As late as the $18^{\text {th }}$ century. she notes. it was common for women to lead their communities in this public demonstration of grief, and the various emotions expressed in their rhythmic lament - denial. anger. bargaining. sadness, and acceptance - are recognized by modern-day psycho-analysts as necessary stages of the mourning process. ${ }^{5 y}$ [t was a practice. however. that was seen as pagan and heathenish by the Catholic church. both in Newfoundland and in Ireland, and was aggressively discouraged. By the middle of the $19^{\text {th }}$ century, ritual keening was increasingly being represented as self-indulgent

${ }^{58}$ These quotations appear in Connolly, Priests and People, pp. 157-8. Diner also notes that a number of contemporary observers in Ireland wrote about a class of protessional keeners, elderly women who made a living mourning the dead...." See Diner. Erin's Daughters, p. 28

${ }^{85}$ Angela Bourke. "The Irish Traditional Lament and the Grieving Process." Women's Studies International Forum, 11:4 (1988), 287-91. 
caterwauling. (One male informant, when asked about the role of women's keening, told me. "Yes, some of them were real bawlers. ${ }^{\text {"to }}$ ) Thus. while most of the other rituals related to death persisted well into the $20^{\text {th }}$ century, this one did not. Its disappearance marks the efforts of Catholic clergy to impose middle-class standards of respectability on their Irish congregation, particularly Irish women - a process that will be discussed more tully in Chapter 8

Indeed, there was a concerted effort by the Catholic church to stop ancient customary practices and undermine the alternative belief system in both Ireland and Newfoundland in the $19^{\text {th }}$ century. Connolly points out that even as early as the $18^{\text {th }}$ century, higher church authorities in Ireland were trying to discourage popular supernaturalism because it threatened their ambition for a monopoly on mediation of the supernatural world and provided alternative mechanisms for meeting the emotional and psycho-social needs of their tlock. But many in their congregation were reluctant to part with their customary practices, for they provided an explanation for what would otherwise have appeared as a meaningless pattern of good and bad fortune, while at the same time enabling people to feel that they exercised some control over that pattern." Thus. while the church unleashed the full battery of their "machinery of discipline" - the confessional. public denunciation, exclusion trom the sacraments. and even

*TP. Interview July 19, 1999.

${ }^{h 1}$ Connolly, Priests and People, p. 119. 
excommunication - it found that these measures were effective only in as much as the congregation was willing to reinforce them through the shunning of non-compliers. Lntil the people, themselves, wished to abandon the ancient system, it would persist, the clergy, meanwhile. could only lead the people where they wanted to go.t2

The tide turned for the Catholic church in Ireland in the second half of the $19^{\text {th }}$ century as adherence to formal religious practices increased markedly Emmet Larkin attributed this transition to the 'devotional revolution' spearheaded by Paul Cardinal Cullen. with its increased church discipline and intensitication of devotional practices, ${ }^{\prime 2}$ Certainly. these reforms spurred an evangelical revival in the Irish Catholic church. But Connolly very compellingly argues that more significant was the dramatic shift in the profile of the Irish population that occurred during the Great Famine Before mid-century. the overwhelming majority of the population was made up of labourers, cottiers. and smallholders - groups that clung tenaciously to the older belief system, after the Famine. this class had been decimated due to death and emigration. and the small tarmer class emerged as the backbone of the population, with aspirations to greater respectability that more closely meshed with the wishes of church authorities. ${ }^{\text {st }}$ Once again. the priests were leading the people where they wanted to go: the composition of their flock had simply

"Connolly, Priests and People, Chapter 3. particularly pp. 119-34.

${ }^{53}$ Emmet Larkin. "The Devotional Revolution in Ireland. 1850-75." in Larkin. The Historical Dimensions of Irish Catholicism (New York: Arno Press. 1976). Chapter 2.

${ }^{n}$ Larkin also acknowledges this demographic shift. but places much greater weight on Cullen's efforts in dramatically increasing adherence to formal Catholic practices. 
changed.

The Catholic population at Newfoundland also experienced the impact of the devotional revolution through the religious personnel regularly recruited from Ireland: but it did not experience the massive demographic and economic transitions that Ireland underwent at mid-century. As the $19^{\text {th }}$ century progressed into the $20^{\text {th }}$ century, many Catholics within rural, plebeian culture continued their customary practices in concert with formal religion, and women's roles in this alternative system - as symbolic figures and as interpreters of the supernatural world - persevered beyond the study period of this thesis But this alternative temale power was perceived by church authorities as competing with. not complementary to. the church's own status as interpreters of the supernatural. It would be discouraged within an effort to impose Church and middle-class notions of respectability on the congregation in general, and feminine ideals of domesticity and dependence on Catholic women in particular (see Chapter 8).

\section{The information highway}

Oh I otten hear men ask why a woman talks so fast Nor how she comes by every bit of news

She's from morning, noon and night. from day until midnight And the way she use her tongue it beats the news... 
There's no use of you beginnin' for to stop a woman's chinnin'

Whatever you does she's equal to whatever it is

When I am working hard I will find her in the yard

And she's talking to her neighbours 0 'er the fence ${ }^{\text {s's }}$

The female gossip, whispering through the garden fence, idly destroying reputations and lives, has been a tenacious image within western culture. Yet the word 'gossip' in the English language did not always have such associations Indeed. the term was originally gender neutral and had connotations of friendship and intimacy. for the earliest definitions in late Old English referred to god-parents or other intimate friends invited to celebrate a christening. ${ }^{\text {.6 }}$ By the middle ages, however, the word 'gossip' had been feminized and denigrated. ${ }^{67}$ Yet we have only recently begun to understand why gossip has so persistently been associated with women and why it has garnered such a high degree of moral and social opprobrium.

The disciplines of sociology and anthropology have been examining and debating

"Lines from a local song, "A Woman's Tongue will Never Take a Rest." collected in Cape Brovle in 1968 See Andrew O'Brien, "Songs from Cape Brovle." MUNFLA Tape 68-16/490. 1967-1968

*'Melanie Tebbutt. Women's Talk? A Social History of 'Gossip' in Working-Class Veighbourhoods, 1880-1960 (Aldershot: Scolar Press. 1995), pp. 19-20. Tebbutt says that traces of this older meaning survived in $19^{\text {th }}$-century dialect in Somerset. where 'gossiping' still reterred to a christening feast or general merrymaking

${ }^{n 7}$ Karma Lochrie. Covert Operations: The Medieval Uses of Secrecy (Philadelphia: University of Pennsylvania Press, 1999), Chapter 2. 
the social significance of gossip for some time. ${ }^{68}$ Early writings in these fields argued that gossip was an effective method of social control or group preservation, particularly within small. pre-urban. morally homogeneous groups. Social control theorists [F. E Lumley. B Malinowski. W. F. Ogburn, and M. F. Nimkoff] maintained that gossip confirmed the validity of the community's norms and values by pressuring the objects of gossip to change their deviant behaviour and by acting as a deterrent to other community members who could potentially become objects of gossip in turn. Group preservation theorists [Max Gluckman, E L. Epstein] argued that gossip served to validate the group by reinforcing its norms and values within the context of mutual group membership and a shared desire to maintain group stability. These functionalist interpretations of gossip. however. came under attack in the latter decades of the $20^{\text {th }}$ century. They did not take account of individual motivations for gossip, critics argued, such as the increase in status of the gossip-bearer as the bearer of secret and important information. They did not represent the dynamics of gossip as a means of distributing information. Yet while other theories have been protfered to address these weaknesses - e.g. gossip as information management [Robert Paine] or as a social form of "discreet indiscretion" [Jörg R. Bergman] - they still do not provide historical insight as to why gossip has been stigmatized and why it has so persistently been linked with women. To address this lack.

${ }^{418}$ The discussion in this paragraph is taken from a theoretical review by Jorg $\mathrm{R}$. Bergman. Discreet Indiscretions. The Social Organization of Gossip, John Bednarz. Jr. trans. (New York: Aldine de Gruyter, 1993), pp. 63-7 and 139-153. The authorities he cites appear in square brackets in the text below. 
teminist scholars in anthropology and sociology [M. Weigle, V Aebischer. R. Borker, D. Jones, Ch. Benard and E Schlaffer, A.-M. Waliullah. B. Althans] have brought forward their own explanatory model: that gossip provides a subversive form of female solidarity that threatens male domination in patriarchal societies; it is thus feared by men, who take measures to discredit and detuse it as a shameful, malicious female practice ${ }^{t \theta}$

Karma Lochri follows a similar line of thought in her study of medieval uses of secrecy. Lochri suggests that from the middle ages to present day. the representation of gossip as a discourse of malice, secrecy, and deception, as well as its association with temininity has served to maintain women as a marginalized group. Gossip. she argues. was and continues to be perceived as "a resistant oral discourse" of the "other" and the association of gossip particularly with women "serves... to reinforce gender ideology and

"B) Bergman dismisses this "so-called 'feminist" literature" as lacking in explanatory power. He argues that women are seen as 'gossipy' simply because the traditional division of labour has put them in a position to be gossip producers to a greater extent than men. Particularly as washerwomen. maids. and servant girls. he argues. women have had far greater access than men to the private affairs of others, and therefore have been perceived to be the more likely gossip producers. Unfortunately, this does little to explain the association of gossip with all women. regardless of occupational group. Furthermore. Bergman. himself. lists a variety of traditionally male occupational groups - barbers. postmen, small shopkeepers. landlords - who have access to private information and are known to be 'gossipy' (he rather naively rules out others. such as doctors, lawyers. priests. and psychotherapists, because they are prevented by professional codes of ethics from revealing the information). See Bergman, Discrete Indiscretions, pp. 63-7. Given this plethora of potential male gossips, then. Bergman's explanation still begs the question why in western culture has this 'morally reprehensible' behaviour historically been associated with women? 
valorize traditional institutional forms of discourse and authority. "Th,

Feminist scholars in socio-linguistics have also developed constructs of dominance and difference in their writings on women's language ${ }^{-1}$ In discussing the trivialization of women's talk, Dale Spender points out that men engage in similar forms of talk with comparable functions, but magnify its importance to preserve their advantaged gender position. She writes

It is not surprising to find that there are no terms for man talk that are equivalent to chatter, natter. prattle, nag, bitch, whine, and, of course, goxsip. and I am not so naive as to assume that this is because men do not engage in these activities. It is because when they do it is called something different, something more flattering and more appropriate to their place in the world. This double standard is of great value in the maintenance of patriarchal order :

However. there has been a tendency among feminist socio-linguists to examine women's gossip only in terms of an ariculation of a women's subculture, an expression of women's concerns and values. Deborah Jones. for example, defines gossip as " . a way of talking between women in their roles as women. intimate in style. personal and domestic in topic

${ }^{-10}$ Lochrie. Covert Operations, p. 57, and Chapter 2 in general.

${ }^{-1}$ See, for example: Jennifer Coates and Deborah Cameron, eds., Women in Their Speech Communities: New Perspectives in Language and Sex (London, New York: Longman. 1988); also Deborah Cameron. ed.. The Feminist Critique of Language A Reader (London. New York: Routledge, 1990; revised ed. 1998).

'Dale Spender, in Tebbutt. Women's Talk?, p. I; citing Spender. Man Made Language (London: New York: Routledge and Kegan Paul. 1980 and 1985), p. 107. 
and setting, a female cultural event which springs from and perpetuates the restrictions of the female role. but also gives the comfon of validation" within the context of the private domain $^{-3}$ Jennifer Coates' more recent discussion acknowledges that both men and women gossip. but argues that women's gossip is different from men's in that it seeks to consolidate friendship, to establish and maintain networks of support and cooperation. She also reintorces Jones's linkage of women's gossip with the private domain. ${ }^{*}$ Both writers are trying to retrieve some of the positive aspects of women's talk. But the danger here is in interpreting women's gossip in terms of an essentialist. homogeneous women's culture that addresses uniquely female concerns and needs; and it denies gossip some of its very public functions

Such interpretations. for example. do not help us understand the complexity of community relations that led to the 1822 confrontation between Ellen Veal and Mary Bowen at St. Mary's - the case which introduced this chapter. Mary. Catharine St. Croix, and Nell Tobin were obviously a part of a unit that transmitted gossip and sexual innuendo about Ellen. her daughter. and her husband Yet the very next year. Nell Tobin had.

${ }^{-3}$ Deborah Jones, "Gossip: notes on women's oral culture." in Cameron, ed. Feminist Critique (1990), pp. 242-50; reprinted from Women's Studies International Quarterly, 3 (1980), pp. 193-8 Jones breaks gossip down into four categories of women's language: house-talk. scandal, bitching, and chatting.

${ }^{-1} J$ ennifer Coates, "Gossip Revisted: Language in All-Female Groups," in Coates and Cameron, eds. Women in Their Speech Communities, pp. 94-122. 
herself. fallen out with the St. Croix family"s - contradicting the notion that female bonding is intrinsic to gossip. Furthermore, the gossip deployed in the Veal-Bowen affair did not offer female resistance to patriarchal domination. but rather attempted to enforce hegemonic norms on female sexuality, indeed. the gossip was as divisive as it was consolidating in terms of female friendships. Thus, while female networking and female resistance are aspects of women's gossip, they do not represent the entire, multi-faceted configuration. As Sally Cole has noted in her study of the women of the Praia. gossip should not be examined as a separate sphere for women, but as an integrated part of social, economic. and political relations of their community. ${ }^{-6}$ It is imporant to acknowledge diversity and divisiveness as well as commonalities in women's experiences. and it is necessary to anchor any discussion of their experiences in the context in which they live, or once lived.

The southern Avalon in the late $18^{\text {th }}$ and early $19^{\text {th }}$ centuries was a rural. preindustrial society - a cluster of small populations, each spatially condensed, which facilitated networking even as it mitigated against privacy. In this context, women's gossip, in some respects. operated differently than in the modern. urban women's networks often studied by socio-linguists. Here, it is helpful to revisit some of the older.

"'PANL. GN 5/4/C/1. St. Mary's: f. 134. Ellen Tobinv. Ann St. Croix. June 27. 1823. and f.135. Bridget St. Croix v: Thomas Tobin. June 30, 1823. This parting of the ways is discussed below in Section 5.6

${ }^{\circ}$ Cole. Women of the Praia, p. 121 
functionalist arguments about gossip in traditional societies and not throw the baby out with the bath water. Did women's gossip on the southern Avalon function to stabilize the community when limited formal mechanisms for group preservation and social control existed and when even informal mechanisms such as kinship ties may have been diluted by the recent emigration experience? ${ }^{77}$

In her study of the comparable society of colonial Virginia. Kathleen Brown uses functionalist arguments as she portrays women 's gossip as a source of alternative female power. Through gossip, she says, women created "informal political networks" in which they could "wield influence over the behavior of their neighbors," regardless of sex or status. As "conduits of information" about the character and lives of local personalities. women helped to maintain community standards in colonial Virginia in wavs beyond the scope of, and often in competition with, more formal legal institutions. ${ }^{-7}$ This interpretation of women's talk is shared by Tebbutt. who perceives gossip as an "arena for moral and political debate" in which the values of the community were shaped: women's gossip. she notes. "expressed the politics of evervday living, and as such was an important vehicle for ... [women's] informal power ${ }^{-\pi}$

"In his extensive study of the Irish at Newfoundland. Mannion has found that Irish migration to Newfoundland, with few exceptions, did not follow channels of kinship to any great degree This finding is stated in Mannion and Maddock, "Inistioge Immigrants."

${ }^{-8}$ Brown. Good Wives, pp. 95-100.

${ }^{-9}$ Tebbutt. Women's Talk?, pp. 1 and 11 . 
Does this conception of women's gossip as a female political network for maintaining communal norms apply to the southern Avalon during the study period? Empirical evidence on women's gossip in the area is limited. Of course. this is historically true of much of women's language because it was usually verbal in nature and persistently trivialized. As Tebbutt points out, women's "so-called loose tongues' and sharp talk were often criticized, but remain largely silent in the written record ${ }^{-80}$ However, some insights can be derived from an examination of the 14 court cases tor the study period involving women in which gossip was a tactor ${ }^{* 1}$

A breakdown of the cases in terms of gossip producer, object, and targeted behaviour provides the protile shown in Table 5.2. This outline suggests that both men and women were equally targeted by gossip in the study: women being the objects in six of the cases. men in seven. with a mixed-sex target in the remaining case All gossipers were of the plebeian community, as were all their targets with the exception of one. This lends some credence to arguments that gossip was frequently deployed to reinforce the standards of behaviour within a closed group. Certainly, there was no evidence of the involvement of middle-class women in these networks. This is not to suggest that middleclass women did not gossip. but that they maintained their own information network that

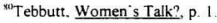

"These cases were tound in the court records for the area located at PANL and PRL. Thev included: eight defamation of character'slander cases: five cases of assault involving or provoked by gossip; and one case of thett which was pursued because of information obtained through gossip. 
Table 5.2-Profile of women's cases involving gossip

$\begin{array}{lll}\text { Sex of producer } & \text { Sex of object } & \text { Targeted behaviour } \\ \text { F } & \text { F } & \text { twitchcraft } \\ \text { F. F. F } & \text { F, F, F, M } & \text { sexual immorality } \\ \text { M } & \text { F. F, F. F } & \text { sexual immorality } \\ \text { F } & \text { F } & \text { sexual immorality, dishonesty } \\ \text { F } & \text { F } & \text { theft } \\ \text { F } & \text { M } & \text { theft } \\ \text { F } & \text { M } & \text { thett } \\ \text { F } & \text { M } & \text { theft } \\ \text { F. F } & \text { M } & \text { unspecified } \\ \text { F } & \text { F } & \text { unspecified } \\ \text { F } & \text { M } & \text { unspecified } \\ \text { F } & \text { M } & \text { unspecified } \\ \text { F. M } & \text { M } & \text { unspecified } \\ \text { M. M } & \text { F } & \end{array}$

did not manifest itself in the court records. ${ }^{x 2}$ Here is an example of class and ethnicity cutting across gender lines to preclude the tormation of an homogeneous women 's subcuiture on the southern Avalon. ${ }^{* 3}$ This is also not to suggest that the plebs did not talk about the gentry or vice versa, but rather that the power of such talk to do harm was

*For example. diarist Robert Carter and his tamily were estranged from $\mathrm{Mr}$. and Mrs Wright (iikely Tomas Wright, merchant at Ferryland, and his wife. Sarah) for an extended period over a matter that began with "some curtness" on Mrs. Wright's part to Carter's daughter. Eliza. in January. 1834. but escalated when Mrs. Wright began "spreading scandal" about the Carter family. Fences were mended, however, for in August. 1836. Carter noted. "Mrs. and Mr. Wright called to-day after staving away more than 12 months" PANL. MG 920. Robert Carter Diary. January 28 and March 22, 1834. and August 9. 1836.

${ }^{* 2}$ The sense of difference between women of the gentry and the plebeian community is discussed further in Chapter 9 . 
defused by the outsider status of the target: a local merchant. for example, would feel obliged to defend his reputation against scurrilous remarks from someone in his own circle and might initiate a court action for libel: unflattering talk from the plebeian community. by contrast. would more likely be dismissed as merely the grumblings of the lower orders.

The one object of a woman's gossip from outside the plebeian community was Christopher Valence (also Vallance), who was the largest employer in Cape Broyle at the taking of the 1800 census, operating two banking vessels and two shallops with 24 tishermen and eight shoremen. ${ }^{x+1}$ Valance took his former employee. Henry Currier (also Coryear). ${ }^{* 5}$ to court in 1809 for trespass. This obviously incited Henry's daughter, Elenor. to stir up ill-feeling in the community towards Valence, for in the very next case on the docket. Valence was charging Elenor with "abusive \& threatening language . \& reporting

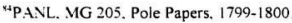

${ }^{* 5}$ Appendix $A$ describes a middling group between gentry and plebeian communities on the southern Avalon whose allegiance was primarily with the plebs - with whom they shared much in terms of work and leisure routines and world view - but who were still connected to the gentry group by ethno-religious and patronage ties. Henry Currier (or Coryear) was one of this group. In the 1800 census. he was listed as a boatmaster for 'Vallance'; he was also listed as a small-scale employer. with one fishing servant and two dieters in the winter of 1799-1800. Like many fishermen who came out to Newfoundland, however, he was upwardly mobile, and likely moved into the vacuum created by the numerous bankruptcies in the traditional planter fishery in the late and postNapoleonic War period. By 1817, he was in possession of three plantations. which he devised by Deeds of Gift to his children (see Chapter 7). In 1818, he hired a clerk for his business and private tutor for his family (see Chapter 6 ). In the 1809 episode, however. his daughter was still appealing to the family's plebeian connections. 
talsehoods of him tending to aggravate the Inhabitants of Cape Broyle against him. ${ }^{* \times 6}$ As with many of the court records for the area. details of the case are slim: but the evidence suggests that Elenor may have been playing against Valence's elevated status to rally support for her father within the fishing community. Thus. even when gossip was aimed against an outsider in terms of class, it was still functioning to identify and maintain the boundaries of the group

The breakdown of targeted behaviours in the above profile also points to the monitoring function of gossip. Thett. sexual immorality, witchcratt - these represented substantial threats to community order and suggest that there was a quasi-legal aspect of gossip networks that supplemented the formal legal system. Certainly, the frequency with which female witnesses gave testimony in court hearings ( see Chapter 6) indicates that the legal system was at least partially dependent on women`s intormation networks tor intelligence on events in the community. Indeed, in one of the 14 cases profiled above. a woman's yossip actually provoked the laying of a charge of theft. When Ann Bowen of St. Mary's brought her neighbour Mary Money to court tor allegedly stealing her brown and blue serge gowns from her garden fence in 1823. she was acting on intormation she had received from Ansty White. Ansty had told Ann that she had seen Mary's children dressed in clothing of the very same fabric and colour, indeed, she had gone to the Money house. inspected the clothing, and satisfied herself that they had certainly been made from

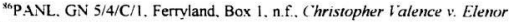
(iurrier. March [?], 1809. 
Ann's missing gowns. Furthermore, Ansty appeared at the court hearing as Ann's only witness. Yet while the defendant produced two witnesses (a merchant's clerk and her own servant) who testified that she had purchased the material and that she had made the children's clothing several months previous to the theft. the local magistrate did not dismiss the charge out of hand (as often happened with cases deemed to be frivolous). indicating that he gave some credence to the statements of Ann and her gossiping neighbour. Ansty, or perhaps feared some backlash, himself, from local gossips. At any rate. he chose the course of discretion and deferred the matter for the decision of the visiting surrogate ${ }^{x \text { * }}$

While there is evidence of women s gossip acting in tandem with the legal system. however, it is likely that it more frequently operated in competition with more formal legal institutions. This would be particularly true of all the instances of gossip that did not appear in the court records. but which served on a more day-to-day basis to define and maintain standards of behaviour in the community.

Certainly. the above cases suggest the deterrent effect that fear of gossip had on community members. In all of these cases. people's characters had been called into question. and the fact that these objects of gossip risked further exposure by laving charges of detamation/slander. or by assaulting the gossip producer and thus airing the slander in court by a more circuitous route. suggests that the victims were highly

${ }^{x}$ P.ANL. GN 5/4/C/1. St. Mary's. ff. 132-3. Ann Bowen 1: Mary Money. March 9 and April 1. 1823. The final deposition of the case has not survived in the records. 
concerned about the impact of the gossip on their personal reputations. Indeed, when Margret Dinn called Elenor Piddle a "whore" and a "perjured villain" in the presence of Elizabeth Feagan and Catharine Lannahan, and suggested that "she coud say many other things besides against her character," Elenor had an additional incentive to lay charges against the gossiping Margret. tor her own husband "threaten'd to breake her bones. it she did not apply to the Court" to clear her good name. ${ }^{\mathrm{kx}}$

While men and women were targeted by gossip in equal numbers in these cases. there is some evidence that the were targeted in different ways. Kathleen Brown observes from the language of slander cases in colonial Virginia that gossip helped to perpetuate "gender-specific standards of behaviour." The reputation of a man. for example, would be tarnished by questioning his honesty and calling him a perjured rogue By contrast. a woman's reputation rested on her sexual morality. and was challenged by terms such as 'whore' and 'jade. ${ }^{-k)}$ Laurel Thatcher Clrich also notes the frequency with which words like 'whore," "jade," 'bawd, "strumpet," and 'trull" were used by village gossips against women. and how powertul a form of defamation this was in colonial New England. The only rough male equivalent was the term 'rogue." she notes, although this aiso had a more general connotation of dishonesty. "For a woman," she argues, "sexual

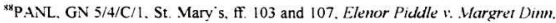
September 5 and October 13.1821 .

"Brown. Good Wives, Nasty Wenches, pp. 99-101. Richter also notes that in colonial Virginia, nothing damaged a woman's reputation more than being called a "whore. See Richter. "Free Women." p. 295 
reputation was everything, for a man, it was part of a larger pattern of responsibility." Such language appeared in only one record of a slander case on the southern Avalon - the Picklle v: Dinn matter, above, in which Margret called Elenor both a whore' and a 'perjured villain.' This was a mixture of the labels so clearly demarcated by gender in the records of Virginia and New England. However, the female epithet whore' did feature in other types of cases. particularly assault matters. ${ }^{\text {"I }}$ In addition, the breakdown of attributed behaviours of gossip victims suggests a gender dichotomy similar to the tindings of Brown and Llrich: almost all accusations of sexual immorality were leveled at women (one man featured in a multiple accusation); by contrast, four of the five accusations of theft were aimed at men.

Of course. these 14 cases represent only a tiny fraction of the gossip that transpired on the southern Avalon in the study period. However. additional insight on temale gossip can be drawn from oral informants in the area. As the song at the beginning of this section demonstrates. the oral tradition supports the perception of gossip as a female preserve: women in groups 'gossiped' about personal and private affairs; men in groups 'discussed' weightier matters - politics. the effect of the weather on fishing or crops, the best fishing grounds, the price of fish and supplies. This viewpoint was

"*lrich, Good Wives, pp. 96-7.

"See. for example. PANL. GN 5/4/C/1. St. Mary's, f 135. Bridget St. Croix : Thomas Tobin. June 30. 1823; also. PRL. 340.9 N45. Ferryland. n.f.. Bridget Murph $\cdot 1$ : (atherine Dauton and Mary Whealon, September 28, 1795. 
expressed by both male and female informants, indicating that the perception of men's talk as important and women's as trivial has been internalized - a view that may have extended back into the study period.

Still. there was an acknowledgment of the positive functions of gossip. In this regard, most informants differentiated between 'useful gossip, in which women of good character were seen to participate. and the type of spiteful venom spewed by the 'real prate-box. Here was a perception of some motivation for female gossip beyond nosiness. idleness, or pure maliciousness. Indeed, when pressed, informants set forth a variety of useful functions of female gossip in the period, which can be summarized as follows a proscriptive role at a time when there were few formal mechanisms for maintaining order in the community: a leveling function in small communities in which it would not do for individuals to set themselves above others or get "too much of a notion of themselves"."2 a means by which women could express themselves and occasionally give vent to their tiustrations, particularly about husbands or perhaps the merchant or parish priest; a mechanism for sharing information among people who had a genuine interest in each other's lives, a means of instructing the young in preferred modes of behaviour by making examples of those who had strayed from communal standards. One informant also recalled her father's telling her that his mother and her circle of female friends had even developed their own form of pigeon English so that when they were discussing such

"GK. Interview May 15, 1998. 
matters, they could not easily be understood by 'outsiders' (i.e., men and young children) ${ }^{13}$ Here, then, are all the elements of subversion and resistance, of social control and group preservation, of networking and co-operation, of social leveling spoken of in the academic texts.

But informants also revealed that women sometimes gossiped because they were simply jealous of what other people had. Women were not always networking. cooperating. building and preserving when they gossiped, then; sometimes they were competing. Thus, any discussion of women's gossip that overlooks the role of envy and rivalry is not comprehensive. So argues Sally Cole in her discussion of the concept of $m$ isja - roughly, a form of envy that resulted in behaviours such as gossip and the use of the 'evil eve' - in the maritime community of Vila Chả. According to Cole

Inveja describes the opposition between households that perceive themselves to be competing for resources. both social and economic Because it is women who are ultimately responsible for managing the household's resources in order to ensure its survival. meja is a powertul presence... in the lives of women. ${ }^{24}$

Because women were household managers. women's imrja was seen to be more powerful

"When the informant's tather, then a young boy, intruded on a gossip session, the speaker would say something like. " I-vra ca-vra no-vra sa-vra di-vras ou-vra lou-vra bevra cau-vra dere-vra li-vra boy-vтa wi-vras [I can t say dis out loud cause dere's a little boy with us] * EP, Interview July 19, 1999.

${ }^{2}$ Cole. Women of the Praia, p. 122, and pp. 108-24 in general. 
than men's in Vila Chả. As the principal household managers on the southern Avalon. plebeian women would also have felt the pressures of competition for resources in small communities. a compelling reason to try to ensure that others did not get "too much of a notion of themselves." Such an interpretation provides some breadth to our understanding of women s gossip, allowing it to transcend gender stereotypes that women always connect while men usually compete."

Women's gossip. then. was a multi-faceted phenomenon. When women on the southern Avalon were 'chewin' the rag, they were often involved in processes more significant than idle prating: sometimes they were building and conserving: sometimes they were tearing down, sometimes they were networking; sometimes they were

"'The perception of women as natural bonders and men as natural competitors has recently been given further 'scientific' endorsement by biological anthropologist Rubin Dunbar in Grooming, Gossip and the Evolution of Language (London; Boston: Faber and Faber. 1996) Dunbar argues that grooming. once the primary means of bonding by primates. became unfeasible amongst human social groups as these groups became ever larger. Language therefore evolved to replace grooming as the most important method of networking. "In a nutshell," he observes, " language evolved to allow us to gossip" (p 79). Furthermore. the chief networkers in primate species. he says. have been female Females are more likely to remain in the group in which they are born and give it coherence over time. Thus, says Dunbar. the impetus to evolve language in humans most likely came from the need to form and maintain female alliances. not through male bonding or hunting activities. as has long been purported. Language permits group members to exchange essential information about the physical and social world, to identify and form ties with other group members, to provide support in times of crisis. This tvpe of communication, so necessary to the survival of the group. is more associated with the cocperation that typifies the female world. Dunbar argues. The male world is much more competitive - focused on mating or acquiring resources (status) that will attract mates. Thus when people talk, "the women are engaged in networking, while the men are engaged in advertising " (p. 177) 
competing. This brings the discussion back to the interpretation of women's gossip as an alternative source of power. Whether it manifested itself as a female solidarity of resistance. or a political network that served to identify, maintain, and sometimes challenge group boundaries. or as a mechanism by which women competed for scarce resources. women, through their information networks, were exercising power in their community. Yet on the southern Avalon. as elsewhere, women's gossip was belittled and denigrated by the dominant culture But as Tebbutt argues. such trivialization stemmed from men's fear of gossip: tor it gave women a forum for asserting themselves in a collectivity that excluded men, it had a powertul socializing function outside the scope of patriarchal institutions: and it had the power to make or break reputations. The stigmatization of gossip actually retlected men's fears of women's ability to transform private affairs into public discussion: it was a deliberate effort "to drain gossip of its power. This was one more indicator that gossip was not a separate sphere for women. but rather an integral part of the power relations of the larger community. And the continuing denigration of women's gossip. on the southern Avalon and elsewhere. meant that this effort to disempower women's words was not an unqualified success

"Tebbutt, Women's Talk?, p. 176: see aiso pp. 7-9 and 220. Jones makes a similar point in "Gossip." p. 245. Thompson also notes men's fears of the power of women's tongues to incite and shame in Customs in Common, pp. 333 and 501. 


\subsection{What 's in a name?}

One of the most obvious indicators that a married woman's identity was subsumed in the person of her husband was her identification by her husband's name. In middleclass culture on the southern Avalon, as elsewhere, women were increasingly addressed only in terms of their husbands' identity: even to people within their own social circle. for example. Sarah Randell became 'Mrs. Robert Carter.' Anne Saunders became 'Mrs. Matthew Morry, Jr.; Harriet Skinner became 'Mrs. Arthur Hunt Carter, and Jane Killigrew became :Mrs. John Goodridge: Indeed. in writing his diary entries, magistrate Robert Carter never once used a married woman's first name - not even that of his own wite - choosing to follow the more formal style of address that, at first glance. might seem merely an affectation, but which also reflected the long arm of coverture

This can be contrasted with forms of addressing women within the Irish plebeian community. where married women maintained strong associations with their natal families and their pre-marital identities. It was not unusual, for example, for a married woman to use and be addressed by her maiden name. even though she had legally taken her husband's name at marriage - a practice that was common in Ireland in the period as well." Cerainly. married women continued to be addressed by their own first names sometimes with the addition of 'Mrs. in deference to increasing age (e g.. 'Mrs. Maggie')

${ }^{97}$ Diner. Erin's Daughters, p. 18. 
When more than one woman in the community had the same name, the last name of a husband might also be used when speaking of the person and not to them in order to differentiate them (e.g.. 'Mrs. Maggie Wade' vis-ä-vis 'Mrs. Maggie Sullivan'), And in small communities, where there were many common first names and surnames. married women with the same names were often differentiated by the addition of their husbands tirst names to their own (e.g. 'Maggie Tim' vis-à-vis 'Maggie Johnny. 'Mary Bill' vis-àvis 'Mary Tom,' or 'Kitty Phonse' vis-ḋ-vis 'Kitty Stephen'). This latter practice could be construed as an indicator of patriarchal domination - a reflection that these women were perceived to be the possessions of their husbands. Given the other circumstances of these women's lives. however. such an interpretation seems rather tacile. Certainly, these women's own names were not lost altogether: unlike middle-class women and the 'respectable" working-class in urban areas. Irish women on the southern Avalon were never reterred to as 'Mrs. Thomas Hearn' or 'Mrs. Stephen Kavanagh, for example, but [Mrs - optional with increasing age] Mary Tom' or [Mrs.] Kitty Stephen.'And those who had more distinctive names carried no reference to their husbands' names at all (e.g. [Mrs.] Julianne').

Furthermore, the issue of 'wife as possession' in the system of nomenclature is even more roundly challenged by another practice in the study area: sometimes the wife's name was added to the husband's for identification purposes. An example from Brigus South in the late $19^{\text {th }}$ century provides an example just outside the study period. In that community, there was a surteit of men bearing the name 'Ned Power,' and so they were 
differentiated by the addition of their wives' first names to their own: 'Sarah's Ned.

'Annie's Ned,' Bride's Ned,' etc. One year, a telegraph operator from St. John's. whose name was also Ned Power, came to work in the community. The newcomer was single. but the system did not collapse in the tace of this anomaly, for he was promptly dubbed 'Nobody's Ned' by the local residents. ${ }^{\text {* }}$

The practice of maintaining personal identity through a form of address may seem a small thing. but in combination with other facets of Irish-Newtoundland women's experience. it reinforces a perception of independence and status within their communities. The only encroachment on the practice was the increasing tendency in court records. especially from the late 1830 s onwards, to identity married women in terms of their husbands In earlier records. it was difficult to determine a woman s marital status unless it was revealed by the context of the case. But increasingly, identification forms such as "Sarah Aylward, Wife of James Aylward," "James Kenney and Ellen his Wife," or even more anonymous torms such as "Mrs. Ryan," "John Bavis and his wife." and the widow of John Doyle appeared in the records. However, this more likely reflected the preoccupations of middle-class magistrates and their recording clerks than a change in perceptions or practice within the plebeian community, itself.

"This anecdote was originally told by Mons. Francis A. Coady, who had served as a priest in the study area. to Dr. Cyril Byrne. Coordinator of Irish Studies at Saint Mary s Lniversity, Halifax. Dr. Byrne kindly provided it to me by email dated September 8 . 2000 


\subsection{Collective actions and private wars}

Another manifestation of women's influence within the plebeian community during the study period can be seen in their public participation in collective actions to enforce communal standards and in individual salvoes of verbal and physical attack to sort out day-to-day power struggles within the community Traditional treatments of the worlds of political activity and public confrontation have tended to treat them as male preserves. but more recent literature has begun to accommodate the presence of women in these spheres of activity and influence. ${ }^{* x}$

There is no surviving evidence of any solely female collective action during the period, and their involvement in incidents involving both sexes has tended to be disguised by the sexually indeterminate language of the day. Such was the case with wrecking and salving activities - discussed in Chapter + as an economic coping strategy but with strong

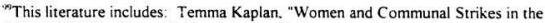
Crisis of 1917-1922," in Renate Bridenthal. Claudia Koonz. and Susan Stuard. eds. Becoming Visible: Women in European History (Boston: Houghton Mifflin. 1987). pp. +29-49. Rosemary Jones. "Women, Community and Collective Action: the 'Ceffyl Pren' Tradition," in John, ed. Our Mothers' Land, pp. 17-41: Bittermann, "Women and the Escheat Movement": Cadigan. Hope and Deception. Chapter 4: Luddy. Documentary History, pp. 245-50. Thompson, Customs in Common, pp. 305-36: and Ulrich. Good Wives, pp. 184-201 Absent from the study area, however, was the common practice elsewhere of men's use of female disguise either to signal the seriousness of the issue. such that the 'weaker' sex would cross over gender boundaries to involve themselves. or to mitigate their own responsibility and pass off the actions as the work of mere 'frail' women. This may reflect the fact that within the plebeian community in the study area. constructions of womanhood did not incorporate frailty or weakness: and neither did middle-class magistrates harbour such perceptions (see below) 
undertones of plebeian justice that can be linked to the current discussion. Similarly. women's participation in the two best-known collective actions during the period - the Ferryland riot of 1788 and the Father Duffy affair at St. Mary`s in 1834-35 - has been muted by latter-day historical interpretations. As in the case of wrecking activity, genderneutral collective terms like 'mob' and 'crowd' have been gendered male. particularly when arrestees in the incidents were men. ${ }^{100}$ But it is difficult to believe that women did not participate in some capacity. and thus it is a legitimate exercise to attempt to interlineate or superimpose their presence, and to retrieve the neutral connotation of collectivities that were reported in contemporary accounts

The Ferryland riot was a clash between rival Irish factions hailing from Munster and Leinster. ${ }^{10 t}$ While Irish taction-fighting has often been presented as the manifestation (often recreational) of grievances that had been nursed for centuries. and certainly ancient grievance provided an enabling mythology, there were usually more immediate causes for particular incidents than the "pure devilment and divarsion" attributed by Prowse "102 The

\footnotetext{
${ }^{\text {tin }} \mathrm{M}$ lost of the above literature refers to the general reluctance of authorities to arrest women in these types of actions

1il The following account is a summary of information taken from the following sources: PANL. GN 2/1/A. 11/388-95 \& 437-41/1788 and $11 / 459 / 1789$ : P.ANL. GN 5/4/C/I. Ferryland. Box I, n.f., Rex. v. various, September 17-30, and October 1, 20, and 25. 1788. Byrne. ed. Gentlemen-Bishops, various correspondence. pp. 62-117. Christopher English. "Collective Violence in Ferryland District. Newfoundland. in 1786. Dalhousie Law Joumal, 21:2 (Fall. 1998), 475-89: Lahey. O Donel, pp. 13-20: and Gerald J. Barnable. "The Ferryland Riots of 1788," An Nasc, 7 (Summer, 1994), 4-9.

1":-Prowse, History of Newfoundland, p. 402. Prowse is actually citing "an old Irishman" as his source.
} 
Ferryland affray was triggered by a jurisdictional dispute between the Prefect Apostolic. James O Donel (a Munsterman), and a renegade priest. Patrick Power (a Leinsterman).

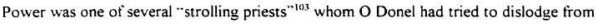
the newly established Catholic mission at Newfoundland: Power had removed himself to Caplin Bav, where he proceeded to stir up the district by charging that $O$ Donel was favouring Munster priests over Leinster candidates in his recruiting for the mission Tensions simmered and then erupted in a large-scale faction fight on the Ferryland downs during the winter of $1787-1788$

This was cerainly not the tirst incident of Irish faction fighting in Newfoundland. for Irish Catholic missionaries admitted that the "ancient feuds between the lay people of Munster and Leinster" had been in evidence in Newfoundland "those to years past. "1ht But the 118 men who were convicted in the ensuing court cases in September found themselves the recipients of harsh justice - stiff tines (ranging from $£ 1$ to 20 with a mode of $£ 5$ ). forfeited wages. floggings, transportation. and banishment - at the hands of the magistrates who represented leading farnilies of the local gentry. As Christopher English has argued. these penalties reflected not only the long arm of the British state. but "the

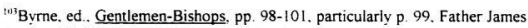
O'Donel to Archbishop Troy, Dublin. December 24. 1789.

${ }^{114}$ Bvrne, ed. Gentlemen Bishops, pp. 69-72 and $110-1$. Father James O Donel to Governor Elliot. 1788, and Fathers Patrick Phelan (Harbour Grace), Edmund Burke (Placentia), and Thomas Ewer (Ferryland) to Cardinal Antonelli. Propaganda Fide. December 14, 1790 
determination of a small elite to maintain order and their own social and economic prominence $^{- \text {tus }}$ within the growing fishing population.

While the severity of the response to the riot was provoked by class tensions. the motivations behind ensuing events were shaded with ethno-religious undertones. ${ }^{\text {tot }}$ In the wake of the trials. Anglo-Protestant magistrates, merchants. and traders in Ferryland immediately seized the opportunity to lobby for the removal of the recently arrived Catholic priests from the shore. They forwarded a memorial to Governor Elliot, voicing their fear "for the safety of our persons, and property" and requesting military protection. ${ }^{107}$ The visiting surrogate at Ferryland. Capt. Edward Pellew, supported their

I"Es English, "Collective Violence." p 487

${ }^{\text {ting }}$ It should be noted, however, that although elements of ethnicity and class obviously underscored this event and the later Father Duffy affair. sectarianism was not a rallying point in either episode. Despite official concerns about the volatility of the Irish population on the southern Avalon (see Chapter 2), in terms of sectarianism, the district was far less explosive than other areas on the island with mixed Irish and English populations. St. John's and Conception Bay. for example. witnessed significant sectarian strife. particularly in the $19^{\text {th }}$ century as a nascent Irish-Newtoundland nationalism asserted itself against the colony's Anglo-Protestant ascendancy. But while these other districts held distinct Irish and English populations, along the southern Avalon, as already noted. the English-Protestant group was almost totally assimilated into the Irish-Catholic ethnic group - doubtless contributing significantly to the quiescence of the district. The only wholesale demonstration of sectarian feeling on record occurred in the election of 1836 (see below). One other episode with the slightest of sectarian undertones was reported in a court case in 1803. in which Nicholas White of Ferryland was charged with assaulting Margret Gibbon on the public road and tearing her cap for having an orange-Coloured Ribband in it." White admitted the assault but pleaded intoxication. He was tined 20s and ordered to keep the peace and be of good behaviour. See PANL. GN $5 / 4 / C / 1$. Ferryland. Box 1. Rex v. Nicholas Whute. May 6. 1803.

${ }^{107}$ PANL. GN 2/1/A, 11/388-9/1788. Petition from the merchants and principal inhabitants of Ferryland to Governor Elliot. undated (likely received by the Governor in 
request; he denounced "Pope, Popery, Priests, \& Priestcraft" in the court house ${ }^{10 \mathrm{x}}$ and intormed the governor that the Protestant community had "reasonable grounds" for their fears ${ }^{109}$ One must wonder, then, why these same concerned Protestant inhabitants sheltered the main instigator. Patrick Power - housing him and feeding him for the next four years until he wore out his welcome with mounting debts. O Donel, in the meantime. defended his mission by advising the governor that the "Seneschals of sedition. if any there are. cou'd be rather found among the envious merchants of Ferryland than among the popish Priests as the voice of prejudice now runs." ${ }^{110}$ The dispute reveals a power struggle between Protestant establishment and Catholic church that most certainly had ethno-religious connotations; but there is no evidence that these undercurrents bled into the plebeian community (which, at the time, would still have contained a sizeable minority of English Protestants. particularly in Ferryland itself)

The other major fracas during the study period involved the destruction in 1835 of a large flake on the beach of St. Mary's that purportedly formed part of the mercantile

early October. 1788. given its placement in the letterbook and the fact that the Governor responded to it on October 9.1788 )

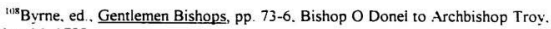
November 16. 1788

1199P.ANL. GN 2/1/A, 11/391-3/1788. Capt. Edward Pellew to Governor Elliot. October 9.1788

"'Bỹrne. ed., Gentlemen Bishops, pp. 69-72, O Donel to Elliot. 1788. 
premises of Slade, Elson and Company. "' This exercise in plebeian justice involved perceptions of grievance based on both ethnicity and class, as the largely Catholic plebeian community, led by the newly appointed parish priest, Father James Duffy, took action against an English-Protestant merchant firm and its agent, John Hill Martin (also MHA for the district and a local justice of the peace). ${ }^{112}$ Martin, in his capacity as magistrate, had refused Duffy permission to build a chapel on a portion of the beach in question: and in his capacity as agent for Slade. Elson. Martin had claimed that title to the beach had been sold to the firm and proceeded to erect a large flake over the entire area. However, the community had long considered the beach to be a commons, an area that had traditionally been used for mending nets and gear and repairing boats. it also served as a right-of-way to the $\mathrm{C}$ atholic cemetery and the neighbouring community of Riverhead. Martin offered Duffy an alternative site for the chapel on wet. marshy ground: but Dutfy declined the offer and organized work teams from his congregation to proceed with the building of the chapel on the beach.

The ensuing events can be brietly summarized as follows. Duffy petitioned Martin

"This account is taken from the following sources: C O 194/94, ff, 1-24, PANL. GN 5/4/C/1. Ferryland. Box 1. ff. 80-1. Slack, Elson \& (ompany v: Rev: James Duffi et al. . October 29 and November 3. 1835: Bishop Michael Fleming, reports and letters cited in Howley. Ecclesiastical History, pp. 323-8: McCarthy, Irish in Newfoundland, Chapter 13. pp 143-61, and Sr. Elizabeth Whelan. "History of the Community of St. Mary's" (Lnpub. research paper dated April 4, 1972, housed at the CNS). Chapter 3, pp. 19-31

1"Governor Prescott reported to the Colonial Secretary in 1836 that the entire community was Catholic save Martin. his two clerks, and one servant. See C O 194/94. ff. 3-10, Governor Prescott to Lord Glenelg, January 4. 1836. 
to remove the company flake as it constituted a public nuisance. Martin refused and. before leaving for a legislative session in St. John's. ordered the clerks at Slade, Elson to refuse supplies to Duffy. Duffy countered by ordering his congregation to destroy the flake, and on January 13, 1835, a large assembly of people proceeded to cut the flake apart with hatchets and burn the debris. ${ }^{113}$ Martin. acting on the advice of Chief Justice Henry Boulton, initiated an action in the Supreme Court of Newfoundland for riot. rebellion. and destruction of property against Duffy and eight other male ringleaders. Dutfy was arrested and made to walk to Ferryland, where he was charged before local magistrates who, according to Catholic Bishop Fleming. " could not restrain themselves from giving expression to their satisfaction at having 'caught' a priest." two constables were despatched from St. John's on board the brig Maria to arrest the remaining ringleaders, but they met with fierce resistance from the community and failed in the attempt. The governor made arrangements with the colonial secretary to send in a ship of war with a garrison of soldiers to re-establish order in the area, but Bishop Fleming appealed to the Catholic community for quiet and to the ringleaders, in particular. to surrender Duffy and the eight fishermen named in the arrest warrants walked to St

${ }^{11}$ This was not the first time a mercantile premises in the harbour had been targetted by the plebeian community. In 1826. magistrate John H. Martin had written Governor Cochrane of an attack on the premises of William Rideout, in which the perpetrators had stolen stores and attempted to burn the premises to the ground. See PANL. GN 2/2, 1/29-32/1826. J. H. Martin. JP at St. Mary's. writing from Ferryland, to Governor Thomas Cochrane. February 13. 1826.

${ }^{114}$ Bishop Michael Fleming, cited by Howley. Ecclesiastical History, p. 327 
John's and turned themselves in, but although two efforts were made to try them (in 1836 and 1837 ). no witnesses appeared for the prosecution. and the charges were finally stayed.

Women are not immediately obvious in the historiography or the oral retellings of the Ferryland riot or the Father Duffy affair. No local Macha Mong Ruath or Ciramme Ni Whalle $e^{112}$ is hailed for leading her people into battle against the enemy. no reference is made to women within the ranks. But it is difficult to imagine that with such major disturbances in their communities, plebeian women were completely in the background Rosemary Jones, in her analysis of the C effyl Pren tradition in Wales. suggests that there are various forms of female participation in collective actions that frequently go unremarked in traditional treatments of such incidents. for example: informal gossip channels that detect and define aberrant social behaviour: social boycott to bring psychological and economic pressure to bear on an offender: acting as spokesperson: initial seizure and/or subsequent verbal and physical abuse of an offender; an inflammatory

"Is These were powertul Irish female leaders. Wacha Mong Ruadh or 'Macha of the Red Hair." forcibly seized the throne of Ireland from her uncles after the death of her high king father in $377 \mathrm{BC}$ and ruled for seven years; she lends her name to Armagh (in Gaelic. Ard.Macha, or 'Macha's Height'), the primal seat of Christianity in Ireland. (irainne Ni Maille (c. 1530-1603), or in its anglicized form. 'Granuaile or 'Grace O Malley. was the daughter of a Mayo chieftain who became the commander of 200 tighting men and three raiding ships that controlled the Connacht coastline. harrying English shipping in the $16^{\text {th }}$ century, she also led trading missions to south Munster and was involved in insurrectionary activities against the English: in the 1590 s. she went to London and negotiated a private truce with Elizabeth [. See Ellis. Celtic Women, pp. 7980 and $214-20$ 
role: and the transmission of the tradition to successive generations ${ }^{116}$ One could add to this list various forms of support services such as providing food, tending injuries, and harbouring fugitives.

It is not difficult to imagine that as the men from Leinster and Munster faced off in Ferryland in 1788. Irish-Newfoundland women played an incendiary role or heaped abuse on those from the 'wrong' county of the home country. Certainly, in his reporting of the incident. surrogate Edward Pellew noted that "many People came and assembled [italics added]" on the downs. hailing not just from Ferryland but from the large harbours on either side. ${ }^{11}$ With such a massive gathering, it would not be difficult to envision women on the sidelines. And. in fact. it is even possible that some women participated in the affray, for according to Nolan, it was not unusual for women in $18^{\text {th }}$-century Ireland to participate in taction fights. often wielding stockings filled with rocks as weapons. ${ }^{11 x}$ The tact that no women were charged in court in the wake of the riots does not disprove such involvement. for authorities were generally reluctant to arrest and prosecute women participants on such occasions because they felt it might diminish the legitimacy of their own police action. Were there women present in the fighting on the Ferryland downs.

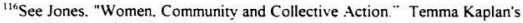
"Women and Communal Strikes." although dealing with urban working-class women of a later period, is also useful in terms of female consciousness activated in defence of family and community.

i"P.ANL. GN 2/1/A. 11/391-3/1788. Capt. Edward Pellew to Governor Elliot. October $9,1788$.

${ }^{118}$ Nolan, Ourselves Alone, p. 32. 
then, and was their presence simply trivialized and downplayed by arresting authorities?

Surely, in the aftermath of the battle. women helped in tending wounds and hiding ringleaders from authorities ( 12 remained at large for some time). And certainly, as the dispute between Power and $\mathrm{O}$ Donel dragged on, these women. as members of the Catholic community, chose to side with either Father Power or the bishop's candidate. Father Thomas Ewer. thereby boycotting the pastoral services of the perceived interloper $^{119}$ And as mothers, they likely helped to pass on a sense of rivalry between the two counties to the next generation. Granted. the experiences of men and women in the episode were differentiated by gender, but it is highly unlikely that women were not involved at all.

Similarly. while modern retellings of the Father Duffy affair speak only of the men of St. Mary's, it is likely that plebeian women in St. Mary's were also involved in the action against Slade. Elson. Doubtless, they played an inflammatory role and provided support services: and while the truck system would not have allowed tishing families the luxury of boycotting their supplying merchant, certainly the episode became one more

${ }^{119}$ Power was excommunicated by Archbishop John Troy of Dublin (see Byme. ed. Gentlemen-Bishops, pp. 88-9. Edict of Archbishop Troy, March 4, 1789), but he maintained considerable support in the district until he left in 1791. In March. 1790. Ewer, acting on $O$ Donel's instructions, renewed Power's excommunication, extending the decree to all who would continue to support Power; Power reciprocated by excommunicating Ewer and all his flock. See Byrne. ed.. Gentlemen-Bishops, pp. 102-4. Father James O Donel to Archbishop Troy, June 13. 1790. This brought about an interesting impasse and ironic repercussions, as noted by community historian Gerald Barnable: "Thus are all Ferryland parish people the descendants of excommunicated Catholics." See Barnable, "Ferryland Riots," p. 8. 
item on the long list of grievances passed from one generation to the next (by women as well as men) that mythologized fishing merchants as what Cadigan has aptly called the "chimera of Newfoundland history. ${ }^{* 120}$

Furhermore. while the nine people who led the incident were all men. a more careful reading of the contemporary historical records suggests that women were likely directly involved in the episode. The deposition of William Lush, chief clerk for Slade. Elson and witness to the incident, did not specify gender in describing the perpetrators. He stated that in addition to the ringleaders. "divers other persons amounting to the number of 80 or upwards "." were unlawtully riotously and tumultuously assembled" and that "the greater portion of the people then assembled" were employed in destroving the tlake. He. himself, heard Father Duffy "order the persoms assembled" to carry out the demolition. When Lush "spoke to several persons then assembled and requested that they would desist." they replied that they could not disobey the orders of their priest. And he heard several others state that "James Duffy had told the congregalon in chapel to break

${ }^{120}$ Cadigan, Hope and Deception, p. vii. Another possible facet of female participation in the incident was suggested to me by one of my oral informants while speculating on the reference in Dean Cleary "s "Notebook" to the women of St. Mary's taking fire from the altar and burning a local house upon the request of Father Duffy (see Section 5.3. above). I have interpreted this action as possibly a rite of exorcism: but my informant suggested that it may have been an act of retaliation in relation to the Father Duffy affair. In either interpretation, there are strong ritualistic overtones in women's use of 'sacred fire' AS. Interview August 30, 1999

${ }^{121}$ There were only 64 adult men in the community of St. Mary's in 1836 . See Newfoundland Population Returns, 1836. 
up and burn the flake and that those who might refuse to do so should have the curse of God and the congregation on them [italics added] ..."1:2

In reporting to the acting colonial secretary at St. John's on the subsequent efforts that were made to arrest the ringleaders, Martin similarly spoke of "the outrageous proceedings of the People" on the arrival of the brig Maria at St. Mary's. Martin had ordered his local constable. Burke, to assist the St. John's constables in effecting the arrests before the presence of the Maria was made known. However, Burke advised that its arrival

was already known to the People, many of whom had been expecting her - that in coming from his own house he had observed a constant. and unusual quick passing of lights from house to house. and which extended throughour the Harbor. that he was persuaded that the People were on the alert, and he could speak from his own knowledge to the fact of their determination not to suffer any man [referring specifically here to the male ringleaders] amongst them to be taken - and moreover it would. in his opinion, be impossible to take any of them on that night, tor if a Constable approached any one of their houses a signal would be made that would bring to it every person concerned in the destruction of the flake. and. perhaps, many not concerned as all the People of the Harhor were in some wav or other, related to each other - [italics added $]^{123}$

1"2C.O 194/94, ff. 19-24. Deposition of William Lush swom before Peter Weston Carter. JP of the Central District. November 13. 1835. and before Chief Justice Henry Boulton. St. John's. Novernber 24. 1835.

${ }^{133}$ C O $194 / 94$, ff. 11-18, J H. Martin to Joseph Templemann, December 22. 
These references to the participants in the action were gender neutral and implied that women as well as men likely contributed to the destruction of the flake and were called upon to ostracize non-participants. They were also likely part of the signaling system that "extended throughout the Harbour" as well as the general menacing presence of the mob that served to protect the ringleaders and prevent their arrest.

This gender-inclusive language can be contrasted with the accounts of proceedings given the following month by the constables and seamen of the Maria when they were dispatched to arrest the ringleaders and failed in the attempt (December 13 and 14 ) A seaman from the yacht said that he had been removed from the vessel by "two armed men" and brought to a larger group of "30 armed men," who questioned him about the numbers of the arresting party and threatened to "make a Sacritice of him" if he did not answer truly. When Martin sent a man to verify the seaman's story. his informant reported encountering " 50 armed men" armed with guns. swords. pews. ${ }^{124}$ and hatchets. Martin ordered local constable Burke to assist the St. John's constables, but Burke advised him that during the Night his house was beset by a greal mumber of men who threatened to shoot him" if he joined the arresting party. Burke felt in such danger that he preferred to relinquish his post rather than "assist on so perilous an occasion". Martin obliged him by promptly dismissing him from his office. On December 14, "groups of men numbering from 20 to 30 . some of them armed," were seen thovering about." and when a small boat

\footnotetext{
${ }^{124}$ This refers to the single-tined prong used in the fishery as described in Chapter $+$
} 
was seen leaving the Maria, a group of "upwards of 60 men" ran to where it was likely to land. only permitting the party to land when it was ascertained that there were no constables on board. ${ }^{\text {tss }}$ These accounts very specifically indicate that an overwhelming (and apparently, ever increasing) presence of "armed men" prevented the arrest of the ringleaders. Yet even here, one is left to wonder whether the participation of women in the mob was omitted: certainly, if the arresting party was trying to justify to the chief justice and governor their inability to complete their assignment. the menace of a mob of armed men may have provided greater justification than a crowd of men, women. and children. It is intriguing that at the end of his report. Martin suggested that the "place seemed less hostile" by December 15. and his description of local resistance returned to the more sexually indeterminate terms of 'mob' and 'crowd.'As Thompson has argued. we must not so quickly rule out the presence of women in these actions because of latterday sensibilities

A lesser known incident, which likely also included plebeian women. occurred in Ferryland district the following year during the election of a local member to the fledgling House of Assembly. Diarist Robert Carter recorded the battle between his cousin. Lieut. Robert Carter. R N. of the local English-Protestant mercantile family. and Irish Catholic Patrick Morris from St. John's, but originally from Waterford. with strong southern Avalon connections because of his involvement in the passenger trade to that area. Here

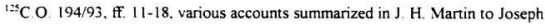
Templemann, December 22. 1835. 
was one of the few occasions when sectarianism flared in the study area as the large IrishCatholic population in the district rallied solidly behind Morris. The day before the polls opened. Father James Duffy led a parade around Ferryland harbour "with a green tlag, his horse's head Stuck with spruce boughs and one in his hand," and on the tirst day of polling, feelings were running high. Again, the contemporary account is quite genderneutral in its language " Large bodies of people assembled from the North and South." Carter noted on November 14 "The crowd very great in and around the Court. Great show of disapprobation by the friencls of Morris to those of Carter but the people were kept in order through Rev. J. Duffy's influence over them [italics added]." Indeed. throughout the course of the polling, the district was "tolerably quiet considering all." according to the diarist. and certainly did not experience the election violence that plagued Conception Bay and St. John's in the middle decades of the century However, the menace of the crowd was still acutely felt by English-Protestant middle-class tamilies in the district. especially as the episode had followed so shortly after the episode at St

Mary s. Reflecting in the aftermath on the ultimate victory of Morris and other candidates "elected by the populace at the Instigation of the Priests, the representatives of the dregs of the People." Carter wrote:

May the Home Government take upon them the rule of this Island or devise some means to put down the amazing excitement now raging between different sects of religions. Protestant and Tory are used as synonymous terms, and down with Tories, and on all occasions by the 
rabble. God send us his divine protection. ${ }^{126}$

The role of women in the episode again must be read into the sexually indeterminate language of the contemporary account, based on the tradition of women's participation in collective actions. Although non-voters, they likely featured prominently in enforcing solidarity within the ethno-religious group and in intimidating rival factions In Ireland, for example. women were urged in chapel to attend at polling stations and mark those individuals who voted against their priests instructions. They intimidated supporters of rival candidates trom attending the polls by threats and physical attacks upon their property and persons. And they participated in election riots, not only in a sumbolic role. bedecked in green sashes with green bushes in their hands, but also in physical confrontations with opposing factions. ${ }^{12 *}$ There is every reason to believe that Irish

${ }^{1:}$ The episode is documented in PANL. GN 920. Robert Carter Diary. November 13-23. and December 31. 1836. and January 1. 1837

1:"See various original documentary reports in Luddy. Documentary History, pp 245-50. Here. tor example, is the outraged report of the The Tipperary Advocate of an I 865 clash between rival factions:

In that yelling crowd of Langanites and $\mathrm{O}^{\prime}$ Beimites. all entangled and struggling in one heaving billow, young and old. lusty and infirm. male and female, were to be found shouting, whistling. groaning, dancing. foaming with irrepressible rage ... here there was a feartul looking scene well looking. well dressed girls. one a perfect Amazon. bared their arms. wound their shawls tightly around them, and rushed with the mellee... That woman there, with the black chenille net and lilac muslin gown. is a perfect maniac... there is a little girl of sixteen. her features distorted and her whole frame quivering with frenzied agitation: now she beats the wooden 
women on the southern Avalon, with a strong stake in the interests of the plebeian community and ethno-religious group, participated in similar ways in intimidating the supporters of Lieut. Carter.

Certainly, female intimidation and incitement played a cole in an episode involving the Irish population in a neighbouring bay - the effort to run Sweetman's agent. James Hogan. out of Placentia in the winter of $1845 / 46$ - * $\mathrm{A}$ ] Storm has been raised against me." Hogan wrote to his principals in January. "My life is sought in open day, their [sic] is a gang here determined to have my life." Hogan complained that this group was inventing and circulating "heaps of calumny of the worst description... to exasperate the people." had ordered the people of the harbour not to ship themselves to him. had attacked his house. "roaring and abusing me threatening my life." and had made several attempts to beat and murder him as well as seamen on board the Jutiet. This was a collective action to replace an agent who was seen to be dealing unfairly with local fishing tamilies: but there were also tactional undertones. for Hogan was a Wexfordman. and his enemies were apparently threatening to roust all his fellow countymen with him. Prominent in the events were several local women: "Mich"s [gang leader Michael Baldwin] wite. Norah and Mary among other women haloo them on and encourage them." Hogan wrote, and *... in the riots lately both Norah and Mary \& Baldwins wife Encouraged the

planks and bites everything within her reach!... 
gang on the street publicly singing out Now the Y. Bellys ${ }^{12 x}$ and Paddy meaning me should hide themselves..."129 Here, then, was direct evidence of plebeian women in a conspicuously incendiary role in a communal action of the period.

A more celebrated example of plebeian resistance, at least in community folk history, is the existence of a band of outlaws in the Renews area known as the Masterless Men. According to the oral tradition. in the mid-18th century, Peter Kerrivan and some companions jumped ship at St. John's and deserted from the British navy. They made their way to the Butterpots near Renews. where they lived off the land. occasionally trading with nearby fishing communities. Over time, they were joined by a number of fishing servants who had deserted from service. escaping the harsh conditions imposed by their fishing masters. Despite repeated efforts by the navy to round them up. the band proved elusive - living in portable shacks suitable for quick escape and leaving false trails in the woods. Most remained at large until the traditional fishery. with its abusive masters. collapsed and they were able to move back into a normal existence in various settlements along the coast. Once again. women are not prominent in the narrative. But the oral tradition does mention in passing that the Masterless Men married women from local settlements and raised families in the woods. Peter Kerrivan, himself, is said to have had

128. Yellow bellies - an epithet for those hailing from county Wexford. The name reterred to the yellow sashes they often wore as an identifving mark.

${ }^{129}$ P.ANL. MG 49. Sweetman Collection. Box 4. File 37. Patrick Hogan to Principals, January 2. 1846. 
four sons and several daughters. ${ }^{130}$ At the Capt. William Jackman Museum in Renews. there is a depiction of the legend painted along one wall by local artist Dane McCarthy the illustration shows a man and a woman, hiding and smiling as two soldiers blunder off in the opposite direction. The oral tradition, then, admits to the existence of 'Masterless Women, even if it does not celebrate them.

While this band are hailed as local tolk heroes. academics are more skeptical of the possibility of long-term survival of such a group, particularly throughout the harsh winters experienced on the island. Nonetheless, in terms of isolation. the barrens and Butterpots of the study area were an ideal place for runaways to hide from authorities. ${ }^{131}$ and the tendency of local residents to harbour deserters was noted in the written record. In 1797. for example. John Dingie. a JP for Bay Bulls who had temporarily removed to Trepassey after the French attack on his home community in 1796. wrote Governor William Waldegrave that he had just received news "that several men had been seen lurking in the woods. and that they were judged to be runaways." He then described the difficulty in apprehending deserters. given the recalcitrance of the inhabitants

${ }^{13}$ Note again the specificity in tracing sons compared with the vagueness in tracing daughters in the oral tradition.

${ }^{131}$ As late as 1833. Robert Carter referred to "a gang supposed to be robbers having passed Westward at the back of the Harbours." See PANL. MG 920. Robert Carter Diary. September 29, 1833. 
... it was then late at night, and the Inhabitants of this place were mostly in Bed - knowing that deserters seldom want a resting place, \& thinking that the Inhahitants might afford them Shelter, $\mathrm{M}^{\mathrm{r}}$. Hunter [a local merchant] and myself considered it as a proper step to apply immediately to $\mathrm{M}^{\mathrm{r}}$ Justice Follett [local JP] for a Warrant to collect together a large body of constables and armed assistants, and to search the houses of the said inhabitants without delay. This was accordingly done and I have the satisfaction to say that the Merchants, and their followers, in their researches, used their utmost endeavours to secure the said deserters, - but I am sorry to add. none were found.

We now thought that by such proceedings as I have mentioned, the said deserters had fled to the westward. but for these two days past. reports are propogated. that the same fellows are still lurking in the skirts of this Town, and these reports, for what 1 can learn, are not without foundation $-\mathrm{M}^{\mathrm{r}}$. Hunter and myself. have had a consultation on the best plan for apprehending them. and we consider that it will be to no purpose to send the Constables into the woods after them - these civil Officers are frequently so timid, where such desperate men are the object, and the common people in general are more inclined to shelter than give up deserters [italics added].... ${ }^{132}$

In 1802. Dingle, now back in Bay Bulls, again wrote Governor John Gambier respecting the frequency with which deserters from the Navy made their way through that community and on to the southwards. where they found sanctuary and employment with the "inhabitants." He reminded Gambier of the 1797 incident in Trepassey. "when a desperate gang. deserters from the Newfoundland Regiment, were lurking about that place" and the "inhabitants" had refused to co-operate with authorities in rounding them

132PANL. GN 2/1/A. 13/163-5/1797. John Dingle, JP of Bay Bulls while at Trepassey, to Governor William Waldegrave. July 28. 1797. 
up. ${ }^{133}$ If the harbouring of deserters was as effective as Dingle's letters imply, the entire plebeian community - women as well as men - had to be part of the network of sanctuary and the conspiracy of silence.

While the written record is somewhat closefisted with evidence of women's involvement in larger-scale collective actions, it is more generous in relation to smallerscale events. Certainly, the court records for the southern district indicate that plebeian women were involved in very public and physical efforts to enforce community standards and to protect personal and family interests. In some of these cases, the women acted individually, in others, they were part of a small collectivity. ${ }^{134}$

The court records reveal various instances of women's use of physical violence to defend family propeny against perceived encroachers. ${ }^{139}$ The women of the Berrigan tamily, for example, were a vital force in the family's struggle to maintain possession of

${ }^{133}$ P.ANL. GN 2/1/A. 16/288-94/1802. John Dingle to Governor John Gambier. September 15 [date is difficult to read], 1802. Note that Dingle's warnings occurred within the context of the United Irishman Rebellion and the 1800 mutiny in the Vewfoundland Regiment, at which time it was felt that every man to the south of St. John's and taken the United Irishman oath (see Chapter 2).

${ }^{134}$ The oral tradition is very reticent about female physical violence. Oral informants generally observed that while women were frequently involved in verbal slanging matches, they did not get into physical fights. One informant (RJ. Interview Mav $9.2000)$ did mention that she used to hear the "old people" talking about women fighting on the beach with splitting knives; however, this was the only example offered. Given overwhelming evidence to the contrary in the court records. however. I am inclined to interpret this reserve as a reflection of the scruples of a later period.

${ }^{13}$ Similar incidents involving plebeian women in periods of early settlement have been described in: Cadigan. Hope and Deception; Bittermann. "Women and the Escheat Movement", Ridner, "Sufficient Maintenance"; and Ulrich, Good Wives. 
their fishing room in Renews harbour in the 1830s and 1840s. In May, 1835, local merchant and magistrate John William Saunders initiated an action of ejectment against Thomas Berrigan. Sr., to recover possession of the fishing premises occupied by the Berrigan family on the south side of the harbour. The records do not specify the reason for the action. It is possible that Berrigan was a tenant of Saunders and was being ejected for non-payment of rent: however, the presence of Saunders storekeeper among the plaintiff's witnesses also suggests that the suit may have been related to a debt for which perhaps Berrigan had entered into a mortgage with his supplier as security ${ }^{136}$ At any rate. Berrigan entered a demurrer, but the matter proceeded to trial in November. 1836, and the jury. on hearing the case, decided in Berrigan's favour ${ }^{137}$

${ }^{15}$ The former scenario is the more likely of the two, although either is possible. given the complex evolution of the ejectment action up to the time the Berrigan matters were being heard. In older English law, the ejectment was a trespass action that could be taken only bv a leaseholder for damages for having been wrongfully dispossessed of property. By the $15^{\text {th }}$ century, the lessee could also seek to recover the remaining term of his lease. This allowed the action to be extended to determine freehold title as well via a legal fiction: Imaginary lessees were created and one sued the other for ejectment: but in reality, the court was determining the freehold rights of the two lessors. By the $17^{\text {th }}$ century, the most common form of ejectment action was that of 'lessor $\mathrm{v}$. lessee". However. it was still used to determine entitlement to freehold as well. Thus, the ejectment of a lessee or the ejectment of a mortgagor in default are both possible interpretations of the Santers v. Berrigan matter. See: David M. Walker. The Oxford Companion to Law (Oxford: Clarendon Press. 1980), p. 395. Bryan A. Gardner, Black's Law Dictionary, $7^{\text {th }}$ ed. (St. Paul. Minn West Group. 1999), pp. 534-5; and John A Yogis. Canadian Law Dictionary, $3^{\text {rd }}$ ed. (Hauppauge. New York: Barron's Educational Series. 1995), p. 77

${ }^{137}$ PANL: GN 5/2/C/4 Writ No 8. J. W. Sannders Esqr. v: Thomas Berrigan. issued September 25 for return November 1,1836 . Action in Ejectment; GN $5 / 2 / \mathrm{C} / 3$. 1835-47 journal. ff. 62 and 64-5. John W. Saunders v: Thomas Berrigan. November 3 and 
But the matter did not end there, for Saunders pursued his claim - at the peril of several court officials and, ultimately, himself. By the fall of 1838. Saunders had convinced the court to issue a writ of possession, but he would soon discover that the Berrigans would not relinquish the premises without a fight. In September. charges were laid by Deputy Sheriff Philip Wright against Anastatia. Edward, Alice. and Bridget Berrigan and Walter Barron for "violently" assaulting him at Renews on August 16 as he tried to execute on the writ of possession. Anastatia was identified in the records as the wife of Thomas Berrigan. Sr. the relationship of the other Berrigan women was not explained. but they were likely daughters, sisters, or relatives by marriage. At the hearing. the defendants were required to enter into sureties to keep the peace for 12 months and to appear in court to stand trial in the next term. ${ }^{15 x}$

There is no surviving record of an 1839 hearing. but on December $31.18+2$. Anastatia. Bridget, and Alice Berrigan were again before the court. along with William Berrigan. to face charges of assaulting yet another deputy sheriff. John Stephenson Allegedly. once again. the Berrigans had obstructed and "violently" assaulted a court official as he attempted to execute on a writ of possession in relation to the property of Thomas Berrigan "the Elder" at Renews. Once again, warrants were issued for the arrest

5. 1836, and GN 5/2/C/8, ff. 74 and 76-7. John W. Saumders v. Thomas Berrigan. November 3 and 5, 1836.

${ }^{138}$ PANL. GN 5/4/C/1. Ferryland. Box 1. n.f., Regina v. Anastatia Berrigan et al.. September 3 and 20.1838 . 
of the parties. and on January 31, 1843. they were required to enter into bonds to keep the peace for 12 months and to appear at trial in the next quarter session to answer Stephenson s charges. (Anastatia was sick and unable to attend this particular hearing at Ferryland, her bond was sworn before the resident JP at Renews, Alan Goodridge.) At the General Quarter Sessions on February 23. 1843. a grand jury returned a bill indictment for "Riot and assault" against the defendants, but a petty jury returned a verdict of "not guilty ${ }^{* 120}$

The tinal trace of the matter in the court records appears in the proceedings of June 13 and 14,1843 John William Saunders swore a complaint that he. himself, had been threatened. assaulted. and prevented from taking possession of the fishing room at Renews by various parties, including James Gearing. Sr. Benjamin Wilcox, and vet another line-up of the Berrigan torces - Thomas. Sr. Thomas. Jr.. Edward. and the everpresent matriarch. Anastatia. Saunders claimed that by this time, he felt that his very life was in danger from the frequent threats and assaults of the Berrigan faction and asked for the protection of the law. The charge against Gearing was dropped for lack of evidence. but the remaining parties were once again arrested and ordered to enter into bonds to keep the peace for 12 months. ${ }^{100}$

${ }^{139}$ P.ANL. GN 5/4/C/1. Ferryland. Box 2. Regina v. William Berrigan, Anastatia Berrigan. Bridget Berrigan, and Alice Berrigan, December 31. 1842. and January 31 and February 23. 1843

${ }^{1+1}$ PANL, GN 5/4/C/1, Ferryland, Box 2 n.f. Regina v. James Gearing. Sr., Benjamin Wilcox. Ectward Berrigan. Anastatia Berrigan. Thomas Berrigan. Sr.. and 
The matter then disappears from view, and we are left to speculate whether or not the Berrigans were successful in holding fast to their fishing premises. But for the present discussion, the most significant point is the presence of the Berrigan women in the midst of the struggle. There were variations in terms of the members of the Berrigan family involved in each case: but Bridget and Alice were involved in two of the three incidents. while the tamily matriarch. Anastatia, was present every time. Their participation was not unusual within the historical context of this fishing-based economy. As essential members of their household production unit, the Berrigan women were defending a family enterprise in which they felt they had an equal stake, using verbal attack and physical force to protect their source of livelihood in the face of perceived injustice at the hands of their supplying merchant and the formal legal system. Additionally, the fact that the family was assisted by neighbours in protecting their property and the tact that petty juries on two separate occasions tound in the Berrigans" favour indicate that their defiance likely enjoyed some support within the plebeian community.

A comparable incident was reported in Renews in 1853-54. Deputy Sheriff Francis Geary complained that when he tried to execute on a writ of ejectment against John Bavis. he was assaulted by Bavis and his wife. A warrant was issued for John's arrest, but when four Constables showed up at the house to accomplish the deed. his wife held firm and swore that he was not going anywhere. Meanwhile. a mob had gathered

Thomas Berrigan. Jr.. June 13. 14. 20, and 27. 1843, and n.f. Regina v. Thomas Berrigan Jr., February 5, 1844. 
outside the house, with bludgeons in their hands, threatening to rescue Bavis if the constables tried to take him by force. The constables were outnumbered and forced to retreat, with the mob following after them, shouting and hissing at them. ${ }^{1+1}$ Again. a woman had played a key role in a public. collective action to protect family property and. indeed. the person of her husband; and the tamily's resistance to the officers of the crown had the backing of the plebeian community in terms of what they perceived to be decent treatment for the Bavis tamily, regardless of what formal laws and court orders had to say on the matter.

Women were not always acting from a defensive position in relation to propery disputes that appeared in the court records. In at least one case, a woman was the aggressor in both the property dispute and the related assault. In 1835. Jane Hayley of Cape Brovle was brought before the magistrate by Henry Coryear of the same place Henry complained that Jane "had dispossessed him of a piece of Ground Granted to him and driven off his Servant with a Hatchet threatening further Violence if molested." Cltimately. Jane relinquished the claim and agreed to pay court costs: but her use of verbal threats and physical attack to dispute possession of the property provides further evidence of women deploving power in the community in the period of early settlement. ${ }^{14 z}$

${ }^{13}$ P.ANL. GN 5/4/C/1, Ferryland. Box 2. n.f. Regma :. John Bants and his Wife. December 29, 1853, and January 5, 1854 .

14:PANL, GN 5/4/C/1. Ferryland, Box 1, fi. 67, Henry Coryear v Jane Hanley. April 8 and 16.1835. Fences were not completely mended between the parties, however, for the following year. Coryear brought Hayley back to court on the matter of an 
Plebeian women rose to the defence of more than real property. Maintaining one's good name was important within the community, as Ellen Veal vividly demonstrated in the episode that introduced this chapter. Elenor Evoy of Ferryland provides another example. for she was involved in several incidents in which her family business and personal reputation were at stake. She and her husband. Michael. owned one of the public houses in the district in the $1790 \mathrm{~s} .{ }^{143}$ Indeed. although the liquor licence for her tavern was issued in Michael's name up to his death in 1798, it is likely that Elenor had much to do with the running of the establishment and may have been sole operator. Certainly, it was Elenor who defended the integrity of the business from aspersions cast by Michael Ryan of nearby Caplin Bay. In July, 1795, Ryan complained to the magistrates that Elenor, along with several other local women. had assaulted him and battered him with stones outside the Evoy public house. In their defence, the defendants claimed that Michael had "several times behav' $d$ Rude to them. and as a Punishment they were Determin 'd to Hustle him." The women were given small fines and reprimanded. The following week. however. Elenor tiled a petition in which she gave her own version of the episode. claiming that Michael had provoked the rock-throwing incident outside her establishment with his rude comments. She, herseif. had not cast any stones. but had simply advised him to move on

outstanding debt in the amount of $\$ 1.16 .10 \mathrm{Cy}$. See PANL. GN 5/4/C/1. Ferryland. Box I. If. 83-4. Henry (oryear 1 . Jame Hayley: January 4. 1836.

${ }^{1+3}$ Lists of liquor licenses issued for the district for various years appear in PANL. GN 2/1/A. and GN 5/4/C/1. Ferryland. Box I 
tor his own good. In response, he had threatened to beat her and defamed her character. accusing her of keeping a bawdy house. Elenor took particular offense at this slur against herself and her business and asked the magistrates for redress. Michael explained that he had spoken "from passion" because the girls were tormenting him, but he was fined £5 pounds (later mitigated to $5 \mathrm{~s}$.) and ordered to keep the peace. Throughout the proceedings, there was no mention of Elenor's husband; it is evident that it was her reputation and her business that were being defended: and the magistrates acknowledged her right to do so, despite the principle of coverture which should have dictated her husband $\mathrm{s}$ attendance in the court room as her legal personality. ${ }^{1+1}$

By 1799, Michael Evoy had died and Elenor's name appeared on the liquor license tor the tirst time. By the taking of the Carter census in 1800. however. Elenor had married a James Welsh (also Walsh) and the liquor license thereatter appeared in his name. Still. Elenor. as the experienced tavernkeeper. likely continued to run the business. One night in late March, 1803. Elenor and new husband James, his brother. Sylvester, and Elenor's son (by her first husband) Patrick Evoy broke into the house of another publican family in Ferryland - Adam and Ann McLarthy - and assaulted and "ill-used" them According to the several informations laid. Elenor and James took on Adam McLarthy while Sylvester and Patrick harried Ann in the passageway of the home. The records are not specific about the cause of the assault. Given that Adam McLarthy was also a local

${ }^{14+}$ PRL. 340.9 N45, n.f., Michael Ryan i: Elenor Evoy et al. and Elinor Evoy :. Lichael Rvan. July 21 and 28, and August 3. 1795 
constable. it is possible that he was, in the eyes of the Welsh tamily, being over-zealous in entorcing regulations on the sale of liquor. But given that the McLarthys also owned a public house, the episode very much has the appearance of a 'turf war' between two rival firms. and the womenfolk - Elenor and Ann - were right in the thick of the fray. This time. Elenor and her cohorts were fined and ordered to keep the peace. Elenor's fine was 50s. significantly less than the 25 imposed on each of James and Sylvester, but more than the 20s. levied against her son Patrick (whose role was more of an accessory). ${ }^{145}$

The court records reveal other instances of women's involvement in family feuds On June 27. 1823, Ellen (Nell) Tobin (the same Nell Tobin who had witnessed the Ellen Veal - Mary Bowen affray the previous year) laid a complaint of assault against Ann St Croix. Ellen advised the court that she had contronted. Ann at a Mrs. Linehan's house that same day and "asked her the reason why she so abused my Sister - and [was] often in the habit of th[rlowing rocks at me and my Brother...." In response. Ellen claimed. Ann "took a stick from out of the fire and struck me several times on the face" Three days later. in a related case (the records are sketchy, but the matching surnames in this small community $^{1 \text { th }}$ suggest a link). Bridget St Croix (presumably, a relative of Ann)

145.PANL. GN 5/4/C/1. Ferryland. Box 1. n.f., Rex v. James Welsh. Rex v: Sivlvester Welsh. Amm.LcLarihy v. Parick Evoy, and Rex v. Elenor Welsh. April 1. 1803.

${ }^{1+6}$ The entire district of St. Mary's, which included the commumty of St. Mary's as well as other pockets of inhabitants in adjacent coves and harbours to the north and south. had only 236 inhabitants wintering over in 1825. See C.O 194/70, f. 227. Governor's Annual Return of the Fisheries and Inhabitants. 1825. 
complained that on the previous evening she had encountered Thomas Tobin (possibly.

Ellen's brother and the victim of Ann's rock-throwing episodes), who had "accosted me and said now you vagabond $[w]$ hore $t$ have you." Bridget told him that she "woud not be wishing for him for a pair of Shoes to touch me." Thomas responded to her gibe by grabbing the broom stick she was carrying and striking her several times. He left her with the dire warning "that he would watch us day and night - to be revenged." 147 The cause of the dissension between the two families is not clear. but what is certain is that women of the Tobin and St. Croix families were very much involved in the quarrel in ways that conflicted with the passive and tragile feminine ideals of middle-class ideology.

Another case involving ill-feelings between families involved the Doolevs and Kenneys of Renews. On September 12. 1850. Maurice and Mary Dooley and their stepson complained to the magistrates that James Kennev and his wife. Ellen. had repeatedly threatened their lives, and they asked for the protection of the law. Warrants were issued for the arrest of the Kenneys and they were brought into court by Constable Sullivan and required to enter into security to keep the peace for 12 calendar months. ${ }^{1+8}$ The motive

${ }^{1+2}$ PANL. GN 5/4/C/1. St. Mary s: f. 134. Ellen Tobm v. Amm St. ( roix. June 27. 1823. and f.135. Bridget St. ('roix i: Thomas Tobin. June 30, 1823. The disposition of these cases is not revealed in the records.

1+x PANL. GN 5/4/C/1, Ferryland, Box 2, n.f., Regima vx. James Kenney and Ellen. his Wife. September 12.1850. Although in the journal entry, the first names of the Dooleys appear as James and Ellen. the initial draft of the proceedings. contained in a file folder with the journal, shows that the complainants were actually "Maurice Dooley. Mary his Wife and Step Son." Apparently, the clerk mistakenly transcribed the first names of the defendants for those of the complainants in the final entry 
for the harassment in this case was not stated in the records. But it is evident that Ellen Kenney and Mary Dooley, like Elenor Evoy or the Berrigan women, were openly involved in asserting and/or protecting their families interests

There was also one case of assault involving a woman's defence of her children although the fact that she struck out against other children landed her in troubled waters with the local court. On October 24, 1820, Ann Prichet was charged with beating and wounding two children belonging to Bryan Dunn. Ann admitted that she had given "two strokes" to one of the children, but that she had been acting in detence of her own children. who were being "ill used" by the others, and in response to "provoking words to herself." The court acknowledged that Ann had not been acting out of "malice." but ordered her to pay a tine of $5 \mathrm{~s}$. and court costs as well as to give security that she keep the peace for 12 months. Ann refused to provide the security and was committed to the local jail - indicating that the magistrates were not deterred by her sex in treating her as any other recalcitrant defendant. ${ }^{109}$

In general. plebeian women on the southern Avalon were not reluctant to use physical violence in sorting out their daily affairs. There were 111 complaints $^{1 \text { s. }}$ of assault involving women (all of the plebeian community) brought betore the local courts during

\footnotetext{
${ }^{147}$ PANL, GN 5/1/C/1. Ferryland. f. 117. Rex 1: Amm Prichet. October 24. 1820

${ }^{150}$ Note that some incidents of assault involved multiple complaints being laid
} Three cases, for example, were general affrays involving both men and women. The number of charges laid was therefore greater than the number of actual incidents reported. 
the period; and while 50 related to male assailants of female victims, 61 involved female aggressors ${ }^{151}$ Furthermore, these women assailants were not particular about the sex of their victims: 32 were women and 28 were men (with child victims in the remaining case). Most episodes involved the use of threatening language and/or physical assault with a variety of motivations defence of personal reputation, employment disputes over wages or ill-treatment, defence of family business, enforcement of community standards. and defence of family property Of course. given the unfortunate parsimony of local cour

\footnotetext{
${ }^{151}$ In gauging the significance of the number of cases found. several factors should be kept in mind. Firstly, court records for the southern Avalon are available only trom 1773 onwards, any references to earlier cases appear only sporadically in governors correspondence. Secondly, the court records are, themselves, incomplete; thus a number of cases which may have involved women have not survived. Thirdly. as noted in Chapter 1. the cases examined here relate almost exclusively to the districts of Ferryland and Trepassey-St Mary's. Finally, the number of adult women in the population of the area for which records have been examined thoroughly was quite small until the last couple of decades of the study period. Only by the 1830 s did it exceed 400 . as the following table indicates:
}

\begin{tabular}{cc} 
Year & No. of Adult Women \\
\hline 1775 & 63 \\
1785 & 150 \\
1795 & 310 \\
1805 & 287 \\
1815 & 363 \\
1825 & 307 \\
1836 & 847 \\
1845 & 994 \\
1857 & 1562
\end{tabular}

Furthermore, the 1857 figure is inflated by a change in the census age categories from It+to $10-$, thus. I am including as 'adults' an additional segment of the population (children from the ages of 11 to 13 ), and one which was not usually before the courts. 
clerks in recording details, there was also an assortment of cases in which the motivation for the assault remains a mystery. In 1839 and 1840. for example, Margaret Ryan of Caplin Bay appeared before the magistrate on two separate complaints by neighbours: tirst, of assaulting and threatening Catharine Reddigan, and later, of using violent and threatening language against John Rossiter and his family ${ }^{152}$ In 1841, John Crotty. a tisherman at Cape Broyle, complained of being assaulted and beaten by Johanna Morrissev and asked tor the Court's protection. ${ }^{153}$ In 1851. Mary Buckley accused Mary Ann Pendergast of striking her on the head with a water bucket, causing a "severe cut on her Head" and making the "Blood to flow copiously from the wound" and all over her elothing ${ }^{154}$ In 1844. Arthur H. O B. Carter brought charges against Bridget Dullanty for throwing stones at him, "severely wounding" him, and thrusting a stick at him.,"154 This was Bridget's second offence; she had already been convicted of an assault against a party named Cose in $1837^{156}$

15:PANL. GN 5/4/C/1. Ferryland. Box 2, n.f. Regina 1: Largaret Ryam. August 13. 1839. and Regina 1: Margarer Rlam, July 22. 1840.

${ }^{153}$ PANL, GN 5/4/C/1, Ferryland, Box 2, n.f., Regina 1: Johamma, Lorrisst. December 28. 1841

${ }^{154}$ P.NL. GN $5 / 4 / \mathrm{C} / 1$. Ferryland. Box 2, n.f. Regma v. Mary .Am Pendergast. August 16 and 19,1851 . 18. 1844.

15sP.ANL. GN 5/4/C/1. Ferryland. Box 2, n. C., Regina v: Bridget Dullanț: April

${ }^{150} \mathrm{PANL}, \mathrm{GN} 5 / 4 / \mathrm{C} / 1$. Ferryland. Box 1 , f 100 . _ Cose v. Bridger Dullann: Mav 6. 1837. 
Certainly, there was a variety of such cases. and while we do not al ways know the mutivations tor the defendants" actions (and doubtless, not all were noble), the physical assertiveness of these women and the court's matter-of-fact handling of these matters suggests that these women's violence was no more shocking to the community than men's indicating a certain tluidity of gender relations within the plebeian community and demonstrating that these women felt they had the right to use verbal and physical intimidation in the public sphere. Examining colonial New England. Ulrich arrives at a different conclusion respecting women's violence. noting that when women used physical force. "they broke through a powerful gender barrier. Violent men were still men: violent women became superwomen, amazons, viragoes."-1 | would suggest. however, that at least on the southern Avalon. the 'gender barrier' was more a highly permeable membranc through which plebeian women easily moved in their daily transactions. despite hegemonic discourses on women's place.

Of course. there were also 71 reported female victims of assaults ranging from threatening language and ill treatment to more serious physical and sexual assaults. The breakdown by sex of the accused in these cases was 32 women and 50 men (with multiple Jefendants in several cases). In feminist scholarship. male violence against women - actual or potential - has been cited as a mechanism of patriarchal control. Yet it is evident that on the southern Avalon. the use of physical violence was not gender-specific. and cannot

'LIrich. Good Wives. p. 191. 
be readily examined as a milieu dominated by male aggressors and female victims. ${ }^{15 k}$ Furthermore. it is important to note that plebeian women in the study area evidently felt that it was their prerogative to take their abusers to cour. Only three were represented in actions initiated by their husbands (who had also suffered an assault or destruction of property during the incidents). The remaining 68 victims provided depositions and appeared in court themselves when summonsed to give testimony against their assailants. These women perceived themselves as individuals with rights which should be protected by the legal system, and they were not deterred by notions of female respectability and self-sacrifice from pursuing these rights in a public forum. The experience of these women with more formal systems of power - their capacity to negotiate the complexities of these systems and the response of authorities to their efforts - will be examined in the next chapter.

\subsection{Conclusion}

Brown's and Llrich's frameworks for discussing gender relations in colonial America - the concepts of fixed gender hierarchies or gender barriers occasionally stormed

${ }^{16 x}$ This finding differs significantly from Judith Norton's in her examination of assault cases in the Planter townships of Nova Scotia in the first 50 years of settlement. Yorton notes: "Women were particularly vulnerable in early Nova Scotia. In the 45 recorded incidents of abuse or assault identified in the early court records, 20 of the victims and five of the assailants were females." See Norton, "The Dark Side." p. 185 
by exceptional women - are too rigid for examining the complexity of gender relations on the southern Avalon in the study period. Indeed, writers such as Riley and Scott have argued effectively that gender in any context is constantly under negotiation and renegotiation - a dynamic process. in which gender hierarchies are constructed. legitimated. contested, and either maintained or redefined. ${ }^{159}$ Furthermore. there are contexts in which the process is likely to be more vigorous: the negotiations. more aggressive. A context of emigration and early settlement - such as that on the southern Avalon in the mid-18th to mid-19th centuries - provides just such a hyper-dynamic moment in time, when gender relations become more fluid. gender boundaries, more permeable.

Furthermore, while separate sphere ideology and feminine ideals of domesticity and passivity were powertul proscriptive conventions. they were not automatically adopted by plebeian and working-class communities. Thus, while middle-class constructs of femininity were infiltrating Newfoundland society, they did not easily insinuate themselves into Irish plebeian culture on the southern Avalon. Women's essential role in community formation and economic life. their powerful position in an alternative belief system, their strong sense of individual personhood, and their deployment of informal power in the community mitigated against the adaptation of middle-class ideologies that did not fit local realities. Furthermore, because the southern Avalon remained a pre-

${ }^{159}$ See: Riley. Am I That Namer.; , and Scott. Gender 
industrial society into the $20^{\text {th }}$ century, plebeian women's status did not undergo the erosion experienced by their counterparts in the industrializing British Isles. In rural Ireland. women were increasingly marginalized from agricultural work in the $19^{\text {th }}$ century. particularly from the post-Napoleonic War period onwards - a trend that was exacerbated not just by mechanization but by a shift in production from labour-intensive tillage to pasturage. The mechanization of dairying and the contraction of the domestic textile industry also reduced women's income-earning capacity, and the result was a critical decline in their status as essential producers in their family economies. This slide, gaining momentum from 1815 , became precipitous at mid-century. The collapse of the potato culture by the 1840 s and 1850 s led to a decimation of the cottier and labourer class which had relied so heavily on female productive work. It also brought to a virtual halt the extensive practice of subdivision and partible inheritance which had permitted virtually universal and early marriage. The remaining farming class in Ireland were more inclined to practice impartible inheritance and primogeniture: one son inherited. and represented an eligible partner for one daughter of another family. who was, in turn, expected to bring with her a sizeable dowry. Marriage became increasingly restricted as families hopes and financial resources focused on the inheriting son and the first-married daughter. The remaining children became 'surplus' - particularly daughters. whose wage-earning opportunities were fewer than their brothers in the changing socio-economic milieu. As a result of massive economic and demographic reorganization in Ireland, then, there was a significant depreciation of women's worth as both producers and reproducers - a decline 
that many responded to by emigrating. ${ }^{160}$ Similarly, in England in the $18^{\text {th }}$ and $19^{\text {th }}$

centuries, accelerating enclosure and the loss of customary rights, the masculinization of

farm labour and dairying under capitalist agriculture, and the mechanization and

industrialization of cottage industries led to the devaluation of women's labour and the

channeling of women's work into sweated labour in cottage manufacturing or into dead-

${ }^{\text {int }}$ For a discussion of this decline in women's status in rural Ireland. see. for example: Daly, "Women in the Irish Workforce": Diner. Erin's Daughters; Fitzpatrick. "Modernisation". Luddy. Documentary History, Mageean, "Women's Prospects", Miller. Dovle, and Kelleher, "'For love and liberty"., Nolan, "Great Famine and Women's Emigration". Nolan. Ourselves Alone; and Rhodes. Women and Post-Famine Ireland In Husbandry to Housewifery, Joanna Bourke also notes the shift in women's economic activities through the $19^{\text {th }}$ century which culminated in 1890 to 1914 in the withdrawal of most Irish women into the home. She suggests, however. that this movement into fulltime housework was a rational choice in the face of declining opportunities and did not necessarily entail a loss of status for women. Many found housework fulfilling. she argues, and a source of creativity and pride. Women's domestic role helped minimize the risk of poverty because they could 'invest' time in children who would care for them in their old age and because their family contribution in terms of housework had greater value as they aged than the labour of aging men, who were more likely to enter poorhouses due to unemployment. Housework removed rural women from monotonous and physically challenging agricultural chores, she argues. And emigration remittances from children increased the value of women's reproductive labour. However. Bourke's celebration of Irish women's withdrawal into domesticity founders under the weight of the costs of the transition, many of which she suggests, herself declining employment and educational opportunities: reduced access to cash resources. increased female dependence on male income eamers. decreased participation in all aspects of life outside the nondomestic sphere, a tendency for women to have less leisure time than men because housework was a continual task: and an increased tolerance of wife abuse justified by the wife's unsatisfactory performance of household tasks. Her argument that women "escaped" economic dependency on relatives through marriage (pp. 273-4) seems to be a contradiction of terms. Furthermore. she appears to accept the sexual division of labour and wage and education differentials in her study period as givens, without reflecting on the processes by which women 's options were channelled so narrowly that they 'chose' domesticity. 
end. low-paying jobs in factories. This was a process in which working-class men were complicit: with increasing competition between the sexes for work, male trade unionists spearheaded a quest for a male 'breadwinner's wage' by espousing female domesticity and denigrating women's paid work: meanwhile. male chartists incorporated female domesticity and passivity into their bid for working-class 'respectability' and the vote ${ }^{1 / 1}$ Along the southern Avalon. however, the economy continued to rely on family production in its main industry, supported by a multi-faceted package of subsistence agricuiture and supplementary income-earning ventures in which women still played a prominent role.

Thus. while separate sphere ideology and feminine ideals of domesticity. fragility. and dependence increasingly circumscribed the lives of many women elsewhere. Irish plebeian women on the southern Avalon enjoyed considerable status and exercised significant authority both in family and community during the study period. Within families. they shared decision-making responsibilities in mixed-sex work processes and were the sole authorities in routines performed by wornen. They were also the primary household managers - juggling resources with consumption demands and monitoring family accounts with local merchants. Women also shouldered responsibility and wielded

${ }^{\text {isi }}$ See. for example: Clark. Struggle for the Breeches; Leonore Davidoff, "The Role of Gender in the 'First Industrial Nation": Farming and the Countryside in England. 1780-1850." in Davidoff. Worlds Between: Historical Perspectives on Gender and Class (Cambridge: Polity Press. 1995). pp 180-205: Hill. Women, Work, and Sexual Politics: Theodore Koditschek. "Gendering of the British Working Class." Gender and History, 9:2 (August. 1997). 333-63. Rendall, Women in and Industrializing Society; Snell. *Agricultural seasonal unemployment; and Valenze. First Industrial Woman. 
power outside the home in the day-to-day life of community. They remained active and essential in the economic sphere - in subsistence production, the fishery, and other forms of economic activity, and as an integral part of the exchange economy that underwrote the resident fishery. They also acted as custodians of the Catholic faith, and as interpreters of the supernatural within an alternative belief system - roles that not only gave them considerable status but also placed them in the vanguard of preserving the ethno-religious identity of the Irish-Catholic community Plebeian women also deployed power through their information networks. Women's gossip - whether it manifested itself as a means of group identification and preservation. or as a site of female resistance. or an expression of competition among women in their roles as household managers - was a component of power relations within the larger community; and its effectiveness was evidenced by the efforts of the dominant culture to detuse its power. Finally, in collective actions and individual interventions, women publicly flexed their muscles (otten titerally as well as tiguratively) as they negotiated space for themselves and their families in the social. economic. and political life of their community. Thus. while plebeian women were barred from the exercise of formal power by their gender and class, within the plebeian community, their access to informal power was considerable. indicating that gender relations were very much a shifting territory in the days of early settlement, and that perhaps women not only made the cannonballs, but fired them too. 
Chapter 6 - "Humble petitioners" and "litigeous person[s]". Southern Avalon women and encounters with formal justice

Feminist scholarship has effectively argued that the British legal system in the $18^{\text {th }}$ and $19^{\text {th }}$ centuries was a patriarchal regime dominated by male legislators. judges, lawyers, and juries. ${ }^{1}$ Women were subject to the authority of the law. but had no formal political voice or access to elected or appointed office at any level. Discriminatory laws, designed by male legislators and enforced by male jurists, reinforced women's subservient status in society. The married woman was most subordinate of all. Lnder the principle of coverture, her legal identity was absorbed by that of her husband. She could not hold property in her own right. enter into contracts. sue or be sued in a court of law She did not even have the right to control her own body. Certainly. she had no legal status in civil actions in the court house. At best. the literature tells us. she could rely on personal intluence in the home and discretionary forms of justice to provide her with indirect access to the formal legal system.

'See, for example: Backhouse. Petticoats and Prejudice; Berkin and Horowitz. eds. Women's Voices, Cullum and Baird, ' 'A Woman's Lot "'. Karen Dubinsky. ...Maidenly Girls or Designing Women?": The Crime of Seduction in Turn-of-the Century Ontario." in lacovetta and Valverde. eds.. Gender Conflicts, pp. 27-66: Susan M.

Edwards. Female Sexuality and the Law: A study of constructs of female sexuality as they inform statute and legal procedure, C. M. Campbell and Paul Wiles, eds (Oxford: Martin Robertson \& Company Ltd.. 1981): Rosen. "Mitigating Inequality". and Ulrich. Good Wives.

"Rosen uses the term "discretionary justice" to describe a diluted form of justice dispensed by authorities on an ad hoc basis to women who were essentially excluded from the formal. rights-based legal system in colonial New York. See Rosen, "Mitigating Inequality." 
However, while women's status within the legal system was indisputably secondary, they were not denied access entirely. Still, there is a tendency in the literature to focus almost exclusively on two tragic images: the female victim of crime or the fermale casualty of discriminatory matrimonial laws - both vulnerable in a system stacked against them. ${ }^{3}$ Presenting the female crime victim as powerless, however, does not acknowledge the agency of many of these women in taking their abusers into public cour settings in pursuit of justice. And using the experiences of married women to generalize about the reception of all women also distorts the picture - leaving the reader with the impression that women were virtually excluded from the system altogether. Granted. the majority of women passed through the married state in adulthood, but many also spent adult vears as single women and widows, life-stages in which they would have had greater access to the legal system. Furthermore. coverture was not always strictly entorced at a local level, and it is theretore important to examine how formal justice played out on the ground within specific historical contexts

The following chapter will examine the extent to which women on the southern Avalon had access to the formal justice system during the period of early settlement *

'A notable exception is Berkin and Horowitz, eds. Women's Voices, which provides a more wide-ranging overview of women's participation in the court life of colonial America.

${ }^{4}$ The justice system in Newfoundland developed somewhat unevenly up to the early decades of the $19^{\text {th }}$ century. Throughout the $17^{\text {th }}$ century, formal justice on the island had been a makeshift affair. dispensed by fishing admirals - the captains of the first fishing vessels to reach every harbour at the start of the fishing season. This system, with a right 
Immediately. some parameters must be established. Women in Newfoundland had no formal political voice throughout the study period and therefore had no input into the making of statutory law (a deficiency they shared with all inhabitants of the island. regardless of gender or class. until representative government was granted in 1832)

Women on the island did not hold office - local or central (a disability shared with Catholics until 1829 ). They did not sit on petty or grand juries They were subject to virtually the same statutory regime as women in other British jurisdictions.' Yet they were

to appeal decisions to the visiting naval commodore, was given legislative sanction by the Newfoundland Act of 1699 In 1729, in grudging acknowledgment of the over-wintering population, the naval governor at Newfoundland was permitted to appoint justices of the peace and surrogates to hear fishery disputes in the absence of fishing admirals and seasonal governors. ts the century progressed, the legal regime at Newfoundland was expanded to include customs officers (1739) and courts of vice-admiralty (1744). over and terminer (1750), and common pleas (1789). However, challenges were raised as to the jurisdiction of these new courts vis-ä-vis the jurisdiction of the fishing admirals that had been established by statute the previous century To resolve the issue. in 1791. a court of civil jurisdiction was introduced. and its jurisdiction was broadened to include criminal matters the following year. Renewed thereafter by annual legislation, the courn, with expanded duties, was made permanent in 1809 . For a discussion of the development of the legal regime at Newfoundland, see: Christopher English and Christopher P. Curran, "A Cautious Beginning: The Court of Civil Jurisdiction. 1791," Silk Robes and Sou westers: The Supreme Cour 1791-1991 (St. John's: Jesperson Press, 1991). English. "The Reception of Law in Ferryland District. Newfoundland. 1786-1812" (Paper presented to a joint session of the Canadian Law and Society Association and the Canadian Historical Association. Brock University. June 2. 1996), and English. "From Fishing Schooner to Colony. The Legal Development of Newfoundland. 1791-1832." in Louis A Knafla and Susan W S. Bunnie, eds. Law, Society, and the State Essavs in Vodern Legal History (Toronto. Buffalo. London: Lniversity of Toronto Press. 1995)

'Even after obtaining a local legislature, Newfoundland continued to adopt much of the legislation passed by British parliament. Two notable areas of exception, however. were inheritance and divorce law, as Chapters 7 and 8 will discuss 
present in the court system, as civil litigants, as complainants and defendants in criminal matters, as witnesses, and as petitioners. ${ }^{\circ}$ Far from being excluded from the system, women on the southern Avalon, especially plebeian women. were a vital part of local court life, and the court room was often a site of their empowerment more so than oppression.

\subsection{Civil litigation}

When generalizations are made from married women's experience about access to the court svstem, the image of the female civil litigant rarely surtaces because married women had no legal status separate from their husbands' until the late $19^{\text {th }}$ century. On the southern Avalon, however, the involvement of women in civil litigation, although not as frequent as men's, was quite extensive during the study period. Their participation broadly fell within the categories of debt collection. employment disputes. landlord-tenant matters, and trespass, and will be discussed in appropriate subsections below.

"Krista Simon describes the presence of women in civil and criminal matters in the court life of nearby Placentia in "A Case Study in the Reception of Law in Newfoundland Assessing Women 's Participation in the Courts of Placentia District. 1757-1823" (Honours Dissertation. Memorial University, 1999).

"Occasional overlapping of cases occurs in the discussion: for example, a case of a woman landlord's collection of rent arrears will appear in both the debt and the landlordtenant sub-sections. 


\subsubsection{Debt collection}

Women or their estates appeared quite trequently in litigation involving debt. emerging as creditors or debtors in 104 cases during the study period. The breakdown of creditor/debtor status in these 104 cases is shown in Table 6.1.*

Table 6.1 - Creditors and debtors in cases involving women

\section{Creditors}

Female

Joint male and female

Male

Total

\section{Debtors}

Female $\quad 25$

Joint female and male 11

Male 68

104

As the above table indicates. there were 76 women creditors (individual and joint) and 36 women debtors (individual and joint) recorded, giving a total of 112 female parties to the collection actions. This suggests that women were twice as likely to be creditors as debtors - somewhat at variance with the stereotypical image but not altogether surprising. given the extent of their participation in the economic life of their communities.

${ }^{\text {R}}$ Linless otherwise specified, all tables in this chapter have been assembled from the database compiled by the writer, as described in Chapter I. Again. in judging the significance of the number of cases discussed in this chapter. the reader should be reminded of the incomplete state of the court records and the low population figures for the area. as noted in fin. 150 of Chapter 5. 
Causes of action varied. although the greatest activity (when specified) occurred in the areas of washing and/or sewing services, merchant or shop accounts, estate matters.

\section{Table 6.2 - Female creditors and debtors - causes of action}

\begin{tabular}{|c|c|c|c|c|}
\hline & $\begin{array}{l}\text { Fen } \\
\text { (indi) }\end{array}$ & $\begin{array}{l}\text { tors } \\
\text { joint) }\end{array}$ & $\begin{array}{l}\text { Fen } \\
\text { (indi }\end{array}$ & $\begin{array}{l}\text { prs } \\
\text { joint) }\end{array}$ \\
\hline & No. & $\%$ & No. & $\%$ \\
\hline Washing and/or sewing & 19 & 250 & 1 & 28 \\
\hline Goods and provisions sold & 9 & 118 & 8 & 222 \\
\hline Estate debts or receivables & $\sigma^{4}$ & 79 & $9^{b}$ & 250 \\
\hline Rent/improvements/damages & 8 & 105 & 2 & 56 \\
\hline Bonds/book debts/ & & & & \\
\hline mortgages/bills of exchange & 5 & 0.8 & 4 & 111 \\
\hline Nursing/midwifery & 3 & 3.9 & 1 & 28 \\
\hline Room and board & 1 & 13 & $3^{6}$ & 83 \\
\hline Medical services & - & . & 1 & 28 \\
\hline Support of illegitimate & & & & \\
\hline child (not own) & 1 & 13 & - & - \\
\hline Sale of sealing gun & $i$ & 13 & . & - \\
\hline Carpentry work & - & - & 1 & 2.8 \\
\hline Sale of piece of ground & 1 & 1,3 & . & - \\
\hline Lnidentified services & 1 & 13 & - & - \\
\hline Unidentified balance of account & 1 & 13 & - & - \\
\hline Unspecified & $\underline{\underline{20}}$ & 26.3 & $\underline{6}$ & 167 \\
\hline Totals & 76 & 1000 & 36 & 100.1 \\
\hline & $=$ & $=$ & $=$ & $=-\infty$ \\
\hline
\end{tabular}


landlord-tenant matters, and bonds/book debts/mortgages/bills of exchange, as indicated by Table $6.2^{\circ}$ The majority of the debts (64.4 percent) were amounts under $\Sigma 10$, but there were a significant number of 'big-ticket' actions, with two of the cases involving amounts in excess of £200 (see Table 6.3).

Table 6.3 - Breakdown of debt collections by amount

\begin{tabular}{|c|c|c|}
\hline & No & $\%$ \\
\hline Under $\varepsilon 1$ & 21 & 202 \\
\hline EI - under ₹5 & 30 & 288 \\
\hline E5 - under ₹ 10 & 16 & 154 \\
\hline 乏10 - under $₹ 50$ & 10 & 96 \\
\hline £50 - under $₹ 100$ & 8 & 7.7 \\
\hline E100-under £200 & 7 & 6.7 \\
\hline £200 and over & 2 & 19 \\
\hline Linspecified & 10 & 96 \\
\hline Totals & 104 & 999 \\
\hline
\end{tabular}

There was only one repeat debtor among the cases surveved. but there were several repeat creditors. Collection actions became something of an occupational hazard for Jane Austen, for example. as she sued eight different debtors through the 1830s and

"Various claims in relation to unpaid wages are not included in this table but are dealt with in the subsection on employment disputes, below. However, the "unspecified" category in this table does contain numerous small amounts that may involve wage claims. although they could also be for services such as washing, nursing, sewing, etc. The decision to include them here is, therefore, somewhat arbitrary. 
$18+0$ s for goods sold and delivered from her shop in Ferryland (all for amounts under £4) "' Margret Kenny of Ferryland was busily tidying up her affairs in the Ferryland area at the turn of the $19^{\text {th }}$ century. possibly just after joining her husband in St. John's. she sued five local individuals during 1799-1800 (four actions, with unspecified causes, were for amounts in the £3-£5 range: the fifth and final action was for £20 for rent and damages in relation to a plantation in Ferryland, but she was non-suited. the court finding her to be a "litigeous person" and ordering her to pay 40 s. to the defendant) ${ }^{1 t}$ Catherine

"See PANL GN 5/2/C/3. 1835-17 journal: n.f. Jane Ansten 1: William Haney: Vovember 6. 1839: and n.f. Jame Austen i: William Sheeham. October 22. 1840. Also. GN 5/4/C/1, Ferryland. Box 1: f. 79. Jane Alustin v. Eumund Keef. October 26. 1835, t 91. Jane Austin v. _. WcKay, October 31, 1836, ff. 91 and 93, Jane Austin v, W. Baltcock. October 31 . 1836. and January 16. 1837 . Also. GN $5 / 4 / \mathrm{C} / 1$. Ferryland. Box ?

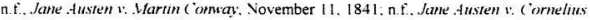
Kelly, Ir., c November, 1844, and n.f., Jane .Austen 1: John Panme, October 20, $18+5$

"All these cases are cited from the St. John's court records in Mannion Name File. Ferryland. "Kenny. Margaret" [Mannion uses the modern spelling of her first name, but the form "Margret" appears consistently in the Ferryland court records.] Margret Kenney also had the dubious honour of being the only repeat debtor among the group. Margret was a rather colourful local character. She first appeared in the Ferryland court records in 1792. when she was being successfully sued by William Young for 21.4 . See PRL. $3+0.9$ N45. f. 18. William Young v. Margret Keney. December 3. 1792. In 1794. she was charged and convicted of selling liquor without a license. See PRL. 3409 N45. n.f. Rex v. Hargret Keney: July 14. 1794 This matter was rectified the following year, howeter. when she received a license to sell liquor in Ferryland district by local magistrate Robert Carter. See P.NL. GN 2/1/A. 13/225-6/1797. Robert Carter to Governor Waldegrave. October 20. 1797, enclosing various accounts, including a list of liquor licenses that had been issued for 1795. In June. 1795. Margret was sued by Margret Duggan for unspecified services performed: Margret Kenny advised the court that she had already provided free room and board to the other woman for three or four months. having taken her into her house "thro Compassion" as Duggan had found herself in "a distressed situation." According to the court clerk. "The parties haveing caluminated each other. and proceeded to scolding, they were dismissed without Cost, and Ordered, that their 
Weston. an Irish-Catholic woman who had married into a powerful middle-class English-

Protestant family. initiated three separate suits (through her attomey) for amounts ranging from $£ 50.18 .3-3 / 4$ to $£ 109.4$ in the period $1787-17900^{12}$ Another middle-class woman. Ann Sweetland, initiated two smaller actions to recover monies for the sale of ground $(40$ s $)$ and rent arrears $(£ 6,19.6)$ in $1798^{13}$ The estate of Mary Ludwigg (or Ludwick), an Irish-Protestant woman who had considerable property and financial interests in the area, appeared as creditor in the 1750 s and 1760 s in four separate matters

Accounts are tinally settled, and that they behave peaceable in future on pain of being prosecuted according to Law, if anv further Complaints." See P.ANL. GN 5/4/C $/ 1$. Ferryland, Box I. n.f. Margret Duggan v: Largret Kemm: June 4. 1795 Later that vear. she and her husband as well as several male servants were charged and convicted of theft and receiving stolen goods: Margret was fined while her husband was not only fined but sentenced to imprisonment and a whipping - a sentence that he mitigated by joining the Newtoundland Regiment. See PANL. GN5/4/C/I. Ferryland. Box I. n.f. Arthur Hum lagent for Leigh \& C $0 . /$ and John Baker /agen for Holdsworths/ v. John Kenm: Largret Kenny. William Power, William Broadfoot. Timothy. Fowler. Patrick Burne, and Richard Dumphy. Thursday. October 6 [8?], 1795, see also Sections 6.2 and 6.3. below. Whether this episode affected her capacity to continue holding her liquor license, or indeed whether she was issued the 1795 license after her husband had left for the Newfoundland Regiment. is not clear from the records. By the turn of the century. Margret had likely joined her husband in St. John's. where he would have been headquartered with the Regiment, as her various debt collections emanated from the St John's court. and neither of their names appeared in the Pole Papers. 1799-1800

12PANL, GN 5/4/Ci1. Ferryland, Box 1: ff. 25-6 and 50-2. ("atherime Weston :: Hammah and William McDaniel, March 8 and 9, and October 5. 1787. ff 3 and 5. (atherine Weston v: Johm Kearney, August 17 and September 15, 1790; and ff. 3-5, and 8. Catherine Weston v. William McDaniel. August 17. September 15. and October 15. 1790

13PANL. GN 5/4/C/1, Ferryland, Box 1: n.f., Anne Sueetland v. John Whelan. June 8, 1798: and n.f., Am Swetland v. Patrick Harvey. August 7. 1798. 
involving mortgage arrears of substantial amounts (£60. ₹109, and £167.4.0) and the adjustment of book debts with another wealthy Irish-Protestant landowner and businessman in the area: Mary's heirs. William and Mary Ludwigg, were represented by William throughout. ${ }^{14}$ And Ferryland washerwomen Mary Bryan appeared in court personally to sue two of her customers in 1803 for amounts which. though unspecified. would likely have fallen in the range of $12 \mathrm{~s} .-15 \mathrm{~s}$. normally paid to laundresses at that time. $^{\text {is }}$

As the above examples suggest, ethnicity and class were often underlying factors in the nature of the causes of action. All the women who sued tor washing and/or sewing services as well as nursing/midwifery services were trom the plebeian community predominantly from Irish backgrounds or English families that had been assimilated by the time their respective suits were initiated. Middle-class women (English and Irish Protestant) were much more prominent in estate matters and collections involving rent. book debts. mortgages. and bonds. The latter were almost exclusively the creditors and

${ }^{14}$ PANL. GN 2/1/A: 1/357/1752. Governor Francis Drake. Order to Thomas Cloney. Ferryland, re: debt to Ludwigg estate. September 26. 1752: $3 / 331 / 1765$. Governor Hugh Palliser. Order re: William Luctwick, for the estate of Mary Luturick, v: James Keen. September 28, 1765, 4/12/1766. Governor Hugh Palliser. Order in William luctwick. for the estate of Mary. Luctwick. v: Richard Ball, September 4. 1766, re: debt to Ludwick estate: and 4/12/1766. Govemor Hugh Palliser. Order re: adjustment of book debts in William Lutwick for the estate of Mary Luctwick $v$. Richard Benger. September 4. 1766

${ }^{15}$ PANL. GN 5/4/C/1, Ferryland, Box l: n.f., Lary Bryan v: Adam McLarth: November 14. 1803: and n.f., Mary Bryan v. Thomas Norris, November 14, 1803. 
debtors in suits involving amounts of $£ 100$ and over (Hannah McDaniel - see Section 6.4 - was the only exception). Plebeian women were overwhelmingly involved in suits under $\varepsilon 10$, however, they were also a robust presence in the middle band. being represented in roughly two-thirds of the suits involving $£ 10$-under $£ 50$ and one-half the suits involving amounts from $£ 50$ to under $£ 100$.

Marital status was also a determining factor in terms of whether these women had legal status in the cases. While all the debts in question were owed to or by women (either individually or jointly with husbands). not all these women appeared personally in the collection actions. Local courts were governed by the principle of coverture. and htisbands often represented their wives in such matters. Thus. in October. 1818, for example, when Mrs. Dollard was owed money for washing services provided to John Veile's tishing servant at Fermeuse, it was her husband. John. who sued Neile for some fish that Dollard claimed had been left on Neile's fishing room by the servant to pay his debt. ${ }^{\text {to }}$ Similarly. two years later. Patrick Pritchett sued William Summers for $18 \mathrm{~s}$. for washing services provided by Pritchett's wife. ${ }^{17}$ In the eyes of the law, husbands also assumed responsibility for the debts of their wives upon marriage. For example. when Mrs. William Coleman ordered two blankets from merchant Samuel G. Carter and

topANL, GN 5/1/C/1. Ferryland. Johm Dollard v. Johm Neile (or Neill), October 16 and 30.1818 . 30. 1820 .

${ }^{17} \mathrm{PANL}$. GN 5/1/C/1. Ferryland. Patrick Pritchett v. William Summers. October 
neglected to pay her account. it was Mr. Coleman who was sued and ordered to pay the debt, even though he claimed (and the plaintiff could not disprove) that he had no knowledge of the order ${ }^{18}$ The husband's responsibility extended to debts contracted before marriage. In 1818, for example, the court permitted Robert and James Carter to collect monies from Jeffery Jass to pay a debt of $£ 8.16 .0$ that had been incurred by Jass's wife. the former Jane Dullanty. before their actual marriage ${ }^{17}$ Similarly, John Power was ordered by the cour to pay a debt of $\{3.5 .3$ which had been incurred by his wife. Margaret Neill. before they had wed. Indeed. although Margaret had property (a bed) from her previous marriage, it was attached only when it was demonstrated that John did not have sufficient security of his own for payment of his wife's debt ${ }^{20}$

Still. of the 112 total female creditors and debtors examined here. only 20 ( 18 percent) were represented by husbands. acting as legal agents (either for the wife only or for the couple) under the law of coverture. Another eight ( 7 percent) were named parties in the actions but were represented by guardians. brothers. or attorneys in the court house; here, ethnicity and class came into play, as all the latter group were members of middleclass families. reflecting a general tendency for gentry women to eschew the public court

\footnotetext{
${ }^{1 *}$ PANL, GN 5/1/C/1, Ferryland. ff 24-5. Samuel (j. Carter : William coleman. January 19, 1818

I9PANL. GN 5/1/C/1. Ferryland, f. 27. Jeffery Jass v. Rohert and James ('arter. January 21. 1818 1818

20P.ANL. GN 5/1/C/1. Ferryland. Samuel G. Carter v. John Power. January 19.
} 
room, regardless of marital status. The remaining 84 temale creditors and debtors ( 75 percent) represented themselves. The relatively low number of actions involving husbands who acted for wives suggests that there was a disproportionate number of single or widowed women among the litigants; but it also hints that the principle of coverture may have been occasionally relaxed in southern district courts. Unfortunately. a lack of comprehensive parish registers makes it impossible to track such a phenomenon. but the proportions are suggestive. Certainly, this was the case with Hannah McDaniel, who acted as petitioner and attorney for her family when financial difficulties arose over an alleged debt to the Weston family (see Section 6.4). And even in cases in which wives were not named legal agents, women sometimes acted as important witnesses when disputes arose as to the validity or amount of a debt ( see Section 6 3). Furthermore, while formal law recognized the husband as legal agent in collection actions ( and whether or not this principle was relaxed by local courts), the control of household finances often played out differently on the ground. for in many fishing families. it was the wife who managed whatever small amounts of cash were on hand. Thus, while a wife from the plebeian community may have been required by law to send her husband to court to collect monevs owed to her for. say, washing services, this did not necessarily signal a relinquishment of control over that money in the same way that it likely did for middle-class women.

Certainly, the local courts did not apply the principle of coverture as a blanket treatment in inappropriate circumstances. In 1818, for example. Hunt. Stabb. Preston. an English mercantile firm operating out of Renews. discovered that they had placed too 
much faith in the repercussions of coverture when they brought a collection action against the estate of Thomas Beaves to recover a balance of $£ 70$ (upgraded to 278.9 .0 the tollowing month). The plaintiffs stated that when Thomas Beaves had died in 1810. he had been indebted to the firm in the amount of $\varepsilon 65$, the remainder of the debt had been incurred by his widow. Elizabeth. since that time. under the head of 'Elizabeth Beaves \& Son." According to Elizabeth, no claim had been brought to her by the firm in relation to her husband's debt since his demise, the debt being of such long standing, the tirm had therefore exceeded the statutory time limit for collection, she argued. She, herself, had maintained credit balances in dealing with the plaintiff's house since her husband's death until 1817. when she, too, had fallen into debt. The firm had proceeded to sell. at public auction, her tishing room, house, and gardens - property that had been left to her by her mother - and purchased it themselves for £201 to cover the debts of both her and her husband. The sale had been made without her consent. Elizabeth claimed, and without lawtul authority, and she asked that she be put back in possession of the premises.

The court reserved judgment until various documents were produced; and the evidence did little to ingratiate Hunt, Stabb. Preston to the court. Apparently, the tirm had. since 1810 , been registering various accounts with the court in relation to Thomas's debt to continue them and thus to prevent the applicability of the statutory limitation period. This had evidently transpired without Elizabeth's knowledge. The cour tound that regardless of the "ingenuity" with which the firm had attempted to continue Thomas s debts. "this Court is ever awake to prevent their effect being extended beyond legal 
bounds." and the statute of limitation was, therefore, as Elizabeth had argued, a bar to the debt. Furthermore, the court found that the property sold under auction had indeed been left to Elizabeth by her mother's last will and testament. Elizabeth 's late husband had never exercised any right to the property: furthermore. Hunt. Stabb. Preston had never demanded it as security, from the misapprehension that all real property of the wife was. under the principle of coverture, the property of the husband and automatically liable for his debts. On the basis that "it has been held to be law that property acquired of the Wife either before or after Marriage over which the Husband has exercised no manner of right or control is not liable to the debt of the Husband." the court rendered judgment that "the Action against the property of the Widdow cannot prevail."."

The principle of coverture, then, was tailored by the local courts to the particular circumstances of a case. and occasionally. set aside altogether.

\subsubsection{Emplovment disputes}

Twenty-five emplovment disputes involving southern Avalon women appear in the records for the study period. These cases involved 17 femaie complainants and seven female defendants acting as legal agents. as well as two instances in which female claimants were represented in court by men (one husband. one former employer against a

\footnotetext{
"PANL, GN 5/1/C/1. Ferryland, If $124-5$ and 162. Humt. Stabb, Preston \& ( $^{\circ} \circ$. 1: the Fstate of Thomas Beaves, November 6 and December 11. 1820
} 
current employer), and two instances in which husbands were the actual defendants but their wives were an integral part of the dispute. As Table 6.4 indicates, there were three main causes of action. refusal by a servant or a master/mistress to honour a shipping or apprenticeship agreement: dispute over calculation of wage balances, and alleged illtreatment:

\section{Table 6.4 - Women's employment disputes - causes of action}

\section{Wages}

Wages: shipping agreement not honoured

Wages, ill treatment, shipping agreement not honoured

III treatment

Shipping agreement not honoured

III treatment: shipping agreement not honoured

Other

Total

${ }^{2}$ These are cases in which shipping arrangements were referred to or produced: doubtless. many in the "wage claims" category also resulted from shipping agreements, but no direct reference was made to such papers in the case records.

Indeed, the only exception was an 1818 matter. in which Kearon Mulloney left his post in Cape Broyle as clerk and teacher with Henry Coryear: the cause of his precipitous departure was a dispute he had had with Coryear's wife, although the details of the 
confrontation were not recorded. ${ }^{22}$

In several cases, there were multiple causes of action. All three major causes overlapped. for example. when Frida Tobin had a falling out with her mistress. Mary Bony (or Bonia) and brought her to court in the fall of 1818 Frida complained that Mary had struck her several times "without any provocation." and then refused to pay her wages. Frida's shipping papers, contracting her for the season from April 7 to October 31, 1818. were produced in court. The defendant admitted that she had assaulted Frida, but insisted that she had not refused to pay her wages. The court ultimately found in Frida's favour and ordered Mary to pay the balance of Frida's wages, a tine of $2 \mathrm{~s}$.. and cour costs. ${ }^{23}$ Similarly, there were multiple causes in a hearing held the very next day on a complaint laid by Catherine Lancrop of St. Mary`s against her employer, John Doody. Jr. Catherine had been shipped by Doody the previous year, but he had still not paid her passage money trom Ireland as per agreement. Doody had also struck her and drawn blood: indeed. the assault was so severe, said Catherine. that she "lay some time for dead." Doody still owed her the balance of her wages at the time of the cour hearing. The court decreed that he pay her passage money and her wages: and Doody was also fined 40 s for the assault on

"P.ANL. GN 5/1/CiI. Ferryland. f. 45. Kearon Mfulloney v. Henry Coryear. May 11. 1818. Mulloney was suing for the balance of his wages. which had been agreed at £15 plus washing

${ }^{3}$ P.ANL. GN 5/4/C/I. St. Mary's. ff. 47-8. Frida Tobin v. Man Bom. September 28. 1818 . 
Catherine and ordered to pay court costs ${ }^{24}$ Two other cases straddled two of the categories Jane Costeloe brought her servant Bridget Whealon to court in 1795, for example, for desertion - having "Eloped from her service," thus failing to honour a verbal employment contract: Bridget countered with a defence of maltreatment, arguing that she had been forced to leave by the constant beatings and scoldings administered by her mistress. .s And when Anstice Dwyer of Brigus South sued Cornelius Kelly, agent tor George and Thomas Kough (see Chapter 4), in 1797, the issues of outstanding wages and shipping arrangements converged.

In all, there were only five actions involving alleged ill treatment of servants. Four involved mistress/female servant relationships while only one involved a master/female servant dyad While the type of service in which these servants were emploved was not stated in any of the cases. it is likely that they were mostly domestic servants, given the more frequent mistress/servant dyad ${ }^{: 6}$ Three of the cases - lohm v: Bony, Lancrop v: Doot: and costeloe : Whealon - had multiple causes of action and have been described

${ }^{4}$ PANL. GN 5/4/C/I. St Mary' s. f. 52 . Catherme Lancrop is John Doodt. .Jr. September 29. 1818 1795.

sPRL. 3409 N45. Ferryland. n. f. Jane costeloe v: Bridget Whealon. August 3.

${ }^{26}$ This assumption, however. must be qualified. Certainly. Frida Tobin (see above) had been hired for the fishing season: thus she might have been an actual fishing servant. although it was also common to take on extra domestic help during the fishing season. Furthermore, it should be noted that many domestic servants were also expected to help out with drying fish at the height of the season. 
above. The other two cases involved complaints of abuse only. In 1795, for example. Mary Whealon of Ferryland complained that her mistress, Margret Wallace. had assaulted her and sought the protection of the court. Margret admitted that she had thrown stones at Mary, but argued that she had been provoked by her servant's abusive language. ${ }^{27}$ In 1835. Nancy Addis of Brigus South complained that her mistress. Mary Power, had beaten her with rocks in her fist and threatened to do her further violence ${ }^{\text {s }}$ It was apparent that the physical abuse in most of these cases did not seem severe by contemporary standards, for the offending employers received lenient treatment: the charges against Costeloe and Wallace were dismissed altogether, while Bony was given a small fine of $2 s$. and Power was bound to keep the peace. Only the mistreatment of Catharine Lancrop by John Doody attracted a fine of any substance - 40 s., and while this case involved the only master/female servant dyad, the more significant fine was likely due to the relative severity of the abuse rather than any affront of sensibilities relating to a man's striking a female servant.

The most common form of complaint in the employment dispute category was non-payment of wages. being cited in a total of 16 cases involving 11 female complainants. three female defendants. one female servant represented by her husband as complainant in court. and a wife of a male defendant who. although not named in the style 1795

27PRL, 3409 N45, Ferryland, n f. Wary Whealonv. Largret Wallace, July 21.

${ }^{28}$ P.ANL. 5/4/C/1. Ferryland. Box 1. f. 71 .. Vancy dddis 1 : Mary Power. September 1. 1835. 
of cause. was integral because her household accounting was in question ${ }^{2}$ This breakdown indicates that women involved in these cases were more often servants (complainants) than employers (detendants). Most of the cases transpired between employers and their employees, or the legal representatives of either. but there were three exceptions. In 1830. Catherine Delahunty tried to sue her son's employer. Thomas Norris. for the balance of her son's wages for "being on the Cut tails" on Norris's boat that summer, the court ordered. however. that she had no cause of action. ${ }^{\text {to }}$ The other two variants involved a claim for unpaid wages entered by a female fishing servant against her master's supplying merchants. Chapter 4 has already discussed the case of Anstice Dwyer, fishing servant for John Sloan, who sued the agent of her emplover's supplying merchants in 1797 because the agent had taken Sloan's entire voyage before the balance of her wages had been paid. Anstice produced a shipping paper in court by which she had agreed to work as a member of Sloan's shore crew for $£ 9$. and the court immediately decided in her favour. ordering the agent to pay her an outstanding balance of $\Sigma+100$ Similarly, in the fishing season of 1818 , Margret Neile (or Neill) was working "in the Service of James Linch curing fish on shore" in Ferryland. Linch s supplying merchants. John and James Munn. took his fish and oil for pavment of their account. before Linch had paid Margret her outstanding wages Margret successtully sued the Munns for the

${ }^{9}$ As noted earlier, some wage claims may be included in the table on causes of action for debt collection under the category 'unspecified. Thus. the actual total number of wage claims for the period may be under-represented in the current section

${ }^{30}$ P.NL, GN 5/4/C/1. Ferryland. Box 1. f. 28. Catharme Delahunty v. Thomas Vorris. November 15, 1830 
outstanding balance of $£ 3^{31}$ Both Anstice and Margret were exercising the privilege of al! fishing servants in Newfoundland to have their wages paid before the accounts of current supplying merchants

Indeed. disputes involving wages were taken quite seriously by the local courts. and when servants complained that their wages had been miscalculated or any balance left unpaid, the courts closely examined shipping agreements and account books of employers to verify balances. This retlected a customary priority accorded in the island's fishing economy to the payment of servants wages - owing not so much to an altruistic principle that the servants be justly treated as to a pragmatic concern that servants have sufficient funds to pay for their passage home after the fishing season - a practice that was given statutory force by Palliser 's Act in 1776 Certainly by the latter $18^{\text {th }}$ century, the payment of wages was not lett to the whim of masters or mistresses, and servants (female and male) enjoyed a high success rate in obtaining outstanding balances from recalcitrant employers (female and male). Of the 16 cases examined here, ten resulted in cour judgments in tavour of the servant complainants. while another three were settled out of court lone assumes with satisfactory compensation to the servant)

Vine of the cases examined here specifically referred to employment agreements * Of these. six involved complaints between employer and employee. but three involved

${ }^{31} \mathrm{PANL}$. GN 5/1/C/1. Ferryland. f. 62. 1/argret Veile v:, John and James Lumm, November 2. 1818 .

${ }^{3}$ Richter discusses a small number of indentured servants in colonial Virginia who sought protection from the court from masters who violated the terms of their indentures. See Richter. "Free Women." pp. 297-8 
mothers' interventions in the employment agreements of their sons. ${ }^{13}$ Hannah McDaniel appeared in 1797 as co-defendant with her son John to answer a complaint by John's employer. Michael Malone, that John had refused to filfill his shipping agreement on his mother's counsel Hannah and John successfully argued that Malone had tried to force John to work outside the agreed geographical range of the shipping agreement. and a settlement was reached. ${ }^{34}$ In 1836 , Elizabeth Madden complained to the magistrates that Michael Curragan (or Corrigan) had refused to employ her son on the terms that had been agreed between the parties; the matter was settled out of court." In 1837. Jane Fitzpatrick requested that her son James be released from his apprenticeship agreement with Robert Pitt. as Pitt had not properly fulfilled his contract with her son, in this particular case, however, the magistrates deemed the matter to be beyond their jurisdiction."

Just as women were given equitable treatment by the courts in terms of wage payment. so too were they afforded similar treatment in terms of employment contracts Employers and employees of both sexes were expected to honour the terms of their

"Rosen observes some incidents of women's petitioning on behalf of daughters who were servants. but does not mention women s intervention in sons' service contracts See Rosen. "Mitigating Inequality." p. 322.

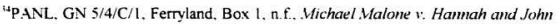
licDamiel, June 9, 1797

"PANL. GN 5/4/C/1, Ferryland. Box 1. f. 89. Elizabeth Madden v. Lichael (iurragan. August 3. 1836.

${ }^{36}$ PANL. GN 5/4/C/1. Ferryland. Box 1. f. 93. Jane Fitzpatrick v: Robert Pirt. January 9,1837 
shipping agreements. Elizabeth Cullen's successful action against James Shortall, who had arranged to have her shipped in Ireland and then refused to take her into service on arrival. has already been discussed in Chapter 3. Similarly, cases already examined above in this section have made reference to women's employment contracts. When Anstice Dwyer sued Cornelius Kelly for her wages, her proof of claim lay in the shipping paper hiring her as shore crew and cook. When Frida Tobin had a falling-out with her mistress Mary Bony, Frida's shipping paper was produced in coun to reinforce her claim for wages. Catherine Lancrop's shipping agreement supported her claim for wages and passage money from her employer, John Doody. As noted earlier, oral agreements were also deemed to be binding legal contracts. In the dispute between Jane Costeloe and Bridget Whealon, for example. evidence was entered that Bridget had been hired verbally for one year at a wage of $₹ 3$, the cour found that despite the beatings and scoldings of her mistress. she must return to service and honour her agreement. ${ }^{17}$ Employment contracts. whether they involved men or women, and whether oral or written. were usually enforced to the letter by authorities in the period.

While the servants on the southern Avalon in the $18^{\text {th }}$ and $19^{\text {th }}$ centuries occupied

${ }^{77}$ See Duzer v: Kelly, Tobin v: Bom: Lancrop v: Dooty: and Costeloe v: Whealon. above A further illustration comes from just outside the study area. When Jane Kelly of Placentia complained to Governor John Campbell that her employer. John Cullin. with whom she had served for 14 years at an agreed rate of $E 14$ per annum, had turned her out without her wages, the governor instructed the local magistrates to enquire into the matter and "cause Cullin to fulfill the Engagement which it may. be proved he made wh the Woman [italics added]. Or if it should be of so Extreme a nature as to require the Interference of the Governor, to provide for her till the Governor has an opportunity of deciding upon this matter.." See PANL, GN 2/1/A, 10/85-6/1784. Governor John Campbell to Alexander Williams and John Brown. JPs, Placentia. October 12, 1784 
the lower social and economic strata. their work was essential to the economy and thus they were not without recourse in terms of ensuring a reasonable standard of living. The various cases examined in this section suggest that certainly by the late $18^{\text {th }}$ century onwards, servants in the study area were not expected to tolerate irregular treatment from masters and mistresses or arbitrary justice from local courts. While there was obviously a certain comfort level within the community for moderate physical punishment of servants. more severe abuse would attract the displeasure of the magistrates or visiting surrogate. Local courts were very accessible in terms of wage claims - by female as well as male servants. And shipping agreements were sacrosanct. with both employers and employees. male and female, strictly held to the terms of the oral or written contracts they had negotiated.

\subsection{Landlord-tenant matters}

Female landlords: Twenty women landlords were involved in disputes affecting their properties on the southern Avalon during the period. ${ }^{38}$ The women were the named

\footnotetext{
${ }^{48}$ This section deals with female landlords as litigants only. The names of female landlords. however. also arose in the records in other matters in which they were not litigants - particularly estate matters. In a protracted dispute between John Nunan and the Carter family over the Richard Nason estate at Ferryland, for example. William Holly deposed in 1850 that his tather. Michael. had rented property - a house. gardens. meadows. and fishing premises - from two landlords - the Nason estate and Mrs. Morry of Caplin Bay. See PANL. MG 247, Carter-Benger-Nason Papers. File 18, William Holly deposition, August 13,1850. The property in dispute had. in fact, been inherited by Nunan from his aunt. Anstice Gorman, who had, in turn. inherited it from the late Richard Nason (see Chapter 7). Women landlords also appeared in merchant ledgers (see
} 
legal agents in all the matters but two: one in which a husband sued for rent owed on property he possessed "by virtue of his wife", and another in which a brother represented the interests of himself, his brother. and his sister. In two other matters, the female landlords were the named parties but represented by others in the court room: a case in which a minor was represented by her male guardian, and another in which an adult woman was represented by a male attorney. Over half the matters arose in the $18^{\text {th }}$ century, reflecting a strong presence of women from the traditional planter society in this category Most of these $18^{\text {th }}$-century matters involved English women, but at least four of these earlier landlords (Barbara Murphy, Alice Thomas, Frances Power. and Hannah McDaniel) were Irish. Furthermore, an Irish presence predominated in this category in the $19^{\text {th }}$ centurv

Eleven of the matters involved actions for rent recovery and/or eviction in relation to houses, gardens. and tishing rooms. These 11 complainants met with varying success. four won their suits (all rent recoveries only) while another two were settled by the parties, two other female landlords were non-suited. one matter went to arbitration and the result was not recorded: one matter was continued with no further indication of the outcome, and the remaining matter appeared in the records only in the form of the writ issued. Three other matters involved actions for debt recovery in which creditors were attempting to attach the rents of female landlords to satisfy arrears on morgages or bonds. One of these matters resulted in the full attachment of rents and another in the partial

Appendix C). 
attachment of the rents: in the third. however, the female landlord successfully warded off her creditor until the matter was finally settled by the parties out of court.

Female landlords also surfaced in litigation involving estates. In 1792, for example, the children of Morris Brazil successfully initiated an action for repossession of a plantation. possibly in Cape Broyle, that had been attached by their father's creditors back in 1784. The family succeeded in proving that their father's debt had been paid and that the rental of the plantation should now accrue in their favour While the family was represented in court by one of the sons (William), all Brazil's children (two sons and a daughter) were to share the proceeds of the rent equally. In the same year. Mary Kennedy successtully sued her brother William Tucker for an equitable distribution of rents from property of their late father - a landmark case in local law on intestacies that will be discussed in greater depth in Chapter $7^{\text {th }}$

Two other estate matters involved disputes over the possession of fishing premises. In 1752. for example. two sisters of James Dunn, Renews planter, successfully pressed their claim before the fishing admirals in the harbour tor possession of their intestate brother's plantation and the right to receive the rents from its current tenant *t

${ }^{39} \mathrm{PANL}, \mathrm{GN} 5 / 4 / \mathrm{C} / 1$, Ferryland, Box 1, ff, 25-6, William Brazil [for the estate of Worrts Braztl/ v: Robert Sparke and George Yard. October 13, 1792.

${ }^{10}$ PA.VL. GN 5/4/C/1. Ferryland. Box 1. ff. 25-6. Wary. Kemecty vil Willam Tiucker. October 13, 1792.

${ }^{11}$ PANL, GN 2/1/A, 2/121-2/1754. Decree of Surrogate Edward Le Cras. September 3. 1754. confirming decision at a Court of Fishing Admirals in Renews. October 2. 1752. The adverse claimant in the matter was Bazil Fielding of Mosquito Cove. Consumption [Conception] Bay. 
Another matter involved a 1772 dispute over possession of a fishing room on the south side of Petty Harbour. William Coombs, who had leased 'Langworthys Room' from the widow Barbara Murphy of Ferryland. was challenging her right of possession of the property, arguing that it had not been occupied or used for the fishery for over 20 vears. However. the governor confirmed Barbara's interest. provided that she erect fishing premises on the property within two years and employ green men on the room. ${ }^{2}$ Barbara must have complied, because in a dispute two years later between William Keen and the same William Coombs, Coombs was described as a tenant of "Barbary" Murphy "3

The remaining matter in this category involved a female landlord and her agent. Frances Power (likely the widow of Patrick Power, a merchant at Renews, and therefore likely middle-class (rish) petitioned the Governor in 1789 to investigate an alleged traud on the part of her agent, James Sparkes. She had left the rental of her plantation in Renews in his hands, but he had remitted no rents since 1786. Sparkes had recently died. but she had received information that he had forged a lease of the plantation to himself for a term 21 years which was now in the hands of his executors, and that the plantation had been sublet to merchants Wills \& Witburn. Governor Edwards instructed magistrate Robert Carter to "make strict enquiry into the Matter." and if proved, to put Frances Power "into quiet and peaceable possession of the said Plantation. and cause the person 1770

"PANL. GN 2/1/A. 4/283-4/1770. Order. Governor Jonathan Byron. October 29.

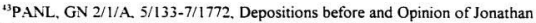
Pitt. Admiral, and Nicholas Mudge, Rear Admiral, at Petty Harbour. September 12.1772. as well as Order of Governor Molineux Shuldham. September 18. 1772. 
who has received the Rents thereof, since the said Sparkes death, to be accountable to her for it, or appear before me at St. John's to show cause for his refusal...."4

While female landlords were not as conspicuous in the southern Avalon records as male landlords, ${ }^{15}$ they were still a significant presence. And regardless of the outcome of their cases, their willingness to litigate made them a force to be reckoned with during the study period.

Female tenants: Women tenants also defended their interests before the authorities on at least seven occasions during the study period. ${ }^{\text {th }}$ Six were involved in eviction actions based on default or expiry of lease and/or rent arrears, while the seventh

${ }^{4}$ PANL, GN 2/1/A, 8/97/1779. Governor Richard Edwards to Robert Carter. JP. Ferryland, October 22, 1779

${ }^{15}$ It is likely that the property interests of a number of middle-class women were masked in the records by the names of male trustees.

${ }^{46}$ As with female landlords, female tenants also surfaced in records on other matters in which they were not litigants. The will of Thomas Norris. $\mathrm{Sr}$. for example, left his son Thomas. Jr. "a potato garden in Ferryland under lease to Catherine Dellahunty" See John Mannion Name File. Ferryland, "Norris, Thomas" (will probated December 1011. 1840). The bondsmen for the administration of the estate of Robert Jordan in Brigus South offered as security a small piece of property being rented by the widow of Joseph Power (likely, Catherine Power) for 30s. per year. See Mannion Name File. Brigus South. "Jordan, Robert, Estate of" (administration - December 14, 1829). In the lengthy dispute between John Nunan and the Carter family in relation to the estate of Richard Nason at Ferryland, several current and former women tenants on the disputed properties were mentioned in various depositions, including Margaret Aylward. who sub-let her premises after moving to St. John's, and Kitty Bryan and her husband Timothy, who occupied a meadow for which the leasehold interest had originally been purchased by Kitty's mother. Ellen Sanders. from Michael Poor. See PANL. MG 247. Carter-Benger-Nason Papers. Files 18, 22, 26, 28, and 29. Women tenants also appeared in merchant ledgers (see Appendix C). 
appeared in court on a matter of rent arrears only. All but one of the female tenants were from the plebeian community, the exception being a member of an English-Newfoundland merchant family: and five out of seven were Irish-Newfoundland women. Five were single or widowed and named as legal agents in the writs issued; one woman was named as codefendant with her husband, and another represented her family's interests due to her husband's incapacity. The records indicate that evictions were ordered in only two cases. In a third case, the landlord plaintift" was non-suited. In the remaining four matters. either orders for continuance were given. or the tenant was granted time to pay rent arrears. None of these latter four matters reappeared in the records - possibly a reflection of the incomplete nature of the records. or possibly an indication that a satisfactory resolution was found between landlord and tenant outside the court house.

In the two matters in which the female tenants were unsuccessful in staving off evicting landlords, the women still managed to buy some time for themselves and their families. For example. Mary Bryan of St. Mary's petitioned the governor in October. 1780. to extend her family's tenancy of a fishing plantation held in her husband's name. Lnfortunately. her husband had been deemed 'insane' and she and her family were about to be turned out of the plantation. The landlord, John Richards, had re-let the plantation to a $\mathrm{Mr}$. Townshend the previous February, without giving the required notice of 12 months, as stipulated by the lease with her husband. The governor, mindful that "the Poor woman and her family must naturally be distressed if turned out of their House $\ldots$ at this time of Year." instructed the local magistrate to settle the matter "as amicably as you can - 
tho I think Mr. Townshend has a right to possess it in time to carry on his fishery next year " Ultimately, then, the change in tenancy occurred. However, the purpose of Mary's petition had been to extend the life of her husband's lease by pleading improper notice. Allowing for the fact that Mary had been aware of the new tenant since the previous February, she and her tamily were effectively being given more than the required 12 months" notice through the governor's intervention. Thus, she was successful in lobbying for extra time to make alternative living arrangements ${ }^{47}$

In a more prolonged matter that ran between 1837 and 18+1. Catherine Dullenty (described as the widow of John Dullenty) tried to ward off eviction from her home and adjoining gardens, first by William Carter, then by the executors of his estate. In fact, the action was initiated for "trespass and eviction." but Catherine s tamily had obviously been in possession of the property for some time, so this was not a straightforward case of trespass. While the records are not specific. it is possible that either Catherine (and/or her late husband) had no written lease, or that the lease had expired and not been renewed. or that after the death of Catherine's husband. Carter had deemed the lease to be void. It is also possible that Catherine was disputing Carter's ownership of the property and was refusing to pay rent. Recorded details are sparse. but the matter was complex. involving several previous owners and the interests of several estates, and it was continued every year by agreement of the parties. Catherine Dullenty appeared in court throughout. but as the matter increased in complexity by $1840-41$. she was assisted by Renews merchant

${ }^{47} \mathrm{GN} 2 / 1 / \mathrm{A}$, 9-reverse end/26/1780, Govemor Richard Edwards to Justice Isaac Follet. Trepassey. October 10, 1780. 
Peter Winser (also Winsor) for the final hearings of the matter. Initially, a special jury sworn in October, 1840, found primarily in Catherine 's favour - allowing her the house and surrounding gardens, with a larger garden being awarded to Carter's estate.

However, a year later, estate executor Robert Carter re-applied for a writ of possession. and the court ordered that the previous verdict be "set aside due to irregularity " (Details are insufficient to determine whether there was legitimate cause for this reversal or whether this was a case of middle-class magistrates rallying around one of their own.) On November 1, 1841, the court ordered the ejectment and awarded damages to the plaintiff in the amount of $£ 40.00$ - inflated considerably trom the $£ 9.0 .0$ originally sought in $1837^{\text {t* }}$

The $18+1$ action against Mary Gaulway of Renews for rent arrears ( $₹ 700 \mathrm{Cy}$ ). brought by J W Saunders as guardian of William Strachan, is also worthy of note. The case was. in and of itself. uneventful, as Mary admitted in cour that she was in arrears. and judgment was awarded in Strachan s favour ${ }^{\text {th }}$ What is intriguing is that the following year. the same Mary "Gulloway" brought charges against the same J. W Saunders for

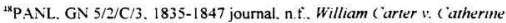
Dullenty: November 10, 1837. November 3 and 7. 1838. October 30 and November 8 . 1839. October 31. 1840, and October 27 and November 1. 1841. The same records appear in $\mathrm{GN} 5 / 2 / \mathrm{C} / 8,1835-1842$ journal. Various writs and summonses in relation to the matter appear in $\mathrm{GN} 5 / 2 / \mathrm{C} / 4$.

${ }^{19} \mathrm{PANL}: \mathrm{GN}$ 5/2/C/3, 1835-1847 journal. n.f., William Strachan. by his (juardian.J. W. Saunders, v. Many Gaulway. October 28, 1841: GN 5/2/C/8, 1835-1842 journal, n.f. William Strachan, by his Guardian .J. W. Saunders, 1: Mary Gauluay. October 28. 1841: GN 5/2/C/4. William Strachan, by his Guardian .J. W. Saumders, v. Wary Gaulway: Summons No 21, issued October 25 for return October 28. 18+1. and Writ No. 20. issued November 2. 1841, returnable "1st day of term." 
assault. ${ }^{50}$ Both sides presented several witnesses but unfortunately, no details of their testimony remain in the records. Ultimately, a special jury found Saunders not guilty. But obviously. hard feelings existed between the parties that may have emanated from the earlier action for rent arrears, and one might speculate whether Mary had initiated a grudge match in the local coun against her tormentor of the previous year. rallying support from several members of the community to back her claims.

While these female tenants met with varying success in these actions. the fact that they appeared in court or petitioned the governor to defend their interests challenges the stereotype of the powerless female tenant at the mercy of the rapacious landlord. It is possible that informal evictions occurred without the support of the court system, but it is not likely that the number would have been high. Certainly, there was not the overcrowding on the land that (in combination with other factors such as changing market conditions and the switch from tillage to pasture) prompted large-scale evictions in Ireland in the $19^{\text {th }}$ century. And one suspects that had many evictions of this type occurred, they would have created a sense of outrage within the plebeian community on the southern Avalon, resulting in communal actions that would ultimately have found their way into the written record.

${ }^{51}$ PANL. GN 5/2/C/3. $1835-1847$ journal. n.f., Regina v. John William Saunders Esquire for assault and Battery of one Mary Gulloway, October 6, 1842. 


\section{$\underline{6.1+\text { Trespass }}$}

Women also defended their property through the law of trespass. Seven such matters were brought before the authorities during the study period: in four, women were the named parties (although one was represented by a male attomey); in the remaining three. husbands acted as legal agents for their wives. Three of the matters involved women trom the $18^{\text {th }}$-century English planter society, while the remaining four involved women from the plebeian community Women claimants were successtul in four matters and unsuccesstul in one; the result of the remaining two cases was not entered

Two of the actions related to fishing properties - both involving $18^{\text {th }}$-century planter women. In 1768, for example. Henry Brook successfully petitioned the governor on behalf of Betty Pottery of Sidmouth. Devon. to have William Simmonds cease building on a tishing room in Bay Bulls upon which she had already erected various tishing works The Governor ordered that Betty could continue to occupy the room provided she used it for the purposes of the fishery and could produce a fishing certificate tor the men employed by her - as stipulated by the seventh and ninth articles of King William s $\mathrm{fct}$ [the Vew foumdland Act of 1699]" Similarly, the widow Catharine Clements became embroiled in $1784-85$ in a suit and counter-suit with James Rows (Rouse) over a fishing premises at Renews. Rows initially sought Governor John Campbell's intervention in 1784 , and the matter was revived by Catharine in surrogate court the following year. 1768.

"P.ANL. GN 2/1/A. 4/109-10/1768. Order. Governor Hugh Palliser. September I. 
Rows claimed that the property had originally been granted to his father in 1732 by Capt.

Thomas Smith, and that his father had built fishing works on it and carried on a fishery there for many years. Although the room had been left to decay since his father's death, Rows admitted. he had recently inherited the property from his deceased mother and had attempted to rebuild a flake there. However, he had been prevented from doing so by Mrs Clements' Master of the Voyage, Stephen Poor, and her son-in-law, Arthur Jackman. Catharine was in possession of an adjoining property. Pottersby's Plantation. which she employed in the fishery. and claimed that the beach area in dispute had long been used first by her late husband and then by herself for the drying of tish. Rows had applied to the tishing admirals for redress but received no satisfaction and therefore applied to the governor for the right of quiet possession of the property and restitution for the trespass His petition was supported by an affidavit from Robert Carter. JP. The governor accordingly ordered that Rows be put in possession of the premises with the proviso that he use it for the purposes of the fishery. However, the fishing admiral at Renews in 1784. Richard Bully, was of the opinion that while neither party owned the property. Mrs Clements" claim was greater by reason of more recent possession. He therefore ordered that Rows' flake be torn down. When the matter was revived in court by Mrs. Clements in 1795 . both parties presented witnesses to support their claims, and the matter remained unresolved. Indeed, by 1806, the property was still under dispute between the parties. ${ }^{\text {s2 }}$

"See PANL. GN 2/1/A: 10/49-51/1784, Petition of James Rows. Renews, to Governor John Campbell, undated but likely August 14, 1784, together with Affidavit of Robert Carter, JP. Ferryland. August 14. 1784: and 19/75/1806, Governor Gower to William Carter, Surrogate at Ferryland. October I, 1806. And see PRL. 340.9 N45. n.f., 
The remaining actions of trespass during the period related to smaller properties. In 1784, Edmond Dunfey (or Dunphy) of Brigus South acted as agent for his wife, Anstis. in successfully suing James Connoly for trespass on land that had been in his wife's possession approximately 15 vears. Connolly was ordered to return the hay he had cut on the land. mend the fences he had broken. and pay a tine in the amount of $5 s^{53}$ At St Mary`s, in 1804, Mary Stokes brought Martin Doyle to cour for trespass on her property while she had been absent in Trepassey. The property had been decreed to Mary by a former surrogate, Capt. Malbon. Martin had apparently obtained the key to Mary's house from her sister under false pretences. and the current surrogate. Timothy Bird. ordered that Martin give up possession of the house within a week. ${ }^{4-}$ In 1817. Walter Vallis of 'Capeland' (Caplin) Bay brought an action of trespass against Patrick Tobin for clearing and enclosing a piece of land that had allegedly been lett to the Vallis family by John Bryan in compensation for board and nursing services from Vallis's wife. The matter was held over until further evidence was made available. "At St Mary's. in 1833, Mary McMahon sued John Quilty for damages of $£ 20,0,0$ for trespass on her property and fenced off the disputed land while awaiting the decision of a court-appointed arbitrator on the matter.

Ferryland, (catharine Clements v. James Rouse, August 31. 1785

${ }^{43}$ P.ANL. PRL 340.9 N45. Ferryland. n.f. Edmond Dunfey v. James ( onmoly: August 26. 1784 . 20. 1804

${ }^{5}$ PRL, 340.9 N45. Trepassey-St. Mary's, n.f.. Mary Stokes v. Martin Dovle. April

5sPANL, GN 5/1/C/6. Ferryland. f. 7. Walter lallis v. Patrick Tobin, October 17. 1817 . 
The arbitrator ultimately ordered that Mary accept the compensation that had already been offered by the defendant prior to the court case: a transfer of the ground upon which her house was built and an additional piece measuring $57 \mathrm{yds}$ by $55 \mathrm{yds}$ by $35 \mathrm{yds}$ by $47 \mathrm{yds}$ plus a right-of-way through Quilty's garden to a well. ${ }^{\text {s6 }}$ In 1836, Mary Brien brought an action of trespass against William Carter. charging that he had entered her premises near Freshwater at Ferryland and unlawfully seized and carried away property valued at £5.7.6 Cy. There are no details in the record as to why Carter had removed the property: if it was for payment of debt, there is no evidence in the records of any collection action initiated by him or of any registered mortgage or bond. At any rate. Mary lost her suit in what could be described as a 'stacked' court room. with Robert Carter. JP. James Carter. and Lieut. Robert Carter. R.Y. along with local constable Richard Sullivan. providing evidence tor the defendant and James H. Carter acting as foreman of the jury $"$

Whether or not their suits were successful. however, women property owners were able to use the law of trespass as an avenue to seek a remedy for encroachment. It was a course that was chosen by at least seven women on the southern Avalon. from both the middle-class and the plebeian communities, during the study period.

\footnotetext{
${ }^{5}$ P.ANL. GN 5/2/C/1. Box 1. ff. 317-8. Many . /chlahon 1: John Quily. October 8. 1833

"PANL. GN 5/2/C/3, ff. 80-1, Lfary Brien : Willam Carler, November 10 , 1836; and GN 5/2/C/8, 1835-1842 journal, f 92. Mary Brine v. William Carler. November 10.1836
} 


\subsection{Criminal matters - female complainants and defendants}

By far. the most prominent presence of women in the court rooms in the study area was in relation to criminal matters - as both complainants and defendants. Indeed, the breakdown of alleged victims and perpetrators in these cases was almost even. with 75 women complainants and 76 women defendants. The familiar image of the female crime victim, therefore. does not reveal the full complexity of women s encounters with criminal justice in the period of early settlement on the southern Avalon.

The charge most frequently leveled both by and against women in criminal matters was that of assault. These cases, ranging from threatening language to more serious physical and sexual assaults. have already been discussed in the previous chapter ${ }^{2 *}$ is noted. women were aggressors ( 61 in total) almost as frequently as they were victims ( 71 in total) - by a proportion of $86: 1$. All defendants and complainants were of the plebeian community, and all but three of the assault victims provided depositions and/or appeared in court themselves to give testimony against their assailants. These complainants were women who felt that they were entitled to the protection of the legal system and were not deterred by notions of female respectability from asserting their rights in a public forum

Furthermore. the testimony of these women was often accepted by the court without corroboration - a phenomenon that applied equally to male and female complainants in assault matters. Here it must be noted that local courts had a propensity

\footnotetext{
Chapter 8 .

${ }^{5 B}$ Matters involving sexual assault and wife-beating will receive greater attention in
} 
to deal fairly leniently with most offenders (of both sexes) by meting out fines and binding defendants to keep the peace. Jail sentences were very occasionally employed, but until the end of the $18^{\text {th }}$ century. jails were perceived mainly as holding areas before trial. transportation, or execution in British jurisdictions. The use of incarceration as a method of correction. in and of itself. did not gain prominence in penal philosophy until the early $19^{\text {th }}$ century, ${ }^{51}$ and even then, alternative sentencing continued as a stopgap in districts such as the southern Avalon that did not have the facilities or funds to accommodate multiple prisoners or even individual inmates for lengthy stays. ${ }^{*}$ These relatively light

${ }^{54}$ See: David Taylor. Crime, Policing and Punishment in England, 1750-1914 (New York. St. Martin's Press, 1998). Chapter 8. Terry Carlson. "Dealing with Otfenders: An Historical Perspective on Corrections in Newfoundland." in Gale Burtord. ed. Ties That Bind: An Anthology of Social Work and Social Welfare (St. John's: Jesperson Publishing, 1997), pp $9[-125$

${ }^{\prime \prime 1}$ In 1788. in the wake of the Ferryland riot. the merchants and principal inhabitants of Ferryland petitioned the Governor for permission to apply the fines levied against the rioters towards the building of a jail and court house in the community. and the Governor acceded to the request. See PANL, GN 2/1/A. 11/388-9/1788, Petition from the Merchants and Principal Inhabitants of Ferryiand to Governor Elliot, undated but $\mathrm{c}$ October. 1788. and 11/394-5/1788. Governor Elliot to Memorialists in Ferryland district. October 9.1788 . But by the 1830 s and early 1840 s, lock-up facilities in the district were still inadequate, according to numerous presentments from grand juries on the southern Avalon. See PANL: GN 5/2/C/1. Box 1. ff. 227-8. Ferryland presentment. October 29. 1830: and $f$. 323. Ferryland presentment. October 21. 1833 (also in GN 5/2/C/1. Box 2): GN $5 / 2 / \mathrm{C} / 3$. ff. $11-4$. Ferryland presentment, November 3,1835 (also in $\mathrm{GN} 5 / 2 / \mathrm{C} / 8$ ); $\mathrm{f}$. 77. Ferryland presentment re: need for jail at Renews. November 9, 1836, and, n. f. St. Mary s presentment October 27. 1837. n.f.. Ferryland presentment. November 7. 1838. $n . f$. Ferryland presentment. November 6, 1839; and n.f. Ferryland presentment. October 27. 1840 And see PANL, GN 2/2: 1/86-90/1826. Ferryland presentments, May. 1826. and $2 / 226-232 / 1827$, Judge Desbarres to Governor Thomas Cochrane, enclosing Ferryland presentments. June 18, 1827. 
sentences $^{\text {bl }}$ may also have eased local magistrates' minds in accepting the uncorroborated testimony of complainants, permitting them to 'err on the side of caution' in terms of determining guilt or innocence to ensure order in their communities.

But while local courts rarely moved beyond the realm of fines and peace bonds in dealing with common assaults. the weight of the penalty varied with the circumstances. as the following cases help to illustrate. In 1818, Margret Leary complained that Edward Connolly had assaulted her: a witness to the incident. Edward McDaniel. testified that he had seen the defendant enter Margret's home and "klench his fist and chuck the plaintiff on the breast and Stagger her". further. he had "used very odious language and threatened her " Connolly claimed that he had been provoked because Margret had been gossiping about him. but he was ordered to pay a fine of 40 s. and court costs in the amount of $27 \mathrm{~s} .10 \mathrm{~d}^{\text {D: }}$ A more serious assault the following year still garnered only a fine and peace bond. Catharine Payne complained that Peter Winsor had come into her house and ordered her to quit same (this was likely an attempted eviction), and that upon her refusal. he had "struck her a blow with his fist on the face and Seizing her by the arms. used all his strength to drag her out - and failing therein, he Seized her by the neck, and held and drag[g]ed her with such violence as nearly suffocated her.... He had used such force in

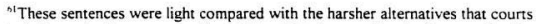
had at their disposal. However. the financial hardship imposed by the fines was hardly insignificant, given wage levels and limited access to cash resources during the period. and thus their punitive effect was usually considerable.

62PANL, GN 5/1/C/1, Ferryland, f 60, Margret Leary v. Ectward Connolly: October 27. 1818. 
the struggle that the marks and bruises were still evident on her face and body. Winsor admitted to the assault and was ordered to pay a fine of $£ 5$. court costs of $£ 2.7 .8$, and to find security in the amount of $£ 30$ to keep the peace for three months. ${ }^{n-3}$ The higher fine and hefty peace bond in this case likely reflected the severity of the second assault (aithough it should be noted that the fine may have been upgraded to fit the financial circumstances of the defendant - a substantial merchant-planter and justice of the peace). Still, the category of punishment did not vary from that for the lesser assault in 1818 Indeed, only one incident of common assault against a woman during the period resulted in a prison sentence - and a short one. at that. In August, 1841. Charlotte Flood of Ferryland complained that several times in the absence of her husband. William Mitchell had assaulted and beaten her and repeatedly threatened to kill her. her husband. and her child. Mitchell was ordered to stand committed for trial and the matter was heard at the quarter sessions in October of that vear. Although the defendant was found guilty of what appears to have been a very serious assault, and despite his previous record (he was already in custody for threatening the local doctor. and had been convicted of two previous assaults in the past year alone), he was sentenced to only 24 hours imprisonment in relation to Charlotte's complaint. ${ }^{\text {nt }}$ Generally, then. fines. peace bonds. and very occasionally, minimal jail time were the punishments of choice for assault in the local

${ }^{33}$ PANL. GN 5/1/C/1. Ferryland, f. 81. Rex. v. Peter Winsor, May 10. 1819

"See PANL: GN 5/4/C/1, Ferryland. Box 2. n.f. Regina v. William Mitchell. August 2 and 9, 1841; GN 5/2/C/3, 1835-47 journal, n.f., Regina $v$. William Mitchell. October 28. 1841; GN 5/2/C/8, $1835-42$ journal, n f., Regina v. William Mitchell. October 28. 1841; and MG 920, Robert Carter Diary. July 31, 1841 
courts. Heavier sentences (including longer imprisonment, whippings, and deportation) were reserved for cases involving extreme violence, particularly in cases involving sexual assault and domestic violence (see Chapter 8).

The other criminal matters that involved women in the area all related to theft and/or receiving charges - a total of 17 charges involving four female complainants and 15 temale defendants (one of whom was represented in court by her husband). Seven of the cases involved the theft or receiving of items of little or no monetary value - mostiy clothing and blankets as well as boughs from a flake and a dead sister's trunk full of personal effects. all four female complainants tiled charges in this category. Nine other incidents. all of which involved female defendants, involved fairly substantial items. housing materials (two), shop goods (three); provisions (one); a boat (one); eight quintals of fish (one): and a composite of saltfish, coal, hay, and shop goods (one). In the remaining case, the nature and value of the stolen items were not revealed.

Just as in assault cases. the local courts were accessible to female complainants in theft cases, and there was no indication that their allegations - even those involving minor matters - were treated with any less attention than men's complaints. Ann St. Croix of St. Mary's, for example, took Elizabeth Feagan to cour in 1821 on what appeared to be little more than a comedy of errors. Elizabeth had apparently burst into Ann's house and taken the blanket from her bed, swearing "by the X [cross] of Christ" that it was the same blanket that had been stolen from the defendant's fence the previous day. Elizabeth claimed that she had realized her mistake by the next day and sheepishly returned the 
blanket. Still, the local magistrate agreed to hear evidence in the matter. including the testimony of a witness who had sold the blanket to Ann originally. and ordered that Elizabeth pay a fine of $1 \mathrm{~s}$. and court costs."s

Just as in assault cases. both male and female defendants. when convicted of minor thefts, were treated similarly and accorded the court's standard correctives of financial penalties and orders to keep the peace and be of good behaviour. In both categories. however, a gender divide did arise in the area of sentences for matters deemed more serious by the courts. While magistrates and surrogates were willing to unleash the full battery of punishments at their disposal - whippings, imprisonment. and transportation against male defendants convicted of thefts and riotous or particularly violent behaviour. they trod more gently in applying these options to women.

This was especially the case with corporal punishment. For example, in 1751. Governor Francis Drake issued a decree in a case heard at Trepassey in which five men and one woman were charged with entering the house of Robert Rose and cruelly beating Patrick and Simon Fennassy "to the Effusion of their blood." The various male perpetrators were sentenced to 39 lashes each and ordered to find security to keep the peace. By contrast. the woman who had accompanied them. Ann Stevens. was found to be an accessory only, and while she, too, was ordered to find security to keep the peace. no corporal punishment was ordered in her case. Drake's judgment. however. implied that she may have participated to some degree in the attack, for he ordered that "if she is 9. 1821

${ }^{5}$ PANL. GN 5/4/C/1. St. Mary's. f. 101. Am St. Croix v: Elizabeth Feagan. April 
guilty of any further crime she is to be whipped \& sent from the Harbour: if she can't find security she is to be sent from the harbour [italics added]." Likely, had she been a man. the governor would not have fired this warning shot ${ }^{\text {to }}$

Another example of official leniency towards women occurred in the theft charges against John and Margret Kenny and various servants in Ferryland in 1794-5. It was evident from the testimony provided by the Kenny's servant. Margret Riely, that Margret Kenny had masterminded most of the activities - scheming with her husband and various servants to steal hav. coal, and saltfish from the Holdsworth premises and a poker. shovel, and two decanters trom the premises of Leigh \& Co. Yet. in the range of punishments meted out to the various parties, Margret's fell in the middle in terms of severity. The spate of thetts garnered fines for all the convicted parties - with John's and Margaret's being the largest ( $₹ 3$ ) as befitted their central position in the crime ring. However. while John and one of the servants were also sentenced to a whipping and imprisonment (remitted when they joined the Newfoundland Regiment), Margret was sentenced to neither - despite the obvious fact that she had been the linchpin in the series of thefts."

Indeed, no case survives in the court records of the area in which a whipping sentence was actually meted out to a woman defendant. By contrast. corporal punishment

‘P.NL. GN 2/1/A. 1/224 and 227/1751. Complaint of Robert Rose. Trepassey. and Governor Drake's decree. August 12.1751

n־P.ANL, GN5/4/C/1, Ferryland, Box 1, n. f., Arthur Hum /agem for Leigh \& $C^{\circ} 0.1$ and John Baker lagent for Holdsworths] v. John Kenmy. Margret Kenmy; William Power. William Broadfoot. Timothy Fowler. Patrick Burne, and Richard Dumphy. Thursday. October 6 [8?], 1795. See also Section 6.3. 
was occasionally allotted to male defendants, particularly in the $18^{\text {th }}$ and early $19^{\text {th }}$ centuries, and especially in relation to property crimes or violent crimes against the person. Several of the ringleaders of the Ferryland riot. for example. were sentenced to whippings along with stiff fines and transportation ${ }^{o x}$ Often, the severity of the punishment detailed in the records seems quite shocking to present-day sensibilities. In 1790, tor example. Thomas Quinn, Pat Lundergan, and William Dullahunty were convicted of stealing six quintals of fish. Quinn was sentenced to 24 lashes on the bare back. then eight lashes at the 'point beach,' eight more at the 'Northside Room,' and a tinal eight strokes back at the court house. To add an element of mortification, he was to walk trom one site to the next with a tish hung around his neck. He and his two cohorts were to be imprisoned until deported." English and Curran have pointed out that violent crimes on the island were often dealt with severely in this period to maintain law and order in what was essentially a frontier society with limited policing resources: similarly. crimes against property were often treated as capital matters because property was at a premium -Property was sacred," they explain, "because so many people had so little."

But even so. corporal punishment meted out to men within the local plebeian community in the study area was sometimes quite severe. In 1792. for example. Andrew Fling was convicted of stealing a gallon of rum from the store of Messrs. Richard Tydel \&

${ }^{38}$ PANL. GN 5/4/C/1, Ferryland, Box I. n.f. September 17-30, 1788.

"PRL. 340.9 N45. Ferryland. ff. 13-4, Garret Dawson v. Thomas Quin et al. October 14. 1790

${ }^{-0}$ English and Curran. "A Cautious Beginning." p. 23. 
Co. The rum's value was only $10 \mathrm{~d}$. Still. Fling was sentenced to 24 lashes on the bare back on the north side of the harbour. 24 at the south side, and 24 at the tlag staff before the Court house: then to be imprisoned until deported - a very harsh punishment for such a minor thett. ${ }^{t}$ And while much has been made of the harsh justice of visiting fishing admirals and naval surrogates in the traditional historiography, two local magistrates assisted the visiting surrogate in the 1790 decision on Quinn, while the 1792 sentence on Fling was ordered by local surrogate Robert Carter together with local magistrates Peter Romnev and Nicholas Brand. This same trio of justices ordered another whipping that same year for a personal affront to one of the magistrates. A local fisherman. John Dillon. was owed money from the estate of William Coman of Ferryland, but the money was stopped by magistrate Nicholas Brand. Dillon went to Brand "and abused him bid[d]ing him kiss his arse." Brand threatened to call for local constable Cox, but Dillon countered. "to the Divil $t$ bob you and Cox too" He met Brand again the next day and again insulted him. "telling him to the Divil I bob you." The local justices ordered that he receive 39 lashes on the bare back at the flag staff before the court house, and then be imprisoned until deported to Ireland on a Vagrant's Warrant." This was an atypically harsh sentence for such a minor assault; a similar affront to a member of the plebeian community would only have merited. at most. a small fine and a peace bond. Of course. these matters occurred just several years after the Ferryland riot, and the English-Protestant magistrates

\footnotetext{
"PRL, 340.9 N45, Ferryland, f. 17. Rex v, Andrew Fling, December 3. 1792.

"PRL, 340.9 N45, Ferryland. f. 16. Rex v. John Dillon. November 14, 1792
} 
may well have been posturing in what was likely a residual fear of the growing IrishCatholic plebeian community. But the punishments were still quite severe. As noted, however, whippings were imposed only on male offenders by southern Avalon courts.

While the courts balked at corporal punishment for women, they were more willing to order imprisonment and transportation for female defendants who came betore them. Women were not imprisoned as frequently as men, but they formed a smaller proportion of the population until sex ratios equalized in the $1850 \mathrm{~s}$. Furthermore, men were not jailed with any great regularity either, even after the paradigm shift in perceptions of incarceration. because the district continued to lack adequate facilities or funds to house prisoners. Still. the courts employed the jails on occasion for both sexes - especially in cases of violent behaviour or larger property crimes.

The longest prison term allotted to women in the area was imposed on Bridget Hegarthy and her daughter Mary Reed of Ferryland In 1842. Benjamin Sweetland. clerk and storekeeper for merchant James H. Carter in Ferryland. told the court that he had reason to believe that the two women had taken an amount of salt beef and pork from Carter's premises and asked the court for a warrant to search Hegarthy's home. Vo sign of the salt meat was found, but when the constable and the storekeeper went down into the cellar. they found a whole assortment of other shop goods: boots and shoes. shirts. men's braces, ladies' hose, yards and yards of materials. chests of tea - everything from a needle to an anchor. Based on the evidence at hand. a petty jury had no difficulty in convicting the two women of larceny. The court also tried to bring Bridget's husband. 
Charles Hegarthy, into its net with a charge of possession of stolen goods. but the jury tound him not guilty. Evidently, Charles had no knowledge of the matter; the enterprise was a mother-and-daughter affair only. The two women were imprisoned for 12 months for this particular caper ${ }^{73}$

This was a stiff jail term, regardless of sex, for the Ferryland cour. Of course, the extent of the theft was significant and likely, the magistrates in the matter, all members of local mercantile tamilies, were sending a strong message to the plebeian community about their intention to protect merchant interests in the area. ${ }^{-4}$ Also, this particular mother-and-daughter team were already 'known' to local authorities. In 1833. Bridget (whose last name at the time was Murphy) had been charged with receiving stolen goods: the chief witness against her had been her daughter, Mary Read. Mary told the court that Bridget had received from her "a quantity of Provisions at different times well knowing the same were the property of Patrick Connors and stolen from the House of the sd. Patrick Connors by directions of her said Mother." ${ }^{-" s}$ Indeed. Bridget seems to have

${ }^{-3}$ P.ANL. GN 5/4/C/1. Ferryland. Box 2: n.f. Regina v. Bridget Hegarthy: and Lary Reed. February 16, 17, 18, and 21. 1842: and n.f. Regina : (harles Hegarthy: Brictget Hegarthy; and Mary. Reed. February 21, $18+2$.

\section{The sitting magistrates were Robert Carter, Peter Winser, John W Saunders, and Matthew Morry \\ ${ }^{-5}$ P.NL. GN 5/4/C/I. Ferryland. Box 1.f 48. Regina v: Bridget Lurphy: April 3.} 1833. There is no indication that Mary was charged in this matter for actually stealing the goods. She may have been a minor at the time. Or it is possible that the charge against her was dropped in exchange for her evidence, although this would be unusual as there is no equivalent in the British legal system of the American practice of permitting criminals to turn state's evidence. 
remained on the dubious side of the law. She came under suspicion again in 1844 for stealing building materials from a house belonging to the estate of William Carter. although in fairness to Bridget. it must be noted that on this occasion. there was insufficient evidence to convict her ${ }^{-0}$

As noted. however, long-term incarceration was rarely imposed by the local courts. Shorter jail terms were more frequently employed to hold persons before deportation. or as an alternative when defendants refused or were unable to pay tines or give security to keep the peace. When Bridget Dullanty of Ferryland, for example, was convicted of assaulting Arthur H. O. B. Carter and "severely wounding" him. she was ordered to pay a fine of $10 \mathrm{~s}$. Stg. or, in default thereof, to be imprisoned tor one week in the local jail. This sentence was somewhat stiffer than the usual peace bond imposed in similar circumstances and may have been precipitated either by the complainant 's status as a member of the prominent Carter family. the severity of the attack. or by the fact that this was a repeat offence for Bridget. At any rate. Bridget opted to pay the fine - Ann Prichet chose the alternative in 1820 when she was convicted of beating her neighbour's children: she refused to pay her fine of $5 \mathrm{~s}$. and provide security to keep the peace, and was committed for an unspecified period of time ${ }^{x}$ The local magistrates, then, were not

\footnotetext{
"PANL, GN 5/4/C/1. Ferryland, Box 2. n.f., Estate of William Carter 1: Patrick (instelloe and Bridget Hegarthy; November 25, 1844

7PANL. GN 5/4/C/1. Ferryland, Box 2. n.f. Regina v. Bridget Dullanty. April 18. 1844
}

${ }^{-8}$ P.ANL, GN 5/1/C/1. Ferryland, f. 117. Rex v. Amm Prichet. October 24. 1820. 
deterred from employing jail terms as punishment against female defendants as circumstances demanded.

Indeed. on at least one occasion, a local court imprisoned temale defendants while leaving a male defendant at large for what appeared to be similar offences. At St. Mary s on October 27. 1837. Anastatia Goff and Mary Daley were tried by jury for an assault and battery of Mary White of Salmonier the previous May. The two were convicted, and the following day. each was sentenced to four days imprisonment and a fine of $\mathbf{\Sigma} 1$ plus court $\operatorname{costs}^{\text {"1 }}$ In the very next case. before the same jury, William Lush was charged with an assault and batterv of Judith Grant in April, 1837; a charge of common assault was added to the indictment the following day. Lush was convicted and sentenced to pay a fine of ₹ 10.100 , but no prison term was ordered ${ }^{\text {Ho }}$ As is often the case with many of the records, details of the cases were scarce. so it is difficult to interpret the difference in treatment of the defendants in the two cases. The charges in both cases were similar. although Lush was charged with an additional count of common assault. The fine levied against the male defendant was much heavier - 110100 vis-a-vis $\Sigma 1$. Yet only the women served jail time. Perhaps the assault and battery perpetrated by the women was more violent. Possibly the local jail could not accommodate both male and female

${ }^{-5}$ P.ANL: GN 5/2/C/3, $1835-1847$ journal, n.f. Regma v: Anaslatia Goff and Lan Daley. October 27 and 28, 1837, and GN 5/2/C/8. 1835-1842 journal. n f. Regina v. Anastatia (joff and Mary Daley, October 27 and 28.1837

${ }^{80}$ PANL: GN 5/2/C/3, 1835-1847 journal, n.f., Regina v: William Lush. October 27 and 28. 1837; and GN 5/2/C/8, 1835-1842 journal. Regina v. William Lush, October 27 and 28,1837 . 
prisoners at the same time (a preoccupation of grand jury presentments of the dav) and the relegation of prison time was merely a matter of 'first come, first served. Or perhaps the local court was tailoring the sentences to the particular circumstances of the defendants: possibly the women were unable to pay a large finer and thus the prison time was added to a lower fine to add weight to the sentence. Certainly, however, there was no leniency shown towards the women in terms of incarceration.

While imprisonment was employed with some discretion, transportation back to England or Ireland was regularly emploved in the $18^{\text {th }}$ and early $19^{\text {th }}$ centuries - a reflection of a still stabilizing population with many recent immigrants whom authorities were happy to 'send home' on fishing and passenger vessels plying between the British Isles and Newtoundland if they landed on the wrong side of the law. Again. this option was used mostly in cases of property crimes or violent or riotous behaviour - all seen as serious threats to the social order. Again. men were more trequently transported than women - largely reflecting the higher proportion of transient men in the local population in the period when transportation to the home country was still a viable option. Nonetheless. the local courts occasionally found cause to remove troublesome female defendants as well.

In some cases, there were gendered undertones in the targeting of women for transportation, particularly in the perception of the nature of the danger they posed to the moral and social order. We have already observed. for example. the threat of transportation being issued against the doctress Mrs. Curry. who inverted the gender order 
with her medical practice on fishing servants at St. Mary's (Chapter 4). The sentence was actually levied against two female complanants, both known prostitutes. in sexual assault matters in the $18^{\text {th }}$ century (these cases will be discussed in greater detail in Chapter 8 ). However. women. like men. also attracted deportation sentences for property crimes. particularly up to the early 1800 s. In September. 1751, for example, Margaret Penny of Bay Bulls was accused of receiving goods stolen by Thomas Power of Watertord. A witness had seen Power revealing the illegal contents of his chest to Penny in her house. the two had apparently then concealed the chest in some hay in Penny's cellar Both parties were sentenced to be transported back to Ireland ${ }^{x 1}$ Similarly, in 1804, when Mary Power of Ferryland district was convicted of breaking and entering into Joseph Smith's store and taking "Sundry Merchandise," the court ordered that she be "Transported from this Island, never to Return." "x: Doubtless, had Bridget Hegarthy and Mary Read committed their theft fifty years earlier. they, too, would have found themselves bound on a ship back to Ireland.

\section{Female witnesses}

Women appeared as witnesses in the court records of the southern Avalon almost as frequently as men, although the presence of witnesses in general (male or female) was

\footnotetext{
"Mannion Name File, Bay Bulls. "Penny, Margaret."

*:PANL. GN 5/4/C/1, Ferryland, Box 1, n.f. Rex v. Mary Power. November 30. 1804
} 
not extensive, as the majority of cases at the local level were decided simply on the evidence of the parties involved. Still, the value of women's testimony to the local courts was manifest as they appeared in a variety of matters. ranging from slander and seduction to debt, eviction, and assault (see Table 6.5). Their testimony sometimes detailed

Table 6.5 - Matters involving female witnesses

\section{Trpe of matter}

Assault (victim = crown witness)
Assault - other
Assault and detamation
Defamation (re: witchcratt)
Dispute re: accounts
Theft/larceny
Property dispute/ejectment
Document witness (will. mortgage.
conveyance, other agreement)
Seduction
Receiving stolen goods
Illegal sale of liquor
Vurder
Unspecified

Total
Yo of female witnesses

68

14

$+$

1

11

10

$+$

5

2

123

extra-ordinary events, but often merely reflected the gleanings of day-to-day experiences. illustrating once again the role of women's information in helping to maintain social order and the extensive overlapping between private and public domains in the period of early 
settlement. ${ }^{33}$

As can be seen from Table 6.5, women witnesses appeared in largest numbers as crown witnesses in cases of assault against their own person. (This was true of male witnesses in the system as well.) These women victims/witnesses have already been discussed as complainants in Section 6.2. but two findings are worth re-iterating here: firstly, that they felt they had access to the judicial sustem to protect their rights, and secondly. that their evidence was usually accepted by the court. often without corroboration - although to some extent, this may have reflected a tendency on the part of local magistrates to 'err on the side of caution' in an effort to maintain law and order with limited facilities.

Women also appeared as witnesses in a variety of other matters. most especially in cases involving assault against others. property and account disputes, theft. and detamation. Indeed. in an 1833 assault case, a woman not only testified for. but acted as

"' Writers on women in colonial America have also discussed the importance of women deponents as sources of information for colonial cours. In particular, they note that women were somewhat akin to 'expert witnesses' in fornication and adultery trials. such matters. however. were not heard in Newfoundland courts. Midwives in colonial America also provided expert testimony in bastardy cases: while a number of these cases did appear in the southern Avalon courts (see Chapter 8), there is no indication that midwives testified, although their fees for lying-in periods were allowed as legitimate expenses of the complainants. For a discussion of women witnesses in colonial America. see: Berkin and Horowitz. eds. Women's Voices, p. 161: Brown, Good Wives. Nasty Wenches, p. 98, Richter, "Free Women," pp. 290-1. Schoten "'The Obstetrick Art." pp. 54-5 and 103, and Ulrich, Good Wives, pp. 54-5. In addition, Paula M. Humfrey observes that a large numbers of female servants acted as witnesses in Court of Arches. the principal court of the ecclesiastical Province of Canterbury. particularly in matrimonial and testamentary suits. See Humfrey, '-I saw, through a large chink in the partition...' What the servants knew." in Valerie Frith, ed, women \& history: Voices of Early Modern England (Toronto: Coach House Press, 1995), pp. 51-80. 
legal representative of, one of the defendants. In Rex $v$. Mauhew Meany and Martin (urreen, co-defendant Meany did not appear in court at all but was represented at the hearing by his wife. Margaret. who successfully defended him against a charge of assault and battery against Thomas Ryan. ${ }^{x+}$

Indeed, the testimony of female witnesses often carried significant impact. The previous chapter has already discussed the quasi-legal aspect of women's gossip networks in identifying and controlling behaviour unacceptable to the community. The presence of women as witnesses (and defendants) in defamation cases helps to illustrate how women's information functioned to bring private issues into the public domain. The same can be said of many assault cases, in which women's testimony helped disclose the details of what were often (although certainly not always) private events. When Patrick Kelly alleged in 1806 that John Flyn had assaulted him in the house of Michael White "some time in the Winter." tor example. his complaint was "provd by Ellenor White to be just." and Flyn was fined 40s. and bound for $£ 20$ to keep the peace. ${ }^{85}$ In a Cape Broyle case in 1787, the evidence of a woman who had attended an assault victim at his deathbed prevailed over

${ }^{84}$ PANL. GN 5/2/C/1. Box 1. ff. 32j-4, and GN 5/2/C/1. Box 2, f. 29 . Rex v. Matthew Meany and Martin Curreen. October 21, 1833. The record notes that while Curreen appeared in person. Meany "appeared by his Wife Margaret Meany." Richter notes that wives sometimes represented their spouses in court in Virginia; but her examples deal with civil matters. not criminal, in which wives acted under power of attorney in husbands" absences, or in one case, because the wife had greater experience in civil litigation through the handling of a former husband's estate. See Richter. "Free Women." pp. 304-5.

$16,1806$.

"PANL, GN 5il/C/1. Trepassey-St. Mary's. n.f.. Patrick Kelly v. John Flyn. June 
the testimony of several male witnesses of the attack that had purportedly led to his demise. In that instance, a man named Hogan charged that Patrick Shea had beaten his uncle, Redmond Ellward (or Aylward), causing his death. Hogan brought forward several male witnesses who had been in the Shea house at the time of the attack, all testifying that Shea had struck Ellward on the side, and later hit him in the head with "a clift of whittling [split of wood]." Ellward had retired to bed, according to these witnesses, complaining of a pain in his side and experiencing difficulty in breathing as a result of Shea s beating However, the court gave considerable weight to the deposition of Honour Tobin, who had been brought in to nurse Ellward and. ultimately, to lay him out when he died several days later. Honour testified that while she had found Ellward quite ill, she had not found any marks of violence on him other than a cut on his forehead: furthermore. during the two days that she tended him, he had been conscious but had never mentioned any attack by Patrick Shea. Relying heavily on Honour's testimony. the court decided that there was insufficient evidence that Ellward's death had been directly caused by Shea's attack and acquitted him. $^{86}$

Women witnesses provided evidence in cases involving thefts of property ranging from clothing and housewares, to poultry and livestock, to housing materials. Indeed. women's intimate knowledge of the lives of employers and neighbours sometimes gave them an edge in detecting when property that had been separated from its rightful owners - when one family's ducks appeared on another family's dinner table, for example, or 1787.

*PANL. GN 5/4/C/1, Box 1, ff, 28-33, _ Hogan v. Patrick Shea, March 26-28. 
when the missing clothing of a certain neighbour had been refashioned into clothing for the children of another family down the road. Women's ability to move between private and public domains gave their testimony considerable weight in such cases. In one quite extensive matter in 1795, the testimony of Margret Riely, a servant at Ferryland, was instrumental in stopping the veritable crime spree of her employers, Margret and John Kenny ${ }^{37}$ Riely's position inside the Kenny household had enabled her to overhear schemes being hatched by the Kennys and several servants (their own and others') to steal various items from two mercantile premises operating in the community - Holdsworths and Leigh \& Co. Riely's watchful eyes had seen suspicious-looking bundles being spirited into the Kenny house or outbuildings, usually under cover of darkness: a bundle of hay arriving after midnight via John Kenny and his servant, several bags of coal delivered at night throughout the winter by a Holdsworth's servant: a bag of dried fish in the early hours of the morning via a dieter with the Kennys and a servant of John Baker, agent for Holdsworth's: fire irons and decanters under the "packet" of a servant of Arthur Hunt. agent for Leigh \& Co. On the strength of Margret Riely's testimony, five of the seven people charged in the action were found guilty by a jury and sentenced to punishments ranging from fines to imprisonment and whippings. ${ }^{\mathrm{k}}$

${ }^{87}$ Humfrey notes that the ability of female servants "to manipulate what they knew and were willing to reveal about themselves and others was a real determinant of power in their lives" See Humfrey, "What the servants knew," p. 54

${ }^{83}$ PANL. GN 5/4/C/I, Ferryland, Box I, n.f., Arthur Hum and John Baker 1: John Kenny. Margret Kenny: William Power. William Broadfoot. Timothy Fowler. Patrick Bume, and Richard dumphy; Thursday, October 6 [8?], 1795. 
Women witnesses also featured in disputes over accounts - usually in relation to accounts of their own families, but occasionally in relation to employers' accounts or matters outside their households. For example. when a dispute arose in 1848 between John Connell and John Power of Brigus South as to the amount of salt fish Power had transported to St. John's on Connell's behalf, the combined weight of the testimony from the defendant's two female witnesses - Catharine Dooley and Sarah Greene - overrode that of the lone male witness for the complainant - Robert Power - and the plaintiff was non-suited and ordered to pay court costs. The evidence offered by the women witnesses related to the amount of fish that had been cured by Connell, then weighed and transported by Power. Given the specificity of their testimony, they were obviously knowledgeable about the fishery and must have been present at the wharf during the consignment of the fish to Power - perhaps being fishing servants or members of a household production unit in the fishery. Certainly. their expertise was accepted by the court. and the defence prevailed ${ }^{*}$

Wives also acted as important witnesses when disputes arose as to the validity or amount of a debt. Although they were not the legal agents named in the styles of cause, it was evident that they saw themselves as having an equal stake in protecting their family's interests. Indeed. in several cases, it was apparent that the wife was primarily responsible for keeping the household accounts. For example, in 1827, when Walter Shelly sued Michael Keanon to recover ₹5.5.8 Stg. due on a "note of hand." it was Eleanor Shelly

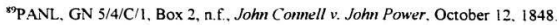


(most likely Walter's wife. although possibly another female relative) who "proved" the debt in court. ${ }^{\% 0}$ In an earlier case, in 1793, when James Warne, a boatkeeper at Trepassey, was sued by his servant Thomas Murphy for outstanding wages, it was Mrs. Warne's accounting that Murphy complained about, claiming that she had overcharged him by £6 and not settled with him a $\Sigma 3$ bill of exchange he had given her. Mrs. Warne attended the court hearing with books in hand to prove the accuracy of her accounting, and the court determined that Murphy's charge was "Malicious and illfounded." Indeed. Murphy was not only disappointed in his suit, but was confined to jail on bread and water for three days. and fined 40 s. ${ }^{91}$ Similarly, in 1786. when a man named Welsh of Ferryland initiated an action against Leigh \& Co for improperly crediting his account for milk, calves, and hogs, Mrs. Welsh appeared in cour to provide supporting evidence in relation to the accounting - without success in this case, as the Welshes were ordered to pay Leigh \& Co the full balance on the books of $271.2 \cdot 9-3 / 4^{92}$

The presence of women witnesses in the court room demonstrates the court's reliance on women's testimony as a credible source of information and a useful resource for the efficient operation of the local justice system. Sometimes. the court was tapping women's more intimate knowledge of the day-to-day affairs of their neighbours and their 1827

${ }^{*}$ PANL. GN 5/2/C/1, Box 1, f. 140, Walter Shelly $v$. Michael Keanon, October 4.

91PRL, 340.9 N45. Trepassey-St. Mary's, f. 15, Thomas Murphy v. James Warne. November 20, 1793 1786

'PRL. 340.9 N45. Ferryland, n.f.. __ Welsh v. Leigh \& Co. September 25. 
capacity to bring private issues into the public arena: but not all the matters to which they testified were private, and a number of women (such as Catharine Dooley and Sarah Greene in the fish consignment case at Brigus South) gave evidence from their status as persons involved in public spheres of activity. Certainly, women were not reticent in coming forward - at least not those from the plebeian community: ${ }^{93}$ although here again. there was a class difference, with women from the middle class recorded only in the capacity of witnesses to documents - a function that did not require their actual presence in the court house. Certainly, there was a willingness on the part of the court to weigh the evidence of female witnesses along with that of male witnesses. Of course. just as in the case of male deponents, some of the testimony of female witnesses was deemed inaccurate or frivolous In an 1819 defamation case, for example, Jane Holehan brought Catherine Walsh to court for spreading rumours that Jane had dried up her cow's milk by force of witchcratt. Jane produced two witnesses - male and female - to substantiate her

"One exception was Elizabeth Feagan, who was called as a witness in a defamation case. Elenor Piddle v. Margret Dimm, at St Mary's in 1821 According to the court records. Elizabeth "came forward as one of the Witnesses. - prayed that an Oath may not be administerd, - that she was on the eve. of being confind. - but stated to the Court that she did hear Margret Dinn call the Plaintiff a Whore, etc. - co-oberating with the affidavit of Catharine Lannahan..." See PANL. GN 5/4/C/1. St. Mary'sff. 103 and 107. Elenor Piddle v. Margret Dinn. September 5. 1821. It is possible that the court was reluctant to take her deposition because a woman on the eve of giving birth was perceived not to be compos mentis. Certainly, the imminence of labour did not deter her from giving an unsworn statement that corroborated the affidavit of another witness, so why the court did not avail itself of a sworn affidavit is puzzling. Still, the wording of the record seems to indicate that the reluctance was more on Elizabeth's par. Perhaps she was aware that the matter would be held over for later determination by the visiting surrogate and felt that she would be unable to attend at that time; or perhaps she was merely happy to have an excuse not to involve herself in an official capacity in a dispute between her neighbours. 
complaint, but the female witness, Ellen Piddle, was somewhat vague in her testimony. The court. finding the case "labouring under such inconsistencys," dismissed the matter with costs to be paid by the defendant. ${ }^{94}$ In this instance, the court was likely happy to divest itself of a matter that the magistrates saw as trifling - although the capacity for defamation within the plebeian community may have been quite real." In general. however, the court seemed as open to the legitimacy of women's testimony as men's testimony. and female witnesses were an integral part of the local justice system.

\section{$\underline{6+\text { Female petitioners }}$}

Court records, official correspondence, and newspapers reveal 57 instances of individual petitioning by women on the southern Avalon during the study period Petitioning required a degree of legal astuteness on the part of these women - not only in terms of drafting the petitions (aithough some may have been drafted by outside parties) but. more importantly, in terms of having an awareness of their rights and an understanding of how to make formal institutions work to their advantage. As the

${ }^{9}$ PANL. GN 5/4/C/1, St Mary's, f. 72, Jane Holehan v. Carherime Walsh, October 8, 1819

${ }^{95}$ Belief in hags and sorceresses within the supernatural realm was real on the southern Avalon. The term 'witch' was only infrequently used in terms of humans. however, and usually to refer to older (often eccentric) women who were thought to have special powers to charm, whether for good or evil (including women with special healing or cursing abilities). The term 'witch' did not carry with it the connotations of satanic worship and unmitigated evil ascribed to it by early modern Christianity. 
following table indicates, women petitioned central authorities and local magistrates and administrators (most wore a double cap) ${ }^{\%}$ on a variety of concerns which broadly fell under the categories outlined in Table 6.6 .

Table 6.6-Causes of women's petitioning

Administration of estates

Probate of estates

Other property matters (estate accounts, right

of possession, attachment for debt, landlord-tenant matters)

Redress for assault, theft, vandalism

Employment dispute (wages, treatment) 3

Matrimonial

Defamation of Character

Relief - special requests

- assistance in care of orphans (1)

- release of son from prison (1)

- proclamation te rude behaviour of fishermen towards women (1)

Total

Women's petitioning has been examined in other historical contexts as a means by which women transcended legal constraints on their participation in public life. Campbell

${ }^{\text {MS }} \mathrm{Certainly}$ by the latter $18^{\text {th }}$ century. local magistrates were spearheading and administering initiatives for relief. local improvements (defence works. jails. roads), and regulation changes (liquor licensing, vagrancy) as well as keeping the governor's office informed of the general state of peace and order in the district. When Newfoundland was granted respresentative government. magistrates were incorporated into the network of local administration and assumed key local positions as commissioners of roads. education. relief, wrecks, etc. 
takes this approach, for example. in her examination of women's petitioning of the New Brunswick legislature in the mid- $19^{\text {th }}$-century. Campbell notes a high level of female involvement in two general categories: petitions seeking some personal or community advantage, and those seeking changes in the law (specifically, prohibition). Through this mechanism. she argues, women helped to shape the political culture of the day ${ }^{7}$. As can be seen from the above table, all the women's petitions on the southern Avalon during the study period were comparable to Campbell's first category (seeking personal advantage or redress). There were no women's petitions requesting changes in the law during the study period. but then, there was no concerted campaign equivalent to the temperance movement discussed by Campbell. In as much as southern Avalon women were aware of their rights and able to use the system to protect them, however, they were participating in the public and political domain.

Rosen has also examined women's petitioning. within the context of colonial New York. Rosen presents the phenomenon as a means by which women could seek redress from a legal system that otherwise excluded them to a large degree. In late $17^{\text {th }}$-century and $18^{\text {th }}$-century New York, she observes, only a small proportion of women sought conflict resolution through the formal court system, petitioning. by contrast. was an "alternative path to justice" for a group that found themselves marginalized from the rights-based legal system of the period. However. the petition was essentially a plea to the "discretionary justice" of governors and other authorities of the day; thus, while it helped

\footnotetext{
97See Campbell, "Disenfranchised but not Quiescent."
} 
women to transcend the legal constraints of the court system, it reinforced deference and subservience on the part of women petitioners. "Thus," she concludes, "informal official justice was tar from the equivalent of formal litigation and only partially mitigated colonial women's lack of freedom. ${ }^{\text {ngs }}$

Rosen makes rather too much of the deferential tone of women s petitions in reinforcing women's subservience. In terms of language, they were using the conventions of the day - formulae followed by most petitioners, regardless of class or gender Certainly, caution must be used in drawing connections between a protocol used as a means to an end and the internalization of social attitudes. In addition. both men and women petitioned for discretionary justice on the southern Avalon, so the mechanism was not gender-specific. Furthermore. at least on the southern Avalon. petitioning was not the only recourse for women in obtaining justice. Indeed, it was often as much a part of or complement to the formal legal system as it was an alternative to formal justice. Most of the petitions examined here ( 38 petitions, or 67 percent) were either submitted to local magistrates as direct entrées into the court system (16) or used to initiate probate or administration of estates (22). Another four ( 7 percent) fell amidst the flurry of petitions for land grants from both men and women in the late 1820 s and early 1830 s as imperial authorities gradually relaxed the impediments to holding title to (as opposed to merely occupying) property. Only 15 petitions (or 26 percent) were directed to local magistrates or central authorities (the governor or chief justice) in a plea for discretionary justice

\footnotetext{
${ }^{78}$ Rosen, "Mitigating Inequality," pp. 313-4 and 325.
} 
comparable to that described by Rosen. Yet not all of these fall neatly into her categorization: four either arose from or were segued into cases in the local courts; and another eight sought resolution of disputes that quite likely would have gone to court had the matters not been resolved - given women's general willingness to initiate such actions Magistrate Robert Carter noted in his diary in April, 1840, for example, that he went to Fermeuse "to view some Land petitioned for yesterday by Mary ONeile - part claimed by W'm Brothers towards Admirals' Cove." The grant was awarded to Mary later that year despite Brothers' adverse claim, but she likely would have pursued the matter in court if necessary. for she had already petitioned the court previously on matters related to her late husband's estate." That same year, Carter noted that he had written James Jackman and "ordered him to desist from interfering with Land petitioned for by Margaret Dunphy at Renews. ${ }^{-100}$ Again. while Margaret sought the magistrate's intervention, she quite likely would not have been squeamish about initiating a suit against Jackman if necessary. for six years later, she sued Nicholas Power for outstanding wages. ${ }^{101}$ It is far more likely, then, that women were petitioning authorities to mediate disputes as a preliminary step in conflict resolution, rather than as an only recourse to justice. Indeed, as has been seen. far from being excluded from formal justice. women were a viable presence in the court life of

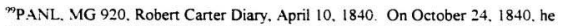
noted. -Delivered Geo Simms, Mary O Neile Grant to be registered \& paid him 5/ Currency rec ${ }^{d}$ from her for it."

${ }^{100}$ PANL, MG 920, Robert Carter Diary. September 15, 1840.

101PANL, GN 5/4/C/1, Ferryland, Box 2, n.f., Margaret Dumphy v: Nicholas Power. September 14. 1846.
} 
the southern Avalon. Furthermore, unlike colonial New York, where, according to Rosen, the legal system became more exclusionary of women as it became more formalized. along the southern Avalon, as the court system evolved in the late $18^{\text {th }}$ and early $19^{\text {th }}$ centuries. formal justice appeared to become even more accessible to women as women's participation in court matters increased (in both absolute and proportionate terms)

If anything, as the formal cour system developed. women's petitioning on the southern Avalon dwindled away - except for probate and administration matters. which surged in the $1820 \mathrm{~s}-40 \mathrm{~s}$. The floodgates for the latter had been opened by the 1824 Jirdicature Act ( 5 ( jeo. $H$ : (up. 67), which gave the chief justice the power to grant administration of intestacies in addition to the previously held power to grant probate ${ }^{102}$ These estate petitions, themselves. demonstrate that women were able to embrace changes in the legal system and use them to their advantage, the petitions also illustrate that interest in matters of property was not just a male province. But petitioning on other matters appears to have been a disproportionately $18^{\text {th }}$-century activity, with only ten individual petitions appearing after the turn of the century on issues other than estate matters (four of which were standard petitions for land grants, not pleas for discretionary justice). Women's appearances in the court rooms of the district rose. however. after the passage of the first Judicature Acts of 1791 and 1792 (31 Geo. III. Cap 29. and 32 Geo. III. ( $\mathrm{ap} .46$, respectively), so they were increasingly using the mechanisms of criminal

${ }^{102}$ English, "Fishing Schooner," p. 84 
charges and civil litigation rather than petitioning to seek resolution of conflicts.

It is tempting to interpret the decline in women's petitioning on matters other than probate/administration matters in terms of ethnicity and class - a transition in traditions. as the Irish plebeian community swelled towards the turn of the century. Certainly, women from the English-Protestant gentry had been a visible presence among the $18^{\text {th }}$-century petitioners, especially in property disputes and estate matters, but their participation dropped off sharply in the 1800 s. And certainly, this group were increasingly represented in such matters by men in their circle (see Chapter 9). However, this does not explain the decrease in overall petitioning, as Irish women also proved to be adept petitioners in all categories 18 out of 22 petitions for probate/administration, for example. 11 out of 19 petitions on property matters. seven out of eight petitions for redress for assault, and two out of three relating to employment disputes Again, the likely explanation of the decline in petitioning on non-estate matters is the greater access to the court system and its apparatus for conflict resolution - and perhaps also a greater willingness on the part of Irish plebeian women to access this more public route.

Of course, the woman who was most constrained by the formal legal system was the married woman, the feme coverle, with no formal legal identity separate from her husband's. For the married woman, then. the petition could indeed be an important alternative for redress from grievance or resolution of conflict. Although the marital status of southern Avalon female petitioners was not always indicated. information that was provided indicates that at least 14 (25 percent) of the women involved in the petitions 
examined were married - a fairly substantial participation - while another 19 ( 33 percent) were widowed ${ }^{103}$ Still it must be noted that married women's petitioning did not always signal lack of access to the legal system. Some of the petitions did emanate from or evolve into court matters involving married women, especially from the plebeian community - either directly or as star witnesses in court matters headed by their husbands names. Indeed, authorities sometimes waived the principle of coverture completely, and permitted married women to represent not just themselves, but also their husbands and/or their families. This was the case in at least five of the petitions examined; and all five petitions came from women of the Irish-Newfoundland plebeian community.

One of this group. Elenor Evoy, whose petition emanated from a desire to detend her tamily business, has already been encountered in the previous chapter (see Section 5.6). Another. Mary Bryan of St. Mary's, and her efforts to borrow time on the lease held by her husband who had become mentally incapacitated, has also been discussed above (see Section 6.1.3). The other three petitions in this category emanated from one of the most interesting petitioners from the Irish-Newtoundland ethnic group. and the most prolific petition writer overall - Hannah McDaniel, alias Carney, of Ferryland. Hannah and her husband. William, took on some big guns in the area - the Westons and Carters.

\footnotetext{
${ }^{103}$ Rosen also discusses a high level of married women's petitioning in colonial New York; however, she generalizes from married women's experience to present petitioning as virtually the only recourse to justice for all women in her study area. See Rosen, "Mitigating Inequality." Intriguingly, Campbell finds. by contrast. that most married wornen petitioners in New Brunswick were involved only in petitions for law reform (specifically, in relation to temperance); they rarely petitioned the legislature on personal concerns, unless they were widowed. See Campbell. "Disenfranchised by not Quiescent."
} 
merchant-planters and magistrates - in a matter that dragged on years in the late $18^{\text {th }}$ century. The family was being sued first by Peter Weston, and then by his widow and executrix. Catharine Weston. in relation to a debt in the amount of $\Sigma 109.5$ that had originally been owed to the Westons by Hannah's father.

Hannah initially appealed to Governor Campbell for intervention in 1784. In a petition that she most likely wrote herself, she explained that because of the debt. Peter Weston had tried to attach a piece of property belonging to her mother. and that the property was eventually attached, or "hemmed in," by Weston's son-in-law. William Carter. Hannah argued that while her mother had dealt with the Weston house for over seven years, she had never received a satisfactory accounting of "them old Arrears " Hannah's mother, Mary Shea. had previously petitioned Governor Montague on the matter and received from the Admiral "a few Lines under Hand to Indemnify her." which had. untortunately. been "mislead." The property had since passed into Hannah's possession at her mother's death. In a deliberate play to Governor Campbell's chivalry. Hannah ended her petition with the following plea : - Your Excellency will take Petitioner's Case into consideration being a poor Woman with a very great charge seven helpless young Children to support maintain \& nourish that never knew anything about these Accounts before.."Campbell was sympathetic and ordered that "Hannah McDonnell and her husband" (an interesting gender reversal) retain peaceful possession of the property "so long as they shall Continue to employ it for the use of the Fishery "

${ }^{104} \mathrm{PANL}:$ GN 5/4/C/1, Ferryland, Box 1, ff. 50-2. Copy of Order of Governor John Campbell. September 10. 1784, with attached Petition from Hannah McDaniel. 
By March. 1787, however, the McDaniels were brought before the local magistrates by Catherine Weston, as Executrix of her late husband's estate. The summons was issued on March 8 to both Hannah and William and ordered them both to appear in court the following morning. However, Hannah initially appeared alone and advised that William had "gone in the woods": her tardy co-defendant joined her in court that afternoon. At this juncture, the Weston camp was attempting to attach the rem for the property, which had since been let by William McDaniel to two local fishermen. Matthew Ronane (also Ronan) and John Grace, for \&22 per year. However. the McDaniels had now crafted the following argument: that they were not truly married. that Hannah's last name was actually Carney (also Kearney), and that they were merely cohabiting even though they had produced seven children over the course of time: therefore. William, who was not legally Hannah's husband. had no claim to the fishing premises she had inherited from her mother. and had no right to lease them. the rents should therefore not be attached to pay the debt. The local magistrates, however, treated the relationship as an informal marriage within the context of the flexible local marriage regime (see Chapter 8 ) and decided that William and Hannah were merely trying to "stave off from paying the Debt." They ordered that the rents for the propeny be paid to Catherine Weston until the

undated but c. September 1784, entered in the Ferryland court records October. 1787. and GN 2/1/A. 1 I/245-7/1787, copy of Order of Governor John Campbell, September 10. 1784. attached to Order of Governor John Elliot, October 5. 1787. While the petition from Hannah's mother. Mary Shea, to Governor Montague has not survived in the records. the grant from surrogate Capt. James Howell Jones (conditional on the governor's approval), dated September 15, 1773, survives in PRL 340.9 N45, n.f., and in PANL. MG 31. Carter Family Papers, File 32. 
debt had been paid in full. The couple, however, refused to comply: so a court order was issued to the lessees of the property advising them to withhold the rent from the McDaniels until further notice. ${ }^{\text {tos }}$

The matter was then referred to Governor John Elliot, although whether by the magistrates or by Hannah through another petition is not directly stated in the records The logical source of an appeal, however, would have been the unsuccessful McDaniel camp. Furthermore. the governor's directions that his ensuing order "be entered in the Records of the District and the Paper to be delivered to the Petitumer [italics added]" suggest that Hannah had again plied her pen to represent her family's interests. If so. she was rewarded for her efforts, as Elliot concurred with Campbell's earlier decision that the Weston claim was not valid, although more from pragmatism than point of law, reasoning that "it would be the means of creating endless confusion throughout the Island if the Governor for the time being was to enter into the merits upon which his Predecessors had founded all their decisions...." He directed the local magistrates to ensure that Hannah and William enjoyed quiet possession of the property ${ }^{10 \%}$

The Weston v. McDaniel matter resurfaced in 1790 . On August 17. Catherine Weston had another writ issued in relation to the debt of $₹ 1094.5$, this time, the action was taken against William McDaniel only, with the implication that the principle of

${ }^{105}$ PANL, GN 5/4/C/1. Ferryland, Box 1. ff. 25-6, Catherine Weston v. Hannah and William McDamiel, March 8 and 9, 1787.

${ }^{176}$ PANL: GN 5/4/C/1, Ferryland, Box 1, f. 50. Copy of Order of Governor John Elliot. October 5, 1787: and GN 2/1/A. 11/245-7/1787. Order of Governor John Elliot. October 5,1787 . 
coverture applied to the debt and the property inherited by Hannah. (Again, no evidence appeared in the records to disprove the McDaniels' claim that they were merely cohabiting: but the magistrates were apparently still disposed to treat the relationship as an informal marriage.) The sheriff served the writ on William and demanded pavment or security for the debt: William refused, and the sheriff attached the property, described as "affishing Room, Dwelling houses, Stage and Flakes." Neither of the parties named in the action appeared at the September 15 hearing of the matter: Catherine was represented by local merchant and magistrate Henry Sweetland; and William was represented, once again. by his wife/partner. Hannah. Hannah produced the previous decisions of Governors Campbell and Elliot as evidence; nonetheless, the court found in favour of Catherine Weston and ordered that William pay the debt and court costs. The final reporting of the matter in the court records is a cryptic note on October 15.1790, that the proceedings had been rescinded by consent of the parties and that the Writs of Attachment and Execution had been destroyed ${ }^{107}$ We are left to speculate by what means the party came to a settlement, although one cannot help but think that Hannah's persistence had worn the Weston camp down. Ultimately, the much disputed property was sold to William Carter bu both William and Hannah in 1795 for $£ 300^{108}$

But the court had not heard the last of Hannah McDaniel. alias Carney. In 1791. she wrote a petition to the chief justice of the Island. John Reeves. in relation to a bond

${ }^{107}$ PANL. GN 5/4/C/1. Ferryland. Box 1, ff. 1, 3. 4-5. and 8. Catherine Weston : William McDaniel, August 17. September 15, and October 15. 1790.

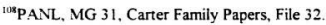


her husband/partner had given six years previously to one Mr. Baker of Ferryland (most likely. John Baker, agent for Holdsworths) as security for a debt of $₹ 100$ Stg. William had agreed to pay $£ 20$ per year towards the debt, she said, but Baker was taking more than this amount each year from the rent of a fishing room that Hannah had leased to try to maintain her family. Furthermore, he was unfairly charging compound interest and was also trying to pressure Hannah to sell the premises to discharge the debt. As in her 1784 petition, Hannah appealed to the chivalry of the chief justice as she asked for relief for herself and her "poor helpless charge of six Children." Again, the petition was obviously in her own words

The Humbel Petition of Hanna McDaniel otherwise Carney most humbly sheweth-

That petitioner begs leave to inform your honor that one Mr. Baker in Ferryland has a bond of Petitioners husbd of One Hundred pounds Sterling these six years - in his hands. \& was to pay but Twenty pounds a year in part payment of said sum- by Agreement and in stead of that sum there was Twenty seven pounds-ten shillings payd aforesaid Baker these two years past that is seven pounds ten shillings more then she Contracted Compound was because the aforesd Mr. Baker wanted to distress petitioner \& her poor helpless charge of six Children. Petitioner set a fishing Roome to maintain herself \& familey - The aforesaid Baker took all this rent to himself tho his Compound agreement was to Receive but Twenty pounds a year and not allow Petitioner a hundred [weight of] Bread - out of his store towards mantaining her heavey charge - The aforesaid Baker several Different times wanted petitioner to sell her Room to pay himself \& likewise wanted her to sign him a Bond for the Intrest of the aforesaid sum after paying more than compound agreed upon yearly the tinnant that occupies petitioners room pays the aforesaid Baker the rent of said Roome without the Petitioners order or Consent- Your Petitioner cannot get no Good of ye said Mr. Baker Therefore Petitioner hopes your honor will Take it into consideration \& vindicate the cause then your Petitioner in Duty [obliteration] will be for Ever bound to pray - 
Chief Justice Reeves agreed with Hannah that Baker had no right to stop the full amount of the rent and that the wording of the bond gave him no right to charge interest, nor to dispose of the skiffs that had apparently been put in his possession as security only. He ordered that Baker apply the $£ 20$ per year taken from the rent directly against the principal and that he take account of each payment on the bond and deliver it up to the McDaniels upon full payment in order "to prevent the Court being troubled unnecessarily with McDaniel's Complaints." "wos

However, the coun would be troubled by Hannah's worries one last time In 1797. Michael Malone of Ferryland brought Hannah and her son John to court because John had reneged on his apprenticeship agreement with Malone "by the Counsel of his mother" According to Malone, John had "absented himself from his service and refused to serve out his time according to agreement." The hearing of the matter revealed. however. that John had been shipped specifically to fish out of the harbour of Ferryland for Malone for the season at $£ 15$ wages: but Malone had hired his boat to Martin Molloy and Thomas Clements of Renews and felt that he had the right to transfer the service of John McDaniel along with the boat. Hannah disagreed with him. and so did the court. finding that Malone "could not dispose of his servant. as he had done with his private property, without the servants consent, and more especially as the servant shipped to fish

${ }^{109}$ PANL, GN 5/4/C/1. Ferryland, Box 1, n.f., Petition of Hannah McDaniel, alias Camey. undated but c. September, 1791, together with Decision of Chief Justice John Reeves, October 12, 1791 . 
out of the Harbour of Ferryland. he could not be compelled to serve out of any other Harbour " Molloy and Clements ultimately agreed to fish out of Ferryland. John McDaniel thereupon agreed to serve them: and the matter was resolved to the McDaniels satisfaction, with court costs of 16 s. to the plaintiff. ${ }^{110}$

By the taking of the 1800 nominal census. Hannah was no longer in the district. Her family was still there, however, which suggests that she had probably died (there are no parish records available for the 1790 s to confirm this). And thus, the court was deprived of one of its most adept petitioners and litigators. For it is evident that the McDaniels, and Hannah in particular. were well able to manouevre within the legal system: these were not just poor simple fisher-folk being out-gunned by members of the community's elite It is also worth noting that it was Hannah, not her husband. who wrote the petitions. framing them in her own words (with detailed explanations and her own idiosyncratic expressions interspersed among the stock petitioner's phrasings): so Hannah was likely literate and certainly able to muster arguments to her cause She appeared to have a basic appreciation of legal principles. She also effectively played the role of a poor distressed woman with hungry children to advantage. especially to officials in St. John's who had no familiarity with her circumstances. Throughout the McDaniels`legal battles. it was Hannah, more than William. who represented the family's interests: and she, herself. even directly represented her husband in the court house on occasion - a relaxation of the principle of coverture. given that the magistrates were eager to treat their relationship as a

${ }^{110} \mathrm{PANL}, \mathrm{GN} 5 / 4 / \mathrm{C} / 1$, Ferryland. Box 1. n.f. . Fichael Malone v. Hannah and John MACDamel. June 9, 1797. 
marriage. Even in the final sale of the long-disputed property to the Carters. Hannah joined with her husband as a signatory to the deed as one of the executors of her mother's estate Her experience contrasts with that of Catherine Weston, who was represented in the proceedings by Henry Sweetland, likely because it would not have been deemed proper or respectable for a woman from a powerful middle-class family to appear in the court house. But it was Hannah, the woman from plebeian culture, who was more empowered by her ability to represent herself in the public sphere and by the community's acceptance of her presence there.

One other form of women's petitioning was evident during the period. In addition to individual petitions, women from the southern Avalon on several occasions signed community petitions for relief from distress. Petitions for relief from the English Shore poured into the local colonial secretary's office from the late $1810 \mathrm{~s}$ into the $1830 \mathrm{~s}$ as poor crop-growing conditions coincided with low tish catches and depressed fish markets to create acute hardship in many areas around the island ${ }^{111}$ While numerous petitions arrived from the south coast and the northern districts year after year. however, there were very few such petitions from the southern Avalon. One came from the district of Bav Bulls in May. 1822. and a presentment from the grand jury of Ferryland sought reliet for the district in $1826,{ }^{112}$ but nothing further was entered into the records by the colonial

\footnotetext{
${ }^{11}$ See numerous petitions throughout the period - especially the late 1820 s and early 1830s - in PANL, GN 2/1/A and GN 2/2.

1"See PANL: GN 2/1/A. 32/424-6/1822, Memorial of the distressed Inhabitants of Bay Bulls to Governor Charles Hamilton, May 6, 1822. and Governor Hamilton to John L. McKie. JP. Bay Bulls, May 8. 1822. and GN 2/2. 1/81-85/1826. Assistant Judge
} 
secretary until the winter and spring of 1832-33 - suggesting that the fishery or potato crop on the southern Avalon may not have suffered as badly and/or that local relief measures (e.g. charitable subscriptions. funds from liquor licenses) in this less heavily populated area were a sufficient stopgap for such distress as did exist. But by the winter of 1832-33. after three consecutive poor growing seasons. requests for relief from the study area joined those from the northern districts and the south coast as fishing families found themselves without seed potatoes to plant and local merchants and administrators declared their inability to extend any further relief from personal or communal resources. Still, the distress on the southern Avalon must not have been as pervasive as other areas at the time: no petitions for community relief appeared from Trepassey-St. Mary's district. only two arrived from Ferryland district (Renew and Fermeuse) and two from Bay Bulls district (Bay Bulls and Witless Bay) ${ }^{113}$

Requests for assistance from around the island generally came in the form of appeals from missionaries, magistrates. and/or ad hoc relief committees - often accompanied by petitions from distressed residents, themselves. Generally, these petitions were signed by household heads - primarily men and widows - with families to support Such was the case with the petition forwarded from Fermeuse in April. 1833. under a covering letter from local merchant Thomas Congdon. Congdon indicated that the petitioners would require 200 barrels of seed potatoes as they had none for planting that

Augustus W Desbarres to Acting Chief Justice Edward B Brenton, November 29. 1826. enclosing presentments from the grand juries of Ferryland (ff. 83-4) and Placentia (f. 85)

${ }^{113}$ See PANL, GN 2/1/A and GN $2 / 2$. 
season. The petition itself, written in a hand different from Congdon's and possibly by one of the petitioners, showed a familiarity with the ornate conventions of petition-writing of the period

Humbly Sheweth that your petitioners in consequence of the great failure of their potato crop last season, together with the quantity which have rotted in their Cellars in Consequence of the early set[t]ing in [of] the past severe Winter before the potatoes were properly secured. or from the Want of maturity in the growth of the crop put in - are totally destitute of seed or the means of providing any for the coming season.

That your petitioners are all people with large families depending on them for support. consequently look forward with Fearful anxiety to the approach of another [bad growing season] Which must bring inevitable starvation on a large portion of them, unless it may by the aid of your Excellency, under the blessing of Divine Providence be averted

In tender consideration of our great necessities and the fearfil consequences that may result from them We humbly pray that your Excellency may be graciously pleased to grant us such relief as in vour Excellencys Wisdom and Humanity may seem meet and your petitioners as in duty bound will forever pray -

The petition was signed by 23 family heads, including two women. Mary Fahey and Catherine Tobin. ${ }^{114}$ This was fairly representative of the petitions received from all districts.

Less typical was the petition received from "Whittys Bay" (Witless Bay) in May that same year. In this instance, eight widows and two men (one described as a "cripple" and the other as "old and infirm") were the only signatories (all by their mark). The

${ }^{114}$ P.ANL. GN 2/2, 12/213-17/1833. Thomas Congdon to James Crowdy. local Cclonial Secretary. April 15, 1833, enclosing Petition of certain Inhabitants of Fermews to Governor Thomas Cochrane. April 15, 1833 
language was much plainer and appealed to the governor's chivalric instincts in relation to widows and their children:

We your Excellency's humble petitioners, poor Widows with large families. being deprived of all possible means of procuring Seed Potatoes, do most respectfully lay our distress before your Excellency, hoping you will take it into your gracious consideration, and send us that relief which your

Excellency may think proper to bestow.

And your petitioners as are duty bound will ever pray -

No reference was made to in the text to the men who had to be supplied due to incapacity, their situation was obviously conflated with that of the "poor Widows with large families" by the petition's author. The family size and specific needs of each petitioner were entered. with the total need assessed at 31 barrels of seed potatoes. A marginal note by the colonial secretary, however, indicates that only 12 barrels were actually sent. ${ }^{11}$ Perhaps the governor was suspicious of the high level of widowhood in such a small community, ${ }^{1 t 0}$ although a couple of fishing disasters could have accounted for this.

In general, however, there seemed to be an official reluctance to send seed potatoes to the southern districts, including the southern Avalon and Placentia Bay. Relief committees in all districts of the island were instructed to assess need carefully and to keep

I'PANL, GN 2/2 12/73-4/1833. John McKie, JP at. Bay Bulls, to James Crowdy. Colonial Secretary. May 21, 1833. enclosing Petition from Inhabitants of Bay Bulls [district] for Relief, May 20, 1833.

${ }^{116}$ In 1825, there were only 25 mistresses in total in the harbour (see C.O. 194. Governor's Annual Return of the Fishery and Inhabitants), in the 1836 census, females 14 years of age and over totaled 135 (see Newfoundland Population Returns, 1836). 
precise records of all seed potatoes and other relief (such as bread and molasses) distributed. The instructions to the southern districts. however, always included firm admonitions that the seed potatoes were to be considered a loan only, to be repaid in kind at the fall harvest. When additional relief was provided in the form of bread and molasses. the colonial secretary took pains to explain that the governor had limited the quantities supplied "as only to be sufficient to support life - \& not to create a desire to depend on the bounty of Gov'. in future. ${ }^{-117}$ This language does not appear in correspondence with the northern districts, and seems somewhat unwarranted, given the limited number of requests from the southern Avalon vis-à-vis the overwhelming dependence of the northern districts on relief distribution for many years. Perhaps authorities questioned the validity of the claims from the south, given that many other areas in the southern districts were coping without assistance. However. there is also a possibility that there was some residual mistrust of predominantly Irish-Catholic districts among Angio-Protestant governors and civil servants of the day

At any rate, this was a very different form of petitioning than the individual women s petitioning examined above, emanating from an extended period of poor growing and fishing seasons - a combination of natural circumstances that brought high levels of distress to numerous Newfoundland communities and ignored gender in its

${ }^{117} \mathrm{GN} 2 / 1 / \mathrm{A} .39 / 21 / 1833$. James Crowdy, Colonial Secretary, to the Committee of Relief for Bay Bulls. January 15, 1833. Similar instructions were sent to John L. McKie. JP. Bay Bulls, in 1822, and to R.F. Sweetman respecting the distribution of relief in Placentia in 1833. See GN 2/1/A: 32/425-6/1822, Governor Charles Hamilton to John L. McKie. May 8. 1822; 39/155/1833. James Crowdy to R. F. Sweetman. November 14. 1833 , and $39 / 174-5 / 1833$, James Crowdy to R. F. Sweetman. November 26, 1833 
impact. Male and female household heads joined in what were, indeed, deferential requests to a central authority for relief from impending starvation. These were extraordinary efforts in exceptional times. not comparable to the individual petitioning described earlier, in which women were acting in a quest for individual justice - whether through the formal legal system or as an effective alternative to it.

\section{$\underline{0.5 \text { Conclusion }}$}

Southern Avalon women found various ways to access the justice system during the study period - even if their way was sometimes impeded by the law's gendered assumption of women's secondary status. Their participation was not as extensive as men's, but they were present in the system in substantial numbers and in a variety of capacities - as civil litigants, as complainants and defendants in criminal matters. as witnesses and petitioners. Indeed, their involvement with the legal system, especially that of plebeian women, increased as the courts became more formalized in the latter $18^{\text {th }}$ century and the early decades of the $19^{\text {th }}$ century

But did authorities treat women differently than men in the matters that came before them on a day-to-day basis? For the most part. local magistrates placed men and women who appeared in the court room on a fairly equitable footing. Yet not all women had ready access to the court room. The greatest bar to women s participation was the common-law principle of coverture. although it should be noted that the status and 
authority of married women in plebeian families likely permitted them a good deal of behind-the-scenes involvement. Still, the local courts generally recognized coverture. although they also made a significant number of exceptions. ${ }^{\text {ix }}$

Husbands were usually recognized as the legal agents of their wives in civil matters involving debt, for example. Nonetheless, the court occasionally permitted married women to initiate actions: Jane Austen and Margret Kenney, for example, sued various debtors in their own right, even though their husbands were alive; and the high percentage ( 75 percent) of female creditors and debtors who represented themselves in the court room suggests that the principle was waived on other occasions as well. It is worth noting here that most local magistrates were also merchants. who permitted married women to hold accounts in their own names if they carried out economic activities independently of their husbands (if Goodridge's and Sweetman's were representative; see Chapter 5). The principle of marital unity, then, was often tempered by local circumstances in a number of spheres.

Magistrates also generally held that husbands were entitled to the property of their wives after marriage - although again they made exceptions. For example, the local court excepted any property of the wife over which the husband had not exercised any control or act of possession. as occurred when Hunt. Stabb. Preston tried to attach property of Elizabeth Beaves to pay her late husband's debts. And there were other occasions on

${ }^{118}$ Berkin notes that the principle of marital unity was also not universally or uniformly applied in the courts of colonial America. although some clung to the English laws that had been transported across the Atlantic. See Berkin, First Generations, p. 155. 
which the principle of coverture was not applied. Mary Bryan, a married woman of St. Mary's. represented her family's interests in 1780 in relation to a property matter although there was cause for relaxation of the principle in that matter as her husband was deemed "insane." A more clear-cut example was that of Hannah McDaniel, who represented herself and her husband in a protracted property and debt dispute in the $1780 \mathrm{~s}$ and $1790 \mathrm{~s}$

There were other cases in which wives represented husbands in the court house As noted above. Margaret Meaney appeared for her husband and successfully defended him against assault charges in 1833. And when John Fowler initiated an action against Richard Shallow for recovery of a property at Renews. it was Shallow's wife who appeared in court and defended the family's claim to the land. At the initial hearing. she stated "that she was taken by surprise in the matter" and asked the court to "grant her time [and] she would produce several material Witnesses to prove her occupancy of the property in possession for a period of over thirty years." The court gave her only until the next morning, but she managed to find two witnesses to establish her claim, and a judgment was initially given in her favour. although a new trial was later ordered on the grounds that the judgment was "contrary to law and Evidence. ${ }^{119}$

And there were grey areas - such as the 1830 complaint of breaking and entering and theft against Robert Fitzhenry by the Rossiter family. The record contains no formal

"P.ANL. GN 5/2/C/1. Box 1. n.f., John Fowler v. Richard Shallow: October 12. 1860. The outcome is not recorded in the Ferryland records as the matter was moved to the Supreme Court at St. John's. 
style of cause that would easily identify the plaintiff, but usually in such cases, the injured party, not the Crown, appeared as plaintiff (the Crown only initiated actions in larger-scale larceny charges). But as the complaint stated that Fitzhenry broke into a locked room in "the dwelling house of John Rossiter" and stole two blankets therefrom, one would expect John Rossiter to be the complainant of record. The charge was not laid by John Rossiter. however, but by "the affidavits of Elizabeth and Mary Rossiter" - obviously related women, although the relationship is not explained. Additionally, all three Rossiters - John. Elizabeth, and Mary - were identified as "Prosecutors" in the record. ${ }^{120}$

Furthermore, while English common law perceived the father as legal guardian of the children of a marriage, local courts sometimes tempered this principle in terms of parental spheres of influence. In 1800. for example. Trepassey doctor Michael Dutton complained to the magistrate that he had frequently seen the children of the Welch family taking boards from a fish stage in the harbour. Although the "Welch family" were the named defendants and the culprits were specifically identified as "the Children of John Welch." it was Mrs. Welch who appeared in court and received the surrogate's warning that her children were to cause no complaint in the future. In this case, it seems that the court went directly to the mother as the parent most likely to be able to enforce the court's judgment. ${ }^{121}$ Furthermore, in matrimonial matters, the court did not always uphold 3. 1830 .

130.PANL. 5/4/C/1, Ferryland, Box 1, f. 21. Rossiter v. Robert Fitzhenry: August

${ }^{121}$ PRL, 340.9 N45, Trepassey, n.f.. Michael Davenport Dutfon v. Welch famuly: September 20. 1800 
the rights of fathers as legal guardians of children. In Chapter 8, for example. several cases involving child custody will be discussed in which wives, even those who had technically 'deserted' the marriage. were given custody of the children of the marriage In some of the cases in which mothers represented their children 's interests, the women had assumed the status of legal guardian in widowhood. as the law permitted. Catherine Delahunty of Ferruland, for example, was a widow when she sued James $\mathrm{H}$ Carter for the seduction of her daughter Ellen in 1827 (see Chapter 8). ${ }^{12}$ and Thomas Norris for her son 's outstanding wages three vears later ${ }^{13}$. Although the records are not clear, Jane Fitzpatrick. who tried to have her son's apprenticeship agreement with Robert Pitt voided in 1837. was also likely widowed or separated from her husband, for parish records indicate that her husband had either died or left between the birth of her daughter in 1826 and the birth of another son in $1828^{124}$ Elizabeth Madden was likely also single. separated. or widowed when she intervened in her sons ${ }^{*}$ working arrangements with local employer Michael Curragan in $1836^{12}$ However, such was not the case when Hannah McDaniel appeared as co-defendant with her son John for having advised John to renege on his shipping agreement with Michael Malone in 1797. John's father. William, was very

I'P.ANL. GN 5/2/C/I. Box 1. ff. 142-5. Catharme Delahumy v. James H. ( arter. October 4.1827

${ }^{13}$ See Delahunty v. Norris, above.

${ }^{13}$ The latter was branded "illegitimate" in the parish records: see PANL. Church of England parish records. Petty Harbour parish. Box 2. Ferryland District. 1820-1860. See also Fitzpatrick : Norris, above.

${ }^{125}$ See Madden v. Curragan, above. 
much alive. for he was listed with the family in the 1800 nominal census. In this case, the complainant and the court chose to prosecute the parent who had provoked the alleged breach of contract, regardless of legal guardianship ${ }^{126}$

Did women, themselves, seek differential treatment from the legal system? Occasionally. women appealed to the chivalric impulses of governors or magistrates in framing their requests or defences. This was particularly true in women's petitioning, in which a variation of the phrase "poor distressed woman with a large family. [ $x$ number ot] children to feed" appeared with some regularity. Whether this form of suasion was an accurate reflection of the woman's circumstances (as was likely the case when the women of Witless Bay were seeking seed potatoes in 1833), or a ploy to win the sympathy of authorities (as one suspects was the case with Hannah McDaniel's petitioning) was probably variable. ${ }^{12 *}$ Sarah Turpin's petition in 1780 from Bay Bulls. requesting the intervention of the governor in relation to the "Rude Behaviour of Fishermen at Bay of Bulls to women who pass along while their Jigging of Squids," was also likely aimed at middle-class sensibilities and notions of propriety and respectability ${ }^{128}$

\footnotetext{
iz See Malone i: .fiDamiel, above. See, also. PANL, MG 205. Pole Papers. $1799-1800$

1:Rosen also notes the "common rhetoric" of poverty in women s petitions. although she argues that. especially in the case of widows, it was likely a "reflection of [their] societal reality" See Rosen, "Mitigating Inequality," p. 318

12xPANL, GN 2/1/A, 9-reverse end/27/1780, Governor Richard Edwards to John Dingle. JP. Bay Bulls, October, 1780 , enclosing a proclamation in response to the petition (the original petition and proclamation were not entered in the records but were referred to in the Governor's covering letter).
} 
In most civil and criminal matters, however, there was no evidence in the court records that female plaintiffs sought preferential treatment because of their sex, nor were there impassioned pleas from female defendants for mercy for the 'gentler sex. For the most part. women took their chances, and their lumps, in the same manner as male participants in the system, and the court dealt with them on this basis. There was an exception. however, in the area of more severe punishment. Here, authorities did tend to treat women differently: there were no cases in which women were sentenced to whippings. and imprisonment and transportation were not applied with the same frequency, although they were certainly employed against women who were perceived as extreme threats to the moral and social order

What is most striking about the matters examined above is the degree of agency exhibited by women on the southern Avalon in their encounters with the formal justice system. This experience appears to diverge from that of women in many other British colonial jurisdictions. Rosen. for example. in her examination of the legal system in colonial New York. states that "Clearly the courtroom... was considered primarily a male. not a female. place ${ }^{-129}$ Yet this image of exclusion does not come into focus on the southern Avalon. A closer comparison can be seen in the women of colonial Virginia. as described by Richter. who "knew how to use the county court system to protect their freedom, interests, and families. "isto Yet even Richter interprets women's presence in the

\footnotetext{
${ }^{129}$ Rosen. "Mitigating Inequality," p. 323. See. also. the literature cited at the beginning of this chapter.

${ }^{130}$ Richter, "Free Women," p. 290.
} 
system primarily in terms of the extension of their roles as wives and mothers - the "public use of household authority." They were not stepping outside the gender roles that had been assigned them by colonial Virginia society, she says, and thus not perceived as a threat to the social order ${ }^{131}$

Yet. as argued in the previous chapter, gender roles on the southern Avalon. particularly within the plebeian community, were less rigid, gender boundaries, more permeable. in the period of early settlement. It is not likely that these women. or the communities in which they lived, saw their lives solely in terms of marriage and motherhood. Indeed, describing women's public actions only in terms of "the extension ot' their roles as wives as mothers" is surely a gender pitfall, for men 's actions in the same types of matters (be it court cases, petitioning, food riots) are never described in terms of "the extension of their roles as husbands and fathers " It is gendered reporting which presupposes that the public woman is an aberration - that some rationale for her public presence must be found rooted in the domestic sphere. that the reasons for her public acts are always different from those which motivate men, and that these reasons must always be selfless.

But the evidence from the southern Avalon suggests that plebeian women often acted from self-interest and in pursuit of individual rights. just as they also frequently acted (as did men) in the interests of their families - families for which they felt they had equal responsibilities. Moreover, the formal legal system. at least at the local level. was not

${ }^{131}$ Richter, "Free Women," pp. 308-9 and fn. 2. 
hostile to their presence on these terms and exhibited a fair degree of flexibility in accommodating not just single and widowed women, but also those married women who presented themselves when the letter of the law refused to acknowledge them. This reception, too, seems to have been at variance with the experiences of women in many other British jurisdictions

There was a subcategory of women's experience with the legal system that is worthy of separate treatment Women on the southern Avalon were also present in the records as testatrices, beneficiaries, executrices, and administratrices in estate matters, in which English inheritance laws and practices were tempered by local circumstances. leading to a more gender-inclusive set of testation practices. Women's encounters with and. indeed, their role in the development of - this local inheritance regime will be discussed in the following chapter 
Chapter 7 - "Whilst Grass Grows or Waters Run". Women and testation practices on the southern Avalon

Bv the $18^{\text {th }}$ century, British inheritance law and customary practice favoured the male line of descent. ${ }^{\prime}$ Women's property rights tacked a precarious course in English common law between the Scylla and Charybdis of primogeniture and coverture. The system of primogeniture dictated that in the case of an intestacy. the eldest son should inherit a dead man's real property, although in the absence of sons, daughters would inherit jointly in preference to male collateral kin. The widow held dower rights - a life interest only in one-third of her deceased husband's real property - but with no right to alienate (e.g., sell or mortgage) the property from the estate, which would ultimately revert to the legitimate heir(s). Among the aristocracy and upper middle class, however, a system of tail male' - the entailing or settling of an estate on a succession of male heirs was widely practiced from the $17^{\text {th }}$ through the $19^{\text {th }}$ centuries and reduced women's access to real property ${ }^{2}$ Furthermore, such property that women did hold became their

'The following discussion of English inheritance law comes primarily trom Amy Louise Erickson. Women and Property in Early Modern England (London: New York: Routledge, 1993), with some additional insights from: Maxine Berg, "Women. Property and the Industrial Revolution," Journal of Interdisciplinary History, XXIV 2 (Autumn. 1993). 233-50; Johnson, "Matrimonial Property Law"; Derek Mendes da Costa. Richard J. Balfour, and Eileen E. Gillese, Property Law, $2^{\text {nd }}$ ed. (Toronto: Edmond Montgomery Publications, 1990); A. H. Oosterhoff. Text. Commentary and Cases on Wills and Succession, $3^{\text {rd }}$ ed. (Toronto: Carswell, 1990), and Alan M. Sinclair and Margaret E. McCallum. Introduction to Real Property Law $4^{\text {th }}$ ed. (Toronto: Vancouver Butterworths. 1997)

-The rule against perpetuities at English common law restricted the vesting of interest in land beyond a period of 21 years after a life in being at the creation of the 
husbands' at marriage under the principle of marital unity, although they could recover in widowhood any freehold property that had been theirs prior to marriage and which had not been disposed of (with their consent) by their husbands.

In the late medieval and early modern period. however, the common law had been tempered by equity, manorial law, and ecclesiastical law. Manorial law, for example. often favoured partible inheritance among sons rather than primogeniture; it also made provision for 'freebench' - a widow's right to a proportion (ranging from one-third to all) of her late husband's 'copyhold ${ }^{-3}$ for the duration of either her life or her widowhood. Ecclesiastical law dealt with leasehold property and chattels (moveable goods or personal property) and advocated a form of community property in marriage and equitable distribution of parental wealth among children. Intestacy law was influenced by ecclesiastical principles, for instance, in its distribution of chattels: one-third to the widow and two-thirds to the children of the deceased; with equal distribution of a widow's goods to all children. Furthermore. ecclesiastical courts often reduced the land-inheriting heir's share of moveable goods in favour of the other children to effect a more equitable distribution of the overall estate. Meanwhile, equity had jurisdiction in all types of property matters and occasionally mitigated some of the harsher aspects of common law in specific

interest. This prevented a person from tying up his or her property tor an indefinite period after death. Nonetheless, the spirit and intention of a tail could be kept alive through the testamentary practices of succeeding generations.

${ }^{3}$ Land held at the will of the lord or according to manorial custom. 
circumstances. Equity also permitted the protection of women's property from the repercussions of coverture by a system of marriage settlements and trust agreements These options. however, were generally pursued by the well-to-do only. Furthermore. women often did not participate in such arrangements and. in effect, forfeited control of their property to male relatives. at least until their widowhood.

The balance of power among these legal systems was shifting between 1300 and 1800. but with the increasing secularization and centralization of the state in the $16^{\text {th }}$ and $17^{\text {th }}$ centuries, the momentum turned in favour of common law. In a process "euphemistically called the "rationalization" of the law." according to Erickson. common and statute law came to dominate other systems: equity was incorporated into common law, while ecclesiastical and manorial law were relegated to the status of 'custom' only something less than actual law ${ }^{+4}$ By the $18^{\text {th }}$ and $19^{\text {th }}$ centuries, in a climate of conservatism in relation to women's rights and status in general. a system of inheritance that had already favoured the line of male descent had become even more restrictive in terms of women's property rights and economic security.

Yet within England, the law was frequently tailored to local conditions and customs. Widows often inherited more real property than the law entitled them, for example, albeit usually with a life interest only. Certainly, they inherited a substantial amount of personal property and cash from both probated estates and intestacies. Women

\section{'Erickson. Women and Property, p. 6.}


also acted as executors, guardians, and trustees - giving them some status in the disposition of family property. Also, pre-mortem endowments were made to younger children. male and female, through marriage settlements and deeds of gift. Among the aristocracy and middle class, primogeniture and tail male were generally favoured, but within plebeian or working-class communities, daughters frequently inherited on a relatively equitable basis with sons. sometimes with 'sole use' provisions to prevent the property from falling into the hands of sons-in-law. This 'share and share alike' principle most often manifested itself in communities in which family members performed productive work together within household economies.

Similar adaptations of English inheritance law also took place in Newtoundland, as Trudi Johnson concludes in her examination of the impact of the local inheritance regime on matrimonial property law. Johnson argues that the reception of the male-centered English inheritance law was mitigated in Newfoundland by local circumstances and customary practices. While English laws in general were tempered by island conditions. the application of property and inheritance law was particularly tenuous, given the uncertainty of the nature of property in Newfoundland until the $19^{\text {th }}$ century - the result of a fishing regime that reserved large portions of land from private use for the benetit of the migratory tishery. Even lands designated for private use could not be held by freehold title. From the passage of the Newfoumdland Acr of 1699 throughout the $18^{\text {th }}$ century.

'This view is also held by English and Curran: see "A Cautious Beginning." 
British authorities permitted uninterrupted possession of such properties, with the proviso that they be employed for the purposes of the sedentary fishery. But the recognition of private property did not really begin to evolve until the $1810 \mathrm{~s}$ to $1830 \mathrm{~s}$, when authorities gave into the demands of an increasing and stabilizing population for greater certainty to land titles. While the definition of property remained uncertain throughout much of the study period , however, this ambivalence did not translate into a casual attitude towards land among residents of Newfoundland. The location of the fishing room - its proximity to tishing grounds and sources of supply and trade, its physical suitability for erecting stages and flakes, its access to wood and water - was vital in the fishing economy ${ }^{\text {D }}$ Of equal imporance was nearby land for houses and gardens to maintain the fishing household within a tenable distance of the tishing room. Fishing families in Newtoundland thus clung to their holdings tenaciously. As Johnson points out, the continuous possession of property was critical as it provided "a measure of economic security in a society with precarious economic conditions. The land was valued. not as an indicator of wealth. but by its proximity to the sea, the very source of livelihood. The transfer of possession. therefore, was crucial."

The importance of property to Newtoundland fishing families was retlected in the evolution of a system of usage and customary practices in which title by quiet possession

"Head. Eighteenth Century Newfoundland

"Johnson. "Matrimonial Property Law." p. 11 
and partible inheritance featured prominently and were recognized by the local community. Johnson notes that local inheritance practices were frequently guided by a concern for the future economic security of all members of the family. The principle of primogeniture was often tempered by concerns for the support and maintenance of widows and daughters. and a 'share and share alike' attitude influenced testation practices. This did not mean that all beneficiaries inherited equally Sons were far more likely to receive fishing premises and gear. with the expectation that they would care for widows and dependent siblings. Widows and daughters. however. would also receive some form of maintenance - often cash, livestock, or personal effects, but sometimes real property bequests that were usually protected from sons-in-law or any future husband of the widow by the establishment of life interests *

${ }^{\star}$ Johnson. "Matrimonial Property Law." Chapter 6. pp. 159-233. See also Ravmond Gushue. "The Law of Real Property in Newfoundland," Canadian Bar Review, IV (May, 1926), 310-4. Ryan. Berkin, and Karlsen note that English rules of inheritance were also refashioned in colonial America and that male testators sometimes left significant shares to wives and daughters. See: Ryan. Womanhood in America; Berkin. First Generations, and Karlsen, "The Devil in the Shape of a Woman" The Economic Basis of Witchcraft," in Kerber and de Hart, eds.. Women's America, $3^{\text {rd }}$ ed. pp 53-72. Karlsen argues. however, that in the context of colonial Puritanism. the refashioned system left female beneficiaries open to accusations of witchcraft because they "stood in the way of the orderly transmission of property from one generation of males to another" $(p .70)$ Quite exceptional in colonial America was New Netherland. which was governed bv Dutch law before and for several decades after its conquest by the English. Lnder Dutch law. married women maintained their separate legal identity and marital property was held jointly, with estates commonly being distributed by joint wills. Widows were thus entitled to one half of the marital estate and also had the right to administer the other half for legitimate heirs. See: Biemer. Women and Property, pp 1-6: and Berkin and Horowitz. eds. Women's Voices, pp. 79 and 166. 
On the southern Avalon, women were in a minority but still a conspicuous presence in the court records and governors' correspondence on estate matters, and evidence of their participation supports many of the conclusions drawn by Johnson." Johnson notes that there were five principal means by which property was designated to family members: deed of gift. deed of conveyance. intestacy, wills. and marriage settlements. Irish-Newfoundland women generally appeared only in the first four categories in the records of the southern Avalon. Various examples will be discussed below and will help to elaborate on the inheritance practices described by Johnson Marriage settlements and trust agreements, as in England, were the province of the wellto-do, and while there were several Irish-Protestant merchant-planter interests on the southern Avalon in the $18^{\text {th }}$ century, few of the women in these tamilies ever came out to Newtoundland: several examples of such agreements involving stay-at-home daughters appear in the Carter-Benger-Nason Papers at the PANL, but thev involve properties in Ireland only and have therefore been omitted from this discussion. Exceptional were the women of the Benger family, who did reside in Ferryland in the $18^{\text {th }}$ centuryt see Chapter 9). but details of their marriage settlements have not survived in the records.

"Both Johnson and I perceive greater flexibility in local testation practices than Cadigan. who sees the inheritance regime as a bulwark of the patriarchal family structure See Cadigan, Hope and Deception, pp 65-8 


\subsection{Wills, deeds of gift, and deeds of convevance}

As wills, deeds of gift, and deeds of conveyance were all methods by which property was bequeathed to family members, and were sometimes used in combination by testators in a system of pre-mortem and post-mortem endowments, they will be discussed together here. An examination of wills for the study period brought forth the names of 65 women on the southern Avalon: ten testatrices and 55 legatees ${ }^{10}$ of the latter, nine also served in the capacity of executrix. Thirty female beneficiaries inherited real property. sometimes in combination with cash and/or personal effects, while 24 female legatees received chattel interests only. ${ }^{11}$ Another 23 women appeared in deeds of gift and deeds of conveyance for the period. Of these. four were transterors while the remaining 19 were recipients of property. All but two of these transfers involved real property. sometimes in combination with moveable goods or personal property Only two deeds marked arm 's length conveyances between non-related parties - one involving a female transferor and the other. a female purchaser. The remaining 21 were testamentary transfers between family members, typical of customary inheritance practices of the period. Of the 19 transferees. 17 received real property, sometimes in combination with personal effects.

${ }^{10}$ Only women who lived on and/or had property interests on the southern Avalon are included in this tally.

"This accounts for 54 of the 55 female legatees: the reference to the remaining beneficiary comes from a court case and the nature of the property she inherited was not specified in the record. 
while the remaining two received personal property only

In concurrence with Johnson's findings, sons on the southern Avalon were favoured in terms of receiving fishing premises, family homes, and other significant pieces of real propeny, while daughters generally received lesser properties (e.g. gardens and small meadows), cash, livestock. furniture and personal effects (as noted, 24 of the 55 female legatees received chattel interests only). in his 1797 will, for example. William Gregory of Brigus South left all his real property, including house. fishing premises (including boats), gardens, and meadows to his sons, John, Thomas, Simon. James, and Richard. His two daughters. Elenor Norris and Mary Holly. were already married and the expectation was that their livelihood would be provided by their husbands" assets. Still. their father lett them each $£ 40$ pounds and a gold ring. ${ }^{12}$ In 1820. two Neill brothers at Admiral's Cove (Fermeuse), Michael and John, executed virtually identical deeds of conveyance in which their respective sons were granted fishing rooms and plantations while their daughters received only livestock (both daughters were named Bridget, and each received two cows and a horse from her father). ${ }^{13}$ By his will in 1834. Michael Neill

12P.ANL, GN 5/1/C/9, ff. 19-20, and 24 (23-4 and 28), Will of William Gregory. October 1. 1797. likely entered in the Ferryland court records sometime in 1814-1815. given its placement in the records. Note that much of the GN $5 / 1 / \mathrm{C} / 1$ and $\mathrm{GN} 5 / 1 / \mathrm{C} / 9$ series at PAVL contain two sets of folio numbers. The alternate set will appear in brackets throughout the citations for these series.

${ }^{13}$ Both deeds were dated May 3, 1820, and appear in PANL, GN 5/1/C/1. Ferryland. f 90 (94) 
of Admiral's Cove (Fermeuse) ${ }^{11}$ initially left the bulk of his $£ 600$ estate to his five sons: he gave his eldest, Constantine, the fishing room and plantation that he had inherited from his own father: and he gave his remaining four sons - John. Michael. Owen. and James the house and fishing premises he currently occupied with the proviso that they care for his "beloved wife Mary" so long as she remained unmarried. (These provisions for the sons were actually confirming transfers that had originally been designated by deeds of gift dated April 16. 1833, the deeds are referred to in the will: they have not survived in the records. or perhaps were never entered.) His surviving daughters were to divide equally all their father's livestock - "horses, cows, heifers, calfs. Bulls, bullocks. pigs, sheep" together with the hay and fodder currently housed with them. Bv a codicil dated the same day, however, he revoked the livestock bequest to his daughters and delegated the animals to the benefit of his wife and all unsupported children. He also stipulated that his wife have $£ 100$ immediately for her own use, and that his daughters each receive $£ 100$ upon marriage. "s These testamentary documents all exemplified a clear-cut division of property along the lines of gender - real property to sons, other forms of property to widows and daughters - with an effort to provide some form of support to all family members.

However, women did inherit real property quite frequently; but when real property

${ }^{11}$ This may have been the same Michael Neill. with a larger family, although there were various branches of the Neill family at Admiral's Cove - all large families of the same collateral kinship group with the same Christian names running throughout.

is Mannion Name File. Fermeuse. "Neill. Michael." Will and Codicil of Michael Neill, both dated October 4. 1834, probated November 12-15, 1834. 
was bequeathed or transferred to a wife or daughter. it was often only for a lifetime or. in the case of widows, until remarriage. This was essentially a means of keeping the property in the family and protecting it from the repercussions of coverture in the event of daughters' marriages or a widow's remarriage. It should be noted, however, that while testators sometimes stipulated that property remain within or revert to the male line of descent, they were more frequently content that property devolve to their daughters and their legitimate heirs. keeping it among lineal descendants of both sexes. Often. the sole and separate use formula was aiso employed in these documents to remove the property from the control of sons-in-law. A life interest was specifically created for women in 17 of the 30 will bequests involving real property and 13 of the 17 gifts/conveyances involving real property examined here. Edmund Dunphy of Brigus South, for example, transferred his house, furniture, personal effects, and four gardens to his wite and daughter. both named Mary, in equal shares, with the stipulation that after his wife's death, the entire property was to devolve to his daughter "in Trust only for the Heirs of her body lawfully begotten." with the turther provision that "[in] default of such Heir the said premises will $\&$ shall revert to the next lawful heir ..." ${ }^{16}$ Similarly. Matthew Ronan of Ferryland left his entire property, moveable and immoveable. including a house. gardens, meadows. cattle. and farming utensils. to his wife "for her sole benefit. use and interest." with the proviso

\footnotetext{
${ }^{16}$ PANL, GN 5/1/C/1. Ferryland. ff. 56-7 (60-1), Deed of Gift. April 24, 1820.
} 
that it descend from her to her grandson. Martin Cullaton. ${ }^{17}$ Robert Carter, $\mathrm{Sr}$., of Ferryland transferred to his daughter Mary Sanders a life interest in a plantation at Ferryland. with the stipulation that the property devolve to her issue upon her death ${ }^{\text {is }}$ In this case, however, the restriction applied to both male and female beneficiaries, for when Mary's son Robert Sanders. in turn. gifted his share of the property equally to all his children (three sons and two daughters) in 1818 , he cited his grandfather's intention that the property should remain in the family, and stipulated that no child of his own could ever dispose of his or her interest in the property to outsiders. ${ }^{14}$ Similarly, the deed of gift by which Henry Coryear transferred his various properties in Cape Broyle harbour to his children in 1817 contained restrictive covenants for his son as well as his daughters. Elenor. Ann, and Sarah received his house, adjoining gardens and meadows, and household furniture, while Elizabeth and Mary received a plantation in Cape Broyle currently occupied by Patrick Kelly, with the proviso that the properties were to devolve

17P.ANL, GN 5/1/C/1, Ferryland, f. 95 (99), Will of Matthew Ronan, undated in copy in court records, but the Proof of Will was sworn November 20, 1824

${ }^{14}$ This transfer is cited in an 1816 agreement reached between Mary's surviving children. Robert Sanders and Ann Sanders Morry (as represented by her husband. Matthew Morry. Jr.). See PANL. GN 5/1/C/9. ff. 30-1 (34-5), Agreement between Robert Sanders and Matthew Morry, Jr., January 9. 1816 . The date of the convevance is not given: however, it likely took place prior to Mary s marriage to Daniel Sanders and preceded Robert Carter's will of 1795, in which Mary was not mentioned. See PANL. MG 31. Carter Family Papers, File 33, Will of Rober Carter, dated March 29, 1795. 10,1818 .

${ }^{19}$ PANL, GN 5/1/C/l. Ferryland. ff. 50-3 (54-7), Deed of Convevance. November 
to "their Heirs lawtully begotten of their respective Bodies"; John received Henry's main fishing premises in Shores Cove, Cape Broyle, but also with the stipulation that the property should pass on to "his heirs Male lawfully begotten."20 Sons, then, were also often limited in their flexibility to dispose of real property through sale, mortgage. or future bequests outside of direct descendants, as testators created 'general tails ${ }^{-11}$ to maintain property, particularly fishing premises, as a means of livelihood tor future generations of the family.

Even when women were given only a life interest in real property, occasionally they were given some discretionary power in relation to its ultimate disposition. In a deed of gift executed on October 10, 1759, for example. John Bole. originally of Ferryland but currently living in America. left his all his plantations. goods. chattels. and personal estate in Newfoundland to his brother Henry's widow - Elizabeth Bole. now Seale. She was to have a life interest only. and upon her death. the property was to devolve to her children by the late Henry - Mary and Elizabeth Bole - and then on to their issue. If one of the daughters predeceased her mother. the survivor of the two was to inherit. John's intention was obviously to maintain the property among lineal descendants of the Bole family and protect it from any claims arising from spouses of Elizabeth or her daughters. The deed

29PANL, GN 5/1/C/9, ff 31-3 (35-7), Deed of Convevance, March 15, 1817

${ }^{2} \mathrm{~A}$ general tail was an estate tail whereby the interest in the land could be inherited by lineal descendants of either sex. Again. such tails would have been subject to the rule against perpetuities at common law. but were often respected by following generations. 
contained a provision, however, that gave Elizabeth some say in the final distribution of the property, for John stipulated that the daughters would inherit only if they were "dutytul to their mother", "if they should disoblige their mother," he declared, "then she is at liberty to leave the said estate and Plantations to whom she shall think proper ...:2 Similarly, in his 1833 will, Simon Nowlan of Bay Bulls left all his plantations. gardens, and meadows to his wife Elizabeth with the proviso that the property was not to leave the Nowlan family. Nonetheless. Simon left Elizabeth with some discretionary power - i.e., to leave the property at her death "to one or as many of the family as she thinks proper (and as an endowment)." although the chosen heir was still "not to sell, let, mortgage. transfer or make over to any person or persons whatsoever. but to have it go successively in the family (of Nowlan)."' Another example was the 1848 will of Lawrence Tobin. a planter at Witless Bay. Lawrence left his fishing room and equipment to four of his sons. and the remainder of his property - land, houses, furniture, and cattle - to his wife. Eleanor. with the condition that she should leave her portion to two sons. Phillip and James. only if she felt they deserved it: "Should they or either of them transgress or do anything contrary to the will of my wife so as it can be made appear." he declared. "I leave it invested in her my

"CNS. MF 236. "Will" of John Bole, Ferryland. October 10. 1759. Although the repository lists this document as a will, its wording strongly suggests that it was a deed of gift, with Bole disposing of his Ferryland property as he was no longer living there.

${ }^{2}$ PANL. GN 5/1. vol. 1, ff. 171-2. Will of Simon Nowlan. July 4, 1833; probated November 2, 1833, Also John Mannion Name File. Bay Bulls, "Nowlan, Simon." 
wife to give their or his part to any of my other sons she consider more deserving of it. "24 Still. most of these women were restricted in re-distributing the estates to maintaining the property within the family.

Very occasionally, women legatees inherited real property with no strings attached. In a memorandum of gift in 1809. for example. Matthew Ronan gave a piece of land to his niece Elizabeth Collitan, "her Heirs, Executors, administrators and assigns. [for] their use and benefit from hence and for ever without any encumbrance or consideration whatever," "'s Similarly, in an 1815 deed of gift. Nicholas Bleake (also Bleacke) gave two-thirds of his land to his son Mickel and one-third to his daughter Catherine to hold absolutely and forever - "whilst Grass Grows or Waters Run ${ }_{+}^{* 16}$ But this type of unconditional bequest of land to female legatees was unusual for wills in the area: indeed, restrictive covenants respecting land were frequently employed by testators. regardless of the sex of beneficiaries

Although sons, and often eldest sons, were generally tavoured in wills, it was not unusual for other family members to have been accommodated by previous arrangements

${ }^{2}$ PANL, GN 5/1, vol. 2. p. 147, Will of Lawrence Tobin. July I1, 1848 Also Mannion Vame File. Witless Bay, "Tobin, Lawrence." Tobin's remaining children (four sons and five daughters) received small amounts of cash - 5s. for all but one son. who received is

${ }^{25} \mathrm{P}$ ANL, GN 5/1/C/1, Ferryland. Memorandum of Gift, July 12. 1809; entered in the Ferryland court records March 1, 1820

${ }^{3}$ PANL. GN 5/1/C/9, f. 34 (38), Deed of Gift, October 15. 1815 
such as deeds of gift or conveyance. This appears to have been how Robert Carter. Sr. allotted his estate to his various offspring in the $18^{\text {th }}$ century. As noted above, he transferred property to his daughter Mary, likely before her marriage to Daniel Saunders. and excepted it from the repercussions of coverture. By his 1795 will. he left the bulk of his remaining estate to his eldest son. William, with an annuity to his wife and small bequests of personal property and cash (one guinea each) to his son Robert and daughters Ann Sweetland and Joan Tessier. These small bequests to younger children from Carter's extensive estate suggest that they had aiready received their endowments by earlier deeds of gift or marriage settlements (Mary's absence in the will suggests that she may have predeceased her father). Pre-mortem endowments may also have been the method by which Lawrence Tobin, above, distributed his estate, for while his widow and four of his sons received the bulk of the estate, the remaining four sons and five daughters received token amounts of cash - $1 \mathrm{~s}$, or $5 \mathrm{~s}$. Such was also probably the case with the estate of Thomas Norris. Sr. In his 1840 will, Norris left his house, gardens, meadows, fishing premises, and four rental properties to his eldest son. Thomas. Jr. His other three children - a son and two married daughters - received only 5 s. each by the will While it is possible that these male testators had each fallen out with large portions of their tamilies. it was far more likely that they had already made arrangements for their other children prior to executing their last testaments. ${ }^{27}$

${ }^{27}$ Mannion Name File, Ferryland, "Norris, Thomas": will dated May 6, 1840 and probated December 10-11, 1840. 
Sometimes the widow and younger children were favoured by a final will - the older heirs having already received their portions. By his 1856 will, for example. Matthew Morry. Sr. of Caplin Bay left his second wife. Ann Carter Morry. a life interest in his extensive estate - including a house, furniture, cattle, book debts. fishing rooms and appurtenances, a Western boat ${ }^{28}$ and coasting schooner. ${ }^{19}$ and all his lands. plantations. and tenements. Her interest in the house, garden, furniture, and cattle were to devolve at her death to Morry's daughter by his first marriage. Priscilla, and her lawtully begotten children (the remaining property is left in limbo by the will) ${ }^{\text {to }}$ The testator had had several children, sons and daughters. by an earlier marriage, but most likely he had already provided for them with pre-mortem transfers. It is also likely that previous arrangements had been made for the major items that would not pass from Ann to Priscilla by the will (fishing premises, boats, gear. book debts. plantations and tenements) to revert to the older children. particularly the eldest son. Matthew Morry. Jr.

However. eldest sons were not always favoured in testation practices. For example, in his 1810 will, Robert Carter, Mariner (of the second generation of the family

${ }^{*} \mathrm{~A}$ schooner-rigged fishing boat used in fishing the banks off the south and southwest coast of the island: much smaller than the banking schooners that carried large complements of crew and dories for several week's fishing on the banks. coastal area.

- A schooner employed in the coastal trade, trading between settlements along a

${ }^{30}$ PANL. MG 237, Matthew Morry Papers. File No. 3. Will of Matthew Morry. Sr. April 25. 1856 
at Ferryland), stipulated that after payment of his debts, the residue of his estate should be divided equally among his wife and three children - Robert, Elisabeth, and James ${ }^{31}$ Carter's son Robert also followed the 'share and share alike' principle in the distribution of his estate. By his will that was probated in 1853, he basically followed the intestacy law in bequeathing to his wite, Sarah. a life interest in his dwelling house, stables and garden. and in one-third of his plantations, tishing rooms, tenements, and other properies (unstated but assumed was that two-thirds would be distributed among the children of the marriage). If she remarried. Sarah was still to receive a life-interest in one-third of the bequeathed property At her death. all the property thus held by her was to revert to the estate and be distributed equally to all their children (sons and daughters). In the meantime. Sarah was to act as executrix of the will and was also granted the power. in her widowhood only, to dispose of any of the property she held by the will if such a transter was necessary for her support. The latter was an exceptional provision in terms of women legatees with tife-interests. ${ }^{32}$

In his 1848 will. Edward Power of Brigus South also apportioned his significant estate quite equitably among his two sons and two daughters (his wife, Brigid Dovle. had

\footnotetext{
${ }^{31}$ P.NL. GN 5/1/C/9. f 8 (12), Will of Robert Carter. June 3. 1810

"The will of Robert Carter appears at PANL. GN 5/1. vol. 2. ff. 145-146. but is undated. Carter died in 1852. A subsequent court case in which Sarah Carter appeared as executrix of the estate referred to the probate of the will in 1853. See P.ANL. MG 247. Carter-Benger-Nason Papers, Files 18, 20. and 33, various papers respecting John Numan vs. Robert Carter and James H. Carter in re: estale of Richard Nason.
} 
predeceased him, as he stipulated his desire to be buried next to her at Brigus) ${ }^{33}$ Although his main fishing premises were left to his sons, the family home and other significant real properties were left to his daughters. Indeed. Power's will was such a model of the 'share and share alike' principle that it is worth summarizing the main bequests here:

- to his sons, Joseph and Nicholas, during the term of their natural lives, the fishing room with stores. stages, flakes, cook rooms. to pass on forever: if the sons were ever to argue over the property, one-half was to be evaluated and sold to the other or to the next closest heir:

- to Joseph, during the term of his natural life, a house and garden with potato field as well as ground near his fishing room which he had bought from Charles Hutchings:

- to Nicholas. during the term of his natural life. a spot of ground on his old fishing room, $60^{\prime}$ by $40^{\prime}$, for building a house, should he require it. as well as the cultivated ground at the back of the old fishing room and the land between the old room and the sea;

- $\quad$ to his daughters. Sarah and Ellen, during the terms of their natural lives, his dwelling house. furniture, goods, the small garden adjoining the house, the garden at the rear of the store adjoining Mark Grace's ground. and the land

${ }^{33}$ See: PANL. GN 5/1, vol. 2, f. 227, Will of Edward Power. October 7, 1848 , also Mannion Name File. Brigus South. "Power. Edward." 
and farm on the 'Hill' held by an 1832 government grant, along with any buildings and farming utensils; with the proviso that if the daughters were to marry or decide to live apart. the property was to be divided equally between the two in accordance with the judgment of the two sons:

- to Sarah. during the term of her natural life. his fishing room known as 'Lookout Room' in Brigus South:

- to Ellen, during the term of her natural life. his fishing room on Brigus Island known as 'Webber's Room':

- $\quad$ to his grandson Edward (son of the late Peter Power). his meadows and gardens currently let to James Doyle in Brigus at a rent of 30 s. per annum. Joseph to act as trustee:

- $\quad$ land occupied by Martin Leary to be divided equally between his two sons and two daughters:

- to Joseph. one cow:

- to Nicholas, one cow and his horse named 'Star'.

- to Nicholas and Joseph, the remainder of all cattle and horses:

- to Ellen and Sarah, all farm produce to be shared equally:

- the land never to be sold out of the family:

- $\quad$ any disagreements to be referred to Robert Carter. JP. Ferryland.

As well as the equitable distribution of the real and moveable property among his children. the other striking feature of Power's will is the life interest created for all children. 
regardless of sex. in the land bequeathed. Every gift of land contained the restriction that the bequest was for the natural life of the legatee only. And in devising the main tishing premises to his sons. Power took extra precautions, stipulating that after their deaths, the property was "to descend to their children and their children's children in succession forever ...": if disagreements arose between the sons over the property or any part thereof. it was not to be sold to strangers but "delivered up to one or other of my descendants at such a valuation as two disinterested and respectable persons may set thereon": the first right of refusal was to be given "to the senior in possession and upon his refusal to take it then to the next senior and so on through the several of my descendants alive in rotation until some of them accept the offer." As a final precaution, he added a clause at the end of the will that no land was to be disposed of in any way outside the family but was to devolve to his lineal heirs - male or temale:

I further will and deciare and all the gifts and bequests aforenamed are made upon this express and positive condition. that is to say. that no part or parcel of the above named landed property shall ever be mortgaged sold or in any way whatever disposed of or made away with but be and remain the property of my descendants in rotation so long as any of them shall survive or be alive and when any of the above named parties shall die his heirs and their respective proportion shail become and be the property of the next akin alive and among those equally near to be justly and equitably divided among the heirs of my descendants for ever

Although the rule against perpetuities acted as a legal bar to Edward's vesting property interests into the remote future. his wishes were respected by family members through the 
years, and much of his property at Brigus South continues to be held by his direct descendants today.

When a male testator had no sons, he generally left his property to his widow (if she had survived him) and daughters rather than to a more distantly related male heir Peter Weston of Ferryland, for example, made his wife. Catherine and two daughters. Catherine and Sarah, co-heiresses of his extensive estate - including several houses. fields. gardens. stores, wharfs, tishing rooms, stages, and flakes in Ferryland harbour - leaving a nephew, William Ludwig, only $1 \mathrm{~s}$. Stg. ${ }^{4}$ William Murray of Ferryland similarly divided his estate between his wife and daughter, except for one piece of ground that was left to the parish priest in payment for masses for the souls of himself and his tormer wife, his wife. Mary, received a $₹ 15$ annuity from a rental property, while his daughter. Mary Barron. received the residue of his $£ 50$ estate, including property, furniture, and personal effects." And the will of John Jenkins of Renews divided his entire estate between his five

\footnotetext{
"Weston's will created a life interest only for his wife. with her third of the property to devolve to the two daughters, or the survivor of them, upon Catherine's death. When the will was submitted for probate, however, Governor Montague effectively neutralized the restrictive covenant on the wife's share by granting "to Catherine and daughters Catherine and Sarah, their heirs, administrators or assigns [this wording gave Catherine the right to transfer her interest in the property outside the family] the quiet and peaceable and uninterrupted possession "of the property. See PANL. MG 31. Carter Family Papers, File 29. Will of Peter Weston. September 28. 1775: and GN 2/1/A. 6/149-53/1776. Governor John Montague. Grant to Catherine Weston and daughters Catherine and Sarah. September 26, 1776

${ }^{75}$ PANL. GN 5/1, vol. 1, ff. 173-4. Will of William Murray. August 17, 1833. administration - February 19. 1834. Also. Mannion Name File. Ferryland. "Murray. William."
} 
daughters - with the share of one daughter who had predeceased him being devised to her surviving heirs ${ }^{36}$

Occasionally. special bequests were made to other female relatives. John Gregory, formerly of Brigus South and then of Ferryland, left the sum of $\varepsilon 4$ to his sister Mary Holly for attending him in his tinal illness. ${ }^{17}$ Robert Carter's 1810 will (see above) stipulated that his mother-in-law. Mrs. Howe, receive $£ 400$ pounds from his estate in repayment of moneys loaned to him over time.

Women on the southern Avalon, then, were a substantial presence as beneticiaries in testamentary documents of the study period. To a lesser degree. they were also authors of wills and deeds of family transfer

\section{Women's wills and deeds of gift or converance}

While women were much more likely to be the recipients of property than testators and transferors, a small number of them executed testamentary documents during the study period. As noted above, evidence of ten women's wills and four women's deeds of

"PANL. GN 2/1/A, 1/122-3 and 126-7/1750, Petition of John Griffin. Renews (seeking mother's share of estate) and decree of Governor Francis William Drake. court hearing at Renews. August 29. 1750.

${ }^{37}$ PANL. GN 5/1/C/1. Ferryland, ff 46-8 (50-52). Will of John Gregory, July 4. 1816. Proof of Will executed November 1. 1819: entered in Ferryland court records November 1. 1819. These parties were the son and daughter of William Gregory, see above. 
gift or conveyance were found in the records examined. And although women beneficiaries came from both the English and the Irish populations on the southern Avalon, with English women predominating, women testators and transferors came predominantly from the Irish community eight of the ten testatrices and three of the four female transferors were Irish or Irish-Newfoundland women.

One of the English testatrices was Rose Steer, originally of Dartmouth but living as a widow in Caplin Bay by the mid-1820s. Rose left substantial cash bequests to her English and St. John's relatives - £50 each to her mother, two sisters, and brother, £100 to a niece. and the remainder of her cash and personal effects to another niece ${ }^{3 x}$ The only other English testatrix in the area was a widow, Mary Keen (or Kean), and by the time she was disposing of her property in the 1790 s, her descendants had already begun to marry into the Irish community. Two wills purportedly executed by the widow Keen (in February 16. 1795, and February 9, 1798, respectively) surfaced in an 1817-1818 cour case in St. John's in which her granddaughter's husband. Thomas Meagher. was being sued by creditors Hunters \& Company for an outstanding debt of $£ 551.16$. The plaintiff was hoping to attach a fishing plantation at Ferryland that Meagher had mortgaged to the company as security for his original debt of $£ 800.42$. The plantation had initially been Mary Keen 's. but Meagher had gained possession of the property through his marriage to

${ }^{\text {ix }}$ See PANL. MG 237. Matthew Morry Papers. File 12, Will of Rose Steer. June 20. 1825 Note that these female legatees are not included in the tally at the beginning of this chapter as they have no connection with the southern Avalon in terms of residence or property holdings. 
Mary's granddaughter, Joan Ryan. Nonetheless. Meagher hoped to cast some shadow on his right to have mortgaged the premises by the production of the two purported wills. The 1795 will devised Mary's fishing plantation at Ferryland to her bachelor son. James. and her granddaughter. Joan Ryan, jointly, with the proviso that the entire property devolve to Joan upon the death of James. The 1798 document was purportedly executed in anticipation of the marriage of Joan to Thomas Meagher, and stipulated that if the marriage took place, the property was to go to Thomas. his children. and their successors forever. provided that Thomas and his family live with Mary and that he act in concert with her for the general good of the property. Neither will was probated. although the St John's court noted that both were entered in the surrogate court records for Ferryland (the Ferryland entries have not survived). The court's attention in 1817-1818 focused on the second will and its creation of an interest for the Meagher children, for if it were legitimate, it would have acted as a bar to the mortgage and an obstacle to Hunters' right to attach and sell the property Lltimately. the second will was deemed a fraud upon presentation of proof that one of the witnesses' signatures was not legitimate. It appears. however, that Mary Keen did write at least one. and possibly two, testamentary documents. even though the second was not validly witnessed. ${ }^{39}$

Two other testatrices were women who lived in Ireland. One of these women.

${ }^{19} \mathrm{See}$ PANL. GN 5/2/A/1: Box 2, ff. 143, 162-5, and 221. Hunters \& compan v. Thomas Leagher. September 18. October 13. and November 3, 1817, and Box 3. ff. 102 and 149-153. Hunters \& Company v. Thomas Meagher. August 27 and September 22. 1818 . See also Mannion Name File. Ferryland. "Meagher. Thomas." 
Elizabeth Ludwigg (or Ludwick) of Waterford, was the widow of William Ludwigg, son of John and Mary Ludwigg - a wealthy Irish-Protestant merchant-planter family with extensive holdings in Ferryland in the $18^{\text {th }}$-century. Although William lived at times in Ferryland, it is likely that Elizabeth never came out to the study area but lived a life of genteel domesticity in the home country. Most of the Ludwigg properties on the southern Avalon were disposed of in the $18^{\text {th }}$ century, but at least one remained in the tamily, for at Elizabeth's demise in 1800 . she left a fishing room. stage. and tlake at Ferryland to William Coman, a merchant from Waterford City operating in the study area. ${ }^{\text {th }}$

Another Irish testatrix also held property in Ferryland through her ties to an 18 thcentury Irish-Protestant merchant-planter in the study area. Anstice Gorman of Youghal, county Cork. was a servant to the family of Richard Nason and Dorcas Benger Nason. and had an illegitimate child. Thomas, by Richard. Both the Nason and the Benger families had extensive holdings on the southern Avalon, particularly in Ferryland. and although most members of the families had returned to Youghal or removed to America by the $19^{\text {th }}$ century. they maintained many of the southern Avalon properties as rental properties. In his 1818 will. Richard noted that his various children had already been provided for by various marriage settlements and deeds of family agreements, which the will confirmed. His wife. Dorcas, had predeceased him. The residue of his estate, including his dwelling house and garden, title to and the rents and rent arrears in relation to several properties in

\footnotetext{
4) Mannion Name File, Ferryland. "Ludwigg, William," citing an entry on his wife. Elizabeth Ludwigg. from the Registry of Deaths. Dublin. 1800
} 
Cork as well as his extensive holdings in Ferryland, he left to his "faithful servant," Anstice Gorman, and their son. Thomas. Furthermore, Anstice was named executrix of his will; and Richard stipulated that if any of his legitimate children disputed the will's contents. they were to be cut off with only Is., regardless of any prior arrangements made on their behalf $^{+1}$ Thus. Anstice and Thomas became substantial landlords in Ferryland. Thomas predeceased his mother in 1826, and Anstice, herself, died on March 5, 1828, By her will. executed the month before she died. she left all the property of any nature that had been bequeathed to her by Richard Nason. including her Ferryland property, to her nephew John Nunan ${ }^{42}$

All other testatrices/transferors in this category were Irish-Newfoundland women. Johnson notes that women's testation practices in Newfoundland. like men's. followed the customary practice of partible inheritance. Unlike male testators. however, they showed a greater concern for the distribution of personal property ${ }^{43}$ These trends were certainly reflected in the 1815 will of Hester Brothers of Fermeuse, in which she carefully apportioned all her real and personal property to her nieces and nephews. a task that was

\section{April 1. 1818}

4'PANL. MG 247. Carter-Benger-Nason Papers. File 7. Will of Richard Nason.

42PANL. MG 247. Carter-Benger-Nason Papers. File 13. Will of Anstice Gorman. February _, 1828 John Nunan would become involved in a protracted dispute with the Carter family over the title and rents of these properties that was still ongoing in the 1850 s (see MG 247 in general).

${ }^{43}$ Johnson. "Matrimonial Property Law." pp. 213-4. 
complicated by the fact that the names of the testatrix and three beneficiaries were the same

Know all men by these presents, that this my last dying will [obliteration in original] is to leave Half my House and Gardens to John Brothers son William and the other half to his Daughter Hester Brothers and likewise Hester Brothers is to have my Bed and she is to have my ring and one Silver spoon Michael Brothers daughter Hester is to have one Silver spoon and half dozen plates and one Candlestick James Brothers Daughter Hester is to have one Silver spoon and one half dozen plates, and one Candlestick James Brothers is to have one Table and [unreadable] Desk, the said William Brothers or Hester Brothers is not to demand the House or Gardens while their Father lives. ${ }^{H}$

But most of the remaining women's wills and deeds examined were simple. singleheir dispositions. In 1804. Mary Whealan bequeathed one-half of the property that had been left to her by her husband to her son. John Magil. as well as the use of the other half until it was required by its proprietor. Bridget Whealan. ${ }^{\text {t5 }}$ Similarly, Mary Berrigan, a widow at Renews. left to her grandson William Berrigan her right to her dwelling house. tishing room. and garden by a will executed in $1826^{\text {th }}$ Often, these dispositions were

"PANL. GN 5/1/C/1. Ferryland. ff. 44-6 (48-50). Will of Hester Brothers. November 21[?]. 1815; entered in the Ferryland court records October 23, 1819.

"SANL, GN 5/1/C/9, f. 3, Will of Mary Whealan, March 19. 1804.

${ }^{16}$ PANL. GN 5/1, vol 1. f 474, Will of Mary Berrigan. March 13. 1826: administration - October 15, 1845. See also Mannion Name File. Renews. "Berrigan. Mary." 
made by widows to children or grandchildren in exchange for support in their old age ${ }^{47}$ This was likely the purpose of the two previous examples and was certainly the stated intent of the following family transters In 1816. Elizabeth Foran of Ferryland granted to her son Patrick Foran her title to her house, meadows, and gardens as well as a rental property in Ferryland "for his present attention to me. in contributing to my support and maintenance and my expectation of his like attention to me in the future. ${ }^{\text {atx }}$ Similarly. in 1831. Margaret Aylward of Admiral's Cove (Fermeuse), a widow who had been living with her son John for the last 14 years of her life. repaid his family for their support in her old age by leaving all her property - a house, potato garden. and turniture worth in total about £10 - to John's son, also named John. ${ }^{\text {99 }}$

Only one female testatoritransferor created a life interest with her gift. In 1817. Mary Whealan granted property on the north side of Ferryland currently occupied by her son John McGill to her granddaughter Mary McGill to hold during her natural lifetime and then to pass on to her lawtully begotten heirs. ${ }^{50}$ Whether this deed was intended to

"The transfer of property to children by aging parents, with the proviso that the parents be properly cared for in their old age, was a common practice in Ireland. Often. the provision for elderly care was stated specifically in a written deed, so that the parents intent would not be open to misinterpretation

${ }^{48}$ PANL. GN 5/l/C/1. Ferryland, If 82-3 (86-7). Deed of Gift. March 25. 1816. entered in Ferryland court records December 3. 1816.

${ }^{19}$ Mannion Name File. Ferryland, "Aylward, Margaret", Will of Margaret Aylward. March 5. 1831, administration - October 24-28, 1833

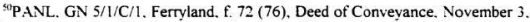
18:7. In addition. Mary Keen's purported second will. see above. created a life interest 
override Mary's 1804 will favouring John (see above) or was related only to a portion of her property is difficult to determine.

In one other instance, a widow who had remarried executed a deed of gift to transfer property held from her former marriage to the children of that marriage in order to protect their inheritance from the repercussions of coverture. In 1814, Mary Neill Dalton. the widow of Constantine Neill of Fermeuse but currently married to James Dalton. transferred to her two oldest sons, Owen and Constantine Neill, her house, meadows and gardens. boats, nets. and seines equally. with the provision that "they are not to put the tour youngest out of the House until they are able to do for themselves." 1 Intriguingly. the deed was executed after her second marriage. although there was no indication in the records that its effectiveness was ever challenged by the recording magistrates or her second husband.

Evidence of the remaining two women testatrices exists only in allusions in court cases. The will of Mary Shea of Ferryland did not survive in the records. but it was referred to in the dispute that arose between her daughter. Hannah McDaniel, and Catherine Weston in the late $18^{\text {th }}$ century (see Chapter 6 ). this reference indicates that she

for Thomas Meagher. stipulating that the property was to be held by him, his children and their successors forever, as noted, however, the will was deemed invalid by the court. although it mav actually have been written by Mary with testamentary intent.

${ }^{51}$ P.NL. GN 5/1/C/9. f. 15 (19), Deed of Gift. May 24. 1814 Johnson also mentions this deed in "Matrimonial Property Law," p. 219. although she refers to it as a will; however, its wording suggests that it was a deed of gift or family transfer. 
was possessed of at least one fishing room at that time of her death which had been granted to her by Governor Montague. and that she had left the room to her daughter. Hannah, presumably by a will that was probated. as her "executors." Hannah and William McDaniel, sold the property to William Carter in 1795. In addition, a fragmentary reference to the will of Catherine Carroll of Witless Bay parish. dated August 25, 1843. appears in the records of her parish priest, Rev. Cleary, to whom she left $£ 2$ to offer up masses for her soul. ${ }^{52}$ This brief allusion invites a discussion of the influence of ethnicity. as well as class and gender, in relation to inheritance practices on the southern Avalon.

\section{Gender, ethnicitv, class, and testation practices}

Despite fairly equitable inheritance practices in the study area. the status of legatee or testator were still tempered by gender difference. Although estates were otten distributed among male and female heirs on a 'share and share alike' principle, male heirs still tended to be favoured with bequests of major fishing premises, with widows and daughters. by contrast. inheriting properties of lesser importance in the fishing economy In terms of testators, the most obvious gender difference manifested itself in sheer numbers. Overwhelmingly, the testators or transferors in the documents encountered were men - reflecting an inheritance regime that, while flexible within the local context.

\footnotetext{
"Mannion Name File. Witless Bay. "Carroll. Catherine": citing entry in Dean Cleary"s records re: Will of Catherine Carroll. August 25. 1843 (died October. 1843)
} 
still favoured male ownership (or possession) of property. Another obvious gender difference was in marital status of the testators: while male testators were single, married. and widowed, most women's testamentary documents examined were written by widows. $^{4}$ Most of these were disposing of relatively small estates, often in exchange for support in their old age. And they tended to be less pre-occupied with maintaining properties in the patriline. although this may simply have been a retlection of the lesser signiticance of the properties they were transferring

In terms of ethnicity, the provision for the saying of masses tor the souls of testators and family members seems an obvious difference between English-Protestant and Irish-Catholic testamentary documents. Yet, it was not a pre-occupation of Irish testators on the southern. Avalon. Other than Catherine Carroll's bequest. above. only two other examples appeared in the records examined - both in men's wills. ${ }^{*}$ This may well be further evidence of the less rigid hold of formal Catholicism on the population during most

S"This can be seen from the documents. but it was also in keeping with English common law. which stipulated that married women could not make wills. And young. unmarried women would usually not have had sufficient pronerty nr motivation to write testamentary documents.

${ }^{4}$ The will of John Carroll of Ferryland left moneys to Father Murphy and Father Brennan for the repose of his soul. as well as those of his deceased parents and sisters. He also bequeathed money for the building of the Presentation convent at Ferryland. See: PANL. GN 5/1, vol. 2, p. 318. Will of John Carroll. December 30. 1857; and Mannion Name File, Ferryland. "Carroll, John." In his 1833 will. William Murray left property at Ferryland to the parish priest to pay for masses for his soul and that of his former wife. Patience. See: PANL, GN 5/1, vol. 1. ff. 173-4. Will of William Murray. August 17. 1833: administration - February 19.1834, and Manion Name File. Ferryland. "Murrav. William." 
of the period. as discussed previously in Chapter 5 .

Certainly. most English and Irish testators in the area shared a preference for 'share and share alike' testation practices, with accommodation being made for all family members, albeit with a favouring of sons in terms of primary fishing premises. While. as Johnson has noted, this was a deviation for the English population (particularly the middle-class English). who had come from a legal tradition of primogeniture and impartible inheritance, it was less a departure for the lrish population, for whom communal property and partible inheritance had been long-standing customary practices This suggests a possible addendum to Johnson's thesis: that the Irish influence on the island may been part of the blend of local circumstances that tempered the reception of English inheritance law in Newfoundland

Aside from a variance in inheritance traditions, the most outstanding difference in terms of ethnicity in testation practices on the southern Avalon appeared in the status of women in testamentary documents. By far. English and English-Newtoundland women predominated as legatees. But as noted above. all but two of the women's wills and one of the women's deeds of gift/conveyance examined here were executed by Irish or IrishNewfoundland women. Although there are insufficient records to draw conclusions. it is possible that English women - mostly from the old planter society and the rising middle class which had extensive estates to manage - were less likely to write testamentary documents because the disposal of their property had already been laid out in trust agreements. marriage settlements. and the restrictive clauses and life interests of wills and 
family transfer agreements written by men. Still. most would have had property in their widowhood: but a number of these women retired in their widowhood to England or St. John's, and any testamentary documents written by them thereafter do not appear in the southern Avalon records."

Overall. English families did feature more prominently in the testamentary documents examined in terms of the size of their estates But there were some substantial Irish estates involved as well - not only the interests of $18^{\text {th }}$-century lrish-Protestant merchant-planter families (e g. Ludwigg, Nason/Benger) and substantial Irish-Catholic planter tamilies (e.g. Neill) but also the interests of families that had begun in fishing service or small-scale family enterprises and accumulated considerable property after coming to the area (e.g. Murray, Power, Tobin). Indeed, the Irish plebeian community was respectably represented among the wills and deeds of gift/conveyance during the period, with the same concern to provide equitably for family members. However. they were proportionately under-represented in the documents examined - perhaps, to some extent, a retlection of the relative literacy of the two groups. Of course, it is quite possible that some of the local Irish executed wills and deeds which were never recorded in the court records. but whose families abided by their testamentary wishes nonetheless. The

"Such was the case with Sarah Carter, wife of Robert Carter, above, who moved to St John's after her husband's death and whose will was penned in St. John's in 1866. See P.ANL. MG 31. Carter Family Papers. File 45(b). Will of Sarah Carter. September 7. 1866. This will is not included in the computations in this chapter because it falls outside the time frame of the study. 
majority of Irish plebeian estates during the period. however. would have fallen into the category of intestacies.

\section{$7+$ Intestacies}

At least 4 l women ${ }^{36}$ appeared in court records in relation to intestate estates on the southern Avalon. Of these, 34 were potential beneticiaries: 13 (nine widows, one mother. one mother-in-law. two of unspecified relationship) petitioned to be appointed estate administratrices by the court: another 21 women were recorded solely as beneficiaries of the estates in question - as widows, daughters. sisters, and cousins of the deceased. All but three of the 34 were of the Irish community The administration of seven women's estates (two valued at £10, one each at £20, £40, £50. and £100. and one of unspecified value) were also included in the records of the period. All but one Catherine Jackman of Renews with estate valued at $£ 10$ - were Irish-Newtoundland women. Inventories of the estates were not available in all the records of the above matters, but of those that were recorded, the estate administration always included the distribution of real property, often in combination with goods and personal effects.

As noted above, the English law of intestacy stipulated that in relation to chattel interests and personal property, the surviving spouse inherited one-third the estate. and the

\footnotetext{
${ }^{5}$ These numbers are conservative, for it is not always possible to decipher references such as 'several daughters' or the sexes of enumerated but unnamed "children."
} 
legitimate children of the deceased, the remaining two-thirds. If the deceased was not survived by a spouse or children, the estate devolved to the next-of-kin. This rather straightforward formula for distribution was complicated in Newfoundland by the treatment of real property as chattels real ${ }^{37}$ in the case of intestacies. Because of the tentative definition of real property rooted in the privileged position of the migratory fishery, the applicability of English inheritance laws to Newfoundland was open to much interpretation well into the $19^{\text {th }}$ century Often, local courts treated an interest in the land as chattels real in the case of intestacies - favouring a division of one-third to the widow and the remaining two-thirds among the children (or equal division among children if there was no surviving widow) over the English principle of primogeniture. Indeed, this interpretation was made law by the fledgling Newtoundland legislature in 1834 with the passage of the ('hattels Real $4 c t(+W m$. II: (cup. 18$)$. Declaring that primogeniture and impartible inheritance were inappropriate for Newtoundland circumstances. the act provided that real property in intestate estates should be distributed. like personal property. as chattel interests. Debates leading up to the passage of the legislation indicated that the spirit and intent of the legislation was to accommodate the more inclusive inheritance regime that had developed through local practice. Nonetheless. colonial courts continued for years to be entangled in interpreting the Act alternately as declaratory - merely confirming a situation that had long existed by custom and usage - or

\footnotetext{
${ }^{57}$ An interest in real property that was less than freehold interest - e.g., leasehold interest in land.
} 
as new law that had not applied to intestacies prior to $1834^{58}$

Even betore the passage of the (hattels Real Acr, however. southern Avalon courts had tended to favour the distribution of real property in intestate estates as chattels real. One such case occurred in 1792, when Mary Kennedy sued her brother. William Tucker. over the distribution of the rent from property of their late father. who had died intestate roughly six years previously: William had taken over the property, which had attracted a rent of $£ 11$ per year for five years. then $£ 8$ the following year. William had originally paid Mary $\varepsilon+$ from the yearly rent, as the "intended bequest" of his tather. but when the rent had dropped to $₹ 8$. he had declared himself his father's sole heir and paid his sister nothing. The court declared that "Lands \& Plantations, in Newtoundland, are nothing more than Chattel Interests. and should. in case of Intestacy. be distributed as such." William and Mary were therefore to share the proceeds equally (presumably, there was no surviving widow) and William was ordered to reimburse his sister half the previous year's rent $(\Sigma t)$ - a sum that was to be witheld from William's wages with Matthew Morty - plus. over time, an additional ₹7 10.0 to make up the deficiency in her share of the rent from the previous five years. Further, the court advised Mary that she did not have to honour the rental arrangement entered into by her brother and could take possession of half the plantation herself if she so desired." This case, involving an Irish-

${ }^{5 R}$ Johnson, "Matrimonial Property Law," Chapter 6

${ }^{59}$ PANL, GN 5/4/C/1, Ferryland, Box 1, ff 25-6. Man Kemmett: v: William Tucker. October 13, 1792. 
Newfoundland woman on the southern Avalon, would prove to be a landmark case in the evolution of Newfoundland law on the treatment of interest in real property as chattel interest in the case of intestacies. ${ }^{\text {tor }}$

The local courts upheld this principle in various cases, including those involving widows and the attachment of real property for debt. In the late 1810 s, for example. Hunt, Stabb. Preston, an English mercantile firm operating out of Renews and struggling to keep its head above water in the post-war depression, learned to their chagrin (and considerable financial disadvantage) that their interpretation of the law of property and inheritance from the home country was not always shared by the magistrates at Ferryland In a collection action against the estate of Catherine Jackman. for instance, they found themselves stymied by the court's application of the law of intestacy in the case of real property they were hoping to attach. In 1813 . Catherine had entered into a mortgage with the firm. offering her house, outhouses, and two head of cattle as security for a debt of $£ 1+3158$, to be repaid at $£ 20$ per year until fully paid. Several years later. Catharine died. and the firm tried to foreclose on the mortgage. claiming that the debt had now risen to $£ 160$. Catharine s children (two sons) intervened. arguing that their father had died intestate in 1807, and as the debt had been contracted by their mother since that time, the mortgagees had the right to attach only the widow's third of the intestate estate. Hunt. Stabb. Preston contended that the father. Arthur Jackman, had died insolvent and a large

\footnotetext{
${ }^{n}$ Johnson discusses this matter as a landmark case in "Matrimonial Property Law." pp. $145-6$
} 
portion of the current debt was owing to the firm by him: thus. his estate should be responsible for that debt. But the sons argued that only their mother's debt had been secured by the mortgage and that only her share of the property had been encumbered The court agreed with the sons and ruled that only the widow's third could be disposed of for the benefit of her creditors. ${ }^{\text {st }}$

The same firm was frustrated again by the court's interpretation of the law of inheritance and coverture in their effort to collect a $£ 50$ balance on the account of William Brandy, a dealer with their house who had drowned in June. 1818. The firm invoked the principle of coverture and tried to take possession of a house and garden which, they claimed. Brandy had owned by virtue of his marriage to the widow of John Doyle. The twice-widowed Mrs. Brandy objected to their claim. arguing that her previous husband had died intestate, leaving a daughter, and that this daughter now had the full right to her father's property as his only heir. The court. however. disagreed with both interpretations. Invoking the law of intestacy, it ordered that Doyle's real property should have been distributed as a chattel interest: one-third to his widow and two-thirds to his child. The second husband. Brandy, had therefore been entitled to only one-third the property by virtue of his marriage to the widow Doyle, and Hunt. Stabb. Preston could

"See PANL GN 5/1/C/1. Ferryland: f. 113. Mortgage. Catharine Jackman to Hunt, Stabb. Preston \& Co., March 27, 1813: and ff. 47. 110. 126. and 161. Humt. Siabh, Preston \& Co. 1. the Estate of Catharine Jackman. June 6. 1818. and April 25. November 7. and December 5. 1820. See also: Mannion Name File. Renews. "Jackman. Catherine" : and PANL. Mildred Howard Collection. Estate Notice. Catherine Jackman. Roval Gazette, May 18, 1815. 
only attach this portion to pay his debt ${ }^{62}$

Of course. the vast majority of intestate estates, involving most of the Irish plebeian community, would not have been processed by the courts. The chattels portion of most would have been low in monetary value; and although many estates would also have included dwellings. gardens, and fishing premises, the distribution was effected in accordance with previously expressed wishes of the deceased and/or customary practices. and acknowledged by family members and the local community. It is likely that these unrecorded divisions followed the "share and share" alike principle that was reflected in written wills - widows assuming possession of homes and gardens for the remainder of their lives. sons being favoured in the inheritance of fishing premises and tamily homes on the understanding that widows and dependent siblings be cared for. and remaining personal property and real properties of lesser value being distributed among the remaining children. Certainly. this method of partible inheritance was familiar to the Irish community and was likely transported from the old country to the new, where it was reinforced by local circumstances. In particular. given the large numbers of male fishing servants - usually non-inheriting sons in Ireland - who married into local families in the period of early settlement. it is likely that local testators made special efforts to ensure that Irish-Newtoundland daughters and their families would have the wherewithal to support themselves: apportioning a piece of family property for a daughter and her new husband.

${ }^{\circ}$ P.ANL. GN 5/1/C/1. Ferryland. ff. 109 and 123-4, Hum Stabb Presion (o. v: the Estate of William Branty; April 25 and November 6, 1820 
for example, was a form of pre-mortem endowment, whether it was accomplished by formal deed or not. In addition, the significant role of women in economic production and their overall status also likely reinforced a tendency towards partible inheritance; certainly. in Ireland. the move to impartible inheritance coincided with the slide in women's economic and social status. particularly from the mid-19th century onwards.

\section{Conclusion}

As inheritance law evolved at the local level, the legal system accommodated local customary practices which advocated a more gender-inclusive system of partible inheritance than the English tradition revolving around the male line of descent. On the southern Avalon, as elsewhere in Newfoundland, testation practices were marked by a more equitable distribution of property than that advocated by English common law

Widows, for example, were often left with substantial property and autonomy by their husbands' wills. And while bequests were usually (although not always) restricted by life interests. widows exercised considerable independence and power in relation to tamily property during their lifetimes. and sometimes had discretionary power in relation to the ultimate disposition of the estate. Certainly, they were not thrown at the mercy of their children by virtue of exclusionary testation practices - a process described by Nanciellen 
Davis in the context of $19^{\text {th }}$-century New Brunswick as "patriarchy from the grave ${ }^{.+h 3}$ While sons were favoured in terms of major fishing premises. daughters also inherited real property - sometimes with life interests, but sometimes without (particularly in cases where children were designated as residual legatees after a widow's death). Furthermore. lineal female heirs were generally preferred over male collateral kin in the disposition of land. even among the middle class. Additionally, chattels were often quite equitably divided between heirs of both sexes and retlected a concern to provide some means of support for all family members.

Of course, women's experiences within the inheritance regime were tempered by gender. ethnicity, and class. Women were far less frequently testators than men. and generally only in widowhood. English-Protestant women predominated as legatees as the extensive estates of the middle class were carefully disposed of throughout the period. Still, the Irish were a respectable presence in the wills of the period. Intriguingly. Irish women were more frequently testatrices than English women - perhaps reflecting the 'passive ${ }^{-n}$ nature of English women's property in the area, or possibly indicating that many of the latter retired outside the study area in their widowhood and thus their wills have been recorded elsewhere

${ }^{\text {sh }}$ Vanciellen Davis, "Patriarchy From the Grave: Family Relations in $19^{\text {th }}$ Century New Brunswick Wills," Acadiensis, XIII 2 (Spring, 1984), 91-100.

${ }^{2}$ Davidoff and Hall use the concept of 'passive' property to describe property held by women from which they could obtain income but over which they could exercise no control. See Davidoff and Hall, Family Fortunes. 
By far. however, Irish women predominated over English women in intestacies both as intestates and as beneficiaries. In those matters that were formally administered. women were the beneficiaries of the customary practices and. ultimately. statutory law in Newtoundland that provided that real property be treated as chattels real in intestate estates. This removed land in intestate estates from the repercussions of primogeniture and stipulated a division along the same lines as chattels: one-third to the widow for her lifetime. ultimately to devolve to the children of the marriage: two-thirds equally divided among the children. Most of the intestate estates within the Irish community, however. would never have come before the courts. As such, their distributions were left to customary practice which, in the period of early settlement, likely favoured security for widows and dependent children and a continuation of the practice of partible inheritance that was still common in Ireland in the late $18^{\text {th }}$ and early $19^{\text {th }}$ centuries

As with the court system, then, the inheritance regime in the study area, in both formal and customary aspects. allowed considerable scope for women s inclusion. The local legal milieu also factored in yet another important aspect of Irish women's lives along the southern Avalon - the perception of Irish female sexuality. Chapter 8 will examine this further in a comparison of attitudes towards Irish womanhood and female respectability within the plebeian community, the local magistracy. and the Catholic church on the southern Avalon. 
Chapter 8 - -To fix [their] character ... in virtue and innocence": The regulation of Irish female sexuality on the southern Avalon

Historians of women have observed that an important indicator of patriarchal domination in a society is the degree to which it seeks to regulate women's bodies in terms of marriage, sexuality. and reproduction. To test the permeability of gender boundaries on the southern Avalon further, this chapter will examine the extent to which efforts were made to constrain irish womanhood on the southern Avalon - by plebeian culture. by the local middle-class community, by the Catholic church - and the degree to which Irish women were effective in carving out sexual territory for themselves in the period of early settlement. The court records of the southern district and the diary of Robert Carter. Jr. a magistrate in Ferryland, provide a backdrop as they reveal a striking scene from the life of an Irish-Newfoundland woman, Peggy Mountain.'

Peggy was the focus of an episode in the mid-1830s that began as a matrimonial matter in the local court but escalated into a public shaming incident. In early December. 1834. she brought her husband. Michael. before the local magistrates for desertion. Peggy was pregnant, and the court ordered that Michael support her and the expected baby; arrangements were to be made with a Patrick Welsh to take her into his home for the

'See P.ANL: GN 5/4/C/1. Ferryland. Box 1. ff. 57-60 and 64. Margaret.Moumtam 1: Michael.Mountain, December 23, 29 and 30, 1834, January 2. 12, and 19, and February 23. 1835; and MG 920, Robert Carter Diary, December 30 and 31, 1834 and January 1, 5. and 12. March 14, 15. 16, 19, 20, 21, 23. and 28, and May 6 and 9. 1835. Note that the name 'Margaret' appears in the court records, but throughout his diary entries. Carter refers to her by the more familiar form 'Peggy.' 
winter at Michael's expense. Michael initially indicated his willingness to comply "as well as his ability would allow," but the very next day, he reneged on his promise "by order of [Catholic parish priest] Father [Timothy] Browne." The priest 's influence was obviously very strong. for Michael held his ground. even when the magistrates ordered that he be put in jail on bread and water for a month tor contempt of court. Meanwhile, Peggy was temporarily placed at a local public house owned by Michael Devereaux, but Father Browne. "under threat of the highest nature he could inflict." ordered that the woman be removed, and as there was no other sheiter available. she was placed in the local jail. Carter was taken aback by the activities of Father Browne. He wrote in his diary

The Priest is inveterate against a poor unfortunate female under his displeasure and against whom he appears to direct his greatest malice and enmity. How such conduct will end let time decide

Matters came to a head rather quickly. Peggy was very ill. and while her food allowance from the magistrates was generous, "the accommodations were extremely uncomtonable. and the jailer reported that there were no coals for heating her cell. Still. the priest did not relent, but spoke out against Peggy in the chapel and wrote an open letter against her that was read publicly at the jail house. In the meantime. the local magistrates arranged for a

- Magistrates Carter. Thomas Wright, and Benjamin Sweetland ordered that she be allowed $5 \mathrm{lbs}$. bread. $3 \mathrm{l} / 2 \mathrm{lbs}$, pork. $1 / 2 \mathrm{lb}$. butter, 1 qt. flour. 1 pint of molasses. $1 / 4 \mathrm{lb}$ tea. and 3 lbs. fish per week. See PANL. GN 5/4/C/I. Box 1. f 60. Order. January 19. 1835. 
Mrs. Cahill to attend Peggy in the jail. Peggy finally gave birth to a daughter on a night so cold that the ink froze in Carter's office and the bread froze in his storeroom. The child survived only a few hours. Peggy was then moved to Mrs. Cahill's house, but again, the priest ordered that she be removed. and finally magistrate Carter, himself. took her in. Several days later, she left for St. John's in the Water Lily and slipped quietly out of the annals of the southern Avalon.

This vignette raises as many questions as it answers. Why was the priest so angry at Peggy? Did he blame her for the breakdown of the marriage? Did he suspect that the coming child was not her husband's'? What threat did he perceive in Peggy's continuing presence in the community? Although we are never told the specific reason for the shaming and ostracization of Peggy Mountain, we are left with a very strong impression that central to the issue was the priest's anxiety over aberrant' female sexuality. Especially intriguing is the sharp contrast between the responses of the local magistrates and the priest to Peggy Mountain's circumstances, tor they represent two important mechanisms for patrolling the boundaries of female sexuality ${ }^{3}$ - the legal system and formal religion.

As Newfoundland was a British fishing station/colony in the study period, an examination of hegemonic discourses on female sexuality in contemporary Britain

'This concept is borrowed from Edwards, who discusses "the patrolling of the boundaries of thought on the nature of the sexuality of women" in Female Sexuality, $p$. 173. 
provides context for the discussion ${ }^{+}$Within the English common law tradition by the $18^{\text {th }}$ century, patriarchal concerns about inheritance and the legitimacy of heirs had produced a legal regime that viewed women's bodies as the possessions of fathers or husbands Women - like children, servants, and other dependents - were deemed to be incapable of controlling their bodies, their skills, their labour. In particular, the chastity value of wives and daughters - their capacity to produce legitimate heirs - required protection. At the same time. enlightenment thought was challenging the association of sinfulness with sexuality that had been the legacy of $17^{\text {th }}$-century puritanism. Yet men and women did not have equal access to the sexual freedom of the age. Enlightenment men acknowledged

${ }^{1}$ The literature upon which the following discussion is based includes: Backhouse. Petticoats and Prejudice; Cullum and Baird, '.'A Woman's Lot"'. Clark. Struggle for the Breeches: Damousi. Depraved and Disorderly; Lenore Davidotf, "Regarding Some 'Old Husbands' Tales': Public and Private in Feminist History," in Davidoff. Worlds Between. pp. 227-76. Davidoff and Hall, Familv Fortunes; Dubinsky, "'Maidenly Girls “”. Karen Dubinsky. Improper Advances: Rape and Heterosexual Conflict in Ontario, 1880-1929 (Chicago and London: University of Chicago Press. 1993): Edwards. Female Sexuality: Hill. Women, Work, and Sexual Politics; Angela John, "Introduction," in John. ed. Unequal Opportunities, Susan Kingsley Kent, Sex and Suffrage in Britain, 1860-1914 (Princeton: Princeton University Press, 1987); Koditschek, "Gendering of the British Working Class": Lynda Nead. Myths of Sexuality: Representations of Women in Victorian Britain (Oxford: New York: Basil Blackwell, 1988): Poutanen. "Contours of Female Vagrancy". Roy Porter, "Mixed feelings: the Enlightenment and sexuality in eighteenth-century Britain," in Paul-Gabriel Bouce, ed., Sexuality in eighteenth-century Britain (Manchester: Manchester University Press. 1982). pp. 1-27: Rendall. Women in an Industrializing Society; Rose. Limited Livelihoods; Rousseau and Porter. "Introduction." in Rousseau and Porter, eds. Sexual underworlds, pp. 1-24, Mary Lyndon Shanley. Feminism. Marriage, and the Law in Victorian England 1850-1895 (Princeton: Princeton University Press. 1989), and Carol Smart. "Disruptive bodies and unruly sex: The regulation of reproduction and sexuality in the nineteenth century." in Carol Smart. ed. Regulating Womanhood: Historical essays on marriage, motherhood and sexuality (London: New York: Routledge, 1992), pp. 7-32 
female sexuality. but feared that in an uncontrolled state, it would pose a threat, not only to property and legitimacy, but to the very foundation of the social order, itself. because of its capacity to debauch the abstracted. rational [male] individualist who was at the core of civic virtue. The safest channel for female sexuality was, therefore, marriage and motherhood: female domesticity was glorified, while the division between the [masculine] public and [feminine] private domains intensified.

These discourses developed turther within the context of late $18^{\text {th }}$-century and early $19^{\text {th }}$-century evangelicalism, as it moided middle-class ideals of female domesticity. fragility. passivity, and dependence. Female sexuality was further constrained as middleclass ideology tashioned a dichotomized construction of woman as either trail, asexual vessel. embodied in the domesticated wife and mother. or temptress Eve. embodied in the prostitute; yet both constructions - respectable wife-mother and "fallen woman" - were necessary to satisfy an 'uncontrollable' male sexuality; and even the sexually passive wite and mother required regulation within the context of marriage and tamily in order to safeguard property and legitimacy. Separate sphere ideology intensified. Women who occupied spaces deemed to be 'public' or who demonstrated a capacity for social or economic independence, even physical hardiness. were increasingly seen as deviant. Oven temale sexuality was particularly problematic for it "disturbed the public/private division of space along gender lines so essential to the male spectator's mental mapping of the civic 
order ${ }^{\cdots s}$ Furthermore, as the $19^{\text {th }}$ century unfolded, male sexuality, although fashioned as "uncontrollable, was increasingly cordoned off into a biological function separate from rational masculinity, while female sexuality, by contrast, took a central position in the construction of womanhood. Woman became consumed by her 'sex.' and legal, medical. and scientific discourses embellished the construction of woman as 'the unruly body' . problematic by her very biological nature and requiring increased monitoring and regulation.

As noted in Chapter 5. British discourses on femininity were spilling over into Newfoundland society through its British legal regime and emerging local middle class. And as seen in Chapter 2. within the Newtoundland context. these perceptions of temale sexuality and respectability took on ethnic undertones as the Irish woman immigrant was constructed as vagrant and whore. a 'problem' requiring special regulation. In particular. the single Irish female servant required monitoring, for her social. economic. and sexual agency flouted middle-class feminine ideals of fragility. economic dependence. and sexual passivity. But how did these constructions of womanhood play out on the southern Avalon of Newfoundland, where community formation was still in its early stages and where gender relations were still contested terrain? And how were they received within the essentially plebeian Irish community of the area? In Britain, middle-class ideals of female domesticity, respectability, and sexual restraint were adopted and refashioned by

Sudith Walkowitz, City of Dreadful Delight: Narratives of Sexual Danger in LateVictorian London (Chicago: University of Chicago Press. 1992), p. 23 
the working class during the $19^{\text {th }}$ century to support their own bid for respectability in the Charist movement and to satisfy the male-centered agenda of trade unionism.

Furthermore, the British middle class encouraged this development of a working-class respectability - one that imitated middle-class ideals while maintaining sufficient difference to preserve class boundaries. But did similar processes occur on the southern Avalon?

\section{Irish womanhood within plebeian culture on the southern Avalon}

As earlier chapters have demonstrated. Irish plebeian women enjoved considerable status and authority within the context of migration and early settlement experiences on the southern Avalon. Their contribution to early community formation and the social and economic life of the area was vital. It was the increasing presence of women that provided the basis for a permanent population: and matrilineal bridges and matrilocal or uxorilocal residence patterns often featured in settlement patterns as male immigrants settled in their wives home communities. Furthermore. Irish plebeian women played an essential role in the almost total assimilation of the old English planter society in the area into the IrishCatholic ethnic group. Especially within plebeian culture. numerous English-Protestant patrilines were integrated into the Irish-Catholic population through marriage with IrishCatholic women. Irish women further reinforced the identity of the ethno-religious group as they mediated between natural and supernatural worlds in both formal Catholicism and a concurrent, ancient system of beliefs and customary practices. In addition. plebeian 
women were an integral force in economic life - in subsistence production, in hospitality and nursing services, as laundresses and seamstresses, as both domestic and fishing servants, as mistresses of fishing premises, and increasingly, as essential members of the shore crews of family production units in the fishery. Their vital economic role was reflected in customary testamentary practices which adhered to a relatively genderinclusive system of partible inheritance, contrasting with the English practice of primogeniture In the social sphere. women s information networks made undercurrents through the broader power relations of the community, functioning as a mechanism for enforcing communal standards and regulating access to limited resources. Women also participated in the politics of interpersonal confrontation - wielding power through verbal wrangling and physical violence in collective actions and individual interventions that were commonplace mechanisms tor informal conflict resolution in the days of early settlement.

It is evident. then. that within the plebeian community of the southern Avalon. Irish womanhood was not engulfed by the constraints of separate sphere ideology or constructions of passivity, fragility. and dependence. Nor was it readily channeled into tormal marriage - a key site for the regulation of fernale sexuality within the English common law tradition and middle-class ideology. In marriage, a woman was accessible to male sexual needs and could fulfill her destiny as reproducer of the race: yet her sexuality could be safely constrained within her roles of respectable wife and mother. Indeed. a woman's entire person was subsumed within marriage With the adoption of the principle of 'marital unity' into English common law, husband and wife became one legal entity in 
the person of the husband. As feme covert, a married woman could not own property." enter into contracts without her husband's approval, sue or be sued. Furthermore, the husband had sole rights to wife's services - both domestic and sexual (the latter, again reflecting a concern for patrilineal inheritance and the legitimacy of heirs). But while the formal marriage was institutionalized as the proper means of ordering society, within plebeian and working-class communities in the British Isles, informal marriages (e g..

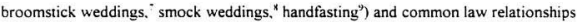
(e.g. "livin' tally ) were not only tolerated by local communities, but seen as legitimate

'As noted in Chapter 7. some women's property was excepted from coverture by trust agreements. but this still often entailed the relinquishment of control to male relatives. at least until widowhood.

In some English and Welsh communities. couples were married by the simple of expediency of placing a broom slantwise across the threshold of a house and jumping over it before witnesses. If either party touched or moved the broom, the marriage was not deemed valid. An informal divorce was just as easily effected by the couple (or. in some areas. the husband. only) stepping backwards over the broom before witnesses. See: Hill. Women, Work, and Sexual Politics, p. 206 and 218, and Stephen Parker. Informal Marriage, Cohabitation and the Law 1750-1989 (New York. St. Martin's Press. 1990). pp. 18 and 27.

*As the name suggests. a smock wedding was an informal ceremony in which the woman was married only in her smock. Because she brought nothing but her smock to the marriage, according to custom, she could maintain her separate identity and hence her own property, financial rights and obligations, as well as rights to her children. See Parker. Informal Marriage, pp. 24 and 69

'Handfasting was practised particularly in the Scottish highlands and in Wales. Couples joined hands and pledged to live together for a year and a day. If the two were compatible, the marriage was extended for life. If the couple wished to part. they merely turned their backs on each other and left the house through separate doors. See: Hill. Women, Work, and Sexual Politics, p. 206 and 218: and Parker. Informal Marriage, p. 18. 
forms of family relationships. ${ }^{10}$ The acceptance of these arrangements reflected a lesser concern about property, legitimacy, and inheritance than amongst the middle and upper classes - although the latter groups brought increasing pressures to bear in the $18^{\text {th }}$ century onwards to reform marriage law

Within the predominantly Irish plebeian community on the southern Avalon, such informal arrangements were similarly seen as acceptable. Indeed, this level of comfort was rooted in cultural tradition, for a different understanding of gender had evolved in Gaelic Ireland - one in which Celtic traditions of transhumance, communal property, and partible inheritance contrasted with English pre-occupations with private property and patrilineal inheritance: one in which the chastity requirement for wives and daughters was muted: one in which tolerance of informal marriage and divorce, illegitimacy. and closer degrees of consanguineous marriage deviated from English norms of sexual behaviour " this system of understanding was eroded over time by the incursions of English law and custom and an increasingly centralized and patriarchal Catholic church. Yet even through

${ }^{10}$ See, for example: Clark. Struggle for the Breeches: Hill. Women. Work, and Sexual Politics; Parker. Informal Marriage; Connolly, Priests and People; Rendall. Women in an Industrializing Society, Ross. Love and Toil; and James G. Snell, In the Shadows of Law Divorce in Canada, 1900-1939 (Toronto: Lniversity of Toronto Press. 1991) Berkin and Horowitz also note the frequency of informal separations and marriages in colonial America. See Berkin. First Generations, and Berkin and Horowitz. eds. . Women's Voices.

"Brown discusses the differences in systems of knowledge about gender between England and Gaelic Ireland in Good Wives. Nasty Wenches, pp. 33-7. See also Beresford. Celtic Women, Chapters 4 and 5. 
the early decades of the $19^{\text {th }}$ century, the Irish-Catholic church was struggling to control still prevalent practices of cohabitation and informal marriages in Ireland - with limited success in most rural areas as non-compliers were operating within local community norms. $^{12}$

There is no surviving evidence that customary marriage mechanisms such as the couple beggar, the runaway match, the elopement, or the abduction were transferred from Ireland to the southern Avalon ${ }^{13}$ - although it could be argued that the "strolling priests"

12 As noted in Chapter 5 in relation to supernaturalism and customary practices in general. the Irish-Catholic church was only able to lead its congregation where it wanted to go. The church would only make inroads on informal marriage practices when the community desired stricter regulation. Connolly argues that this tightening of control coincided with the demographic shift that occurred during the Great Famine. In preFamine Ireland. frequent subdivision of land had permitted a less rigid marital regime among the landless majority of the population. However. with the collapse of the potato cuiture and the decimation of the landless class at mid-century, the small farmer emerged as the dominant social group in Ireland. Farmers required a more cautious management of family land and greater control over marital arrangements in order to ensure the careful transfer of property to the following generation (reflected in the increasing incidence of the arranged 'match' in post-Famine Ireland and the wholesale shift to impartible inheritance). Church efforts to regulate sexual activity and marriage simply meshed with the social and economic requirements of this rising farmer group - hence. their increasing success after mid-century. See Connolly. Priests and People, Chapter 5.

${ }^{13}$ The 'elopement' is self-explanatory, but the other methods require clarification. 'Couple beggars' were suspended priests who made their livings from performing marriages outside church jurisdiction. They were frequently employed by couples who had difficulty in meeting the requirements of a formal marriage (e.g. lacking parental consent, being too closely related or of mixed religious backgrounds) or who simply could not afford the formal ceremony. The 'runaway match' was another option for a couple who could not obtain parental or clerical consent to their marriage. The pair would spend a night together at the home of a sympathetic relative or friend and. being thus 'compromised' (particularly the woman), forced the issue. Reluctant parents ofter relented and consented to a more formal marriage; and the church usually acquiesced after 
that plagued Prefect Apostolic, later Bishop, James O Donel in the early years of his mission at Newfoundland may have fit the bill of couple beggars. ${ }^{14}$ Certainly, marriages were performed by magistrates on the southern Avalon; and in the absence of Catholic clergy. some semblance of a religious ceremony was performed by lay people, including women. In addition, couples simply cohabited, in both long- and short-term arrangements. In 1789, Father Thomas Ewer, the Catholic priest stationed at the new Catholic mission in Ferryland, complained of the irregularity of marital arrangements in his parish. 15 What Ewer was observing were trequent incidents of common-law relationships and informal marriages, separations, and divorces in the area - part of a marital regime that kept fairly loose reins on female sexuality and. in effect, provided treedom for a number of

a period of penance had been observed. The 'abduction' employed similar pressure tactics: a young woman who had been abducted was 'compromised' and most parents and the church would ultimately agree to the couple's marriage. Some abductions were genuine. and were employed as a means of obtaining the fortunes of the daughters of wellto-do farming families. Others were staged, with a suitable display of maidenly reluctance on the part of the abductee. See Connolly, Priests and People, pp 200-10.

${ }^{1+}$ There were several priests on the island when $O$ Donel arrived who were functioning without faculties from any bishop. including Father Patrick Power. who attempted to establish himself as parish priest in Ferryland in opposition to O Donel's appointee, sparking the Ferryland riot (see Chapter 5). These missionaries claimed to be operating under ancient Papal authorization that was outside the jurisdiction of any bishop. Aside from their lack of compliance. $O$ Donel found their morals and habits to be egregious, and often wished himseif rid of these "strolling priests." See Byme, ed. Gentlemen-Bishops, pp. 1-142, the quotation comes from O Donel to Archbishop Trov. Dublin. December 24. 1789. pp 98-101.

${ }^{15}$ Byme. ed. Gentlemen Bishops, pp. 77-9. Father Ewer to Archbishop Troy. Dublin. November 30, 1789. 
women from the repercussions of coverture.

It is difficult to calibrate the extent of such relationships on the southern Avalon. given the lack of parish records for much of the study period. particularly before the 1820s However, the 1800 nominal census of 166 family groupings in Ferryland district suggests the existence of up to 33 such relationships. either currently or in the recent past (see Appendix D for discussion). References to informal arrangements also appeared occasionally in court hearings and governors correspondence. As part of the process of obtaining a grant in 1750 to Pigeon's Plantation in Ferryland, for example. Elizabeth Gobbet, who had lived with Elias Pigeon before his death. had to swear to the court at Ferryland that she was not currently married to one John Allen, but that they were "only keeping company together. ${ }^{-1 /}$ In a 1757 petition for maintenance. Elinor Coombs of Bay Bulls complained to Governor Edwards that her husband of one year, Michael, had been "persuaded" by Ellen Williams "to Quit his Wife and live with her which he at present Continues to do ${ }^{\circ 17}$ In 1759. Henry Tucker petitioned the Governor for title to a plantation of his deceased mother in Ferryland: the property was currently in the possession of one Thomas Power. with whom his mother had been living "in the state of

${ }^{16}$ PANL. GN 2/1/A, 1/115, 136 and 141/1750. Petition and Deposition of Elizabeth Gobbett, "commonly call'd Elizabeth Allen." August 27 and 31. 1750. and Patent granted to her by Governor Francis Drake. August 31, 1750.

1'P.ANL. GN 2/1/A. 2/396/1757. Order in response to Coombs' Petition, Governor Richard Edwards to Justices of the Peace at Bay Bulis, October 14. 1757. 
incontinency without being married to him. ${ }^{-18}$ In 1787. Hannah (Carney) and William McDaniel admitted to the local court that they were not actually married but living common law ${ }^{19}$ In 1802. Mary Stokes of St. Mary's sued William Kearney for her deceased mother's possessions because William and her mother had not been married but merely living "in adultery. "20 Such arrangements were not uncommon; and they were accepted by the local population (unless individual, material advantage could be gained by censure in formal petitions and civil actions) - especially when children were cared tor in stable family relationships and did not become a charge on the community

Even Irish plebeian women who entered into formal marriages on the southern Avalon were not readily constrained by gender ideology because of power they derived trom their vital role as co-producers in family economies. Like their counterparts in 18thcentury rural Ireland, married women had considerable input in family and community decision-making. wielding power both within and outside their households In both cultures, the bounds of female 'respectability' were reconciled with women's social and economic agency. and women (married and single) worked and socialized - even fought. smoked, and drank - in public areas

${ }^{18} \mathrm{PANL}$. GN 2/1/A. 3/44-5/1759. Order of Governor Richard Edwards to the tishing admirals and magistrates of Fertyland. October 13, 1759

1"PANL. GN 5/4/C/1. Ferryland. Box 1, ff. 25-6. Catharine Weston v. Hamah \& William .LFDamel, March 8, 1787.

20RL. 3409 N45. St Mary s. n. f. Lary Stokes v. William Kearney, September 30. 1802 . 
In general, then, middle-class anxieties about regulating female sexuality did not easily insinuate themseives into Irish plebeian culture on the southern Avalon because they did not mesh with the exigencies of day-to-day life. And, as noted in Chapter 5, plebeian women's status during the study period did not erode dramatically on the southern Avalon as it did in rural Ireland, where the marginalization of women from agricultural work and the collapse of both the domestic textile industry and the potato culture, that processes that had begun by the early $19^{\text {th }}$ century, led to a depreciation of women's economic and social status. Along the southern Avalon. by contrast. women's value as essential producers in the tishing economy, as well as reproducers of family work units within that economy. remained intact and forestalled any masculinist project within plebeian culture to circumscribe their lives

But what efforts were made by local middle-class administrators. merchants. and churchmen to rein in plebeian womanhood on the southern Avalon? To examine the question. let us return to the two key players in the Peggy Mountain story - the court system and the Catholic church. To what extent were they patrolling the boundaries of female sexuality in the study period?

\section{Irish plebeian womanhood and the cour system}

Within the British legal tradition, the court system - a patriarchal regime dominated by male legislators. judges, lawyers, and juries - was one of the chief mechanisms for the 
regulation of female sexuality. ${ }^{21}$ However, it is important to recognize women's agency within this framework and to anchor their experiences in specific historical contexts. As Chapter 6 has demonstrated. plebeian women were a vital part of the court life of the southern Avalon, using the court room as one of several alternative venues for conflict resolution. Their visibility in the court system and the often pragmatic treatment they received at the hands of magistrates in the area suggest that the legal milieu - at least at the local level - may not have been as 'inhospitable' as it was in many other British jurisdictions. Indeed. justices of the peace tended to accord relatively equitable treatment to the men and women who came before them. But how did local. middle-class magistrates respond to matters dealing specifically with female sexuality? An examination of such cases reveals evidence of a degree of laissez faire on the part of local magistrates in monitoring plebeian womanhood in the study area.

\subsubsection{Seduction and paternity suits}

Seduction law in the $18^{\text {th }}$ and early $19^{\text {th }}$ century fit comfortably with constructions of female sexuality as passive and woman as legal possession. This civil action - usually taken against a recalcitrant suitor or an employer who had compromised a female servant could only be initiated by a woman's legal guardian, not the woman herself. The tort was

"See: Backhouse. Petticoats and Prejudice; Cullum and Baird, "'.t Woman's Lot ${ }^{\cdots}$. Dubinsky, "'Maidenly Girls"'. and Edwards. Female Sexuality. 
based in the English common-law principle that a master could sue for the loss of a servant's services due to injury: just as a servant was seen to be the property of his or her master, so too was a single woman seen to be the property of her guardian (usually, her father). The guardian, not the woman, was considered to be the injured party in the action, and damages were evaluated in terms of the guardian's loss of a daughter's domestic services during pregnancy and lying-in - not in terms of her pain and suffering or reduced social and economic expectations :-

The seduction action was not uncommon in other jurisdictions. It is intriguing. then, that only one case survives in the court records for the study area. On October 4 . 1827. Catharine Delahunty complained that James H. Carter had seduced her daughter. Ellen. As Ellen's tather had been dead for 16 years. her mother initiated the suit and asked for compensation for the loss of Ellen's services in the amount of $£ 100$. Ellen, herself. appeared at the trial as a witness. She told the court that for the past year. Carter had persistently courted her attention, first by offers of work - knitting socks, cutting 'sounds' on the stage head - and then by more romantic dint of arranging assignations in the woods to cut firewood. According to Ellen, on their second excursion into the woods. Carter had "used some liberties", she had resisted his advances. but he had succeeded in having "connexion" with her. The couple went on several more woodcutting expeditions. and eventually. Ellen became pregnant. Her mother claimed that Ellen had been unable to

"'See Backhouse. Petticoats and Prejudice; and Dubinsky. "'Maidenly Girls.575 
carry out her duties from the seventh month of her pregnancy onwards, that her recuperation from childbirth had been slow, and that her capacity to work thereafter had been reduced as a result. Ellen's sister. Catharine Kelly, appeared as a witness for the defence, claiming that she had recently had to warn Ellen against "walking with Robert Brine ... a married man." Her mother countered with character witness Martin Conway. who swore that he had "never seen Ellen Delahunty conduct herself differently from what well behaved Girls in her situation in life do." The effort by the defendant to present Ellen as an 'unchaste' woman would not have disproved Catharine's suit, as the action was for compensation for loss of household services only: however. he may have been hoping to lower the award for 'damaged goods. Certainly, the jury awarded far less than the §100 pounds sought by Catharine; but the assessed damages - $230 \mathrm{Cy}$ - were still substantial for the period. and a significant award for this particular cour ${ }^{23}$ Indeed, given that seduction suits generally garnered higher awards than paternity suits and given that James Carter was a member of a wealthy middle-class family in Ferryland. Catharine and Ellen demonstrated a fair degree of legal savvy in proceeding in this manner Certainly, no local awards under the bastardy law approached $£ 30$ during the period.

Still, the bastardy action provided another option for pregnant women who wished to make reluctant fathers live up to their paternal responsibilities Lnlike the seduction suit. the bastardy action was taken by the woman. herseif. Backhouse says that in Canada.

\footnotetext{
${ }^{3} \mathrm{PANL}$. GN 5/2/C/1. Ferryland. Box 1, ff. 142-5. Catharine Delahunn. 1: Sames H. Carter. October 4. 1827.
} 
such proceedings were neither as prevalent nor as successful as seduction actions. But on the southern Avalon. the bastardy suit was the more common approach - suggesting. again. a degree of female agency in the court life of the area. Court records reveal nine bastardy cases for the period. Granted. this number was not overwhelming. and suggests that either there were other, informal community mechanisms to bring to bear on reluctant fathers. or that single mothers on the southern Avalon had better social and economic prospects on the southern Avalon than elsewhere (e.g., reasonable expectations of work. future marriage, or family support) ${ }^{2+}$ Perhaps the mere threat of legal action encouraged

${ }^{24}$ Illegitimacy was deemed a serious breach of moral standards in most British and colonial jurisdictions, it was frowned upon by local communities and condemned and regulated by civil and religious leaders alike, with single mothers bearing the brunt of the social shame. See, for example: Backhouse. Petticoats and Prejudice; Berkin and Horowitz, eds. Women's Voices; Cullum and Baird. "A Woman's Lot "'. Errington. Wives and Mothers; Allyson N May, "'She at first denied it Intanticide Trials at the Old Bailey." in Frith. ed women \& history, pp. 19-49: and Richter. "Free Women." Still. bundling' (parent-approved. pre-marital sex) and pre-marital pregnancy were tolerated within plebeian communities, provided couples were moving towards a stable family arrangement. See Hill. Women, Work, and Sexual Politics, pp 174-95. The Irish literature also indicates that illegitimacy brought tremendous social shame to both the mother and child: however, much of the discussion is weighted towards the $19^{\text {th }}$ century. when women's overall status was in decline. Irish historians point to the low illegitimacy rates in Ireland compared with contemporary European rates and suggest that this was due to early and universal marriage before the Great Famine as well as a sexual chasteness that ran contrary to the sexual ribaldry reflected in Gaelic literature and customs. However, illegitimate birth records do not take account of pre-nuptial conceptions. which are impossible to trace but may have been more frequent than many Irish historians have allowed for (Connolly. for example. optimistically sets them at one out of ten births vis-avis two out of five for England: Mageean. however. notes that they may have been quite high and thus the extent of premarital sexual activity in Ireland is masked by the statistics). In such cases, local community mechanisms likely came into play to encourage the couple to marry. See, for example: Connell. Irish Peasant Society, Chapter 2: Connolly. Priests and People, pp. 186-218. Diner. Erin's Daughters, pp. 21-24, Mageean. "Irish Women's 
some fathers towards financial or marital commitment. Still, it is significant that when less formal methods failed, these nine women were willing to take the public and political action of bringing the purported fathers of their children to court and that in doing so, they acted as autonomous legal entities rather than legal dependents.

The final disposition of these cases appears in only six of the nine records: in all six. support for the child was ordered: and in three of these cases. the mothers were also awarded lying-in expenses. In April, 1791, for example, Carherine Audle (also. Oudle), a single woman of Ferryland, appeared before the magistrates and named John Murray. Sr. a tisherman of Ferryland as the father of her unborn child. The court immediately ordered Murray to appear before them and give a bond for the maintenance of the child. Catherine gave birth to a boy on April 22, and on April 25, the court issued an order of filiation and maintenance. Murray may have disputed paternity of the child. for the wording of the order indicates that he "hath not shewd sufficient Cause why he should not be the reputed Father of the Child." Nonetheless, the mother's affidavit prevailed. and Murray was ordered to pay the tollowing support and expenses

the sum of ten shillings. toward the Laving in of the $s^{d}$ Catherine Audle $\& y^{*}$ maintenance of $\mathrm{y}^{\varepsilon} \mathrm{s}^{4}$. Child, to the time of making this Order - ... the sum of two shillings weekly \& ever $[y]$ week from this present time for the maintenance of the $s^{4}$. Child - so long as the Child shall be chargeable to the $s^{4}$. Harbour - . [or alternatively] weekly \& ever [y] week $\mathrm{y}^{c}$ sum of two shillings \& sixpence, in Case the $s^{d}$ Catherine Audle shall not Nurse or

Prospects.“ pp. 78-9; Nolan, Ourselves Alone, pp. 28 and 35 
take Care of the Child herself $\_$-s

That same year. Manus Butler admitted to fathering the child born of Elizabeth Carney (likely of Ferryland) the previous August. The court was very thorough in its support order for £9 196 , detailing expenses for a midwife's attendance (£1.1 0), nursing services for a childbed illness suffered by Elizabeth ( 22.2 .0 ), and the nursing and clothing of the child from its birth the previous August to the May court heanng date ( 26.166 ). The following week, the magistrates ordered continuing maintenance for the child in the amount of 3 s. $6 \mathrm{~d}$ per week : ${ }^{\text {a }}$

There is no indication that either the mother's character or her sexual history was called into question in these cases. In addition, the mother's word seemed sufficient to establish paternity. although in three of the nine cases. the fathers also admitted the claim In four of the cases, the purported tathers had already left the district - although this was usually before the bastardy claim was actually made. reflecting again the transience of the male fishing population. In one case, more dramatically, a reluctant tàther, William Walsh. ran from the courtroom and later successtilly resisted arrest by brandishing a large knite at the two constables who had been despatched to fetch him back. Walsh was not

"PANL. GN 5/4/C/1, Ferryland. Box 1, n.f., Catherime Audle [also. Oudle/ : Johm Murran: Sr. April 3/4 (both dates appear in record) and 25, 1791. This case is also noted in English. "Reception of Law." pp. 39-40.

${ }^{3}$ P.ANL. GN 5/4/C/1. Ferryland. Box 1. n.f.. Elizabeth Carney v. Manus Butler. May 16 and 23, 1791. Also noted in English, "Reception of Law." p. 40. 
apprehended. but several of his companions were later fined for helping him escape justice." Indeed, the court took pains to arrest absconding fathers or, if unsuccessful, to attach any wages remaining in the hands of employers in the district. Of course, the magistrates were primarily motivated by the concern that mother and child would become a charge on the community; this is evident in the stock phrasing of various sworn complaints. laid out in the language of the court: "the said bastard Child is likely to become chargeable to the Port of ....-28 But the bastardy law provided women with some

"PANL. GN 5/4/C/1. Ferryland. Box 1. ff 86-8, 95. Largaret Mackey 1: William Walsh. April 29 and May 9, 1836, and February 15, 1837

28 The urgency of this issue was noted by local Colonial Secretary Edward B Brenton to Attorney General James Simms in 1826 after two recent cases had come before the magistrates involving mothers who had abandoned their illegitimate children. Brenton asked what measures could be taken against "these unnatural parents so as to compel them to suppor their children or to punish them for the desertion of them." Simms replied that the English law would not apply, interwoven as it was with a system of parochial poor law that did not exist in Newfoundland. The property of offending parents could be attached. but the mothers in these cases appeared to be "as destitute of property as of principle." Only legislative enactment would be effectual to check such offences, he felt. See PANL, GN 2/1/A, 35/329-331/1826. Edward Brenton to James Simms. April 28. 1826 and James Simms to Edward Brenton. April 29. 1826. The issue was given priority by the newly formed House of Assembly in Newfoundland with the early passage (on June 12. 1834, in its second session) of 4 William 4 , (ap. - An Act to provicle for the Haintenance of Bastard Children. By the terms of this Act. a woman about to be delivered of an illegitimate child could swear to its paternity before a justice of the peace The purported father was to provide security for maintenance of the child or. in default. be jailed. If he felt he had been wrongfully charged, "or if the Person charging him be a Woman of ill-fame, or a common Whore," he had recourse to appeal in the next quarter sessions (Note the discrimination against the 'unchaste' woman in the statutory law: whether this scruple was closely adhered to by the local courts in bastardy actions is uncertain, but as noted, there was no reference to the previous character of the mother in any of the southern Avalon cases herein.) To ensure further that the child would not become a charge on the community, any two magistrates could, at their discretion. require 
recourse to financial assistance and the opportunity to act as independent agents in the court. Furthermore, local magistrates were receptive to their claims and made reasonable efforts to have fathers acknowledge their responsibilities. ${ }^{-9}$

\subsubsection{Intanticide and concealment of birth}

The vast majority of defendants in infanticide and concealment of birth cases in British and colonial courts shared a similar profile: they were young. unmarried, plebeian or working-class women, especially servants. Most of these women, already caught in difficult socio-economic circumstances. acted out of fear of the social disgrace and reduced emplovment prospects that unwed motherhood would bring. Courts were generally reluctant to prosecute and juries were generally reluctant to convict on

either the mother or the father to provide security in the amount of $₹ 20$ Stg. to be disbursed by the magistrates for the care of the child. Ultimately. then, both mother and tather were deemed financially responsible for the child. Of the nine cases examined on the southern Avalor, five were heard before the passage of this Act, four, atter its enactment.

$\therefore$ Absent among southern Avalon prosecutions, and Newfoundland cases in general, were the fornication prosecutions that were still common in England and colonial America up to the late $18^{\text {th }}$ century. In these other jurisdictions. both male and female parties to sexual intercourse outside marriage had been punished by $17^{\text {th }}$ - and early $18^{\text {th }}$. century courts. But by the middle of the $18^{\text {th }}$ century. perceptions of women as moral guardians had constructed fornication as a 'woman's crime." although this perception was. itself. being challenged by the end of the century as the concept of 'seduction' gained greater currency. See Uirich. A Midwife's Tale, pp. 148-9. As noted above, however, the seduction action had its own pitfalls for women in terms of their being perceived as sexually passive possessions of guardians. 
infanticide charges; the lesser charge of concealment was more often successfully tried. although even in such cases. the court often demonstrated a certain tolerance, or at least an understanding. of the desperation and limited options that motivated the mothers actions (although sentences for mothers convicted of concealment in Newfoundland were generally heavier than those meted out in Canada)

Remarkably, no cases of infanticide or concealment of birth survive in the court records for the study area. It is unlikely that local courts would have turned a blind eve to such matters. However, as noted earlier, illegitimacy did not carry the same stigma within the Irish plebeian tradition on the southern Avalon as it did in English middle-class ideology. Also, it is likely that family or community support cushioned the hardship of illegitimate births and that single plebeian mothers were thus in a stronger position to survive socially and economically than those in many other areas. Furthermore, given the responsiveness of local magistrates. plebeian women had access to the court system to seek financial assistance from reluctant fathers. Thus, the fear of unwed motherhood was likely not as keenly felt on the southern Avalon as in certain other jurisdictions "

"See. for example: Backhouse, Petticoats and Prejudice; Berkin and Horowitz. eds., Women's Voices; Cullum and Baird, "'A Woman's Lot "', May, "'She at first denied it ${ }^{\prime}$ : and Llrich. Good Wives.

${ }^{31}$ Connell notes that infanticide rates were more significant than illegitimacy rates in Ireland. but again. he is working with data from the $19^{\text {th }}$ century. when women's economic and social options were in decline. See Conneil, Irish Peasant Society, Chapter 2. 


\subsubsection{Prostitution}

The manifestation of female sexuality that most induced patriarchal anxieties about the moral order was prostitution. More than any other woman, the prostitute. with her blatant sexual agency, flouted middle-class constructions of female passivity and threatened the rationality and self-control that defined middle-class masculinity Furthermore, by conducting her business in public. she transgressed the caretul ordering of separate spheres Yet, ironically. courts in British jurisdictions often treated prostitutes with a degree of tolerance, seeing them as a necessary social evil, they were an essential component of servicing an 'uncontrollable' male lust that was bevond the capacity of respectable' wives and mothers. Thus, only the most outrageous examples received the full brunt of the legal system. 12

Intriguingly, no evidence survives in the court records of the southern Avalon of any specific charges laid against women for prostitution or the catchall vagrancy. On the surtace, this suggests that there was a dearth of concern among local constables and magistrates about women of "ill repute." There were, however, two sexual assault cases in

${ }^{32}$ See: Backhouse. Petticoats and Prejudice; Edwards. Female Sexuality, Randolph Trumbach. "Modern prostitution and gender in Fammy Hill: libertine and domesticated fantasy," in Rousseau and Porter, eds. Sexual underworlds, pp. 69-85. Poutanen notes. however. an increased targeting of female vagrancy. particularly prostitution. in Montreal through the early decades of the $19^{\text {th }}$ century as uncertainties and unrest arising from changing socio-economic conditions induced an emerging male bourgeoisie to demand greater state control of the street life of the city. See Poutanen, "Contours of Female Vagrancy." 
which the court did take action against female complainants who were deemed to be threats to the moral order. In 1773, for example, Mary Keating accused Stephen Kennely of attempting to sexually assault her. He had come into her house, she claimed. and "sat upon the Bed after her husband went out... [and] treated her in a barbarous and cruel manner wanting to get his will of her." Kennely would have killed her. Mary claimed. had not one John M Graugh prevented him. Various "principal Inhabitants" of Ferryland testified, however, that the Keating house was a "disorderly house" where they entertained "riotous friends", the defendant. Kennely. by contrast, was represented as "a man of an Honest Character." On the basis of these character profiles. the magistrates ordered that Mary and her husband be "turned out of the country." ${ }^{33}$ The court took similar action against Catharine Power of Renews, a woman notorious for her drunken and promiscuous behaviour. when she complained of a sexual assault in 1806 . Catharine alleged that William Deringwater, or Drinkwater. had entered her house sometime between 10:00 p m and midnight while she was sieeping and had assaulted and ill treated her. The jury. however, was not convinced by the "unsoported solitary deposition" of this "woman of" infamous character " Furthermore. a defence witness swore that he had put Catherine to bed intoxicated earlier in the evening, and three others testified that Deringwater had been at his own home at the time of the alleged assault. The court acquitted the defendant and

"PRL. 340.9 N45. n.f., Mary Keating v. Slephen Kennely. September 14. 1773: see also Mannion Name File. Ferryland. "Keating. Mary." 
ordered that the plaintiff, Catharine, be sent back to Ireland at the first opportunity ${ }^{34}$

The most intriguing aspect of each of these two cases is the order for removal of the complainant. As noted in Chapter 6, local courts issued sentences of transportation to the home country with some regularity in cases involving property crimes, especially in the $18^{\text {th }}$ century. However, in terms of breaches of the peace or crimes against the person, an order of deportation was generally issued only in the most extreme cases of violence or riotous behaviour. Therefore, the banishment of Mary Keating and Catharine Power suggests that the behaviour of these women of "infamous character" was similarly seen as an extreme threat to the moral and social order; that, despite a generally relaxed attitude towards the conduct of plebeian women, there were some boundaries set for their sexual behaviour by the middle-class magistrates of the southern Avalon.

\section{2.+ Rape}

While plebeian women on the southern Avalon were often aggressors as weil as victims of physical violence in the study period, the status of rape victim was exclusively a temale preserve in $18^{\text {th }}$ - and $19^{\text {th }}$-century courts. Incidents of rape, like other forms of male violence against women. are seen as indicators of unequal power relations between men and women. It is again intriguing, then, that only eight cases involving complaints of

\footnotetext{
${ }^{34}$ PANL. GN 5/4/C/1. Ferryland, Box 1, n.f., Catharine Power at the Sitit of the (rownv. William Deringwater, alias Drinkwater. September 20. 1806.
} 
rape or assault with intent to commit rape survive in the local coun records for the period Of course, such incidents were likely under-reported; on the other hand, women s ability to fend for themselves in physical confrontations may have acted as a deterrent to sexual assault as well. Of the eight reported cases. three resulted in guilty verdicts and three were dismissed: in another, the defendant was cleared of the rape charge but found guilty of a common assault, any record of the disposition of the remaining case has not survived. Two of the three dismissals emanated from Keating $v$. Kennely and Power v. Deringuater (above): there is insufficient detail in the records on the third case to determine the reason for discharge."

This middling conviction rate might initially suggest an ambivalent attitude towards the crime on the part of the southern Avalon magistrates. In the cases resulting in convictions. however. there appeared to have been a certain responsiveness to women complainants on the par of the magistrates and juries. Corroboration was obviously not essential to proving the charge. for in only one of the three cases - the attempted rape of Mary Jenkins - did the complainant provide a corroborating witness. In the Jenkins matter, the main offender had absconded and could not be brought to trial, but two of his companions were deemed accessories and ordered to pay fines ( $\mathbf{\Sigma} 1$ each) and actual

"In 1831, a jury acquitted John Power of assault with intent to commit rape after hearing the testimony of two witnesses - alleged victim Mary Ann Lanine and Bridget Lanine. Whether the two women substantiated or contradicted each other's testimony is not clear from the record, but at the end of the day. Power was a free man. See PANL. GN 5/2/C/1. Box 1. ff. 267-8, Rex. on the prosecution of Mary A. Lamine, I: Johm Power. October 14. 1831 . 
compensation to the victim ( $₹ 2$ each) - an unusual resolution of an assault case for this particular court. Even the witness for the complainant - a timid shoemaker who had been present in the house at the time of the attempted rape - was tined for not rendering assistance.: In the other two cases ending in convictions (in 1829 and 1841 ). the defendants were given prison terms of 12 months and one month. respectively. Both attacks - but particularly the 1829 assault in which the defendant violently beat an Aquaforte woman on the public road "with an intent... against her will feloniously to ravish and carnally know [her [" - appeared to have warranted sentences bevond the court's usual range of smail fines and orders to keep the peace for lesser assaults.

In many jurisdictions, the treatment of female sexuality as a precipitating factor in sexual assault made the rape trial an ordeal for victims. Consistently and effectively. "a model of temale sexuality as ugent provocateur. temptress or seductress ${ }^{-1+1}$ was deploỵed by the defence as the sexual. moral. and social history of the complainant and her previous relationship with the accused were minutely examined to determine how she had

'PANL. GN 5/4/C/1. Fertyland. Box 1. n.f. Re: Larn Jenkins. February 24. 1794 (this is the date that appears in the records. but the year was more likely 1795. as the record talls between matters heard November 17. 1794. and May 20, 1795).

'PANL: GN 5/4/C/1. Ferryland. Box 1. t. 2. Rex เ: Timorhy Callahan. August 21. 1829: GN 5/2, C/1. Ferryland. Box 1. ff. 227 and 229-30. Rex v: Timothy Callehan, October 29. 1830; GN 5/4/C'1. Ferryland. Box 2, n.t.. Wary Place v. John Higgins. February 17. $18+1$.

${ }^{4}$ Edwards. Female Sexuality, p. 50. See also: Backhouse. Petticoats and Prejudice: Cullum and Baird. 'AA Woman's Lot ${ }^{\cdots}$; and Dubinsky. "'Maidenly Girls. ${ }^{\prime \prime}$ 
'contributed to her own downfall.' On the southern Avalon, however, the former character of the woman complainant was called into question in only two cases - the alleged assaults of Mary Keating and Catharine Power (above) - reflecting the persistent attitude in the justice system that women of 'ill repute' could not be raped. Yet only in the case of Mary Keating did the court make its finding solely on the basis of the previous characters of the parties involved (although it is possible that it may have come to the same decision in Power v. Deringwater, even without the four defence witnesses, based on the flagrant 'immorality' of Catharine Power).

\subsubsection{Loss of consortium}

As noted above, under English common law, a husband had legal rights to his wife's body, with exclusive rights to her domestic and sexual services. If denied her sexual services. a husband could seek a writ of habeas corpus to force his wife to return to the matrimonial bed. He could also initiate various court actions against a third party and demand compensation for loss of consortium: criminal conversation (having sexual relations with the wife), enticement (encouraging the wife to leave her husband); and harbouring (providing the wife with refuge after she had run away). Wives had no similar recourse in the law.

There were only two brief references to matters respecting loss of consortium on the southem Avalon during the study period. In the 1773 court records for Ferryland 
district, a court order directed Simon Pendergrass to pay Edward Farrel £ 5 in compensation for having had "criminal correspondence" with Farrel's wife - a relationship that had apparently been going on "for some time. "39) The other matter was fleetingly referred to in the letterbooks of the colonial secretary's office at Newfoundland. In October, 1760. Governor James Webb ordered William Jackson. JP of the district of Trepassey, "to take up and send hereunder custody one Clement $\mathrm{O}^{\prime} \mathrm{Neal}$, who has carried with him ye Wife of Jos' Fitzpatrick as Likewise all his Moveable Effects. " in It is difficult to tell from the wording of the order whether $\mathrm{O}^{+}$Neal and his effects were to be arrested (in which case, a comma should have appeared after "Fitzpatrick") or whether O Neal had caused offence by taking away both the wife and the effects of Fitzpatrick (as the given punctuation indicates). If the latter, it would be interesting to know which was deemed to have caused the greater injury to Fitzpatrick - the loss of his wife or his other 'possessions. However, given the standard wording of court orders and punctuation stylings of the period. the former interpretation is likely correct.

While details are sketchy. there does appear to be a difference in the way the two cases were handled - possibly reflecting a difference in attitude between the authorities involved (local vis-a-vis central). The Ferryland court seems to have dealt fairly leniently

\footnotetext{
${ }^{39}$ PRL. 3409 N45, n.f., Order. William Parker. Surrogate. to Simon Pendergrass. October 8. 1774; see also Mannion Name File. Ferryland, "Farrell. Ed "

${ }^{40}$ P.ANL. GN 2/1/A. 3/115/1760, Order of Governor James Webb to William Jackson. JP. District of Trepassev, October 6, 1760.
} 
with the 1773 case: a small payment was ordered to compensate the plaintiff. Farrel. for a rather long-term encroachment on his rights. The other order, issued by the governor after a hearing at St. John's, had a more ominous and punitive tone: $O$ 'Neal was to be arrested and his effects, attached; not stated but implied was that Mrs. Fitzpatrick was to return to the matrimonial home and bed. While the evidence is meager. it is possible that the local magistrates had a laxer attitude towards the issue of consortium than authorities more removed from local circumstances.

Certainly, the scarcity of consortium cases for the study period ties in with the prevalence of intormal marital arrangements. the acceptance of informal separation and divorce, and the lack of pre-occupation with primogeniture and legitimacy in the study area - all elements of a marriage regime that kept relatively loose control over female sexuality.

\subsubsection{Wifebeating}

The southern district court records for the period reveal only four cases involving domestic violence against women. As with incidents of rape. domestic violence was likely under-reported, although the low numbers may have been a further indicator of plebeian women's significant status within their families and their ability to hold their own in physical struggles. At any rate, the magistrates on the southern Avalon appeared to be sympathetic to the woman complainant in each of the reported cases. In two matters. the 
alleged abusers were made to enter into peace bonds and ordered to return for trial: untorunately, the final judgments in these two cases were either not recorded or have not survived. The other two matters resulted in what were essentially court orders for separation and maintenance. There was no indication in the records that in their handling of the four cases. the magistrates made any effort to encourage the complainants to return to their husbands.

Indeed, in a 1791 matter involving extreme domestic violence. the court moved quickly to protect wife and children and remove them from the abusive situation. Margarett Hanahan (also. Hanrahan) complained on January 31 that upon returning home the previous evening, she had discovered her husband. Thomas, trying to suffocate their youngest child and that he had later "ill-used" and flogged their older child with a bough "to oblidge it to make water." When Margarett had tried to interfere. Thomas had threatened her with a hatchet. The court observed the marks of violence on wife and children and sentenced Thomas to 39 lashes on the bare back as well as imprisonment until he could provide security for a peace bond. The magistrates also granted Margarett's request to be separated from her husband. And two and a half months later, the cour ordered the husband to leave the district - effectively. an order for divorce over 175 years before the Supreme Court of Newfoundland had jurisdiction to grant divorces. ${ }^{41}$ Given

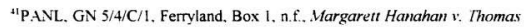
Hanaham. January 31, February 1, and April 11,1791. English discusses this case and interprets the judgment as a "virtual divorce" in "Reception of Law," pp $40-2$ 
the flexible marital regime at the local level, Margrett was certainly free to move into an informal family arrangement; indeed, she did precisely this, for in the 1800 census, she and her two children were recorded as living with John Ellis at Ferryland. ${ }^{12}$

In none of the southern Avalon cases were women forced to remain in abusive marriages or be deemed to have deserted and forfeited all rights to maintenance and child custody. Furthermore, the outcome of Hamahan v. Hamahan indicated the court's willingness to punish excessively violent husbands in kind. The cases were few, but their disposition certainly contrasted with $18^{\text {th }}$ - and $19^{\text {th }}$-century cases in England and planter Nova Scotia, for example, in which courts generally dealt with wifebeaters rather leniently and encouraged women to return to abusive situations for the sake of preserving the marriage, regardless of the violence of the assault - an approach which frequently placed battered women in even greater danger and which certainly discouraged the reporting of domestic violence $^{15}$

${ }^{12}$ PANL. MG 205. Pole Papers. 1799-1800. This option was also pursued by other separated or deserted women in the area (see below)

${ }^{43}$ See, for example: Anna Clark, "Humanity or justice? Wifebeating and the law in the eighteenth and nineteenth centuries." in Smart, ed. Regulating Womanhood, pp. 187206: Margaret R. Hunt. "The great danger she had reason to believe she was in: Wifebeating in the Eighteenth Century," in Frith, ed, women \& history, pp. 81-102: Norton. "The Dark Side." pp. 183-4; Hill, Women, Work, and Sexual Politics; and Shanley. Feminism. Marriage, and the Law. 


\subsubsection{Desertion, separation, and maintenance}

Local magistrates were not often called upon to hear matters involving separation and maintenance. Indeed. Newfoundland courts did not obtain jurisdiction in matrimonial causes until 1947 and in the granting of divorce until 1967. ${ }^{\text {th }}$ They did. however. exercise a de facto jurisdiction in granting separations, or divorces a mensa et thoro ['from bed and board ${ }^{\circ}$. and support for deserted spouses and children. ${ }^{15}$ On these bases, at least seven

\section{"English. "Fishing Schooner," p. 84.}

${ }^{15}$ Again. the priority of ensuring that deserted families not become a charge on the community was evidenced by the early passage by the new local legislature of $+\mathrm{Wm}$. $t$. ('ap. 8. An Act to afford Relief to wres and ( hildren. Deserted by their Hushands and Parents (June 12. 1834). Here was an acknowledgment of women as legal entities with responsibilities under the law, for the Act stipulated that "any Person. being such Husband, Father or Horher" who had absconded or was about to leave "his or her usual place of abode" without making provision for a wife, child. or children left behind was to be apprehended and required to enter into security to provide reasonable support for the deserted family members. Upon retusal or neglect of this requirement, justices or magistrates were empowered to attach wages or seize goods and chattels belonging to the offender of sufficient value to provide sufficient maintenance. The Act stated that upon "willful" refusal or neglect on the part of the offender. the said "Father. Husband or Wife shall be deemed a Rogue and Vagabond [epithets usually reserved for male recusants in colonial courts]." and could, at the discretion of the justices or magistrates, be imprisoned for a month on bread and water (an option taken by the Ferryland magistrates against Michael Mountain). Further, the Act provided that if "any person being a Father. Husband or Mother, and being able to work, by his or her neglect of work, or by spending his or her money in Ale Houses, Taverns, or in any other wasteful and improper manner," thus failed to provide support, would be "deemed to be an idle and disorderly person." and the justices or magistrates were empowered to sentence the offender to prison and hard labour. "or. not being a female, to Labour on the Public Roads," for a period not exceeding 14 davs. [Italics added throughout.] As in the case of bastardy actions, any person who felt him- or herself wrongly charged could appeal the decision in the next quarter sessions. While this legislation did not explore the possibility of a wife's deserting 
matrimonial cases presented themselves during the study period.

Only one of the actions was initiated by the husband. This case was exceptional for the southern Avalon in that it was the only matter in which a husband was awarded a form of child support. In 1750. Philip Moloy (also. Molloy) of Ferryland petitioned the cour for redress after his wife had turned him and his child (whether a child of the marriage is not specified) out of the house. After examining Mrs. Moloy and several local inhabitants, the court ordered that "the Wife do pay him three Pounds which is to be in full of all Demands he shall pretend to have on the House and Goods in Consideration that he has a Child to maintain."

In the remaining six cases. wives maintained custody of the children of the marriage - perhaps a turther reflection of the more transient nature of the male population through much of the period. but again demonstrating the stabilizing role of women in eariy communities. All six of these cases were initiated by wives, on grounds of desertion, neglect. and/or ill treatment. and the local magistrates again demonstrated pragmatism and responsiveness to the women involved - sanctioning de facto separations and awarding maintenance for wives and children. In a 1791 case. for example. the court ordered that

a husband, and denied women offenders the dubious honour of serving their time on road work (perhaps, too public a spectacle; evidently. other forms of hard labour were permitted), it was relatively gender-inclusive, recognizing the financial accountability of both men and women in the support of their families. Of the southern tvalon cases herein. only Loumiain v. Moumtain was heard after the passage of this Act.

${ }^{16}$ P.ANL. GN 2/1/A, 1/115/1750, Re: Petition of Philip Moloy; August 27. 1750. 
Philip Forestall provide support to his wife and child in the amount of 3 s.6d. per week and ordered that mories be stopped from his wages for this purpose, the magistrates also directed the local constable to put Mrs. Forestall in possession of the family home Effectively, the court was acknowledging a separation that was already playing out on the ground and ensuring that wife and child were provided for There was no indication in the records that Mrs. Forestall was encouraged by the magistrates to reconcile with her husband ${ }^{+7}$

Indeed, none of the wives in these six matters were pressured by the court to return to their spouses, and support was ordered whether it had been the wife or the husband who had deserted or committed marital infidelity. Furthermore, women who had separated from their husbands were not expected to live the remainder of their lives in sexual denial or forfeit all rights to child custody and support. ${ }^{\text {}}$. On March 14. 1791, for

${ }^{17}$ PANL, GN 5/4/C/1, Ferryland. Box 1, n.f., Re: Forestall. June 13. 1791. Also noted in English, "Reception of Law,"

${ }^{18}$ Again, this contrasts with cases in most British jurisdictions, where the character of the wife. both during marriage and after separation. was at issue in awarding child custody and support. Within the English common-law tradition, wives had to prove their 'worthiness' to the court. Those who committed adultery or deserted the marriage except under the most extreme circumstances (e.g. the husband's adultery in combination with violent abuse, incest. or bestiality) lost entitlement to custody and maintenance. Indeed. a wife who had sexual relations with a man other than her husband even after separation was no longer entitled to support. See, for example: Backhouse. Petticoats and Prejudice; Cullum and Baird, "'A Woman's Lot "'. Errington, Wives and Mothers: Hill. Women, Work, and Sexual Politics; Joan Perkin, Women and Marriage in NineteenthCentury England (Chicago: Lyceum Books, 1989); and Smith. "Desertion and Widowhood " 
example. Mary Dunn laid a complaint that her husband. Timothy Dunn. had refused to support their child and asked tor the court's assistance. The court ordered that $£ 5$ be retained from Tim's wages for the maintenance of the child " The recording of the case is sparse and there is an automatic inclination to interpret the situation in terms of a husband's desertion of wife and child. It is possible. however, that Mary may have been the one to leave the marriage, especially given that maintenance was awarded for the child only Certainly, the nominal census taken for the district several years later, in 1800 . indicates that Mary was cohabiting with a William Hennecy. She was then using the name "Mary McCue" - possibly her maiden name, or the surname of an intervening husband/partner. In the 1800 household were Mary's child by Tim. Martin Dunn (born 1786/87). and four Hennecy children (the first of whom was born 1788/89 - two to three vears before Mary's day in court). ${ }^{\text {so }}$ The two sets of records together raise the possibility that Mary may have already left Tim Dunn at the time of her 1791 action (unfortunately, parish records do not exist for the time frame, making the tracking impossible). If this was the case. Mary's desertion did not influence the court's 1791 decision in terms of awarding her support for Tim's child. Nor does any hint of moral judgment survive in the records of Mary's later living arrangements. Under the English legal regime inherited by

"P.ANL. GN 5/4/C/1, Ferryland, Box 1, n.f.. Mary Dumn 1: Timothy Dumn. March 14. 1791. Also noted in English, "Reception of Law," p. 39. The records do not indicate whether this was a lump-sum settlement or an annual maintenance

SPANL. MG 205. Pole Papers, 1799-1800. 
Newfoundland, a woman who committed adultery, even after separation, would no longer be entitled to support from her husband and would often lose custody of any children of the marriage ${ }^{s 1}$ Yet there is nothing in the records to indicate that this happened in Mary's case (although this may also have merely been a reflection of Tim Dunn's lack of interest in pursuing the matter)

Similarly. Ann St. Croix of St. Mary's was not penalized for her post-separation relationship with another man. On October 16. 1821. Ann brought her husband. Benjamin St Croix, to court for neglect and ill treatment and sought an order for support for herself and their seven children. Ann was only 33 years old and much younger than her 77 -yearold husband - a tact that the cour clerk obviously felt worthy of note as he underscored their ages twice in the court records. The unhappy couple had already been living apart since 1819 , and the cour recognized this de facto separation. It also ordered Benjamin to give up the use of his house and garden to Ann and the children. to pay her $\Sigma 6$ at the end of the current fishing season. and to pay $£ 5$ annually for the future support of the children. who were to remain in Ann's care." Meanwhile, in the two years since the couple had ceased cohabiting, Ann had obviously taken alternative measures to support herself and her large family. Indeed. she may have already moved into another. informal marital relationship with one Edward Power. a fisherman of St. Mary's. Whether this was the

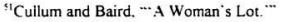

'PANL. GN 5/4/C/1. St. Mary's, f. 111 . Amm St. Croix v. Benjamin St. Crotx. October 16, 1821 
case. or whether her newfound freedom from Benjamin had simply put her in a celebratory mood is unclear, but on July 17,1822 , almost nine months to the day after her courtsanctioned separation from her husband. Ann gave birth to a male child who, she claimed. had been fathered by Power. That October, she went back to court to seek support for the child from her new paramour, but he had already left the area and was not expected to return. Nonetheless, the court ordered that the balance of his wages with his current employer in the amount of $\varepsilon+15+$ be retained for the support of the child. and that from this amount, 40s be paid for lying-in expenses, and 3s. per week support until the wages were depleted. ${ }^{53}$ Furthermore. there was no hint of moral judgment about Ann's extramarital relationship with Power. and she was not deemed to have thus jeopardized her original claim for child custody or support from her former husband. St. Croix.

Neither was the wife's character during the marriage at issue in awarding support. as an estranged husband in Biscay Bay. near Trepassey. learned in 1804 In a maintenance hearing on August 13. 1804, Mary Kearney told the court that her husband, Andrew, had "turned her to Door" about 15 months earlier and that she had since been supported by her brother. Andrew testified that since their marriage. Mary had "behaved very III frequently getting drunk and totally neglecting her household affairs." Furhermore, six months after the nuptials, Mary had been delivered of a male child who, according to Andrew, was not his. Yet, despite the husband's insinuations of Mary's slatternliness and

\footnotetext{
${ }^{53}$ PANL, GN 5/4/C/1. St. Mary's. ff. 130-1, Amm St. Crorx v: Ectward Power. July 17. 1822.
} 
sexual immorality, maintenance for Mary was ordered in the amount of 3s. per week for life. provided that she had no children by any other man. Furthermore, the order was issued despite the fact that Mary obviously had some alternative means of support (her brother), thus, the court was acting not out of concern that Mary would become a charge on the community, but in recognition of her right to maintenance from her husband who had turned her out of the matrimonial home. Indeed, this is the only case on record for the southern Avalon in which the court had the husband sign a written maintenance agreement (Andrew's signature was joined by that of Michael Kearney, possibly his father or brother, as extra surety)..$^{54}$

As we have seen at the beginning of the chapter, Peggy Mountain was also not penalized by the local court for what was likely a perceived extra-marital indiscretion. The magistrates acknowledged the de facto separation of the couple, and ordered her husband to pay support for wife and expected child. They also made various efforts to find alternate accommodations for Peggy, and ultimately, after repeated interference by the parish priest. magistrate Robert Carter, himself. took her in for several days. Throughout his diary entries of the incident, Carter's tone was usually sympathetic, never judgmental.

What is most striking in the above discussion of the cour life of the southern district is its relatively benign regime over female sexuality when compared with other jurisdictions in Britain, Canada, and even Newfoundland (particularly St. John 's).

${ }^{5 .}$ PRL. 340.9 N45. nf. Mary Kearney v. Andrew Keamey. August 13. 1804 
Christopher English has offered some explanations for the court's pragmatism in its dealings with both men and women in the late $18^{\text {th }}$ and early $19^{\text {th }}$ centuries. He notes that the Juclicauture AcIs of 1791,1792 , and $1809^{55}$ had provided that English law be received in Newfoundland only "'. so far as the same can be applied. "' The local magistrates were men with stakes in the community, he argues, who dispensed justice based on an understanding of local issues and a familiarity with local inhabitants; if English law was deemed deficient or inappropriate for Newfoundland situations, local magistrates simply made new law : These are useful insights into how the lega! regime manifested itself on the ground in many outports during the period.

However. local magistrates and administrators on the southern Avalon were also part of the emerging middle class with its middle-class ideals of femininity Certainly. the behaviour of women within their own class was carefully monitored, particularly by the $19^{\text {th }}$ century Although there were some $18^{\text {th }}$-century women of the local gentry who had led public and independent lives, most women of this class were retiring into genteel domesticity by the following century (see Chapter 9). Wives and daughters socialized only with other middle-class families in the area or in St. John's (some. such as the Carters. also wintered in England). They married members of their own class. They did

55 +9 (jeo. III. Cap. 2-

${ }^{56}$ English, "Reception of Law," p. 44. See also English and Curran, "A Cautious Beginning." Berkin also notes the tailoring of English laws to local circumstances in some American colonies. although she notes that others preserved the older laws. even after England, itself, had abandoned them. See Berkin. First Generations, p. 155. 
not labour on flakes or in fields as did plebeian women, rather, their work entailed the rearing of children and the supervision of domestic servants. They did not appear personally in the court house, in such matters that did involve them, such as probate or debt collection, they were represented by men from their own circle. Certainly, their names did not appear in any of the cases involving assault, bastardy, slander, rape. or domestic violence. (This is not to suggest that such incidents did not occur among the middle class, but merely that they were not played out in public.) These women's lives were increasingly circumscribed by the parameters of middle-class ideology: indeed. the gentility and respectability of these women helped to maintain class boundaries in small tishing communities, where contact between middle-class and plebeian men was more trequent and social distance, therefore, less clearly demarcated

Yet, while middle-class contemporaries in Britain were trying to encourage a modified form of respectability among the working-class - one that involved a refashioned construction of female respectability - middle-class magistrates/administrators on the southern Avalon had reason to pause in trying to impose restrictions on plebeian women. These men were predominantly either merchants or agents, themselves. or were connected by kinship or marriage to local mercantile families that made their money by supplying local fishing families in return for their fish and oil. And the resident fishery had become overwhelmingly dependent on household production in which the labour of plebeian women. work that took place in public spaces on stage head and flake. was essential. In addition. these women. in their various economic capacities, were an intrinsic part of the 
exchange economy and the truck system - the system of supply and credit which underwrote the resident fishery. The working woman was not a 'social problem": she was an economic necessity. Therefore, it was not in the interests of local magistrates to encourage the withdrawal of plebeian women into the private sphere. ${ }^{57}$

And now, let us turn to the final key player in Peggy Mountain's drama and another question posed at the beginning of the chapter. Why was the contrast in the response of priest and magistrates to Peggy's situation so striking?

5" In this regard. resident magistrates may have been more pragmatic and utilitarian than governors. chief justices. and visiting surrogates who were not directly involved in the tishery. This may, to some extent, explain the difference in my observations and those of Cadigan in relation to the court's perception of women's "place' in Conception Bay particularly in the debt collection cases of Butler and Lundrigan. Cadigan argues that the purpose of the whippings imposed by surrogates on these men was to punish them tor the roles their wives played in physically resisting the attachment of their properties for debt The two men were being disciplined, says Cadigan. not so much for their contempt of court in a socially turbulent time. as has always been believed. but because of their inability to keep their womenfolk in line - their failure as patriarchs - as the court tried to impose a gentry-bourgeois model of patriarchy on the local fishing population. See Cadigan. "Whipping Them into Shape: State Refinement of Patriarchy among Conception Bay Fishing Families. 1787-1825." in McGrath. Neis. and Porter. eds. Their Lives and Times. pp. $48-59$. It is possible that the involvement of visiting surrogates rather than local magistrates in these two cases was a factor in their outcome. Still. it is difficult to understand why. if the intention of the court was to make examples of these two men as tailed patriarchs, the surrogates permitted the message to be so completely lost on the local community. Why play into the hands of local reformers by leaving the entire population suffering from the 'misapprehension' that the punishments were for contempt of court? And how are we to interpret the attitudes of two surrogates as representative of the broader local legal regime? Certainly. similar actions by wives on the southern Avalon did not attract corporal punishment for their husbands. The Butler and Lundrigan matters aside. however. Cadigan still observes a much greater effort by courts in Conception Bay to impose standards of female respectability and domesticity than I have found in my study area - again inviting further investigation in terms of the differences in ethnic mix and economic development in the two areas. 


\subsection{Irish plebeian womanhood and the Catholic church}

Woman [Eve] destroyed life's gathered crown:

But woman [Mary] gave long-lasting joys of life.

Columbanus (Irish missionary, $7^{\text {th }}$ century)

Father Browne was also a man with a stake in the local community: he. too. was familiar with local circumstances and personalities, for he had been at the mission in Ferryland for twenty years. Yet he did not try to accommodate Peggy as did the local magistrates. Instead. he hounded her out of the community, because her 'aberrant sexuality deviated from his perceptions of female respectability.

Certainly. Father Browne's reaction was not out of line with church efforts to monitor female sexuality. When the Catholic religion was finally permitted to operate openly in Newfoundland after 1784, the priests were overwhelmed by the numbers of informal family arrangements in their new mission. In Father Ewer's 1789 report on Ferryland district, it was the indecency of women's having multiple partners that became the particular focus of paternalistic concern (or, perhaps, blame), as he noted:

The magistrates had for custom here, to marry, divorce \& remarry again different times. \& this was sometimes done without their knowledge, so that there are nomen living here with their th hushand each man alive \& form different familys in repute. I would wish to know if these mariages are but simple contracts confirmed \& disolved by law. or the sacrament of matrimony received validly by the contracting partys. If the latter it will be 
attended with much confusion in this place. with the ruin of many familys \& I fear the total suppression of us all as acting against the government [italics added]

British authorities at Newfoundland had acknowledged the validity of local marriage customs, given the lack of access to formal marriage rites in the period. ${ }^{50}$ But the Catholic church, grown far away from its Celtic-Christian roots by the latter $18^{\text {th }}$ century, was not so sanguine, and while realizing that it must tread carefully around local regulations, was determined to untie such bonds that vet "remain[ed] to be separated from aduitery " ${ }^{-(x)}$ With the priests, then. came a concerted effort to bring women into formalized marriages within the precepts of the church; and as their efforts met with increasing success (as revealed by the parish records available from the 1820 s onwards), the options of

"Burne, ed. Gentlemen Bishops, pp. 77-9, Father Ewer to Archbishop Troy. November 30, 1789. Prefect Apostolic James O Donel had already expressed similar concerns to Leonardo Antonelli. Cardinal Prefect of Propaganda Fide. See Byrne. ed. Gentlemen Bishops, p. 55, O Donel to Antonelli, c. December, 1785. The clergy were also worried about the closeness of consanguinity in Newfoundland marriages. See, for example. Byrne, ed. Gentlemen-Bishops, pp. 329-33. Bishop Thomas Scallan to Cardinal Francesco Luigi Fontano. Prefect of Propaganda Fide. October 6. 1822.

"While marriage according to the rites of the Church of England was the legal standard in Britain through much of the period. in Newfoundland. marriages solemnized by Catholic clergy were acknowledged, and those performed by lavmen, such as justices of the peace, were permitted in the absence of authorized clergy. In 1824. Catholic clergy were put on equal footing with Anglican clergy in terms of celebrating marriage; in 1833 . authority to celebrate marriage was also extended to Dissenter ministers. For a discussion of early marriage law in Newfoundland, see Johnson, "Matrimonial Property Law." pp $120-32$.

${ }^{\infty}$ Byrne, ed. Gentlemen Bishops, p. 55. O Donel to Antonelli. c. December. 1875 
cohabitation and informal separation and divorce disappeared.

The dichotomized construction of woman as respectable wife and mother or temptress Eve was also part of church discourse. And even the respectable woman was seen to have inherited from her foremother the proclivity to tempt man - a further rationale for the monitoring of her sexuality by the morally and intellectually superior male members of the church. ${ }^{\text {s1 }}$ Women - especially women in their sexual prime - were constructed as 'occasions of $\sin$. Thus, with the priests came the practice of 'churching' women atter childbirth: a perfunctory, shady ritual - usually a few prayers mumbled at the back door of the priest's residence over a woman who had to be 'purified' tor the 'sin' of conceiving a child. With the priests also came a more systematic shaming of adulterous wives and unwed mothers, reflecting a sexual double standard that laid the "sin" of pre- and extramarital sexual relationships overwhelmingly at the feet of 'unchaste' women. Particularly in terms of illegitimacy. mothers were punished more harshly than fathers. suffering public humiliation, even ostracism, as they were denounced from the altar and denied (either for a limited period of public penance. or indefinitely) churching and the sacraments. ${ }^{62}$ Here.

${ }^{61}$ The concept that women, as descendants of Eve, had inherited her proclivity for temptation was espoused by most Protestant sects as well. Of the Christian religions. only the Quakers believed that the burden of Eve's 'sin' had been transmuted by Christ's death and resurrection. See Berkin and Horowitz, eds., Women's Voices, pp. 125-6.

6:The information on women as 'occasions of sin. 'churching, and shaming comes from the oral tradition of the area. The Irish literature also notes that the greatest disgrace for illegitimacy was borne by the mother and, to a lesser extent, the child, particularly as the $19^{\text {th }}$ century progressed. Indeed, that century was marked by a decreasing tolerance of illegitimacy and increasing sexual restriction. The Catholic Church in Ireland was 
then, was a reinforcement of the chastity requirement of middle-class ideology.

Church efforts to control 'unruly' womanhood and protect female 'virtue' gained momentum after Bishop Michael Fleming took over the reins in the 1830s. The need to patrol female chastity, for example, underscored his appeal to the ringleaders of the Father Duffy affair to surrender quietly to authorities, as he begged them to

contemplate the establishment of a military Section among your wives and daughters at a season when of necessity your avocations will require the abandonment of your families, of your homes and firesides to the unbridled licentiousness of soldiers without the presence of a single magistrate, a single local tribunal to restrain them. ${ }^{33}$

The monitoring of female sexuality and virtue was also the primary motivation in Fleming's decision to bring the Presentation nuns to Newfoundland from Galway in 1833. In his 1837 repor to Propaganda Fide. he expressed his abhorrence of the way in which "the

extremely active in patrolling sexuality and found its efforts meeting with increasing success as its desires meshed more closely with the more 'respectable' farming class that predominated in post-Famine Irish society. As on the southern Avalon, however, church discourse fashioned a sexual double standard. See. for example: Connolly. Priests and People; Diner, Erin's Daughters; Megeean, "Irish Women's Prospects". Miller with Doyle and Kelleher. "'For love and liberty"', and Nolan. Ourselves Alone. Marks notes that Protestant churches in Upper Canada also carefully monitored the sexual behaviour of their congregations, although their efforts were aimed more at establishing a single sexual code for both men and women rather than reinforcing the sexual double standard of secular discourses. See Marks. "'No Double Standard?"”

${ }^{n 3} \mathrm{McC}$ arthy, Irish in Newfoundland, pp. 157-8. citing Bishop Michael A Fleming. Pastoral Letter. May 10 
children of both sexes should be moved together pell-mell" in the island's schools and found their intermingling to be "dangerous" and "impeding any improvement of morals. "st In a later letter to Father $\mathrm{O}^{\circ}$ Connell, he explained his urgency in sponsoring the sisters mission. even at considerable personal cost:

I felt the necessity of withdrawing female children from under the tutelage of men, from the dangerous associations which ordinary school intercourse with the other sex naturally exhibited, for whatever care could be applied to the culture of female children in mixed schools. they must lose much of that delicacy of feeling and refinement of sentiment which form the ornament and grace of their sex. Besides, viewing the great imfluence that females exercise over the moral character of socten - the great and useful and necessary influence that the example and the conversation of the mother has in the formation of the characler of her children, as well male as female - $\mathrm{I}$ judged it of essential importance to fix the cinaracter of the female portion of our community in virtue and innocience. by training them in particular in the ways of integrity and morality: by affording them the very best opportunities of having their religious principles well fixed, by imparting to them. while their young minds were daily receiving the elements of a general and useful education. a course of religious instruction that should teach them the true value and the proper use of those mental treasures by which they were being enriched; for I felt that which all must feel - namely, that when once the future mothers are impressed with the truths of religion - once they are volidly instructed in the Divine precepts of the (iospel. once their young minds are enlarged and enlightened, and strengthened by educational knowledge, the domestic fireside is immediately made the most powerfiul cuaxilian to the school, and instruction and true education. the basis of which is virtue and religion. are instilled into the little ones at their mother's knee, and they go abroad by-and-by. into school or into society, with all the elements that fit them to become virtuous citizens [italics

\footnotetext{
NRCASJ, Fleming, Reporn (1837), pp. 3-4
} 
added]. ${ }^{\text {.5 }}$

It was vital, he felt, that young Newfoundland women be removed from mixed schools in order to protect "that delicacy of feeling and refinement of sentiment which form the ornament and grace of their sex." In separate schools. the nuns could "fix ... [their] character in innocence and virtue," prepare them for motherhood and domesticity. and lead them to their destiny as moral guardians of their families. A curriculum that included knitting, netting, and needlework (the three $\mathrm{N}$ 's of feminine training) would ease the transition from work on flakes and in gardens to pursuits more properly reflecting womanly respectability. ${ }^{\text {on }}$ And "solidly instructed in the Divine precepts of the Gospel." they would abandon the ancient customary practices that were an alternate source of female power

In this last ambition. the Church was acting as more than a vehicle of middle-class gender ideology As noted in Chapter 5, the status of Irish women as mediators of the supernatural world was in competition to the Church's own authority within the spiritual realm. Church efforts to diminish the power of the alternative belief system, and consequently women's role as spiritual guides within the informal system. can be seen as

"C.NS. Michael Anthony Fleming, "Letter on the State of Religion in Newfoundland." January II, 1844, addressed to the Very Rev. Dr. A. O'Connell. Dublin (Dublin: James Duffy, 1844), p. 18.

${ }^{\star}$ See Galgay, McCarthy, Bruce, and $\mathrm{O}^{\prime}$ Brien, Pilgrimage of Faith, particularly Chapter 9. "Ministry of the Presentation Sisters on the Southern Shore." 
part of a larger agenda of the Irish-Catholic church in the $19^{\text {th }}$ century to broaden its range of influence - institutionally, geographically, socially, economically, and politically - in Ireland and abroad ${ }^{67}$

The Presentation sisters did not actually arrive in communities on the southern Avalon until the $1850 \mathrm{~s}$ and $60 \mathrm{~s}$. and thus the impact of their role in domesticating young women in the area fell primarily outside the current study period ${ }^{\text {os }}$ But the effort to rein in unruly womanhood had begun with the arrival of sanctioned Catholicism, and was articulated as early as Father Ewer's expression of concern about women s living arrangements. Furthermore. the endeavor intensified as the $19^{\text {th }}$ century unfolded. The church's efforts fit perfectly with middle-class ideology of the day tnd while a contlict existed for local magistrates between ideology and economic reality, there was no such contlict for the church in the pursuit of its civilizing mission on the southern Avalon

${ }^{n 7}$ For a discussion of the development of an institutionalized Catholic church in Newfoundland under Bishop Fleming, and its increasing influence in the social and political life of the colony, see John E. Fitzgerald, "Conflict and Culture in IrishNewfoundland Roman Catholicism, 1829-1850" (Ph.D. Thesis. Lniversity of Ottawa. 1997)

${ }^{n}$ Ironically. convent living provided those women who entered with some of the freedoms that the church's espousal of female domesticity and passivity was endeavouring to confine: treedom from the domestic authority of fathers and husbands; freedom from domestic routines; freedom to perform socially useful work (teaching, nursing, social work) without the loss of 'respectability' this normally would have entailed for women who remained single. Also, convents were all-female institutions with considerable autonomy in running their day-to-day affairs, although they were increasingly brought under the control of the male church hierarchy after the Middle Ages. See Caitriona Clear. "The Limits of Female Autonomy: Nuns in Nineteenth-Century Ireland." in Luddy and Murphy, eds. Women Surviving, pp. 15-50. 
Within the framework of Catholic orthodoxy, the denial of female sexuality, the celebration of selfless motherhood, and the increasing pressure on women to transform their homes into spiritual havens, removed from the outside world, were impelling women to retire into domesticity and respectability ${ }^{69}$ These pressures would intensify as the repercussions of the devotional revolution in the Irish-Catholic church of the latter $19^{\text {th }}$ century were felt through the regular recruitment of religious personnel from Ireland ${ }^{\prime \prime}$

"This impetus is noted in the Irish literature cited above. Campbell also observes a similar phenomenon in New South Wales. He notes that the Catholic church discouraged women 's involvement in rough agricultural work and "unteminine labour." Middle-class ideals of domesticity and fragility were espoused and the "Holy Family" was exemplified as a model for all Irish families. The Irish mother, located firmly within the home, was deified. Indeed, the church actually invented a link between female domesticity and a 'traditional' and distinctive Irish way of life - a linkage that had been far from the reality of many Irish women's lives. See Campbell, Kingdom of the Ryans, pp. 130-2.

"Brian Clarke has argued that as a result of the devotional revolution. IrishCatholic women in industrializing Toronto gained some moral authority in their homes at a time when their economic contribution to the household was increasingly discourted. Recruited by the church to promote an increase in devotional practices. these women were exhorted to create spiritual havens for husbands and children, removed from the materialism of the outside world Still, their moral authority was very much grounded in the cult of domesticity. and Catholic women were located very firmly in the home, with some mediating influence between household and parish. It was also an influence rooted in constructions of female 'virtues' of piety, purity, obedience, humility, dependence, selfsacrifice, and service - as epitomized by Church images of the Virgin Mary. Like Mary. Catholic women could create a 'holy family' by instructing their loved ones at the domestic hearth. Clarke observes that this image of 'true womanhood' was quite convenient for Irish-Catholic men, and while it gave Catholic women some authority in the home. it gave them very little influence outside it. And although they participated significantly in parish fund-raising, selling their baked and hand-crafted goods at bazaars and fairs. their contribution was seen as an extension of their roles as wives and mothers. and they were subservient to male clergy, sodalities, and finance committees. See Brian P Clarke. Piety and Nationalism: Lay Voluntary Associations and the Creation of an IrishCatholic Community in Toronto 1850-1895 (Montreal: Kingston: McGill-Queen s 
(One oral informant, a St. Mary's woman in her 80 s, tells the story of a great-uncle chastizing her grandmother for singing around the house: "What are you doing sitting there singing." he demanded. "when you should have your 'bades' [rosary beads] in your hand? $?^{\cdots+1}$ )

Still, church constructions of femininity met with resistance from the plebeian community because they clashed with the realities of plebeian women's lives But some inroads were being made by the 1830 s. Father Browne's success in hounding Peggy Mountain out of Ferryland suggests a widening of the wedge A further indicator was the virtual withdrawal of plebeian women from the court room on matters specifically related to female sexuality Although they continued to appear in the records on matters such as debt, wages. common assault, and property, their willingness to pursue matters such as sexual assault, domestic violence. bastardy. separation. and maintenance seemed negligible after the 1830s, only four such cases survive in the records - one sexual assault (1841). one case of domestic violence (1843), and two bastardy suits (both 1854) - despite a growing population. Women were increasingly reluctant, then, to air these matters in public - a reluctance that can be linked more to church attributions of shame and guilt to female sexuality than to magisterial hostility. Increasingly wary of public court actions. plebeian women were left with the weaker options of either handling these matters

University Press. 1993). Chapter 4.

'MY, Interview September 11. 1999. 
privately, or not pursuing them at all.

\section{$\underline{8+\text { Conclusion }}$}

Middle-class ideals of female domesticity and respectability were infiltrating Newtoundland society during the study period through its English legal regime and an emerging local middle class of administrators. churchmen. and merchants. But such middle-class constructs of female respectability did not easily insinuate themselves into Irish plebeian culture on the southern Avalon - where women had played such a significant role in community formation, where women held property and inhabited public spaces such as court house and stage head. where they had a joint custodial role in terms of culture and a powerful place in an alternative belief system that ran in tandem with formal Catholicism. and where they played vital roles in subsistence and the production of saltish for the marketplace. Furthermore, while local administrators and magistrates on the southern Avalon, such as Carter, were part of the emerging middle class with its middleclass ideals. and certainly they carefully monitored the behaviour of women within their own class. they had reason to pause in trying to impose restrictions on plebeian women. As members of local mercantile networks, they were dependent on the presence of plebeian women in the public economic domain. These local magistrates cum merchants therefore had a vested interest in forestalling the equation between plebeian female respectability and the private sphere. The Catholic clergy, by contrast, saw the regulation 
of "unruly" womanhood as part of their civilizing (and consolidating) mission in Newtoundland and pursued this goal with increasing zeal as the $19^{\text {th }}$ century progressed While church ideals on femininity conflicted with plebeian realities, their efforts were already making inroads as the Water L.ily slipped its moorings at Ferryland and carried Peggy Mountain into historical obscurity. 


\section{Chapter 9-The 'other' woman: Gentry life on the southern Avalon}

Throughout this thesis. English-Protestant middle-class women have been used as a foil for Irish-Catholic plebeian women on the southern Avalon. While these local gentry women are not the subject of this dissertation, some discussion of their lives is warranted in order to elucidate the various comparisons that have been made. ${ }^{1}$

\section{English gentru women}

These gentlewomen were the wives and daughters of local mercantile and professional men. Their husbands, fathers, and brothers were merchant-planters. mercantile agents, ship owners and captains, naval officers, doctors. and Anglican clerics men who also served as magistrates and local administrators (e g. school board members. road commissioners, relief commissioners. customs collectors. and directors of hospital boards). and whose names appeared regularly on the grand jury lists and presentments tor the area. From the mid-1830s onwards. they also formed the pool from which

'The following discussion will be based primarily (although not exclusively) on women in the Carter family of Ferryland, for two main reasons. Firstly, the family epitomizes the middle-class group in the study area in terms of their range of activities and life experiences. Secondly, a fair number of written sources are available on the family. making their lives more readily accessible to the modern-day historian. Among these sources are the Carter Family Papers (PANL, MG 31), the Carter-Benger-Nason Papers (PANL. MG 247), the Robert Carter Diary (PANL, MG 920; also available at the Ferryland Museum and at MHA. MF-053 [typed transcript. 1832-1837 only]). and the Mary Ann Simms Scrapbook (PANL. MG 708). 
representatives to the island's House of Assembly were elected. This emerging middle class was tied economically to the plebeian community through interdependence in the fishery. Nonetheless, they maintained social distance through their separate ethnoreligious pedigree, exclusive patterns of marriage and socializing, and different forms of consumption, housing, dress, and behaviour.

One of the defining elements of their class identity was the construction of middleclass womanhood. Middle-class men, by necessity, had to associate with the outside community on a daily basis. Some of their activities - their orchestration of supply and credit. their court and administrative functions - reinforced the power dynamic between gentry and plebeian communities. But the regular intermingling of men of both social groups on waterfront premises, in gardens and fields, in stores and public houses. tended to blur the boundaries of class somewhat within the small fishing villages of the area Thus, the removal of middle-class women from the public sphere, the increasing separateness of their lives, and in particular, the contrast between their lives and those of plebeian women, were instrumental in reinforcing class perimeters on the southern Avalon.

This contrast between middle-class and plebeian women, however. was less stark in the mid-1700s than it was a century later. for feminine roles among the local gentry were not static over the study period. and the life experiences of these women changed in several respects over the span of a hundred years. The most obvious difference was their residence patterns, for most wives and daughters of the merchant-planters operating on the study area up to the late $18^{\text {th }}$ century remained in the home country: few ever set foot 
on the southern Avalon. One of the earliest exceptions was Anne Wylley Carter. who came out to Ferryland from Sidmouth, Devon, with her husband, Robert, at mid-century. Indeed, according to local tradition, it was Anne who decided that the family would settle on the southern Avalon, for while Robert had intended that Ferryland be a stopover on the way to the mainland. Anne "put her foot down and refused to go further." Her instincts served her well, for the couple founded a local dynasty which carved out an extensive commercial, administrative, and judicial niche in the area and became one of its most wealthy and powertul families during the study period.

Anne's life would have been quite different from that of her granddaughters. or even that of her daughters later in the century. Despite the Carters' relative affluence, their original accommodations would have been more rudimentary in what was essentially still a fishing outpost with more temporary residents than long-term inhabitants. Still, they likely built or moved into a multi-roomed house more commodious than a fishing family's residence - perhaps a dwelling vacated by an outgoing merchant-planter, and likely combining the functions of residence and business. ${ }^{3}$ Nonetheless. housewifery would have

\section{'DA. correspondence dated March 8. 1999}

'Pocius describes the house of contemporary merchant Arthur Holdsworth in Ferryland. Built around 1770 , it measured $60^{\prime}$ by $24^{\prime}$ and was constructed of stone. The ground floor consisted of a parlour, counting house. and shop; the second level contained four rooms, the house was topped with an attic fitted as warehousing space for dry goods. The property contained several other buildings: a stable. cooper's shop. barking house. and a row of fishermen's cottages. This house, together with other structures. including another large, two storey structure with hipped attic and chimneys, is shown on the "Holdsworth Map" drawn when the plantation was surveyed for sale c. 1835. See Pocius. 
been more limited. until the family become more firmly established and until amenities increased and their housing became more elaborate. Anne's household production duties likely included outdoor as well as indoor work, although. unlike plebeian women. she would not have done shore work in the fishery and her work outside the home would have been largely supervisory. More similar to plebeian women, but unlike her $19^{\text {th }}$-century descendants, she also would have taken significant responsibility tor household management in terms of the actual balancing of household needs and resources. Indeed. it is quite likely that she perceived herself as an able planter and businesswoman in her own right. Because there were few other gentry families in the area. Anne's duties as hostess would have been less elaborate than those of $19^{\text {th }}$-century women. And because her opportunities for contact with other people of her class would have been limited. it is likely that she intermingled with the plebeian community more frequently than her temale descendants and was more involved in the day-to-day life of the community Indeed. according to local tradition, Anne was no shrinking violet. She is credited with leading the women of Ferryland. for example. in defending the harbour against the French in 1762 While their menfolk were away defending Bay Bulls, it is said. Anne and other local women stationed themselves at the gun battery on Isle aux Bois. at the mouth of the harbour, and thwarted the attempt of two French warships to raze the settlement. ${ }^{4}$ For

"Architecture on Newfoundland's Southern Shore," pp. 13 and 15

${ }^{4}$ DA. correspondence dated March 8, 1999 
their efforts in fighting the French, the Carter family was granted the strategically placed Isle aux Bois for use in the fishery (albeit the grant was in Robert's name, reflecting patriarchal patterns of control in property ownership).

Like most women of her day, regardless of class. Anne outlived her husband. She inherited from Robert's estate an annuity of $£ 30$ and the use of his household furniture during her widowhood, with the proviso that she would forfeit both upon remarriage. The couple's eldest son. William. received the bulk of the estate. while three other children were left small cash amounts (one guinea each) and personal property (e g. clothing. books). It is most likely that children other than the primary heir. William. had already received their portions from the estate through a network of deeds of gitt, marriage settlements, and trusts that were characteristic of their class. Within this system. femaie heirs were usually beneficiaries of passive property from which they could obtain income but over which they could exercise no control. Anne's annuity, administered by her son William as executor of the estate and subject to forfeiture upon her remarriage, was a typical example."

5ANL, MG 31. Carter Family Papers, Will of Robert Carter. Sr.. March 29. 1795. Another child. Mary Sanders, had already received her portion, likely before her marriage. and may have predeceased her father. See Chapter 7.

'According to Erickson, an annuity usually came from a rent charge on land that had been purchased with the cash portion the wife had brought into the marriage. The rent provided a source of income for the couple and a means of maintaining the wife in widowhood, with the advantage of keeping the main estate intact for the heir. Erickson describes it as "a form of inheritance designed to create dependence." See Erickson. Women and Property, pp. 25 and 70. 
Still. as noted in Chapter 7. testation practices in Newfoundland did not always conform to an English norm of primogeniture and impartible inheritance, even among the middle class. Although Robert Carter. Sr., opted to follow the English tradition, his second son and namesake did not. Robert, Jr. would follow the local preference of "share and share alike ${ }^{\prime}$ in the disposition of his estate. By his last will and testament, made shortly before his death in 1810 . he left the residue of his estate (after payment of a debt to his mother-in-law) to his wife. Eliza, and three children, Robert. Elisabeth, and James, in equal shares.

Robert. Jr. was a mariner and had married Elizabeth ("Eliza") Harris Howe. the daughter of a Devonshire glazier, in Dartmouth in 1789. Eliza typified a new generation of gentry women who were adopting a local residence pattern in greater numbers. Eliza came out to the study area with her husband, and while she may have returned to England on occasion. she was still residing in Ferryland in the 1820s, travelling back and forth occasionally to St. John's, where she ended her days in $1851^{*}$ By this time, the lives of gentry women on the southern Avalon had begun to change. More and more, the household was becoming the primary setting for their activities, as they withdrew from outdoor work. Houses had become larger, with two to three stories. multiple rooms, and

'PANL, GN 5/1/C/9, f. 8 (12), Will of Robert Carter, June 3. 1810.

${ }^{\text {x}}$ See: PANL, MG 920, Robert Carter Diary: and FMDB. File 02B. Morry and Carter Families. 
elaborate furnishings, ${ }^{9}$ requiring a sharpening of focus on housewifery as a more conspicuous display of consumption honed class distinctions. Increasingly, these women's lives revolved around the management of household servants and rearing of children, the entertainment of social peers, and regular visits to St. John's and England to maintain family contacts, to arrange for the schooling of their sons (Eliza's sons, for example, were schooled at Teignmouth), and to check out the latest fashions in furnishings and dress.

More and more, their economic inactivity was becoming a hallmark of status and atfluence.

"For example, in PANL. MG 31. Carter Family Papers, there are two sketches of quite elaborate houses. One is labelled "The Judges old house in Ferryland" (possibly belonging to vice-admiralty judge William Carter) and shows the façade of a large, twoand-one-half storey stone structure with four portals suggesting four separate residential units, a central archway for carriage entrance to the stores, six glazed windows on the main floor and 12 on the second, and a high A-framed attic (no chimneys, but this was obviously an oversight). See File 61 . The other is a cartoon sketch and shows the façade of a two-and-one-half storey structure with two end chimneys for heating, a high Aframed attic, a shed extension at the back, a side extension with a door and three windows, and an ornate entranceway flanked by two glazed windows on either side: people in early 19th-century dress appear in each of the windows: separate. in the same garden, is a smaller building, possibly a separate servants' quarters; the property is surrounded by a picket fence. The sketch is not dated but the paper contains a watermark. John Hayes 1822. See File 66. Pocius provides a description of the substantial home built by the mercantile family Sweetland in Caplin Bay in the early $19^{\text {th }}$ century. The house was a "full-Georgian structure," typical of those built in Nova Scotia and New England. with imported frame, two and one-half storeys, large rooms, large central hallway, and end chimneys, indicating upper-storey hearths for heating. He also describes the contemporary home of the Morry family, a smaller, but still substantial, "Georgianinfluenced" two-storey structure with kitchen and parlour on the first floor separated by a central stairway, and two end chimneys. indicating that the upper story was heated by separate hearths. rather than by warm air rising from below. See Pocius. A Place to Belong, pp. 204 and 223-4. 
Still, it was acceptable for women in difficult financial straits - widows, for example - to engage in certain genteel forms of economic activity like teaching ${ }^{10}$ or innkeeping. Such was the fate of Mrs. Tree. the widow of an American loyalist captain who had accompanied her husband to Ferryland from Boston. The couple had lost considerable property during the American Revolution. and her husband's estate being thus diminished by the time of his death, Mrs. Tree turned to running a public house in the 1790s to maintain her lifestyle. ${ }^{11}$ Eighteenth-century diarist Aaron Thomas described his

${ }^{10}$ Of course. teaching was not an option on the southern Avalon until the $1830 \mathrm{~s}$. Eliza Coulman, Anne Wylley Carter's great-granddaughter, was the first teacher for Ferryland and Caplin Bay under the newly appointed school board in 1836 . See Chapter 4

"In the 1800 family census for Ferryland that forms part of the Pole Papers. a widow by the name of Bridget Tree appears as the head of a household with her son, Philip, aged 28, still living at home. Doubtless, this was the merry widow of Thomas's joumal. Nonetheless. there was no record of her holding a liquor license - yet another example of the hidden participation of women in this trade. In 1795. the year of Thomas's writing, a liquor license for Ferryland district was issued to "Frances" Tree - doubtless a clerical error See PANL, GN 2/1/A, 13/225-6/1797, Robert Carter to Governor Waldegrave. September 7. 1797 (reporting retrospectively). There are no surviving licensing records for 1796 and 1797. By 1798 and 1799, the licensee is listed in the masculine form of the name, as "Francis" Tree. See PANL. GN 5/4/C/1. Ferryland, Box 1. n.f. List of liquor licenses issued for 1798 and 1799 . The widow had a son Francis who may have been living with her in the late 1790 s. although he had established his own household with wife and one-year-old child by the 1800 census. It is likely. then. that the license was being issued in his name, even though his mother ran the inn. Another possibility is that the license continued to be issued in the name of the widow's late husband. which was also "Francis." At any rate, the name - in either the masculine or feminine form - no longer appears on the lists of licensees after 1799 . There is no way to ascertain whether the widow died shortly after the taking of the census in 1800 , whether she ceased operating the business, or whether she carried it on 'informally' after the former license-holder had left her household. 
encounter with the "corpulent" and convivial Mrs. Tree at her establishment, the London Inn, where he found her to be "in a very comfortable situation,... [with] a large and roomy House and Genteel Furniture." He reported.

A Gentleman may have as good a Dinner and Rest at this House as any in Newfoundland. I Din'd here the day I made the Tour on Four Covers. Viz. a Boiled Leg of Pork. Fowls, Lamb, Ducks. Pudings, Green Pease and other Vegitables, served up with Sauces and Gravys. Had an Epicure been one of the Guests he could not a found fault with a single Dish. ${ }^{12}$

While Mrs. Tree was in reduced circumstances, having to run a "House of Entertainment." she was certainly more comfortably appointed than the woman at Thomas s next stop. for when Mrs. Tree could not accommodate his request to sell him some fowls tor his journey. Thomas searched around the settlement and eventually found himself. "amidst the rugged Barren and Houses." at the door of an Irish household

There was no person at home except a Weoman, the Mother of the Family. and she was ill in Bed. After thumping for some time at the door I heard a voice in the adjacent place (I cannot call it a Chamber). I went into it and beheld the Weoman in Bed. apparently very ill... She related. at large. how many weeks she had been in Bed, how old she was. how many Children she had got. the age of her Husband, the part of Ireland she came from, how hard the times was. how slow the Fish bite at present and that there was nothing to be got but Flint Biscuits in Newfoundland. ${ }^{13}$

\footnotetext{
IThomas, Newfoundland Joumal, p. 110

${ }^{13}$ Thomas, Newfoundland Journal, p. 114.
} 
One suspects that her table would not have exhibited the same range of epicurean delights as Mrs. Tree's.

So the widow Tree still enjoyed a certain degree of material prosperity. but she was straddling the boundary of middle-class 'respectability' and plebeian 'vulgarity' - a condition that she recognized, herself, as she lamented her lack of proper society to Thomas. "I should like to go to Britain with you for the sight of a Friend would be very enteraining to me, having never yet seen one...." she told him; and then, inviting him to join her in a drink. " . my Friends are my Irish Fishing Servants now in the Kitchen who. I am confident. will be as noisy and as merry and as friendly with you as your best Friends in England. providing you pay tor the Liquor [emphasis in original] ${ }^{-14}$ Thus, she found her position somewhat compromised by her requirement to work, her status rather tarnished when compared with other widows of her class who had been better provided for by their husbands' estates: Anne or Eliza Carter, for example. or Catharine Weston and Ann Sweetland - women who did not have to go out into the world to support themselves, women whose financial affairs and litigation in relation to property and estate matters were generally handled by male relatives or other men in their circle. ${ }^{\text {t? }}$

"Thomas. Newfoundland Joumal, p. 113

${ }^{15}$ Various examples can be found in the cour records for the area and in P.ANL: MG-31. Carter Family Papers, MG 247, Carter-Benger-Nason Papers, and MG 920. Robert Carter Diary. 
Indeed, throughout the study period, marriage was the most acceptable means of support for gentry women, and it increasingly became their only respectable option as their withdrawal into domesticity became a mark of middle-class status. Of course, these unions had to be carefully arranged, for marriages among the middle class were social and economic partnerships between families rather than between individuals (such as in the plebeian community). Strategic alliances helped to expand networks and consolidate family holdings; as such, they were instrumental in the formation and reintorcement of class in the study area. Because the economic and social stakes were higher, then. middleclass marriages were more heavily orchestrated than plebeian marriages; and in the process, middle-class women were more subject to commodification - treated as marriageable possessions by which kinship networks. contacts. and capital could be expanded $^{\text {to }}$ Lnregulated marriages. by contrast. threatened to erode carefully established socio-economic networks. A small island in Ferryland harbour stands testament to the importance of 'proper' marriage choices for local gentry women. The island is called -Vancy's Portion and lies just off the shore of Isle aux Bois, it is a small hummock of land with no beach area - useless for grazing sheep or drying tish. According to the oral tradition, it was the only endowment of Judge Carter from his large estate to his daughter

${ }^{16}$ This was the case with middle-class women in the home country as well. See Davidoff and Hall, Family Fortunes. 
Nancy, who had married beneath herself and thus incurred her father's wrath ${ }^{17}$

With pressures on their young to enter into suitable marriages, the southern Avalon gentry became a largely endogamous group in terms of ethnicity and class, especially by the $19^{\text {th }}$ century. either marrying within their own local circle or recruiting partners from middle-class families in St. John's or areas in England such as Dartmouth and Topsham, where traditional links in the fishery continued to be maintained An examination of the partial Carter and Morry family trees in Appendix E. for example. demonstrates a common pool of families from which marriage partners were drawn Carter, Morry. Sanders, Sweetland, Lemessurrier. Tessier, Rendell, Skinner. Williams - all middle-class families with significant interconnections in their private and public lives

${ }^{17}$ The oral tradition does not identify which of the judges Carter this story describes. Several generations of $\mathrm{Carters}$ held positions in the judiciary during the period: the original Robert $C$ arter was a surrogate and justice of the peace; his son William was a vice-admiralty judge: and his grandson Robert was a magistrate. The story most likely relates, however, to the first Robert Carter, local surrogate, who fought the French in St. John's and whose wife. Anne, spearheaded the defence of the Isle aux Bois. Robert was the original grantee of the island as a result of this family service. He and Anne had a daughter Anne (possibly the disobedient Nancy) who married Sam Hill of Topsham. perhaps this was an unsuitable match. After Sam died. Anne married Henry Sweetland. a merchant-planter from Devon, who certainly would have been an acceptable choice. She later married Matthew Morry. Sr. thus forging an alliance with another significant mercantile family in the area. Her father's will. described above and in Chapter 7 . leaves the bulk of his estate to his first son, but he likely doled out portions earlier by marriage settlements and trusts - perhaps including 'Nancy's Portion' at her first marriage. Neither William. the vice-admiralty judge, nor Robert, the magistrate, had a daughter Anne. aithough the latter had a daughter named Fanny. It is possible that in the retellings of the story over time. 'Fanny's Portion' has transfigured into 'Nancy's Portion." The facts of Fanny's life do not match, however. as in 1843, she married a suitable candidate - William Rendell. a St. John's merchant. 
Daughters were provided with numerous opportunities to meet acceptable future husbands, as the gentry socialized exclusively amongst their social peers at home and when visiting St. John's and England. While there was a high degree of mixing of middleclass men in terms of their economic and administrative functions as well as social networks (e.g., dinners, clubs, trouting. hunting and shooting parties), there were various heterosocial gatherings as well: walks, picnics, boat rides, teas and dinners, dances. carriage and sleigh rides. and carefully arranged long-term visits with families in the marriage pool

But outside this properly supervised social whirl, the lives of middle-class women became increasingly circumscribed as the first half of the $19^{\text {th }}$ century unfolded. More and more. middle-class assumptions of femininity shaped their lives. Women were no longer expected to carry out the traditional tasks of housewifery but rather to oversee their performance by household servants. Withdrawal from outdoor work was complete as women's activities revolved around the domestic hearth. Daughters received a general liberal education. and a wide range of interests from gardening to politics was encouraged. but their training was directed towards their future roles as wives, mothers. household mistresses, and diverting hostesses - in contrast to the business or professional orientation of their brothers' education. Like gentry daughters in the home country and in mainland colonies, they were expected. as potential wives, to develop "an aura of respectable leisure" and to contribute to "gentry's culture of hospitality" that would reflect well on 
future husbands. ${ }^{18}$ While plebeian daughters cooked and cleaned. made fish. tended gardens, foraged through woods and meadows for firewood and edible plants, middleclass women went on picnics, sketched pictures. wrote poetry. and cultivated appropriate feminine accomplishments as they strived towards an English middle-class ideal. ${ }^{19}$ And their gentility and respectability, their everyday behaviours and dress, and ultimately, the behaviour and dress of their children helped to maintain class boundaries in small communities where the nature of economic activity necessitated greater mixing of men of both classes

Typical of this generation of women was Sarah Rendell Carter, a St. John's

${ }^{\text {tx} B r o w n, ~ G o o d ~ W i v e s, ~ p . ~} 296$ See also: Berkin. First Generations, and Davidotf and Hall. Familv Fortunes.

1"The Roben Carter Diary (PANL. MG 920) provides some insights into the pursuits of gentry daughters in the period. The Mary Ann Simms Scrapbook (PANL, MG 708 ) provides a more vivid study, and is discussed in greater detail below. See also a poem by Tom Flood (a local versifier) transcribed by Ann Carter, November 10. 1843, in the Carter Family Papers (PANL, MG 31. File 63). It is a temperance poem. which obviously appealed to Ann's sensibilities. with a moral lesson about the evil effects of drink upon a fresh-water fisherman, who falls in a pond and drowns after imbibing too much rum:

The moral of this mournful tail [sic]

To all is plain and clear

A single drop to[o] much of rum

May make a watery bier.

And he who will not sign the pledge

And keep the promise fast

May be in spite of fate a stiff

Cold water man at last 
woman. who married Robert Carter (grandson of Robert and Anne Wylley Carter, son of Robert, Jr., and Eliza Howe Carter) on April 25, 1815. 20 Sarah was a daughter of a St. John 's mercantile family that was part of the Carters' social and economic network. No diaries or letters written by Sarah survive in public repositories, but her husband's journal for the period from 1832 to the day before he died in 1852 is available, and through his entries, it is possible to steal a glimpse of what life was like for the wife of this local magistrate and businessman.

The diary begins long after the couple had married, and well after the birth of their seven children." so it provides no insight into Sarah's efforts to adjust from town living to life in a fishing community. and from a sheltered girlhood to married life. It does not tell us how the couple were introduced: likely, she met Robert on one of his numerous trips to the capital, although it is possible that the couple were first introduced on the southern Avalon, for an excursion to Ferryland to stay with tamily friends would have made a suitable holiday for a young woman of the St. John's middle class. provided she was

${ }^{2}$ FMDB, File 02B. Morry and Carter Families, and DA, notes provided at interview July 20, 1999

${ }^{2}$ Anglican parish records are available from 1820 onwards. They list the baptisms of the three youngest children only (Mary, Harriet. and Emily) between 1825 and 1828 . According to FMDB, File 02B. Morry and Carter Families, the first three children (Robert. Eliza, and Fanny) also arrived in quick succession between 1814 and 1817 . The birth or baptism of the middle child, James, is not recorded. Harriet died in her infancy. and Emily succumbed to scarletina just before her ninth birthday. 
properly chaperoned." How ever they met, it is clear that the couple did not immediately set up their own household upon marriage, for on September 15, 1833 - more than 18 years after they had wed - Robert noted the day as the fifth anniversary "of residing at the Northside of the Harbour in my own home." It is likely, then, that the couple had lived for some time in Robert's family home with his widowed mother, Eliza. ${ }^{3}$ Given the powertul position of widows in stem family households, we can only speculate whether Eliza's presence eased Sarah's transition into married life or made it more difficult tor her to establish herself as household mistress

Robert's phrase "my own home" is very telling, for Sarah seems to have been such a peripheral part of his life She is a shadowy, amorphous figure in her husband's diary referred to. when she is mentioned at all, as "Mrs. Carter" or "Mrs. C." never by her first name. and certainly never by any term of endearment. ${ }^{*+}$ Indeed. Sarah seemed to spend

2-Throughout Carter's diary, there is a constant tratfic of visitors. male and female. between St. John's and the Ferryland-Caplin Bay area. Women, married or single. travelled with suitable companions to ensure that they would not be compromised physically or socially. On one occasion. however. one of the Carters' female friends was forced to return to St. John's unaccompanied, and Carter expressed his concern at such an impropriety: "Miss Anna Hoyles left us by the Smipefish to return to St. John's against my wishes, there being no other female or other respectable passenger. but Cullin is a steady man and from appearances must have reached St. John's by sunset." See entry dated October 6, 1833 .

${ }^{23}$ Robert's tather died in 1810 , but his mother lived until 1851 . It is evident that she spent her final years in St. John's. for Robert wrote to her there on a regular basis.

${ }^{24}$ Granted, the use of "Mr." and "Mrs." by spouses in addressing each other in public was a middle-class affectation in general. See Davidoff and Hall. Family Fortunes But it seems odd that Robert Carter did not relax this convention in his private journal. 
much of her time in St. John's with her family, and frequently travelled to England to visit relatives and to bring her sons. Robert and James, to and from school in Teignmouth. where their father had been educated before them." Their daughters. by contrast. were educated at home, where they learned the domestic skills and genteel ants that would make them attractive potential wives.

The couple led far more separate lives than plebeian couples of the period. Even on significant occasions such as Christmas Day or wedding anniversaries. Sarah did not appear to be in Ferryland. Note, for example, the following entries:

December 25, 1833 John Pollard and Henry Prim dined with me this dav [italics added].

December 25, $1839 \quad \ldots \mathrm{M}^{\mathrm{r}}$ Bowman [the newly arrived Anglican minister] \& family dined with $m e$ this day [italics added]

and

even when discussing more emotional matters such as the death of a child or Sarah's frequent and long absences. Perhaps he saw the diary as 'public' space in that it might be read by others after his death. Still, the sense of distance between the spouses is palpable. As noted in fin. 21. the FMDB indicates that the first son. Robert, was born in 1814 - a year before the couple married. Were the couple forced to marry? Was Robert. Jr. . even Sarah's child, or had he been born of another woman and adopted by Sarah after marriage? Perhaps therein lies some basis for the coolness between the couple. Or perhaps this was simply an arranged marriage in which the spouses did not develop any great degree of affection for each other.

"The diary contains numerous references to the sons' departures and homecomings Robert also noted on October 12,1832 , that it was his $42^{\text {nd }}$ birthday and that he had passed nearly 29 years in Newfoundland. indicating that he had been in England until he was 13 years of age. 
The $21^{\prime \prime}$ Anniversary of my wedding day. My wife in England, sailed in December. Not a letter from England to this date, from her or any other of my friends there. ${ }^{26}$

It is evident, however, that the couple had not anticipated remaining in Ferryland permanently when they first married, and perhaps as the likelihood of Roberi's leaving became more remote. Sarah simply carried on her life elsewhere as much as possible Certainly, Robert did not have as much opportunity to travel as his wife - likely because of business and magisterial commitments - and a strong sense of claustrophobia occasionally surfaces in his writing. For example.

October 12, 1832 This day I accomplished my $42^{\text {nd }}$ year, having passed in Newfoundland very nearly 29 years of that time. in which time [ have seen many changes but have observed the trade to be of that nature as never to allow any one concerned in the fishery to rise to affluence in any Outport, useless to regret it as my property lays here and cannot be now realized. ${ }^{27}$

October 12.1840 This day I complete my Fiftieth year of Age - thirty seven of which have been spent in this Place except

${ }^{26}$ Sarah did not return until August 6, although several letters did arrive from her in May and July. She brought their son. Robert, home from school with her. This particularly lengthy stay occasioned the strongest show of sentiment in Robert's diary in relation to his wife. "Aug. 7,1836. Thankful beyond all things for safe return of my wife and child." Various other entries in the diary also suggest Sarah's absence on other anniversaries.

"7he cod fishery at Newfoundland was, indeed. severely depressed at this time. 
having gone occasionally to England but not that for 14 years past.

and

April 25, 1841

This is the $26^{\text {th }}$ anniversary of my Wedding day the chief part of which period has been passed in Ferryland very contrary to my Expectations when 1 married - 28

Even when Sarah was at home in Ferryland. her existence seemed frequently to be separate from that of her husband. Unlike plebeian women, who otten joined their mentolk in productive work. Sarah's household duties were all indoor and largely supervisory. Even this managerial role must have been limited by her frequent absences and also, occasionally, by lengthy illness. Through the first half of 1834 , for example. Robert's diary is peppered with entries such as: "Mrs Carter very ill," and "Mrs. Carter ill in bed all day - Did not go out." The entries become increasingly terse: "Mrs. Carter confined to her room to-day": "Mrs. Carter in her bedroom". "Mrs. Carter in her room" and one wonders whether she was availing herself of the fainting couch." Still. she

${ }^{2 x}$ Note that Sarah again seems absent. However. she was home on some anniversaries, such as April 25, 1835: "Walked out over the Downs with Mrs. Carter. Eliza and Fanny. This is the $20^{\text {th }}$ anniversary of my marriage. Had no party last year or this.

59ee entries dated February 27 and 28, April 10, April 13-17, 22, and 25, and July 25. 1834. The comments about Sarah's lingering illness all appear at the end of entries about weather and other local news, almost as an afterthought. But Robert was not a man without feelings. He was moved, for example, to devote an entire entry to the death of his dog: "Poor Snap died of his wounds last night having been dreadfully marred about the 
managed to step forth on occasions that spring and other years, usually to join her husband and children in the rounds of heterosocial activities typical for their circle:

$\begin{array}{ll}\text { March 16.1834 } & \begin{array}{l}\text { Mrs. Carter, seif and son, with J.H.C. [his brother. } \\ \text { James Howe Carter] drink tea at Caplin Bay. }\end{array} \\ \text { March 25. 1834 } & \begin{array}{l}\text { Mrs. Carter, self and Eliza invited to dine with the } \\ \text { Judge. the former did not dine there but came up in } \\ \text { the evening, not having returned from sleighing in } \\ \text { time to dress. }\end{array} \\ \text { July 31. 1834 } & \begin{array}{l}\text { Went to Isle du Bois to tea - Mrs. C. and Fanny my } \\ \text { brother, Mr. Shears. S. Prowse and other children. }\end{array} \\ \text { August 12. 1835 } & \begin{array}{l}\text { A party to dinner at Isle du Bois at my invitation. } \\ \text { ladies and gentlemen. which passed off very } \\ \text { comfortably... Danced in the evening. }\end{array}\end{array}$

How much time Sarah spent socializing exclusively with other women in the area is not evident from Robert's writing. Indeed, his diary creates the impression that women socialized more frequently in mixed activities. although this may be because of his inattention to the details of women's lives that did not intersect his own. But certainly.

head by large dogs a few nights ago. poor faithful little fellow. He is buried at the top of the rock back of the kitchen." See entry dated August 2. 1836. He was also terribly upset when his daughter Emily died of scarletina. providing an almost daily charting of her condition to the exclusion of almost any other news until the end: "Poor dear little Emily a little better but my hopes are very faint that she will recover" (February 12, 1837): and finally. "Wind N.E. a good deal of snow falling. All hopes of my dear Emily's recovery fled. At 4 P.M. dear Emily breathed her last - dear little soul" (February 13. 1837). See virtually all entries from January 28 and February 18 (Emily's funeral). 1837. 
her participation in mixed gatherings and in the extension of hospitality to guests was one of the necessary methods by which Sarah, as a middle-class woman, contributed to her family's status. As Brown notes in relation to colonial Virginia. hospitality was a means of reinforcing the family's public reputation for affluence and power by opening up for scrutiny the circumstances of their domestic lives. ${ }^{30}$ Here, the gentry woman played a significant role for, as Morgan similarly observes in relation to Upper Canada, the "figure of the "lady" was important in "constructing social space" through a form of socializing peculiar to the middle class. ${ }^{\text {. }}$

As the diary progresses. however. Sarah is mentioned with less and less frequency. and one wonders how much time she was spending away from Ferryland. Perhaps the sorrow of her daughter Emily's death of scarletina in early $1837 \mathrm{kept}$ her increasingly away from home. Certainly, Robert's socializing took on more homosocial aspects dinners and shooting parties with male relatives and friends. even a dinner club formed in January, 1842, with six members to meet weekly at Three Corner Pond "2

"3r Brown. Good Wives, p. 271.

"Morgan, Public Men and Virtuous Women, p. 227. Errington also observes that gentry women in Upper Canada were "public representatives of their class" and were expected to take an active role in social functions and philanthropic work as a means of reinforcing their husbands' status and influence. See Errington. Wives and Mothers, Chapters 6 and 7: quotation from p. 132. See also: Berkin, First Generations; Kross, "Mansions. Men, Women", and Ryan, Womanhood in America.

${ }^{12}$ The club was initiated on January 17, 1842, and later diary entries indicate that it did continue for some time. 
At any rate, it is obvious that Sarah's geographic mobility was much greater than that of plebeian women of the area, while her productive and managerial roles were more limited. Like many women of the period regardless of class, however, Sarah outlived her husband by several decades; and in her widowhood, she was, perhaps, more influential than she had been as a wife in terms of the powers she was granted under her husband's will to act as executrix and dispose of properties as necessary for her support (see Chapter 7). Whether she exercised these powers or relinquished the practical control of such matters to male relatives is unclear; certainly, she left court appearances on estate matters to male attorneys. She spent her final years in St. John's and died at her Cochrane Street home in 1879 at the age of $877^{\text {" }}$ Following the principal of 'share and share alike typical of 19th-century Newfoundland testation practices, she lett all her property to her five surviving children equally, with the express provision that the shares of her married daughters "shall be for their sole and separate use and not subject to either the debts or control of their respective husbands. ${ }^{-34}$

Sarah's slightly younger contemporary was Harriet Maria Skinner Carter, the daughter of Harriet Williams and Col. Thomas Skinner. commander of the Royal Newfoundland Regiment at St. John's. Harriet's family was also part of the St. John's

${ }^{33}$ FMDB. File 02B. Morry and Carter Families, and DA, notes provided at interview July 20. 1999

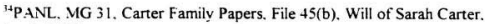
September 7. 1866. 
circle with whom the Carter family socialized, and on May 27. 1826, she wed Arthur Hunt Carter (a first cousin of Sarah's husband and the son of vice-admiralty judge William Carter and (atherine Weston) and began married life in Ferryland. ${ }^{35}$ Perhaps the marriage was a love-match, or perhaps its chief purpose was to shore up St. John's-Ferryland connections. At any rate, monetary gain was not Arthur's primary motivation, for Harriet's uncle George Williams in England congratulated Harriet on having for a husband "a man of sense and liberality who has chosen a wife for her personal merit in despite of the disadvantage of fortune $\ldots$. its

In fact. Harriet had not come to the marriage completely empty-handed. She was supposed to be receiving the income from an annuity of $£ 17$ - a portion of the rental from a St. John's property in the estate of her mother's brother. Monier Williams. ${ }^{37}$ The annuity was actually held by her father, in right of his wife, now deceased. and had at one point been signed over to another party as security for debt. However. Harriet's brother. Lieut. Thomas Skinner, had cleared the debt for his father in 1824, with the understanding that the rental thencetorth be paid to Harriet. This was another typical example of the

${ }^{35}$ FMDB. File 02B. Morry and Carter Families: and DA, notes provided at interview July 20.1999. To further demonstrate the interconnectedness of these families. Harriet's maternal first cousin Ann Williams Hutchings married Arthur's brother. Lieut. Robert Carter, R.N.

"PANL. MG 31. Carter Family Papers. George Williams to "My dear Niece" [Harriet Carter], August 6. 1826.

${ }^{37}$ See PANL. MG 31. Carter Family Papers. Files 4 and 10 
passive property of which middle-class women were beneficiaries. Atypically in this case. however, the annuity did not pass over to Arthur in right of his wife upon their marriage. as technically, the annuity remained in her father's name (or so Arthur later argued to the trustees in his bankruptcy). Still, it was primarily Arthur who corresponded with various interested parties in relation to the matter throughout the years, and it is therefore likely that Harriet had ceded practical control of the matter to her husband. This appeared to be the assumption of her uncle George Williams, who approached her in 1833 to consent to a potential sale of the property "when you have consulted with $\mathrm{M}^{\mathrm{r}}$. Carter (your husband) $\cdots$ Unfortunately for Harriet and Arthur, the benefit of the annuity was never fully realized as there were ongoing disputes among the beneficiaries of the Monier Williams estate over the disposition of the property, the amount of rental. and the arrears owing by tenants. As late as 1847 (well after Harriet's death), Arthur was still trying to collect the balance of arrears."

The annuity, although small, might have provided some comfor to the couple in the tenuous financial situation in which they found themselves soon after marriage. Arthur, himself, was described in the Anglican parish records as a gentleman, ${ }^{-50}$ reflecting

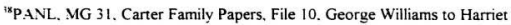
Carter. March 5. 1833

${ }^{39}$ P.ANL. MG 31, Carter Family Papers. File 10, draft of letter from Arthur Carter to Tom Skinner. 1847.

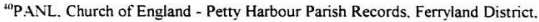
Box 2. Arthur was the only 'gentleman' listed in the records, all his contemporaries' 
the moneyed status of his family, but by the late 1820 s and early 1830 s, he was encountering financial difficulties and undergoing bankruptcy examinations. Still, he threw himself enthusiastically into farming and agricultural experiments. and successfully applied for a grant of land at Merrymeeting River, Ferryland, which he had already staked and clear-burned" Harriet boasted to her English relatives that he was "indefatigable in his exertions on his new estate. ${ }^{142}$

Harriet had received the liberal education typical of young women of her class and carried out a correspondence with her uncle George Williams in England that demonstrated not only a high degree of literacy, but also an interest in international politics and agricultural experimentation (especially in introducing new plant species into Newtoundland). ${ }^{13}$ Indeed. George placed a good deal of stock in Harriet's observations about farming as a viable alternative to fishing on the island. In 1827. he commented in a letter to Arthur on Harriet's acumen:

occupations were recorded more specifically - e g. 'merchant,' 'merchant/planter.' 'master of merchant vessel. etc. See Chapter 3. footnote 55. It is likely, then. that he had no source of income other than family money.

"PANL, MG 31. Carter Family Papers, File 36. Arthur's request for a government position, however, was refused See PANL. GN 2/1/A. 38/400/1832. James Crowdy. Colonial Secretary, to Arthur H. Carter. Ferryland. October 15. 1832.

4'P.ANL. MG 31. Carter Family Papers. File 26. Harriet Carter to "My dear uncle" [George Williams], c. late 1820 s or early 1830 s.

${ }^{43}$ PANL, MG 31, Carter Family Papers, Files 5, 19, and 26. 
I mean to... acknowledge the gratification I had from the details which your intelligent wife gave of your country, and its present condition - It would not be the worst proof that Bathurst and the rest of them who set themselves up to govern our colonies gave of their fitness for the affair if they were to seek such sources of information as this of my cousin Harriett, for the dull fellows in whom they put their trust seem only to mislead them.... Harriets account of the prosperous farms that are growing up around you makes me almost languish for a lot myself of 300 Acres, and I really think I shall make some effort towards it....

Although Harriet's optimism about the agricultural potential of the Ferryland area may have been misplaced. apparently her uncle treated her opinions with respect. Harriet and Arthur sent local plant specimens and produce to George, and he, in turn, sent them seeds and seedling plants to introduce into their Ferryland holding. There is one reference to Harriet's sending out servants to pick berries. and her uncle remarks upon the delicious taste of "the Capillaire berries [creeping snowberries], the fruit of her research.....4: It is evident from most of the correspondence, however, that while Harriet was intellectually interested in agricultural experimentation. she was generally removed from the actual process - that the operation and management of the farm was in Arthur's hands and that he and hired servants provided the labour.

In a letter to George, undated but written c. 1830 . Harriet admitted, "I am not very

"PANL, MG 31, Carter Family Papers, File 19, Excerpt of letter to "My dear Sit" without signature but, from the context, obviously George Williams to Arthur Carter. March 13, 1827

4.P.ANL, MG 31, Carter Family Papers. File 19, George Williams to "My dear Sir" [Arthur Carter], May 13, 1827 . 
strong myself not half so hardy as I ought to be to make an active Farmers wife [emphasis her own]. ${ }^{n+6}$ Arthur had been detained by bad weather during a recent trip to St. John s and was so set back in his farm work that he had given over the care of the farnily's kitchen garden to Harriet. a responsibility that seemed to overwhelm her somewhat. although it would certainly have been a comforable domain for women within the plebeian community (or, for that matter. Arthur's grandmother. Anne Wylley Carter) Harriet attributed her general feeling of weakness to the fact that she was still nursing her 14-month old daughter, and looked forward to regaining her strength after the child was weaned. One cannot help but compare this lengthy recovery trom childbirth with the immediate return to productive work by plebeian women after a nine-day lying-in period Turning from matters ayricultural. Harriet demonstrated great enthusiasm for the "very pretty gown" of the latest spring fashion that she had recently received from her uncle and her English cousins: - .. it was the first of it's kind imported into Ferryland." she wrote. "which I am sure you will think added not a little to it's value." This was not the first reterence in the correspondence between the two in relation to dresses or materials being sent out to Harriet. ${ }^{47}$ and she was quite grateful for the gifts because she

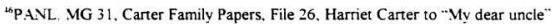
[George Williams], c. late 1820 s or early 1830 s. All the following quotations from Harriet are excerpts from this letter.

${ }^{57}$ In an 1826 letter, for example, George indicated to Arthur that when he wert to Liverpool to find a vessel to carry his mail to Newfoundland, he would send out some "trifle" and a brief note to Harriet. See PANL. MG 31. Carter Family Papers. File 19. excerpt of an undated and unsigned letter, but obviously George Williams to Arthur 
was aware of the importance of her dress and her behaviour in maintaining social distance in the small community of Ferryland and also in preserving her family's position amongst their social peers. She wrote:

my dear kind Uncle I feel truly obliged for the trouble you have taken to put me in possession of the material and information to be fashionable. Dress seems every day becoming a subject of increasing importance \& without attending in some measure to it we can hardly "pass blameless" thro the crowd - [emphasis in original]

Indeed. Harriet was conscious of her social status and seemed to remain aloof from women of the plebeian community. She was even reluctant to hire local female heip for the kitchen garden, for example: "The people here I am sorry to sav are not at all too honest. and if we hire a woman ... for a day or two. it is impossible to leave her a moment if we wish the seed to be put in our own ground." This same sense of class and ethnic difference had been articulated some thirty-five years earlier by the gregarious Mrs. Tree. Her experience in the hospitality trade may have made her less fastidious about the company she kept. but her sardonic comments about her Irish "friends" revealed that a

Carter. likely accompanying a short note to Harriet Carter dated August 6.1826. And on March 13. 1827. George again wrote to Arthur: "I was desirous of sending Harriet some little article of dress by this vessel, but my daughters who are the more competent judges in such important matters say that we had better wait till the 'Spring fashions' come out when we shall be enabled to supply the demands of Ferryland with the newest specimen of taste..." See PANL. MG 31. Canter Family Papers, File 19, George Williams to ".My dear Sir" [Arthur Carter], March 13. 1827. 
sense of separateness from the plebeian community already existed - a distance that was even more pronounced within the next generation of gentry women in the area.

Still, while Harriet's circumstances contrasted in many respects with those of most Irish women on the shore, some of her concerns would have been shared with other women in the population. She wrote about family health matters, for example

my little girl. 14 months old.. had the whooping cough all the winter and the small pox was in Ferryland since the beginning of Lent. my children had not been vaccinated against Cow-pox and no virus was to be obtained until lately, however Thank God they both escaped the former [smallpox] and have since taken the latter disease [cowpox] I hope. effectually [for immunization to smallpox].

But in general. common experiences such as marriage. childbirth. or potential widowhood did not create gender solidarity across class boundaries on the southern Avalon. Women such as Harriet and Sarah Carter were isolated from women of the plebeian community by education, mannerisms, life-style, and economic inactivity. In this last regard, these $19^{\text {th }}$ century middle-class women were even more removed from the larger community than their husbands' grandmother, Anne Wylley Carter, and one senses their isolation and constant longing to be elsewhere - in St. John's or England. closer to a larger society of their own social peers. Sarah eventually escaped to St. John's. But Harriet's concerns about her inability to endure her new lifestyle came to early fruition. She had five children in fairly quick succession in the late $20 \mathrm{~s}$ and early $30 \mathrm{~s}$ - the last. her namesake. born in 
August 1834 - and then she died the following year at the age of $36^{48}$ The parish register did not record the cause of her death; neither did her diarist cousin-in-law. She may have fallen victim to a disease such as dyptheria or scarletina, or she may have died of complications from giving birth - a common fate for women of the period, and a tate that ignored ethnicity and class ${ }^{\text {t9 }}$

${ }^{2 x}$ PANL. Church of England - Petty Harbour Parish Records, Ferryland District. Box 2. Harriet's death was also noted in PANL. MG 920, Robert Carter Diary, July 20. 1835

${ }^{19}$ Maternal mortality rates were high in the late $18^{\text {th }}$ and the $19^{\text {th }}$ centuries. Ulrich estimates that the maternal mortality rate experienced by Martha Ballard's patients was 5 per 1.000 births, compared with the late $20^{\text {th }}$-century rate in the United States of 1 per 10.000 births. Still, her record was impressive compared with rates in $17^{\text {th }}$ - and $18^{\text {th }}$. century English villages (ranging from 10 to 29 per 1.000 ) or late $18^{\text {th }}$-century London and Dublin hospitals (generally ranging from 8 to 39 per 1.000 . with some exceptionally high rates in epidemic years). See Utrich. A Midwife's Tale, pp. 170-3 and Table V. British sources also report high maternal mortality rates during the period. The British Lving-In Hospital rates for $1749-88$ ranged from 16 to 60.8 per 1.000 and the Queen Chariotte $s$ Hospital mean rate for 1860-64 was 42.4 per 1,000. In England and Wales overall. however, rates had dropped to 5 to 6 per 1.000 by $1850-60$. Still, they were high compared with late $20^{\text {th }}$-century rates of 0.15 per 1.000 in England and 0.17 per 1.000 in Scotland. See: Irvine Loudon. "Deaths in Childbed from the Eighteenth Century to 1935," in Philip K. Wilson, ed. Childbirth: Changing Ideas and Practices in Britain and America 1600 to the Present, vol. 5 (New York; London: Garland Publishing, 1996), pp 195-235. particularly pp. 196-7 and 214, and Tables 1 and 4. and Margaret F. Myles. Textbook for Midwives, $8^{\text {th }}$ ed. (Edinburgh: London: New York: Churchill Livingstone. 1975), p. 635. Statistics on maternal mortality are not available for Newfoundland for the study period of this dissertation. However. Mcnaughton provides some early $20^{\mathrm{m}}$-century data. indicating that rates were still in the range of 6 to 9 per 1.000 well into the $1920 \mathrm{~s}$ Indeed. in 1923. Newfoundland's rate of 6.2 per 1.000 was in the high range for Western countries (with rates from 2 to 6.6 per 1,000). See Mcnaughton. "Newfoundland Midwife," pp 66-73 and Tables I, 3, and 4. All the above sources agree that only in the 1930 s did maternal mortality rates begin to decline significantly. and quite precipitously, as standards of obstetric care improved dramatically. 
Representative of the next generation of middle-class women on the southern Avalon was Mary Ann Simms Carter, who married Robert and Sarah Carter's son Robert in the late 1840s. Mary Ann was the daughter of George Simms, a justice of the peace in Trepassey and colleague of her future father-in-law. Indeed. Robert Carter's diary indicates that she and her parents were occasional visitors to the Carter home in the late $1830 \mathrm{~s}$ and $1840 \mathrm{~s}$, doubtless, the hospitality was reciprocated, and it is also likely that Mary Ann was part of the larger social gatherings attended by members of both sexes. Mary Ann and Robert married on June 1, 1847, and the couple had ten children over the course of their marriage. ${ }^{\text {so }}$

Mary Ann left a tracing of one brief moment of her life in the form of a scrapbook - a collection of pencil sketches and poetry assembled over the period of her early womanhood (late teens, early twenties) before her marriage to Robert. ${ }^{31}$ It suggests a genteel and sheltered upbringing, from the inscription on the flyleat -

Mary Ann Simms

Given to her at Christmas

By her Affectionate Papa.

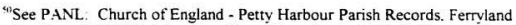
District. Box 2, and MG 708. Mary Ann Simms Scrapbook, 1839-1844, particularly the typed family tree charts inserted at the front of the collection.

"PANL. MG 708, Mary Ann Simms Scrapbook. 
- to the tranquil drawings of country scenes (some, far too pastoral to be of the area and possibly done in England or copied from pictures) and the various moral sayings surrounded by embossed floral borders. Most of the scrapbook, however, is taken up with poetry. with titles reflecting properly feminine concerns of the heart and hearth -Remembrances," "On the hearts Struggles," "Secret." "Song of the Spirit of Love," "Friendship." "Domestic Love." "The Path of Life." Most telling are a series of highly emotional poems written in 1844 by Mary Ann and various friends. It is obvious from the content that Mary Ann was leaving Trepassey, possibly in preparation for marriage "The Brides Farewell" suggests that she was devastated at leaving the shelter of her childhood home:

Why do I weep? - to leave the vine

Whose clusters 0 er me bend?

The myrtle - yet, oh! call it mine!

The flowers I loved to tend?

A thousand thoughts of all things dear.

Like shadows o'er me sweep

I leave my sunny childhood here

Oh! Therefore let me weep!

The poem goes on to bid farewell to a cherished sister, who has been her close companion

SI I refer here to the handwritten poems (as opposed to the typeset poems by published poets that appear occasionally throughout). Some of the handwritten poems were Mary's offerings; others may have been transcribed by her but not original: many more were obviously written in the book by friends. as they were addressed to her. written in different hands, and/or signed or initialled by other parties. 
"by stream, by shore, in song, in praverful sleep"; a doting father, "whose eye o'er all my youth hath smiled"; a loving mother, whose "lips... have lulled me with your strain, eyes have watched my sleep." Each verse ends with the entreaty: "Let me weep!"

There follows a series of poems that suggest that Mary Ann had love interests other than her future husband, and that what was likely an arranged marriage to consolidate two powerful local families was having a profound effect on at least two disappointed romantic partners and a circle of close girlhood friends. Immediately following "The Brides Farewell" come the following verses. signed "John"

As o er the cold sepulchral stone Some name arrests the passer-by:

Thus, when thou view'st this page alone.

May mine attract thy pensive eve!

And when by thee that name is read.

Perchance some succeeding year.

Reflect on me as on the dead.

And think my heart is buried there.

Another hand takies over with this unsigned offering:

To Mary

Lines addressed to a young Lady on bidding her farewell

10 Sep 1844

Adieu. dear Maid. stern fate decrees

That we must shortly sever

And if we n'er should meet again

Adieu adieu for ever. 
I'd say could I with impious thoughts

Accuse the warp of heaven

Why has the wish to call thee mine

Without the power been given?...

The handwriting looks similar to that of " $\mathrm{AM}^{c} \mathrm{LH}$ " or "A.M", who penned several other dramatic leave-takings. all on July II. 1844: "The Parting Kiss." "Lines in the evening of separation," and "To $x \times x \times \sim$

Since now the hour is come at last,

When you must greet your anxious lover:

Since now our dream of bliss is past.

One pang. my girl, and all is over

The poem goes on to describe various romantic encounters between the couple. and ends

This is the deepest of our woes.

For this our tears these cheeks bedew

This is of love, the final close

Oh! God. the fondest. last adieu!

Various other love poems appear in the album. None are signed or initialed by Mary

Ann's future husband, Robert Carter.

The scrapbook entries end in 1844. as if signalling the end of Mary Ann's youth.

The image that remains with the reader is one of a genteel young woman, much loved and 
indulged by family and friends, who was suddenly thrust from her childhood paradise into the reality of a marriage of convenience. Whether or not she was happy in her marriage as indeed some parties to arranged marriages were - the public record does not reveal. But her pathway there - from cosseted child to cultured and romantic young woman to obedient daughter to dutiful wife and mother - was one that was followed by many other young women of her class in the period.

Mary Ann represents the final generation of gentry women during the study period. Her experiences betore entering into marriage were quite different from those of young women of the plebeian community at the mid-19th century; indeed. her life also varied significantly from that of her husband's pioneering great-grandmother. The overall impression created by the experiences of the Carter women is one of decreasing intluence and increasing withdrawal into genteel domesticity as one generation succeeded the next. Of course. the movement was not simultaneous for all middle-class women of the area. and for a number. domesticity and economic idleness may well have remained more a social ideal than a reality: Mrs. Tree, for example, could not afford the luxury of economic inactivity, her lived experience a contradiction of the model that was being constructed by middle-class discourse of the day. But it was an ideal that was aspired towards by these women and their families in a way that was not embraced by women of the plebeian community in this time frame. And various references to female acquaintances in Robert Carter's diary indicate that a significant number of women were moving steadily towards the ideal by the latter decades of the study period as they were 
increasingly circumscribed by the domestic sphere.

\section{2 'Exceptional' women}

This discussion of gentry women in the study area. seen primarily through the lives of the Carter women. has created an image of a homogenous group in terms of ethnicity. but real life is rarely so tidy. While class did tend to be linked with ethnicity along the southern Avalon - with most of the middle class being English Protestant and most of the plebeian community being Irish Catholic (or in the process of being assimilated into that ethno-religious group through intermarriage) - there were exceptions, particularly in the earlier part of the study period For example, in the $18^{\text {th }}$ century there were various IrishProtestant merchant-planters operating in the area. some of whose wives and daughters lived at least part of their lives on the southern Avalon. The Benger family provides a good example Chapter 4 has already described the process by which Mary Kirke, the widow of David Kirke II, married James Benger, a merchant from Waterford, and became the matriarch of a significant mercantile and landholding family in Ferryland. Their son. John. became a merchant-planter and justice of the peace in the area. He married a St. John's woman. Serah, and the couple had six children - three girls and three boys. Serah resided in Ferryland with her husband (although she doubtless visited her relatives and friends in St. John's on occasion). Meanwhile, John Benger had formed a partnership with Richard Nason of Youghal, and the two held various properties in Ferryland. Aquaforte. 
Fermeuse, and Renews which they used in their trade or rented to various tenants. Their alliance was reinforced when John's daughter. Dorcas Benger, married Richard's son. Richard Nason, $\mathrm{Jr}$, in 1754 . The parties entered into a marriage settlement; although details are not available. it is possible that certain southern Avalon properties were transferred to Richard, Jr., at that time. ${ }^{s s}$ Certainly, Richard, Jr, and Dorcas brother. John. Jr., were managing the properties during the second half of the century The oral tradition suggests that the marriage between Dorcas and Richard. Jr., was not a happy one and that Dorcas was one of the unfortunate women for whom an economic union between families did not develop into a companionate marriage. Dorcas bore eight children and died at Ferryland, likely when she was in her late forties or early tifties. ${ }^{\text {st }}$ Richard moved with his children back to his family home in Youghal. passing the sole management of the properties over to his brother-in-law, John. He ultimately left his Ferryland properties to his Irish mistress. Anstice Gorman, and their son Thomas Nason by his will of 1818: and

\footnotetext{
"A marriage settlement is mentioned in PANL, MG 247. Carter-Benger-Nason
} Papers. File 18, but no details are given. Richard's will of April 8.1818. also refers to the marriage settlement (apparently, it was dated January 8.1754). but the only provision mentioned was that a trust of $£ 500$ was to be created to provide for any children who had not reached the age of majority and inherited property in Ireland or been properly accommodated by way of marriage settlements by the time of Richard's death. See PANL. MG 247. Carter-Benger-Nason Papers, File 7. Will of Richard Nason. April 8. 1818

${ }^{4}$ Dorcas had died sometime before her sister Rachel left Ferryland in 1782 Speculating that she was in her twenties when she married. it is reasonable to assume that she was between 45 and 55 at her death. See PANL, MG 247. Carter-Benger-Nason Papers. Files 3 and 37 
as Thomas predeceased his mother, the properties devolved to Anstice and ultimately, to her nephew John Nunan." Meanwhile, Dorcas" sister Rachel had married another merchant-planter. William Dobel, of Boston. in 1765; the couple had six children, all born in Ferryland. Their marriage, from various accounts, appears to have been somewhat happier than that of Dorcas and Richard Nason. Rachel and William left Ferryland in 1782, and William left the management of his Ferryland properties to John Benger. Jr. (likely at least some part of the properties had come to William by way of a marriage settlement with the Bengers as well). The couple lived in Ireland for two vears and then settled on an estate on the banks of the Delaware, near Philadelphia. where they were joined by Rachel's unmarried brother and sister. Thomas and Mary. William died there in 1788 and Rachel "did not long survive the loss of so kind \& indulgent a Husband whom she soon followed..."

Another Irish-Protestant mercantile and landholding family in the area were the Ludwiggs, also of Waterford Certainly, John Ludwigg operated out of the area and was justice of the peace there in the late 1720 s and early 1730 s. Whether he was joined on the southern Avalon by his wife, Mary, is unclear, but she did inherit his interest in various

"See: FMDB, Benger Family; PANL, MG 247, Carter-Benger-Nason Papers. especially Files 3. 18, and 37 ; and Mannion Name Files, Ferryland. "Benger" and "Nason."

${ }^{56}$ PANL. MG 247. Carter-Benger-Nason Papers, Files 3 and 37. Letter from Elizabeth and Emmeline Bennett to Robert and Peter Weston Carter, June 26, 1847, and notes from a Dobel family bible. See also Mannion Name Files. Ferryland. "Benger" and "Dobel." 
properties in the area and, in turn. left them to her children. William and Mary Fitzwalter.

who remained in Ireland and disposed of the properties by the turn of the century. Thus. there were Insh-Protestant gentry women living or holding interests on the southern Avalon, although most of these families had moved by the turn of the $19^{\text {th }}$ century and were winding up their interests in the area.

While the local gentry of the $18^{\text {th }}$ century were almost wholly Protestant (be it English or (rish), they were not exclusively so William Coman, for example. was a Catholic merchant from Waterford City with substantial holdings in the Ferryland area in the $18^{\text {th }}$ century. And at least one Irish-Catholic woman married into gentry ranks. Catherine Cooney of Kilkenny married Peter Weston, an English-Protestant merchantplanter and ultimately a justice of the peace at Ferryland. Their daughter. Ann. married William Carter, who would become a vice-admiralty judge for the island. Thus. Catherine became the matriarch of two powerful local families. She and both her daughters coinherited considerable properties at Peter's death"s and she was still administering her

"Various cour cases involving Mary Ludwigg's estate have been cited in Chapter 6 See also Mannion Name File. Ferryland, "Ludwigg."

${ }^{5 B}$ In P.NL. MG 31. Carter Family Papers, File 29, there is a certified true copy of a will executed by Peter Weston. dated June 14. 1775, which leaves his entire estate to his wife, Catherine, and two daughters. Catherine and Sarah, in equal shares to be held severally. His wife's share was to be a life interest and, at her death, was to devolve to the two daughters or the survivor of them. Daughter Catherine was to receive her share on her wedding day. Daughter Sarah was to receive her third upon attaining the age of 18 years. Weston's wife and Edmund Gormond were named Executors of the estate and Guardians of his daughters. (Note that their daughter Ann received nothing by the Will: likely, she had already received her portion in a marriage settlement when she wed 
portion at the turn of the century, initiating various suits against recalcitrant debtors and tenants (although she was usually represented in actual court hearings by men from her circle). Like her contemporary Anne Wylley Carter, then, Catherine kept her hand in the management of her financial affairs and also wielded some power in the broader life of the community. Indeed, when Catholic Prefect Apostolic James O Donel was having difficulty in establishing his nominee. Father Ewer, at Ferryland in the late 1780 s because he could not unseat a maverick priest. Patrick Power, it is likely that Catherine was key in rallying middle-class sympathy for the renegade (intriguing, as the group was largely Protestant). Irish church authorities felt that the matter could be resolved if Catherine could be convinced to switch allegiance and use her considerable influence to persuade the middle-class community to withdraw their support of Power. In 1788. Father Phelan, the Franciscan Superior at Watertord. wrote to Archbishop Troy of Dublin:

I was advised to write to Doctor Lanagan [Bishop of Ossory] in favour of Mr Ewer \& had that interest been gain'd. Power must. all at once, fall to the ground: Viz a lady of great influence lives in Feriland by name, a Widow Weston a Roman Catholik \& a native of Kilkeny [Power's home county]. [ wrote to Dr. Lanagan \& requested he $d$ write to this Lady. \& recommend $\mathrm{Mr}$. Ewer to her as being the only clergyman qualified to officiate, and also to withdraw her protection from Power \&c. The Doctor has not answered me. \& it's very probable he has not wrote to Feriland

William Carter) On September 26, 1776, Governor John Montague issued a grant of the estate to mother and daughters as co-heiresses and co-executrices. See PANL. GN 2/1/A. $6 / 149-53 / 1776$. 
this makes me suspect he is for Power ${ }^{59}$

Typical of her generation of gentry women, then, Catherine was more powerful than her daughters and grand-daughters. And like the Benger women, she demonstrates that not all members of the middle class on the southern Avalon had an English-Protestant pedigree, particularly in the $18^{\text {th }}$ century.

However. the ethno-religious homogeneity of the group began to firm up by the late $18^{\text {th }}$ century and into the early $19^{\text {th }}$ century, as many Irish merchants voluntarily wound up their affairs in the area or went bankrupt. Yet even this consistency varied somewhat geographically, for in St Mary's district, a number of Irish names had begun to creep into the grand jury lists by the late 1830 s, indicating that at least several members of that ethnic group had become principal inhabitants. property owners. and businessmen of the area by that time. This contrasted markedly with Ferryland district, where only a couple of Irish names - Cashin and $\mathrm{O}$ Neil - had sufficient family status and property to be considered "principal Merchants and Gentlemen" of their communities by the latter part of the study period $^{\text {No }}$ Neither was part of the Carters' social network.

59 Byme. ed. Gentlemen-Bishops, pp 105-6. particularly p. 106. Father Phelan to Archbishop Troy, February 4, 1788. Phelan was likely correct in his assumption about Lanagan. because the English-Protestant, middle-class community, including Catharine and her son-in-law William Carter, continued to shelter Power for some time thereafter

${ }^{*}$ The Rules of the Supreme Court established in 1826 stipulated that grand jurors be drawn from "the principal Merchants and Gentlemen" of the community (Rule 20). Petty jurors were to be drawn from those male inhabitants, 21-60 years of age, who 
One more set of exceptions must be noted to the class-ethnicity connection. Just as the gentry on the southern Avalon were not all English Protestants, similarly, not all English Protestants in the area were of the middle class. This was particularly true of the $18^{\text {th }}$ century, when English-Protestant servants were still coming out to the area to work in the fishery. (The artisanal group - carpenters, blacksmiths, sail-makers - also tended to be English-Protestant.) As noted earlier, however, Irish servants increasingly replaced English servants in the tishery, and the English plebeian community was increasingly assimilated into the Irish-Catholic ethno-religious group. Still, there were hold-outs into the $19^{\text {th }}$ century, such as the Halls, Perrymans, and Paynes of Aquafore, or the Boons and Butlers of Ferryland. The women in these families. like Irish women in the plebeian community, were involved in economic production, and, like other plebeian women, they participated in community life, sometimes in interpersonal confrontations that brought them to the attention of authorities. Several incidents will serve to illustrate the point.

On Wednesday, June 22. 1842. Ellen Payne of Aquaforte lodged a complaint with the court that on the previous Friday and Saturday, Sarah and Catherine Payne had violently beaten her and had forcibly removed her six-month-old child from her custody ${ }^{\text {s1 }}$

owned real property of any amount or rented property at an annual rental of at least £12 per annum: also included on the lists were the sons of the aforesaid while they lived with their fathers (Rule 24). See P.ANL, GN 5/2/C/1. Box 1. Royal Charter instituting the Supreme and Circuit Courts, January 1826, with attached General Rules and Orders of the Supreme Court of Newfoundland.

${ }^{1}$ PANL. 5/4/C/1. Ferryland, Box 2. n.f., Regina v. Catherine Panne and Sarah Panne. June 22. 1842. 
The records are frustratingly sparse, but it is highly probable that these women were related to each other, either by blood or marriage. This could possibly have been a situation in which the two perpetrators felt that the mother was unfit and were taking matters into their own hands as next nearest female relatives of the child. Although Catherine and Sarah were ordered to give security to keep the peace for 12 months for this particular episode, Ellen's problems with her assailants did not end there. In August of 1851 . she again complained to the court that she had been "assaulted, abused. threatened and beaten" by Catharine and Sarah, who had now been joined by Elizabeth Frost and Barbara Sisk (or Sesk), also of Aquaforte." Again. the motivation for the incident is missing from the record, but the episode suggests a collective shaming or disciplinary action by a group of women against another in their community A more explicit example of an attempt by English-Protestant plebeian women to entorce community standards again involved women of Aquaforte. including the everpresent Sarah Payne. ${ }^{63}$ The incident unfolds through the recording of two back-

"P.ANL, GN 5/4/C/1, Ferryland, Box 2, n.f., Regina v: (atharine Panme, Sarah Panne. Elizabeth Frost, and Barbara Sisk, August 12, 1851

${ }^{63}$ Sarah. herself. had other life-experiences that were not atypical for plebeian women on the southern Avalon. She had a child, likely illegitimate. with George Jones in August. 1842, the Anglican minister initially recorded the birth as illegitimate. then crossed out the notation; but Sarah's surname was listed separately. which the minister only did in cases of illegitimacy. The couple had another child in 1845, and this time, the parents were listed as George and Sarah Jones. However. there was no record of the couple having married within the church, either between the two births. or indeed any time from 1829 onwards, when the marriage records began. It seems likely, then, that Sarah and George may have entered into an informal family arrangement (hence. the minister's 
to-back court cases in 1854. On July 13, 1854, Mary Ann Perryman of Aquaforte appeared in court to name Marmaduke Clow of Ferryland as the father of her unborn child and to seek support. The very act of confronting him in open court in an effor to make him admit tinancial responsibility was, itself, a public and political act. Marmaduke. however, denied that he was the father. ${ }^{\text {th }}$ The next day, he was waylaid at Ferryland by Mary Ann s neighbours from Aquaforte. Peter and Sarah Payne, who began to abuse him by John Morry's wharf. Peter was carrying a hatchet and thrust it into the whart in a threatening fashion. When Marmaduke tried to escape. Sarah Payne grabbed him and struck him several times. Peter and Sarah took turns threatening him with the hatchet, and Sarah varied the routine by throwing rocks at Marmaduke ${ }^{\text {of }}$ The fact that Marmaduke was a court official (acting Clerk of the Peace) and had sufficient connections to have Henry Morry (of the local mercantile family) stand bond for him may have caused concern

uncertainty in recording Sarah's surname and her first child's status). The court references to her as Sarah 'Payne' in 1842.1851, and 1854 reinforce this interpretation. (There is no other Sarah Payne in the Anglican records for this period: Sarah's daughter. born in 18+2. was also named Sarah. but likely used the surname of her acknowledged father. George Jones. Regardless, she would have been too young to have been involved in any of these incidents that ended in the court room.) Several other plebeian couples within the English-Protestant community appeared as parents in the baptismal records but no corresponding marriages were entered in the marriage records. Given that Anglican ministers were not consistently available in the area, they, too, may have entered into informal marriages.

${ }^{64}$ P. ANL, GN 5/4/C/1. Ferrỵland. Box 2, n.f., Lary Am Perngman v . Larmatuke (Fow: July 13. 1854

${ }^{4}$ P.ANL, GN 5/4/C/1. Ferryland. Box 2. n.f., Regina v. Peter Payne and Sarah Panne. July 14, 1854. 
that the alleged father was going to escape formal justice. Also, the fact that Marmaduke was not originally trom the southern Avalon (he hailed from Port-aux-Basques) may have added motivation to the Paynes' concern about his adherence to local norms of behaviour. $^{\text {th }}$ Meanwhile, if Mary Ann Perryman's claim was true. Marmaduke's upcoming nuptials to Mary Johnson likely gave him strong motivation to deny paternity.

Unfortunately, the final disposition of the case is not indicated in the records: but it is worthy of note in terms of the efforts of these women to enforce community standards by shaming a man into assuming his paternal responsibilities. Although evidence on EnglishProtestant women of the plebeian community is sparse, given their relatively low numbers at the time the court records began, these anecdotes suggest a willingness to involve themselves in the politics of interpersonal confrontation. Certainly, they were essential producers in family economies. like their Irish counterparts, and likely enjoyed a similar degree of authority and status as a result of their productive activity and the generally more equitable gender relations that pervaded the plebeian community during the study period.

${ }^{66}$ Marmaduke's marriage to Mary Johnson the following year records his place of residence as Port-aux-Basques. See PANL, Church of England - Petty Harbour Parish Records. Ferryland District, Box 2, September 2, 1855. 


\subsection{Conclusion}

The core of the gentry on the southern Avalon was formed by a group of families with English-Protestant ethno-religious ties who held key mercantile. protessional. and administrative positions in the community. Gentry women were thus members of the most powerful tamilies in the area. They travelled more than plebeian women, had broader educations. more amenities and consumer goods. better housing and dress Yet in many respects. they had less influence in home and community than women from the plebeian community, particularly by the early $19^{\text {th }}$ century. Lnlike plebeian women. who continued to negotiate status and influence for themselves in flakes and fields, in court house and tavern, in the everyday running of their households, middle-class women were increasingly marginalized from the public sphere of economic production. from community politics. even from the tinancial aspects of household management. Widowhood gave some an entree into economic activity, but most confined their public appearances to church-going and properly chaperoned travel and heterosocial events, where they conveyed status and gentility through their dress. their mannerisms, and their networks of acquaintances and friends Of course. this was a process that unfolded over several generations the relatively public and active lives of Anne Wylley Carter or Catherine Weston, for example. contrasted with the more circumspect activities of the amorphous Sarah Carter and her frail cousin-in-law. Harriet. But even these earlier gentry women eschewed shore and field work, and were absent from the court room and the public house. And increasingly. 
the activities of middle-class women played out in the domestic sphere or in public gatherings that were social in aspect. Totally absent in the study area were the types of activities that gave middle-class women elsewhere a 'respectable' admittance into the public sphere - church fund-raising and philanthropic work, for example, or anti-slavery and temperance movements. Along the southern Avalon, the lives of these women focused increasingly inwards on domestic concerns, particularly on the rearing of children and the supervision of servants. While their economic idleness became a hallmark of their class, this inactivity disempowered gentry women and relinquished their lives ever more to the mediation of patriarchy. 
Chapter 10 - The slender thread cast on

By the latter $18^{\text {th }}$ century, the slender thread had begun to stretch across the North Atlantic as Irish women came to the southern Avalon from the southern counties of Ireland - Wexford. Waterford. Kilkenny, Tipperary, and Cork. Like the broader waves of Irish migrants to the island of Newfoundland, they weighed their choices - balancing land shortage. economic recession, and the contraction of domestic textiles in the homeland with opportunity in the Newfoundland fishery - a potential that was always tempered with risk in this persistently uncertain industry. Leaving behind the comfort and security of familiar landscapes and broader kinship groups, they set out as single women or within nuclear family groups to negotiate their way through new territory - not just in terms of geographical locality but also in terms of shifting social and economic terrains

Given that the Newtoundland passenger trade was largely unregulated. the passage for most Irish migrants to the study area was difficult - the provisions ranging from very basic to dangerously inadequate; the accommodations, from rudimentary to appalling. Still, the majority survived the Atlantic crossing and either landed on the southern Avalon or disembarked at St. John's and wended their way southward. Some women came out 'on order' from local employers. others 'shipped' themselves when they arrived Some women arrived in family groups, accompanying husbands or fathers who had already had some experience as servants in the fishery and were hoping to branch out on their own. As increasing numbers of women arrived, they had a stabilizing effect on community populations, for they tended to be permanent migrants and provided marriage or 
cohabitation partners for the still largely transient male fishing population. Along the southern Avalon, large numbers of male fishing servants increasingly found wives among incoming Irish women and, more significantly in the $19^{\text {th }}$ century, among first- and secondgeneration Irish-Newfoundland women in the area. Matrilocal and uxorilocal residence patterns often featured in community formation as male immigrants settled in the home communities of their wives. Irish women played another vital role in the establishment of the Irish population in the area as numerous English-Protestant patrilines were brought into the Irish-Catholic ethno-religious group through intermarriage with IrishNewtoundland women. By the early decades of the $19^{\text {th }}$ century, a thriving Irish planter society had established itself along the southern Avalon.

The reception the Irish received from British authorities on the island. however. was grudging at best. Irish servants increasingly became the mainstay of the fishing labour torce from the mid-1700s onwards, yet their ever expanding presence was greeted with increasing alarm by authorities. In particular. official discourse focused on those who remained behind in St. John's in the otf-season, constructing Irishness in terms of idleness. drunkenness, and disorder. Treachery, too, was set forth as an essential characteristic of the Irish. particularly among those to the south of St. John's, who were seen as poised to take advantage of any weakness in the British defence of the island and ever ready to join forces with the French and Americans. Part of this official discourse honed an image of Irish women as immoral and unproductive.

Yet this was not the construction of Irish womanhood that evolved on the 
southern Avalon. As Irish women accommodated themselves to the new rhythms of a fishing/subsistence agriculture economy, their ability to contribute to the productive and reproductive power of their households became an intrinsic part of how they were perceived by the plebeian community and how they defined themselves. Almost all adult women worked in subsistence agriculture - performing physically challenging tasks such as clearing, digging, planting, weeding, manuring, harvesting, gleaning, and animal husbandry. Women were also the responsible for processing their families raw production for household use. Increasingly from the latter 1700 s onwards, women performed shore work for household production units in the fishery, gradually replacing transient male shore crews and ultimately filling the void left on shore by the collapse of the traditional planter tishery based on hired labour. Women's vital role in household production was reflected in a household division of labour that delegated work routines in terms of pragmatism and availability, not on gendered equations of men's work with outdoor. productive. or skilled labour and women's work with domestic. reproductive. or unskilled tasks. Neither did the concept of woman primarily as helpmate to her husband develop in the study area. In the essential work of fishery and subsistence production. women worked along with the men, and while some specific tasks were differentiated roughly by sex. there was also much overlapping of routines. with members of each sex occasionally 'helping the other as necessity demanded. Indeed, women in the plebeian community felt they had equal stakes and equal responsibilities in family enterprises. Certainly, they did not aspire to be 'freed' from outdoor work through the hiring of servants, rather. servants 
were hired for domestic work to 'free' their mistresses for more important productive work. Women also worked in various economic capacities outside household production - as domestic and fishing servants, as laundresses and seamstresses, in the hospitality trade and community health services. Some combined household production with paid work and/or the sale of agricultural surplus in a package of economic coping strategies that helped their families survive or even enjoy some small luxuries. The working woman. then, was not problematic within the plebeian community in the study area. The good. hard-working stump of a girl - a construction that was transported from the home country - rooted well in southern Avalon soil.

The status and authority of Irish plebeian women in tamily economies spilled over into other aspects of family and community life. These women were usually the primary household managers; indeed, a woman's ability to juggle household demands and resources could make the difference between comfort or poverty, even survival for those tamilies living close to the margin. The names of women - single, widowed. and married appeared in various capacities in merchant ledgers, indicating that they were a significant part of the exchange economy that underwrote the local fishery. In general, their visible presence in the broader economic sphere - in their work routines and economic agency was a source of power for these women well beyond the study period. Religion was another source of female power within the largely Irish plebeian community. Not only did women play a custodial role in formal religion - performing baptisms and marriages in the absence of priests. teaching children their prayers - but they also had a powerful place as 
mediators in the alternative pre-Christian religious system that was operating in combination with formal Catholicism. And women's information networks - whether functioning as sites of networking, group preservation, female resistance, or competition were inextricably bound up in the power relations of early communities in the area.

Irish plebeian women maneuvered within and between two systems of justice and conflict resolution. Within the plebeian population, women frequently took matters into their own hands. using verbal and physical aggression in a show of informal power that was consistent with their status and authority in family and community. As an alternative to, or sometimes in conjunction with, the politics of informal confrontation, women brought their quarrels and their abusers into the courthouse. The formal legal system. at least at the local level, was not hostile terrain, but a milieu that offered a viable option tor these women in obtaining the justice which they perceived to be their due. Indeed. as the court system became more formalized. Irish women seemed to embrace this system based on individual right rather than discretionary justice. Granted. women were excluded from the formal system in terms of legislative or official functions: but they were a vital part of local court life - as civil litigants, as complainants and defendants in criminal matters. as witnesses and petitioners - and the cour room was otten a site of their empowerment more so than oppression. Furthermore, within both systems. formal and informal. women participated not purely in an extension of their roles as wives and mothers - an interpretation that constrains our understanding of their actions to fit pre-conceived gender roles - but also as self-interested parties in pursuit of individual rights. Moreover. 
both systems were receptive to their participation on these terms.

Because Irish women on the southern Avalon were successtul in carving out territory for themselves in the social, economic, and political life of early communities, there were few efforts within plebeian culture to circumscribe their lives. A bare semblance of patriarchal authority was maintained outside the home, in most families, however. this veneer masked a more equitable sharing between spouses of decisionmaking and production responsibilities. Indeed, a significant number of women were not bound by the legal restrictions of formal marriages and coverture. particularly up to the early 1800 s, as a relatively benign regime on female sexuality permitted various intormal family arrangements and the options of informal separation and divorce. But even the majority of women who did enter into formal marriages were not easily constrained in terms of informal status and authority because of their vital role as producers in family economies

But what of outside intluences - middle-class ideology and Catholic church discourse - that were constructing femininity in terms of domesticity, fragility, sexual passivity, and economic dependence? Such rhetoric made few incursions in plebeian culture because it clashed with the reality of women's lives. Indeed. local middle-class families also showed little interest in encouraging such standards of behaviour for plebeian women because they comprised a local mercantile network that was reliant on plebeian women's presence in the public spaces - in shore work, in support services tor the local fishing population. and in the exchange economy that underwrote the resident fishery 
These families would have therefore been poorly served by encouraging plebeian women to move into the respectability of the private sphere. But the Catholic church found no clash between ideology and economic reality as it pursued its civilizing mission on the southern Avalon from the late 1700 s onwards. With the priests came an increasing restriction of female sexuality, a denigration of women's outdoor productive work, and an idealization of Irish motherhood based on self-denial. virtue, and domesticity. While church rhetoric often conflicted with the lived experience of Irish-Newfoundland women. some impact was being felt by the latter decades of the study period. as pronouncements from the altar and disciplinary mechanisms such as shaming and denial of the sacraments whittled away at plebeian women's sense of selfhood.

Still, Irish plebeian women in the study area maintained their status more effectively than gentry women in the area. Middle-class women of the $18^{\text {th }}$ century had likely been involved in the economic activity of their families - although they would not have been present on flakes or in fields like plebeian women. Certainly. they supervised household affairs and led relatively public and active lives in their communities. By the turn of next century. however, the lives of gentry women were becoming increasingly circumscribed by middle-class ideology. Indeed, the economic idleness and increasing gentility and domesticity of these women helped to maintain class boundaries in small fishing communities where middle-class and plebeian men frequently interacted. thus blurring the edges of class perimeters. Although middle-class women enjoyed greater wealth and amenities than plebeian women, they were. in many ways, less powerful than 
women from the largely Irish plebeian community.

Irish women on the southern Avalon also maintained greater status and authority into the $19^{\text {th }}$ century than those who had remained in the home country. In Ireland, the massive economic and demographic changes that occurred throughout the 1800 s witnessed a severe decline in the status of rural women. The transition from tillage to pasturage, the mechanization and masculinization of agricultural work and dairying. and the contraction of the domestic textile industry led to a devaluation of women s productive work. Meanwhile. the collapse of the potato culture at mid-century suspended the practices of subdivision and partible inheritance that had permitted universal and early marriage. The farming class that predominated numerically in post-Famine Ireland turned increasingly to the restrictive practices of impartible inheritance, primogeniture, and the arranged 'match' - with family hopes and resources pinned on the inheriting son and the first-married daughter. Many rural Irish women thus found themselves as surplus' daughters with limited opportunities for paid work. Many responded by emigrating. But on the southern Avalon, the continuing value of women's productive work remained unchallenged in the study period, and Irish women's status as essential contributors to family productive units persevered. Furthermore, the relative availability of land for tishing premises and subsistence agriculture. disproportionate sex ratios in early communities, 'share and share alike' testation practices, and the desirability of large families to share in family production enhanced women's opportunities for becoming mistresses of their own households. Thus, while social and economic flux eroded the 
status of rural women in Ireland, along the southern Avalon, Irish plebeian women's status as essential producers and reproducers within family economies remained intact and provided them with considerable influence within both their households and the broader network of community power relations. The slender thread thus proved to be quite resilient within the context of new world experiences along the southern Avalon 


\section{Appendix A - The plebeian community}

The term "plebeian" is used in this thesis in the sense that it was defined by $\mathbf{E}$. P Thompson in his discussion of $18^{\text {th }}$-century English society. As in England. the plebeian community on the southern Avalon in my study period was not a working class because it lacked a class-consciousness - "a consistency of self-definition.... clarity of objectives: the structuring of class organization." But there was a distinct and vigorous plebeian culture. with its own rituals, its own patterns of work and leisure, its own world view Furthermore, the plebeian community did share a common consciousness and exert political pressure on specific occasions in relation to specific issues - either in the form of the ' $m o b^{\prime}$ in direct collective actions or as the menacing presence behind anonymous actions and threats. As Thompson argues. plebeian culture was not revolutionary. but neither was it deferential: "It bred riots but not rebellions: direct actions but not democratic organizations. ${ }^{~} 1$ On the southern Avalon. the plebeian community was comprised primarily of fishing servants, washerwomen, seamstresses, midwives, artisans. small-scale boatkeepers and 'planters' (resident, as opposed to migratory, fishing employers), and by the $19^{\text {th }}$ century, numerous 'independent' fishing families (in as much as they could be independent from their merchant suppliers).

The polar opposites to the plebs in Thompson's "societal field-of-force" were the English gentry (the patricians), who exercised cultural hegemony through their control

'This discussion borrows from E. P. Thompson, Customs in Common (London: Merlin Press. 1991), Chapter 2, quotations from pp. 57, 64, and 73. 
over office and preferment, the law, credit, the distribution and sale of goods or raw materials, the deployment of favours and charity, and the symbolism of hegemony. Their smaller-scale equivalent on the southern Avalon were the local merchants or merchants agents, vessel owners and masters, Anglican clergy, and more substantial boatkeepers and planters. part of an emerging middle class in Newfoundland in the late $18^{\text {th }}$ and early $19^{\text {th }}$ centuries, who functioned as quasi-patricians in the study area with their control of employment opportunities. relief. supply and credit. and administrative and magisterial functions. They also maintained social distance from the plebeian community through religious affiliation (most were English-Protestant vis-à-vis the largely Irish-Catholic plebeian community) and exclusive patterns of socializing and marriage (see Chapter 9)

There was a reciprocity between the plebs and the gentry on the southern Avalon for they were tied to each other through interdependence in the fishery. The relationship was tar from equal, but, as Thompson notes, the concept of paternalism and deterence which is frequently invoked to describe pre-industrial societies would not do justice to the complexity and underlying tension of the relationship. The gentry may have seen themselves as benevolent patrons. and the plebs accepted the gentry's paternalism. but on their own terms: deference was accorded only on a conditional basis, to the degree that it enabled them to extract what they needed for their own advantage and self-preservation In the process, the plebs recognized the gentry's political and economic power, but they were also resistant to it. and sometimes openly.

Linda Little has written about incidents of plebeian collective action in Conception 
Bay in the 1830 s which demonstrated a vibrant plebeian culture in that area " Such episodes on the southern Avalon were not as frequent or of the same magnitude, perhaps because the area participated only marginally in the sealing industry - a site of nascent working-class consciousness in St. John's and Conception Bay in the early decades of the $19^{\text {th }}$ century - and also because ethno-religious tensions were muted in the more homogeneous population of my study area. Still, there was evidence of resistance in the historical record which became manifest in forms of protest typically deployed by plebeian communities, such as anonymous notes, assaults, cattle maiming, vandalism, and theft directed against the gentry as well as parades and the use of symbols as mechanisms of group identity and unity

Some of these episodes involved women and are discussed in Chapter 5 . Several other examples will serve to demonstrate. Among the family papers of the Carters. merchants and magistrates on the southern Avalon, for instance, there are examples of anonymous notes and songs written about the gentry. including the following offering about the Morrys - a merchant family in Caplin Bay:

A set of rogues are in this town Who truth and justice both disown They are a petty pygmy cian And named the motl[e]y maggot gang

'Linda Little. "Plebeian Collective Action in Harbour Grace and Carbonear. 1830$40^{*}$ (M.A. Thesis. Memorial University, 1984). 


\section{Chorus}

Sing loud the motley maggot gang

sing ho the motley maggot gang

come join my chorus every one

and echo loud the maggot gan[g]

The poor they oft oppress and wrong and cloak it mong their g[u]iling throng

they are a bandit wicked clan

and named the motley maggot gang

Sing loud the motley \& $\& c^{3}$

The song continues in a similar vein for several more stanzas. concluding that "the cozening rob[bers] ought to hang." One verse refers to a cattle-maiming incident - a torm of popular protest that was a common manifestation of whiteboyism in $18^{\text {th }}$-century Ireland, and likely transferred to the southern Avalon. for there were several other incidents reported during the study period which likely had ethnic and class undertones * And there were numerous incidents evidenced in court records of theft from and malicious damage to mercantile premises during the study period.

The menacing presence of the plebs in the anonymity of the night also caused gentry concerns. In an 1835 presentment. for example. the members of the grand jury for

'PANL. MG 31. Carter Family Papers. File 64. File 64 - "The Motley Maggot Gang." A similar offering, entitled "The Grinder" appears in File 65 of the series.

${ }^{4}$ See. for example. PANL: GN 5/4/C/1. Ferryland. Box 1. f. 73. James Walsh 1 : John Rossirer. September 7, 1835; GN 5/4/C/1, St. Mary's, f. 137. Christopher and Burk v. Kielly. October 6. 1823: and MG 920, Robert Carter Diary, Friday, August 30. 1839. "Robert Pitts Cow found so injured near Val Keefes Garden as to render it necessary to kill her. Person unknown." 
Ferryland district expressed their fear of the

great risk and danger to which we are nightly exposed of having our Houses and Stores and other Property destroyed by Fire from the Inhabitants in the different Towns carrying pieces of Wood on Fire in their hand thro' the Streets and Lanes in the said Towns....

Although this could be construed as merely a commentary on unsafe lighting practices. the issue certainly seemed to have a more sinister aspect in 1839 , when the grand jury voiced the same concern about the carrying of firebrands in combination with the following complaint:

That they view with indignation the anonimous papers now handed them (together with the certainty of a Cow and two horses having been shot) and deplore most fervently, that Individuals should be found capable of such atrocious conduct, and trust that means may be adopted to detect the perpetrators thereof and prevent a recurrence of the same.

Clearly. the threat of plebeian reprisal underscored the gentry's worries about the nocturnal activities of local inhabitants.

Deputy sheriffs, bailiffs, and constables were frequently harried and assaulted in the

'PANL. GN 5/2/C/3. ff. 11-4. Grand Jury Presentment. Ferryland, November 3. 1835

"PANL. GN 5/2/C/3, n.f., Grand Jury Presentment. Ferryland. November 6. 1839. 
pertormance of their duties, most notably in attaching property to satisfy court judgments for debt. Such was the case in 1817, for example, when local constable Edward Power attempted to attach the voyage of Patrick Kent and Patrick $\mathrm{Crane}$ of Cape Broyle for payment of a debt owing to W \& B. Sweetland and Co. Kent and his boat crew spirited the fish away to Kent's wharf in Island Cove, where Power caught up with them and attempted to seize the tish and boat. A by-stander. John Howlet, provoked the crew. saving. "You are very quiet men or you would pew that fellows guts out." Others present refused to render assistance to the constable. Ferryland magistrate Andrew Morrison. who witnessed the episode, testified that Kent declared, "He [Power] might as well attach his prick as that fish," and noted that both officials feared for their lives.

Here, a discrepancy had arisen between the perceptions of the formal legal system and local fishermen in relation to the entitlement of a supplying merchant. Typicallv. such incidents garnered the support of the plebeian community - either in direct action or noncooperation with authorities. A number of these incidents involved women and are discussed in Chapter 5 A similar sense of plebeian justice motivated the over-zealous salving of wrecked vessels in the area - again, episodes that involved plebeian women (see Chapter 4). Pre-emptive removal of items and interference with magistrates. deputy sheriffs. and wreck commissioners were regular occurrences at wreck sites and

"The court ordered Kent to pay $₹ 20$ fine and sentenced him to 14 days in jail. The sentence was remitted in Supreme Court. Mannion Name File, Cape Broyle. Patrick Crane," and "Patrick Kent," citing PANL. GN 5/2/A/1, November 14, 27, and 28, and December 10 and 17.1817 . 
demonstrated an alternative plebeian interpretation of the equitable distribution of salvaged goods. A different sense of faimess also underpinned the occasional plundering of 'merchants' and ships' stores, usually in periods of distress or emergency. The inhabitants of Bay Bulls and Renews, for example, removed supplies from fishing ships in their harbours and distributed them among their communities during the terrible "winter of the rals" of 1817 - a period of high distress throughout the English Shore resulting from the post-Napoleonic War recession and a disastrous fishing season in $1816^{*}$ Similarly, when American privateers were harrying the southern Avalon during the revolutionary war, the merchants and principal inhabitants of Renews complained that the Irish population were plundering dry fish and stores." an episode that was repeated in 1796. when the French were wreaking havoc in the area ${ }^{10}$ While these actions were interpreted by English-Protestant merchants and government officials as evidence of the treasonous nature of the Irish population. it is more likely that the largely Irish plebeian community were simply taking advantage of the moment to enforce an alternate distribution of the fish and stores. with a pragmatic view that they were certainly more entitled to them than the enemy.

Of course, real life is always messy and this black-and-white division of plebeian

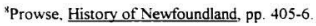

"PANL, GN 2/1/A. 7-reverse end/96-8/1778, Petition from the merchants and principal inhabitants of Renews to Governor Montague. July 29, 1778.

${ }^{10}$ Mannion Name File Collection, Renews. 
and middle-class cultures masks various shades of grey. There were socio-economic gradations within both groups - a small-scale planter, for example, was in a more privileged social and economic position than a fishing servant; a large merchant with several vessels, more comfortably situated than a clergyman. Furthermore, there was a middling group of modest-sized planters or boatkeepers and lesser court officials (sheriffs. constables, gaolers, etc.) who shared in the rituals and routines of the plebeian community but sometimes tound their allegiance turning to the gentry either because of shared ethnoreligious background. dependence on the gentry for their commissions. or simple social ambition.

Furthermore, neither the plebs nor the gentry aiways acted in unanimity Numerous court cases involving assault and civil litigation attest to small fissures between individual members of the plebeian community. And there were occasional cracks in middle-class solidarity - especially when opportunity for preferment presented itself. Most disagreements were minor squabbles over government office and took place within the confines of the group. More public was the alliance of English-Protestant merchant and magistrate Peter Winsor (also Winser) of Aquaforte with Catholic priest Father Duffy of St. Mary's in the 1836 election campaign. The two joined forces against local middleclass candidate Lieut. Robert Carter to support a drop-in candidate from St. John's. IrishCatholic merchant Patrick Morris. " When the polls opened. Winsor spoke against Carter.

"The alliance was unusual, not only because of Winsor's class and ethnicity. but also because of the very recent acrimony between him and Father Duffy. According to 
using "very tantalizing language towards him to create popularity among the crowd, ${ }^{-12}$ He did his part in delivering at least some of the Protestant vote, for according to Carter's diarist cousin, "Mr. Winsor, his son and brother with all the protestants in Aquafore [a predominantly Protestant community] joined Rev J Duffy's party and voted for Patrick Morris to their shame." ${ }^{13}$ By November 24, Carter had withdrawn his candidacy, and Morris was declared elected on November 28. (The election for the entire island, however. was declared null and void by the governor. as the election writs had not been properly sealed Litimately, this was a very satisfactory result for Peter Winsor, for he. himself. was elected in the newly called election in 1837.)

But while individual quarrels occurred within the plebs and the gentry, the two

Robert Carter's diary, Duffy had spent the winter of 1834 at Winsor's house, but had abused the hospitality shown him by baptizing two of Winsor's daughters into the Catholic faith the following summer. Hard feelings carried through the next spring. for when Winsor's vessel. the Pelter. was leaving for the seal hunt. Duffy cursed the boat and all who would dare to sail on it - a powerful deterrent within a largely Irish-Catholic district. Nonetheless. by the fall of 1836 , fences had been mended and the two joined forces to elect Morris. See PANL, MG 920, Robert Carter Diary, August 10, 1834. and February 24. 1835 . Winsor also identified himself with the plebeian community on at least one other occasion. In June, 1836. Robert Carter noted in his diary that a public notice had been attached to $\mathrm{Mr}$. Wright's (likely Thomas Wright) fence. warning people not to sign a paper in circulation in support of Mr. Wright as stipendiary magistrate. because no one in the district had sufficient abilities for the position but merchants or those connected with them, and, as a group, they were "unfitted thereby to hear a case." The notice was dated June 4 and signed "the friend of the people. P. Winsor" PANL. MG 920. Robert Carter Diary. June 5,1836

\footnotetext{
15.PANL. MG 920. Robert Carter Diary, November 14, 1836.

${ }^{13}$ PANL, MG 920. Robert Carter Diary, January 1, 1837.
} 
groups appear distinctly in the historical record - each sharing a group consciousness that was separate from the other's, even as their mutual economic interdependence brought their worlds in proximity. The middle class wielded considerable local economic and administrative power and maintained their separateness through carefully arranged marriages, exclusive socializing, and different forms of consumption. housing, and conduct. The plebs acknowledged the gentry's power, but a mask of public deference hid a more subtle culture of resistance and reprisal. 
Appendix B - Questionnaire for oral history project

\section{Migration and community formation}

- Most of the early settlers in Newfoundland came originally from England or Ireland. Do you know where your ancestors came from?

- Do you have any ancestors from Ireland? What part of Ireland? County? Town or Parish? [ask about both sides of farnily]

- Can you tell me anything about the people in your family who first came out here? tre there any stories in your family about why they came to Newfoundland? how they got here? why they came to the Southern Shore in particular?

- [If trom Ireland] - What did they do before they came out here [agriculture?] Did they have much experience in fishing? Are there any stories in your family about how they made out. how they adjusted to the change. when they came out here?

- Any stories about women in particular? Why did they came out here?

- Again, looking at your own family, or others, if you are familiar with them - did women come out here on their own? with husbands? with family? with other women'? Are there any stories you have heard about their crossing the Atlantic'?

- When looking at how communities formed, historians and geographers have usually looked at surname clusters - people with the same surname living close to each other This means they are tracing things through the male line - how men's sons have settled nearby. and then grandsons settled nearby. and so on, until you have a whole cluster of people in an area with the same surname. But $I^{\circ} \mathrm{m}$ also interested in how networks of women may have been involved in early community formation - e.g. perhaps a local girl married an Irish fishing servant and they ended up living on her family's land; or a group of daughters or sisters married incoming fishing servants and they mostly ended up living in the same community. Do vou know of any situations like that involving women in your own family? in other families in the community?

- [Try to ascertain whether informant assumes that all families on the shore are Irish, or all Catholic: ask whether some are English.] Back in the late1600s. every planter-fisherman on the Southern Shore was English. Even today, a good number of surnames on the Southern Shore are English [mention informant 's. if applicable]. Yet today, almost everybody here has a drop of Irish blood in them and most family lines are almost all Irish. Even the government has called this place the "Irish Loop".

- Have you heard any stories about this change from an English planter society to an Irish-NF society?

- When did it start happening?

- Are there any stories about intermarriage. conversion. and so on in your own family? Or in other families that you have heard about? 
- What role might women have played in this process?

- Back in the early days, where did single women find marriage partners? [e.g., from among visiting fishing servants? from among the men in the community? from outside communities?] How common was it for a woman to marry and settle down on her family's land, or in the same community as her family? How common was it for women to move to other communities after marriage [back in time, not in own lifetime]?

- I have heard it suggested that some Irish women who did come out here were what we would today call "upwardly mobile" - they married men here who already had property, oftentimes men a bit older than themselves. or they and their husbands bettered themselves on this side of the Atlantic. Have you ever heard anvthing like that about early settlers of the community?

- How did Irish immigrants hear about Newtoundland? How and what did they hear about the possibilities of making a living here? Have you heard any such stories from your family history or others in the community?

- Did most emigrants stay once they came here? Did they move on to other parts of Newfoundland? To the mainland?

- Did any move back to Ireland or England?

- Do you have any specific information about your family tree that you would be willing to share with me? [If applicable. show the family tree charts I have already prepared to prompt.]

- I've mostly been asking about your own family, but do you know any kind of background information about other individuals or families that came out to this community, especially women. and especially from Ireland?

\section{Work}

In the early days of the Newfoundland fishery. migratory fishing servants travelling back and forth from England and Ireland - provided most of the labour. But eventually, family work units took the place of servants in many places.

- How did families work together at the fishery? [Will likely be told that fathers and sons, brothers, and so on fished together; and wives and older daughters were involved in the salting and drying on shore. ]

- My mother is from Cape Broyle, and I know that in her generation. and certainly in my grandmother's time, women worked on the flakes. Was 
that always the case? How long ago did women work at making fish?

- When do you think the change - from servants to family labour - took place on the Shore?

- Did it happen everywhere on the Shore? Or just in some communities?

- Why did it happen?

- Was it associated with one type of fishing over another?

- What exactly did women do in terms of processing the fish? Can you describe for me what they did? [prompt - go as far back in time as possible]

- Were all women in fishing families involved in making fish? If not. why not?

- Were some people concerned about what was fitting work for women to do" Did anybody look down on it, in the early days'?

- Was the attitude different from place to place? Did it change over time?

- How do you think those women who were involved in the process felt about their work? [Prompts: Were they pleased to be contributing to their family incomes? Did they take pride in getting the cure right? Or were they anxious to be rid of the job? Was there any shame attached to their doing hard physical work like that?]

- How did other people in their families or in the community view women's work in the fishery? [Same kind of prompts]

- Have you ever heard of a woman actually fishing on the ocean. If not. why not? [e.g., bad luck?]

- [Make sure that informant is distinguishing between recent past and earlier period]

- Many of these women would have been born locally and grew up with the fishery But a good few would have emigrated here from Ireland, where they had no background in the fishery [farming, some domestic textiles]. Have you heard any stories about how they may have had to adjust to life in NF? [prompt - women in particular]

I know that many women worked as servants in the old days - "shipped girls". my grandmother used to call them.

- What kind of work did they do? [Prompts: Did they do household work cooking, cleaning, minding the children, and so on? Did they do work on the flakes or in the gardens?]

- Was this a common thing for young women to do? Was it common for fishing families to have servant girls? Or did they work only for well-to-do families? 
- Was it more likely something women did before marriage, or as widows. or was it something that women did throughout their lives?

- Did servant girls free up time for the women in the household? If so, what did these women do with their extra time [leisure? other household work? productive work on flakes and in gardens?]

- Ive also read of cases in which shipped girls were actually fishing servants: they worked on shore and had shipping papers, just like men fishing servants. Have you ever heard of this type of thing? If so, was it common? Was it more common in some harbours than in others?

- Have you ever heard of women being in charge of a fishing rooms? Mistresses of plantations? [ If so, were they mostly widows?]

- [Make sure informant distinguishes between recent past and earlier period]

- What other types of work did women do in the early days? [likely, will get responses re gardens, hay, spinning, knitting, berrypicking, preserve making, etc.] [get informant to distinguish between recent past and earlier period]

\section{- $\quad$ Gardening.}

- What types of things were grown: [herbs? flowers? vegetables? hay"]

- Were gardens or meadows seen as the responsibility of a particular sex? or shared?

- Thinking about the various tasks involved in gardening or hay-making were tasks assigned to specific persons based on sex, or age, or the time of vear'?

- plowing or digging [with what?]

- fertilizing? [what used? who carried? who spread?]

- who prepared seeds?

- planting?

- watering? how? who responsible?

- weeding?

- pest control? diseases - Potato wart of canker, club root in cabbage and turnip? - who responsible for detecting problems and fixing them?

- Harvest? Any special meal related to harvest? Any ritual significance?

- preparation of gardens for winter

- $\quad$ preserving and pickling - e.g. pickled cabbage

- cutting, spreading. cocking hay?

- Animal husbandry
What kind of animals did people keep back in time? 
- Who was responsible for looking after them? Men? Women? Shared?

- Were some animals associate more with women than others? Why?

- Ask about the care that was required.

- Was there ever any tradition of dairying on the Southern Shore? Keeping cows to sell dairy products? Or were cows kept just for family's purposes/subsistence?

- Some of the things I've read about women on the Southern Shore in the early days being involved in other types of work. Have you heard of women being involved in any of the following back in the old days:

- Midwifery:

- What did midwife do?

- Was there more than one midwife in a harbour at a time?

- How were they paid - cash or kind?

- Household chores as well as attending mother and child?

- Length of lying-in period?

- Were they seen as skilled? Were they respected?

- Nursing of fishing servants or other temporary residents:

- Ask specifically about treating non-family members

- Again, ask about skill, respect

- General healing, first aid - family and community

- Who was primarily responsible for family health care?

- Did women do amputations?

- Stitch cuts?

- Set bones?

- Did some visit sick more regularly than others? Sit up with the sick and dying in the community?

- Ask about folk remedies

- How did women learn about healing?

- Was healing associated with one sex more so than the other?

- Laving out of the dead

- Was this seen as women's or men's work?

- How was the dead body prepared?

- $\quad$ Taking in boarders - fishing servants, dieters, others

- Washing for fishing servants, bachelors, well-to-do

- Sewing and knitting for same

- Running public houses or taverns [alone? with husbands? widows?]

- Shopkeepers

- $\quad$ Schoolteaching 
- How did people get water for use at home - drinking, cooking, washing, etc. Who was responsible for drawing water? How far did they have to go? How heavy were the loads. Ask about use of hoops to carry water.

- Who was responsible for cutting wood/gathering firewood?

- Who was responsible for picking berries and gathering other edible plants?

- Who built houses? Were women involved in any way - physical labour, planning? Who was responsible for household repairs? [make sure informant goes back in time]

- What other household responsibilities did women have? [likely responses cleaning, cooking, childcare, spinning, sewing, knitting]

- Who looked after children when women were on the flakes or in the gardens'?

\section{Hiternative economic strategies}

- Begging I notice from reading history books and governors' letters. etc., that there were some periods back in the early $1800 \mathrm{~s}$ in particular that fishing families ran into some hard times - especially in the $1820 \mathrm{~s}$ and $1830 \mathrm{~s}$. It seems to me. though, that people on the Southern Shore were not sending in petitions for relief from the Governor - seed potatoes. flour - as often as people in. say. CB or TB

- Why do you think that was? [better fishery? local community better able to fend for selves?]

- Still, by the 1830 s, even communities on the Southern Shore were sending in petitions for seed potatoes. By that time. in CB and TB. women and children were seen begging in larger communities like Harbour Grace. Have you ever heard of that kind of thing - women and children begging on the shore?

- If so. was it a regular sort of thing (say a particular time of year?) or just once in a blue moon, when they were really desperate.

- What type of numbers would have been involved?

- Did men beg, or was it just women and children? [if latter. why? - likely masculinity issues: but also, were they the more logical people. economically, as in Ireland, and the ones likely to get the best response?]

- Shebeening. My great aunt Sarah's husband used to run rum from St. Pierre. and 
she used to sell it from a little store that she kept at the side of the house. Now she used to sell regular merchandise in the store, but local people knew they couid always get a bit of the 'other' as well.

- Have you heard of other women being involved in this kind of thing especially back in time?

- If so, where did they get the liquor?

- How important do you think the income would have been to these women and their families?

- Involvement of widows?

- Back in Ireland, selling illegal whiskey was called "shebeening"; have you ever heard the word "shebeening" or "shebeen house"?

- Did people make their own liquor? How was it made (ingredients? technology? locale?) Were many people doing it? Did they do it back in time?

- Wrecking When I was young, I heard stories about wrecking activity on the shore

- ships being deliberately lured into the rocks in bad weather, for example

- Have you ever heard any stories like that?

- Do you think they are true?

- What areas were best known for it?

- Did women participate in any way? If so, how?

- Now a number of people would not have deliberately run a ship aground. but if they found the ship in trouble, they might have gone out and taken cargo or materials such as doors and trunks off it. Have you heard any stories like that?

- Do you think they are true?

- What areas?

- Were women involved?

- Of course, once a ship was abandoned by a crew, it was legal to perform salvage operations. Also. lots of wreckage would just wash up on shore and people could have just picked up things that had washed in with the tide. My own grandparents' house in Cape Broyle had a door from a wreck in it. How common was that type of thing?

- What areas?

- Did people have reservations about doing it? Why, or why not?

- Did some people look down on others for taking things from wrecks?

- Were women involved - in going out in boats? in combing the beaches?

- $\quad$ Prostitution They call prostitution "the oldest profession" and it cenainly seems to exist just about everywhere in the world.

- Have you ever heard of cases, back in time. of women working as 


\section{prostitutes?}

- If so, who would have been their customers?

- Why would they have become prostitutes?

- How would they have been regarded by the community?

\section{Illegitimacy}

- How did the community regarded illegitimacy back in time?

- Did they strongly disapprove, somewhat disapprove, or were they more accepting

- Who do you think was held more responsible for an illegitimate baby? Mother? Father? Both equally? Why?

- How did the Catholic church look at illegitimacy? Did the church treat the parents of illegitimate children the same?

- Was there a difference in how the church looked at illegitimacy and how the community felt about it?

- Back in the days long before any kind of social services, how would an unmarried women fend for herself and her child? Any ideas? [family? seen as community responsibility? court action against father? ]

\section{Property and inheritance}

- Again, thinking back to early days, have you ever heard of women owning or inheriting any of the following:

- $\quad$ tishing premises

- $\quad$ fishing boats or equipment

- houses

- $\quad$ gardens or meadows

- livestock

- cash or jewelry

- household furniture or other items

- Were there any sort of "rules of thumb" in terms of inheriting? For e.g.:

- Everyone inherit equally:

- Daughters did not inherit property unless there were no sons:

- Sons got fishing premises and equipment: daughters got homes and gardens;

- Daughters got livestock, furniture, case and jewelry only?

- What about widows? What kind of things would they inherit? Would it be for their lifetime only or until remarried? Have you ever heard of a widow's third? 
- Was it common for people to write out Wills and Deeds in the old days? Are there any in your family from back before the mid-1800s.

- Do you think there was any difference in terms of English families and Irish families in terms of the way they left their property to their families?

\section{Women and power}

- $\quad[\mathrm{m}$ interested in how much power and authority women had in the early days in terms of their families or communities.

- How much say did women have in family decision-making [prompt to go back in time]?

- Decisions involving fishing? Making fish?

- Gardens and crops?

- Marriage - whom to marty? when to marry?

- Child-rearing, discipline, education, etc.

- Who looked after the family's finances? Who dealt with the merchant? Who looked after any cash the family had? Who was the main household manager?

- If the family was involved in disputes with, say, another family over a garden of shore space, or with the merchant. or with a sheriff. or whatnot would women feel that they had the right to speak up in these types of situations?

- If decisions had to be made concerning the community - say where a road was built or the building of a church or school - would women have had any say in these matters?

- Were there certain areas that were more women's domain than men's and vice versa?

- Did one sex have more power and authority than the other?

- $\quad$ If responses tending in that direction. ask about potential gap between the ideal and the reality. E.g. were men supposed to be in charge. but actually women had a good deal of authority?

- Have you ever heard of a woman in the old days using physical violence to get her point across - either against another woman or against a man.

-

- Have you ever heard of any special women's activities during which women would get together just with each other for any type of reason [carding? quilting? e.g.] What were the purpose of these sessions?

- share the work?

- social aspect? 
- $\quad$ air frustrations?
- gossip?

7 Culture

- How important to you think it was for Irish people in the early days to hold onto their Irishness?

- What role do you think Irish women played in holding onto Irish culture on the Southern Shore?

- language

- customs

- beliefs

- $\quad$ songs and stories

- food preparation

- tools

- $\quad$ clothing styles

- housing styles

\section{Religion}

- There was no Catholic mission in Ferryland district until 1789, and many communities would not have seen a priest very often in the early days. Yet this shore became a very Catholic shore, despite the fact that most of the earliest people here were English Protestants:

- How much of a role do you think women played in holding onto religious rituals and beliefs. especially in these early days? Did they have any role, or did people rely on the occasional priest coming by?

- Do you think one sex or another would have been more concerned about holding onto religious beliefs? Or were they about the same?

- Who performed baptisms and marriages or read pravers over the dead when there was no priest available?

- Some of the old-time priests used to complain about women pertorming baptisms and marriages when a priest wasn t available. Have you ever heard of this?

- The old-time priests also used to complain that people used to get "divorced" or separated by the magistrates back in the 1700 s and would then "marry" again. Have you ever heard of these types of relationships back in the old days? e.g., women with more than one husband? men with more than one wife? [specify not widowed] 
- Back in treland in the $18^{\text {th }}$ and early $19^{\text {th }}$ centuries. two types of religion were practised by trish Catholics - formal religious practices recognized by the Church mass, sacraments, later benedictions, etc; and informal practices that had roots in pre-Christian days but were adapted to the Catholic religion. Many of these practices may have been carried over to Newfoundland. Have you heard of:

- $\quad$ visiting holy wells [prompt - Father Duffy's well]

- $\quad$ the "pattern" - pilgrimage to a holy site, circuits on knees, prayers combined with social aspects such as dancing, drinking. story-telling. etc

- Any special attachment to Saint Brigid? Who was she? Particular observances?

- Storm after St. Patrick's day - Sheelagh's Brush. Who was Sheelagh?

- People with special powers - to cure or bring harm.

- Were there any figures used to frighten children to keep them from being bad, e g. or keep them from going to a dangerous place - boo-man, tairies. Jacky Lantern. Mostly male? female? mixture? Any background on specific local women used to scare the young?

- Were there women with special healing power, or who could charm away specific ailments? [e.g., woman whose married and maiden names were the same; seventh daughter (of a seventh daughter)]. Where did the power come from?

- Were there both men and women charmers? Either more common?

- Were there men or women who had special powers to do harm? e.g., - evil eye, witches? Men or women more common?

- Was it common for widows to have powers good or bad?

- Describe the old hag. Female figure? Why?

- Have you heard of the bibe or banshee. Female? Why?

- Were there people with special powers in terms of seeing the future [possible e.g. prophetic dreams. reading tea leaves. seeing future spouse's faces in mirrors, setting raw eggs in window and then throwing out onto road -first to walk over has same initials as future spouse]. Were these type of things associated with one sex over another. or both equally?

- Did you ever hear of ritual cursing - calling down harm on enemies? If so. were women involved? Was one sex more likely to do this than another? Fairies:

- Was belief in fairies strong?

- Was it equally strong between sexes?

- What measures could be taken to protect people from fairies?

- Who would have primary responsibility for protecting loved ones e.g., fairy buns in baby blankets or pockets?

- Ask to describe the old-time wake [prompt for drinking. singing. dancing. story-telling, sexual ribaldry, anti-clerical references] Ask informant 
specifically about wakes in days of early settlement - any stories? songs? Who would prepare corpse? sit up with corpse?

- Women in Ireland used to "keen" [sort of a wailing lament] at wakes or at the graveside in Ireland. Did women ever do that on the Southern Shore back in time? What purpose did it serve. Why do you think the practice stopped?

- Did women go to funerals and gravesides in the old days? If not, why not?

- Do you think men or women played a more important role in maintaining these old beliefs? Or do you think it was about the same?

- In Ferryland in particular - Have you ever heard of the story of Peggy Mountain $1833-4$ ? [If informant recognizes name: Why was the priest, Father Brown. mad at her' What were the contents of the letter that was publicly read in the gaol house? Why was she attacked by two other women in community?]

- Have you ever heard of the story of Father Duffy converting Peter Winsor's daughters to Catholicism?

- Have vou heard the story of Father Duffy having women at St. Mary's take tire from the alter to burn a house'? [Ritual? Why women?]

- How much power did the priests actually have in the community in the old days?

- Were they religious leaders only? Or did people look up to them in other areas - e.g. politics, important decisions, etc

- Did people do everything that the priests told them unquestioningly?

- Did people listen to the priests' advice as a respected leader but follow their own conscience if they felt they had to - especially in matters that were not directly related to the Church?

- Would they disobey the priest without too much concern? How much would this depend on whether or not the matter was directly related to religion or not? How much would this depend on whether or not the priest would "find out"?

- Did the priests back in time treat both sexes differently or about the same?

- Tell me about the churching of women? How was it done? Why was it done?

- Were boys and girls educated together in early schools? When the Presentation Sisters came to the Southern Shore, what kind of changes did thev bring about in terms of girls' education? What were they hoping to accomplish? Did they make a lot of difference in terms of girls' training? 
- Were fees ever paid directly to the priest - i.e., to go into his own pocket - for performing certain things like baptisms, weddings, funerals? Or were fees paid to the church?

- In certain places in Ireland in the late 1700s and early 1800s, there were outbreaks of anti-clericism: groups like the Whiteboys acting against or speaking out against the priests - sometimes just anonymous notices or notes posted against church property; sometimes actual physical assaults on the priests. Did anything like that every happen on the shore in the early days? Would women have been involved in such things in any way?

\section{Ethnicitv/class}

- One of the things that is often said about NF outport communities is that they are relatively 'egalitarian' - people are very equal in status, one person is as good as the next. Still, I think that most communities had some families that were considered more genteel or more 'grand' than others.

- Were there any in this community, going back in time?

- Why do you think they were more 'grand' than others?

- Especially in terms of women, how would there lives have been different from those of say an ordinary fisherman's wife?

- work [servants]

- education

- $\quad$ choice of marriage partners

- dress

- $\quad$ homes, furniture, etc.

- travel

- $\quad$ presence in public places - flakes, gardens, courts. etc

- Did the women from grander families have more power or less in their families? communities?

- Do you think ordinary women wanted to be like the grander folks. or were they content with their own lives?

- Did the women folk from the grander families and the more ordinary families mix together? [If sometimes did - when? e.g. childbirth?] Or were they more likely to keep to their own?

- Would the men from different backgrounds have had more or fewer opportunities to mix with each other than women? If so. why?

\section{Plebeian iustice}

- Often times, when a couple of families hold themselves a bit above the rest or are 
trying to take more than their fair share, then the ordinary people will try to take them down a peg or two. Have you ever heard of that type of thing back in the early days?

- anonymous notes or posters put up on the properties of grander types?

- people organizing a protest against, say, a merchant or a fishing master. or

a judge, or politician?

- riots?

- Have you ever heard of women participating in these types of things?

- Have you heard about the Father Duffy affair? Were women involved?

- Tell me about the Masterless Men. Were any women involved in their activities?

These days, we have government and police forces and so on to regulate society. But back in the days when there were no policemen and the courts sat only once in a blue moon, how did the community maintain peace and order' How did it keep people from misbehaving too much? e.g., Often small communities will have things like shaming rituals - people who misbehave are ducked in water, or paraded around the community in strange clothing with people laughing at them and sometimes even injuring them. Anything like this on the Southern Shore?

- Sometimes, even when the courts and police were operating. people did not always behave the formal law, if they felt that it was not being "fair" or not acting to the benefit of the community. For example, if a bailiff or deputy sheriff was ordered to seize or take over a fisherman's premises because he had tallen into debt - people in the community might rally round to protect the family and the property from falling into the hands of the law.

- Have you heard of any such incidents?

- Have you heard of women participating?

- Have you heard any stories, songs, etc., about women and gossip? What purpose did gossip serve? [Possible responses - just a matter of being nosy? Venting? Helping to preserve community standards? monitor people s behaviour?] Do you think gossip was associated more with one sex than another? If so. why? If associated more with women - ask if men gossiped? If not. why not? Did men get together and talk? What did they talk about?

- Were women involved in mummering? Prompt to go back to stories about old days - not recent times

- Did they dress up and visit?

- What time of day or night? 
- Were there large groups of people?

- How did they behave moving from house to house [casual walking or marching? quiet or rowdy? fights? chasing? - women's involvement?]

- Did they carry anything in their hands -sticks. canes, hobby horse

- Inside houses, how did they behave? Quiet or rowdy?

- Tricks played - especially by women?

- Did women dance, sing, recite, tell stories or jokes, play instruments?

- I've heard that men sometimes wore women's clothing. Why? Did women wear men's clothing? Why?

- Was there a mummers' play? Were there any women figures, or male figures dressed up in women's clothing? Why?

- Who would be responsible for seeing to the mummers needs - woman of house, man of house, both?

\section{Spatial separation}

- $\quad$ [For community with mixed population\}: Sometimes when people from different backgrounds migrate to an area, we find that they set themselves up in their own separate areas - like a Chinatown, or a Little Italy. Did the English and Irish here set themseives up in different parts of the harbour? Or were they all mixed in together?

$$
\text { - Prompt re "Irishtown" in Bay Bulls. e g. }
$$

- Were there physical spaces that were associated with a specific sex? e g. kitchen women, fishing-boat - men? Prompt about possible grey areas

- Did women ever go out in fishing boats? If no, why not? If bad luck.

$$
\text { why? }
$$

- $\quad$ foreshore - drying fish

- $\quad$ stage head

- $\quad$ gardens and meadows

- merchants premises

- court house

Prompt about issues such as physical suitability, respectability. power?

- Are there any place names around here that relate to women - e.g. Lady's Cove. Old Woman's Scrape? Why were they so named?

\section{Material culture}

- Many families hold onto keepsakes or souvenirs from people in the past. Does your family have any souvenirs from the past that you would associate with 
women? [e.g. butter chum, needlework, spinning wheel, carder]

- Name and description

- How old?

- Purpose? How long in use? Still in use? Same purpose?

- Where was it used - house [room]. garden, flake, etc.

- Who was original maker?

- Who originally used?

- Significance of any markings or colour[s] of item?

- Was it associated with any particular time of year [e.g., Christmas], or group [women, catholics, e.g.]

- Any stories associated with it?

- Does it bring good or bad luck?

- Any association with Ireland? Transfer of culture'?

- Can you tell me anything about houses back in the early days? What type of homes would people have lived in? Describe the layout. Did people remain in the same type of house, or did they improve it as time progressed? Any similarities to homes back in Ireland? How much input did women have in the building of houses?

\section{Written material}

- One of the hardest things about research about women is finding anything written by them or about them. Even the most ordinary type of item, like a personal letter or shopping list, can tell us something about a woman's life. Would you have any old writings by anyone - men or women - in your family - letters. diaries. cookbooks. poems, songs, business accounts - that you would be willing for me to have a look at?

- Do you have a family bible that would contain information about your family back in time, and if so. would you be willing to let me have a look at it?

\section{$1+$ Miscellaneous}

- Is there anything about women settlers - English or Irish - that we haven t touched on yet today that you would like to tell me about? Songs, stories, old sayings. anything from your family history? from the community's history? 
置Memorial

University of Newfoundland

CERTIFICATION OF ETHICAL ACCEPTABILITY

FOR RESEARCH INVOLVING HUMAN SUBJECTS

Date theerkeonsh 5502.17

Name of applicant: Willeen Keough

Department History.

Agency: ISER $1753-1845$

We the undersigned member os the Memorial University of New foundland Art Research Committee. having examined the application of a grant to support the above-named project, consider the expenmental procedures, as outlined by the applicant, to be acceptable on ethical grounds for research involving human subjects.

MEMBERSHIP OF THE COMMITTEE

NAME

DEPARTMENT

POSITION

SIGNATURE

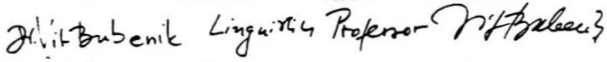

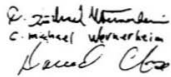
Es min F. Lxhikent
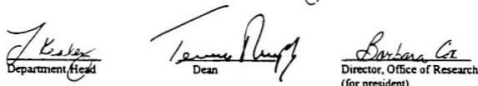

(for president)

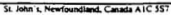

696 


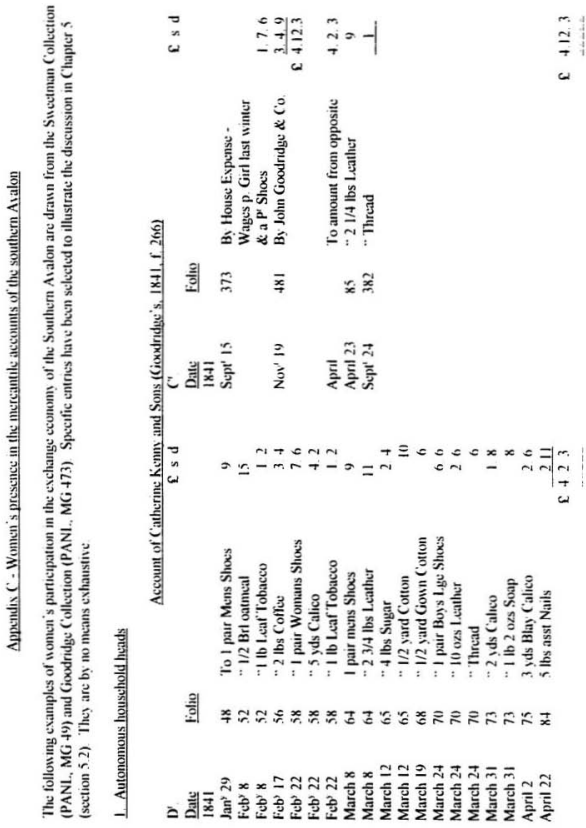




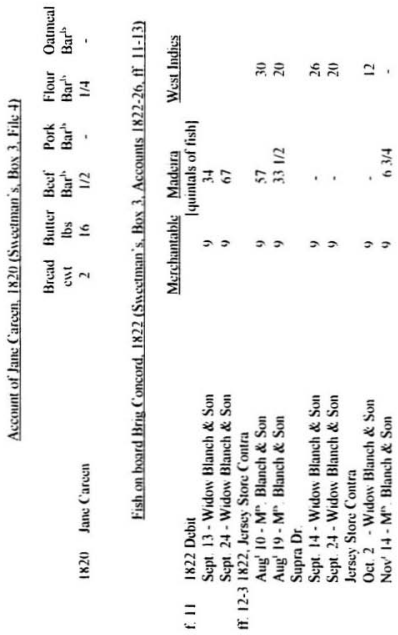




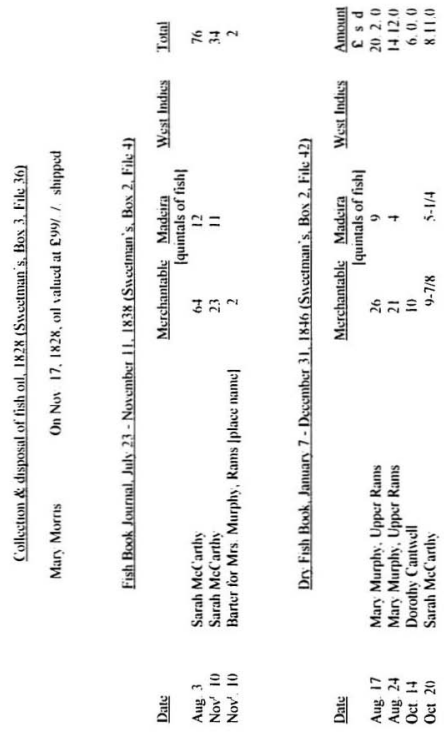

ริ 


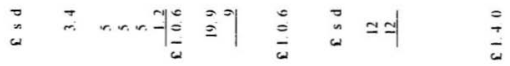

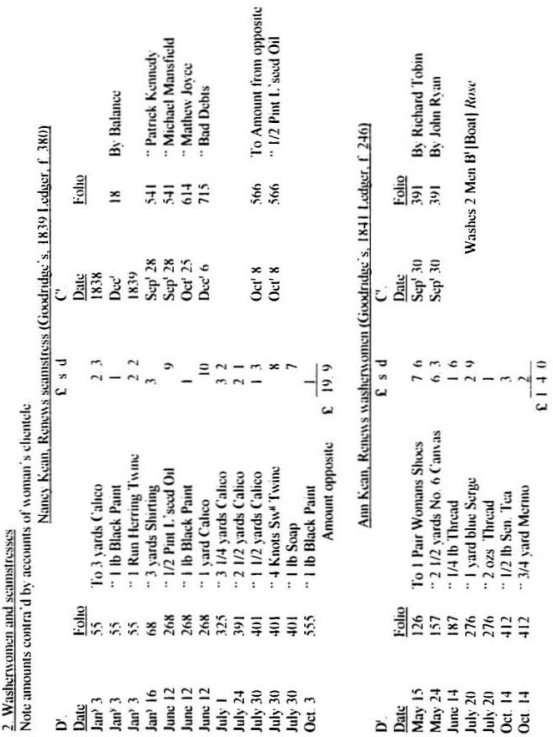



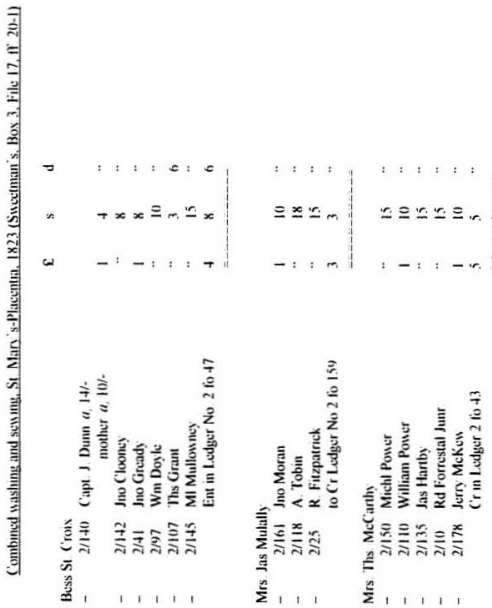


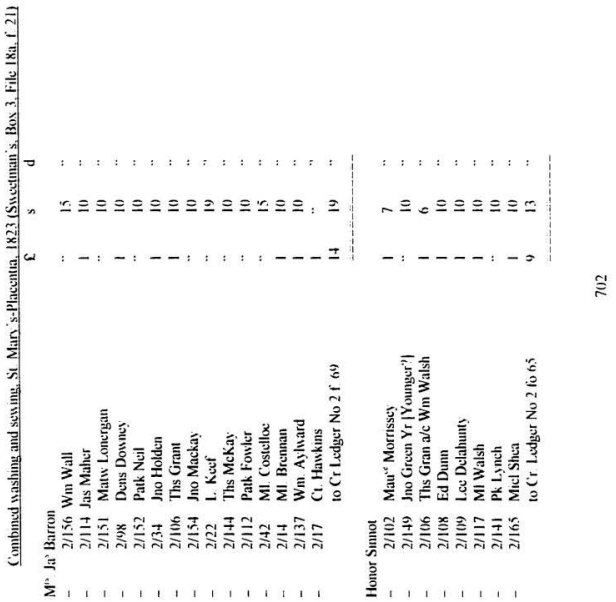




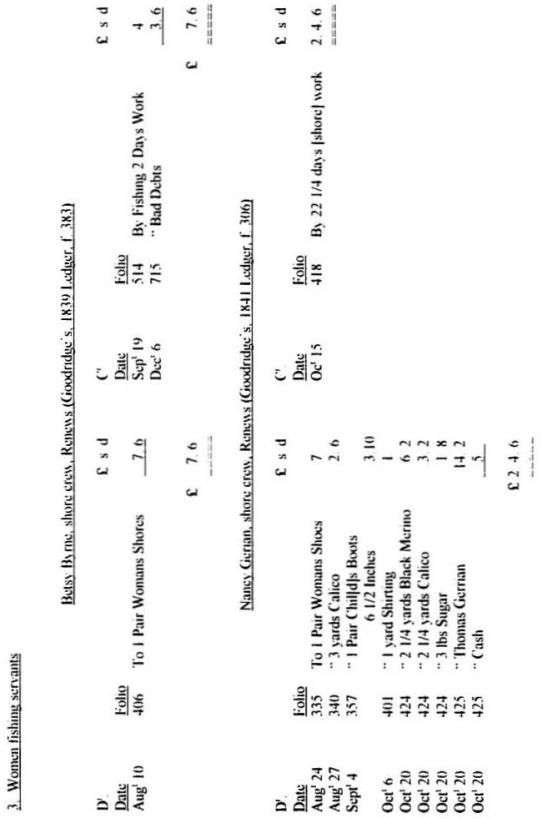




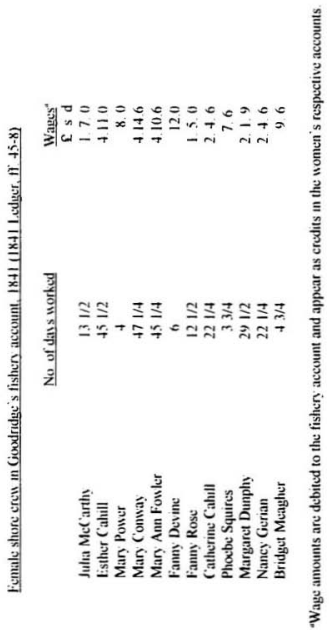




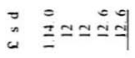
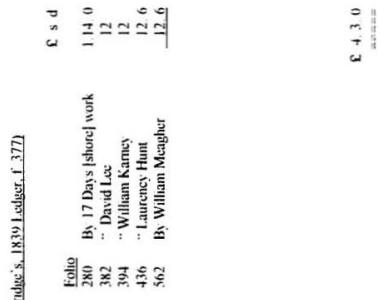

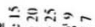

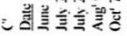

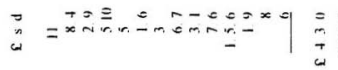

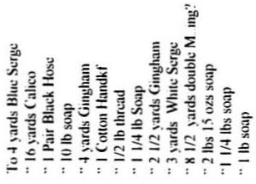

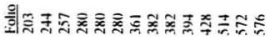

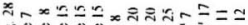

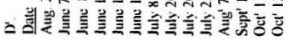




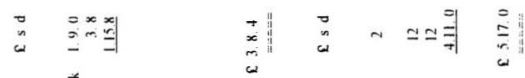
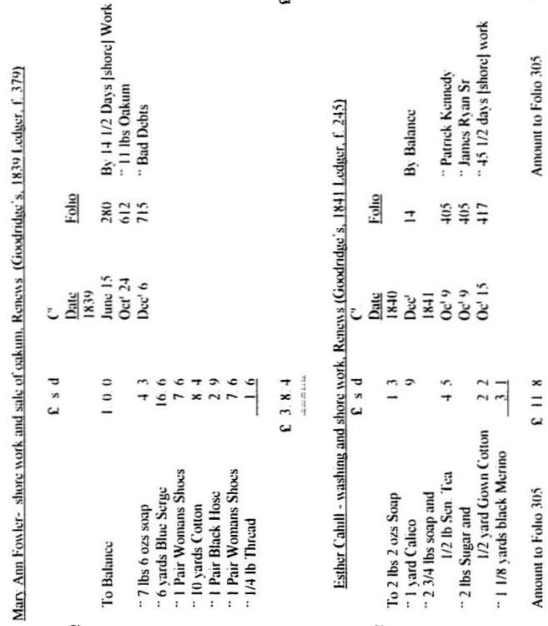

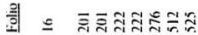

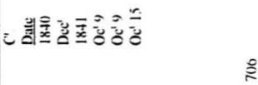

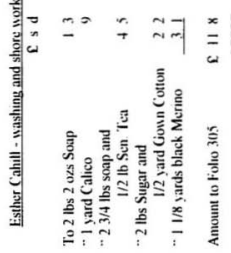

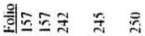

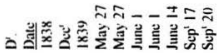

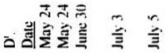




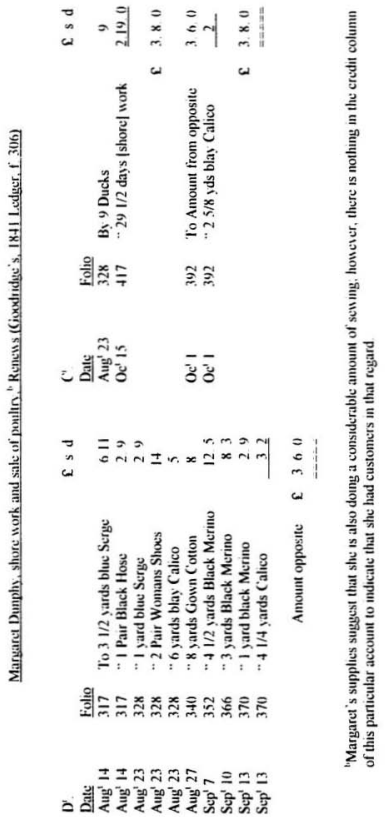

E 


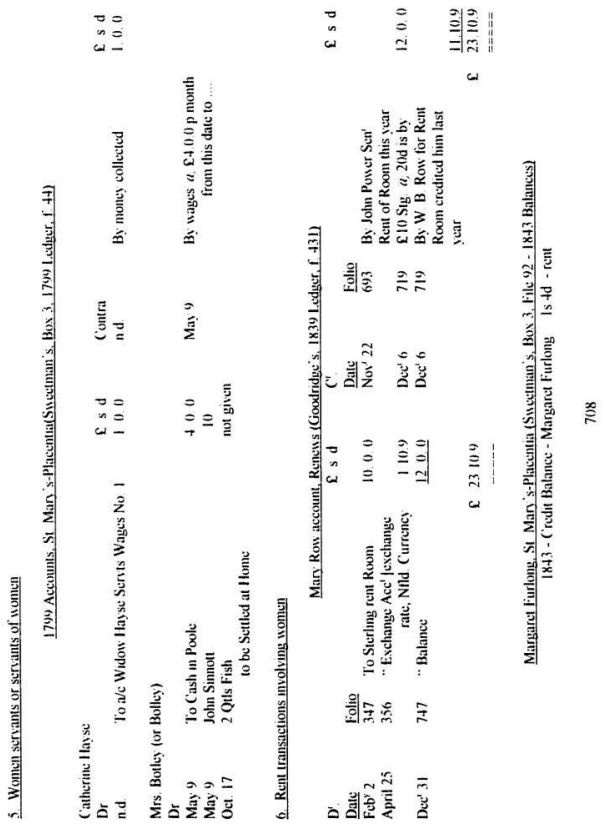




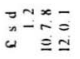

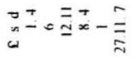
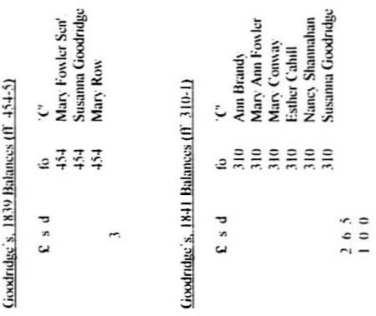

ڤ

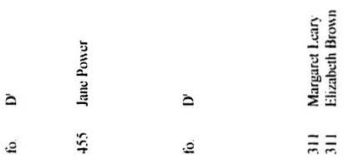




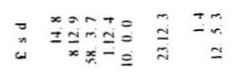

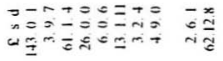

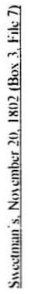

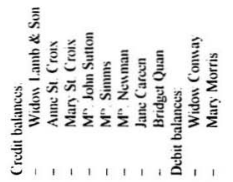

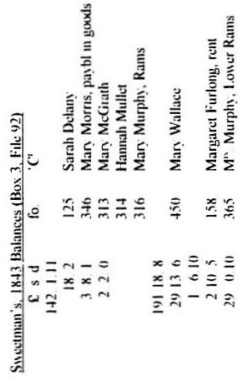

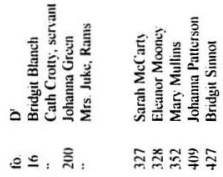




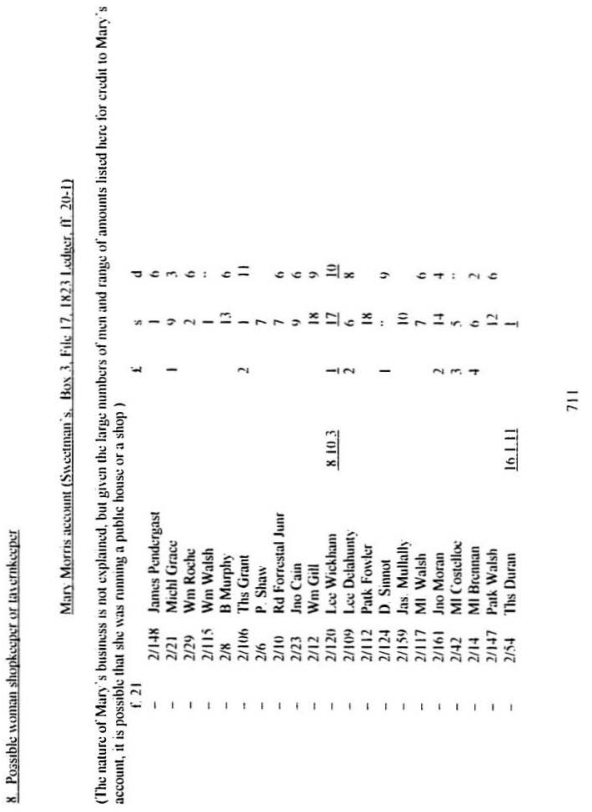




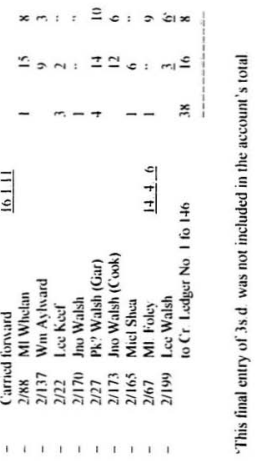




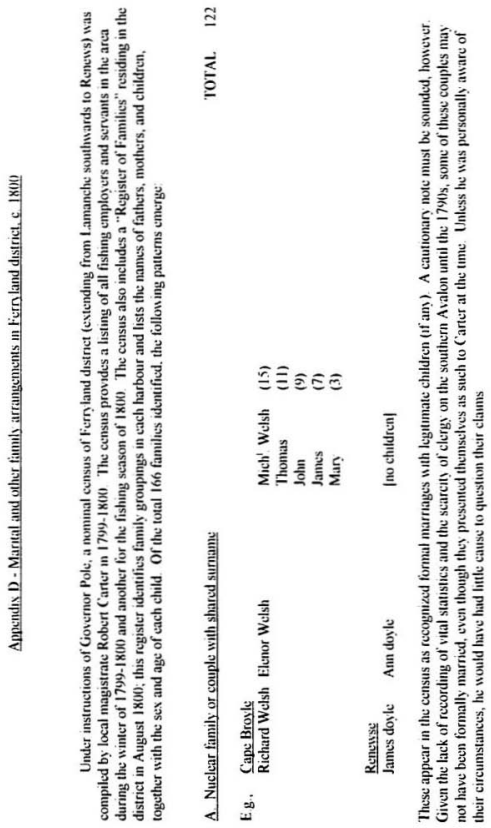




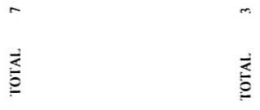

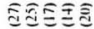
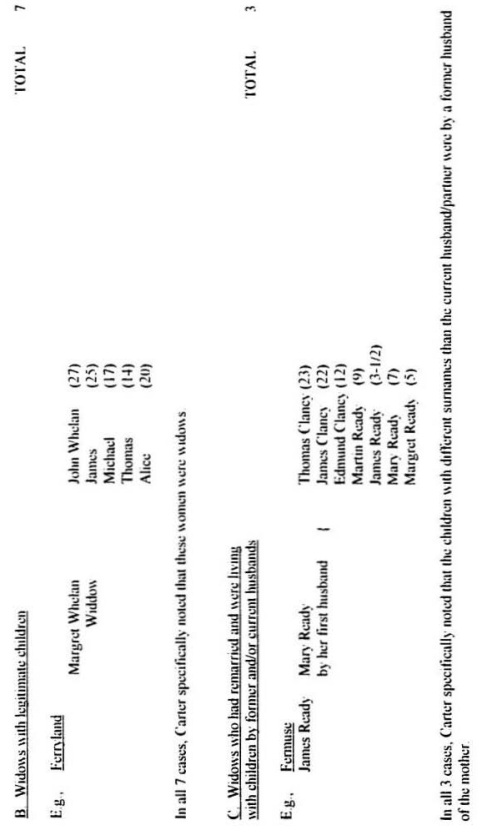

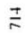




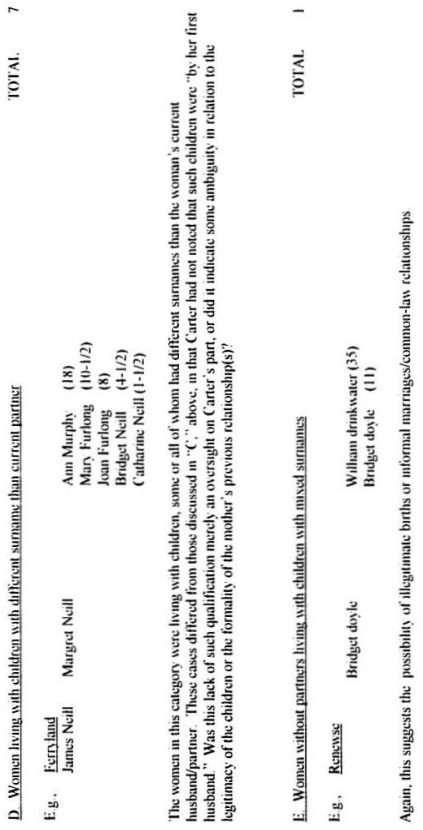

$\frac{n}{n}$ 

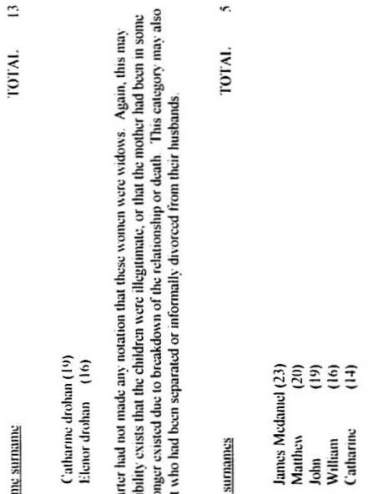

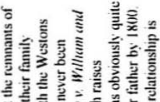

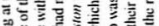

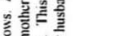

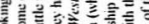

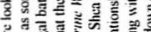

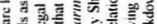

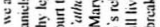

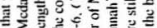

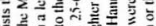

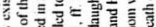

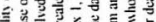

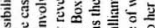

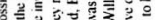

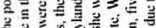

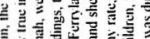

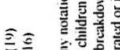

들

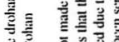

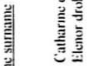

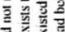

를

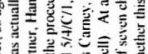

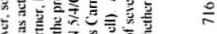

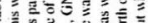

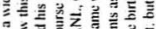

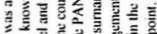

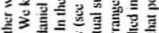

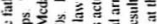

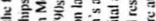

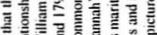

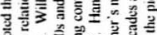
을 츨

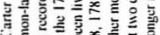

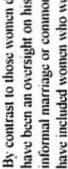

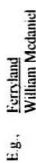

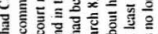

急

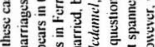

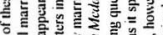

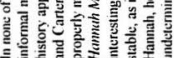




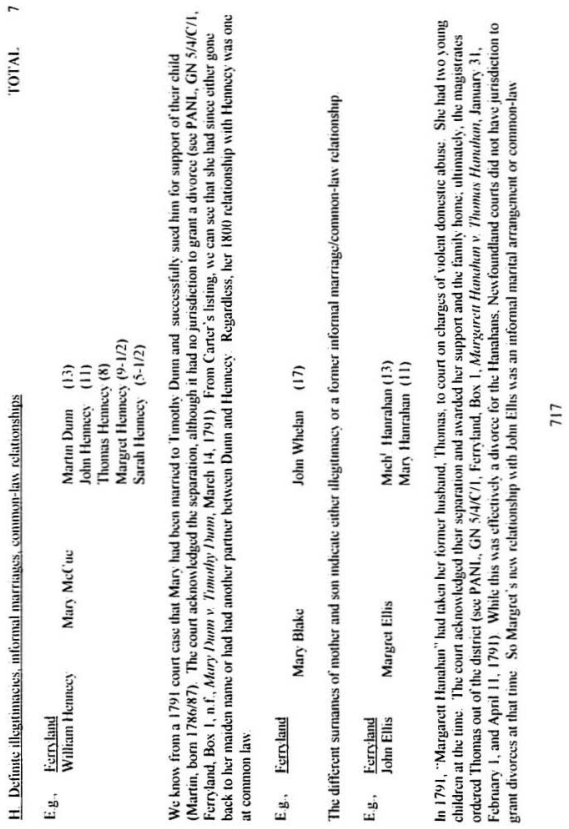




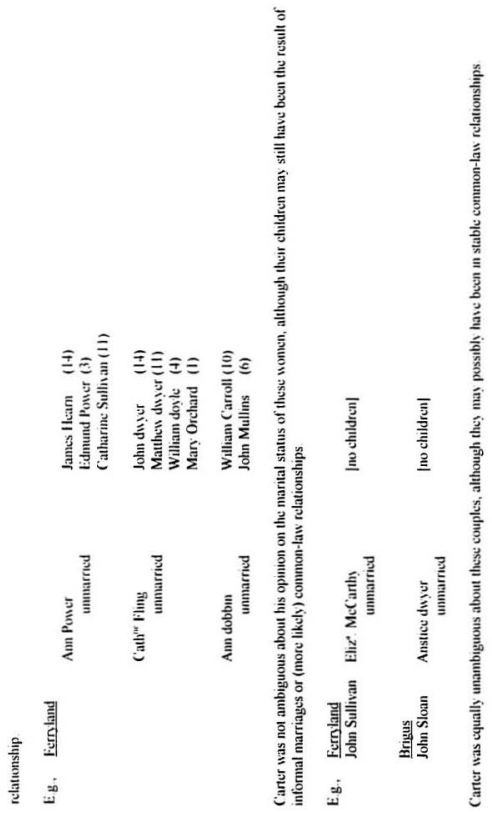


Appendix E - Partial family tree - Morry-Carter families. Ca!

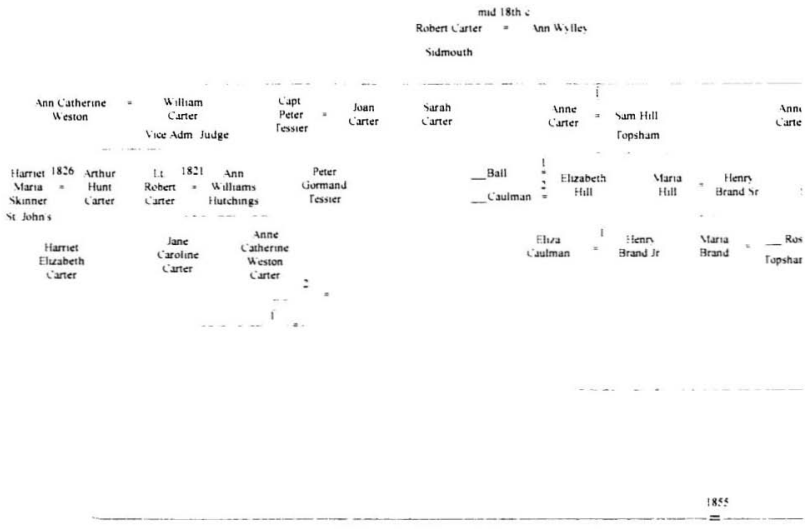

SOLRCES: DA. Interview July 20. 1999: FMDB - File 02B: PANL. MG : 
ry-Carter families. Caplin Bay and Ferryland. mid-18th to mid-19th centuries

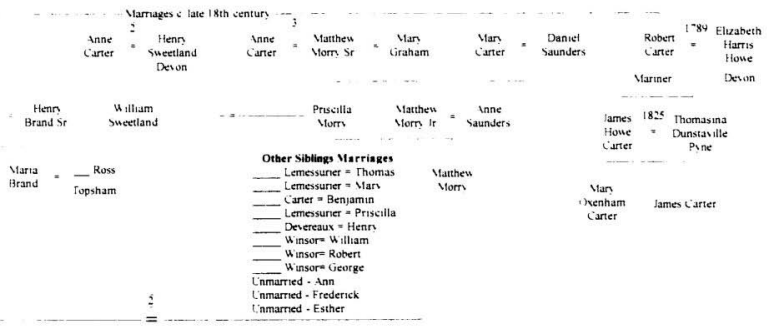

trthut

Kamp

Morr!

$18 \leqslant 2$

$=$

1855

File 02B: PANL. MG 205. Pole Papers. 1799-1800: and PANL. MG 3I. Carter Family Papers. 


\section{BIBLIOGRAPHY}

\section{Primary Sources}

\section{A. Manuscripts}

\section{$\underline{\text { CNS }}$}

C.O. 194 Series - correspondence between authorities at Newfoundland and the Colonial Office in Britain.

MF 236. Will of John Bole, Ferryland, October 10, 1759

Whelan. Sr. Elizabeth. "History of the Community of St. Mary s." Lnpub research paper dated April 4. 1972.

\section{FMDB}

Files on the following families: Benger, Carter, Coady, Costelloe, Culleton.

Curran, Goff, Healey, Hynes, Johnston, Keough, Morry, Mountain, Ryan. Sullivan, Swain. Williams

Robert Carter Diary, 1832-1852.

$\underline{\mathrm{MHA}}$

Keith Matthews Collection - early census material of British naval authorities at Newfoundland and correspondence to the Board of Trade. Britain.

MF-053. Robert Carter Diary. partial typescript, 1832-1837.

MF-105, Letterbook of Capt. Michael Richards. Commander at Fort William. $1700-1703$

MF-191. Letterbook of Edward Kough, 1818-1834.

R 95/20. "List of Inhabitants' Names, the No. of Their Families, 1708." Trans from C. O. 194/4, ff. 253-56, by W. Gordon Handcock.

Undergraduate Research Papers - Anthropology 2230 Collection.

Undergraduate Research Papers - Geography 2000 Collection. 
Undergraduate Research Papers - History Collection.

\section{MUNFLA}

Johnson, Zita. "Calendar Customs and Rites of Passage at Renews." MUNFLA ms. 68-011D. Unpub. research paper, Memorial University. 1967-1968.

O'Brien. Andrew, "Wake. Funeral and Burial Customs in Cape Broyle" MUNFLA ms. 68-016C, Unpub. research paper, Memorial University. 1967.1968

----- "Songs from Cape Broyle." MUNFLA Tape 68-16/490, 1967-1968

\section{NLGS}

Various genealogical records for communities in the study area. including birth. marriage, and death records and gravestone listings.

PANL

G. 2/1/A, outgoing correspondence from the Newtoundland governor's otfice as recorded by the local colonial secretary. 1749-1834.

GN 2/2. incoming correspondence to the Newtoundland governor's office as recorded by the local colonial secretary. 1825-1891

GN 2/39/A. early census material for the study area. 1675. 1677. and 1681. as well as submissions to the Board of Trade respecting the advantages and disadvantages of the planter fishery, 1675, 1677, and 1691.

GN $5 / 1$. Registry of Wills. vols. 1 and 2

GN 5/2/A1, Court records. Central district.

GN $5 / 1 / \mathrm{C} / 1.5 / 1 / \mathrm{C} / 6.5 / 1 / \mathrm{C} / 9.5 / 2 / \mathrm{C} / 1.5 / 2 / \mathrm{C} / 3.5 / 2 / \mathrm{C} / 4.5 / 2 / \mathrm{C} / 8.5 / 4 / \mathrm{C} / 1$. Court and probate records (various), Ferryland and Trepassey-St. Mary's Districts.

GN 21/1/A. Department of Education. Minute Book of the Protestant Board of Education for the District of Ferryland. 1836-1837. and 1843-1878. 
GN 21/6/2. Department of Education, Minute Books of the Roman Catholic Board of Education for the District of Conception Bay, 1836-1857.

MG 31. Carter Family Papers

MG 49 , Sweetman Collection, various loose materials, including business correspondence and accounts.

MG 204, Papers of Governor Thomas Duckworth.

VG 205. Papers of Governor Charles Morice Pole, including a nominal census of Ferryland district comprised of: register of families. January 1 . 1800: list of masters. servants, and dieters, winter. 1799/spring. 1800, and list of masters, servants, and dieters, August 13, 1800.

MG 206. Papers of Governor Thomas Cochrane

MG 237, Matthew Morry Papers.

MG 247. Carter-Benger-Nason Papers.

MG +73 , Alan Goodridge \& Son Collection, particularly the business ledgers tor 1839 and 1841

MG 598. SPG Collection, particularly Series C. D. E. and G.

MG 708, Mary Ann Simms Scrapbook.

MG 920. Robert Carter Diary, 1832-1852

Mildred Howard Collection - vital statistics from Newfoundland newspapers.

Parish Records:

Church of England:

Petty Harbour Parish. Ferryland District: baptisms - 1823 onwards: marriages - 1829 onwards; deaths - 1827 onwards.

(Records for other parishes in study area fall outside time trame) Roman Catholic.

Bay Bulls Parish: baptisms - 1830 onwards.

Witless Bay Parish: baptisms - 1831 onwards: marriages - 1830 onwards, deaths - 1901 onwards. 
Brigus South Parish: headstone data, 1879.1900.

Renews Parish: baptisms - 1857 onwards; marriages - 1838 onwards.

Trepassey Parish: baptisms - 1843 onwards; deaths - 1856 onwards.

St. Mary's Parish: baptisms - 1843 onwards; marriages - 1844 onwards: deaths - 1891 onwards.

(Other records for the study area are available but fall outside the time frame).

PCA

-The Four Foundresses First Letters Home to Ireland" - file containing letters of

Mother Mary Bernard Kirwan and Sisters Magdalene O'Shaughnessey.

Mary Xavier Lynch. and Mary Xavier Molony. 1833-1834.

Ravmond J Condon, "A Brief History of the Early Catholic Missionaries on the Southern Shore." Unpub. research paper, Labrador City. April 23. 1983

$\underline{\text { PRL }}$

$3+09 \mathrm{~V} 45$. Surrogate Court Records. Ferryland and Trepassey-St Mary's districts. 1773-1804.

971.8/S A8/NR. Sweetman Letterbook. 1788-1804, and miscellaneous items

NLGS

Vital statistics data, headstone data, and parish registers for various communities in the study area.

\section{$\underline{\text { RCAASJ }}$}

100 Series. Bishop James O Donel Papers, 1784-1806.

101 Series, Bishop Patrick Lambert Papers, 1807-1816

102 Series. Bishop Thomas Scallan Papers. 1817-1829.

103 Series, Bishop Michael A. Fleming Papers. 1829-1850 - which includes Dean Patrick Cleary's, "A note on church history [1784-1850]." 


\section{Private Collections}

Mannion, John. Name File Collection - database on Irish immigrants to Newfoundland from the $18^{\text {th }}$ century onwards. Private Collection. St. John's.

Unidentified mercantile journal. 1881-1892, found in the White-Maher house at Ferryland prior to its demolition c. 1960 s and currently in the possession of DA of Ferryland.

\section{B. Newspapers}

Newtoundland

Vewtoundlander

Public Ledger

Roval Gazette and Newtoundland Advertiser

Irish

Clonmel Gazerte

Cork Evening Post

Waterford Chronicle

Waterford Herald

Wextord Herald

\section{Unpublished Manuscripts from the Study Area}

Barnable, Gerald. "The Ferryland Magistracy." Unpub. manuscript. Ferryland. n.d.

----- "An Outline of Renews History." Linpub. manuscript. Ferryland. December, 1992.

Calvert Come Home Year Committee, "From Caplin Bav. 1920 to Calvert. 1995 " Calvert: Calvert Come Home Year Committee. 1995.

Croft, Agnes, Janet Curran, Sheila Hynes. Catherine Fennelly, Dot Fennelly. Rick Kenny. Randy Crane. "A Glimpse into the Past." Unpub. manuscript. Ferryland, n.d. Sketches by Jack Barnable. 
Ferryland Historical Society. "Ferryland Bibliography." Unpub. listing of newspaper items relating to Ferryland, n.d.

Hurd. Lisa, Donald Hurd, Guy Barnable, Jennifer Power, and Jim Walsh "Research Report on Living History Potential at Ferryland." Unpub. manuscript, Ferryland, April. 1995.

O'Brien. James Joseph (Jim Joe). "Cape Broyle. 1959-60" Unpub. community history written c. 1960. Copy in possession of author.

-...- "Cape Broyle" Unpub chronicle of the old families of Cape Brovle. 1971. Copy in possession of author

-.-.- "Leahy Family." Unpub and untitled notes on the Leahy family at Cape Broyle, n.d but likely c. 1971. Copy in possession of author.

-.... - The Oldridge Family." Unpub. notes on the Oldridge tamily at Cape Broyle, n.d but likely c. 1971. Copy in possession of author.

Power, Jennifer. "Research Reports." Linpub. manuscripts. Ferryland. February. 1995 (Background notes for Hurd et al. report cited above, review of secondary literature and numerous oral interviews on a range of topics relating to historical Ferryland - general history, religion, medicine. the role of women. social customs. superstitions. shipwrecks. education. the economy. etc.).

Untitled and undated directory of inhabitants of Ferryland from the $17^{\text {th }}$ century to the $19^{\text {th }}$ century. prepared for the Colony of Avalon site. Ferryland.

\section{Published Documents}

Anspach. Rev Lewis A. A History of the Island of Newfoundland. London Anspach. 1819

Fleming. Mons. Michael A. Report of the Catholic Mission in Newfoundland in North America. Submitted to the Cardinal Prefect of Propaganda. Rome: Printing Press of the Sacred Congregation, 1837

-..- "Letter on the State of Religion in Newfoundland." January 11. 1844. addressed to the Very Rev. Dr. A. O'Conneil. Dublin. Dublin: James Duffy, 1844 
Howley, Rev. Michael F. Ecclesiastical History of Newfoundland. Boston: Doyle and Whittle, 1888, reprint Belleville, Ont.. Mika Publishing, 1971

Pedley, Rev Charles. The History of Newfoundland London: Longman. Green, Longman. Roberts and Green. 1863.

Reeves, John. History of the Government of the Island of Newfoundland. London: 1793, reprint Wakefield: New York: S. R. Publishers: Johnson Reprint Corporation, 1967.

Thomas, Aaron. The Newfoundland Journal of Aaron Thomas, Jean M. Murray. ed London: Longmans. Green, 1968

Journal of the Legislative Council. St. John's: Queen's Printer, 1836-1878

Vewtoundland Population Returns. 1836 St. John's: s.n. 1836

Vewtoundland Population Returns, 1845. St. John's: Ryan and Withers. 1845

Vewtoundland Population Returns, 1857. St. John's: s.n.. 1858. Extract from the Journal of the House of Assembly. 1858 (Sessional Papers)

Statutes of Newfoundland, 1834- 1860.

\section{E. Oral Interviews and Personal Correspondence from Informants}

AK, Calvert/Caplin Bay, Interview August 26, 1999

AOB. Cape Broyle, Interview August 25, 1999.

AOT. Calvert/Caplin Bay. Interview July 19, 1999

AS. Calvert/Caplin Bay (formerly of Trepassey), Interviews July 21 and August 30, 1999.

AY. St. Mary's (formerly of Gaskiers), Interview September 10. 1999

DA. Ferryland, Interview July 20.1999. Also, handwritten notes. July, 1999, and correspondence dated March 8, 1999. and January 31. March 13. and Christmas. 2000. 
EOB. St. John's (formerly of Cape Broyle). May 4. 2001.

EP. Calvert/Caplin Bay, Interview July 19, 1999

ER, Calvert/Caplin Bay, Interview August 23. 1999.

FOB, St. John's (formerly of Cape Brovle), Interviews 1972 and 1974

FW. Cape Broyle. Interview 1974

GK. St. John's (formerly of Cape Broyle). Interviews 1972, 1974, Mav 15, 1998. and March 26 and May 4. 2001

JJOB. Cape Broyle, Interviews 1972 and 1974

JK, Ferryland, Interview August 24. 1999

JOB. Cape Broyle (formerly of Calver/Caplin Bay), Interviews 1972 and 1974

JTOB. Cape Broyle. Interviews 1972 and 1974

JW. Ferryland. Interview May 9, 2000

MD. Ferryland. Interviews July 27 and August 24. 1999

MK. Renews, August 31, 1999

MOB. Cape Broyle. Interview July 22. 1999. and handwritten notes. July. 1999

MY. St. Mary's. Interview September 11. 1999.

RB. St. John's (formerly of Calvert/Caplin Bay), Interview March 26. 2001

RJ. Ferryland. Interview May 9, 2000.

TB. Brigus South. Interview June 22. 1999

TP. Calvert/Caplin Bay, Interview July 19, 1999.

WC. Ferryland. Interview July 21. 1999. 
Byrne, Cyril (Coordinator of Irish Studies at Saint Mary's University, Halifax). Email dated September 8, 2000.

\section{F. Other}

Displays at the Capt. William Jackman Museum, Renews.

\section{Secondary Sources}

Adams. William Forbes Ireland and Irish Emigration to the New World from 1815 to the Famine. New York: Russell \& Russell, 1967, reprint of 1932 ed.

Akenson, Donald H. Being Had Historians, Evidence, and the Irish in North America, Don Mills, Ont. P. D. Meany Publishers. 1985

-..-- Small Differences: Irish Catholics and Irish Protestants, 1815-1922. An International Perspective. Kingston; Montreal: McGill-Queen's Lniversity Press. 1988

-..-. The Irish Diaspora: A Primer. Toronto: P. D. Meaney, 1993

-...- The Irish in Ontario \& Study in Rural History. $2^{\text {nd }}$ ed. Montreal: Kingston. London: Ithaca: McGill-Queen's University Press. 1999

Antler, Ellen. "Women's Work in Newfoundland Fishing Families." Atlantis, 2 : 2 (1977). $106-13$

Backhouse. Constance. Petticoats and Prejudice Women and Law in NineteenthCentury Canada. Toronto: Osgoode Society, 1991.

Baines. Dudley. Emigration from Europe, 1815-1930, Economic History Society Studies in Economic History. Houndmills. Hampshire: Macmillan Education Ltd. 1991

Baines. Robin. Margrette Kleinig. Deborah Oxley. and Eric Richards. "Migration and Opportunity: An Antipodean Perspective." International Review of Social History, 43:2 (1998), 235-63.

Barnable, Gerald J. "The Ferryland Riots of 1788 " An Nasc, 7 (Summer. 1994), 4-9

Basch. Norma. "Family Values in Colonial New York." Reviews in American History, 
$23.3(1995), 397-401$.

Berg, Maxine. "Women, Property and the Industrial Revolution" Journal of Interdisciplinary History, XXIV:2 (Autumn. 1993), 233-50.

Bergman, Jörg R. Discreet Indiscretions The Social Organization of Gossip, John Bednarz. Jr., trans. New York: Aldine de Gruyter, 1993.

Berkin, Carol. First Generations: Women in Colonial America. New York: Hill and Wang, 1996

-..... and Leslie Horowitz, eds. Women's Voices, Women's Lives: Documents in Early American History. Boston: Northeastern University Press, 1998.

Bielenberg Andy, ed The Irish Diaspora. Harlow: Pearson Education. 2000

Biemer, Linda Briggs. Women and Property in Colonial New York: The Transition trom Dutch to English Law, 1643-1727 Ann Arbor: UMI Research Press. 1983

Boase, Rev. Leonard, ed. Catholic Book of Knowledge, vol. 3 . London: Virtue and Company, 1961. Reprinted Chicago: Catholic Home Press, 1962.

Bouce. Paul-Gabriel. ed Sexuality in eighteenth-century Britain. Manchester: Manchester University Press. 1982.

Bourke, Angela "The Irish Traditional Lament and the Grieving Process." Women's Studies International Forum, $11: 4$ (1988). 287-91.

Bourke, Joanna. Husbandry to Housewifery Women, Economic Change, and Housework in Ireland, 1890-1914. Oxford: Toronto: Clarendon, 1993.

Bradbury, Bettina. Working Families: Age, Gender, and Daily Survival in Industrializing Montreal. Toronto: McCleiland \& Stuart. 1993.

Bridenthal. Renate. Claudia Koonz, and Susan Stuard. eds. Becoming Visible Women in European History. Boston: Houghton Mifflin. 1987.

Brown. Kathleen M. Grood Wives, Nasty Wenches, and Anxious Patriarchs: Gender. Race, and Power in Colonial Virginia. Chapel Hill; London: University of North Carolina Press, 1994. 
Burford. Gale, ed. Ties That Bind: An Anthology of Social Work and Social Welfare. St. John's: Jesperson Publishing, 1997

Bury. John B. The Life of St Patrick. Freeport: Books for Libraries Press, 1905, reprint 1971

Byrne. Cyril J, ed Gentlemen-Bishops and Faction Fighters: The Letters of Bishops 0 Donel, Lambert, Scallan and other Irish. Missionaries. St. John's: Jesperson Press. 1984.

---- "The Brig Thomas Farrell" An Vasc, 41 (Winter, 1991), 6-7

-.---. and Harry, Margaret, eds. Talamh An Eisc Canadian and Irish Essays Halifax: Nimbus Publishing, 1986

Cadigan. Sean. Hope and Deception in Conception Bay: Merchant - Settler Relations in Veufoundland, 1785-1855. Toronto: Lniversity of Toronto Press. 1995

-.---.- "The Moral Economy of the Commons: Ecology and Equity in the Neufoundland Cod Fishery, 1815-1855." Labour Le Travail. +3 (Spring. 1999), 9-42

Cameron. Deborah, ed The Feminist Critique of Language A Reader London, New York Routledge. 1990, revised ed 1998

Campbeil, Malcolm. The Kingdom of the Ryans: The Irish in Southwest New South Wales, 1816-1890 Sydney: University of New South Wales Press, 1997

Carter. Kathryn. Diaries in English by Women In Canada 1753-1995: An Annotated Bibliography. Ottawa: Canadian Research Institute for the Advancement of Women. 1997

Cell, Gillian. English Enterprise in Newfoundland, 1577-1699 Toronto: University of Toronto Press, 1969

Christianson. Gale Edward. "Population. the Potato and Depression in Ireland 1800 1830." Eire-Ireland. 7:4 (Winter. 1972), 70-95.

Clark. Anna The Struggle for the Breeches: Gender and the Making of the British Working Class. Berkeley: University of California Press, 1995.

Clarke. Brian P. Piety and Nationalism. Lav Voluntary Associations and the Creation of 
an Irish-Catholic Community in Toronto, 1850-1895 Montreal, Kingston:

McGill-Queen's University Press, 1993

Clarkson, L. A. "Love. Labour and Life: Women in Carrick-on-Suir in the Late Eighteenth Century." Irish Economic and Social History, XX (1993), 18-34

Cleary. Patricia "'She will be in the shop' Women's Sphere of Trade in EighteenthCentury Philadelphia and New York." Pennsylvania Magazine of History and Biography, 119.3 (1995), 181-202.

Coates. Jennifer, and Deborah Cameron, eds Women in Their Speech Communities. New Perspectives in Language and Sex London: New York: Longman, 1988

Cole. Sally Women of the Praia: Work and Lives in a Pornuguese Coastal Community Princeton Princeton Liniversity Press, 1991

Connell, Kenneth H. The Population of Ireland, 1750-1845 Oxford. Clarendon Press. 1950

-.--.- Irish Peasant Sociery: Four Historical Essavs. Oxford Clarendon Press, 1968

Connolly, Sean J Priests and People in Pre-Famine Ireland, 1780-1845. Dublin. Gill and Ltacmillan. 1982

Conrad. Margaret Recording Angels: The Private Chronicles of Women from the Maritime Provinces of Canada, 1750-1950. Ottawa. Canadian Research Institute for the Advancement of Women, 1982

-.-.-. ed. They Planted Well: New England Planters in Maritime Canada. Fredericton. Acadiensis, 1988

---., ed. Making Adjustments: Change and Continuity in Planter Nova Scotia, 1759. 1800 Fredericton: Acadiensis, 1991.

-.---., ed. Intimate Relations: Family and Community in Plarice - Vova Scotia, 1759. 1800 Fredericton: Acadiensis. 1995

-...-. Toni Laidlow, and Donna Smyth. No Place Like Home: Diaries and Letters of Nova Scotia Women, 1771-1938. Halifax: Formac Publishing, 1988

Conway, Sheelagh. The Faraway Hills are Green: Voices of Irish Women in Canada. 
Toronto: Women's Press, 1992

Costa. Derek Mendes da. Richard J. Balfour, and Eileen E Gillese. Property Law $2^{\text {N }}$ ed Toronto: Edmond Montgomery Publications, 1990.

Crawford. E Margaret, ed. The Hungry Stream: Essays on Emigration and Famine Belfast Centre for Emigration Studies. L7ster-American Folk Park, and Institute of Irish Studies. Queen's U'niversity. 1997

Creveccoeur, Hector St. John de Letters from an American Farmer London, New York J. M. Dent \& Sons and E. P Dutton. 1912, reprint 1951.

Cullen, Louis M. The Emergence of Modern Ireland, 1600-1900. New York. Holmes and Meier Publishers, 1981

Cullen. Mary. and Maria Luddy eds. Women. Power and Consciousness in 19th-Century Ireland. Dublin Attic Press, 1995

Dalv. Mary "Women in the Irish Workforce from Pre-industrial to Modem Times." Saothar, 7 (1981), 74-82.

Damousi. Jov Depraved and Disorderly Female Convicts, Sexuality and Gender in Colonial Australia. Cambridge Cambridge L'niversity Press. 1997

Danaher. Kevin. Irish country people. Cork: Mercier Press, 1966

Davidoff. Leonore Worlds Between: Historical Perspectives on Gender and Class Cambridge: Polity Press, 1995

and Catherine Hall. Family Fortunes: Men and women of the English middle class, 1780-1850 Chicago: University of Chicago Press, 1987

Davis. Graham. The Irish in Britain, 1815-1914 Dublin: Gill and Macmillan. 1991

Davis. Nanciellen. "Patriarchy From the Grave: Family Relations in $19^{\text {th }}$ Century New Brunswick Wills." Acadiensis, XIII 2 (Spring, 1984), 91-100

Dayton, Cornelia Hughes. "Turning Points and the Relevance of Colonial Legal History." William and Mary Quarterly, 50:1 (1993), 7-17

Women Before the Bar: Gender, Law, and Society in Connecticut. 1639-1789 
Chapel Hill: University of North Carolina Press. 1995

Diner, Hasia R. Erin's Daughters in America: Irish Immigrant Women in the Nineteenth Century. Baltimore; London: The Johns Hopkins Lniversity Press, 1983

Ditz. Toby L. Property and Kinship Inheritance in Early Connecticut, 1750-1820. Princeton: Princeton Úniversity Press, 1986.

Doyle. David. "The Irish in Australia and the United States: Some Comparisons. 18001939 " Irish Economic and Social History, XVI (1989), 73-94.

Doyle, Gerald S, ed. The Old Time Songs and Poetry of Vewfoundland. St John's: Gerald S. Doyle, 1927

Drake. Michael, ed., Time, Familv and Community Perspectives on Familv and Community History Oxford; Cambridge: Open University in Association with Blackwell Publishers, 1994

Drudy, P J.ed. The Irish in America. Emigration. Assimilation and Impact. Irish Studies 4 Cambridge; London; New York: Cambridge Lniversity Press, 1985

Dubinsky, Karen. Improper Advances: Rape and Heterosexual Contlict in Ontario. 18801929 Chicago and London: University of Chicago Press. 1993

Dunbar. Robin. Grooming. Gossip and the Evolution of Language London: Boston: Faber and Faber, 1996

Edwards. Susan M. Female Sexuality and the Law A study of constructs of female sexuality as they inform statute and legal procedure C. M Campbell and Paul Wiles, eds. Oxford: Martin Robertson \& Company Lid., 1981.

Eldridge, Larry D. ed. Women and Freedom in Early America. New York: London. New York University Press, 1997.

Elliott. Bruce S. Irish Migrants in the Canadas: A New Approach. Kingston; Montreal: McGill-Queen's University Press, 1988.

Ellis. Peter Berresford. Celtic Women: Women in Celtic society and literature. London: Constable, 1995.

English, Christopher. "The Reception of Law in Ferryland District. Newfoundland. 1786- 
1812" Paper presented to a joint session of the Canadian Law and Society Association and the Canadian Historical Association. Brock University, june 2, 1996

-..... "Collective Violence in Ferryland District. Newfoundland. in 1786" Dalhousie Law Journal, $21: 2$ (Fall, 1998), 475-89

-..-.-., and Christopher P Curran. "A Cautious Beginning. The Court of Civil Jurisdiction. 1791." Silk Robes and Sou westers: The Supreme Cour 1791-1991 St. John's: Jesperson Press, 1991

English, Tracy M. "Big Wages, Glorious Climate and Situations Guaranteed A Study of the Migration of Irish Women to Great Britain for the Period 1861 to 1911 ." M. Thesis, Memorial University of Newfoundland. 1999

Erickson. Amy Louise Women and Property in Early Modern England. London; New York: Routledge. 1993.

Errington. Elizabeth Jane. Wives and Mothers, Schoolmistresses and Scullery Maids Working Women in Upper Canada, 1790-1840 Montreal. Kingston. London. Buffalo McGill-Queen's Liniversity Press. 1995

Fallows, Marjorie Irish Americans. Identity and Assimilation. Englewood Cliffs Prentice-Hall. 1979

Faris. James C Cat Harbour A Newfoundland fishing settlement St. John's: ISER. 1972

Field. Agnes. "The Development of Government in Newfoundland. 1638-1713 " M.A. Thesis, University of London, 1924.

Fitzgerald, John E. "Conflict and Culture in Irish-Newfoundland Roman Catholicism. 1829-1850 * Ph.D. Thesis, University of Ottawa. 1997

Frager. Ruth A Sweatshop Strife: Class, Ethnicity, and Gender in the Jewish Labour Movement in Toronto. 1900-1939. Toronto: Buffalo: London Liniversity of Toronto Press, 1992.

Frith. Valerie. ed women \& history Voices of Early Modern England. Toronto Coach House Press. 1995. 
Galgay, Frank, and Michael McCarthy Shipwrecks of Newfoundland and Labrador, 4 vols. St John's: Harry Cuff Publications, 1987, and Creative Publishers, 1990. 1995. and 1997

..---., Sr. Teresina Bruce, and Sr. Magdalen O'Brien. A Pilgrimage of Faith. A History of the Southern Shore from Bav Bulls to St Shott's St. John's: Harry Cuff Publications. 1983

Gardner, Bryan A. Black's Law Dictionary, $7^{\text {th }}$ ed. St. Paul, Minn.. West Group. 1999

Gentilcore, R. Louis, ed Historical Atlas of Canada vol. 2 Toronto Lniversity of Toronto Press. 1993

Goldstrum, J M, and L. A Clarkson, eds Irish Population, Economv and Societv Essays in Honour of the late K. H. Connell. Oxford Oxford Lniversity Press. 1981 .

Graham, B J, and L. J. Proudfoot, eds. An Historical Geography of Ireland. London Academic Press Limited, 1993

Grant. Joan, ed. Women, Migration and Empire. Stoke-on-Trent Trentham Books. 1996

Gray, Jane "Gender and Plebeian Culture in L7ster " Journal of Interdisciplinary History. 242 (1993), $251-70$

Green. Anna and Kathleen Troup. eds The houses of history A critical reader in twentieth-century history and theory. New York: New York University Press. 1999

Gribben. Arthur. ed The Great Famine and the Irish Diaspora in America Amherst: Lniversity of Massachusetts Press, 1999

Guildford. Janet. and Suzanne Morton. eds. Separate Spheres. Women's Worlds in the 19th-Century Maritimes. Fredericton: Acadiensis Press. 1994

Gundersen, Joan R. "The Non-institutional Church: The Religious Role of Women in Eighteenth-Century Virginia." Historical Magazine of the Protestant Episcopal Church, 51:4 (1982), 347-57.

Gushue, Raymond "The Law of Real Property in Newfoundland." Canadian Bar 
Review, IV (May, 1926), 310-4

Hall. Catherine White, Male and Middle-Class Explorations in Feminism and History New York: Routledge, 1992.

Handcock. W Gordon. Soe longe as there comes noe women Origins of English Settlement in Newfoundland. St. John's. Breakwater Books. 1989

Handlin. Oscar Boston's Immigrants. Cambridge. Mass. Harvard Lniversity Press. 194 !.

Hanrahan, Maura, ed. Through a Mirror Dimly Essays on Veufoundland societv and culture. St John's: Breakwater. 1993

Harris, Ruth-Ann. The Nearest Place That Wasn t Ireland Early Nineteenth-Century Irish Labor Migration. Ames: Iowa State Lniversity Press. 1994

Harzig. Christiane, ed. Peasant Maids - City Women From the European Countryside to Liban America. Ithaca: London: Cornell Liniversity Press. 1997

Head. C Grant. Eighteenth Century Newfoundland. Toronto McClelland and Stewart in association with the Institute of Canadian Studies. Carleton Lniversity. 1976.

Hearn. Mona. Below Stairs: Domestic Service Remembered in Dublin and Bevond. 1880-1922. Dublin: Lilliput Press, 1993

Hedrick, Joan D The Oxford Harriet Beecher Stowe Reader New York; Oxford Oxford University Press, 1999

Hill, Bridget. Women, Work, and Sexual Politics in Eighteenth-Century England. Oxford: Basil Blackwell, 1989

....-.- Servants English Domestics in the Eighteenth Century Oxford: Clarendon Press, 1996

Hoffman. Ronald. Princes of Ireland. Planters of Maryland A Carroll Saga, 1500-1782. collaborated with Sally D. Mason. Chapel Hill: University of North Carolina Press, 2000

Holmes. Janice, and Diane Urquhart, eds., Coming into the Light. The Work, Politics and Religion of Women in Ulster, 1840-1940. Belfast: Institute of Irish Studies, 
Queen's Lniversity. Belfast. 1994.

Houston, Cecil J, and William J. Smyth. Irish Emigration and Canadian Settlement: Patterns.Links, and Settlers Toronto: University of Toronto Press, 1990

Hoy, Suellen. 'The Journey Out: The Recruitment and Emigration of Irish Religious Women to the L'nited States. 1812-1914." The Joumal of Women's History, 6.47 I (Winter/Spring, 1995), 64-98.

Iacovetta. Franca, and Mariana Valverde, eds. Gender Conflicts: New Essays in Women's History. Toronto Lniversity of Toronto Press, 1992.

Innis. Harold ti The Cod Fisheries: The Study of an International Economv Toronto University of Toronto Press, 1940, 1954

Jensen, Katherine "Oral Histories of Rural Western American Women. Can They Contribute to Quantitative Studies?" Intemational Joumal of Oral History, 53 (November. 1984), 159-67

John. Angela V ed Unequal Opportunities Women's Employment in England, 18001918. Oxford: Basil Blackwell Ltd. 1986

......., ed Our Mothers' Land Chapters in Welsh Women's History. 1830-1939 Cardiff University of Wales Press. 1991

Johnson, Trudi D. "Matrimonial Property Law in Newfoundland to the End of the Nineteenth Century “ Ph. D Thesis, Memorial L'niversity of Newfoundland. 1998

Jordan. Jean P. "Women Merchants in Colonial New York " New York History, 584 (1977), 412-39

Karlsen. Carol F. The Devil in the Shape of a Woman Witchcraft in Colonial New England. New York: Norton. 1987

Kealey. Linda, ed. Pursuing Equality: Historical Perspectives on Women in Newfoundland and Labrador. Social and Economic Papers No. 20 St. John's. ISER. Memorial Lniversity, 1993

Keamey, Richard, ed. Migrations The Irish at Home \& Abroad. Dublin: Wolfhound Press, 1990. 
Kennedy, Robert E., Jr. The Irish: Emigration. Marriage and Fertility. Berkeley Lniversity of California Press. 1973

Kent. Susan Kingsley. Sex and Suffrage in Britain, 1860-1914 Princeton: Princeton University Press, 1987.

Kerber. Linda Women of the Republic Intellect and Ideology in Revolutionary America Chapel Hill: Universty of North Carolina Press. 1980

...-.-., and Jane Sherron de Hart, eds.. Women's America: Refocusing the Past, 3 eds. New York. Oxford Oxford Liniversity Press, 1982, 1987, and 1991

Knatla, Louis A. and Susan W S Bunnie. eds. Law, Society, and the State: Essays in Iodern Legal History Toronto. Buffalo. London Liniversity of Toronto Press. 1995

Koditschek. Theodore "Gendering of the British Working Class." Gender and History, 92 (August, 1997), 333-63

Kross. Jessica. "Mansions. Men. Women. and the Creation of Multiple Publics in Eighteenth-Century British .Norh America." Journal of Social History, 332 (1999), 385-408

Lahey. Raymond J. James Louis O'Donel in Yewfoundland 1784-1807. The Establishment of the Roman Catholic Church. Shannon Ryan and G. M. Story. eds St. John's: Newfoundland Historical Sociery, Pamphlet No. 8. 1984.

Larkin. Emmet. The Historical Dimensions of Irish Catholicism. New York: Arno Press. 1976.

Leydesdorff, Selma. Luisa Passerini, and Paul Tompson, eds. Gender and Memory. International Yearbook of Oral History and Life Stories, vol. IV Oxford: Oxford Liniversity Press, 1996

Light. Beth. and Alison Prentice, eds. Pioneer and Gentlewomen of British North America 1713-1867, Documents in Canadian Women's History, vol. 1. Toronto New Hogtown Press, 1980.

Lindstrom, Varpu. Defiant Sisters: A Social History of Finnish Immigrant Women in Canada. Toronto Multicultural History Society of Ontario. 1987; 1992 
Little, Linda. "Plebeian Collective Action in Harbour Grace and Carbonear, 1830-40" MA. Thesis, Memorial University, 1984

Lochrie, Karma. Coven Operations. The Medieval Lses of Secrecy Philadeiphia. Lniversity of Pennsylvania Press, 1999

Lockhar, Audrey. Some Aspects of Emigration from Ireland to the North Amencan Colonies Between 1660 and 1775 The Irish-Americans Series New York Amo Press. 1976, reprint of M. Litt. thesis. Trinity College. Dublin. 1971

Luddy. Maria. "An Agenda for Women's History. 1800-1900" Irish Historical Studies, XXVTII 109 (May, 1992), 19-37

Women in Ireland, 1800-1918 A Documentary History Cork: Cork L'niversity Press. 1995

and Cliona Murphy, eds. Women Surviving Studies in Irish Women's History in the 19 th and 20 th Centuries. Dublin Poolbeg Press. 1989

MacCurtain, Margaret, and Mary O'Dowd "An Agenda for Women's History. 15001800 " Irish Historical Studies, XXVTII 109 (May. 1992), 1-19

.---.-. eds. Women in Early Modern Ireland Edinburgh Edinburgh L'niversity Press. 1991

MacKay. Margaret. "Nineteenth Century Tiree Emigrant Communities in Ontario" Oral History, 9-2 (Autumn. 1981), 49-60

Mac Laughlin. Jim. Historical and Recent Irish Emigration A critique of core-periphery and behavioural models London: Liniversity of North London Press. 1994

ed. Location and Dislocation in Contemporary Irish Society: Emigration and Irish Identities. Cork: Cork University Press, 1997

MacRaild. Donald M. "Crossing Migrant Frontiers: Comparative Reflections on lrish Migrants in Britain and the United States during the Nineteenth Century." Immigrants \& Minorities, 18.2 and 3 (July/November, 1999), 40-70

Main. Gloria L. "Gender. Work, and Wage in Colonial New England." William and Mary Quarterly, $51: 1$ (1994), 39-66 
Major, Kevin, ed. Doryloads. St. John's: Breakwater Books, 1974

Mannion, John J. "Irish Imprints on the Landscape of Eastern Canada in the Nineteenth Century A study in Cultural Transfer and Adaptation." Ph. D. Thesis, University of Toronto, 1971

-2.-- The trish Migrations to Newfoundland." Unpub summary of a public lecture delivered to the Newfoundland Historical Sociery, St. John's. October 23, 1973

-.--.- Irish Settlements in Eastern Canada: A Study of Cultural Transfer and Idaptation. Toronto: Liniversity of Toronto Press. 1974.

-...- - The Impact of Newfoundland on Waterford and its Hinterland in the Eighteenth Century " Paper delivered at the Annual Conference of Irish Geographers. University College. Galway. April 22. 1977.

-..-.- "Migration and Lpward Mobility: The Meagher Family in Ireland and Vewfoundland, 1780-1830" Insh Economic and Social History, XV (1988), 5470

-.-.- "Tracing the Irish A Geographical Guide," The Newfoundland Ancestor, 9-1 (Spring. 1993). 4-18.

----.- ed The Peopling of Newfoundland Essays in Historical Geography. Social and Economic Papers No 8 St. John's. ISER. Memorial Liniversity, 1977

Martin. Ronald. ed. and comp. Poems of Action. Sentiment and Reflection. St. John's: s.n., 1945.

Matthews, Keith. "A History of the West of England - Newfoundland Fishery " D Phil Thesis. Oxford University, 1968.

-..-.- Lectures on the History of Newfoundland. 1500-1830 St. John's: Breakwater Books. 1988.

McCaffrey, Lawrence J. The Irish Diaspora in America. Bloomington. London: Indiana University Press, 1976

MfCarhy. Michael. The Irish in Newfoundland 1600-1900: Their Trials, Tribulations and Triumphs. St. John's: Creative Publishers, 1999. 
McCormack, Bridget. Perceptions of St. Patrick in Eighteenth-Century Ireland. Dublin: Four Courts Press, 2000

McGrath. Carmelita, Barbara Neis, and Marily Porter, eds. Their Lives and Times: Women in Newfoundland and Labrador: A Collage St. John's: Killick Press, 1994

McLintock. A. H. The Establishment of Constitutional Government in Newtoundland, 1783-1832. London: Longmans, Green, 1941

Menaughton. Janet. "The Role of the Newfoundland Midwife in Traditional Health Care. 1900 to 1970 " Ph.D. Thesis, Memorial Lniversity, 1989

McPherson. Kathrun, Cecilia Morgan. and Nancy M. Forestell, eds Gendered Pasts Historical Essavs in Femininity and Masculinity in Canada. Oxford Oxford Lniversity Press. 1999

Merritt, Susan E. Her Story II: Women from Canada's Past. St Catharines, Ont. Vanwell Publishing, 1995

Miles. Lion G. "Anna Bingham. From the Red Lion Inn to the Supreme Court." Yew England Quarterly, 69:2 (1996), 287.99.

Miller. Kerby A. "Emigrants and Exiles: Irish Cultures and Irish Emigration to Vorth America. 1790-1922." Irish Historical Studies, XXII.86 (September, 1980). 97125

-.-.- Emigrants and Exiles: Ireland and the Irish Exodus to North America. New York, Oxford: Oxford University Press, 1985

Mokyr. Joel Why Ireland Starved:A Quantitative and Analytical History of the Irish Economy, 1800-1850. London; Boston: Sydney: George Allen \& Lnwin. 1983

.....-- and Cormac O Grada. "Emigration and Poverty in Prefamine Ireland." Explorations in Economic History, 19.4 (October. 1982), 360-84

Morgan, Cecilia. Public Men and Virtuous Women: The Gendered Languages of Religion and Politics in Upper Canada, 1791-1850. Toronto; Buffalo; London: University of Toronto Press. 1996.

Murphy, Maureen. 'Charlotte Grace O'Brien and the Mission of Our Lady of the Rosary 
for the Protection of Irish Immigrant Girls " Mid-America. An Historical Review, $743(1992), 253 \cdot 70$

Sfurray. Hilda Chaulk. More Than Fifty Percent: Women's Life in a Newfoundland Outpor, 1900-1950. St. John's Breakwater Books, 1979

Myles, Margaret F. Textbook for Midwives, $8^{\text {th }}$ ed. Edinburgh, London, New York Churchill Livingstone. 1975

Nead. Lynda. Myths of Sexuality: Representations of Women in Victorian Britain Oxford, New York: Basil Blackwell, 1988

Nemec. Thomas F "The Irish Emigration to Newfoundland." Newfoundland Quarterly, 691 (1972b), 15-24.

...-.- Trepassey, 1505-1840 A.D. The Emergence of an Anglo-Irish Newfoundland Outport," Newfoundland Quarterly, $69 \cdot 4$ (1973), 17-28.

-..-- The Irish emigration to Newfoundland a critical review of the secondary sources." Guest lecture delivered to the Newfoundland Historical Society. St John's. March 30, 1978

...-.- An Ethnohistorical and Ethnographic Study of the Cod Fishery at St Shott's. Newfoundland" (Ph.D Thesis, University of Michigan, 1980)

Neville. Grace. "'She Never Then After That Forgot Him": Irish Women and Emigration to the Linited States in Irish Folklore." Mid-Amenica. An Historical Review, 743 (1992), $271-89$

Newson. Harry The Law of Salvage. Towage, and Pilotage London William Clowes and Sons. 1886

Nolan. Janet A. Ourselves Alone. Women's Emigration from Ireland, 1885-1920 Lexington: University Press of Kentucky. 1989

Nolan, William, and Kevin Whelan, eds. Kilkenny History and Sociery - Interdisciplinary Essays on the History of an Irish County. Dublin: Geography Publications. 1990.

Nordvik, Helge W., and Lewis R. Fischer. "Peter M. Stuwitz and the Newfoundland Inshore Fishery in 1840," Newfoundland Studies, 1:2 (Fall. 1985). 129-40 
Norton, Mary Beth. Libertv's Daughters: The Revolutionary Experience of American Women, 1750-1800. Boston; Toronto: Little. Brown and Company. 1980

--.-- The Evolution of White Women's Experience in Early America." American Historical Review, $89 \cdot 3$ (1984), 593.619

O'Connor. Thomas. The Boston Irish A Political History Boston: Vortheastern Lniversity Press, 1995.

O'Dea. Shane. "Simplicity and Survival: Vernacular Response in Newfoundland Architecture" Society for the Study of Architecture in Canada Bulletin, 82 (June. 1983), +11

O'Dowd. Anne. Spalpeens and Tattie Hokers: History and Folklore of the Irish Migratory Agricultural Worker in Ireland and Britain Blackrock: Irish Academic Press. 1991

O'Farrell. Padraic Superstitions of the Irish Country People Dublin. Cork: Mercier Press. 1978

Otfen. Karen. Ruth Roach Pierson, and Jane Rendall, eds. Writing Women's History International Perspectives Bloomington, Indianapolis: Indiana Liniversity Press. 1991

O'Flanagan. Patrick. Paul Ferguson, and Kevin Whelan, eds Rural Ireland. Modernisation v Change, 1600-1900 Cork Cork Liniversity Press. 1987

Ogilvie. Sheilagh C., and Markus Cerman, eds. European proto-industrialization. Cambridge: Cambridge Lniversity Press, 1996.

O Grada. Cormac. "A Note on Nineteenth-Century Irish Emigration Statistics." Population Studies 29.1 (March, 1975), 143-149

Ireland A New Economic History, 1780-1939 Oxford Clarendon Press. 1994

O'Neill, Kevin. Family and Farm in Pre-Famine Ireland The Parish of Killashandra. Madison: The University of Wisconsin Press, 1984

Oosterhoff, A. H. Text, Commentary and Cases on Wills and Succession, $3^{\text {rd }} \mathrm{ed}$. Toronto: Carswell, 1990 
O'Sullivan, Patrick, ed. Patterns of Migration. Irish World Wide Series, vol 1 Leicester, New York: Leicester University Press. 1992.

The Irish in New Communities Irish World Wide Series, vol. 2 Leicester. New York: Leicester University Press, 1992

-..-.- The Creative Migrant Irish World Wide Series. vol. 3 Leicester. New York Leicester L'niversity Press, 1994.

....... Irish Women and Irish Migration. Irish World Wide Series, vol \& London. New York: Leicester University Press. 1995

.....- Religion and Identity, Irish World Wide Series, vol. 5 London, New York Leicester L'niversity Press. 1996

...-.- The Meaning of the Famine. Irish World Wide Series, vol. 6 London, New York: Leicester Lniversity Press, 1997

Parker. Stephen Informal Marriage, Cohabitation and the Law 1750-1989 New York St Martin s Press. 1990

Parr, Joy. and Mark Rosenfeld. eds Gender and History in Canada Toronto Copp Clark. 1996.

Perkin. Joan. Women and Marriage in Nineteenth-Century England Chicago Lyceum Books. 1989

Perry. Adele. '.'Oh I'm Just Sick of the Faces of Men': Gender Imbalance, Race. Sexuality, and Sociability in Nineteenth-Century British Columbia " BC Studies, 105 and 106 (Spring/Summer. 1995), 27-43

Philpin. C. H. E. ed Nationalism and Popular Protest in Ireland Cambridge Cambridge Lniversity Press, 1987

Pocius. Gerald L. "English Styles and Irish Adaptations: The Emergence of Newfoundland House Forms on the Southern Shore." Paper presented to a joint meeting of the Irish Newfoundiand Society and the Newfoundland Historical Society. January 29, 1981

...-.- -Architecture on Newfoundland's Southern Shore Diversity and the Emergence of New World Forms." Societv for the Study of Architecture in Canada Bulletin. 
82 (June, 1983), 12-9

...-.- A Place to Belong: Communitv Order and Everyday Space in Calvert. Vewfoundland Athens. London. University of Georgia Press, 1991.

Pope. Peter "The South Avalon Planters, 1630-1700* Ph.D. Thesis, Memorial Lniversity of Newtoundland, 1992

Porter, Marilyn. "She was Skipper of the Shore Crew . Votes on the History of the Sexual Division of Labour in Newfoundland," Labour/Le Travail, 15 (Spring, 1985), 104-25

Prentice. Alison. and Susan Mann Trofimenkoff, eds. The Veglected Majority Essays in Canadian Women's History Volume 2. Toronto .McClelland and Stewart, 1985

Prowse, Daniel W A History of Newtoundland from the English. Colonial and Foreign Records. London. New York: MacMillan, 1895, reprint Belleville: Mika Studio. 1972

Reece. Bob '.'Such a Banditti' Irish Convicts in Newtoundland. 1789 Part I." viewtoundland Studies, 131 (Spring. 1997), 1-29

Rendall. Jane Women in an Industrializing Society England, 1750-1880 Historical Association Studies. Oxford Basil Blackwell. 1990

Rhodes. Rita. Women and the Family in Post-Famine Ireland. Status and Opportunitv in a Patriarchal Society New York: Garland, 1992

Riley. Denise "Am I That Name?" Feminism and the Category of Women in History Vinneapolis: University of Minnesota Press, 1988.

Roberts, Elizabeth A Woman's Place An Oral History of Working-Class Women, 18901940 Oxford: Basil Blackwell Publisher Limited, 1984

Rose. Sonva O Limited Livelihoods: Gender and Class in Vineteenth Century England Berkeley, Los Angeles: University of California Press. 1992.

Rosenberg, Neil V. ed Folklore and Oral History. St. John's. Memorial University, 1978.

Ross. Ellen. Love and Toil: Motherhood in Outcast London: 1870-1918. New York: 
Oxford: Oxford University Press, 1993.

Rousseau. G. S , and Roy Porter, eds. Sexual underworlds of the Enlightenment. Chapel Hill: Lniversity of North Carolina Press, 1988

Rowe. G. S. -Infanticide, Its Judicial Resolution, and Criminal Code Revision in Early Pennsylvania." Proceedings of the American Philosophical Society, 1352 (1991). 200-32

Ryan. Mary P Womanhood in America: From Colonial Times to the Present New York: New Viewpoints, 1975

Ryan. Shannon "Fishery to Colony A Newfoundland Watershed. 1793-1815." Acadiensis, XII 2 (Spring. 1983). 34-52.

...-.. The Ice Hunters A Histon of Newfoundland Sealing to 1914 St John's Breakwater. 1994

Salmon. Marylunn. "The Legal Status of Women in Early America. A Reappraisal." Law and History Review, 11 (1983), 129-51

Sawyer. Jeffrey K. "'Benefit of Clergy" in .Maryland and Virginia." American Journal of Legal History, 341 (1990), 49-68

Scally. Robert James. The End of Hidden Ireland Rebellion. Famine, and Emigration New York, Oxford Oxford University Press. 1995

Schrager. Samuel. "What is Social in Oral History?" International Joumal of Oral History, 42 (June. 1983). 76-98

Scott. Joan Wallach Gender and the Politics of History. New York: Columbia University Press, 1988

Seary. E R. with Sheila Lynch. Family Names of the Island of Newfoundland, rev. ed. St. John's Memorial Lniversity of Newfoundland, 1984.

Shammas. Carole. Marylynn Salmon. and Michel Dahlin. Inheritance in America: From Colonial Times to the Present. New Brunswick: Rutgers University Press. 1987

Shanley, Mary Lyndon. Feminism, Marriage, and the Law in Victorian England, 18501895 Princeton: Princeton University Press, 1989 
Shannon, William V. The American Irish New York: Macmillan, 1963

Shapiro, Ann-Louise, ed. Feminists Revision History New Brunswick: Rutgers Lniversity Press, 1994

Sharpe. Panela, ed. Women's Work: The English Experience 1650-1914 London: New York: Sydney, Auckland: Amold. 1998.

Sharpless, Rebecca "The Numbers Game: Oral History Compared with Quantitative Methodology." International Journal of Oral History, 7:2 (June. 1886), 93-108

Simon. Karen. "A Case Study in the Reception of Law in Newfoundland. Assessing Women 's Participation in the Courts of Placentia District, 1757-1823 " Honours Dissertation. Memorial Universitv. 1999

Sinclair. Alan M., and Margaret E. McCallum. Introduction to Real Property Law $4^{\text {th }}$ ed. Toronto. Vancouver: Butterworths. 1997

Smallwood. Joseph R. ed. Encyclopedia of Newfoundland and Labrador, vol is St. John's Harry Culf Publishers. 1991

Smart. Carol. ed. Regulating Womanhood: Historical essays on marriage, motherhood and sexuality London: New York: Routledge. 1992

Smith. Babette \pm Cargo of Women Susannah Watson and the Convicts of the Princess Roval. Kensington. New South Wales University Press. 1988

Snell, James G In the Shadows of Law Divorce in Canada 1900-1939 Toronto University of Toronto Press, 1991

Speth. Linda E. "More than her 'Thirds': Wives and Widows in Colonial Virginia." Women and History, 4 (1982). 5-41.

Strong-Boag. Veronica, and Anita Clair Fellman, eds. Rethinking Canada. The Promise of Women's History. Toronto: Copp Clark Pitman. 1986

Sullivan. Charles, ed Ireland in Poetry New York: Harvey N Abrams, 1990.

Swift. Roger, and Sheridan Gilley, eds. The Irish in the Victorian City. London: Croom Helm, 1985 
- The Irish in Britain, 1815-1939. London: Pinter Publishers, 1989.

-.-.-. The Irish in Victorian Britain. The Local Dimension. Dublin. Four Courts Press. 1999

Swyripa, Francis. Wedded to the Cause: Ukrainian-Canadian Women and Ethnic Identity, 1891-1991. Toronto: University of Toronto Press, 1993.

Taylor. David. Crime, Policing and Punishment in England, 1750-1914. New York St Martin's Press, 1998.

Tebbutt, Melanie Women's Talk' A Social History of 'Gossip' in Working-Class Yeighbourhoods, 1880-1960 Aldershot: Scolar Press, 1995

TeBrake, Janet K. "Irish Peasant Women in Revolt: The Land League Years " Irish Historical Studies, XXVTII 109 (May, 1992), 63-80

Thomson. Alistair. "Moving Stories: Oral History and Migration Studies" Oral History. 271 (Spring, 1999), 24-37

-2.-. Tales of the Century Biennial National Conference of the Oral History Association of Australia, 2-5 September 1999. State Library of Victoria. Melbourne" Oral History, 28 I (Spring, 2000), 25-7

-.--.- Michael Frisch. and Paula Hamilton "The Memory and History Debates: Some International Perspectives." Oral History, 222 (Autumn, 1994), 33-43.

Thompson. E. P Customs in Common London: Merlin Press, 1991

Thornton, Patricia A Dynamic Equilibrium: Settlement. Population and Ecology in the Strait of Belle Isle, Newfoundland, 1840-1940" Ph. D. Thesis, University of Aberdeen, 1979

Toulson, Shirley. The Celtic Year: A Month-by-Month Celebration of Celtic Christian Festivals and Sites Shaftesbury, Rockport; Brisbane: Element, 1996.

Trofimenkoff, Susan Mann, and Alison Prentice, eds. The Neglected Majority Essays in Canadian Women's History. Toronto: McClelland and Stewar, 1977.

CTrich. Laurel Thatcher. '“A Friendly Neighbor': Social Dimensions of Daily Work in Northern Colonial New England." Feminist Studies, $6: 2$ (1980), 392-405 
...... Good Wives Image and Reality in the Lives of Women in Northern New England. 1650-1750 New York: Alfred A Knopf, 1982.

A Midwife's Tale The Life of Marha Ballard. Based on Her Diary, 1785-1812. New York Afred A. Knopf, 1990

Valenze, Deborah. The First Industrial Woman New York: Oxford: Oxford University Press. 1995

Valiulis, Maryann Gialanella, and Mary O'Dowd, eds. Women in Irish History Dublin. Wolfhound Press. 1997.

Vaughan, W E , ed A Vew History of Ireland, vol V Oxford Clarendon Press, 1989

Vorst. Jesse. et al. eds. Race, Class, Gender Bonds and Barriers Toronto Between the Lines in cooperation with the Society for Socialist Studies, 1989

Walker. David M. The Oxford Companion to Law Oxford Clarendon Press, 1980

Walkowitz. Judith. City of Dreadful Delight: Narratives of Sexual Danger in LateVictorian London. Chicago University of Chicago Press, 1992.

Weinberg. Sydney Stahl. "The Treatment of Women in Immigration History A Call for Change." with "Comment" by Hasia R. Diner and by Maxine Schwartz Seller Journal of American Ethnic History, 11 ( (Spring, 1992), 25-67

Westerkemp. Marilyn J. Women and Religion in Early Amenca, 1600-1850. The Puritan and Evangelical Traditions. London; New York: Routledge. 1999.

Williams. Alan F Father Baudoin's War. D'tberville's Campaigns in Acadia and Vewfoundland, 1696, 1697, Alan G Macpherson. ed. St John's: Memorial L'niversity. 1987.

Williams. Seima R Demeter's Daughters The Women Who Founded America, 1587. 1787 . New York: Atheneum. 1976.

Williamson, Jeffrey G. "The Impact of the Irish on British Labour Markets During the Industrial Revolution." Journal of Economic History, XI VT 3 (September. 1986). 693-720.

Wilson, Philip K, ed. Childbirth: Changing Ideas and Practices in Britain and America 
1600 to the Present, vol. 5 New York; London: Garland Publishing, 1996

Wokeck. Marianne S. Trade in Strangers: The Beginnings of Mass Migration to North America. University Park, Penn. Pennsylvania State University Press, 1999

Wood-Martin. W. G Traces of the Elder Faiths of Ireland, vol. 2. Port Washington; London: Kennikat Press, 1970, reprint.

Yogis, John A. Canadian Law Dictionary, $3^{\text {rd }}$ ed. Hauppauge, New York Barron's Educational Series, 1995 




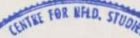

JUL 181978

OPAPORIAL UNIVES ND

2. NEWEOUNDI 
